UNIVERSIDADE DE SÃO PAULO

FACULDADE DE FILOSOFIA, LETRAS E CIÊNCIAS HUMANAS DEPARTAMENTO DE FILOSOFIA

PROGRAMA DE PÓS-GRADUAÇÃO EM FILOSOFIA

\title{
PEQUENA HISTÓRIA DO MAL: ANSELM KIEFER E WALTER BENJAMIN
}

\author{
Lílian Santiago-Ramos
}

SÃO PAULO

2009 
UNIVERSIDADE DE SÃo PAULO

FACULDADE DE FILOSOFIA, LETRAS E CIÊNCIAS HUMANAS

DEPARTAMENTO DE FILOSOFIA

PROGRAMA DE PÓS-GRADUAÇÃO EM FILOSOFIA

\title{
PEQUENA HISTÓRIA DO MAL: ANSELM \\ KIEFER E WALTER BENJAMIN
}

\author{
Lílian Santiago-Ramos
}

Tese apresentada ao Programa de Pós-graduação do Departamento de Filosofia da Faculdade de Filosofia, Letras e Ciências Humanas da Universidade de São Paulo, como requisito parcial para obtenção do título de Doutor em Filosofia.

ORIENTADORA: Profa. Dra. Olgária Chain Féres Matos

SÃO PAULO

2009 


\section{Lilian Santiago-Ramos}

\section{Pequena História do Mal- Anselm Kiefer e Walter Benjamin}

Tese apresentada ao programa de Pós-graduação em Filosofia do Departamento de Filosofia da Faculdade de Filosofia, Letras e Ciências Humanas da Universidade de São Paulo, para obtenção do título de Doutor em Filosofia, sob a orientação da Profa. Dra. Olgária Chain Féres Matos.

COMISSÃO EXAMINADORA

Profa. Dra. Olgária Chain Féres Matos

Orientadora

Departamento de Filosofia-FFLHC-USP

Profa. Dra. Sônia Salzstein Goldberg Departamento de Artes Plásticas-ECA-USP

Prof. Dr. Ricardo Fabbrini Nascimento

Departamento de Filosofia-FFLCH-USP

Prof. Dr. Tales A. M. Ab'Sáber Instituto SEDES-SAPENTIAE-PUC

Prof. Dr. Mário Henrique D'Agostino Faculdade de Arquitetura e Urbanismo-USP

São Paulo, 13 de outubro de 2009. 


\section{Ficha Catalográfica}

Santiago-Ramos, Lilian

Pequena História do Mal: Anselm Kiefer e Walter Benjamin/Lilian Santiago-Ramos; orientadora: Olgária Chain Féres Matos. - São Paulo : USP- Departamento de Filosofia, 2009.

V, 362 f.: 53 ils.; $30 \mathrm{~cm}$

Tese (doutorado) - Universidade de São Paulo Departamento de Filosofia.

Inclui referências bibliográficas.

1. Catástrofe 2. Mal 3. Progresso 4. Ruínas 5. Arte Contemporânea 6. Romantismo 7. Nazismo I. Matos, Olgária. II. Universidade de São Paulo. III. Departamento de Filosofia 
A Olgária, Soledad e Tales: três estrelas da redenção.

À memória de Mara e Juanita:

Duas arcanas do inteiramente outro. 
Temos, desta forma, um sonho de função poética de Freud sobre si mesmo, refletindo toda a existência de sua obra máxima nele mesmo, o seu valor e os seus riscos, numa concepção radical sobre o ser que se faz ao desconhecer algo do próprio percurso em que se constitui, que necessita atentar aos próprios sonhos para acontecer na jornada mesma do mistério humano, e que corre todos os riscos ao apresentar tal matéria processual de sua humanidade a um outro.

Tales A.M. Ab'Sáber 


\section{AGRADECIMENTOS}

Esta tese representa o resultado de um percurso intelectual ao longo de seis anos (2003-2009), e só foi possível graças ao apoio que recebi de familiares, colegas e amigos durante toda essa travessia.

Primeiramente, quero expressar minha gratidão aos meus familiares e íntimos por terem sempre apoiado minhas escolhas acadêmicas e todas minhas extravagâncias e desvios metodológicos com muita paciência, carinho e amor. À Felícita, minha mãe, a Héctor, meu pai, e às minhas irmãs, Sonia e Maggie, e aos meus sobrinhos e sobrinhas, em especial a Sophia, pelas novas esperanças e a Damaris porque é a prima de meus olhos. Sua presença na minha vida é o alicerce existencial do meu trabalho.

Nos meus périplos acadêmicos fora do Brasil gostaria de reconhecer a presença de amigos, colegas e grandes interlocutores que tem se mantido presentes na minha vida direta ou indiretamente através do tempo: da minha passagem pela Califórnia Amália Llombart, Arturo Giráldez, Miriam Smith, Cecilia Méndez, João Camilo dos Santos, João Camilo Penna, Ana Sofia Ganho, José Checa, José Salgado, Jorge Luis Castillo, Antonio Ocaña, nos meus dias montrealeses queria lembrar a generosa acolhida de Sebastianne Bage, por ter me apresentado a cidade e introduzido duas novas paixões: Montréal e a sinologia através da leitura François Cheng, Amaryll Chanady e o Departamento de Literatura Comparada da Universidade de Montréal e a Maryse e Roger, de meus dias washingtonianos cabe destacar a presença de Evelyn Canabal, Zaida e Boris, Ghada Almaboudh, Juan Arbona, Fabrice Sciore, Zennia Hancock, Phyllis Peres, Hernán Sánchez, Martial Friedenthié e Cerue Diggs. 
Às principais cúmplices islenhas, amigas em todas as horas: Maga Jiménez, Wandy Rivera, Jasmin Santiago, Juana Cabello, Miriam Muñiz, Nelche Vanmarrising, Lissette Castro, Nelly Vega, Elisa Colón, Cana Cabán, Lena Burgos, Michelle Silvestriz, Irma Rivera e aos "chicos": Richie Delgado, Ramón Sepúlveda, Carlitos Muñiz, Edwin Cruz.

Agradeço, particularmente, a Laura Delgado, que generosamente facilitou meu acesso às bases de dados das universidades norte-americanas por meio do programa Pro-quest.

Ao professor Luis Pérez, agradeço pela amizade, tantas cumplicidades, carinho entranhável e apoio dispensado ao longo de todos esses anos.

$\mathrm{Na}$ minha experiência acadêmica brasileira, gostaria de reconhecer aqui meu profundo agradecimento ao professor Ricardo Fabbrini Nascimento pela generosidade do tempo sem tempo, o rigor e a leitura acurada no exame de qualificação que encaminhou instigadoramente esta pesquisa. Também aos professores José António Pasta, Maria das Graças de Souza, Caetano Ernesto Plastino, Leda Tenório Motta, Jõao A. Frayze-Pereira, Nelson Brissac Peixoto, Vladimir Safatle, Massimo di Felice, Arley Andriolo, Rita Cássia Paiva, Eduardo Natalino dos Santos, por todas as conversas e aulas esclarecedoras.

À professora Leila Maria Brasil Danziger, pela acolhida cordial e pela interlocução a distância.

$\mathrm{Na}$ professora Sônia Salzstein Goldberg encontrei um entusiasmo e uma dedicação ao ensino como uma urgência na tarefa de pensar que me marcaram profundamente. Obrigada pela terna acolhida, pela generosa interlocução e pelo assombro que suscita estar presente em cada uma de suas aulas. 
A Tales Ab'Sáber por ter restaurado meu sonho e propiciar este awakening.

Aos amigos e amigas que fizeram dessa minha picaresca paulistana uma experiência mais leve atenuando com sua presença o expressionismo dessa civitas malum: Naira Assis, Rosângela Zanchetta, Daniela Augusto, Marcelo Osório, Ivan Farah, Rosane Pires e sua pequena Luisa, Débora Tabacoff, Mário Lins, Simone Souza, Marie Océan, Juliano Gouveia, Márcia Basso, Marcos Noyori, Valentin Ferenczi, Marçal e Maeve Lourenzoni, Bettina Schütze, Dra. Mária Claudia, Alexandra Fasano, Daniela Neves, Edu, Erivânia, Carol, obrigada a todos pela amizade, carinho e a acolhida constante.

À Rosane Pires por me acompanhar sempre, especialmente nos últimos dias deste delirante momento chamado finalização da tese, por toda tua alegria transbordada e transbordante, por saber me conter nessas horas em que meu espírito de drama queen parecia alcançar sua melhor performance, pela generosa dedicação e pela palavra certa nessas horas tão incertas. Muito obrigada!

À Michelle Urcci pelo apoio, contenimento e pelas dicas, pelos truques e pelos orçamentos low budget para evitar a bancarrota absoluta quando da impressão. Obrigada!

Ao meu professor de alemão, Marco Luiz Bortolazzo.

Aos colegas e amigos da FFLCH: Ari Tank Britto, Maria Cristina Theobaldo, Roberto Barros Freire, Natália Fujita, Márcio Moraes, Aléxia Bretas, em especial, a Yanet Aguilera, uma das mais avivadas defensoras do tema desta tese quando foi timidamente apresentado para a professora Olgária Chain Féres Matos em 2005.

Gostaria de reconhecer todo o apoio e tempo concedidos pelo Departamento de Filosofia da Universidade de São Paulo. Agradeço em especial o carinho e a acolhida do pessoal da Secretaria do 
Departamento: Marie M. Pedroso, Maria Helena de Souza, Verônica Ritter, Luciana Nóbrega, Roseli Hasenfratz, Geni Ferreira Lima e Ruben D. Cabrera.

Agradeço em especial a paciência, o carinho, apoio e compreensão de Júlio Fuji, da Comissão da Pós-graduação. À Capes pela bolsa de um ano, e à Fapesp pela bolsa de dois anos.

À professora e amiga Soledad Bianchi Lasso, por todo lo que hemos compartido juntas, porque contigo fue la primera vez que vi a Kiefer en el Museo de Filadelfia (Nigredo) y contigo fue la segunda vez que vi a Kiefer en la Galería Nacional de Washington ( $O$ anjo da História e Tzim-tzum) y porque contigo fue la primera vez que escuché detenidamente a Carmen Delia Dippiní. Tantas telas de Lúcio Fontana rasgadas en esos boleros ... Gracias!

À professora Olgária Chain Féres Matos que com sua paixão pelos gregos desde As suplicantes até $A$ tempestade me encaminhou na delicada tarefa de ser testemunha do que nos tem sido transmitido pelo gênio pagão de Esquilo e de Shakespeare. Se o espírito que deles emana apenas raras vezes se tem ofuscado na nossa época, vale a pena fazer um novo esforço para indicar por que as obras esplêndidas, que tem sobrevivido tanto tempo e a tantas catástrofes continuam suscitando em nós um estado de permanente perplexidade. O desejo de Olgária salvar a aura nelas é uma tentativa de ressuscitar nosso Gewissen, ou seja, nossa consciência ética, que talvez dependa mais de nossa abertura ao sagrado que de nossa filosofia.

I am not certain that I could have finished this project without your consistent generosity. You provide what every writer needs - a quiet and hospitable place where to work - Thanks for let me in. Thanks for let me stay in your Country. Thanks for being as unique as your proper name: Olgária. 
À Natália, pelas orquídeas, pelos livros, pelos cafés fríos, pelas tardes embelezadas assistindo os filmes de Zurlini, de Fuller, de Jarkman, Won Kar Wai, de sentir o peso do ridículo pela tragédia de Geni, em toda "Toda nudez será castigada", pelo pastel de feira, pelos olhares, pela respiração, pela dança, por Inhotim, pelas músicas, pelas cumplicidades, pelo bailado, por todas tuas presenças, tuas chegadas, tuas companhias que sempre me lembram desse verso de Heine: Es kommt mein Weib, schön wie der Morgen/Und lächelt fort die deutschen Sorgen. 
Santiago-Ramos, Lílian. Pequena História do Mal: Anselm Kiefer e Walter Benjamin. 2009. 362 f. Tese (Doutorado) - Faculdade de Filosofia, Letras e Ciências Humanas. Departamento de Filosofia, Universidade de São Paulo, São Paulo, 2009.

Resumo: A presente pesquisa procura reunir as reflexões pictóricas de Anselm Kiefer no âmbito da tradição intelectual da literatura, do mito, da história e da religião, e que se condensam na categoria da catástrofe de O Drama Barroco Alemão e do Trabalho das Passagens de Walter Benjamin. Procuraremos mostrar o estatuto da metrópole como o lugar do Mal, inscrevendo as produções artísticas de Anselm Kiefer no campo do pensamento trágico da vida, no sentido de viver sem o Bem e sob o amparo do Mal. Kiefer apresenta-se como o pintor cujas produções oscilam entre a Hybris do progresso e o terror da máxima destruição, do silêncio e do automatismo voltados para uma permanente catástrofe. Ao fim, delineia-se uma utopia negativa de uma barbárie positiva em meio ao Mal, que se tornou radical na nossa contemporaneidade.

Palavras-Chave: Catástrofe - mal - progresso - ruínas - arte contemporânea - romantismo - nazismo.

Santiago-Ramos, Lílian. Pequeña historia del Mal: Anselm Kiefer y Walter Benjamin. 2009. 362 pgs. Tesis (Doctorado) - Facultad de Filosofía, Letras y Humanas. Departamento de Filosofía, Universidad de São Paulo, Brasil, 2009.

Resumen: La presente investigación reune las reflexiones pictóricas de Anselm Kiefer en el ámbito de la tradición intelectual de la literatura, el mito, la história y la religión, condensadas en la categoría de catástrofe de El Drama Barroco Alemán y del Libro de los Pasajes de Walter Benjamin. Procuraremos mostrar el estatuto de la 
metrópolis como el lugar del Mal, inscribiendo las producciones artísticas de Anselm Kiefer en el campo del pensamiento trágico de la vida, en el sentido de vivir sin el Bien y bajo el amparo del Mal. Kiefer se presenta como el pintor cuyas producciones plásticas oscilan entre la Hybris del progreso y el terror de la máxima destrucción, del silencio y del automatismo abismados para una permanente catástrofe. Al final, se delinea una utopía negativa de una barbárie positiva en medio al Mal, que se tornó radical en nuestra contemporaneidad.

Palabras claves: Catástrofe - mal - progreso - ruínas - arte contemporánea - romanticismo - nazismo.

Santiago-Ramos, Lílian. Short Narrative of Evil: Anselm Kiefer and Walter Benjamin. 2009. 362 pp. Ph.D. Dissertation- College of Philosophy and Humanities. Department of Philosophy, University of São Paulo, Brazil, 2009.

Abstract: The present Dissertation attempts to bring together Anselm Kiefer's pictorial reflections toward the intellectual tradition sphere that encompasses Literature, Myth, History and Religion, all condensed by the Catastrophe label detached from The Origin of the German Tragic Drama and The Arcades Project both written by Walter Benjamin. The depiction of the Modern Metropolis as an embodiment of Evil is part of Anselm Kiefer artistic poetics. Kiefer depicts himself as the painter whose pictorial masterpieces oscillate between the Progress Hybris and the Terror of the supreme destruction, silence abysses in an ineluctable catastrophe. Towards the end, a negative utopia is outline from a positive barbarism, among the Evil that became radical in our contemporary societies.

Key-words: Catastrophe - Evil - Progress - Ruins - Contemporary Art - Romanticism - Nazism. 


\section{SUMÁRIO}

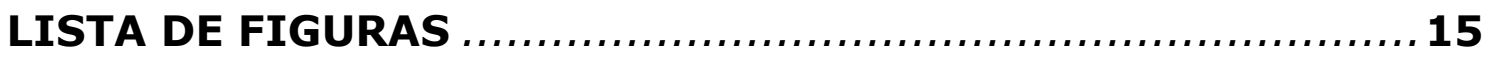

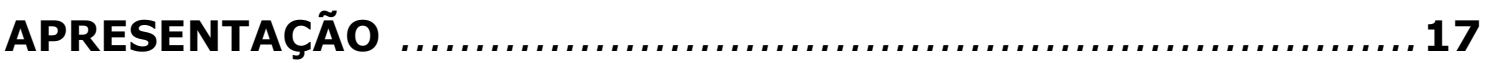

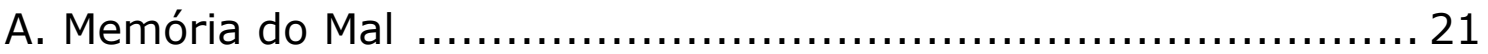

B. Catástrofe e aniquilação ................................................ 39

C. Pictura e Poesis da catástrofe ...................................... 83

\section{I.MEMÓRIA DO MAL}

A. Anselm Kiefer: Pintor da Memória .................................. 123

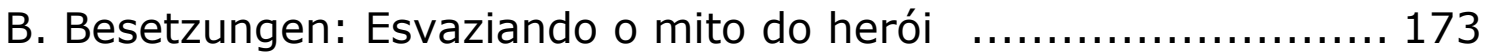

C. Beuys e a mitologia alemã do artista redentor .................... 200

\section{CATÁSTROFE E ANIQUILAÇÃO}

A. O Monumental e o Teutônico: O mito do espírito alemão .........2 213

B. Os heróis espirituais da Alemanha .................................. 244

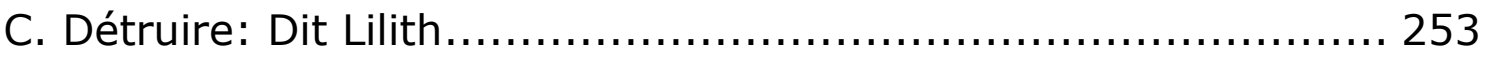

\section{PICTURA E POIESIS DA CATÁSTROFE}

A. Filosofia, Pintura e Poesia ......................................... 286

B. Sulamith: Mulher de cinza ....................................... 315

C. Margarethe: Mulher de palha .................................... 329

CONSIDERAÇÕES FINAIS ......................................... 338

BIBLIOGRAFIA CONSULTADA $\ldots \ldots \ldots \ldots \ldots \ldots \ldots \ldots \ldots \ldots \ldots \ldots, 351$ 


\section{LISTA DE FIGURAS}

Figura 1. A inundação de Heidelberg, p.22

Figura 2. Pinturas de Nero,p.23

Figura 3. Ocupações, p.26

Figura 4. Viajante Observando um Mar de Neblina, Caspar David Friedrich, p.28

Figura 5. Chuva de estrelas, p. 32

Figura 6. Terra entre dois rios, p.46

Figura 7. Quebra de Vasos, p.65

Figura 8. O anjo da história, p.71

Figura 9. Interior, p.80

Figura 10. Lilith, p. 90

Figura 11. Paisagem Árida, p. 91

Figura 12. Filha de Lilith, p. 93

Figura 13. Sulamith, p.94

Figura 14. Margarethe, p.95

Figura 15. A areia das urnas, p. 97

Figura 16. Teus cabelos dourados, Margarethe, p. 98

Figura 17. Wilhem Kreis, p. 101

Figura 18. Athanor, p.103

Figura 19. Essa escura claridade caída das estrelas, p.105

Figura 20. Tzim-tzum, p.112

Figura 21. Piet Mondrian-A batalha de Hermann, p.129

Figura 22. Tio Rudi. Gerard Richter, p. 145

Figura 23. Stoffbilder. Blinky Palermo, p.148

Figura 24. Fond III. Joseph Beuys, p.151

Figura 25. Koll visitando Kiefer, p.156

Figura 26. Caminhos da Sabedoria Universal: A Batalha de Hermann, p. 161

Figura 27. Os 13 homens mais cobiçados. Andy Warhol, p. 164

Figura 28. Atlas para 48 retratos. Gerard Richter, p.167

Figura 29. Ocupações, p.176 
Figura 30. Símbolos Heróicos, p.183

Figura 31. Símbolos Heróicos, p.183

Figura 32. Você é pintor, p. 189

Figura 33. Ao pintor desconhecido, p.192

Figura 34. Ditirambos. Markus Lüpertz, p.197

Figura 35. Para Genet, p.198

Figura 36. Resurrexit, p.210

Figura 37. Varus, p.215

Figura 38. Árvore com a Paleta, p.218

Figura 39. Nothung, 1973, p.220

Figura 40. Controvérsia Iconoclasta, p. 227

Figura 41. Quadrinidade, p.235

Figura 42. Os heróis espirituais da Alemanha, p.253

Figura 43. Lilith, p.255

Figura 44. Jerusalém, p.293

Figura 45. Interior, p.317

Figura 46. Ao pintor desconhecido, p.318

Figura 47. Athanor, p.319

Figura 48. Ao ser Supremo, p.321

Figura 49. Sulamith, p. 322

Figura 50. Albert Speer, p.323

Figura 51. Wilhem Kreis, p.324

Figura 52. Teus cabelos dourados, Margarethe, p.332

Figura 53. Teus cabelos de cinza, Sulamith, p.334 


\section{APRESENTAÇÃO}

O Mal [...] infiltrara-se aos poucos, em silêncio, em doses aparentemente inócuas [...] como uma corrente subterrânea que cresce e se agiganta antes de emergir, repentina e impetuosamente.

Zygmunt Bauman

Anselm Kiefer tem ganhado a rubrica de pintor doctus, ${ }^{1}$ colecionador de infinidade de poetas, escritores e pensadores que vêm, assim, a povoar seu universo plástico. ${ }^{2}$ Interpelados por seus nomes ou pela sua produção, por paixões declaradas ou não exprimidas, ora incorporados na tela, ora nos títulos das mesmas, seus amigos e interlocutores insuflam o espaço pictórico de seu trabalho. Flanar pelas paisagens e caminhos do museu pessoal de Anselm Kiefer exige se adentrar em cada um dos volumes de sua biblioteca em que assuntos como a alegoria, judaísmo, a história, o mito, o Mal, a catástrofe, a poesia, a literatura e a filosofia instalamse de maneira vertiginosa. Nas suas telas, podemo-nos deparar com nomes próprios como os de Kant, Richard Wagner, Nietzsche, Heidegger, Hegel, Paul Celan, Carl Jung, Huysman, Jean Genet, Stefan George, Ossip Mandelstam, Kleist, Hölderlin, Rilke, Marx, Lilith e Walter Benjamin. Por essa razão, a citação na obra de Kiefer apresenta-se como um elemento que restaura uma aura de uma atividade vital desaparecida. Como constatara Andrea Lauterwein,

1 Nomeação atribuída por Andrea Lauterwein no seu delicado trabalho intitulado Anselm Kiefer et la poésie de Paul Celan. Paris: Du Regard, 2005.

${ }^{2}$ Em entrevista com Roberto Andreotti e Federico De Melis, Kiefer, ante a

2 Em entrevista com Roberto Andreotti e Federico De Melis, Kiefer, ante a pergunta: "Da questo avvio di conversazione mi sembra che non ci si sbagli: Kiefer è un pittore-filosofo, e un filosofo in senso proprio." Kiefer responde: "La pittura è filosofia." (A partir desse início de conversa não me parece que haja erros: Kiefer é um pintor-filósofo, e um filósofo na verdadeira acepção do termo. Kiefer: A pintura é filosofia). Cf. ANDREOTTI, Roberto; DE MELIS, Federico. "Con la storia dentro la pelle." In: Anselm Kiefer, Merkaba. Charta: Milano, 2006, p. 29. 
esse método citacional de Kiefer pode ser aproximado de um verdadeiro modelo da memória, em que a presença fantasmal de algum objeto do passado paralogiza e imobiliza bruscamente o tempo presente. Esse gesto restaurador comporta um valor em si próprio, pois a citação pode remeter a uma menção edificante depurada ante o tribunal da História. ${ }^{3}$

Estes nomes próprios responderão quase sempre a um conceito filosófico reverberante ou a uma referência literária pujante: a aquarela Ek-sistenz de 1975 e a pintura Das Geviert (Quadrinidade) (unidade dos quatro elementos) glosam conceitos chaves de Heidegger ; ${ }^{4}$ a instalação $O$ Anjo da História relê o Angelus Novus das Teses sobre o Conceito de História de Walter Benjamin, ${ }^{5}$ evocando a pintura de Paul Klee. Cette obscure clarté qui tombe des étoiles, (essa escura luminosidade caindo das estrelas) oxímoro tomado de Corneille de conotações virgilianas, torna-se título evocador de uma série de pinturas expostas em Paris em $1996 .{ }^{6}$ Em meio a todas as citações e assuntos referidos à filosofia, à história, ao mito e à literatura, existe uma reflexão sobre o Mal que também pode ser extraída das telas Kiefer. Interessa-nos mergulhar nesse universo

\footnotetext{
${ }^{3}$ Lembremos que a citação no pendor benjaminiano, não é apenas uma referência a outro texto, mas uma referência a um texto de um passado mais ou menos remoto, esta associação, no entanto, se torna um pouco mais compreensível. A citação, além de servir de conexão entre o presente e o passado, manifesta ao mesmo tempo como um autor se posiciona com relação a este passado. Citar é rememorar o passado a partir do ponto de vista específico de um determinado presente. Cf. OTTE, George. "Rememoração e citação em Walter Benjamin." Revista de Estudos de Literatura, vol. 4, out. 1996, pp. 211-223; Cf. LAUTERWEIN, Andrea. op.cit., p. 17.

${ }^{4}$ Para entender estes conceitos na sua relação com a pintura de Kiefer, Cf. BIRO, Matthew. Anselm Kiefer and the philosophy of Martin Heidegger. Cambridge: Cambridge University Press, 1998.

${ }^{5}$ Esta afinidade eletiva entre Kiefer e Benjamin apresentou-se ante nós como uma iluminação metodológica sugerida no trabalho de Leila Maria Brasil Danziger, Anselm Kiefer e a pergunta pela Alemanha. Dissertação de Mestrado apresentada ao Departamento de História da PUC-Rio, abril 1996. ${ }^{6}$ Cf. ARASSE, Daniel. Cette obscure clarté qui tombe des étoiles. Cat. Exp. Galerie Yvon Lambert, Paris, 1996.
} 
pictórico de Kiefer em que dialoga com o Mal em uma relação possível e, ao mesmo tempo, complexa. O perigo maior para um artista contemporâneo, consideramos que consiste na tentação de desconhecer o verdadeiro apogeu da problemática do Mal, em particular, da perversidade do Mal moral, mas também da dor, ou seja, do Mal que a tradição chamava de mal físico. Nossa abordagem não pretende se esquecer do drama da desgraça e o crime porque a história, que quase por inteiro se tem transformado em narrativa sobre o vestígio do passado e as ruínas do futuro, como nos fala Walter Benjamin, ${ }^{7}$ exige de todos nós uma acurada atenção a um único elemento indispensável: as oportunidades e as vias de uma esperança que possa ser qualificada de absoluta. Justamente em circunstâncias de desventura extrema, de derrota aparentemente definitiva de qualquer restituição histórica possível, a produção pictórica tem dado vida à causa da história de uma humanidade cujo nome tem sido apagado da língua dos homens com a justificativa de que assim podia se superar uma essência que estava destinada a um passado irrecuperável. Com Anselm Kiefer, a pintura do pós-guerra, recupera as bases de qualquer possível renovação de nossa humanidade. Trata-se da razão que faz frutificar os outros modos da palavra, sendo por ela, desmascarados, sem piedade, os erros e os percursos erráticos. O milagre e o mistério deste gesto de doação que procede do lado das vítimas se encaminham a todos os homens e chega a proclamar, inclusive, em uma hipérbole inaudita, a responsabilidade de cada um, de si próprio, atraindo, sem dúvida, a atenção de qualquer homem reflexivo sobre 0 sentido que semelhante sabedoria tem atribuído à dor, ao infortúnio e ao sofrimento. Neste arco de problemas, a obra do pintor alemão Anselm Kiefer será analisada a partir de categorias filosóficas do livro Origem do Drama Barroco Alemão de Walter Benjamin. Talvez não

7 Cf. BENJAMIN, Walter. Origem do drama Barroco Alemão. Trad. Sérgio Paulo Rouanet. São Paulo: Brasiliense, 1984. 
existam dois pensadores que tenham dado mais força de expressão a um lugar soberano da história e seu potencial catastrófico que estas duas figuras. Não se trata apenas do rigor e a constância crítica de suas reflexões, mas suas produções estendem até as últimas conseqüências interrogações sobre a existência humana e a história, indagações geralmente reconhecidas por sua beleza, precisão e eloqüência, assim como pela dificuldade que apresentam, uma complexidade em que os próprios textos e pinturas podem parecer ambíguos e, às vezes, confusos, justamente porque sua linguagem permanece singularmente exata nos limites de uma possível expressão, quando ela se torna seu próprio objeto de pesquisa. Talvez porque Kiefer e Benjamin expõem quase num sentido oracular o que é, em última instância, a experiência das catástrofes históricas, no entanto, ambos pensadores também têm sido acusados, em ocasiões, de uma espécie de ocultismo ou misticismo, um ônus que a presente pesquisa não pretende abordar, mas tenta desbravar apesar do que possa ser apresentado com certo tom apocalíptico. Consideramos importante que ambos pensadores e seus críticos possam parecer estar particularmente expostos ao que poderia ser chamado de perífrase catastrófica, o que faz deste perigo periférico uma questão central em muitas perspectivas. Cogitamos que a tese principal desta pesquisa poderia ser assim resumida: por cuidar de conceitos sobre história e arte extremamente semelhantes, Kiefer e Benjamin apresentam, de maneira inexorável, a história como uma única catástrofe, em que todas as coisas apresentam uma iminente aniquilação, mas, justamente por essa razão, também se tornam poderosas fontes de uma infinita esperança. Que essa esperança apresente pólos opostos nas suas figurações, nomeadamente para preencher a presença do tempo, um tempo robustecido de infinita presença, incluindo um passado inteiro, no caso de Benjamin, e uma inteira ausência das coisas abortadas no tempo, em Kiefer, constitui o maior desafio desta pesquisa, mas também seu principal interesse. 
Comum aos dois pensadores é o fato de que a esperança é colocada, em todo caso, ao final do tempo, desconsiderando se esse final é entendido como a presença infinita do tempo ou sua infinita ausência. Para ambos, este final não é estritamente iminente, mas, imanente em si próprio, o que faz dessa esperança um caudal de significações e também uma realidade. Nem sempre o final está por vir, pelo contrário, sempre é uma relação começada, e nesse espaço estreito entre o final e o começo, entre o todo e o nada, está inserido nada mais do que a história do mundo na sua integridade.

\section{A. A MEMÓRIA DO MAL}

Schimmelgrün ist das Haus des Vergessens. Paul Celan ${ }^{8}$

Na obra de Kiefer, o Mal parece ser a lógica de agravos precedentes, às vezes o castigo aplicado a nós mesmos devido a uma culpa de nossos antecessores. Assim, para Kiefer, a noção de fatalidade não significa o inescrutável de uma vontade divina. Mesmo incorporado a várias religiões, ou melhor, a certos grupos religiosos, o fatalismo é a pretensão de saber ou de adivinhar algo do fatum, algo a que todos estariam sujeitos. Enquanto a moira inflexível pressiona como corretivo dos deuses, o fatum acaba sendo dificilmente compatível com o monoteísmo, que não tolera interferências de poderes alheios. Na verdade, a natureza quebra, com sua indiferença, a disputa entre os valores confrontados entre o Bem e o Mal. A obra de Kiefer questiona o princípio de razão suficiente sendo ela a que coloca o homem como incapaz de acolher o princípio sem princípio, a causa sem causa que fundamenta os seres,

"Verde-mofo é a casa do esquecimento." Fragmento de "A areia das urnas." Cf. CELAN, Paul. Arte poética. O Meridiano e outros textos. Trad. Jõao Barrento e Y.K. Centeno. Lisboa: Cotovia, 1996. 
dissociando assim sua vontade da vontade divina. A presença do Mal tem sido uma reflexão central na obra de Kiefer.
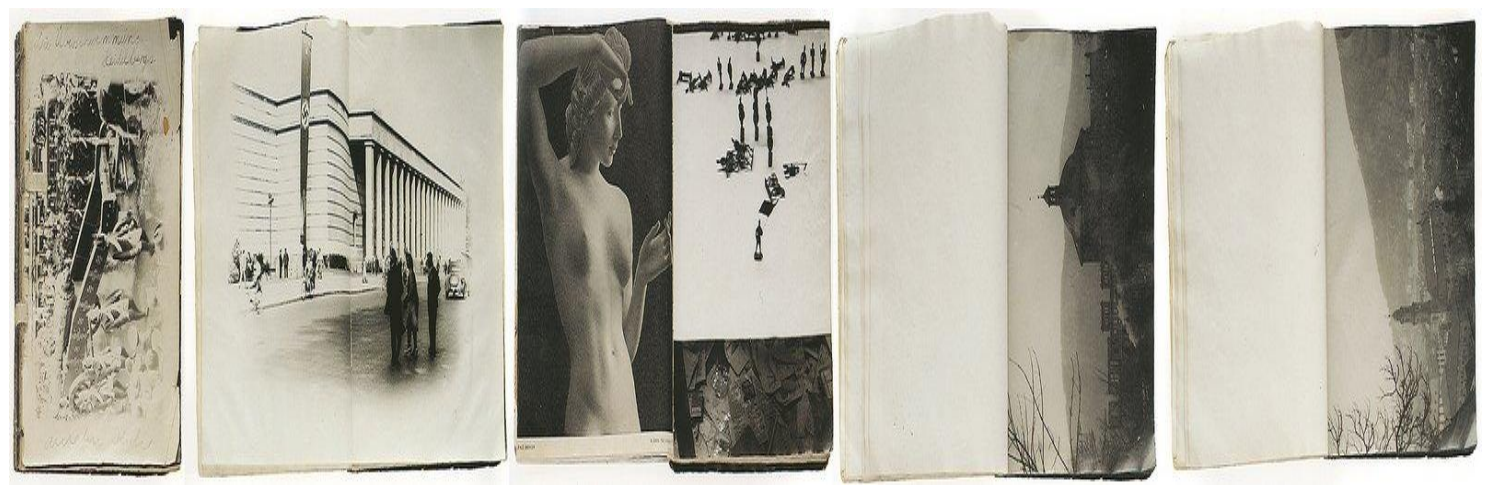

Figura 1. A inundação de Heidelberg/Die Ueberschwemmung Heildelbergs,1969. Livro de artista. 140 páginas. Fotografias originais em óleo com cobalto s/papel. Coleção privada.

Desde seus primeiros trabalhos no fim da década de 60, o artista orientou sua pesquisa em torno da permanência do Mal no mundo contemporâneo. Pensemos nos dois livros que compõem Die Ueberschwemmung Heildelbergs (A inundação de Heildelberg) (fig.1), Kiefer, ainda estudante em Karlsruhe, apocalipticamente, anunciou a possibilidade do rompimento de um dique do rio Neckar, o que causaria a inundação da cidade. ${ }^{9}$ Os livros compostos por fotografias apresentam uma visão do desastre a partir do ponto de vista de um contemplador situado no castelo que domina a visão da cidade. Essa visão quase romântica da destruição da cidade lembra-nos as narrativas do incêndio de Roma executado por Nero. Como detalhe curioso, o nome do Imperador Romano aparece inscrito em outra obra de Kiefer, Nero Malt (Nero Pinta)(fig.2) correspondente ao mesmo período dedicado ao escritor francês, Jean Genet. O escritor francês e o Imperador romano magnetizam o jovem artista alemão certamente pelas mesmas razões: ambos são epítomes de uma

9 O que, na literatura, o escritor americano William Faulkner, quatro décadas antes, teria preconizado para uma cidade do Sul dos Estados Unidos e, de fato, foi o que aconteceu em Nova Orleans em 2006, após a brutal passagem do ciclone Katrina. 
extravagante conjunção entre alta espiritualidade e alta marginalidade. ${ }^{10}$ Kiefer não ilustra o texto quando ele glosa os fragmentos da história que pretende restaurar, pois ele traslada a remanescência auditiva desses fatos àquele sentido retiniano que produz a imagem.

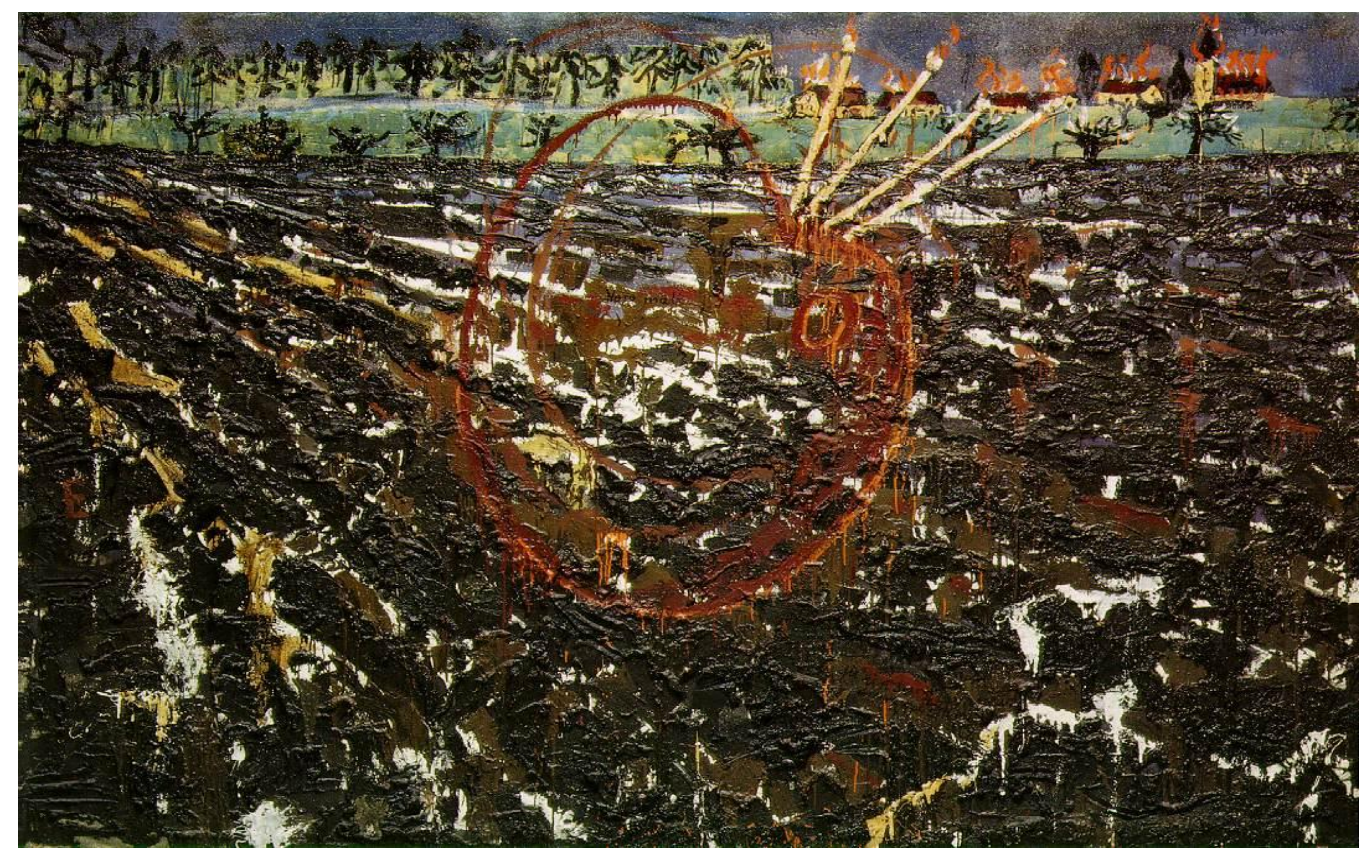

Figura 2. Nero Pinta/Nero Malt, 1974. Óleo s/tela. $75 \times 6 \times 98 \times 9$ $\mathrm{cm}$. Galeria de Arte Moderna, Munique.

\footnotetext{
${ }^{10}$ Nero foi discípulo de Sêneca, filósofo estóico, e governou nos primórdios de sua incumbência com moderação e benevolência. Seu agir político sofreu, no entanto, uma progressiva decadência espiritual e moral, degenerando-se por completo. Quanto a Jean Genet, o escritor fundamenta seu virtuosismo como escritor no seu passado marginal, de sua experiência como batedor de carteira (pickpocket), mas enraíza a origem de sua ultrajada propensão errática em sua homossexualidade. Nero, nas versões míticas da história romana, parece ser o primeiro em expressar o desejo escópico mais retorcido: a piromania como pulsão morte. Seu desejo de assistir a destruição tem sua forma por antonomásia em expiar a catástrofe: muito mais irresistível ao olhar do tirano que um corpo masculino nú é, sem dúvida, um corpo desfigurado pelo fogo. Benjamin discute no Drama Barroco a figura jânica do tirano e do herói que sempre acaba sucumbindo a seu delírio de poder, pois ele se torna vítima da desporporção entre dignidade hierárquica desmedida de que Deus o investiu, e a miséria da sua condição humana. Ver BENJAMIN, Walter, op.cit., p. 94; Cf. BRASIL DANZIGER, Leila Maria. op. cit., p.30.
} 
Suas telas tornam-se rascunhos de palavras soltas, que parecem emitir um rumor, um eco de algum acontecimento histórico, de alguma narrativa teutônica, de alguma literatura dilacerada e dilacerante. Outra maneira de transferir essa fragmentação da história consiste em utilizar certos paradigmas dos assuntos evocados nos materiais que emprega: a palha, a cinza, o chumbo, a areia, o cabelo, as espigas, os vidros; todos eles transpõem suas idéias na técnica pictural mesma. Essa leitura guiada pela dança dos materiais é também compartilhada por Márcio Seligmann-Silva:

A pedra, o metal, a terra, o barro (o corpo com sua pele e os seus fluidos) também entram em cena como ingredientes de re-memorialização (re-temporalização e espacialização) da obra de arte. Se é verdade que todo objeto de cultura testemunha uma barbárie - catástrofes, traumas etc -, esse movimento de "revolta de matérias" a que assistimos na cena artística e a relação (metonímica ou metafórica) que a obra estabelece com a nossa memória explicitam esse teor testemunhal da arte contemporânea. ${ }^{11}$

Dessa maneira, produz-se uma espécie de transfusão do sensualismo dos fatos tomados nos textos ao corpo da pintura, que não precisa mais da exterioridade das palavras. A introdução destas substâncias materiais com as referências à literatura e os assuntos caros à reflexão filosófica, estendem, por exemplo, o imaginário beuysiano da matéria como selo da consciência a uma forma nova da memória dos materiais. A intensidade do diálogo com a matéria levará Kiefer a se encontrar com paradigmas poetológicos, com a presença da figura de Paul Celan, e suas concepções da memória, da paisagem ou do fragmento, mas também com paradigmas históricos e filosóficos, e suas concepções do mito, da alegoria, do Mal e da catástrofe. Kiefer compreende a história nazista alemã, afastando-se de qualquer olhar celebratório. Ele se apropria das imagens históricas do nazismo, não para se revelar um nazista alucinado, senão como um modo de enfrentar, como um artista alemão contemporâneo, a estetização

11 Cf. SELIGMANN-SILVA, Márcio. O local da diferença: Ensaios sobre memória, arte, literatura e tradução. São Paulo: Editora 34, 2005, p. 29. 
fascista da política. Voltar à estetização da política é aceitar a responsabilidade por um passado horrendo, a barbárie e o extermínio. Neste sentido, a questão volta-se para as personagens da cultura alemã, como Wagner, Hegel, Thomas Mann, no embaralhamento de tempos reais e míticos, representações espaciais e perspectivas filosóficas. Seus quadros tratam da ambição de Wagner, de Hegel, ou um Doutor Faustus de produzir suas Gesamtkunstwerk ou obra de arte total - o drama musical, a filosofia do espírito, o grande romance -. A escala de todos eles é monumental, e todos estes artistas exigem muito de sua recepção, esperando que o público conheça história, música, mitologia e lendas alemãs em detalhe para compreender as referências das suas obras. O gesto de Kiefer é de autoquestionamento, trata-se de uma autoconsciência pictórica que desmente toda mistificação. Outra questão pertinente é o revisionismo como princípio conceitual capaz de conduzir à pergunta pela identidade alemã na obra de Kiefer. Ele não insiste na construção de um mito para servir de modelo identificatório: ele deixa propositalmente emergir a latência mítica recalcada na história ocidental. O olhar dirigido ao passado por Kiefer não almeja imobilizar a história e eliminar suas contradições. A tentativa de idealizar o passado e anular seus antagonismos engendraria simplesmente novos mitos. O artista não faz uma defesa do mito, ele se esforça para deixar transparecer sua reivindicação de presença no curso da modernidade tardia. A tradução das ruínas e desses fragmentos da história que se transformam em imagens melancólicas é constatado por Leila Maria Brasil Danziger:

Também as bibliotecas de chumbo de Kiefer e ainda seus aviões -"Mohn und Gedächtins" ("Papoula e Memória", título de um dos primeiros livros de Celan) -, exibem a história como fardo, a modernidade como ruína. O excesso de história desconectado do presente - ou desprovido de força plástica capaz de reativá-lo - resulta em esquecimento. Diante dos imensos volumes de chumbo, sentimo-nos fascinados, é certo, mas, sobretudo, 
impotentes, paralisados, melancólicos, tal qual o anjo da gravura de Dürer, ao qual o artista faz menção em várias obras. $^{12}$

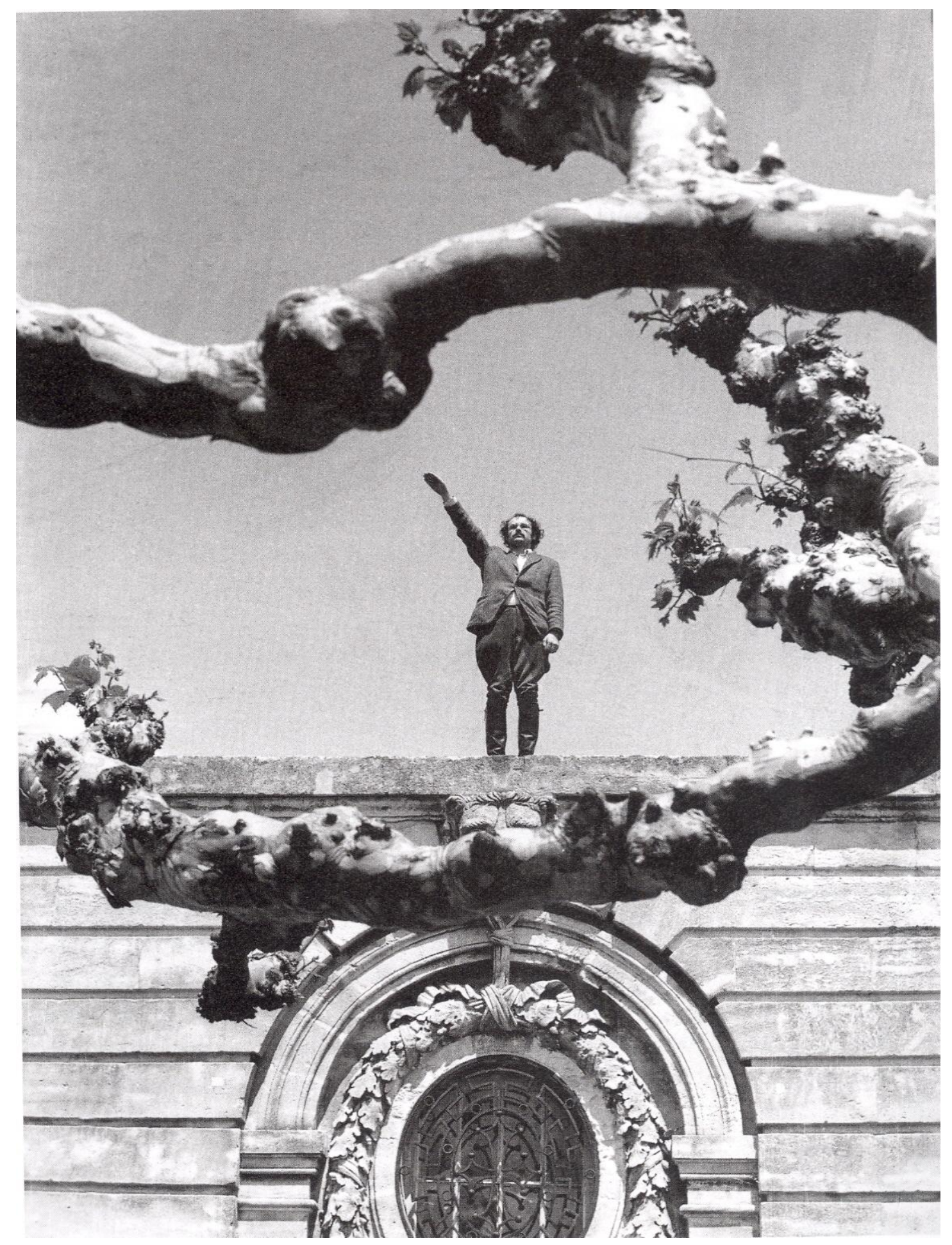

Figura 3. Ocupações/Besetzungen, 1969. Album de artista. Fotografias originais.

${ }^{12}$ Cf. BRASIL DANZIGER, L. M. op. cit., p. 31. 
No clima neoconservador de meados da década de 1980, os historiadores alemães mais uma vez debateram abertamente as questões da responsabilidade alemã pelo holocausto, a necessidade alegada de historicizar o passado fascista e o problema de uma identidade nacional alemã. Já nos anos 70, Kiefer havia começado a inquietar os alemães ao confrontar diretamente aquela ligação histórica entre nacionalismo e fascismo em seu trabalho. Em 1969 ele transgrediu o tabu contra a representação do que se chamava Nazikitsch - em uma série de fotografias chamada Besetzungen (Ocupações, [fig.3]) -. Kiefer foi denunciado como um neonazista apenas por ter tentado estabelecer um diálogo com imagens proibidas. Essas provocadoras fotos mostravam o próprio Kiefer em vários cenários na Europa, vestindo calças militares de equitação e fazendo a saudação hitlerista. Ao assumir a identidade do nazista ocupando a Europa, Kiefer confrontou o passado através da sua própria ironização. ${ }^{13} \mathrm{Na}$ série de fotografias, Ocupações, o motivo de

13 Linda Hutcheon propõe no seu livro Teoria e política da ironia, uma relação do termo a partir de uma comunidade discursiva, ou seja, ironia "em uso", uma execução da ironia conforme ao uso em meio a um cenário social e político. Para Hutcheon, o envolvimento de Kiefer com a iconografia relacionada com o nazismo é uma maneira de confrontar o fato inescrutável de que, como um artista alemão hoje, Kiefer não pode evitar lidar com a estetização nazista da política: "O que ele pode fazer, e o que eu agora acho que ele tem feito, é voltar aquela estetização contra si própria por meio da ironia e, com isso, aceitar responsabilidade pelo passado." Se com a ironia cai a arte na sua própria desolação e ruína, não é porque seja um programa, porém pela dissociação de que tem partido essa ironia - o que nos faz pensar no fundamento da arte no romantismo - e que vai se reservando apenas numa interioridade crescentemente imediata. Portanto, a ironia poderia ser lida como o processo pelo qual, na via da perda progressiva da realidade objetiva, resta apenas um sujeito desprovisto de determinações e carente de uma matéria significante em que depositar vivamente seu conteúdo já dissolvido. Nesta perspectiva, a característica fundamental da ironia é sua negatividade. A ironia também representa uma interrupção, uma morosidade, um momento no processo de reflexão, pois para os românticos, como Benjamin constatou, "não existe Ser fora da reflexão." Para Márcio Seligmann-Silva, a noção romântica de ironia reafirma a concepção alegórica no seu sentido de abertura para o infinito. Cf. HUTCHEON, Linda. Teoria e política da ironia. Trad. Júlio Jeha. Minas Gerais: UFMG, 2000, pp. 150-168; Cf. SAFLATLE, Vladimir. Cinismo e falência da crítica. São Paulo: Boitempo, 2008. 213 p; Cf. SELIGMANN- 
duelo artístico é mais explícito com relação ao domínio da recepção pública da obra, mais concretamente, com a generalizada leitura conservadora que a caracteriza. O choque da incompreensão ocupou, sem dúvida, um papel relevante na criação plástica de Kiefer. Aquilo que mais parece revoltá-lo eram os epítetos de nazista. Que as suas pinturas chocassem, fossem malditas, não deixaria de the agradar, pois o obstáculo estimula. Entretanto, o conservadorismo da crítica o desilude profundamente. Até que ponto a história alemã era central na sua produção, ao contrário do que certas afirmações irônicas

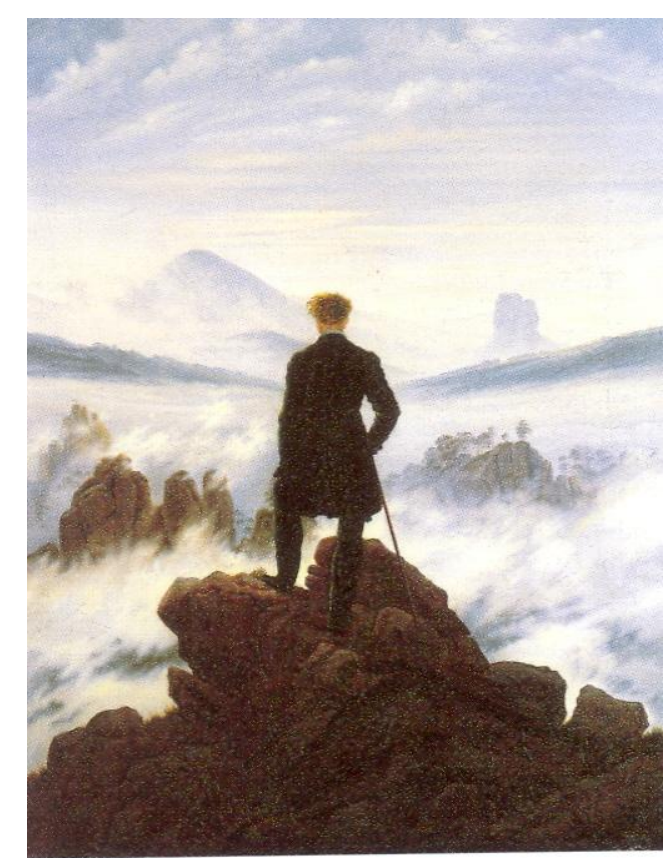

Figura 4. Viajante Observando um Mar de Neblina, 1818. Caspar David Friedrich. Óleo s/tela. 74, $5 \times 94 \times 8$ $\mathrm{cm}$. Kunsthalle, Hamburgo.

parecem deixar entrever? A imagem heroicizante de si como nazista é sempre estranhamente pequena em escala com respeito aos monumentos nos quais se apresenta. Em um conjunto de fotografias $\mathrm{Em}$ um conjunto de fotografias ele está de pé em uma banheira: não existe uma multidão fazendo saudações nazistas, exceto que ele está em pé, de maneira messiânica, sobre a água.

Em outra série de fotografias, ele adota o Viajante Observando um Mar de Neblina, de Caspar David Friedrich (fig.4), e inserindo o nacional-socialista na herança romântica da Alemanha - ao mesmo tempo assume uma distância posando de viajante em terras ignotas -. Nosso ponto de vista é indicar que o projeto para um jovem artista é o de despedaçar o tabu da representação nazista e isso agressivamente - com o que não pretende apenas se remeter ao passado, mas também representá-lo,

SILVA, Márcio. Ler o livro do mundo - Walter Benjamin: Romantismo e crítica literária. São Paul: Iluminuras, 1999, pp. 37-41. 
encarná-lo em seu próprio corpo para entendê-lo, para confrontar, por meio de um exercício de inversões e de artifícios, a recusa alemã pós-Auschwitz de se reconciliar com as dimensões estéticas do passado político. No entanto, a questão importante que permanece para nós não é se Kiefer é um protofascista, mas a retomada da iconografia nazista como modo ideal de se lidar com o terror fascista. Seguindo as indicações de Andreas Huyssen, mostraremos que a saudação Sieg Heil naquelas fotografias iniciais deve ser lida como um gesto conceitual ${ }^{14}$ que nos lembra que, realmente, a cultura nazista ocupou, explorou e abusou de maneira muito efetiva do poder do visual, especialmente o poder do monumentalismo maciço e de uma perspectiva de ponto central, confinadora e mesmo disclipinadora. O fascismo, além disso, tinha pervertido, abusado e sugado territórios inteiros de um mundo de imagens alemãs, transformando tradições literárias e icônicas em meros ornamentos do poder e, com isso, deixando a cultura pós-1945 como uma tábula rasa destinada a provocar uma crise de identidade. De acordo com Andreas Huyssen:

[...] para localizar o projeto estético de Kiefer em seu contexto cultural e político específico, o contexto da cultura alemã depois de Auschwitz fora da qual cresceu e para qual dá forma estética, e que o estimulou durante longos anos de pouco reconhecimento, e na qual, eu argumentaria contra reivindicações superficiais de transcendência e universalidade, finalmente permanece vinculado - em suas

\footnotetext{
14 Para Carl Schmitt o ato político por excelência é o gesto do soberano o que representa um ato de decisão. Esse gesto é melhor expressado no momento de determinar o estado de exceção, pois é nesse ato que se suprime o direito, de modo que tudo fica subordinado à determinação do soberano. Bem entendido, toda política nasce e se legitima na decisão do soberano. "Soberano es aquel que decide sobre el estado excepción," escreve Schmitt em "Teología política." Cf. SCHMITT, Carl. Estudios políticos. Madrid: Doncel, 1975, p. 35. Carlo Levi aborda de outra forma essa concepção schmittiana: "El ídolo estatal sólo puede mantenerse mientras tenga ante sí un extranjero: un enemigo necesario que deberá ser continuamente expulsado y continuamente vuelto a encontrar, una víctima providencial." Cf. LEVI, Carlo. Miedo a la libertad. Valencia: Ed. Alfons el Magnànim, 1996, p. 105.
} 
forças, em suas fraquezas, e acima de tudo, em suas ambigüidades. ${ }^{15}$

A tentativa mais imediata de Huyssen neste artigo é definir um contexto para as obras de Kiefer estabelecendo a ressonância continua que o passado alemão tem no seu presente e, talvez mais implicitamente, como esse fenômeno tem capturado a atenção do público americano. ${ }^{16}$ Para fazer isto, Huyssen vincula Kiefer a três fenômenos culturais que estavam acontecendo na Alemanha Ocidental no momento: o Novo Cinema Alemão, o Neoexpressionismo e a chamada Historikerstreit (A Querela dos Historiadores). Primeiro, em ordem cronológica, eclode o Novo Cinema alemão que consistia nas obras de Fassbinder, Herzog, Wenders, Schloendorff, Kluge, Von Trotta, Ottinger entre outros. Huyssen nota que muitos destes trabalhos eram conduzidos pela pergunta da identidade alemã, derradeiramente enraizados no fato de que o passado fascista alemão e o presente democrático do pós-guerra encontravam-se inescapavelmente vinculados. Segundo, os Neoexpressionistas - ou die neuen Wilden - seu modo representacional suscitou

15 "[...] to place Kiefer's aesthetic project in its specific cultural and political context, the context of German culture after Auschwitz out of which it grew and to which it gives aesthetic form, which energized it during long years of little recognition, and to which, I would argue against facile claims of transcendence and universality, it ultimately remains bound - in its strengths, in its weaknesses, and most of all in its ambiguities". Cf. HUYSSEN, Andreas. "The terror of history, the temptation of myth," October 48, Spring 1989, p. 26.

16 Porque a recepção de Kiefer nos Estados Unidos tem se encontrado inúmeras vezes com o furor entusiástico em vez da imediata suspeita que suscita nos alemães. Huyssen sugere que devido à fácil compreensão do contexto alemão do pós-guerra, o público americano tem se inclinado pela fascinação ou romantização das tentativas alemãs de ajuste de contas com o passado, sendo, assim, menos críticos na sua recepção da obra do pintor, caindo na sua glorificação inocente. Para Benjamin Buchloch, América é o lugar onde Anselm Kiefer fraguou sua carreira, o que significa que América é capaz de interpretar ou de desejar o ambíguo, embora não seja capaz, assim, de produzi-lo. Cf. HAXTHAUSEN, Charles, "America's spiritual hero: The reception of Anselm Kiefer in the United States." Paper presented at the University of Wisconsin, Madison, March 1991; Cf. BUCHLOCH, Benjamin; DAVID, Catherine; CHEVRIER, Jean-François. "El potencial del arte". Acción Paralela 5, p. i. 
imediatamente um debate sobre a legitimidade da volta à figuração após a Abstração, do Minimalismo e da Arte Conceitual. De um modo similar, o Expressionismo Alemão provocou o debate mais acirrado sobre a estética e a política do modernismo nos anos 30, portanto, as estratégias pictóricas Neoexpressionistas e sua política da representação, foram rapidamente submetidas ao escrutínio da crítica devido às semelhanças entre este movimento e a arte figurativa regressiva apoiada pela Alemanha Nazista. Terceiro, assistimos o debate da Historikerstreit. Neste debate entre historiadores acontecido no ano 1986, os pesquisadores da história alemã levantaram questões sobre a responsabilidade alemã pelo Holocausto e a alegada necessidade de historizar o passado fascista e o problema da identidade nacional alemã. Tratou-se, então, de um debate em que várias facções do conservadorismo alemão buscavam tirar partido do seu passado ignominioso. Sua aspiração era a de normalizar a história alemã e desvincular o nacionalismo alemão da sombra do fascismo, uma espécie de purificação do passado alemão para o benefício da agenda ideológica conservadora. Em síntese, estes três fenômenos testemunharam como a cultura alemã estava ainda mal assombrada pelo seu passado. Anselm Kiefer e seu trabalho, como parte dessa cultura, devem ser vistos como uma forte expressão contrária a todo este tamiz de assuntos peculiares à cultura alemã do pós-guerra. A pintura de Kiefer introduz complexas ambigüidades na dimensão do passado quando esta carrega a dimensão profética do futuro. Também a distinção entre crime e ato puro será cheia de conseqüências uma vez que para Kiefer, suas ações de arte têm sido um ato político. Kiefer verifica este fato teórico, só que seu braço pinta morte e devastação. O pintor se torna conscientemente o demiurgo da vingança cujo sangue não recai sobre ninguém e sobre todos. Essa escolha purificadora através do fogo apenas pode se produzir pelo choque tremendo entre a constância harmoniosa da natureza e o Mal. O seu ciclo de pinturas 
conhecidas como Chuva de estrelas (fig.5) lembra ainda aquelas existências quase minerais, rítmicas, voltadas para o respirar cósmico que pretende recuperar.

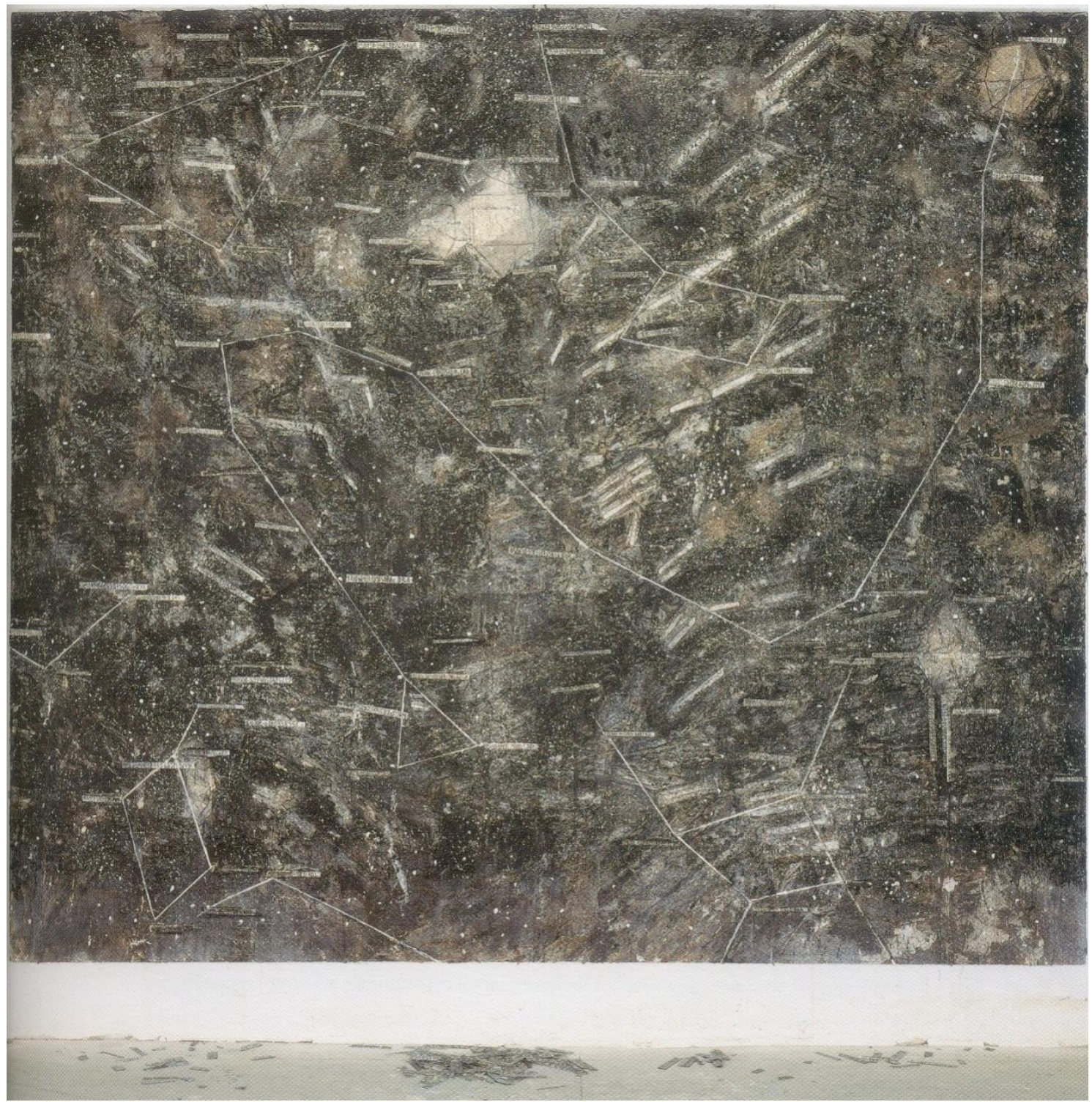

Figura 5. Chuva de estrelas, 1998. Emulsão, acrílico, esmalte s/tela com fragmentos de vidro. $465 \times 530 \mathrm{~cm}$.

Joseph Beuys representa uma presença importante nos trabalhos iniciais de Kiefer, e certamente a partir do final da década de 1960, o exame clownesco que Kiefer faz da relação que sua nação e ele próprio têm com a história e identidade mostra essas influências. Aqui o sentido da escolha, por parte de Kiefer, de assuntos politicamente delicados não apenas para explorá-los técnica e 
intelectualmente, mas também para relacioná-los com sua própria posição, particularmente temas que envolvem a obra de artistas e pensadores simpatizantes ou aprovados pelo nazismo, e cujas reputações foram subseqüentemente marcadas por essa associação: Heidegger, Clausewitz, Wagner. O grande interesse apresentado por Kiefer pelo repertório mitológico alemão: os Nibelungos, a Floresta de Teutoburgo, a batalha de Armênio, as marchas de Bradenburgo, o Reno, as grandes narrativas universais, os mitos mesopotâmicos, gregos e egípcios, a Bíblia ou a Cabala, não se encontram subordinadas à pulsão de uma comemoração redentora ou nostálgica do mito. O mito apresenta-se aqui rebaixado ao nada pela encenação feita pela própria história, desobjetivado de idéias transcendentais. Contudo, permanece uma referência psicológica selvagem que permite a Kiefer expor os fenômenos históricos com fórmulas pictóricas, completando as explicações racionais, às vezes, deterministas, que nos oferecem as ferramentas objetivas da ciência.

Na série de Áticos de 1973, por exemplo, até as variadas versões consagradas à Batalha de Armênio entre 1977 e 1978, Kiefer tem figurado a destruição dos mitos germanos como fundamento da ideologia heróica da pureza de sangue. Os traços de violência da pintura e os materiais contingentes ou já mesmo pó (palha, cinzas, cabelo, areia) indicam uma vontade evidente de apresentar o motivo em um estado de niilismo. Kiefer procura fixar, no espaço imaginário da obra, o redemoinho excessivo de memórias captadas através do tempo e que pretende evocar nas suas telas. O artista pinta de memória. As imagens que a sua memória capturou ao longo de suas pesquisas e deambulações pela história, o mito e a literatura, assaltam-no no seu ateliê, onde se dedica a pintá-las. O pintor envolve-se então em um duelo com essa avalanche de memórias procurando extrair delas o essencial, procurando, com seus materiais, 
"extrair o eterno do transitório". ${ }^{17} \mathrm{~A}$ ideologia do mito encontra-se dissolvida embora sua forma literária seja reanimada e representada por uma figuração abismada. A Kiefer não interessa neutralizar o conteúdo da pintura do feito histórico. Visualizar a abominação da História permite-Ihe reativar a dimensão psicológica de sua memória. Como o sonho, o mito não possui a capacidade de escolha entre o Bem e o Mal; sua função ética não se constitui senão a partir da interpretação do próprio sujeito histórico. Kiefer não leva o espectador a mão, mas o confronta com elementos em que ele próprio rejeita espontaneamente a sobrevivência psíquica, adensando os sedimentos iconográficos de sua obra com uma pesada carga de pessimismo irônico nos nomes e na permanente ensonação que opera na lógica do flanar. Pensemos em Lilith, nesta incomparável tela, os motivos centrais da cidade, em torno dos quais considerável porção do projeto pictórico de Kiefer se tem desenvolvido, surgem, num fulgurante formato emblemático, sobrepostos de forma indissociável. Aquilo que Lilith encena na figura do limiar, aparece aqui, na forma de uma incrustação, de uma imaginação do espaço urbano, uma prega do real onde se mostra um estrato subjacente de organicidade, associado às esferas semânticas, que mutuamente se entrelaçam, da cidade, do feminino, da origem ou da infância. A debilidade, a atrocidade do real, que se expressa na imagética molecularização depredadora da cidade, desdobra-se por meio da poética visão de artista na vitalidade maníaca de um multiforme, protéico e gigantesco espaço pulverizado em São Paulo. ${ }^{18}$ No emblema alegórico da cidade

${ }^{17}$ Cf. BENJAMIN, Walter. op. cit., p. 88.

18 Não será então que a imprevista onda de vitalidade que assoma o pintor na seqüência deste encontro se deva não tanto à existência daquela vitalidade orgânica originária voltada para a destruição? Mas, por outro lado, serão essas duas fontes de vitalidade, a que o pintor assinala conscientemente e aquela que o afetaria a um nível inconsciente, tão diversas entre si? Ou seja, não será a visão transfiguradora do pintor também uma alegorização da vitalidade estilhaçada da cidade? Será que Kiefer canta à desgraça alegre que incita a destruição. $O$ vigor, o incitamento, provém da coincidência oximonórica de desgraça e 
a pintura apresenta-se tal como esta se proporcionou. Em outras palavras, como uma pintura que aparece na aridez experiencial da enlouquecida modernidade urbana, e que, em vista do sobresforço a que se vê submetida na sua luta pela sobrevivência, comporta uma dimensão de vitalidade aberrante e de disformidade fragmentária. $\mathrm{Na}$ pintura inaugural de Kiefer conjugam-se, e articulam-se em pregas, os aparentes opostos de desgraça e ventura, fragilidade e virilidade, rigor e exuberância. Atente-se, com maior detalhe e agudeza, naquela surpreendente e inesperada visão do pintor. Logo no instante inaugural da transfiguradora visão do artista, se encontra a dimensão corpórea das proporções carnais: Lilith. Esta expressão deve ser lida como um duplo genitivo: proporções da carne, do corpo, mas também, uma necessária carnalidade das proporções. No instante inaugural, a visão do artista, a arte pictórica procura guiarse por um imaginário estético de pendor monstruoso, que privilegia a desproporção, a feiúra, o grotesco e a desarmonia. Por motivos de clareza expositiva, é possível considerar quatro planos onde a importância do choque na experiência da modernidade se tornou particularmente relevante para a criação artística: o plano históricofenomenológico da vivência (Erlebnis) moderna; o plano estritamente estético; o plano sócio-literário das relações do pintor com a sociedade; o plano do inconsciente - individual e coletivo -. O impacto da experiência de choque nesses diferentes planos assume formas diferentes, ainda que relacionadas. A influência direta do choque manifesta-se no plano fenomenológico-experiencial através de uma crescente tirania da consciência, de um acrescido risco de trauma e das manifestações modernas de tédio existencial - o spleen-. ${ }^{19}$ No plano da produção artística, nota-se um acrescido

contemplação, que é paralela, senão mesmo coincidente, com a combinação de debilidade e vitalidade, que caracteriza o estado convalescente.

19 Em Parque Central Benjamin afirma: "O spleen é o sentimento que corresponde à catástrofe em permanência. O spleen põe séculos entre o presente e o momento que acaba de ser vivido. É ele que, incansavelmente, 
intelectualismo manifesto ou subentendido: manifesta-se numa anteriormente desconhecida importância de questões formais e programáticas; uma vontade mais adequada à realidade experiencial, a escola estética que melhor traduza as perplexidades da época histórica - anuncia-se assim a idade dos ismos -. No plano social, o choque expressa-se na marginalização das vanguardas, e numa crescente diatribe entre a ordem estabelecida e as manifestações artísticas. No plano do inconsciente, o embate da experiência de choque é necessariamente indireto, e exprime-se negativamente numa intensificação do papel da repressão associada a uma proliferação da experiência traumática nas estéticas da modernidade.

Entre os quatro planos acima considerados, caberá destacar o histórico- fenomenológico, atribuindo-lhe um papel central, tendo em consideração que é historicamente originário e determinante de todos os outros. As referências ao fator de choque na esfera fenomenológica e experiencial proliferam na pintura de Kiefer, seja de forma explícita ou por via implícita. A dinâmica de choque estrutura a nível essencial as pinturas Lilith, Paisagem Árida, Filha de Lilith: basta reparar na sucessão fragmentária, aparentemente caótica, de quadros, percepções, memórias, de sensacões e sentimentos, que constituem as pinturas. O nômade urbano deixa-se incessantemente bombardear por experiências fragmentárias, passeando entre a multidão, assemelhando-se ao amante da vida universal a que se refere Baudelaire, em O pintor da vida moderna:

O amante da vida universal entra assim na multidão como num imenso reservatório de eletricidade. Pode-se também compará-lo, ele mesmo, a um espelho tão imenso quanto a esta multidão; a um caleidoscópio dotado de consciência que, em casa um de seus movimentos, representa a vida múltipla e a graça móvel de todos seus elementos. É um eu insaciável do não-eu que, a cada instante, o manifesta e o

estabelece antigüidade." Cf. BENJAMIN, Walter. "Parque Central", In: Rua de mão única. São Paulo: Brasiliense, 1987, pp.154-155. 
exprime em imagens mais vivas do que a própria vida, sempre instável e fugidia. ${ }^{20}$

Espelho e caleidoscópio da multidão, o eu da modernidade é um eu insaciável do não eu que, através da criação artística, se transfigura em imagens mais vivas do que a própria vida. Ao contrário da efemeridade da vida, a arte extrai o eterno do efêmero, salvaguardao da corrupção que afeta irrevogavelmente a vida. Por seu turno, na produção artística, o eu banha-se no não-eu da obra - na sua incontornável materialidade -. Em comentário à passagem de Baudelaire, acima transcrita, afirma Leo Bersani:

O apetite insaciável do self pelo nonself destrói certamente um equilíbrio, mas não é exatamente o equilíbrio entre o self e o mundo; é antes, em termos freudianos, o equilíbrio entre as estruturas do ego e as inumeráveis (latentes, suprimidas, reprimidas) representações que geralmente não são permitidas para romper as fronteiras do ego. Os estímulos externos que nos mexem com gravidade e eroticamente são esses que reativam - mais rápido do que possam ser dominados-vestígios de memória de outros estímulos. O nonself em que um self particular procura com grande euforia ser apagado é a história internamente inscrita da relação do self com o mundo. Muito estranhamente, então, a penetração do artista pela "imagem externa da vida" é também um afastamento de todas essas cenas reais; é um sair de si, na verdade, um rompimento incontrolável dos próprios limites da subjetividade, o que é também uma auto-expansão excepcional, uma espécie de celebração do self enquanto mundo, em suma, um gozo narcísico). ${ }^{21}$

20 Cf. BAUDELAIRE, Charles. O pintor da vida moderna. Trad. Teresa Cruz. Lisboa: Vega, 1993, p. 18.

21 "The insatiable appetite of the self for the nonself does indeed destroy an equilibrium, but it is not exactly the equilibrium between the self and the world; it is rather, in Freudian terms, the balance between ego structures and the innumerable (dormant, supressed, or repressed) representations that are generally not allowed to break through the ego's boundaries. The external stimuli that gravely, and erotically, "shake" us are those that reactivate - faster than they can be mastered - memory traces of the other stimuli. The nonself in which a particular self seeks ecstatically to be obliterated is the internally inscribed history of the self's relations with the world. Very strangely, then, the penetration of the artist by the "picture of external life" is also a turning away from all such real scenes; it is a going 
De acordo com a hipótese de Bersani, o principal efeito dos estímulos exteriores que conseguem penetrar a barreira defensiva do ego - ou seja, o principal efeito dos choques - seria a reativação de memórias "latentes, suprimidas, ou reprimidas". ${ }^{22}$ A penetração do eu pelo não eu é apenas uma dissolução ilimitada do eu nos domínios ilimitados do não-eu. Na medida em que os choques perceptivos se fundem com as memórias inconscientes que reativam, a dissolução do eu na realidade exterior reverte-se numa penetração da realidade pelo ego. Em outras palavras, o fator de choque que transpõe a barreira defensiva da consciência manifesta-se fenomenologicamente enquanto reativação de memórias involuntárias, as quais se fundem com os dados da percepção consciente, que não mais são investidos com a experiência do eu, e assim o espelham. $O$ mundo é radicalmente subjetificado. Bersani observa, que a parcela de fator de choque que excede a barreira defensiva da consciência não se pode manifestar enquanto fenômeno consciente, provocando uma ativação da esfera do inconsciente. ${ }^{23}$ O que limita a análise de Bersani é, contudo, uma submissão ao pólo narcisista, no qual o mundo é subsumido pelo sujeito. Porque o processo a que a pintura de Kiefer, e os ensaios de Benjamin, se referem, e encenam textualmente, é mais complexo. A expansão narcisística do eu pelo mundo é também uma radical reificação do eu. Um impulso fragmentário do choque na modernidade estimula a totalização narcisística do sujeito, mas no mesmo processo, estilhaça-se e o reduz a fragmentos perceptivos sensações, memórias, vivências -. Na tensão oximórica entre

out of oneself, indeed an uncontrollable breakdown of the very boundaries of selfhood, which is also an exceptional self-expansion, a kind of celebration of the self-as-world, in short a narcissistic jouissance". Cf. BERSANI, Leo. The culture of redemption. Cambridge, Massachussetts: Harvard University Press, 1990, p. 74.

22 Deixemos de lado a questão de como algo suprimido pode ser reativado; é claro que Bersani alude nesta passagem aos dados da memória involuntária tal como a concebe Benjamin, a partir de Proust e Freud.

23 Tal projeção dos dados da memória involuntária nos conteúdos da percepção Benjamin designou de aura. 
totalização e fragmentação, o sujeito dissipa-se e expande-se; o mundo apaga-se e tudo invade. Ou seja, não mais se sustentam as categorias do sujeito e do mundo: o mundo só existe enquanto limiar do eu e eu só existe enquanto limiar do mundo.

\section{B. CATÁSTROFE E ANIQUILAÇÃO}

The human organism is an atrocity exhibition at which he is an unwilling spectator. J. G. Ballard

O conceito de catástrofe, que, segundo Benjamin, não representa a aniquilação total do mundo. Apenas a palavra história (ou tragédia ou Trauerspiel) permanece essencialmente ambígua, nomeando ambos os acontecimentos da história e seus feitos escritos, para que toda a história considerada como catástrofe não possa ser dissociada da escrita da catástrofe. Deixando a catástrofe em questão como um assunto menos violento do que a flagrante destruição ou o cataclismo num sentido apocalíptico, mas também como algo mais perigoso e insidioso num sentido menos evidente que nem sequer pode ser visto, nem muito menos, conhecido, há uma espécie de desconhecimento da catástrofe como Kiefer e Benjamin sugerem. A escrita ou pintura da história não introduzem apenas a catástrofe senão também o princípio esperança (Ernst Bloch), nomeando a possibilidade de um final da catástrofe histórica. ${ }^{24}$ Para

24 O princípio esperança é a obra seminal de Ernst Bloch, um gigantesco inventário das imagens do desejo, dos sonhos e das figuras de antecipação utópica tais como emergiram na história da filosofia, da literatura, da arquitetura e da música, nas utopias dos contos de fadas e nas utopias arquitetônicas modernas. O lugar privilegiado da manifestação da aparição utópica e da realização de $O$ princípio Esperança é a consciência antecipadora. Segundo a descrição que Bloch apresenta da estrutura da consciência antecipadora, ela se manifesta, em primeiro lugar, no sonho diurno. Os sonhos diurnos são estruturas fundamentais, "sonhos para a frente," ou seja, sonhos saturados de conteúdos de consciência utópica. Eles podem ser o lugar da concepção das imagens utópicas. Podem 
que a história ou a pintura aconteçam, proverbialmente, com seus escritos ou com seus traços, sempre terá que acontecer ao final. Para fazer visível o que está essencialmente invisível, para reportar o inimaginável na região da imagem, para fazer o presente propício uma origem do passado, será necessária uma ficção que expresse, desta maneira, o que é inexprimível. Desastre, no sentido empregado por Benjamin, não é nada além de alegoria, ainda que alegoria não seja meramente uma lúdica técnica imagística, mas expressão, assim, como são a linguagem e a escrita. A alegoria da história representada como uma imensa catástrofe chamada progresso remete-nos à nona tese sobre o conceito de história representando o Anjo da história, freqüentemente interpretada como uma imagem do infinito desespero no rosto de um tempo infinito. Para Benjamin, toda alegoria é essencialmente ambígua e, finalmente, neutra na representação da história, como a expressão facial do Angelus Novus desenhado por Paul Klee, em quem se baseia. ${ }^{25}$ Este curso de falta de

preconizar o futuro e iniciar uma produtividade criadora. Bloch tem suas restrições face ao pessimismo histórico de Walter Benjamin, ao opor sua visão apocalíptica de um progresso pervertido que fulmina a civilização e a humanidade, ao princípio de "otimismo militante." Para Arno Münster, esse "otimismo militante" expressa-se numa filosofia da práxis renovadora definida como "ciências das tendências," como prática renovadora e construtiva que tenta apoderar-se de todas as possibilidades reais indicando o futuro na realidade presente, que procura trabalhar na transformação do mundo em "pátria" (Heimat). Cf. BLOCH, Ernst. O princípio esperança. Vol. I-III. Trads. Nélio Schneider; Werner Fuchs. Rio de Janeiro: Editora UERJ, 2006; Cf. MÜNSTER, Arno. "Ernst Bloch e Walter Benjamin: Afinidades e diferenças a propósito da interpretação messiânica da história." In: MÜNSTER, Arno. Ernst Bloch. Filosofia da praxis e utopia concreta. São Paulo: UNESP, 1993, pp. 55-79.

${ }_{25}$ Benjamin foi o grande arquiteto da consignação da obra poética de Baudelaire ao escudo da alegoria. A relevância da reflexão sobre a alegoria no pensamento de Benjamin remonta à sua reprovada tese de livredocência apresentada à Universidade de Frankfurt sobre a Origem do Drama Barroco Alemão, publicada três anos depois em 1928, ainda que gestada durante dez anos de pesquisa. Nos anos trinta, no contexto da análise da modernidade encetada no projeto das Passagens, e nos ensaios dedicados a Baudelaire a que aquele projeto encaminhou, Benjamin retoma essa reflexão e encontra, em pleno século XIX, um revival, um novo uso, da alegoria. Onde, então, reside a ousadia da noção de alegoria apresentada por Benjamin? Rejeitando a tradição iniciada por Goethe que considera a 
expressão que permite que o rosto assuma qualquer expressão, incluindo a de horror, mas também a de calma e paciência. Em outras palavras, a causa do desespero na imagem alegórica talvez se torne princípio esperança por causa da natureza alegórica da imagem em si própria, que pode ser vista como uma intervenção messiânica que deterá a história e o tempo por meio de uma redenção apocalíptica. ${ }^{26} \mathrm{Se}$, para Benjamin, a catástrofe parece abrir o curso

distinção entre símbolo e alegoria em função da forma como a idéia e o conceito relacionam o particular com o geral, Benjamin submete essa distinção à categoria do tempo. Destarte, a desvalorização romântica da alegoria justificada pela sua arbitrariedade e singularidade, ou seja, como símbolo imperfeito, é impugnada por Benjamin, que encontra na alegoria um processo de significação tão importante como o símbolo, do qual difere radicalmente. Para Benjamin, a alegoria não é um simples recurso estético que o artista arbitrariamente escolhe mas sim uma forma de expressão que o mundo objetivo the impõe como um imperativo cognitivo. Segundo Benjamin, "Certas experiências (e assim certas épocas) foram alegóricas [...]". A alegoria predomina em épocas de crise, refletindo um sentimento de impermanência, de despersonalização e de aniquilação do mundo histórico. Cf. BENJAMIN, Walter. Drama Barroco. op. cit., p. 198; Cf. BUCKMORSS, Susan. The dialectics of seeing: Walter Benjamin and the Arcades Project. Cambridge : MIT University Press, 1990, p.168. Ver versão para português, Dialética do olhar: Walter Benjamin e o projeto das Passagens. Trad. Ana Luiza Andrade. Belo Horizonte: UFMG, 2002.

${ }^{26}$ A alegoria barroca, no pendor benjaminiano, deriva em linha direta da crença renascentista de que os hieróglifos egípcios eram uma escrita divina feita de imagens naturais, na qual as imagens se ajustavam diretamente às idéias divinas sem qualquer espécie de arbitrariedade. Essa tradição crítica se estenderia aos textos da tradição bíblica e da mitologia greco-latina. Devido a uma superabundância de fontes canônicas, as imagens naturais que constituiam a linguagem divina vêem-se sobredeterminadas por interpretações contraditórias. Como resolver, então, os paradoxos resultantes dessa proliferação arbitrária de alegorias que carateriza 0 Barroco? Segundo Benjamin, a estetização arbitrária da alegoria barroca só se pode resolver pela conversão da sua própria natureza contraditória num emblema do divino. Assim, por meio de um enigmático paradoxo, a arbitrariedade transitória da alegoria torna-se o espelho negativo da eterna verdade divina. Tal inversão semântica permite que, por exemplo, a caveira seja, não apenas uma mera alegoria da transitoriedade humana, mas seja também, numa segunda leitura de caráter teológico, uma alegoria da Ressureição da carne. Nessa duplicidade da alegoria barroca reflete-se uma contradição da atitude do homem barroco perante ao mundo da história e da natureza. Por um lado, a melancolia do alegorista resultava da contemplação de uma natureza abandonada por Deus à insondabilidade da morte, manifestando, assim, negativamente, uma cumplicidade com o mundo. Resulta, então, que, ao projetar toda a esperança para uma esfera 
para uma perspectiva escatológica em que a história e o tempo param para a consecução da redenção do mundo e da humanidade e o passado ao instante da morte, para Kiefer a necessidade desse momento será, necessariamente, negada. Para Benjamin o conceito de tempo preenchido na absoluta presença do agora se opõe à visão de Kiefer sobre a completa ausência do tempo, um tempo irredimível sem presença e sem presente. Como sugere Eric Kligerman, "a alegoria de Kiefer sobre o Trauerarbeit retoma das ruínas do passado, mas de forma alguma promete uma redenção para essas ruínas". ${ }^{27}$

Os conceitos Mal, Catástrofe e Redenção, são necessários para entender as conseqüências da metafísica capitalista do imanentismo, da secularização religiosa de Deus subsumido ao destino do homem e das relações entre estado de exceção e insegurança jurídica. Como se trata de uma redenção mundana, Kiefer opera um deslocamento dos conceitos da tradição teológica e política, como Mal, Catástrofe e Redenção - o que o pintor propõe em termos de uma questão de método. A história apresentada por Kiefer manifesta, na ferida aberta, a presença de catástrofes humanas ainda mais abomináveis e massivas que as registradas nos anais mais antigos da história e, de fato, as conseqüências da desolação que tanto Mal tem trazido

divina absolutamente alheada do mundo concreto, o alegorista transforma a lealdade ao mundo, que a melancolia insinua, numa traição a esse mundo. O alegorista reduz o mundo histórico a um estatuto de pura ilusão, de mera alegoria da verdade divina. Dessa forma, elimina o Mal, que reina no mundo concreto, ao equalizá-lo ao estatuto alegórico. Cf. BENJAMIN, Walter. ibidem, pp. 188-204. Cf. BOLLE, Willie. "Alegoria, imagens, tableau." In: NOVAES, Adauto, (org). Artepensamento. Sao Paulo: Companhia das Letras, 1994, pp. 411-432; Cf. SALGADO, José. "Alegoria e modernidade em Benjamin." In: SALGADO, José. "A experiência de um ocidental: Cesário Verde, Walter Benjamin e a experiência poética da modernidade." Tese de Doutorado apresentada ao Departamento de Espanhol e Português da Universidade de Califórnia, Dezembro 1997, pp.170-177.

27 "Kiefer's allegory of Trauerarbeit takes from the ruins of the past but does not in any way promise a redemption for these ruins." Cf. KLIGERMAN, Eric. Scenes of witnessing in Paul Celan, Anselm Kiefer and Daniel Libeskind. Tese de Doutorado apresentada ao Departamento de Literatura Comparada da Universidade de Michigan, 2001, pp.214-215. 
consigo são seguramente apenas perceptíveis. Conforme Andreas Huyssen, a equação de Kiefer de fascismo e pintura - revelada na série dos Áticos - toma uma diferente conotação. Huyssen sugere que, como Celan e Adorno, Kiefer acredita que os horrores perpetrados pelo Nazismo têm conduzido à derradeira crise da arte do pós-guerra:

O fascismo revelou não apenas em que medida a poesia e a pintura nunca poderão ser proporcionais ao mundo da violência histórica, como também demonstrou a maneira pela qual a política pode explorar cruelmente a dimensão estética utilizando-a a serviço da violência e da destruição. ${ }^{28}$

A pintura de Kiefer que glosa o projeto fascista de Wilhem Kreis para - Mausoléu dos Grandes Soldados Alemães em Berlim (1939), originalmente projetado como um monumento para glorificar os soldados do Terceiro Reich, sofreu uma transformação na imaginação de Kiefer. Essa imagem foi metamorfoseada num inquietante memorial para as vítimas da Shoah. ${ }^{29}$ Este monumento de interiores

28 "Fascism has not only revealed the extent to which poetry and painting can never be commensurate to the world of historical violence. It has also demonstrated how politics can ruthlessly exploit the aesthetic dimension and harness it in the service of violence and destruction". Cf. HUYSSEN, Andreas, op. cit., p. 41.

29 O conhecimento dos nomes é para a nossa cultura equivalente ao conhecimento das coisas, idéia ponderada em toda a metafísica ocidental. No caso da nomeação da -destruição dos judeus da Europa - título do estudo de Raul Hilberg - efetivada pelos nazistas, e a idéia de viver nos nomes que tem preeminência na cultura judaica parece insuficiente sob o termo genocídio, referente também à tentativa de destruição de vários outros grupos nacionais, étnicos e religiosos. O termo judeocídio, utilizado por alguns, também resulta incompleto porque poderia ser atribuído a cada um dos tantos povos que foram vítimas de alguma forma de violência extrema. Afirmar o acontecimento de Auschwitz como quintessência da violência histórica poderia distender a singularidade histórica absoluta desde evento-limite para subtraí-lo à história, afirmando-o como místico ou metafísico-teológico, como reclama George Steiner. Na contramão de Steiner, encontramos Giorgio Agamben denunciando, no seu livro $O$ que resta de Auschwitz, a intromissão de categorias teológicas que fazem do Holocausto uma nova teodiceia. Para Agamben, Auschwitz apresenta-se como um fenômeno único, mas não se trata de um acontecimento indizível, pois não é preciso conferir ao extermínio o prestígio da mística. As denominações Holocausto, Churban, Shoah, Auschwitz, Solução Final 
implicam determinadas abordagens históricas, memoriais e ideológicas. Parece quase impossível abarcar esta violência histórica sob uma denominação unívoca, como também subordiná-la a uma carregada metafísica que abranja reconstruções informadas por posições tão diversas. Giorgio Agamben, por exemplo, identifica no termo Holocausto não apenas a "equação inaceitável entre fornos crematórios e altares", mas também resgata sua "herança semântica que possui desde a origem uma coloração antijudaica." A história semântica do termo Holocausto é principalmente cristã, pois corresponde à doutrina complexa do sacrifício na Bíblia. Leila Maria Brasil Danziger escreve que antes da divulgação do termo Holocausto, Elie Wiesel conta que após a guerra era comum entre judeus a pergunta: "onde você estava durante o Churban?" A palavra conota, em hebraico, destruição. Churban - ou mais precisamente Terceiro Churban - insere o projeto nazista de extermínio em franca relação com as duas destruições do Templo de Jerusalém. O termo Churban caiu no esquecimento sendo preterido, inicialmente entre os judeus, em favor de Shoah - devastação, catástrofe em hebraico. A pregnância religiosa foi progressivamente desarticulada por historiadores, escritores e teólogos que, em Israel, recusaram o endereçamento do conceito a suas raízes religiosas e sua interpretação em sentido metafísico. Pretenderam, inversamente, retirá-lo de suas pesadas conotações de expiação e castigo. O modo como o próprio termo é utilizado atualmente é plural e, conforme a seu passado bíblico, reporta experiências contemporâneas. Os filmes Shoah de Claude Lanzmann e Hitler. Um filme da Alemanha, de Syberberg e Bach in Auschwitz de Michel Däeron são materiais necessários para pensarmos este assunto. Márcio Seligmmann-Silva resgata Rashomom de Akira Kurosawa como outro filme para refletirmos sobre a questão do testemunho. Nesse filme - que também partilha um cenário em ruínas e a volta ao murder scene - as várias versões borgeanas de um crime se sucedem, sem que reconheçamos o lugar apropriado da verdade. Nessa teatralização da história como tribunal não falta a figura dos mortos que aparecem para depor. Para Jean-Pierre Dupuy a Shoah designa uma catástrofe exclusivamente natural, mesmo que os sobreviventes dos massacres nucleares de Hiroshima e de Nagasaki se refiram à catástrofe utilizando a palavra japonesa tsunami. No entanto, Solução Final refere-se, bem entendido, ao processo burocrático e industrial de extermínio que tornaria a Alemanha Judenrein - limpa de judeus. Endlösung, Judenrein, Judenevakuirung (evacuação dos judeus) -, entre outros termos, caracterizam uma retórica da ambigüidade, repleta de eufemismos e perífrases. Os ideólogos nazistas cogitaram uma linguagem adequada à decisão de extermínio, que, uma vez cumprida, deveria, como os judeus, desaparecer sem deixar documentos nem vestígios. Mais do que reiterar o topos do inominável, estas tentativas de definição pretendem renovar as formas existentes de aproximação, testemunho, compreensão e representação deste acontecimento histórico, sem jamais esquecer a advertência de Saul Friedländer, de que o grande perigo da memória de Auschwitz, é que esqueçamos o horror por trás das palavras. Cf. BRASIL DANZIGER, L.M. Corpos de ausências. Berlim e os monumentos a Auschwitz. Tese de Doutorado apresentada ao Programa de Pós-graduação em História Social do Departamento de História da PUC-Rio, Março 2003; Cf. Idem. "Shoah ou holocausto: A aporia dos nomes." Arquivo Maari. 
cavernosos evoca no espectador paralelos com os fornos de cremação usados pelos Nazistas para reduzir a cinzas as vítimas da Shoah. O tamanho monumental da pintura exacerba os sentimentos de terror enquanto ortógonos proeminentes da insidiosa perspectiva central empregada e tratam de absorver o espectador dentro desta lutuosa fornalha. Contrário às séries arquitetônicas, neste trabalho, de acordo com Huyssen, Kiefer aborda com talento o uso do poder do fascismo. A evocação do horror do Holocausto funciona efetivamente para criar uma distância crítica do espectador, um espaço para contemplar e expressar o luto. Como Andreas Huyssen conclui:

Transformando um espaço arquitetônico fascista, dedicado ao culto pela morte dos Nazistas, em um memorial para as vítimas do Nazismo, ele cria um efeito de Umfunktionierung crítico genuíno, como Brecht o chamaria, um efeito que revela um telos genocida fascista em seus próprios espaços memoráveis celebratórios ${ }^{30}$

Kiefer também apresenta o problema de natureza religiosa. A pervivência do judaísmo após dois milênios de perseguição e depois de Auschwitz coloca em si o enigma da relação entre o homem e o

Revista digital de Estudos Judaicos da UFMG. 2007; Cf. SENKMAN, Leonardo. "Simja Sneh y los límites de las representación testimonial de la Shoah." In: SELIGMANN-SILVA, Márcio. História, memória, literatura. O testemunho na era das catástrofes. Campinas: UNICAMP, 2003, pp. 247298; Cf. ARENDT, Hannah. Eichmann em Jerusalém. Um relato sobre a banalidade do mal. Trad. J.R. Siqueira. São Paulo: Companhia das Letras, 1999; Cf. AGAMBEM, Giorgio. Quel che resta di Auschwitz. L'archivio e il testimone. Torino: Bollai Edotire, 1998; Cf. STEINER, George. Linguagem e silêncio. São Paulo: Companhia das Letras, 1988. Cf. SELIGMANN-SILVA, Márcio. "Catástrofe, história e memória em Walter Benjamin e Chris Marker: A escritura da memória." In: Idem, op. cit., pp. 391-418; Cf. FRIENDLÄNDER, Saul. Reflections of Nazism: An essay on kitsch and death. Bloomington: Indiana University Press, 1992; Cf. DUPUY, Jean-Pierre. "A tentação de apagar a política com a técnica." In: NOVAES, Adauto. $O$ esquecimento da política. Rio de Janeiro: Agir, 2007, pp.411-432; Cf. NASCIMENTO, Lyslei. "Memória e testemunhas: A Shoah e o dever da memória". Ipotese. pp. 89-103.

30 "By transforming a fascist architectural space, dedicated to the death cult of the Nazis, into a memorial for Nazism's victims, he creates an effect of genuine critical Umfunktionierung, as Brecht would have called it, an effect that reveals fascism's genocidal telos in its own celebratory memorial spaces". Cf. HUYSSEN, Andreas, op. cit., p. 43. 
divino. Tanto mais quanto a urgência de fazer confluir as próprias fontes com os caudais da filosofia ocidental tem sido - quase misteriosamente - sentido apenas no nosso século, após o florescimento da cultura judaica. Kiefer interna-se pelos caminhos da radical originalidade, mostrando os nexos da catástrofe firmemente enraizada na tradição judaica. Que contêm o Talmud, o Midrash ou a Cabala, ou os relatos hassídicos, que propiciam a tenacidade de viver e pensar naqueles que têm atravessado as crises históricas mais profundas?

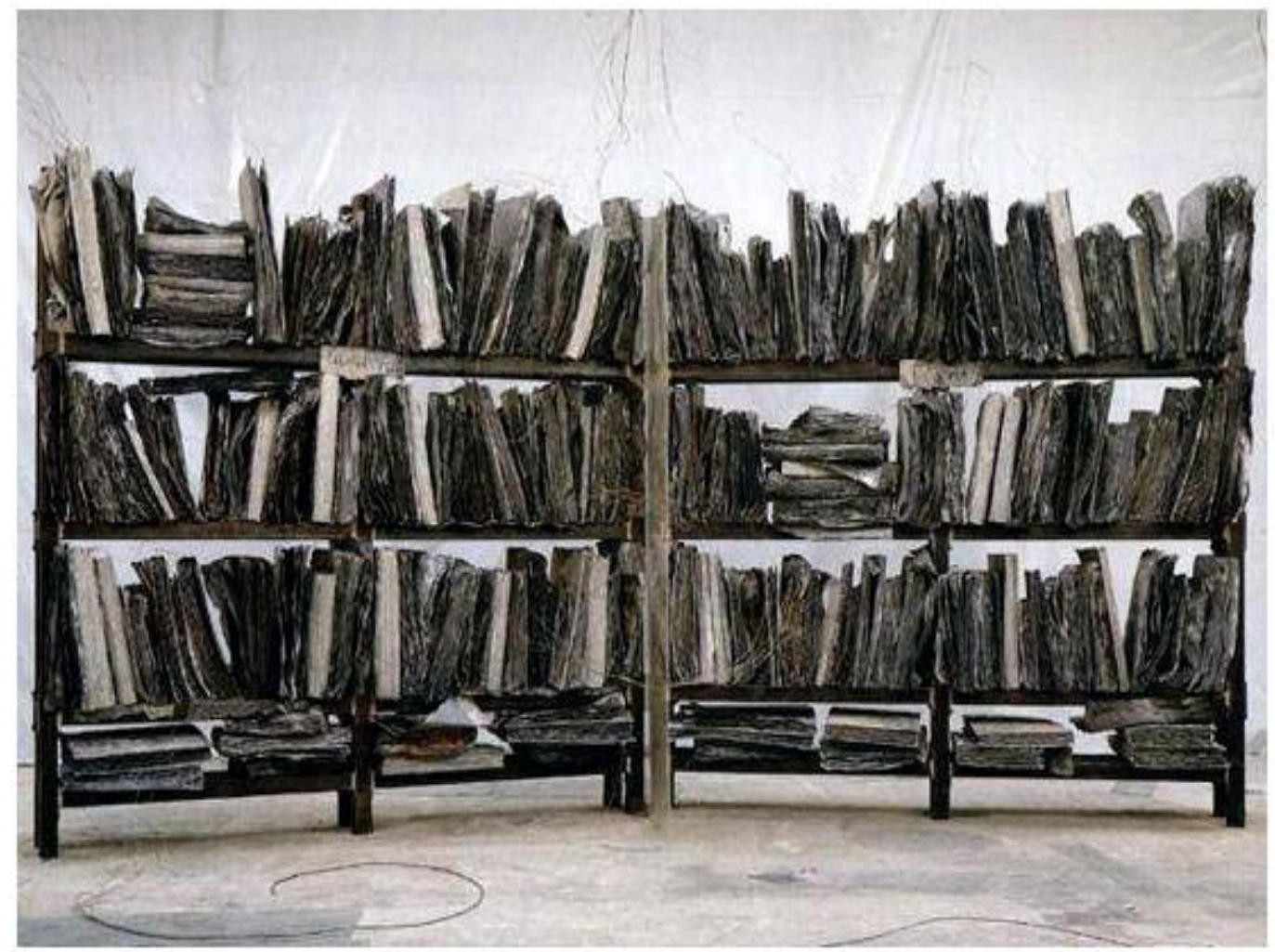

Figura 6. Terra entre dois rios/Zweistromland, 1985/91. Aproximadamente 200 livros de chumbo em duas prateleiras com vidro, arame de cobre, fotografias originais, argila, serapilheira, grãos, terra, cabelo humano, fotografias de revistas. $390 \times 350 \times 200$ cm. Coleção Astrup Fearnly, Oslo, Noruega

A obra de Kiefer, Zweistromland (Terra entre dois rios) ${ }^{31}$ (fig.6) cerca de duzentos livros de chumbo dispostos em duas estantes com

${ }^{31}$ Aliás, Quebra dos Vasos (Bruch der Gefässe), escultura de Kiefer que faz parte de um grupo de obras compostas por prateleiras de aços e grandes livros de chumbo, dentre as quais a mais célebre é certamente 
três prateleiras altas, duas pequenas placas de chumbo - Tigres e Eufrates - remetem à ação do tempo acumulado em oxidações, sedimentos e fragmentos de materiais incrustados no metal, sobrepostos em folhas de chumbo. Esta obra de Kiefer apresenta uma imagem labiríntica do universo. Trata-se de uma escultura que pode se desamarrar da ação do tempo, ceder ao trabalho do ônus do tempo e envelhecer na imobilidade absoluta que o estado de melancolia sugere. Na biblioteca de chumbo - metal entre os mais pesados, empregado na construção de ataúdes e refratário à radiação -, os livros, que podem pesar até uma tonelada e, foram trabalhados ao longo de quatro anos, são literalmente incunáveis. ${ }^{32} \mathrm{~A}$ exposição

Zweistromland. Cerca de duzentos livros de chumbo dispostos em duas estantes com prateleiras de quatro metros de altura e oito de comprimento envolvem o espectador. Sobre elas duas pequenas placas de chumbo Tigris e Euphrat - remetem ao título da obra, Terra entre dois rios: a Mesopotâmia. A obra possui ainda o título alternativo em inglês The high priestess, carta do Tarot que simboliza a distinção entre Gnosis e Ciência. Em relação com a magia e a Cabala cabe lembrar que o hassidismo nasceu na Europa central e foi divulgado pelos calonitas. A doutrina básica do hassidismo não representava à magia taumatúrgica, porém uma alucinada tentativa de fazer de todos os atos humanos meras sombras do ato supremo do amor por Deus. O hasside, o santo, oferece sua vida ao amor pelo seu criador ao que necessariamente se submete a cada instante e em todo momento da existência. A palavra tem para o hassidismo, assim como para Kiefer, um enorme poder: a Quebra de Vasos triunfa na presença do destino e diante do Mal. Daí a grande vontade de Kiefer em conhecer as formas exatas em que se manifestou a Lei de Moisés e sua pesquisa tenaz pelos significados esotéricos. A palavra é, assim, uma fonte de poder mágico, ou seja, de High Priestess. Consultar o texto de ZWEITE, Armin. The high priestess, Londres: Anthony d'Offay Galery, 1989; Cf. BRASIL DANZIGER, L. M. op. cit., p. 172; Cf. BENITO-VESSELS, Carmen. La palabra en el tiempo de las letras. Una historia heterodoxa. México: Fondo de Cultura Económica, 2007, p. 138.

${ }^{32}$ O livro incunável ou paleotipo, denominação que abrange os impressos até $\mathrm{o}$ ano 1500 inclusive, começou imitando fielmente os modelos manuscritos. O incunável pretende, em um princípio, o barateamento de custos do livro e em seu caráter subalterno no que diz ao códice manuscrito, não alterava as suas principais características: grande tamanho, a fonte utilizada e o fato de deixar espaços a fim de incluir miniaturas, letras capitais e títulos, todos realizados à mão. A utilização de abreviaturas, assinaturas, registros, formulários do texto e escassas e sóbrias portadas, são uma lembrança da sua elaboração. Todavia, as inovações trazidas pelo incunável são também evidentes: o papel consagrase sobre o pergaminho como suporte da escrita: poucos serão os incunáveis 
parcial de seu conteúdo é possível unicamente através de outro livro. Contudo, constitui-se uma obra em si mesma, fruto da parceria entre Kiefer e o historiador da arte e diretor da Kunsthalle de Düsseldorf Armin Zweite. Não existe distinção entre filosofia da composição e produção. Coube ao artista a escolha de vinte e oito livros, dentre os duzentos volumes. Entre estes vinte e oito, selecionou nove páginas duplas de cada volume para serem analisadas por Zweite. A seleção a cargo do artista e não do historiador testemunharia o desejo de controlar a recepção da obra. Metal oxidado, resíduos orgânicos e fotografias - vistas do ateliê, paisagens desoladas, nuvens, mares,

imprimidos sobre pergaminho, ilustrados com belas miniaturas e destinados ao uso de magnatas e reis; a mancha de tinta passa a ser mais compacta e o texto terá uma distribuição artística, ora em duas colunas se o livro for de grandes dimensões, ora no centro da página com tipos grandes, emoldurado por glosas e rodapés diversos em tipos de dimensões menores; começa a se perceber a utilização dos grandes formatos preferentemente para temas religiosos, enquanto que os menores se destinam à leituras de teor recreativo. É notória a mudança experimentada no tratamento tipográfico das portadas, cuja inexistência acostuma ser quase geral neste período, e a aparição no lugar do título apenas acompanhado dalgum gravado. A ilustração decorrerá nos primeiros anos da gráfica ao sistema manual, em que a miniatura permanecerá assim como a rotulação de títulos e epígrafes. No entanto, a ilustração será substituída por belas xilografias sobre os motivos mais diversos: retratos, escudos nobiliários e religiosos, paisagens, ilustrações científicas. Interessantemente, a autoridade do manuscrito começa por impor os tipos góticos alemães salvo no caso de Itália e de Espanha, que preferem os humanísticos ou redondos, com certa especialização em temas religiosos, os primeiros, em vez dos profanos e textos dos clássicos greco-latinos, os segundos. O latim será a língua franca, porém a proporção difere em cada país e também nos assuntos, predominantemente o religioso - Bíblias, comentários bíblicos, textos litúrgicos, missais, devocionários, sermonários, livros de horas que na França excepcionalmente imprimiram-se em papel - sobre o literário: clássicos greco-latinos, tratados filosóficos, gramáticas latinas, literatura em língua vulgar e traduções de obras piedosas. Trás certo nomadismo, o assentamento nos grandes núcleos de população se imporá ao amparo da demanda cada vez maior do livro imprimido não apenas por parte das instituições, mas também por particulares, dando assim origem ao nascimento das primeiras oficinas tipográficas. Todas elas contribuíram ao desenvolvimento de uma nova arte que deixou seus ricos frutos ao amparo dos bem custodiados muros das bibliotecas (algumas de chumbo) que preservam os incunáveis. Cf. PORRO HERRERA, M. J. Las universidades andaluzas y el libro. Córdoba: Consejería de Educación y Ciencia, Junta de Andalucía, 1994. 
ruínas, usinas abandonadas, megacidades (São Paulo, Chicago) -; um repertório de imagens e materiais que condensam a terra, o ar, a água e o fogo aparecem nesta obra. ${ }^{33}$ Imagem não é exatamente um termo adequado para descrever as obras de Kiefer. Suas telas, sempre manipuladas e interferidas por materiais diversos, recusamse a se tornar puramente imagens. Se as bibliotecas originalmente ergueram-se na vontade de civilização, a biblioteca de chumbo de Kiefer parece destinada a ser um documento de barbárie. ${ }^{34}$ Ao redor deste trabalho Nelson Brisaac Peixoto elabora:

${ }^{33}$ As dimensões arquetípicas dos elementos - fogo, água, terra e ar levantam infinidade de associações em diversas culturas e épocas. Cada elemento corresponde a uma etapa do processo alquímico, análogo ao processo de autoconhecimento, segundo os estudos de Jung. Lembremos que os elementos para os gregos transformavam-se uns nos outros e evoluíam em diversas combinações. Cada elemento está assimilado a um conjunto de condições dadas à vida, e isso numa concepção evolutiva, na qual o desenrolar do ciclo tem início com o primeiro elemento (Água), para terminar com o último (Terra), passando pelos termos intermediários (Ar e Fogo). Assim, tem-se uma ordem quaternária da natureza, temperamentos e etapas da vida humana: Inverno, primavera, verão e outono; da meianoite ao nascer do sol, do nascer do sol ao meio- dia; do meio-dia ao poente; do poente à meia-noite; linfático, sanguíneo, bilioso, nervoso; infância, juventude, maturidade, velhice; formação, expansão, culminação, declínio. Os gregos associavam aos quatro elementos quatro faculdades do homem: moral (fogo), estética e alma (água), intelectual (ar) e física (terra). Galeno, por exemplo, correlacionou os elementos aos fluidos do corpo humano: bílis ou bílis amarela ou cólera ao fogo; sangue ao ar; fleuma à água e bílis negra ou melancolia, à terra; os quais originaram os quatro temperamentos: colérico, sangüíneo, fleumático e melancólico. Cf. LEICESTER, Henry M. The historical background of chemistry, Boston: Dover Publications, 1971, p. 34.

${ }^{34}$ Sobre a função da Biblioteca e a leitura na cultura ver Alberto Manguel, Uma história da leitura. São Paulo: Companhia das Letras, 1997, p.68. Manguel faz um histórico da leitura, das hipóteses de seu surgimento ao processo democratizador desencadeado pela invenção da imprensa, que permitia um contato direto com o livro, sem a intermediação do comentador - seja ele intelectual ou religioso. (O próprio formato dos livros foi, ao longo dos tempos, deixando de ser majestático e voltado apenas para as consultas em biblioteca até atingir a versão de bolso, possibilitando assim a participação do livro na intimidade do leitor, agora levado para a cama, para as viagens, passeios pelo campo, etc.) Um dos centros deste relato é a possibilidade de libertação que a leitura individual faculta ao leitor, que através dela pode encontrar os seus caminhos sem a necessidade de nenhum guia. Atividade criativa por excelência, a leitura forma os espíritos livres que encontram nela muito mais do que um dogma, 
Uma biblioteca de chumbo, sucedâneo da Biblioteca de Alexandria, destruída pelo fogo. Antigos livros que contam como era a cidade, imagens de um mundo que não existe mais. Uma espécie de pesquisa arqueológica dos despojos do apocalipse, uma tentativa de preservar - na forma de livro - elementos para um eventual renascimento da civilização. ${ }^{35}$

mas o hábito do questionamento. Este processo autonômico foi lento. Primeiro precisou- se conquistar o hábito de ler em silêncio (as leituras eram em voz alta), garantindo assim a liberdade de escolher (as bibliotecas eram essencialmente coletivas) qualquer tipo de obra e tirar delas as conclusões mais adequadas ao sujeito da leitura: "um livro que pode ser lido em particular e sobre o qual se pode refletir enquanto os olhos revelam o sentido das palavras não está mais sujeito às orientações ou esclarecimentos, à censura ou à condenação imediatas de um ouvinte". Assim, a conquista da privacidade foi um passo importante para o estabelecimento do papel libertário do ato de ler, levando ao reconhecimento de que só existe realmente uma biblioteca na memória do leitor - o livro acaba assim visto como meio de uma informação que só poderá ser reconhecido por quem se entrega a ele. Colocar no leitor e não no texto o centro da leitura é subverter o poder da informação em favor do da invenção - em nossa sociedade globalizada, onde se vive sob a ditadura da informação, este recorte da história da leitura é de grande significado. 0 leitor não apenas se faz ao ler como faz a literatura neste ato de doação de sentido ao livro. Aprender a ler, portanto, ultrapassa o nível de decodificação de uma mensagem unívoca, sendo o exercício mais pleno de uma autoridade reflexiva que o ser humano pode adquirir. Todo e qualquer patrulhamento (quem passou pelas Faculdades de Letras sabe do que estou falando) é um retrocesso histórico na medida em que ignora os direitos do leitor individual, da leitura fundante, em nome de um sentido préfabricado. A leitura enquanto atividade narcisista é a mais fecunda. Daí Manguel empreender uma liquidação do lugar comum segundo o qual quem lê se fecha para a vida, isola-se do mundo, deixa de viver. Na verdade, o ato da leitura é muito mais amplo do que a decodificação de textos - é algo que está presente em todos os momentos de nossa vida, na leitura da realidade, da qual o debruçar-se sobre o texto é apenas uma parte. Podemos dizer que esta história da leitura está centrada no leitor, que é objeto de análise do segundo segmento da obra em questão. Embora seja vasta a tipologia do leitor, do que rouba volumes ao que coleciona e classifica, do que lê na cama ao que vive em bibliotecas e arquivos, uma característica é comum a todos: são seres que passam por cima das limitações de tempo e espaço, de classificação e de galvanização dos conteúdos, tornando presente e atual toda obra por ele habitada, situações que ficaram sem verdadeiro futuro.

35 Cf. PEIXOTO, Nelson Brissac. Paisagens urbanas. São Paulo: Marca D'Água, 1996, p. 242. 
Nela não encontramos vestígios de uma civilização, mas signos vazios de uma humanidade abolida aparecem como a marca do vazio e do nada. Como constata Leila Brasil Danziger, perante esta obra resulta quase impossível não se remeter à Biblioteca projetada por Jorge Luis Borges, essa que esclareceria os mistérios básicos da humanidade: "el origem de la Biblioteca y del tiempo". ${ }^{36}$ Em um tempo sem tempo, a origem de todo sentido pode ser lida, com muita sorte, na Biblioteca de Babel de Jorge Luis Borges:

es verosímil que esos graves misterios puedan explicarse en palabras: si no basta el lenguaje de los filósofos, la multiforme Biblioteca habrá producido el idioma inaudito que se requiere y los vocabularios y gramáticas de ese idioma. Hace cuatro siglos que los hombres fatigan los hexágonos [...] Hay buscadores oficiales, inquisidores. Yo los he visto en el desempeño de su función: llegan siempre rendidos; hablan de una escalera sin peldaños que casi los mató; hablan de galerías y de escaleras con el bibliotecario; alguna vez, toman el libro más cercano y lo hojean, en busca de palabras infames. Visiblemente, nadie espera descubrir nada. ${ }^{37}$

A biblioteca de Benjamin, do mesmo modo que Kiefer e Borges, homologa a biblioteca com a escala do universo (talvez em Benjamin mais definida por um universo subjetivo, enquanto Borges e Kiefer se deslocam para universos cosmológicos, alephicos). Lembremos que a imagem da biblioteca de Benjamin se complementa com a seguinte elaboração que encontramos na sua iluminação "Desempacotando minha biblioteca":

Coleccionadores são pessoas de instinto prático; quando conquistam uma cidade desconhecida, sua experiência Ihes mostra que a menor loja de antiguidades pode significar uma fortaleza, a mais remota papelaria um ponto-chave.

${ }^{36}$ Cf. BRASIL DANZIGER, L. M. "Imagens e espaços da melancolia: W. G. Sebald e Anselm Kiefer." Revista Brasileira de literatura comparada, n. 10, 2007, pp.127-146.

37 Cf. BORGES, Jorge Luis. "La biblioteca de Babel." In: BORGES, J. L. Ficciones. (1944). Obras Completas Vol. I. Buenos Aires: Emecé, 1996, pp. 465-471. 
Quantas cidades não se revelaram para mim nas caminhadas que fiz à conquista de livros! ${ }^{38}$

A Biblioteca de Agnon fora incendiada como a da Alexandria. Mas o fim dos livros - habent sua fata libelli, Horácio é citado neste fragmento de "Desempacotando minha biblioteca" - pode ser a morte natural, como o inevitável declínio das civilizações antes da irrupção de uma catástrofe final. Para Kiefer se anunciam tempos em que o verme fatal e a simples caducidade complicam as escolhas das bibliotecas. Num sentido mais amplo, para preservar o valor de um exemplar único ou muito raro, é preciso encerrá-lo num santuário, proibir su uso, sua simples leitura, seu manuseio e sua contemplação. A transmissão do conteúdo só será garantida por uma nova relação com a aura. ${ }^{39}$ Só quem tem feito uma excavação arqueológica buscando os livros almejados, só quem tem perseguido as marcas de uma escritura decriptável mais eterna, fundacional, tem logrado alcançar um escombro arcano da Biblioteca. ${ }^{40}$ Que a biblioteca tanto para Benjamin quanto para Kiefer e Borges seja interminável, labiríntica, faz possível a existência da escritura, suscita uma suspeita, expõe o vazio do insondável. A biblioteca de Kiefer possui entradas inumeráveis, embora, dificilmente, queira alguém se arriscar e caminhar entre vidros e escombros e, definitivamente, entrar na catástrofe para contá-las. A biblioteca de Kiefer possui uma ordem, embora seja definida por seu caos. Sua estrutura ruinosa é sua proteção frente às desmesuras de um leitor perigosamente curioso, insatisfeito por causa dos umbrais de vidro e arame que não pode transgredir.

${ }^{38}$ Cf. BENJAMIN, Walter. Rua de mão única. Trad. Rubens Rodrigues Torres Filho e José Carlos Martins Barbosa. Obras Completas V. II. São Paulo: Brasiliense, 1995, pp. 227-235.

39 Cf. MISSAC, Pierre. Passagem de Walter Benjamin. Trad. Lilian Escorel. Sâo Paulo: Iluminuras, 1998, pp. 62-71.

40 O sábio cabalista, decifrador da palavra divina, tem sabido buscar a promessa detrás de cada letra, o secreto da criação do universo, no "catálogo de catálogo" da biblioteca infinita. 
Benjamin nos lembra na Origem do Drama Barroco que a "Renascença investiga o universo, e o Barroco, as bibliotecas." Ele afirma que "o livro é considerado um monumento permanente ao teatro da natureza, rico em coisas escritas." Benjamin menciona um trecho do prefácio do editor de Ayrer às obras do poeta notável pela ênfase na melancolia como o estado do espírito do tempo, Benjamin glosa o seguinte trecho:

Considerando as pirâmides, colunas e estátuas, de todos os materiais, com o tempo se danificam ou são destruídos pela violência ou simplesmente se desfazem [...] cidades inteiras abundam, submergem e são inundadas pelo mar, ao passo que livros e escritos estão isentos dessa destruição, pois os que se perderam num país e num lugar podem ser reencontrados facilmente em inúmeros outros países e lugares, na experiência humana não há mais nada duradouro e imortal que os livros. ${ }^{41}$

Essas descrições do prefácio citado por Benjamin certamente aplicam-se à escultura de Kiefer, sobretudo, a essa percepção da impossibilidade da linguagem do tempo penetrar na insondabilidade da instalação-biblioteca, pois a obra parece se resistir à ação do pesquisador, do crítico, do erudito ou do especialista que jamais poderá descobrir nada, nem mesmo acedendo ao íntimo mistério da obra. A sucessão de desacontecimentos na história encontra-se nesse perímetro onde a ruína é mais escombrosa. A obsolescência e os restos parecem apresentar um caminho humano para assimilar a ação inquietante do tempo. Como sugere Leila Brasil Danziger:

Ao contrário da ampulheta - injusta metáfora temporal, em que o tempo desliza uniforme e suavemente -, em Terra de dois rios, o tempo age com a força da inércia, acumula-se e mostra-se literalmente um fardo; é certo que dentro de anos ou décadas, o trabalho tenha adquirido novas feições. ${ }^{42}$

${ }^{41}$ Cf. BENJAMIN, Walter. ibidem, p. 165.

${ }^{42}$ Cf. BRASIL DANZIGER, L. M. ibidem, p. 140. 
Esse cuidado com o tempo é também advertido por Nelson Brisaac Peixoto:

A pintura de Kiefer manifesta a contradição entre eternidade e efemeridade. Se a evocação do passado serve para neutralizá-lo, quase apagar suas marcas, esse processo equivale também a um trabalho da lembrança. Uma tentativa de junção do permanente com o transitório assim como do enigmático com o familiar, do transcendente com o imanente. ${ }^{43}$

Tal pareceria que o único agente bem sucedido na obra é o tempo. A arte parece ser o caminho alternativo para a barbárie porque logra transformar a injúria em um rumor, em uma alegoria. Na alegoria ruinosa se detém o tempo, aglutina-se o escombro da experiência vivida nos livros da biblioteca de chumbo de Kiefer. A obra pode transformar o tempo em eternidade quando o homem se adentra na ruína. Acordar e esquecer (que para o pintor significa o trânsito de Athanor para a morte) que se apaguem as imagens atordoantes do passado, aquelas que assaltam impiedosamente o sonho do pintor que, no entanto, as persegue através de um persistente itinerário pictórico, talvez sua própria duração, suas confessadas aspirações de alquimista.

A categoria mais ampla da experiência humana da catástrofe, como refletida na arte ou na literatura, estabelece uma classificação dos textos como literatura traumática. Kiefer, pela mediação da arte, transforma o trauma em experiência. Como constata Márcio Seligmann-Silva, as pesquisas das scholars norte-americanas Dori Lau, Shoshana Felman e Cathy Caruth são centrais para abordar essa discussão. Pois eles representam uma espécie de volta à história, sob o signo da história como trauma que problematiza a noção de acontecimento histórico. Para Seligmann, a relação entre trauma e o sublime pode ser sugerida da seguinte maneira:

${ }^{43}$ Cf. PEIXOTO, N. B. op. cit., p. 242. 
O trauma, para Freud, é caracterizado pela incapacidade de recepção de um evento transbordante - ou seja, como no caso do sublime: trata-se, aqui também, da incapacidade de recepção de um evento que vai além dos limites da nossa percepção e torna-se, para nós, algo sem forma. Essa vivência leva posteriormente a uma compulsão à repetição da cena traumática. ${ }^{44}$

Cathy Caruth, por seu turno, define trauma como:

[...] como experiência esmagadora de acontecimentos catastróficos repentinos em que a resposta ao acontecimento ocorre na freqüência demorada, em aparência descontrolada de repetitivas alucinações e em outros fenômenos intrusivos. ${ }^{45}$

Dentre das características do trauma, Caruth registra as seguintes:

Há uma resposta, às vezes demorada, a um acontecimento ou acontecimentos esmagadores, que toma a forma de repetidas alucinações intrusivas, sonhos, pensamentos ou comportamentos enraizados no acontecimento, junto com um entorpecimento que pode ter começado durante ou depois da experiência, e possivelmente também aumente a excitação (e a anulação) de estímulos lembrando o acontecimento. ${ }^{46}$

A memória fica em suspenso diante da manifestação do Mal absoluto e da morte em uma dimensão até então desconhecida; em vez da comparação a linguagem tende para uma literalidade paradoxal, para uma manifestação, muitas vezes descarnada, do real se resistindo à simbolização. Em Terra entre dois rios, a constelação Borges-Kiefer, estudada por Leila Brasil Danziger, pode ser extremada através da

${ }^{44}$ Cf. SELIGMANN-SILVA, Márcio. "A história como trauma." In: SELIGMANN-SILVA, Márcio; NETROVSKY, Artur (orgs.). Catástrofe e representação, 2000, p.84.

45 "[...] as overwhelming experience of sudden catastrophic events in which the response to the event occurs in the often delayed, uncontrolled repetitive appearence of hallucinations and other intrusive phenomena". Cf. CARUTH, Cathy. Unclaimed experience: trauma, narrative, and history". Baltimore: Johns Hopkins University Press, 1996, p. 11.

46 "There is a response, sometimes delayed, to an overwhelming event or events, which takes the form of repeated, intrusive hallucinations, dreams, thoughts or behaviors stemming from the event, along with a numbing that may have begun during or after the experience, and possibly also increase arousal to (and avoidance of) stimuli recalling the event". Idem, ibidem, $\mathrm{p}$. 4. 
leitura de outro conto de Borges, "Funes el memorioso", história relevante para destacar a Kiefer e sua memória do Mal. ${ }^{47}$ Em "Funes el memorioso", o protagonista adquire uma memória ars recordatoris produto de uma queda:

Más recuerdos tengo yo solo que los que habrían tenido todos los hombres desde que el mundo es mundo [...] Mis sueños son como la vigilia de ustedes [...] Mi memoria, señor, es como vaciadero de basuras [...] Ao cair perdeu o conhecimento; quando o recobrou, o presente era quase intolerável de tão rico e tão nítido, e também as lembranças mais antigas e mais triviais. ${ }^{48}$

Essa übermemória condena a Funes a um estado de vigília permanente e em seguida à morte. Desde a perspectiva de Borges não existe o olvido. O universo aparece como um todo múltiple, numeroso, alojado em sua portentosa memória que acolhe o diverso no Uno. Essa unidade do passado e do futuro parece ser o outro rosto do presente. Para a memória de Funes ou de Kiefer a idéia do passado é consubstancial. O tempo numeroso da vida cotidiana é a eternidade. Estamos a um passo de contrapor esses dois aspectos: tempo e narração. O tempo é invenção da eternidade, a história é a corrosão do tempo. A queda de Funes parece introduzir a memória total, em que existe um antes e um depois da queda. Por isso, Funes, uma vez exercida sua memória de elefante descobre um novo limite para sua prodigiosa capacidade mnemônica: a irreversibilidade do tempo linear, no qual o homem pode projetar, mas não desfazer o já realizado. A queda de Funes não é sequer um fato que aconteceu no passado, mas uma categoria própria deste tempo, revelado como possível de ser revivido ad infinitum. Leila Maria Brasil Danziger descreve estes efeitos memoriosos:

47 Cf. BRASIL DANZIGER, L. M. op. cit., p. 143; Cf. Idem. "O jornal e o esquecimento." Ipotesi. Revista de Estudos Literários. vol. 11, n. 2, 2007, pp. 167-177.

${ }^{48}$ Cf. BORGES, J. L. "Funes el memorioso." In: BORGES, J. L. Artificios. (1944). Idem, ibidem, pp. 485-490. 
Submetidos ao peso de uma história autoritária, seríamos condenados a uma insônia permanente. Ora, é justamente o fardo de uma eterna vigília, de uma memória sem falhas que se abate sobre o jovem Funes, imobiliza-o e o leva à morte. Sua capacidade mnemônica é incompatível com a vida e o pensamento [...] Irineu não era dotado de força plástica - a capacidade de determinar em que nível o passado deve ser esquecido, pois tanto o ponto de vista histórico quanto o ahistórico são necessários para a saúde de um ser vivo, indivíduo, povo ou civilização. Um organismo saudável é capaz de cicatrizar as feridas, substituir as perdas, reconstruir as formas fragmentadas. ${ }^{49}$

Kiefer luta contra toda forma de olvido, frente a ela, se acautela na memória, regressa mil vezes a suas lembranças, a seus livros, à sua biblioteca de chumbo; também se encapsula na escritura como refúgio do erudito ante a ameaça da barbárie informacional. Olvidamos para lembrar; suportamos a dureza da marcha porque somos capazes de olvidar o sofrimento das gerações passadas. Contudo, sempre existem os que lembram, os que insistem, como Irineu, embora não queiram, em manter vivo o polvo da memória que vai tomando conta de tudo. Kiefer, também memorioso, pertence a essa estirpe de pintores atravessados por uma imaginação pictórica destinada a voltar ao passado, a se empapuçar de imagens dessas regiões borradas que a maioria dos homens prefere passar por alto. Kiefer se sente assaltado pelos fantasmas do passado, é um pintor que se deixa levar pelos rumores de um tempo que dilacera 0 presente. Na consideração de Leila Maria Brasil Danziger:

Na obra de Kiefer, a ação do tempo acumulada em oxidações e sedimentos, incrustados no metal, sobreposto em folhas e folhas de chumbo, constitui-se uma advertência aos excessos da memória, e, ao mesmo tempo, por sua presença física contundente, pode ser sentida também como

${ }^{49}$ Cf. BRASIL DANZIGER, L. M. ibidem, p. 143. 
uma resistência ao caráter volátil e efêmero de nosso universo informacional. ${ }^{50}$

Borges costumava falar, "sólo una cosa no hay. Es el olvido." Tema que percorre a obra de Borges, o universo pictórico de Kiefer e que constitui uns dos eixos temáticos da reflexão crítica de Walter Benjamin. A memória parece ser tão temida, esse terrível cansaço de Funes, suas noites de insônia, o vasto horror de lembrar para sempre el ayer, o suplício da dor reiterada em que fala Leila Maria Brasil Danziger. Para Kiefer a memória é também pertença, uma narrativa onde se encontram a esperança e a dor acumuladas por todas as gerações que, como ele nos apresenta, inalaram o pó da derrota; a memória carrega o ônus de uma promessa edificante, é o tenaz combate que Kiefer estabelece contra os fantasmas do deus oblivionis, sua maneira mais garbosa de restituir a memória das gerações que se tem perdido no redemoinho da história. Kiefer oscila entre a memória e a história; mergulha no vigor heróico dos antepassados, de antigas civilizações sepultadas pela areia da história que poetas como Celan, como Borges, tentam recuperar da noite dos tempos. Essa memória acolhida por Kiefer parece ser resgatadora, como aquela imagem que aparece nas "Teses sobre o conceito de História" e através da qual Benjamin nos fala sobre a memória como reparadora das gerações vencidas, da enorme tarefa que lhe cabe ao historiador:

Articular historicamente o passado não significa conhecê-lo "como ele de fato foi". Significa apropriar-se de uma reminiscência, tal como ela relampeja no momento de um perigo. Cabe ao materialismo histórico fixar uma imagem do passado, como ela se apresenta, no momento do perigo, ao sujeito histórico, sem que ele tenha consciência disso. $O$ perigo ameaça tanto a existência da tradição como os que a recebem. Para ambos, o perigo é o mesmo: entregar-se às classes dominantes, como seu instrumento. Em cada época,

50 Cf. BENJAMIN, Walter. Magia, arte e técnica. São Paulo: Brasiliense, 1987, p. 143. 
é preciso arrancar a tradição ao conformismo, que quer apoderar-se dela. Pois o Messias não vem apenas como salvador; ele vem também como o vencedor do Anticristo. $O$ dom de despertar no passado as centelhas da esperança é privilégio exclusivo do historiador convencido de que também os mortos não estarão em segurança se o inimigo vencer. $E$ esse inimigo não tem cessado de vencer. ${ }^{51}$

A memória, e isso tanto Benjamin quanto Kiefer o reconhecem, comporta conteúdos altamente dilacerantes e leva as marcas inapagáveis do punitivo. Onde Kiefer nos oferece as imagens mais sublimes, precisamente ali é onde a pontada de dor se torna mais insustentável. O olvido, como reconhece Leila Maria Brasil Danziger, cura as feridas, mas também coloca em nós o silêncio aterrador e cega nossos olhos que biblicamente estão comprometidos com a interdição do último olhar. "Jamais poderemos resgatar totalmente $o$ que olvidamos", escreve Benjamin no seu livro Infância em Berlim. ${ }^{52}$ O choque que produziria seria tão destrutor, assim como foi para Funes, pois nesse justo instante deixaríamos de entender a razão de nossa melancolia. ${ }^{53}$ Tanto a escrita de Borges como a pintura de

${ }^{51}$ Cf. LÖWY, Michel. Walter Benjamin: aviso de incêndio. uma leitura das teses "Sobre o conceito de História." Trad. Wanda Nogueira Caldeira. São Paulo: Boitempo, 2005.

52 Cf. BENJAMIN, Walter. "Infância em Berlim." In: BENJAMIN, Walter. Rua de mão única. Obras Completas Escolhidas II. São Paulo: Brasiliense, 1987. 53 Trata-se do que falou Benjamin no Parque Central: "A lembrança é a relíquia secularizada. A lembrança é o complemento da vivência, nela se sedimenta a crescente auto-alienação do ser humano que inventariou seu passado como propriedade morta. No século XIX, a alegoria saiu do mundo exterior para se estabelecer no mundo interior. A relíquia provém do cadáver, a lembrança, da experiência morta, que, eufemisticamente, se intitula vivência." O problema de Funes obedece à ordem de um ensimesmamento, de um saber reflexivo que pode conduzi- lo aos seus limites e, mesmo, como aparece no Drama Barroco, à loucura, por via de uma queda vertiginosa no abismo da acedia, impelindo-o à estranheza, à alienação e consequente impossibilidade absoluta de agir. Benjamin fala do Grübler (o cismador, meditativo) aquele que se coloca saturninamente sob o signo da rememoração: "[...] A situação do cismativo [Grübler] é a de um homem que possuiu a solução do grande problema, mas que a esqueceu em seguida. E agora ele medita, menos sobre a coisa do que sobre a reflexão que ele levou a cabo sobre o seu sujeito. O "pensamento do cismativo" (Grübeln) é então colocado sob o signo da rememoração. $O$ cismar do melancólico e do alegorista são feitos da mesma madeira". Estas 
Kiefer são apotropaicas, no sentido que nos revelam o abismo para nos proteger melhor dele. ${ }^{54}$ Contra a própria auto-alienação que recria o passado como uma possessão morta existe a necessidade de criar uma maneira diferente de mortandade em um passado diferente. Essa é a tarefa, para Benjamin, do alegorista melancólico, melhor representado na era moderna pela figura de Baudelaire. 0 melancólico no enclave de Benjamin é aquele que seu mais fervoroso desejo é interromper o curso do mundo para interromper uma visão progressiva da vida na qual as coisas simplesmente continuam seu percurso.

Centenas de livros, talvez de memórias, afanam-se por arrebatar em sua direção a grande quantidade de leitores. ${ }^{55}$ Nós, leitores ou

passagens permitem-nos concluir algo mais acerca de Funes, possibilitandonos a compreensão de que o seu gesto é o daquele que procura estabelecer a mediação entre a imagem e a significação, no interior da rememoração histórica. Redimir as coisas, num gesto alegórico, juntando à significação uma imagem e vice-versa. Essa é uma visão alegórica e saturnina, melancólica, que encontra-se no olhar barroco e sua visão arruinada da natureza e da história. Cf. BENJAMIN, Walter. "Parque Central." ibidem, p.172; Cf. Idem. "Baudelaire". In: Passagens. Belo Horizonte/São Paulo: UFMG/Imprensa Oficial, 2006, p. 454.

${ }^{54} \mathrm{O}$ termo apotropaico refere-se à imaginada eficácia de recursos mágicoprofiláticos, com o intuito de evitar infortúnios, deter maldições, pragas ou feitiços, apartando-os através de algum meio privilegiado: objetos ou procedimentos alegóricos supostamente investidos de um poder extraordinário, de uma força ativa que inibe as potências demoníacas hostis, desvia os golpes dos inimigos, impede o contágio das impurezas, exonera o aziago. Quando se fala em apotropaico, alude-se, pois, a defesas imaginadas eficazes, apoiadas em qualquer coisa de intangível, mas aptas a protegerem do sinistro e do infausto. Ora, tanto nas histórias de Borges quanto na imaginária pictórica de Kiefer, se faz referência a artes mágicas, talismãs ou feitiços como maneiras ecológico-bárbaras de conter as forças estranhas. Cf. MOREIRAS, Alberto. Tercer espacio: literatura y duelo en América Latina. Santiago, Chile: Arcis-Lom, 1999; Cf. Idem."Circulus Vitiosus Deus: Borges y el fin de la memoria."Siglo XX/20th Century, 1992, pp. 111-130; Cf. FORSTER, Ricardo, "Walter Benjamin y J. L. Borges: la ciudad como escritura y la pasión de la memoria." In: FORSTER, Ricardo. El exilio de la palabra. Ensayo en torno a lo judío. Santiago, Chile: Arcis-Lom, 1997. Consultar o texto de ARIGUCCI, David. Enigma e comentário: ensaios sobre literatura e experiência. São Paulo: Ed. Schwartz, 1987.

${ }^{55}$ Os topoi da enciclopédia, da biblioteca, do arquivo, da coleção, os livros de artistas, tornaram-se assuntos pertinentes à arte e ao pensamento contemporâneos. As bibliotecas de Kiefer podem ser consteladas com as 
espectadores dessa obra, ficamos confusos pelo fato de que os livros encadernados em chumbo possam ser associados com letras mortas. A lutuosidade que se desprende desses livros de chumbo, tem um único sentido: arrastar aos leitores à biblioteca. Nesta instalação não temos encontrado um leitor cansado da leitura, essa leitura de uma literatura, um mito, ou talvez de uma história passada que todos se negam a ler voluntariamente chegando a ser tornar leitura imposta por meio da violência. Diante de Terra entre dois rios, contemplando com espanto os cacos de vidro esparsos no chão, o leitor de Kiefer reencontra a cegueira na forma inicial e terrível do testemunho do instante em que a instalação revela-se também uma espécie de Biblioteca da destruição em que fazer visível a mais profunda experiência de abjeção, tem provado, sem saber, a experiência do horror. Kiefer nos faz entrar nas suas instalações, no seu monumentalismo, demandando sempre uma leitura acurada, fundada na filosofia, no mito, na literatura, na história, seu campo é o da alegoria, com a auto-referência e os paradoxos que problematizam a relação da linguagem, a imagem com a verdade e o sentido. Para

obras de artistas tais como Christian Boltanski, Micha Ullman, Ilya Kabakov, Hanna Darboven, Rachel Whitehead. Na filosofia, com o Atlas Mnemosyne de Aby Warburg e as Passagens de Walter Benjamin. Para Leila M. Brasil Danziger, trata-se, na verdade, de antienciclopédias que além do fato de desistirem da totalidade, desconfiam na separação entre fato e ficção, memória e história. O projeto Iluminista da Encyclopédie de Diderot e D'Alembert tentou fazer um inventário dos modos de conhecimento humano e dos espaços habitados, com o intuito de enclausurar em duas lombadas esse conhecimento absoluto. No fichamento enciclopédico, além de serem compilados, os objetos são minuciosamente desmontados, desmembrados por index, rebaixados a seu sentido unitário mínimo. A razão ilustrada tentou acomodar o saber às novas formas de controle dos saberes e disciplinas emergentes. O uso contemporâneo da paixão enciclopédica pelo artistas e escritores contemporâneos (Bohumil Hrabal, Danilo Kîs, Georges Perec, Gonzalo M. Tavares, todos excitados pela leitura de Jorge Luis Borges) é subvertido; seus conteúdos se encontram com gestos irônicos e paródicos. Para Dazinger: "As antienciclopédias contemporâneas não descrevem um mundo de imagens transparentes e ordenadas, como queriam os iluministas, mas sim uma trama opaca, onde textos e imagens desafiam o discurso da afirmação e da semelhança. Seria pouco dizer que dedicam-se à memória; lidam, é inegável, com a memória traumática." Cf. DANZIGER, Leila M. "Tarefa infinita."ibidem, p. 45. 
Benjamin, a alegoria se torna diferente nas mãos do alegorista. A alegoria converte-se peça de um saber oculto. Este é o fundamento do caráter escritural da alegoria. A vontade de saber acumulada nas bibliotecas de chumbo de Kiefer realiza-se na experiência da escritura enquanto imagem. Um trecho de Benjamin, que sugestivamente traça sua leitura sobre o Barroco e seu ciframento escritural, será suficiente aqui:

A riqueza das cifras, que o alegorista encontrou no mundo da criatura, profundamente saturado de história, justifica a queixa de Cohen sobre o "desperdício." Essa riqueza pode ser desproporcional ao poder exercido pela natureza, mas a volúpia com a que significação reina, como um negro sultão no harém das coisas [...] A função da escrita por imagens, do Barroco, não é tanto o desvendamenteo como o desnudamento das coisas sensoriais. O emblemático não mostra a essência "atrás da imagem". ${ }^{56}$

A aventura pictórica de Kiefer é uma máquina geradora de imagens que giram em torno da descomposição pictórica do tempo, da matéria, da narrativa indecifrável e da forma mesma do mistério na pintura. Kiefer, artista da memória, quer mostrar não apenas os cacos desse passado catastrófico, mas a impossibilidade de reinscrevê-los de modo total. Uma passagem de Nelson Brissaac Peixoto, a seguir, detalha o memorialismo atrofiado do pintor a partir da impossibilidade de representar a história na sua totalidade:

Estes livros são como um catálogo: armazenam aquilo que se tenta salvar da desaparição; Um verdadeiro inventário do que restou. "Não é possível representar a história, só seus restos." Kiefer é um colecionador, como os antigos habitantes das passagens. No seu ateliê - como nos livros, se acumulam os detritos de um mundo acabado. ${ }^{57}$

Kiefer não pode ser entendido à luz de uma determinada estetização da catástrofe e muito menos à luz de uma estética voltada para uma normalização moral da representação da dor. O pintor, como em suas

${ }^{56}$ Cf. BENJAMIN, Walter. Drama Barroco. op.cit. p. 207.

${ }^{57}$ Cf. PEIXOTO, N. B. op. cit., p. 242. 
telas e instalações, sulca o caminho pelo qual a arte precisa se reproduzir. Ele nos mostra como a arte, desamarrada das perceptivas classicistas, pode retomar assim o seu papel de transformação (como alquimia) e como local de experimentação e abalo das ideologias (como vanguarda) de turno. Daí sua relação íntima com a dor (trágica) e a ironia (seu legado romântico) corrosiva e ao mesmo tempo auto-reflexiva. ${ }^{58}$ Cathy Caruth aponta uma dimensão talvez

${ }^{58}$ No livro Necesidad de la ironía, Valeriano Bozal descreve os efeitos da institucionalização da arte e de seu significado como objeto de consumo estético no modo de recepção das obras de arte. Com a perda do mundo como referência, a arte justifica sua existência como projeto reflexivo. A arte pesquisa sobre suas formas, seus meios, seus materiais e suas condições de recepção. Os meios artísticos deixam, por assim dizer, de ser meios e passam a ser ferramentas de auto-exploração e autodefinição. Trata-se da descrição básica da arte a partir das vanguardas até a concepção artística encarnada nos textos de Clement Greenberg, figura medular da teoria moderna da arte. A arte moderna, eximida de seu papel representacional apela à sua própria construção como matéria e como meio. Comparece nessa questão o esforço kantiano, como fala Thierry de Duve, da arte procurar suas próprias condições de possibilidade; mas este esforço sempre mostra um sentido aporético, uma figuração que mesmo os críticos e os historiadores da arte olham com perplexidade. A arte que procura sua essência, extremando seus limites, tem chegado à situação de que a maior indagação reflexiva, maior resulta sua indefinição. Contudo, não existe limite que a própria arte não possa ultrapassar. Superou, bem entendido, todas as tribulações irônicas do mictório de Duchamp: retornou à pintura, à escultura, voltaram os objetos, a arquitetura, a literatura, a música, incorporou-se o cinema e a fotografia, meios que, conforme Walter Benjamin, transformaram a experiência da recepção artística por causa de seu caráter reprodutivo. A autonomia, a reflexividade e a reinstalação do estético retornaram como aditamentos de uma arte que se bajulava de ser moderna e autônoma. Esse clamor pelo estético como elemento determinante do artístico encontrou seu nicho teórico nas produções críticas de Clement Greenberg, Michael Fried e Rosalind Krauss. Frente a esse campo de teorização, a arte contemporânea reforça sua postura representacional, sua interdepêndencia com outros discursos e estabelece seu lugar numa sociedade onde o prazer estético também pode ser uma mercadoria. As obras da modernidade artística, despojadas de seu valor negativo, são objetos de contemplação nos museus e adquirem importância como os produtos culturais quintessenciais da sociedade de consumo capitalista. A arte moderna se institucionaliza, perdendo, assim, seus traços mais transgressores. Cf. BOZAL, Valeriano. Necesidad de la ironía. Madrid: Visor, 1999; Cf. LUZ, Afonso; RIVITTI, Thais et al. "Sintoma e intuição." Entrevista com Thierry de Duve. Novos Estudos 79, Novembro 2007, pp. 211-226; Cf. ALCARAZ, Maria. "Síntomas posmodernos y artistas desenfadados." Daimón. Revista de Filosofía. n. 22, 2001, pp. 173-181; Cf. 
vital na compreensão das poéticas da memória: o trabalho, certamente não de superação, mas de certa convivência com o trauma, passa pelo despertar de teor levinasiano para a ética e para a responsabilidade:

Enquanto em "A interpretação dos sonhos Freud" introduz o sonho como uma explicação exemplar (ainda que enigmática) da razão pela qual dormimos - como não enfrentamos adequadamente a morte fora de nós -Lacan sugere que já no coração deste exemplo está o cerne do que mais tarde se tornaria, em Além do princípio do prazer, a noção freudiana de repetição traumática, e especialmente os pesadelos traumáticos que, como diz Freud, "despertam o sonhador para um novo pavor". Na análise de Lacan, o sonho de Freud não é mais sobre um pai dormindo diante de uma morte externa, mas sobre a forma como a própria identidade do pai, como sujeito, em seu despertar traumático, está vinculado ou fundado na morte à qual ele sobreviveu. Isto é, o que o pai não consegue compreender na morte da criança, torna-se o fundamento mesmo de sua identidade de pai. Sugiro que, ao relacionar, portanto, o trauma à própria identidade do eu e à própria relação com os outros, a leitura de Lacan nos mostra que o choque da visão traumática revela, no coração da subjetividade humana, não tanto uma relação epistemológica, mas antes uma relação que pode ser definida como ética, com o real. ${ }^{59}$

FOSTER, Hal. "The art of cynical reason." In: FOSTER, Hal. The return of the real. Cambridge:Massachusetts: MIT University Press, 1996, pp. 99-126.

59 Observa Caruth: "a responsabilidade diante do outro no momento de sua morte (ou morte potencial), [...] ressoa no pensamento ético de Emmanuel Lévinas. Lévinas escreve, de fato, sobre um acordar - éveil à partir de l'autre - que está ligado a um momento fundamental, também associado com o trauma, em "Philosophie et l'éveil". (p. 11). Por que existe o mal? Se Deus é o autor e o sentido da criação, porque está permitindo o mal? Retornam à memória os argumentos de Epicuro, citados por Lactâncio em sua De ira Dei (cap. 13): Se Deus quer suprimir o mal e não pode, é fraco, portanto, não é Deus; e se pode e não quer, é hostil. Colocando- se o dilema em seus justos termos, ou não existe o mal ou Deus é responsável pela sua existência. Mal, aqui, vem entendido como mal físico, mal moral e penúria espiritual. Como diz Emmanuel Lévinas, o mal é a negatividade enraizada na própria constituição do homem. Pode ser uma negatividade referida a certos estados da existência humana, ou bem pode se configurar como negatividade absoluta, como deficiência ontológica insuprimível. A dor do inocente, o sofrimento inútil e inexplicável, que provoca o desabafo contido nas duras e rebeldes palavras de Jó, tem recebido, como se conhece, respostas mitológicas, religiosas e filosóficas de distintos gêneros. 
A rememoração está presente como a quintessência da concepção teológica de história entre os judeus. Kiefer, a igual título de Benjamin, recorre à Cabala, pois a racionalização do campo histórico não tem mais recurso à luta de classes ou à autotelia. Em Brüch der Gefässe (Quebra de Vasos) (fig.7), por exemplo, grandes lâminas de vidro misturam-se aos livros de chumbo colocados em três grandes prateleiras.

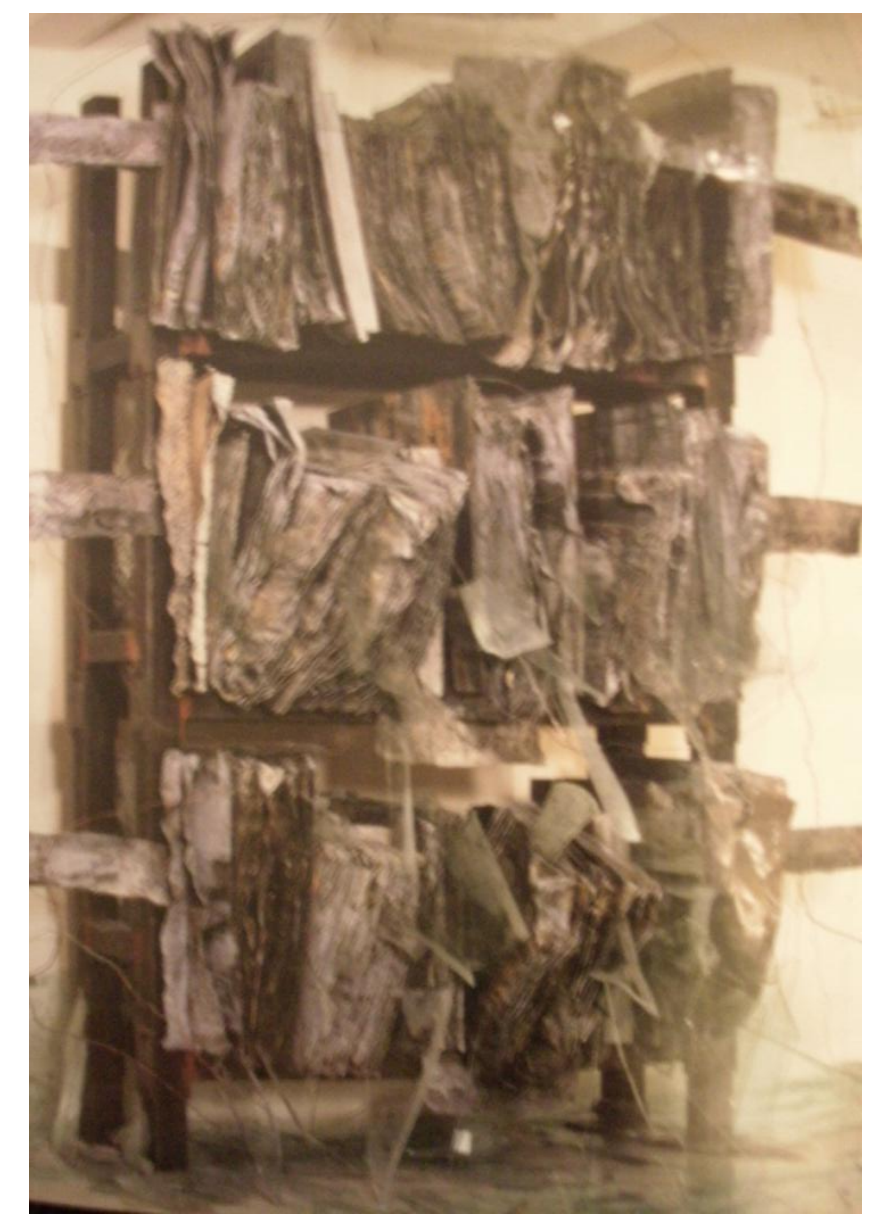

Figura 7. Quebra de Vasos/Brüch der Gefässe, 1990. Escultura em ferro, com acrílico, chumbo, vidro e fio de cobre. $380 \times 350 \times 150 \mathrm{~cm}$.

Museu de Arte de Saint Louis, Missouri.

No terreno filosófico, as diferentes tentativas para dar sentido à presença do mal têm procurado sempre ir além do mero fenômeno do sofrimento ou da dor. O mal vem enquadrado, assim, em uma ordem cósmica mais ampla, dentro da qual resulta ser funcional e é pensado dentro de critérios de justiça retributiva. Cf. LÉVINAS, Emmanuel. Autrement qu'être ou audelà de l'essence. La Haye: Martinus Nijhoo, 1974; Cf. CARUTH, Cathy. "Modalidades do despertar traumático", In: SELIGMANN-SILVA, Márcio. Catástrofe e Representação, op. cit., p. 112. 
Enormes estilhaços se despencam das páginas e espalham-se caoticamente pelo chão, produzindo um verdadeiro campo minado que envolve a obra obstaculizando sua apreciação. Os vidros abatidos por uma catástrofe distante, porém, ainda visível, perpetrada por Belzebu ou por Lilith e suas filhas, caem desventuradamente de pesados volumes recobertos de chumbo azulcinza, cinza-verde, verde e cinza, por vezes mantido por uma lâmina de ferro. Trata-se, talvez, de livros incunáveis, anais gloriosos de uma catástrofe passada ou vindoura, todos catalogados, laminados pelo tempo. Embora seja a ação da escultura que mais articule a idéia de integridade, os estilhaços pressupõem a existência de outra metade, reafirmando o caráter fragmentário da obra. Nela inscrevemse, alternadamente em um percurso circular, as palavras Ain e Sof, que em hebraico significam, respectivamente, nada e infinito. Fios de arame percorrem as estantes de cima a baixo, reforçando essa lábil circularidade do conjunto. Nove pequenas chapas retangulares de chumbo dispõem-se simetricamente à esquerda e à direita, no centro e também na parte superior da estante. Uma décima chapa de características semelhantes encontra-se no chão, misturada aos cacos de vidro e religada à estante pelos fios de arame. As dez chapas contêm os nomes das dez Sefirót, ${ }^{60}$ os dez atributos divinos,

${ }^{60}$ As sĕfirot organizam-se em três colunas: masculina ou positiva, feminina ou negativa e central ou intermédia e, além do mais, se distribuem em quatro níveis ou mundos: espiritual, intelectual, emocional e físico; 1) keter é a coroa, a fonte, marca a entrada ao mundo infinito, representa a inteligência, 2) hokmah é a figura do padre universal, é a sabedoria eterna, inspirada, o conhecimento puro; 3) binah é a mãe universal, é a compreensão; 4) hesed representa o šabbat, o amor e a doçura que os humanos podemos compartilhar; 5) gĕburah contém a energia do juízo e a restrição e exige que haja conseqüências de nossos atos; 6) tiferet leva a energia da beleza e o equilíbrio ideal, é o coração da árvore da vida; 7) nĕsah leva a energia da vitória e representa a idéia de continuidade e eternidade; 8) hod associa-se com a profecia, é a contrapartida de nĕsah, nela materializa-se a potência masculina de hesed e nĕsah, é análogo ao óvulo na concepção humana; 9) yěsod é como uma grande reserva onde se reúnem todas as sěfirot que estão sobre ela; 10) malkut, os cabalistas a chamam "o reino," é a mais baixa das sěfirot, é o mundo do universo material. Kiefer tenta estabelecer uma relação entre as dez sĕfirot e os dez 
noções caras à Cabala. ${ }^{61}$ A Quebra de Vasos representa um conceito estrutural na literatura cabalística, pois se trata do momento em que se introduz o Mal no mundo. No início havia apenas Deus sem limites - Ein Sof -, o Ser Infinito. ${ }^{62}$ Como, então, pode existir o mundo, se Deus está em toda parte? Para deixar lugar à criação, Deus contraiuse em Si mesmo, retirou-se em um auto- exílio. Esse momento de contração é conhecido como o Tzimtzum, idéia que reverbera nas

mandamentos; de fato, cada sĕfirah representa uma qualidade essencial de cada mandamento, a escala representada pelas dez sĕfirot é, em realidade, uma escala similar à escala de Jacó. Cf. Carmen BENITO-VESSELS, La palabra en el tiempo de las letras. Una historia heterodoxa. México: Fondo de Cultura Económica, 2007.

${ }^{61}$ Cabala também tem como acepções tradição e receber. Não pode se falar em uma doutrina cabalística programática; na Cabala não existem dogmas nem regras particulares, a Cabala é uma doutrina da vida. A palavra Cabala escreve-se com $\mathrm{K}$ quando aludimos à tradição judaica, com $\mathrm{C}$ quando se refere à tradição cristã e com $Q$ quando se reporta à tradição hermética egípcia. O conceito da palavra, da escritura, do devekuth ou comunhão, do conhecimento através da letra são princípios comuns às três tradições. O mundo da Cabala organiza-se em níveis ou camadas de existência: 1) emanação ou pensamento divino (Atziluth) 2) criação (Briah) 3) formação (yĕsirah) e 4) expressão (Assiah). No primeiro nível encontrase Elohim ou os diferentes aspectos de Deus, a divindade descende às distintas esferas da realidade e se faz presente em todas as coisas. Segundo os cabalistas, a alma tem três partes: ruah, onde se localiza a consciência espiritual, neshmah, ou a faísca que o homem recebe da divindade, e nefeš que é o sopro da vida. Um dos princípios básicos da Cabala propõe o Messias como um ser que está dentro de cada um de nós. Cf. ABRAHAM, Azriel; WAXMAN, Bob. Kabbalah simply stated. A Conversation with the Rabbi. Minnesota: Paragon House, 2004, pp. 1-26; Cf. BENITO-VESSELS, Carmen. ibidem, p. 140.

$62 \mathrm{O}$ vidro e as pedras preciosas ganham suas simbologias da mística flamenca medieval e dos Cânticos dos Cânticos, assim como nos capítulos finais do Evangelho de São Jõao, onde se descreve a nova Jerusalém como uma cidade de ouro, clara como o cristal. O vidro - que se associa com o cristal, algo assim como um cristal aprimorado - aparece como um novo material transformado em demiurgo da renovação espiritual. Lembremos que o vidro expressionista está associado com o reflexo da luz. A arquitetura de cristal expressionista não deseja participar da falta de sensualidade objetiva, buscando uma "nova calidez." $O$ interesse de Benjamin por esse material sem aura ("Experiência e pobreza") tem inspiração scheebertiana. Benjamin entende que, com Paul Scheebart, a arquitetura funcional pode ser um momento de transição, talvez, em direção a uma nova calidez do cristal policromado transfigurador. Cf. PENHT, Wolgang. La arquitetura expresionista. Barcelona: Gustavo Gili, 1975. 
telas de Kiefer, afirmando, ao mesmo tempo, uma criação e uma destruição, ou seja, uma contração e uma explosão. Ressignificada por Isaak Lúria, a idéia do Tzimtzum não significa mais a concentração de Deus em um único ponto, mas sua retração longe de um ponto. Deus recua de Si mesmo. Como afirma Gershom Scholem, ${ }^{63}$ o Tzimtzum representa o símbolo mais profundo do abandono que possamos imaginar. Segundo Lúria, a retração de Deus ocorreu na esfera do julgamento ou rigor (sefirát de din). Em nosso mundo, constituído pelo espaço vago após o exílio interior de Deus, permaneceram partículas do seu rigor somadas à partículas de sua luz. O princípio ativo, a centelha da criação, a letra Yod, inicial de $Y H W H$, representa uma imagem do nome divino. Os vasos (kelim), motivo recorrente na literatura cabalística, encarnam a criação propriamente falada, metáfora sugerida para toda porção de matéria que ampara a luz divina. O primeiro homem criado (Adam Kadmon) é considerado o vaso culminante da criação. Após uma luta complexa entre a luz da letra Yod e os resíduos da luz de Deus que restaram no espaço liberado após sua retração, a intensidade dessa disputa de luz fez com que os vasos das Sefirót inferiores, presentes em Adam Kadmon, não resistissem e quebrassem. Grande parte da luz trazida pela letra Yod, esse princípio ativo, retornou imediatamente à sua origem divina. Pequenas partículas, no entanto, despencaram com os vasos. Separadas da fonte, misturadas aos remanescentes do rigor divino que constituem o amálgama dos vasos, essas porções de luz degeneraram, adquiriram identidade própria se transformando nas forças malignas do universo. Como Scholem explica:

63 Cf. SCHOLEM, Gershom. As grandes correntes da mística judaica. Trad. Dora Ruhman. São Paulo: Perspectiva, 1972. 
O processo de restauração é a terceira etapa na cosmogonia luriânica que segue não apenas o zimzum acima mencionado, mas igualmente a segunda etapa, assim chamada quebra de vasos, ou shevirah, "a morte dos reis." Isto era nada menos do que uma catástrofe cósmica [...] Os vasos foram quebrados, a fim de pavimentar o caminho para a recompensa e punição nos submundos que estão supostos a emergir como a última fase da criação. Depois da quebra de vasos, o processo de restauração torna-se uma tarefa que os seres humanos devem enfrentar, recreando os vínculos originários que acostumavam conectar o homem com o Ein-Sof. O processo de restauração é referido como tikkun, o mais complexo e elaborado processo de todas as três etapas estabelecidas por Lúria. Como um processo restaurador e sanador, se estende para o tempo presente [...] O narrador torna-se parte desse processo restaurador - ele embarcou involuntariamente nesta viagem do tikkun. Devido ao poder do mal sobre a humanidade, a duração deste processo está imensuravelmente estendida, mas - aqui nós entramos a um ponto na doutrina de Lúria que apelou muito fortemente ao indivíduo. ${ }^{64}$

A Quebra de Vasos de Kiefer representa um universo alegórico, suas são ruínas circulares, essa Babel em escombros permanece presente na linguagem dos gnósticos e leitores da Cabala: a imagem do mundo como um encadeamento de sílabas escuras, a idéia de uma palavra absoluta o de uma letra cósmica: as 10 sefirot, Ain e Sof. A obra de Kiefer conjetura a soma de conhecimento prefigurada em

64 "The process of restoration is the third step in Lurianic cosmogony that follows not only the aforementioned zimzum, but also the second step, the so-called "breaking of the vessels," or shevirah, the "death of the kings." This was nothing less than a cosmic catastrophe [...] The vessels were broken in order to pave the way for reward and punishment in the lower worlds that are due to emerge as the last phase of the creation". Following the breaking of the vessels, the process of restoration becomes a task human beings must face, recreating the original bonds that used to connect man with Ein-Sof. The process of restoration is referred to as tikkun, the most complex and elaborate process of all three stages laid out by Luria. As a healing and restoring process, it extends into the present time [...] The narrator becomes part of this restorative process - he has involuntarily embarked on this journey of tikkun. Owing to the power of evil over mankind, the duration of this process is immeasurably extended, but - and here we come to a point in Luria's doctrine which appealed very strongly to the individual". Cf. SCHOLEM, Gerschom. On the Kabbalah and its symbolism. New York: Schocken Books, 1965, p. 67. 
uma obra última que contém todas as permutações consideráveis do tempo e da palavra. Para Benjamin, "a escrita alfabética, enquanto combinação de átomos gráficos, está mais afastada que qualquer outra escrita sagrada". ${ }^{65}$ Essa vontade de preservar o caráter sagrado da escrita a expõe a outro alfabeto. Para Kiefer a escritura representa um modo genuíno de se aproximar ao mistério do nome. Biblioteca e Cabala vão se expandindo até o infinito tecendo uma imagem grafológica do universo. Para Kiefer existe uma permanência de uma história, os traços firmes de uma biografia que, apesar da diáspora babélica, redescobre através dos livros os fragmentos de uma identidade perdida. A Quebra dos Vasos parece indicar o momento pecaminoso do encontro entre espírito e matéria, pois toda gênesis articula as transformações dolorosas que Ihe são inerentes. Kiefer transforma esse momento inaugural do Mal em estética da catástrofe. O Mal aparece em meio à decisão de retração de Deus, dando lugar à arte, justa e pertinente metáfora para o acontecimento da pintura de Kiefer. Como afirmava Scholem, ${ }^{66}$ no judaísmo bíblico o Mal está "entrelaçado na textura do mundo," na escritura de Deus existe um lugar destacado para ele; mas o judaísmo enxerga nele, não uma possibilidade de fuga deste mundo malfadado, a manifestação evidente de uma criação degradada, senão a pluralidade de Deus, sua extraordinária e insondável complexidade. ${ }^{67}$ Por meio do Mal,

${ }^{65}$ Cf. BENJAMIN, Walter. Drama Barroco, op. cit., p. 198.

${ }^{66}$ Cf. SCHOLEM, Gershom. As grandes correntes da mística judaica. op. cit., p. 137.

${ }^{67}$ A imagem da história como um acúmulo de fragmentos, tão preciosa para a reflexão benjaminiana, tem seu fundamento na mística cabalística. Benjamin elaborou sobre essa visão da história como uma catástrofe no seu ensaio sobre a tradução e indicou em que medida essa atividade promete não uma cópia do comunicado na língua original mas sim uma salvação do tikkun: "Assim como os cacos de um vaso, para poderem ser recompostos, devem seguir-se uns aos outros nos menores detalhes, o modo de designar do original, fazendo assim com que ambos sejam reconhecidos como fragmentos de uma língua maior, como cacos são fragmentos de um vaso. E precisamente por isso, ela deve abstrair do propósito de comunicar." Trad. Susana Kampff Lages. Márcio Seligmann-Silva:"Assim como os cacos de um vaso para serem reencaixados devem seguir uns aos outros nos 
Deus acompanha ao homem pelas trevas da vida para fazer possível a plenitude da luz; embora também isto constitua um sinal ante a vanitas da vida, emerge como sinal que mostra aos homens seus próprios limites. O pensamento gnóstico também se fará cargo deste pessimismo radical. À diferença das interpretações rabínicas, os gnósticos encontrarão sua razão de ser não no homem, senão na mesma criação. Talvez por isso, para Kiefer, o gnóstico mascarado como o chama Jean-Nöel Vuarnet, o estalido do mundo, a certeza de sua catástrofe, constitua uma espera e ao mesmo tempo um cumprimento. Na catástrofe está o sinal porque dela depreendeu-se o começo e ela está nos esperando enquanto concluímos nosso percurso.

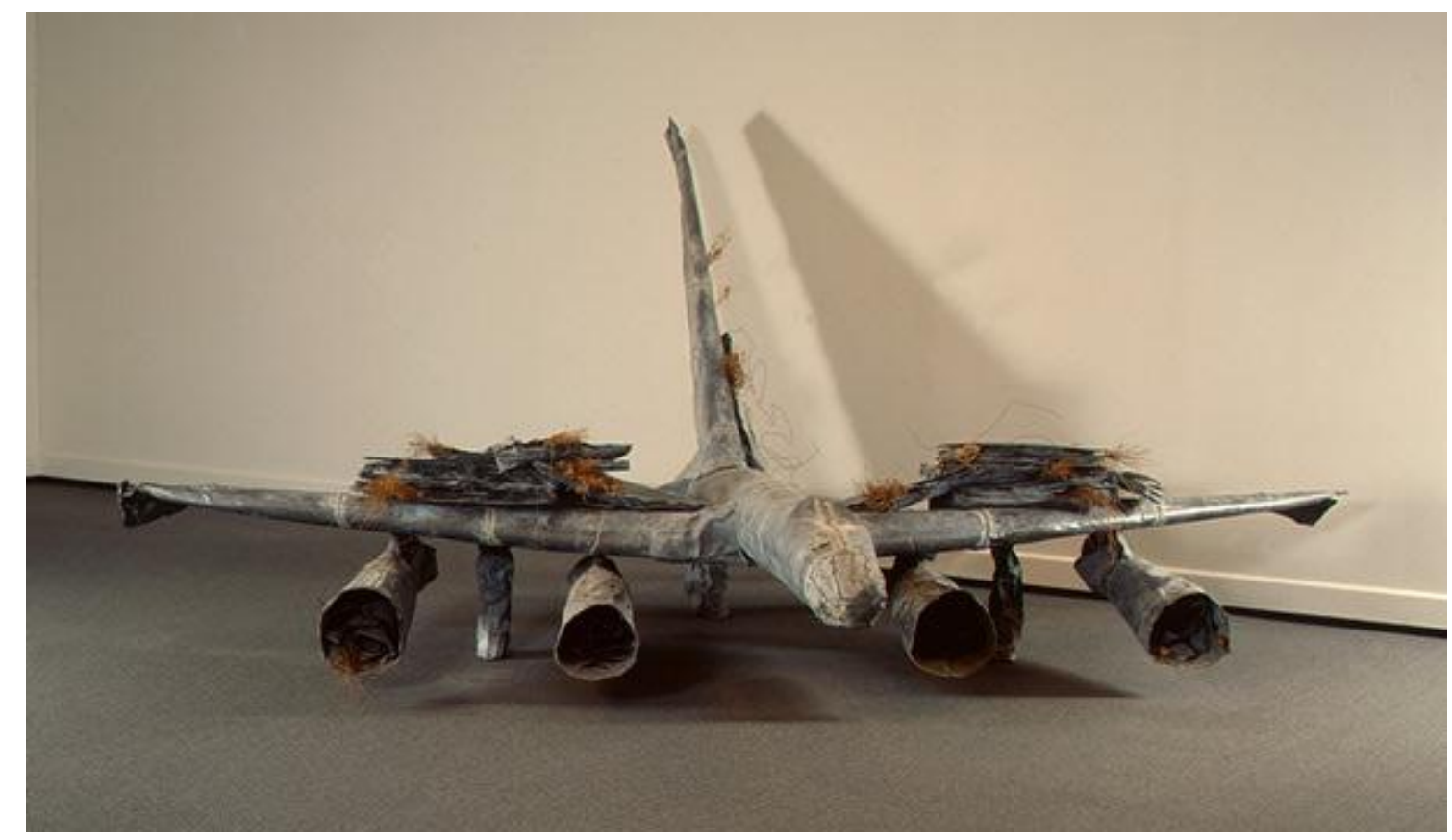

Figura 8. O Anjo da História, 1989. Escultura em chumbo, vidro e papoula. 250 × 630 × $650 \mathrm{~cm}$. Galeria Nacional de Washington

mínimos detalhes, mas não devem ser iguais, assim a tradução ao invés de se igualar ao sentido do oirginal, deve antes reconstruir com amor na própria língua o seu modo de intentar até os mpinimos detalhes para tornar, desse modo, ambas [línguas] reconhecíveis como cacos e ruínas de um vaso, como ruínas de uma linguagem maior." Cf. SELIGMANN-SILVA, M. História, memória e literatura. p. 464. Cf. BENJAMIN, W. "A tarefa do tradutor." In: BRANCO, Lucia C. "A tarefa do tradutor. Quatro traduções para o português." (trad. Susana Kampff Lages) Belo Horizonte: UFMG, pp. 66-81. 
Para Kiefer, o homem encontra o ser na efetividade criadora do Mal, é na sua radical latência e quase na extenuação demiúrgica do Anjo da História (fig. 8) que o gnóstico pode encontrar o sendero da verdade. Neste sendero da verdade, poderia se dizer, encontramos a experiência de Benjamin. Seu mundo intelectual está completamente atravessado pelo romantismo alemão com alguns elementos da cosmovisão judaica. Benjamin retomou, por meio de suas conversas com Scholem durante os anos finais da Primeira Guerra Mundial, seus laços com a literatura judaica, se fazendo cargo de um sentimento dividido por ambas as tradições: a idéia de que a catástrofe e o fracasso esperam ao homem moderno e que apenas no extremo do desassossego ergue-se a esperança. Ricardo Forster, dedicado ao estudo da presença judaica na obra de Benjamin, revela o alcance dessa leitura no autor para a gestação de seu conceito de messianismo:

Benjamin, en todo caso, al reunir la alegoría barroca, el pesimismo romántico y el catastrofismo de cierta tradición judía fecunda su idea del mesianismo: "que, al metamorfosearse, continúa desempeñando en la última parte de su obra um papel primordia" adquiriendo en él "un carácter profundamente apocalíptico, destructor. El principio de destrucción [...] sugiere ahora como un aspecto de la redención, que se manifiesta en la inmanencia y se realiza a través de la historia del trabajo humano. ${ }^{68}$

Como os anjos talmúdicos descritos por Benjamin, O Anjo da História de Kiefer, lampejante e franzino apesar de seu material ser de chumbo. Como sabemos, os anjos - que anunciam catástrofes, mas possuem também função redentora - introduzem um tema essencial no pensamento de Benjamin, sua crítica a uma "concepção do tempo homogêneo e linear". Ao comentar o anúncio da Revista Angelus Novus, Jeanne-Marie Gagnebin observa que:

[...] os anjos talmúdicos são o indício de um outro tempo que o das comemorações; eles introduzem, na cronologia

${ }^{68}$ Cf. FORSTER, R. "Walter Benjamin y el judaísmo."op. cit., p. 92. 
linear e morosa que costumamos chamar de história, uma cesura imperceptível mas que transforma esse continuum histórico, tão ocupado a se perpetuar a si mesmo. ${ }^{69}$

O avião de Kiefer parece ofuscante e aniquilador principalmente após uma superexposição luminosa, a silhueta humana desaparece, deixando-nos momentaneamente cegos hipersensibilizados pela aparição. O título da obra - O Anjo da história - remete à união dos aspectos de aniquilação e júbilo, que marcam o êxtase e que para Benjamin constitui "o conceito de uma verdadeira atualidade: fulgurante, evanescente e destruidora". ${ }^{70}$ Com Benjamin, se defaz a suposta divisão entre história e memória, no texto de Márcio Seligmann-Silva encontramos uma boa síntese, quando afirma:

O tempo para ele não é vazio mas sim denso, poroso matérico. Nas suas mãos a teoria da história, antes ligada à ciência da história, passa a ser uma teoria da Memória e assume os contornos de um trabalho mais próximo do artesanal, no qual o "historiador" deixa as marcas digitais na sua obra. O tempo deve deixar sua marca no espaço; ele é telúrico, pesado: como nas esculturas e quadros de um Anselm Kiefer. ${ }^{71}$

A obra de Kiefer também realiza sua tarefa angelical, compreendida como aniquilação e redenção, pois é atravessada por operações simbólicas e também concretas (inundar, queimar, transformar, cortar, mutilar, detonar, quebrar, rasgar, acumular) que procuram a destruição, como meio de vivenciar e talvez compreender (o que não significa de modo algum justificar) a banalidade do $\mathrm{Mal}^{72}$ que

${ }^{69}$ Cf. GAGNEBIN, Jeanne Marie. "O hino, a brisa e a tempestade: dos anjos em Walter Benjamin." In: GAGNEBIN, J. M. Sete aulas sobre linguagem, memória e história, Rio de Janeiro: Imago, 1997, pp. 125- 126.

70 Cf. BENJAMIN,Walter. "Teses sobre o conceito de história". op. cit., p. 167.

${ }^{71}$ Cf. SELIGMANN-SILVA, Márcio. "A catástrofe do cotidiano, a apocalíptica e a redentora. Sobre Walter Benjamin e a escritura da memória." In: DUARTE, Rodrigo; FIGUEIREDO, V. (orgs.), Mimeses e expressão. Belo Horizonte: Editora UFMG, 2001, p. 366.

${ }^{72}$ Em uma notória passagem de Os Irmãos Karamazov, e descrevendo ao íncubo do Ivan Karamazov, Dostoiésvski nos dá esta sugestiva imagem do mal, do demônio. Na verdade, o diabo não tem outro ideal do que se 
constitui parte de sua herança. Caberia ainda mencionar, como destaca Leila Maria Brasil Danziger, outro artista cuja poética não se relaciona necessariamente ao trabalho da memória, mas diretamente à ética: Barnett Newmann e a atualidade fulgurante de sua pintura, associada por Lyotard, em texto extraviado e extraviante, ao tema das Anunciações e das Epifanias e dos Profetas. Lyotard comenta: "Um quadro de Newman é um anjo. Não anuncia nada, é o próprio anúncio." ${ }^{13}$ Muito já se falou sobre o interesse de Newman, a igual

encarnar definitivamente em uma faxineira grotesca e obesa, e logo fazer acreditar em tudo o que ela sustenta como verdades, além de ir à igreja e acender uma vela como um ato de devoção. O mal cotidiano que emerge do íncubo de Ivan Karamazov é o mal tornado banal, habitual. O diabo, ao se tornar banal, ganha realidade e eficácia, executa sua encarnação no mundo, vestindo as roupagens grandiosas e terríveis condizentes ao excesso luciferino, misturando-se de tal modo com o habitual que, graças a este seu caráter mostrengo, logra que seja esquecida até sua própria existência. Como é sabido, o tema da banalidade do mal constitui o resort da reportagem de Hannah Arendt sobre o processo relacionado como criminoso de guerra nazista Adolf Eichmann. Contudo, este assunto percorre, em geral, outros escritos de Arendt como, por exemplo, seu livro de juventude sobre Rachel Varnhagen. Pode ser banal, de uma parte, a figura de Eichmann (swallow), o relato de suas ações e a maneira na qual ele obedecia as funções que Ihe eram próprias. O extermínio dos judeus é executado com uma atitude serviçal e rotineira, do mesmo modo no qual o pequeno burguês, honesto funcionário e pai de família procede com suas tarefas. De outra parte, no entanto, a banalidade é justamente o que vem desesperadamente buscado por quem tem consciência de estar excluído da própria comunidade civil por conta de sua exceção, a despeito de todas as tentativas de assimilação, no contexto social e estatal em que vive a própria história. Por isso, fala Arendt, apropriando-se das palavras de Rachel Varnhagen, que "para quem deseja encarnar a vida mesma, tanto em seu inquietante primor como na banalidade inevitável e vulgar, isto pode ser mais importante que se sentir excepcional". A banalidade em si própria, torna-se, para o judeu, um fim a ser alcançado se não for um espelhismo, o espelhismo de uma impossível assimilação. Cf. ARENDT, Hannah. Raquel Varnhagen. Judia alemã na época do romantismo. Trads. Antônio Trânsito e Gernot Kludash. Rio de Janeiro: Relume De umará, 1994.

${ }^{73}$ Lyotard, decidido em mostrar que a obra de Barnett Newman pertence à estética do sublime e que, de um modo mais geral, as vanguardas artísticas contemporâneas nomeadamente a arte abstrata e arte minimalista "estão em germe na estética kantiana do sublime", escolhe este artista como exemplo, por antonomasia, da estética do sublime que está em jogo no hic et nunc da própria obra, no acontecimento que ela é, em si, como artefato. Daí que o filósofo vá buscar em Kant o conceito de apresentação negativa. A partir deste conceito elabora uma definição de sublime como "apresentação de que existe inapresentável". Lyotard introduz destarte a 
título que Kiefer, pela Cabala. A partir do conceito de Tzim-tzum momento da grande retração de Deus de si mesmo dando lugar à criação -, surge o Zip, o vazio vertical que corta suas regiões de cor. Por mais abstrata que sejam as obras, elas não deixam de convocar a tragédia de seu tempo. Pouco antes da segunda guerra, Barnett Newman escrevia:

Chegamos finalmente à posição trágica dos gregos [...] $A$ nova tragédia é de novo a tragédia da ação no caos da sociedade: é interessante notar que esta idéia grega se encontra também entre os hebreus. ${ }^{74}$

Para o pintor, a nova abstração deve se entregar novamente à liturgia trágica. Newman, enervado, afasta-se da pintura no início dos anos 1940, "enfastiado com idéias e ideologias da época", como conta Mel Bochner. ${ }^{75}$ Seu esforço encaminha-se em direção a uma abstração distinta da tradicional, pois esta, despojada de tema

ideia de um sublime particular da arte moderna, a partir do qual se define uma estética historicamente determinada: aquela que tem origem no Romantismo e é levada a cabo plenamente nas vanguardas pictóricas do nosso século. O artigo de Barnett Newman intitulado "The sublime is Now," após fazer uma curta travessia que vá de Longino a Burke, Newman conclui que a arte moderna européia, desde os impressionistas, passando pelos cubistas, Dadá, Mondrian, foi incapaz de se desembaraçar do conceito de beleza (apesar de ter nascido da vontade de aniquilá-lo, diz Newman). Esta abortada missão histórica estaria, segundo o artista, a ser levado a cabo na América, onde, relaxados do peso da cultura européia, os artistas podem negar "toda relação entre a arte, a beleza e a procura da beleza". A questão colocada para esses artistas não é "que pintar?", mas "como criar uma arte sublime?", num tempo onde se perdeu toda a transcêndencia e elevação que garantiam a sublimidade. Esta arte sublime idealizada por Newman, é uma arte desamarrada de toda nostalgia, de todo olhar nostálgico da história. Dessa maneira Newman vai procura no "terror of Self" a matéria de sua pintura. Esse terror do que não pode ser conhecido. Cf. LYOTARD, Jean-François. "Barnett Newman. O instante." Revista Gávea n. 4, Rio de Janeiro, PUC-Rio de Janeiro, janeiro 1987, p. 84; Cf. Georges DidiHuberman "Supposition du lieu: L'apparition du lontain." In: DIDIHUBERMAN, Georges. Devant le temps. Paris: Minuit, 2000, pp. 248-260; Cf. NEWMAN, Barnett. "The sublime is now." In: HARRISON, Charles; WOOD, Paul (orgs.). Art in theory 1900-1990. Oxford: Basil Blackwell, 1992.

74 Cf. BOCHNER, Mel. "Barnett Newman: pintura escrita/escrita pintura." Arte e Ensaio, n. 9, Rio de Janeiro: EBA/UFRJ, 2002, p. 71.

${ }^{75}$ Idem, ibidem., p. 71. 
(subject matter), permanece comprometida "exclusivamente com seus meios, com formas geométricas em si mesmas". Bochner afirma que para Newman, o único verdadeiro tema do artista é a reunião entre ética e estética: "Se a arte deve se dirigir ao sublime, a pintura deve tornar-se uma questão ética, um guia para se distinguir o certo do errado". ${ }^{76}$

Se, para Newman, a criação está engajada com a tragédia como fundamento, para Kiefer, a atividade pictórica é, paradoxalmente, sempre associada a gestos alternados de construção e destruição. Seu processo de formalização traz, esteticamente, uma pulsão pela destruição. Nesta parte de nosso trabalho, encontramos a elaboração do conceito de história em Benjamin - cuja missão é a de responder aos desafios políticos da sua época ("As teses sobre o conceito de história" foram redigidas entre os últimos meses de 1939 e os primeiros de 1940, embora se encontrem formulações antecipatórias em um texto publicado em 1915 "Sobre a vida dos estudantes") como proposição de categorias capazes de representar uma idéia de salvação (eine rettenden Einfall) [um estalo súbito da idéia de salvação] para a humanidade, o que será importante para Kiefer.

Com uma concepção extravagante do materialismo histórico, a utopia identificável em certas articulações da história, e que em nada se relaciona com uma promessa cuja efetivação é sempre diferida no espaço ou no tempo, Benjamin faz apelo a uma verdade escatológica como critério de conhecimento histórico, isto é, em um sentido imanente que insere uma catastrophica no seio da história justamente para resgatar o que, nesta, perdeu-se com as concepções naturalistas do tempo histórico - aquelas que estão na base do historicismo e do seu correlato material, o conceito de progresso. A famosa diatribe benjaminiana contra o progresso é o resultado de sua

${ }^{76}$ Idem, ibidem, p. 72. 
concepção da historiografia como destruição da totalidade, a leitura de Márcio Seligmann-Silva insufla esta leitura:

Mas Benjamin nunca foi "apenas" um "pensador e filósofo do tempo": ele também era um teórico das imagens e da dimensão espacial das mesmas. Tempo e espaço não constituíam para ele - kantianamente - apenas a grade transcendental do nosso modo de pensar; assim como a História não era o discorrer linear do tempo rumo à sociedade perfeitamente "racional." Antes, Benjamin estava preocupado em estabelecer, ou, na verdade, em desvendar o elemento espacial que envolve e detém o tempo. A sua reflexão sobre a História valoriza a sua interrupção pontual - determinada num aqui e agora; privilegia a cesura no tempo: o verso-volta, a dança em ziguezague e não a prosa linear. O tempo para ele não é vazio, mas sim denso, poroso -matérico. Nas suas mãos, a teoria da História, antes ligada à ciência da História, passa a ser uma teoria da memória e assume os contornos de um trabalho mais próximo do artesanal, no qual o "historiador" deixa as marcas digitais na sua obra. O tempo deve deixar sua marca no espaço; ele é telúrico, pesado: como nas esculturas e quadros de um Anselm Kiefer. ${ }^{77}$

O recurso de Benjamin a certas categorias teológicas foi quase sempre encarado como tributário da suas incursões no judaísmo e, portanto, sujeito às mesmas ambigüidades e hesitações com que, ao longo da sua obra, faz emergir um cenário cultural judaico. A correspondência com seu amigo Scholem é bastante esclarecedora. As suas intuições de uma ordem messiânica tornam-se statement quando, na terceira tese, Benjamin diz "nada do que aconteceu deve ser dado por perdido". Decerto, somente a uma humanidade redimida cabe plenamente em herança o seu passado. O que significa: "só a uma humanidade redimida o passado se tornou citável em cada um de seus momentos. "178 Kiefer acatou este ensinamento, extremando este inesgotável jogo da citação com o qual, não define apenas sua

77 Cf. SELIGMANN-SILVA, Márcio. "Catástrofe, história e memória em Walter Benjamin e Chris Marker: a escritura da memória." In: SELIGMANN-SILVA, Márcio, (org.). História, memória, literatura. O testemunho na era das catástrofes. Campinas, São Paulo: Editora UNICAMP, 2003, pp. 391-418.

${ }^{78}$ Cf. BENJAMIN, Walter. Drama Barroco. op. cit., p. 23. 
estratégia para assaltar a vulnerabilidade da cultura alemã do pósguerra, senão que também oferece imagens tão particulares onde entrelaça a idéia de catástrofe com sua percepção que nossa época está sendo mais uma vez assombrada por uma nova forma de barbárie, nos brindando com uma certeza, que emerge constestatariamente, de que o cumprimento dos tempos ainda espera por uma transformação. Para Benjamin, o passado tem sempre um grau de segredo que o torna redimível e carregado de agoricidade, de Jetztzeit. Benjamin concebe a história, seus encadeamentos e seus desprendimentos, a partir da idéia da temporalidade messiânica que se opõe à conceição especificamente moderna do progresso profano da história, se apropriando da idéia judaica do jetztzeit, como escreve Franz Rosenzweig. Os traços desta redenção despontam, inesperados, em detalhes e fragmentos das telas de Kiefer: Jerusalém, Zweistromland, Inneraum. O tema messiânico é inseparável da idéia de ruptura da continuidade histórica e do corte com a tradição. Sem a idéia da redenção, não poderíamos compreender aquela de uma responsabilidade revolucionária em relação ao passado, entendida como missão redentora. "Só o próprio Messias completa todo o acontecer histórico (vollende alles historische Geshehen)" [acontecimento total da História]. ${ }^{79}$ Precisamente no sentido em que apenas ele redime, termina a relação entre esse acontecer e o messiânico. Por isso, como escreve António Guerreiro: "[...] o reino de Deus não é o telos da Dynamis histórica; ele não pode ser considerado como meta (Ziel). De um ponto de vista histórico, é o termo (Ende) e não a meta." 80

A ordem do profano não pode ser construída com base no pensamento de Deus, por isso a teocracia não tem nenhum sentido político, mas apenas um sentido religioso. Parece-nos que as ruínas e

\footnotetext{
${ }^{79}$ Idem, ibidem, p. 187.

${ }^{80}$ Cf. GUERREIRO, Antônio. O acento agudo do presente. Portugal: Cotovia, 2000, p. 17.
} 
as explosões em Kiefer têm este sentido imanente da obra iluminada a partir da própria obra, como em Benjamin. Para Benjamin, a crítica deveria, então, fundamentalmente, iniciar com o comentário, se bem que a sua meta última seja a descoberta do conteúdo da verdade da obra, que, ao final do ato crítico, tornará a se reunir com o conteúdo coisal. A partir da interpretação do conteúdo coisal de "As Afinidades Eletivas de Goethe", como conteúdo mítico, a oposição entre logos e verdade de um lado, e de mito por outro, torna-se uma argumentação própria da Aufklärung. A tensão mito e antimito - que para Adorno não deixa de ser aquela de todo o pensamento de Benjamin - reflete - se justamente nos pólos determinantes da filosofia da linguagem. Mito e antimito, violência e redenção são os temas comuns a Kiefer e Benjamin.

Cogitamos que o desejo de Kiefer é certamente acordar do pesadelo da história nazista, banir, deixar para trás o terror e os monstros. Situado perigosamente perto do abismo que pinta, ele se mantém lá, sem cair no silêncio, nem na tentação de se autodestruir. Entretanto, seu reconhecimento do pesadelo da história revolucionária não acaba na tendenciosa post-histoire; por outro lado, Kiefer não cede aos tentáculos do cinismo. Nisso, sua estética de resistência consegue convencer como obra de arte. Trata-se da história do fascismo nazista e stalinista, os dois piores inimigos da experimentação estética, que Ihe revela a própria estrutura mais profunda de seu fazer artístico. Assistimos uma crítica mais abrangente, porque não destaca apenas as mais avançadas formas de solução artística. Benjaminianamente, Kiefer pretende instrumentalizar as potências expressivas da arte de épocas passadas para restituir um espaço de resistência no presente. Como nos adverte Andreas Huyssen, ${ }^{81}$ a apropriação do passado cultural permanece dialogicamente relacionada com as contingências

81 Cf. HUYSSEN, Andreas. Memórias do Modernismo. Trad. Patrícia Farias Rio de Janeiro: UFRJ, 1997. 
históricas e com as necessidades do presente; ela baseia-se no registro simbólico da resistência antifascista, e, portanto, não se dispõe nem a clamores pela verdade universal nem a uma simples e solipcista postura parodística como Linda Hutcheon afirma:

Minha premissa óbvia ao argumentar em favor de uma ironia crítica forte na obra de Kiefer é que, na arte visual, como na verbal, é possível pensar a ironia não como dizendo uma coisa e significando outra, mas em vez disso, como um processo de comunicação que implica dois ou mais significados sendo jogados contra o outro. A ironia está na diferença; a ironia faz a diferença. ${ }^{82}$

Kiefer constrói a paisagem da contemporaneidade no sentido de um território sinistrado, um desastre que deixa traços que não são apenas os signos da memória da adversidade, mas também produz uma arquitetura do espaço. Uma terra devastada engendra sua própria memória através de traços que se sedimentam.

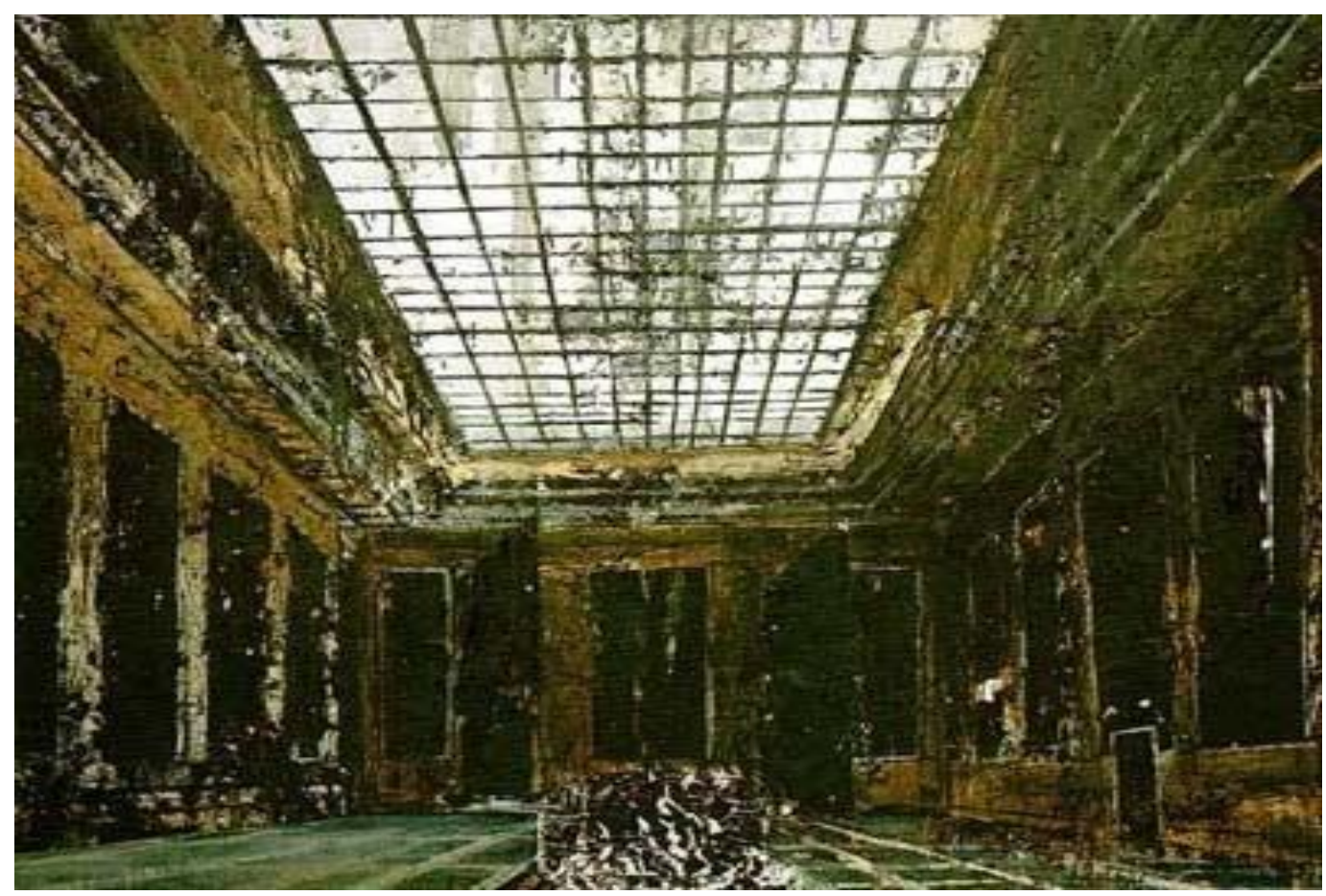

Figura 9. Interior/Inneraum,1981. Óleo, acrílico, emulsão s/tela. 287 x $311 \mathrm{~cm}$. Museu Stedelijk, Amsterdam.

${ }^{82}$ Cf. HUTCHEON, Linda. op. cit., p. 156. 
Nos trabalhos de Kiefer identificados como interiores ou Inneraum (fig. 9), uma atmosfera de perigo é reclamada em inumeráveis formas. O perigo é evocado através de uma natureza ameaçadora: fogo, cobras, sangue e armas. O perigo também é conotado pelo opressor tamanho e o vazio da suas obras. Também os territórios calcinados, arrasados ou devastados podem ser fascinantes - o fascínio de Kiefer por São Paulo - porque eles revelam as formas e o esqueleto da natureza arruinada, eles fazem parte de um universo onde o poder da destruição persiste em forma de uma renascença negativa. Para Kiefer, a força da memória fará ressurgir em cada momento a mitologia das metamorfoses dessas ruínas atuais, existenciais. As imagens da memória ultrapassarão o ato de conjuração. Elas forjarão a figura do destino que será feito sob à medida de uma relação cósmica. Essas imagens são correlatas ao cosmos kieferiano retratado por Andrea Lauterwein:

A renuncia da Luz pintura de 1999, que se insere numa série de pesquisas sobre o macrocosmos e o microcosmos, deve seu nome a uma das últimas coletâneas de Celan, aparecida a título póstumo, em 1970 [...] A renuncia da luz - que é necessário entender como uma necessidade individual, mas também como um constrangimento social, dado que Celan escreve este poema durante uma estada ao hospital psiquiátrico - parece impedir o luto e a obscuridade propícios à memória das mortes. A pintura de Kiefer representa um céu constelado, em que as estrelas estão munidas de rótulos numerados. O que sabemos, é que Kiefer reproduz o sistema de numeração das estrelas feito pela Nasa, e que apoia-se, paralelamente, sobre uma teoria de Robert Fludd segundo a qual cada estrela do céu corresponde a uma planta na Terra. A referência à coletânea de Celan e, pelo seu intermediário, aos sofrimentos póstraumáticos do sobrevivente, reforça a nossa antecipação interpretativa: os números espontaneamente serão associados aos números de identificação tatuados no antebraço dos deportados e, portanto, informados à desumanização e à fabricação serial da morte). ${ }^{83}$

83 "La peinture Contrainte de lumière de 1999, qui s'insère dans une série de recherches sur le macrocosme et le microcosme, doit son nom à l'un des 
Por meio da arte, Kiefer sugere que o terror intrínseco à razão pode ser contido, que a ameaça de barbárie pode ser mantida à distância. Kiefer sempre se aproxima perigosamente daquele terror da razão; mas é ela que consegue também insuflar os recursos artísticos para reconstituir a própria experiência do terror. ${ }^{84}$ Cogitamos que um é inseparável do outro. Em última instância, sua estética é a aquela de uma consciência expandida, que tenta controlar os poderes do inconsciente e da barbárie por meio da representação pictórica. Contudo, no final das contas, o objetivo de resistir à ameaça regressiva é um gesto político para Kiefer. A maneira como tal aspiração possa ser alcançada representa-se por míticas imagens. Há uma ausência na pintura que se torna rubrica da esperança de libertação: a história desse espaço vazio aguardando para ser preenchido. Esse anjo benjaminiano da história acabou de despertar para o mito. Aliás, é uma concepção do romantismo que articula formas pictóricas em Kiefer, segundo Kolya Michael Rice:

derniers recueils de Celan, paru à titre posthume, em 1970 [...] La contrainte de lumière - qu'il faut comprendre comme un besoin individuel, mais aussi comme une contrainte sociale, puisque Celan écrit ce poème durant un sejour à l'hôpital psyquiatrique - semble empêcher le deuil et l'obscurité propices à la mémoire des morts. La peinture de Kiefer représente un ciel constellé, dont les étoiles sont muniés d'étiquettes numérotées. Ce que nous savons, c'est que Kiefer reproduit le système de numérotation des étoiles par la Nasa, et qu'il s'appuie, parallèlement, sur une théorie de Robert Fludd selon laquelle à chaque étoile du ciel correspond une plante sur la terre. La référence au recueil de Celan et, par son intermédaire, aux souffrances post-traumatiques du survivant, renforce notre anticipation interpretative: les chiffres seront spontanément associés aux números d'identification tatoués sur l'avant-bras des déportés et, donc, rapportés à la déshumanisation et à la fabrication sérielle de la mort". O número e seu simbolismo têm um lugar saliente na Bíblia, na Torá e em toda a literatura secular européia da Idade Média. Para um amplo tratamento deste tema, consultar o estudo de Ernst Curtius, "Numerical Composition," In: CURTIUS, Ernst. European Literature and the Latin Middles Ages. Princeton, New Jersey: Princeton University Press, 1967, pp. 501-510. Cf. LAUTERWEIN, Andrea, op. cit., p. 176.

${ }^{84} \mathrm{O}$ Apotropaion não apenas adverte o pintor de ser um infausto demiurgo. O emprego do Apotropaion deverá também impedir um eventual ataque, contra o qual devemos estar preparados. Desta maneira, a aproximação teimosa de Kiefer converte-se num escudo protetor. Kiefer reformulou até mesmo o apocalipse com seu gesto Apotropaion. 
Assim, o uso de Kiefer do motivo romântico do monumento ao Soldado Desconhecido, aqui deslocado e posicionado como monumento ao artista desconhecido, podia ser lido como uma crítica ao mito do gênio artístico. Entretanto, Huyssen afirma que esta leitura parece um pouco forçada, já que "essas inscripções particularmente lingüísticas e conceituais, são elas integrais aos mitos dos guerreiros", os heróis e o gênio estético foram suportes principais da cultura da classe média a partir do romantismo. ${ }^{85}$

Kiefer resiste estoicamente à tentação do final, que caracteriza a sensibilidade do pós-guerra, mas, talvez, sua tentativa de pensar o presente por meio do passado e mantê-lo, embora, experimentalmente, interstícios para um futuro desembaraçado de terrores e pesadelos.

85 "Thus Kiefer's use of the romantic motif of a monument to the Unknown Soldier, here displaced and posited as a monument to unknown artist, could be read as a critique of the myth of artistic genius. However, Huyssen contend that this reading seems a bit force, since these particular linguistic and conceptual inscriptions, "are themselves integral to the myths of warriors," heroes and aesthetic genius that have been major props of middle-class culture since romanticism". Cf. RICE, Kolya M. The burden of a national legacy: An examination of Anselm Kiefer's reflection on the German past. Dissertação de Mestrado apresentada ao Departamento de Arte da Universidade de Rice, em Houston, abril 1994, p. 58. 


\section{PICTURA E POESIS DA CATÁSTROFE}

Os filósofos são de certo modo pintores e poetas; os poetas, pintores e filósofos. Os pintores, filósofos e poetas; e os verdadeiros poetas, os verdadeiros pintores e os verdadeiros filósofos se apreciam e se admiram reciprocamente.

Giordano Bruno ${ }^{86}$

Nas obras de Kiefer encontram-se referências à língua e sua vitalidade para a compreensão do recurso a palavras nelas, pois em estado de dicionário, as mesmas se aproximam de glossolalias, cujo sentido é um limiar. Ou as palavras vêm a significar e, assim, a barbárie é rejeitada, ou, então, a língua recai em instrumentalidade, atestando a mutação dela e de seu caráter civilizador no capitalismo belicista. Eis aqui que Kiefer encontra-se com Celan e Walter Benjamin, nas suas imagens herméticas, ${ }^{87}$ mudas, quando próximas

86 "Idem ad utrumque proximum est principium, ideoque philosophi sunt quodammodo pictore atque poëtae pictores et philosophi, pictores philosophi et poëtae, mutuoque veri poëtae, veri pictores et veri philosophi se diligunt et admirantur." Opera, II-II, p. 113. Cf. BRUNO, Giordano apud ORDINE, Nuccio, O umbral da sombra. Trad. Luiz Carlos Bombassaro. São Paulo: Perspectiva, 2006, p. 227.

87 No uso acadêmico moderno os termos hermético e hermetismo são ambos usados para reportar assuntos aparentemente diferentes. O primeiro corresponde à esoteria, enquanto o segundo está vinculado à alquimia. No contexto da literatura árabe, os acadêmicos modernos geralmente usam a palavra hermético não apenas para se remeter a obras associadas com o nome de Hermes, mas também a toda espécie de trabalho alegadamente gnóstico, neoplatônico, neopitagórico ou esotérico. A sistematização do pensamento alquímico ou hermético (em honra ao deus egípcio e grego da escritura, Hermes Trismegisto, "o três vezes grande", fundador da alquimia e autor dos primeiros tratados relativos a dita arte; ele é: "the principal figure in the mystical literature collectively known as Hermetica. He is thought to be a combination of the Greek Hermes and the Egyptian god of wisdom, Thoth." Realiza-se em Alexandria, o centro cultural do mundo helênico. Aí efetua-se a síntese do pensamento alquímico por meio da conjunção de três sistemas principais: "These were Greek philosophy, eastern mysticism, and Egyptian technology." Leicester comenta a respeito: "In Alexandria for the first time, the artisans came in contact with the ferment of ideas [...] The theories of the philosophers could be applied to the processes carried out by the artisans, and the abstruse speculations could be limited by actual acquaintance with the behavior of matter in many 
dos mortos, estão sempre em decalagem com a quantidade de metáforas que podem ser empregadas para falar da Shoah. Para Walter Benjamin, por exemplo, no momento em que fomos espoliados da possibilidade de apreender as coisas e os acontecimentos enquanto experiências fundadas na própria língua, na ordem da tradição, a literatura torna-se a última trincheira de uma verdadeira experiência. Vale dizer que esta aproximação é animada pela natureza conflitiva da poesia de Celan: ele coloca em jogo a controvérsia incessante entre duas memórias incompatíveis, mas necessariamente complementares e confronta, assim, certos mitos fundadores da identidade alemã e da identidade judaica, para fazer entrever suas diferenças, seus vínculos intrincados e suas reprocidades. Tanto Andrea Lauterwein ${ }^{88}$ quanto Daniel Arasse têm destacado essa proximidade de práticas artísticas do pintor e do poeta: o luto pela cultura alemã em Kiefer, indissociável do luto da prática clássica exprimido pela pintura: "Kiefer continue Celan pour son propre compte," escreve Arasse, sugerindo que a memória de

forms [...] for the first time occurred a union of theoretical and practical chemistry, and from this union came a totally newgrowth, alchemy." É importante notar a dualidade inerente dessa declaração. O conhecimento teórico e especulativo mais o conhecimento prático e tecnológico equivalem à arte hermética. A transmutação alquímica representa a metáfora paradigma da pintura de Kiefer, gerando o movimento que promove a transformação catalítica do código pictórico kieferiano. Contudo, o conceito próprio de metáfora implica tanto a translação ou o deslocamento da significação ou das significações a outro nível de figuração ou de figurações, assim como a substituição ou mudança de uma palavra ou expressão por qualquer por outra. O processo da transmutação alquímica, como requisito imprescindível para a consecução da Grande Obra ou o Magnum Opus pelo alquimista e esta última como objetivo de toda uma vida do verdadeiro filósofo hermético, é, sem dúvida o mais conhecido e, também, curiosamente, o menos entendido dos processos alquímicos. Kiefer preparase a passagem da linguagem para as metáforas herméticas. As metáforas são sentidos concentrados e decalados das coisas que problematizam o princípio de identidade para reaver a transmissão de experiências com os traumas da história, há perda de identidade e impossibilidade de constituição de uma outra porque falta a experiência que a metáfora traz de volta. Cf. LEICESTER, Henry M. The historical background of chemistry, Boston: Dover Publications, 1971, p. 34.

${ }^{88}$ Cf. LAUTERWEIN, Andrea. op. cit., pp. 91-93. 
Celan é articulada no seio de outros deslocamentos. ${ }^{89} \mathrm{Em}$ um dos ensaios mais evocativos sobre a relação de Kiefer com a história alemã, Andreas Huyssen descreve suscintamente o transitar de pintor para a poesia de Celan:

Nessas pinturas onde Kiefer se volta para as vítimas do fascismo, o olhar melancólico sobre o passado, dominante nas pinturas da arquitetura, é transformado é um genuíno sentido de luto. E a obsessão aparentemente autoindulgente e narcisista de Kiefer com o destino da pintura a revela aqui em sua mais ampla dimensão histórica e política. ${ }^{90}$

A convicção de Kiefer que o pensamento judeu está presente na memória alemã, e que precisa ser atualizada, ecoa a prática poética de Celan, incontornável na vontade de recolocar a tradição hebraica no coração da língua e da poesia alemãs. Kiefer orbita na galáxia celiniana, reagindo a esse dom da memória. Desse fato, Kiefer acaba respondendo ao clamor de Celan de se enjudeizar, um enjudeizamento definido como "un chemin por comprendre la poésie," como "une solidarité-pour-l'autre-et-son-secret."11 Aqui literatura e pintura se reúnem seguindo analogias, correspondências e semelhanças na intuição de Baudelaire. Lembremos que no ensaio "Sobre a linguagem como tal e a linguagem do homem" (1916), Benjamin expõe abstratamente como antítese - elemento concreto e abstrato da linguagem, nome e palavra, símbolo e alegoria - o que nas suas pesquisas ulteriores se divisa na representação do mito e da sua simbólica no ensaio de "As Afinidades Eletivas de Goethe" (1923), na alegoria antimítica no Drama Barroco (1928), na

${ }^{89}$ Cf. ARASSE, Daniel. op. cit., pp. 136-153.

90 "In these paintings, where Kiefer turns to the victims of fascism, the melancholy gaze at the past, dominant in the architecture paintings, is transformed into a genuine sense of mourning. And Kiefer's seemingly selfindulgent and narcissistic obsession with the fate of painting reveals itself here in its broader historical and political dimension". Cf. HUYSSEN, Andreas. "The terror of history, the temptation of myth." October 48, Spring 1989 , p. 40.

${ }^{91}$ Cf. LAUTERWEIN, Andrea. op. cit., pp. 96-98. 
representação da simbólica mítica dos mundos técnicos e dos nomes das ruas e na própria alegoria antimítica de Baudelaire. Essa dialética da sobrevivência dos temas do mito e do antimito adjudica exatamente na teoria da linguagem a indicação de Adorno: "As intenções de Benjamin não se preenchem com o triunfo sobre o mito, mas no seu resgate reconciliador. ${ }^{\prime \prime 2}$ As figuras do pensamento da linguagem e aquelas do pensamento sobre $o$ mito convergem também nas suas formas concretas de significação. Para Benjamin, a linguagem é a faculdade de expressão presente em todas as coisas. Nela se encontra a comunicabilidade das coisas, não as próprias coisas. A linguagem não comunica nada exterior: comunica-se a si própria. Daí resulta que o que é comunicado na linguagem - nada se comunica por meio da linguagem - não pode ser delimitado ou medido externamente; conseqüentemente, cada linguagem contém a sua própria e única infinitude, a possibilidade ilimitada das suas ocorrências, pressuposta em cada uma delas. O tema do duplo duelo paralelo que confronta o artista contemporâneo com a matéria crua da experiência e com a sua criação artística é de crucial importância na obra de Anselm Kiefer, seja em termos explícitos ou, mais amplamente, de forma implícita. A cristalização do caos experiencial em poliedros plásticos, densos e cortantes na sua deceptiva monumentalidade, é uma das pulsões mais intensas da sua obra e uma das marcas mais notórias do seu gênio plástico - um gênio altivo no despojamento, expressão de uma autêntica vocação, que nem o profundo espanto dos seus contemporâneos demoveu da obstinação com que nunca pactuou com a facilidade ou a mediocridade historicista e esteticista que o circundava. É essa obstinação de duelista que o move a procurar nos sombrios cenários

${ }^{92}$ Cf. ADORNO, Theodor W. Sobre Walter Benjamin. Trad. Carlos Fortea. Madrid: Cátedra, p. 223. 
da história, as sementes de outra, nova e autêntica, crueldade plástica - autêntica porque única e alheada das modas vigentes. ${ }^{93}$

Os domínios da fenomenologia da experiência de choque histórico e da estética da modernidade articulam-se na plástica de

93 A relação de Walter Benjamin com a vanguarda expressionista é paradoxal, na verdade ambivalente. Benjamin escreveu seu livro Drama Barroco Alemão, tendo o expressionismo literário em seu horizonte. Antes havia acunhado seu conceito estético do inexpressivo como enclave de interpretação e de crítica literária, polemizando com conceitos psicologistas como o de empatia (Einfülung) de Worringer, precursor teórico e inspirador do expressionismo arquitetônico e pictórico. A oposição de Benjamin à cultura expressionista passou por desarmar seus precedentes românticos e os conceitos básicos sobre os quais se sustentava - gênio, símbolo e criação -. Posteriormente Benjamin passa a realizar uma tarefa construtiva no que diz respeito à arte, encontrando em canteiras como o surrealismo de Breton, Aragon ou em Proust, Kafka e Brecht, os materiais para pensar uma alternativa revolucionária para a arte, longe dos parâmetros nos quais se moviam tanto o expressionismo literário quanto o modernismo arquitetônico, documento que substituiu o expressionismo, na sua maturidade, como movimento. Benjamin não pôde desarmar com facilidade as bases epistemológicas do expressionismo arquitetônico como o tinha feito com a experiência narrativa ou a pictórica, pois de suas ambíguas utopias depreenderam-se certas idéias da arquitetura monumental nazista assim como o revolucionário movimento moderno Bauhaus. Benjamin citou no seu ensaio "Experiência e Pobreza" a Paul Scheebart, o mentor do expressionismo arquitetônico, e interpretou alegoricamente a imagem das passagens parisienses em claves muito próximas à Glaskultur de Paul Scheebart e Bruno Taut, muito mais próximas das visões mágico-extáticas do primeiro expressionismo que de sua apropriação funcionalista por parte do movimento moderno. No que diz respeito ao cinema expressionista, embora Benjamin não o acolhesse como assunto de reflexão direta, no seu ensaio "A obra de arte na era de sua reprodutibilidade mecânica", ele deixa clara sua postura em relação ao que chamava de cinema artístico, outra mercadoria aurática que oculta sua condição inumana sob as vestiduras da velha arte com o fim de não alterar o discreto charme da burguesia, incapaz de encantar o mundo que comanda. À margem desta experiência cinemática totalitária cujo perigo foi reconhecido por Benjamin, no entanto, o cinema expressionista de Fritz Lang, em Metropolis, mais especificamente, pode se destacar como a cimeira do cinema mais reacionário da época. Metropolis estava destinado a inflamar a sede de mito na multidão, a transformar à multidão em massa informada ante o projeto absolutista de uma cidade-obra de arte, meca da superioridade da raça. Ver KRACAUER, Siegfried. De Caligari a Hitler. Uma história psicológica do cinema alemão. Trad. Teresa Ottoni. Rio de Janeiro: Jorge Zahar, 1988; Cf. GAMARRA QUINTANILLA, G. Estética urbana. Ciudad, cine y mito. De Walter Benjamin a Metrópolis. Tese de Doutorado apresentada ao Departamento de Cinema da Universidad del País Basco, 2008, p. 175; Cf. PEHNT, Wolfgang. La arquitectura expresionista. Madrid: Visor, 1975. 
Kiefer de forma que se pode considerar próxima daquela que Baudelaire analisa em Le peintre de la vie moderne. É impossível conceber a criação de uma obra como Besetzungens sem pressupor, pelo menos, e além de outros elementos, um duplo duelo experiencial. Por um lado, deixa-se adivinhar, nas entrelinhas dessa obra, uma ampla experiência deambulatória pela história alemã uma deambulação movida por uma atenção voraz aos detalhes da imagética nazista, em duelo com uma sufocante abundância de impressões sensoriais, procurando fixá-las na memória. Por outro lado, um duelo do artista com os elementos retidos na sua memória voluntária e com a matéria-prima lingüística a que recorreu no heróico esforço plástico de interferir nas fotos. Nessas intervenções o motivo do duelo artístico é mais explícito em relação ao domínio da recepção pública da obra, mais concretamente, com à leitura conservadora generalizada que a caracteriza. Onde localizar então o choque no contexto da economia que gere esta tensa configuração onde se confrontam a intangibilidade dos sentimentos finos, a exatidão da prosa e a venalidade artística? Onde a fluidez da experiência interior se debate com o materialismo pragmático da ciência e a adulação interesseira. A idéia da literatura como refúgio e laboratório da experiência foi avançada por Benjamin a propósito das relações entre a obra de Proust e a teoria da experiência de Bergson:

[...] a obra de Proust Em busca do Tempo Perdido pode ser vista como uma tentativa de produzir experiência sinteticamente como Bergson imagina, sob as condições atuais, pois há cada vez menos esperança que ela surja naturalmente. ${ }^{94}$

O gênio de Proust encontra expressão privilegiada na importância que atribui à involuntariedade na percepção e na memória. A nãointencionalidade nem sempre foi requisito da experiência. Na experiência comunicada pela tradição, e na experiência acumulada ao

${ }^{94}$ Cf. BENJAMIN, Walter. "Sobre alguns temas em Baudelaire." In: Um lírico no auge do capitalismo. p. 105. 
longo da vida, em direção ao seu inevitável desfecho mortal, a formação de "imagem de si mesmo" - que assinala o acesso à experiência autêntica - não decorre de uma total independência de fatores volitivos e conscientes, nem assume necessariamente um incomunicável caráter privado. A privatização e generalizada incomunicabilidade moderna da experiência pessoal, interior, resulta de uma crescente incapacidade de "assimilar os dados do mundo em redor em termos de experiência." As vivências fragmentárias da Erlebnis não permitem ao homem ou à mulher moderna a formação da imagem de si onde a experiência se cristaliza. Mas por outro lado, a experiência das correspondências da memória involuntária, por si só, é igualmente insuficiente para qualificar como experiência verdadeira, histórica -as correspondências consideradas isoladamente relacionam-se com a experiência verdadeira da mesma forma que o historicismo que procura ressuscitar o passado se relaciona com o materialismo histórico, ou seja, em termos análogos àqueles que distinguem Erinnerung de Jetztzeit. As correspondências necessitam, pois o seu contraponto dialético para produzir a mútua conflagração e legibilidade, a temporalidade que caracteriza a experiência histórica. Ou seja, toda a memória involuntária necessita o contraponto dialético da imediatez do choque do agora único de sua legibilidade. Correspondências e choque unem-se numa imagem dialética, cristalizam-se de forma instantânea numa dialética imóvel. Pode-se atribuir a Kiefer uma posição inaugural no percurso de reconstrução imagética e visual da história alemã. Cogitamos que esse momento inaugural admitiria o termo de des/umbramento ternamente cruel. Como foi possível ser o pintor desse acontecimento vergonhoso, o instaurador de um olhar inédito sobre as lamentáveis possibilidades do mundo, no interior do tempo suspenso na vergonha e o drama que é, por antonomásia, o tempo da consciência como instância onde o eu e o mundo definitivamente se desarticularam, e que vive da glosa interminável dessa desarticulação. 
Figura 10.

Lilith,

1990.

Pintura

com

cinzas. 230

$x 224 \mathrm{~cm}$.

Coleção do

Artista.

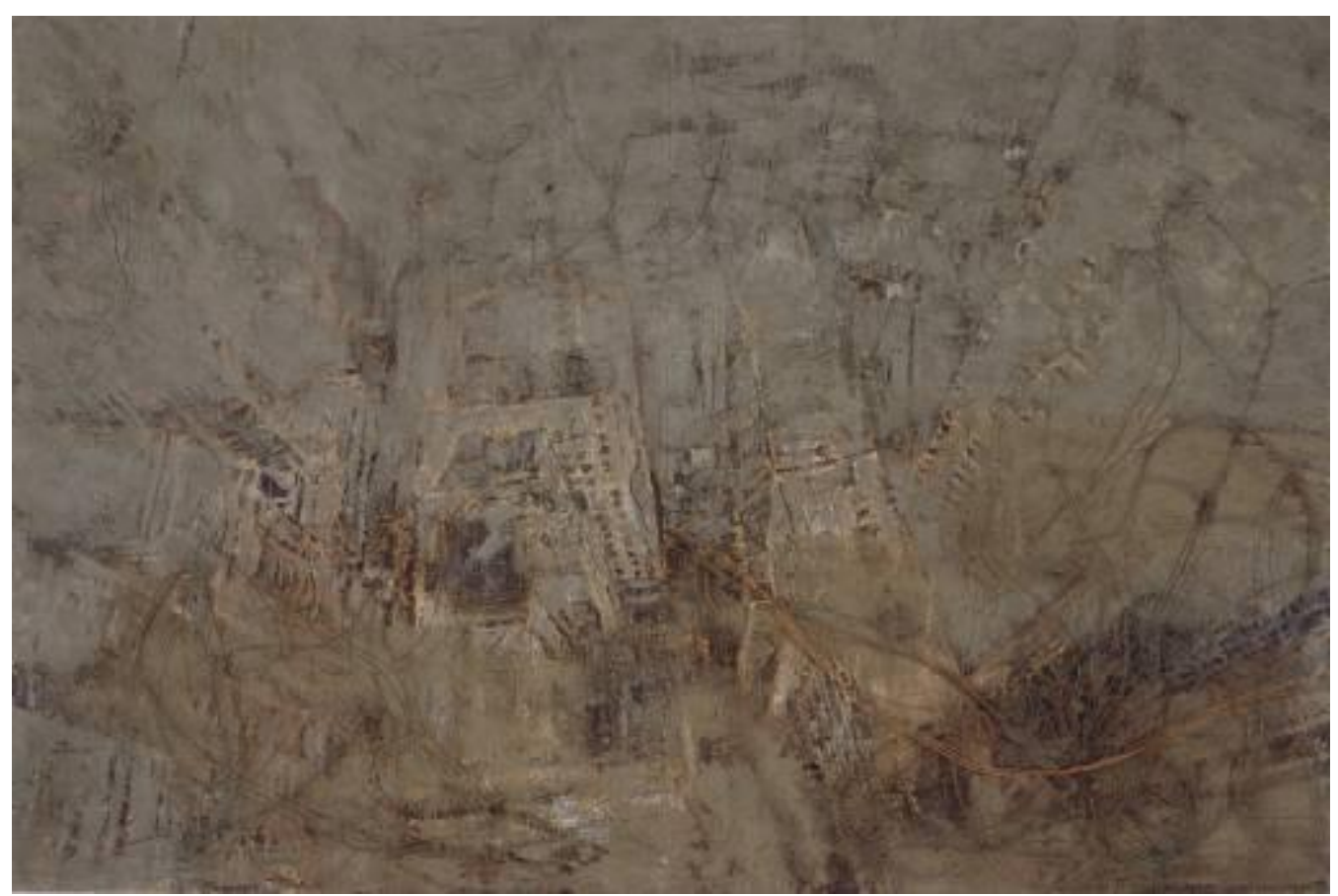


Semelhante argumentação se justificaria no caso de Lilith (fig.10) de Kiefer, na qual a deambulação urbana do pintor se parece subordinar a uma mais abrangente tendência alegórica. Tal seria o caso das pinturas deambulatórias Paisagem Árida (fig.11) e Filhas de Lilith (fig.12) cuja dimensão alegórica ressaltamos. Nessas pinturas, de uma certa perspectiva, a deambulação do pintor surge como um pretexto para a introdução dos quadros alegóricos que os constituem: a alegorização da catástrofe da empresa citadina na figura feminina de Lilith; e a complexificação dessa mesma alegoria em Filhas de

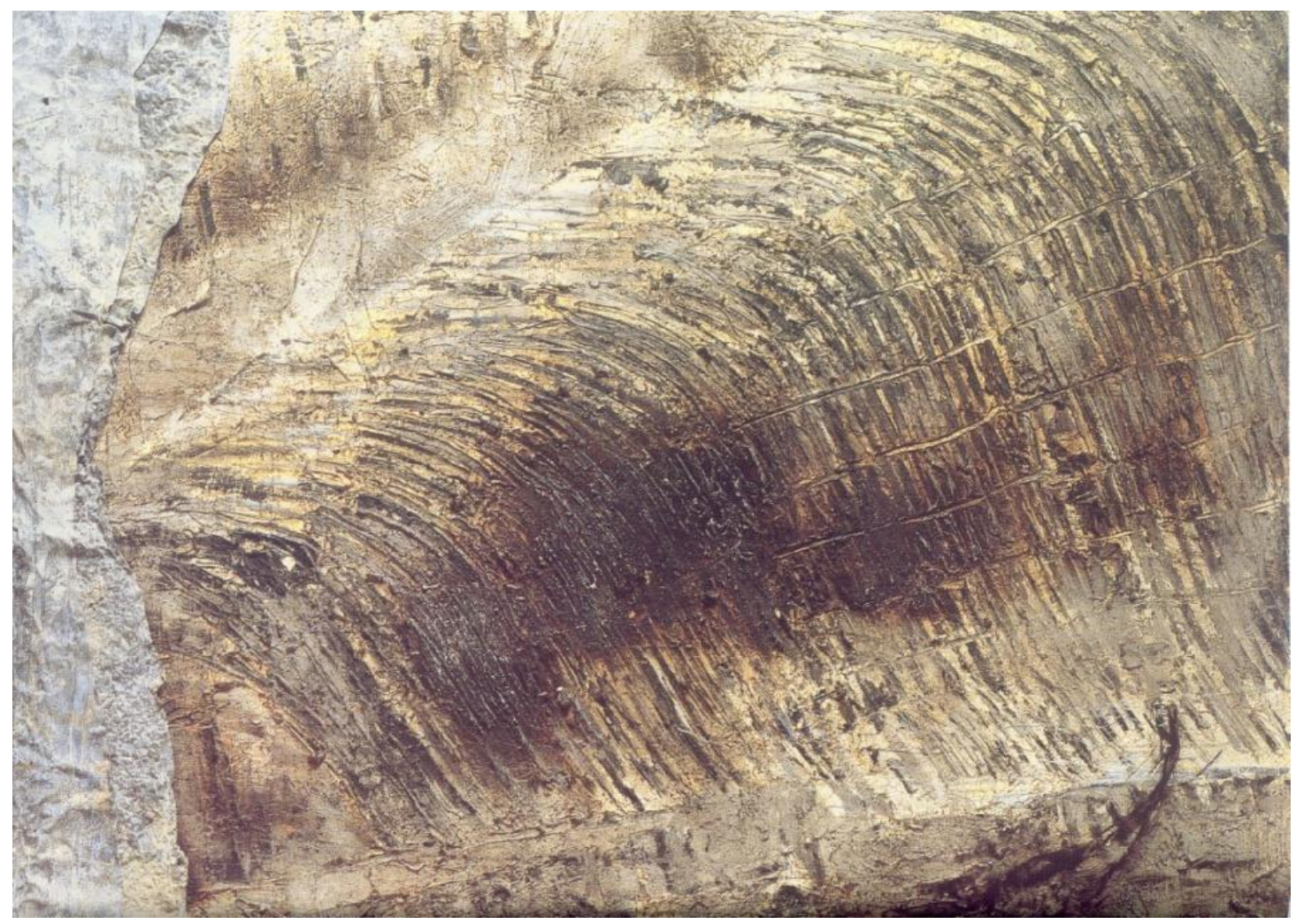

Figura 11. Paisagem Árida/Barren Landscape, 1987/89. Acrílico, emulsão, cinzas e giz s/tela com chumbo, cabelo de mulher e serpentina de aquecimento. 330 x $560 \mathrm{~cm}$. Coleção Astrup Fearnley, Oslo, Noruega.

Lilith, em resultado do seu desdobramento num compósito oximórico de fragilidade e vitalidade excessiva, que se deixa emblematizar na figura dúplice cidade-demônio.

Mas essa aparente subordinação da deambulação metonímica em relação ao propósito alegorizante confronta-nos, contudo, com outra questão. Se essa subordinação é assim tão óbvia, manteriam 
aqueles quadros a sua identidade caso o efeito deambulatório fosse suprimido? Consideremos, em primeiro lugar, a hipótese extrema de uma mera apresentação do quadro alegórico sem a presença física do pintor no espaço da pintura. À semelhança, pois, das impessoais alegorias barrocas. Parece evidente que a função alegórica das figuras femininas nestes quadros está diretamente dependente da sua coexistência física com o pintor, ao qual são contrastadas. O ser lingüístico das coisas é a sua linguagem, e o mesmo se aplica ao homem. Que distingue então a linguagem do homem da linguagem das coisas? O homem comunica-se na nomeação das coisas que, por seu lado, comunicam, no seu ser lingüístico, a sua entidade mental ao homem - de outra forma, como as poderia nomear? A nomeação é a verdadeira natureza da linguagem. Deus criou as coisas ao nomeálas com seu verbo divino, mas no homem ele criou a própria capacidade de nomear e de conhecer as coisas por meio dos seus nomes. Há, pois, que distinguir claramente entre a palavra criadora do Deus e a adâmica linguagem humana dos nomes. A potência criadora do verbo divino permanece inacessível à linguagem humana, que, paradoxalmente, não obstante à sua infinitude, mostra-se originariamente imperfeita e pobre em face da palavra divina. Só palavra criadora de Deus é pura expressividade, coincidindo integralmente como o ser mental divino. Daí Lilith e os nomes próprios nas telas de Kiefer como Margarethe e Sulamith que, são, de fato, dois nomes femininos. Elas interessam-nos porque seus nomes próprios se interpõem na ação do poema de Celan, Todesfuge, e nas pinturas de Kiefer Sulamith (fig.13) Margarethe (fig.14) às vezes, sua vinculação sintática perde-se, a fim de denominar as suas histórias. Estas duas mulheres de Kiefer e de Celan devemos dizer, podem ser consideradas como duas forças argumentativas, que se referem a um lugar histórico e psíquico. Os nomes de Margarethe e Sulamith alcançam o estatuto de topônimos na genealogia alegórica que Kiefer nos propõe. O nome de Sulamith refere-se, de fato, à 
esposa ideal de cabelos escuros, figuração da amada de Salomão, no "Cántico dos Cánticos." ${ }^{95}$ Quanto a Margarethe, ela evoca uma outra esposa ideal: a moça dos cabelos dourados do Fausto de Goethe, o protótipo da mulher submissa e projeção da imagem divina. Esta dupla de mulheres ideais remete-nos à dupla de esposas quintessenciais que aparece na literatura hebraica e novotestamentária: Sulamith e Maria ou, por metonímia, a Sinagoga e a Igreja. O apreço pelas figuras literárias entende-se, sem dificuldade, à luz de uma indiscreta paixão de Kiefer, e, de uma não tão deliberada escolha de assuntos com que sua obra se viu dialogando. Prosa, para Kiefer, não se refere aqui, contudo, a uma forma literária ou a uma prosaicidade da linguagem plástica, nem sequer à linguagem pragmática das ciências, mas a um discurso elaborado com uma contaminação de uma possível eficácia utilitária. A exatidão da prosa parece aproximá-la antes do rigor da filosofia.

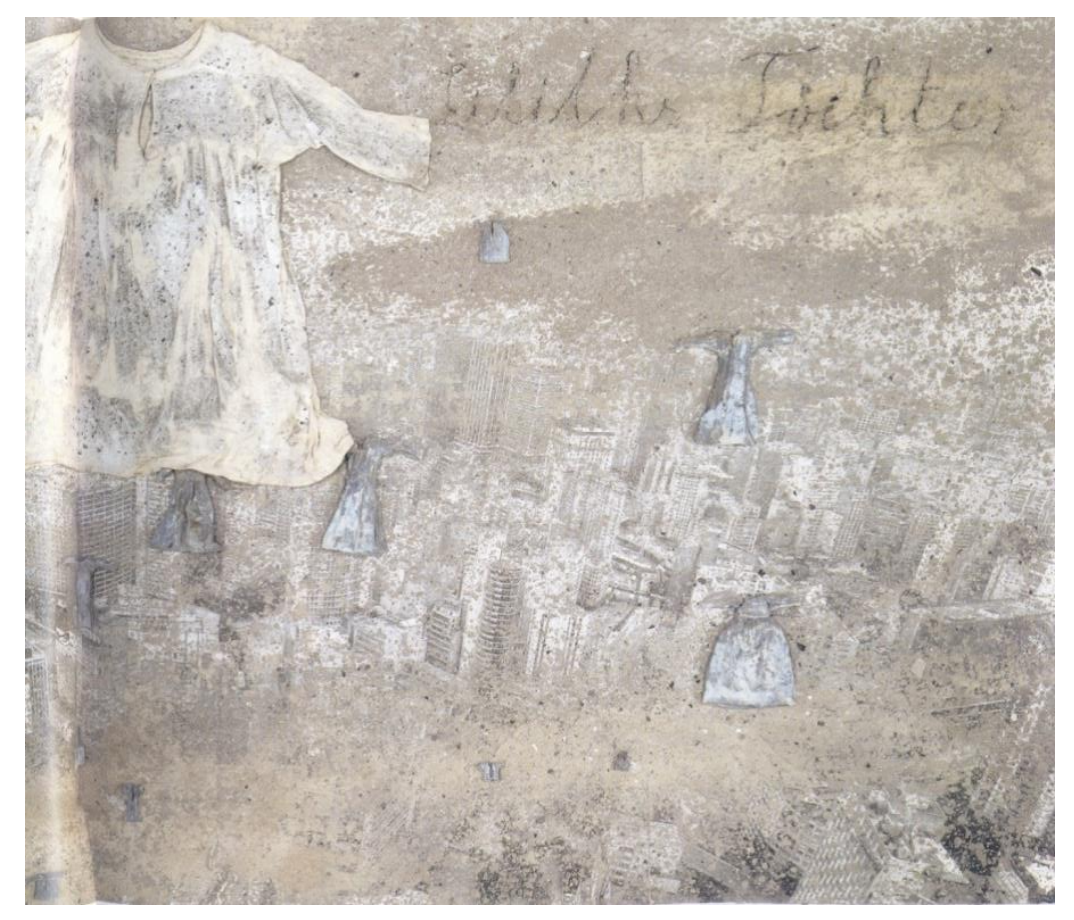

Figura 12. Filha de Lilith/Liliths Töchter, 1998. Técnica mista. $124 \times 271 \mathrm{~cm}$. Coleção do Artista.

${ }^{95}$ Cf. FONTES BRASIL, Joaquim. Eros, tecelão de mitos. Rio de Janeiro: Iluminuras, 2003. 
A prosa produz-se neste espaço enigmático dedicado à poesia de Celan e à escritura de Ingeborg Bachmann, $A$ areia das urnas, (fig. 15) uma tela onde a finura poética dos sentimentos e a exatidão cognitiva da linguagem se tocam, transmutam-se e comunicam-se. A prosa é uma intuitiva ciência dos sentimentos, uma rigorosa cartografia das suas constelações mais sutis e volúveis, uma exata ciência da inocência perdida. Onde localizar, então, o choque no contexto da economia que gere esta tensa configuração em que se

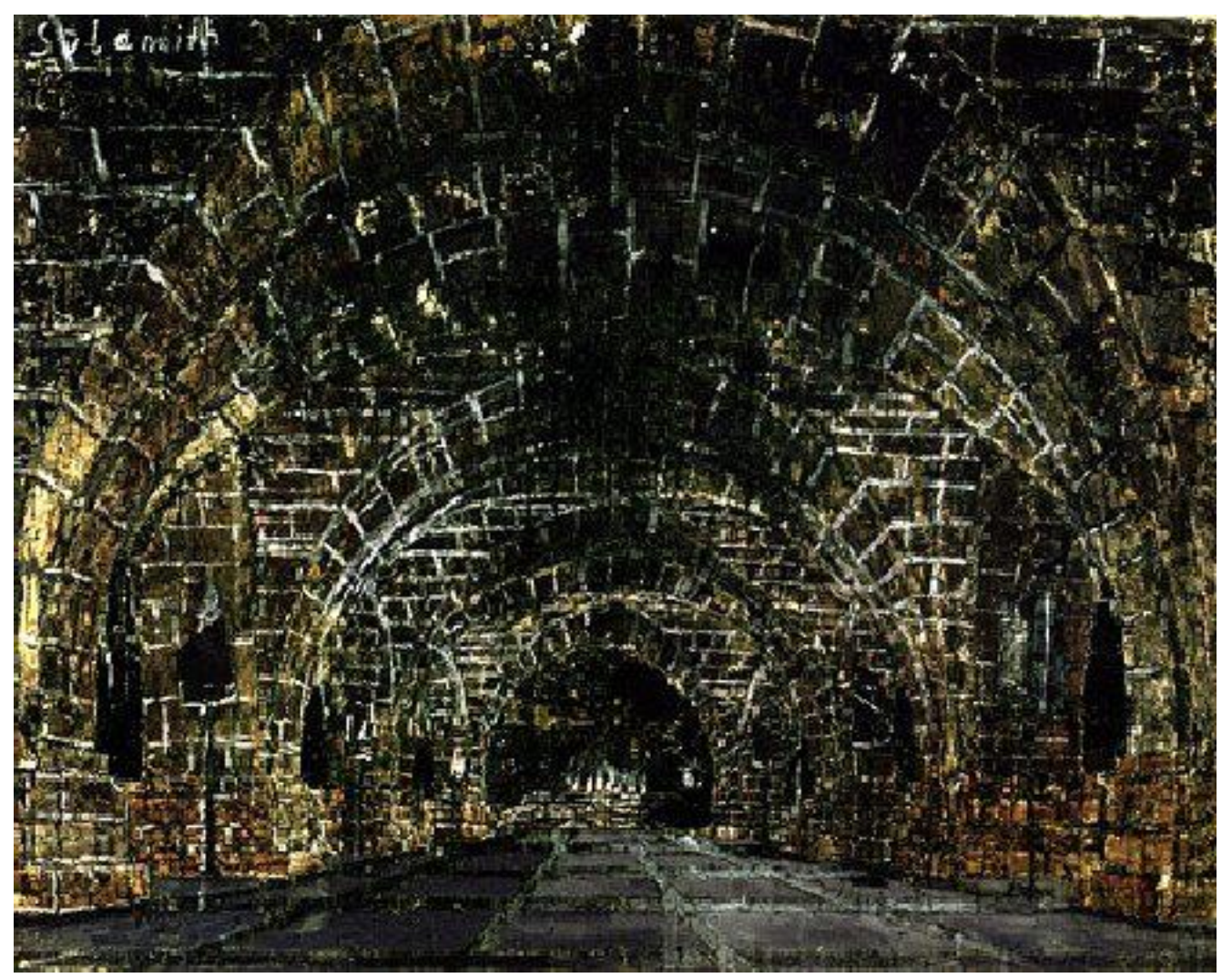

Figura 13. Sulamith, 1983. Óleo, emulsão, xilogravura, esmalte, acrílico e palha s/tela. $290 \times 370 \mathrm{~cm}$

confrontam a intangibilidade dos sentimentos finos, a exatidão da prosa e abstração artística? Onde a fluidez da experiência interior se debate com o materialismo pragmático da ciência e com a adulação interesseira? Onde o lirismo da poesia de Celan se descobre sufocado pela necessidade prática de responder a um mundo circulante que não mais lhe corresponde? 


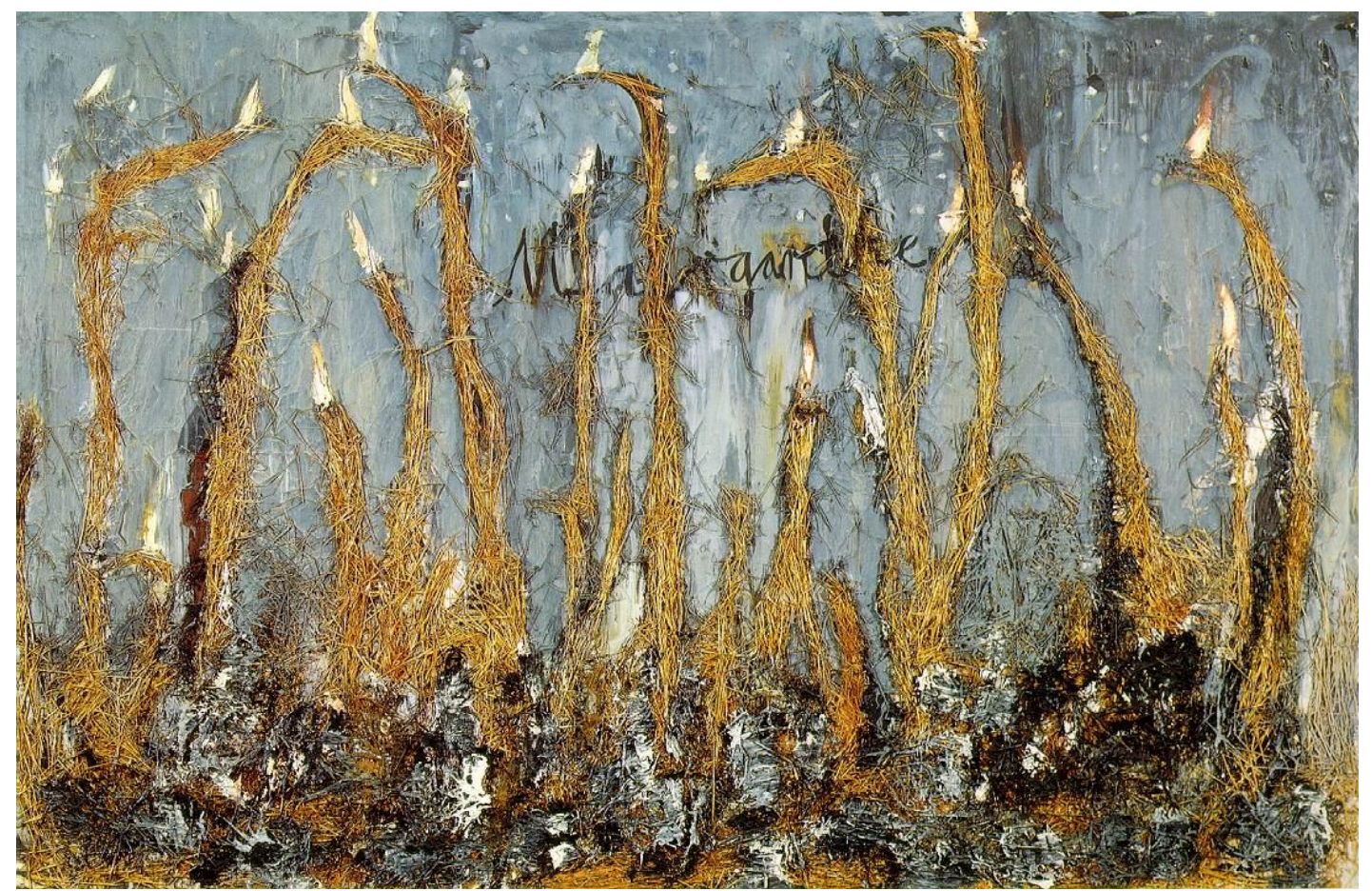

Figura 14. Margarethe, 1981. Emulsão e palha s/tela. $280 \times 380 \mathrm{~cm}$. Locação desconhecida

Dein Goldenes Haar Margarethe (Teus cabelos dourados Margarida) (fig.16) estabelece um nexo com a poesia de Celan Todesfuge; instala-se no limite do eu e do tu, na sua própria fenda. Kiefer preserva a ferida de Celan inscrevendo-a como um gesto de memória. Denkmal refere-se em alemão ao monumento, à estela erigida in memoriam do acontecimento. Memoriosa é a poesia de Celan para o pintor, cicatriz que não acaba de suturar, sinal de lembrança, marca do Mal como valor pontual da existência, a pintura de Kiefer encena a ferida de Celan. Encontramos como centro de gravidade kieferiana a "Fuga da Morte" uma paisagem de abismos negros em que se dispersam a palha, carvão, cinzas, argila, areia, cabelos e outros materiais submetidos ao rigor do tempo; a terra sulcada por cicatrizes aparenta infertilidade. Esta paisagem, embora sua pulsação destrutiva e, ao mesmo tempo, geradora de sua própria representação, percorre o conjunto total da produção artística de Kiefer. A natureza aparece como uma paisagem de cultura, que não 
significa mais uma realidade individual, como na pintura romântica, ${ }^{96}$ mas um modelo sobre o qual se desarraiga a história coletiva. A abordagem de Kiefer, em muito de seus trabalhos, está impregnada de riscos nos quais ele sempre estabelece um constante diálogo entre a materialidade e a elegância, entre o ideal e o ominoso.

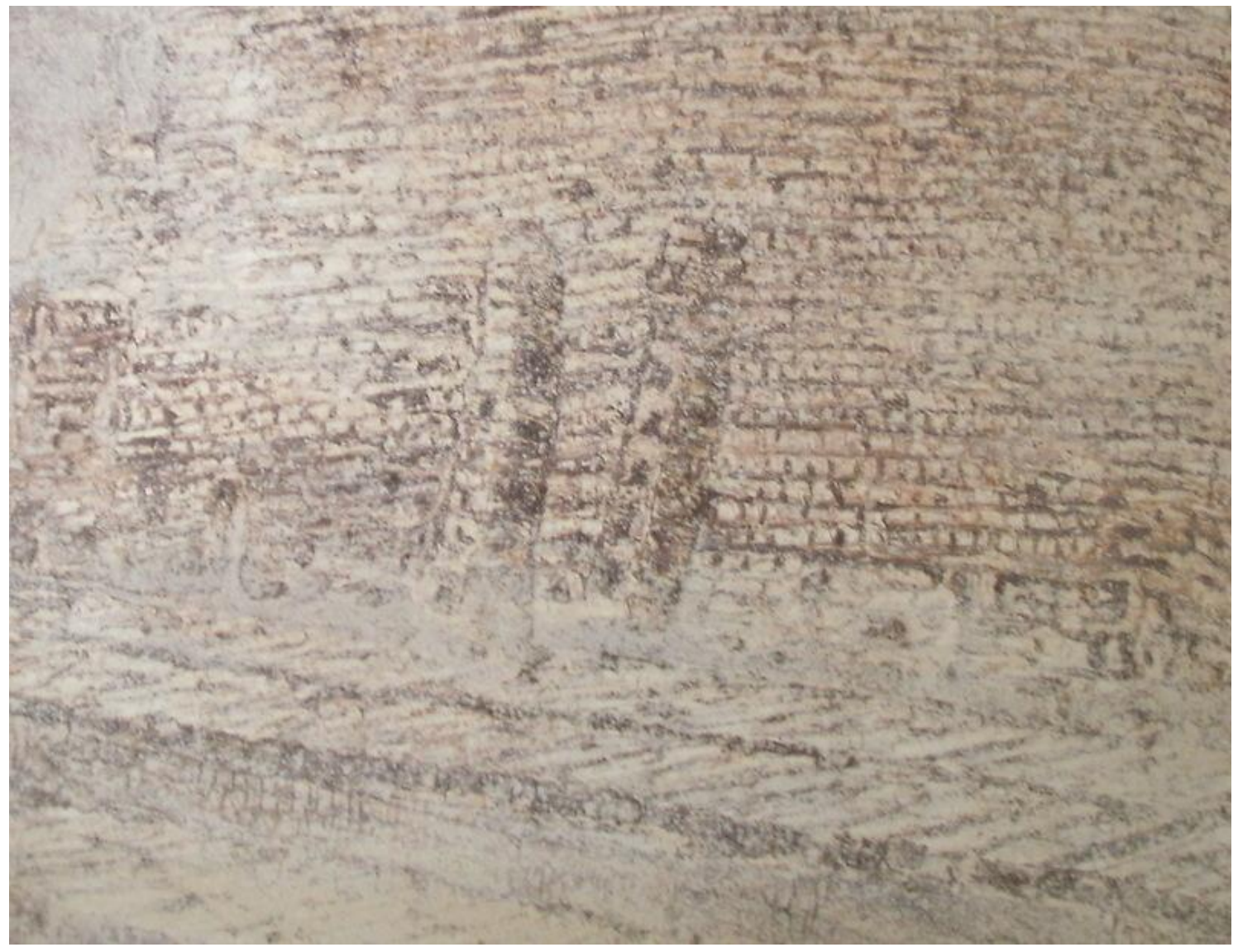

Figura 15. A areia das urnas/Der Sand aus den Urnen, 1997. Emulsão, esmalte, acrílico e areia s/tela. $280 \times 560 \mathrm{~cm}$.

A verdade, para ele, assim como para outros artistas alemães anteriores a ele, abrange mais do que pensamos como belo (na sua acepção romântica), discordando do poeta Yeats, que acreditava na beleza como uma mera matéria de aparência. Para Kiefer, a verdade do artista resulta ser ainda mais complexa. Pensemos, por exemplo, nos trabalhos produzidos na década de 80, consagrados aos interlocutores de Paul Celan, as pinturas e os livros que citam a

${ }^{96}$ A pintura romântica e sua presença na obra de Kiefer serão abordadas no segundo capítulo. 
poesia de Ingeborg Bachmann (1926-1973), e ocupam um lugar seminal. A delicadeza e a beleza particular dessas obras nos fazem sentir até que ponto Kiefer sente-se próximo de Bachmann. Uma espécie de correspondência estabelece-se entre a escritora e o pintor, um intercâmbio de referências acumuladas com o tempo. $O$ nome de Bachmann ${ }^{97}$ evoca uma escrita que luta persistentemente contra o esquecimento do Nazismo. Nascida em Klagenfurt, na Áustria, filha de um educador filiado ao partido nacional-socialista em 1932, ela partiu de sua condição histórica e pessoal para descrever os deciframentos psíquicos da geração posterior. Na sua primeira coletânea de poemas de 1953, O tempo aprazado, (adiado) Bachmann ilustra uma paisagem devastada pelos epígonos do Nazismo. Na série de romances consagrados às maneiras de morrer, Malina e os fragmentos póstumos Franza, ela desvela a permanência de uma mentalidade que visa a destruição do Outro, criando, assim, o laço entre a história individual e a história coletiva.

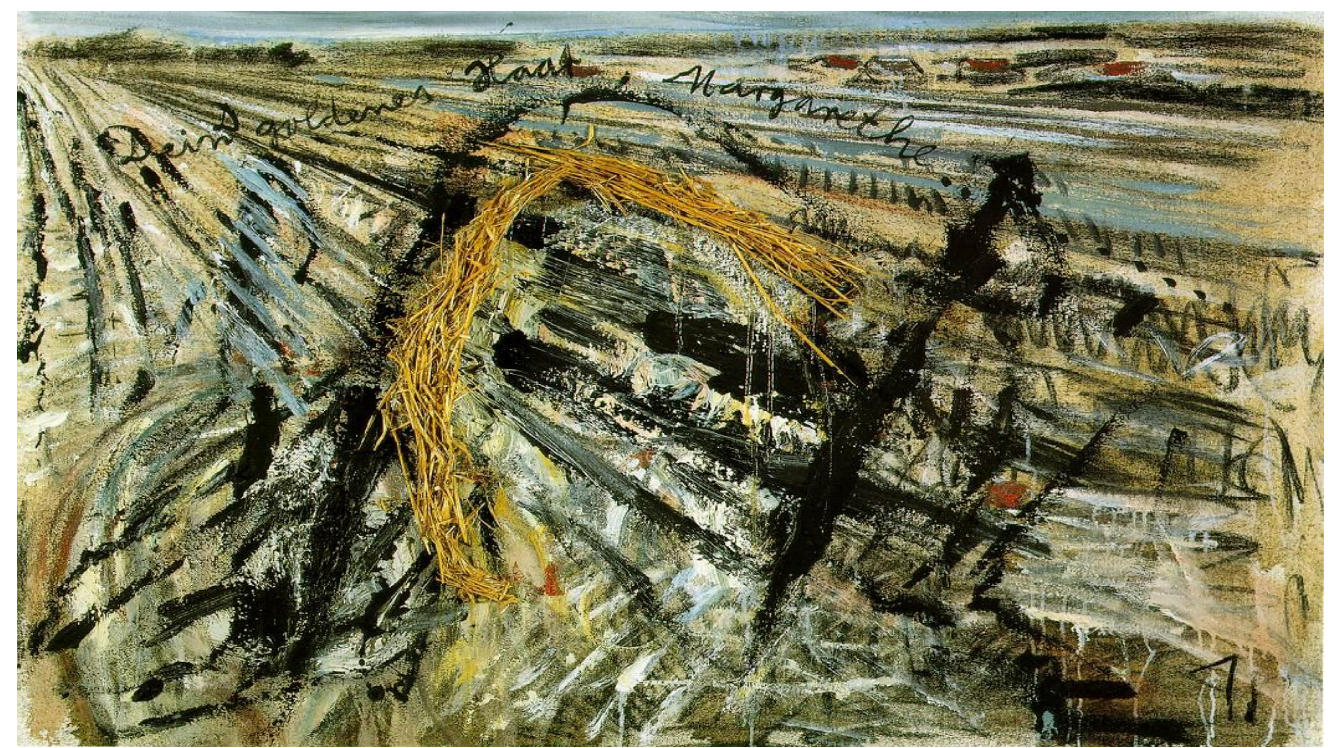

Figura 16. Teus cabelos dourados, Margarethe/Dein Goldenes Haar Margarethe, 1981. Óleo, acrílico, emulsão, carvão e palha s/tela. $130 \times 170 \mathrm{~cm}$.

97 Cf. BACHMANN, Ingeborg. El caso Franza. Trad. Consuelo Rivas. Madrid: Akal, 2001; Cf. Malina. Trad. São Paulo: Siciliano, 1993; Cf. O tempo aprazado. Trad. Judite Berkemeier e João Barrento. Portugal: Assírio e Alvim, 1992. 
Bachmann possuía uma acurada consciência de seu passado ignominioso, exacerbada pelo seu improfícuo relacionamento com Paul Celan. Seu desacontecimento amoroso revela-se no seu conceito da poesia: no tempo em que Celan reduz a potência afirmativa da poesia à morte histórica, Bachmann abandona a poesia e a utopia erótica para se debruçar sobre a morte órfica. ${ }^{98}$ Além da iniciação à poesia e à memória das vítimas, o diálogo entre Bachmann e a obra de Paul Celan encarna um paradoxo fecundo: encena o impossível reencontro de memórias de uma experiência coletiva submetida à dizimação, e de uma testemunha da Shoah, ao mesmo tempo em que a dependência recíproca de suas memórias.

98 Ingeborg Bachmann, escritora e também poeta, faz mais do que reatualizar o mito grego pois a sua trajetória literária e biográfica vai do caminho da decadência à exaltação no amor intermediado pela morte. Sofre a desativação de sua voz poética, em crise de silêncio bergmaniano em Malina, acaba por se tornar espelho da própria morte. A escritora, por sua vez, distanciada de sua função vivencial, associa-se ao de-functus, que cabe à morte recolher, cumprindo a significação que etimologicamente reveste 0 nome de Orfeu que atende à sua orphné, em que convivem, de modo indiferenciado, pulsões de amor e de morte. Para Bachmann a morte, dialetizada com Eros, adere a outro tipo de existência, a que decorre do desejo: no que ela tem de decrepitude, de desolação e de repetitividade tediosa. A morte anerótica, morte pela morte, apenas cristaliza a doença, a obsolescência e a solidão, enquanto a morte órfica por antonomásia seria a última morte, aquela que se vivencia no clímax das paixões e na dimensão criativa - que despoja o homem dos retornos à vida e, num determinado momento, faculta à psyché. Esta é uma morte traspassada pelo desejo como desidero, orientada para o esclarecimento que nos guia, mas do qual estamos indefectível e necessariamente afastados. A verdadeira morte para um órfico encontra correlato apenas no paroxismo ou na dimensão criativa, (seja da poesia, seja da concepção decorrente da união de corpos), que eterniza a beleza, a reprodução, a transformação, a continuidade. Não sabemos se constituiria um erro interpretar o mito de Orfeu e Eurídice como uma história de amor, assim como foi a história amorosa entre Celan e Bachmann. Com Bachmann, a poesia naturalmente silenciosa de Celan se torna sobrenaturalmente ruidosa. Bachmann, escritora e poeta à procura de seu poema, assume o enfrentamento da morte com a mesma obstinação com que Celan deseja decifrar o seu próprio enigma: o de ser ser de linguagem (daí suas tantas interpretações heideggerianas que proliferam por toda parte). Por isso, Celan atira-se ao vazio. Nele descobre que o sentido é a morte do mistério. Buscá-lo na sua integralidade implica excluir o pensamento do homem, colocar-lhe um ponto final. Ver BLANCHOT, Maurice. The gaze of Orpheus and other literary essays. Trad. Lydia Davis. New York: Station Hill Press, 1981. 
A apropriação que Kiefer faz das referências de Bachmann, está vinculada com sua simultânea tentativa de dialogar com a memória de Paul Celan. Os escritos bachmannianos escolhidos por Kiefer, têm, notoriamente, uma relação bastante expressiva com a obra de Celan. Na tela intitulada $A$ areia das urnas, um edifício aparentemente abandonado luta por se fazer uma presença ao ponto de se confundir com um turbilhão produzido por uma tempestade de areia num deserto. O deserto sugere a impossibilidade do sentido, certa figura da errância em franca descoberta das pegadas de um real substraído. É também, como expressa Edmond Jabès, uma figura de interrogação, um gesto determinado de quem está disponível para a pergunta da esfinge, de quem compreende que no deserto as imagens fluem também da memória, se misturam com uma paisagem aberta, oblíqua e vazia. ${ }^{99}$ No deserto a realidade se torna linguagem, alegoria de uma imanência fadigada, de uma imediatez aburda. Também representa um freio à demanda de absoluta inteligibilidade de um sujeito que, lançado à experiência angustiante de caminhar no deserto, vê-se obrigado a desconfiar das imagens e de suas próprias produções intelectuais, de seus códigos e certezas. Como estabelece Jean Bollack, a orientação inicial da areia representa a linguagem da poesia de Celan, o triunfo da memória sobre o tempo. ${ }^{100}$ O grão de areia é, por conseguinte, uma redução da linguagem a sua partícula mais atomizada, tornada silêncio. É no deserto que se vive a experiência extrema da orfandade, do mesmo modo em que também se experimenta a invenção poética. Pois, o todo e o nada estão ali. Lembremos que um grão de areia no olho pode provocar a formação de uma lágrima, a palavra areia torna-se, então, agente de lágrimas.

${ }^{99}$ Cf. JABÈS, Edmond. Del desierto al libro. Entrevistas com Michael Cohen. Madrid: Trotta, 2000.

${ }^{100}$ Cf. BOLLACK, Jean. Poésie contre poésie. Celan et la littérature. Paris: PUF, 2001. 
Nessa tela de Kiefer, a inscrição do paradigma celaniano aparece como uma espécie de emanação de três traços lineares colocados na frente de um edifício que parece representar um mausoléu. O pouco de ar que resta para respirar atua no trânsito de uma tempestade de matéria originária. A areia, essa palavra da memória que fala sobre a ausência dos mortos e que em certos casos, suscita lágrimas, recobre o mausoléu de Kreis (fig. 17) de um denso véu.

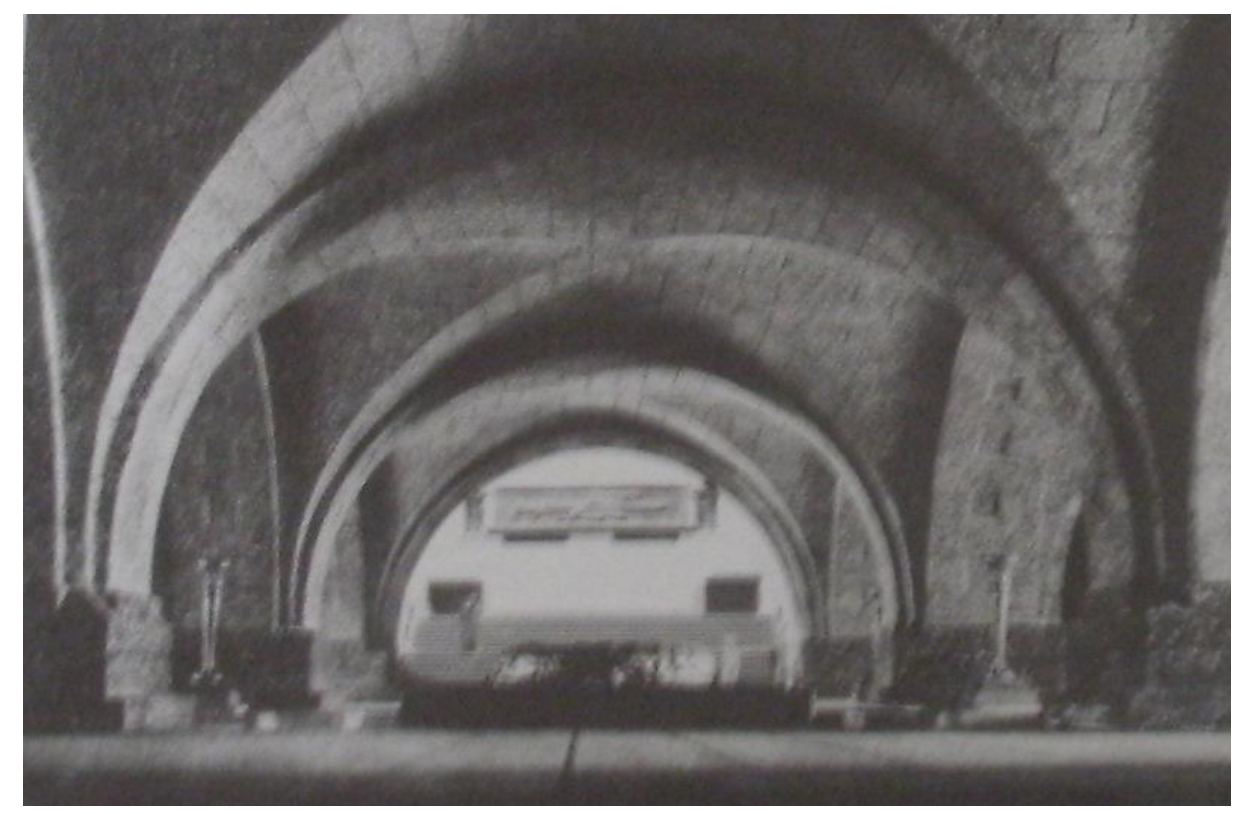

Figura 17. Wilhem Kreis. Fotografia de um modelo de cripta para os soldados alemães, interior. 1938-1941.

O deserto está povoado de silêncios, de rumores apenas audíveis, de imagens borradas que as palavras dos homens tentam resgatar. Atravessar o deserto com Kiefer é se internar no abismal, recorrer com os olhos bem abertos nosssas próprias memórias fragmentadas e nossa fragilidade espiritual. Para Kiefer a cultura se tem desertizado no justo instante em que uma proliferação malsã de mensagens, palavras e acções empurram ao homem e afundam-no no vazio da insubstancialidade, porque a experiência do deserto, de seu trânsito, é um modo de regressar sobre nossos passos para volver a formular as perguntas essenciais. Voltar ao deserto pode anunciar uma condição conservadora, pois nos comunica a falta de sentido de nossas interrogações, sua absoluta inutilidade. 
Simplesmente se nos desloca em direção ao intemporal que é uma forma do inexistente. No entanto, esse deslocamento em Kiefer oferece uma perspectiva invalorável do reencontro com a experiência do deserto; pois através da poesia de Celan e de Ingeborg Bachmann, com essa tradição da palavra, podemos agudizar nosso olhar ante o império da imagem. No deserto a memória conduz a lugares onde o pensamento se engasga sem poder alcançar a compreensão definitiva. Para Kiefer a memória está feita de areia do deserto que faz impossível encontrar esse lugar de paz, porque sua areia é evanescente, está feita de nossas próprias indagações. Deserto é o lugar mais apropriado para a manifestação pessoal, porque foi desertado por Deus: o lugar que deixou ser se revogando, se retirando. Precisamente ao estar assim abandonado, torna-se imagem do verdadeiramente Outro.

Nesse deserto encontra lugar a palavra de Celan, a tinta negra da palavra e da escritura, a poesia de Celan. No deserto Kiefer deixa a Celan a oportunidade de encontrar a linguagem do mundo, os signos dispersos de uma grafia universal que reporte, labirinticamente, a origem. O deserto de Kiefer é deserto-linguagem, é uma expressão de um vínculo escuro, oblíquo, nascido de uma implosão divina, de uma falha impossível de curar. O judaísmo de Celan permite a Kiefer quebrar a impenetrabilidade de uma cultura cristalizada em sua própria imagem especular. Frente a esta cultura, Kiefer desanda o caminho em direção ao deserto. No deserto Celan e Bachmann são donos de aquelas palavras que nos retraem à origem, daquelas palavras que moram nos buracos de nossas memórias. A fetichização da matéria como objeto transicional de duelo não encobre a transformação do mausoléu nazista. Trata-se da anamnese de uma inscrição mítica, a indexação do nome de Bachmann e da poesia de Celan que ressignificam o massacre nazista de Kreis. Por meio de Ingeborg Bachmann, Kiefer configura uma 
nova criptagem de uma interlocutora da poesia de Celan em uma imagem memorial alemã da morte. Bachmann representa para nós uma espécie de Sulamith que problematiza a aporia de sua própria geração, confrontada pela dificuldade de simbolizar uma memória em aberta recusa. No que tange à essa dicotomia memória e simbolização diante da força que a ars oblivionis acapara, Benjamin afirma que o historiador materialista deve visar a construção de uma montagem: "vale dizer, de uma collage de escombros e fragmentos de um passado que só existe na sua configuração presente de destroço". ${ }^{101} \mathrm{~A}$ literatura sobre Auschwitz e sua metarreflexão, nesse sentido, têm-nos mostrado a impossibilidade de dividir radicalmente os campos da simbolização literária e a memória.

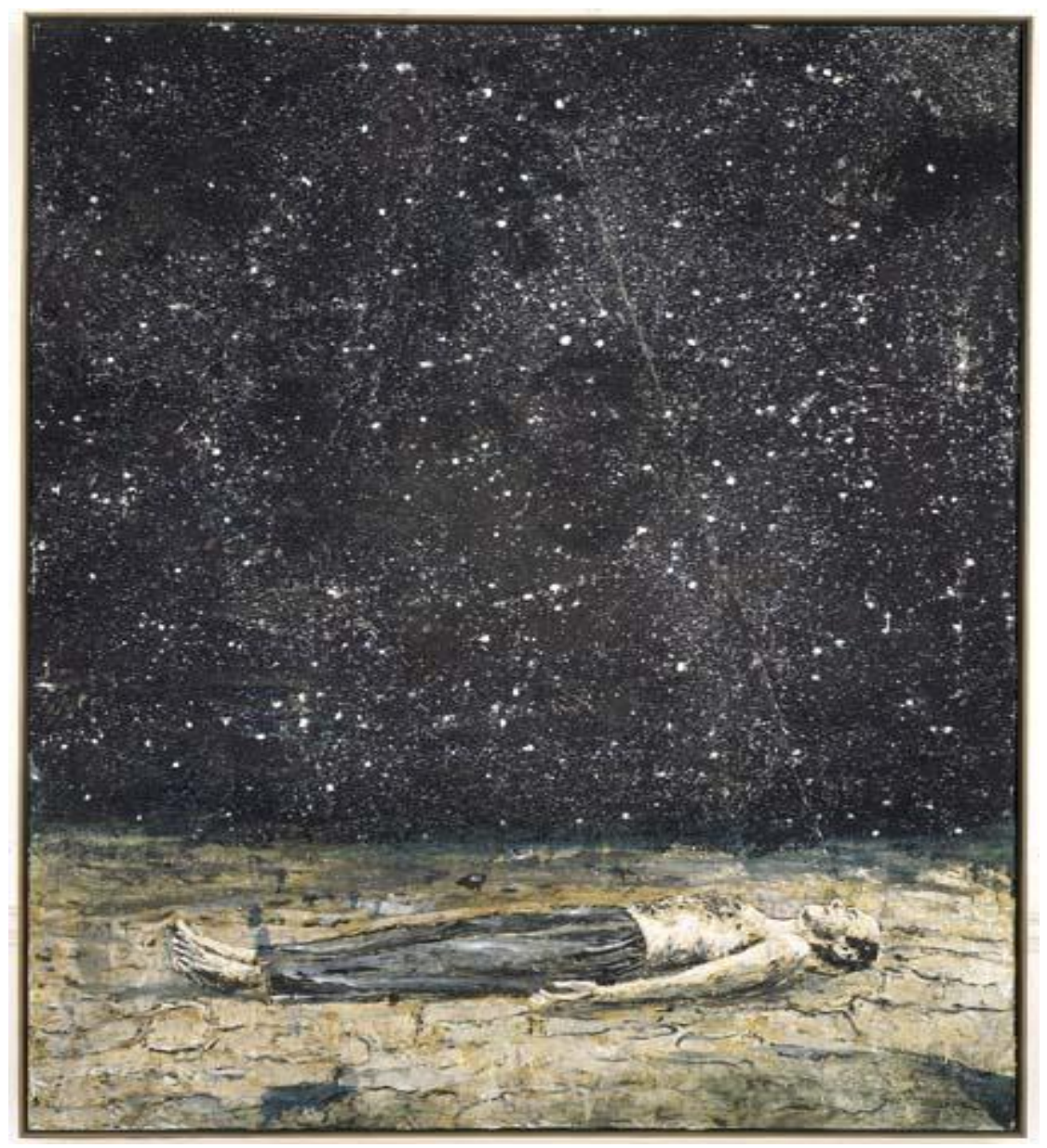

Figura 18. Athanor, 2007. Emulsão, esmalte, óleo, giz, chumbo, prata e ouro s/tela de linho. $10 \times 4,30 \mathrm{~cm}$.

${ }^{101}$ Cf. BENJAMIN, Walter. Drama Barroco. op. cit., p. 89. 
Numa linguagem silenciosa, brilha a palavra divina, mas aquela necessita da nomeação humana para se manifestar. Nos nomes, a linguagem humana traduz a linguagem silenciosa das coisas, conferindo-Ihes uma voz, ainda que imperfeita e mediada por um processo de tradução. Toda tradução pressupõe um excesso que necessariamente Ihe escapa, um núcleo intraduzível, logo incomunicável, inexprimível. Kiefer e sua tela Athanor (fig.18), em seu forno de alquimista, acaba traduzindo a matéria, no caso o chumbo, em obra de arte. Da figura heróica do começo da sua produção pictórica, voltada para a história e a cultura alemãs (sombra do nazismo e seus correlatos estéticos com o romantismo), ao homem jogado no chão, sugerindo o sonho e ao mesmo tempo a morte, Anselm Kiefer tem percorrido proteicamente um longo caminho. Seja o que for Athanor, sujeito ou objeto, fictício ou real, essa representação expressa até que ponto o pensamento e os sentimentos do artista são fisicamente encarnados e vividos. O corpo alongado pode ocupar diversas posições, visto de perfil ou de modo horizontal.

O céu estrelado apresentado em seus trabalhos a partir de 1996 na série Cette obscure clarté qui tombe des étoiles, (fig. 19) reaparece encenando a relação entre Céu e Terra e seus variados avatares pictóricos na constelação de Kiefer: pinturas, aquarelas, livros de artista ou fotografias. Para o pintor, o corpo humano é um microcosmo vinculado a um macrocosmo, e as forças do universo estão em nós. Kiefer adora citar esta consideração de Kant: "O céu estrelado acima de nós, a lei moral em nós." A arte representa um elo possível entre o mundo do real e o mundo do imaginário. Esta ambivalência traduz-se na usina própria da pintura, em sua materialidade impregnada de peso e leveza. Athanor representa assim uma superposição de materiais que o artista vai transformando por sedimentação, recobrimento, enterramento e ressurgimento, 
operações que apelam a uma espécie de alquimia pictural. Trata-se de uma pintura imbricada com a escultura e com o relevo. Kiefer constrói sua pintura por uma operação de destruição e reconstrução. Essa encenação do caos originário restaura a violência dos meios pictóricos que testemunham a energia vital do pintor que impacta duravelmente a visão do espectador.

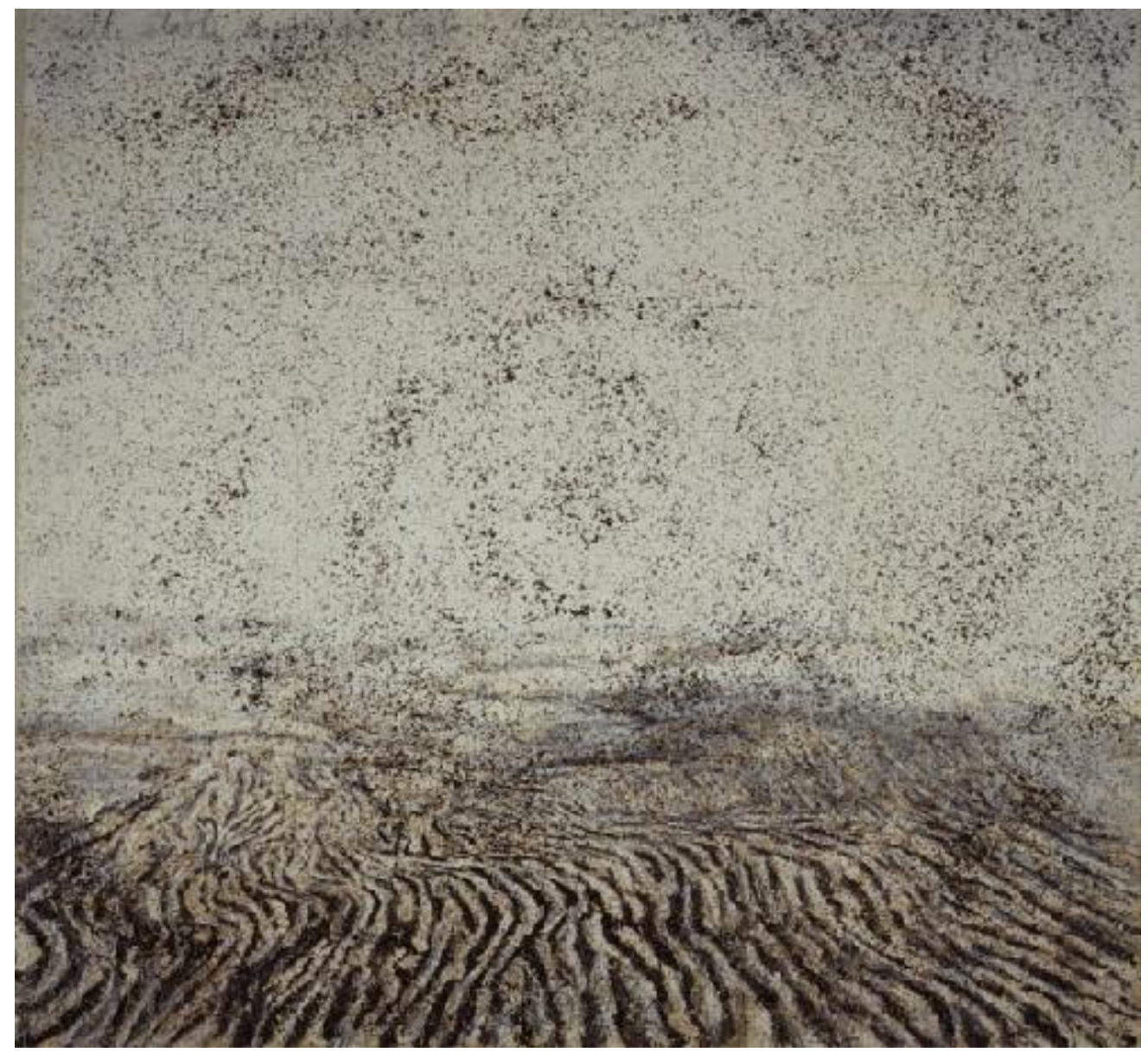

Figura 19. Essa escura luminosidade caíndo das estrelas/Cette obscure clarté qui tombe des étoiles, 1996. Emulsão, acrílico, grãos de tornassol s/tela. $520 \times 560 \mathrm{~cm}$.

Walter Benjamin reformula o mito bíblico da queda em termos de uma queda da linguagem paradisíaca dos nomes, única, capaz de conhecimento perfeito - ou seja, de perfeita tradução - na multiplicidade diferenciada, e cognitivamente imperfeita, das linguagens históricas. Kiefer, por seu turno, devolve Sulamith desmarcada, a seu marco original, a sua cena primitiva, restituindoIhe sua existência histórica e fundante. O silêncio da linguagem pode 
ter um duplo significado em Benjamin e Kiefer: ou o silêncio mudo do confisco da experiência, a latitude das significações, a insignificância das coisas (o silêncio dos combatentes das guerras da técnica) ou o silêncio que prepara a palavra aurática da reconstituição do sentido das coisas. A queda da faculdade de nomeação originária na faculdade de julgar, que gera abstração, interrompe a comunhão dos humanos e das coisas nos nomes, que deixam de ser uma origem e um fim em si mesmos, e passam a comunicar algo exterior.

O importante para Kiefer é o conhecimento do Bem e do Mal, da esfera referencial do mundo objetificado que condena a linguagem humana à mera conversa superficial: a remissão do pecado original da queda na linguagem representacional e a libertação da culpabilidade que se the associam dependem agora da natureza mágica, ainda que severa, do julgamento. Após o trabalho de luto imposto a todo artista alemão nascido em 1945, Kiefer reencontra uma pulsão criadora no resgate dos mitos originários da criação do mundo, exemplos que the permitem conferir à arte e à cultura um lugar possível após Auschwitz. A tarefa que Kiefer se impôs foi a de transformar o metal em ouro, o material em espiritual, o luto em melancolia, o êxtase em graça e o silêncio em linguagem. De fato, de acordo com a versão benjaminiana da origem mítica da lei (moral), - sua instantaneidade -, ela surge em resposta à entropia semiótica das linguagens pós-babélicas, que se manifestam na exteriorização reificada dos signos, bem como na escravização da linguagem na conversa mundana. Como resultado dessa sobrenomeação - à qual se alia um adensamento do meio de comunicação, cada vez mais opaco, a natureza, abandonada pela graça divina com que investia a pura nomeação - vê a sua aparência profundamente mudada. A natureza veste luto, cobre-se com um véu de melancolia. Kiefer também expressa essa nostalgia benjaminiana dos tempos e das culturas pré-científicas. Ele procura saberes, 
conhecimentos nas mitologias e nas religiões que possam permitir ao homem restaurar um laço direto com a natureza e o universo. Eis sua passagem pela mística judaica que o tem orientado, segundo Daniel Arasse, "de uma dimensão existencial à espiritualidade, às meditações de ordem cósmica". 102 Athanor, por exemplo, conjuga essas dimensões espaço-temporais, o presente e o passado imemorial. Esta pintura apresenta-nos outra visão das relações entre a arte e a história, entre o artista e a humanidade. Uma versão teatral, espetacular, de natureza essencialmente poética. A linguagem, tanto para Benjamin quanto para Kiefer, tem o sentido da projeção universal da sensibilidade sobre o Outro para sentir o mesmo que ele, é portadora da vontade metodológica de captar a substância subjetiva do autor de uma obra ou da época e pretende ocultar a perda de substancialidade do sujeito, a sua desespiritualização. Benjamin não deseja falar do crítico, nem do sujeito, nem de sentimentos: seu tema é a interioridade do próprio objeto. Para descrever este interior, o filósofo se vale do objetivismo da forma metafísica. Assim como a vontade em Benjamin é o domínio de si próprio, é um princípio ascético de aprendizagem, a contemplação filosófica em Kiefer recupera a plenitude de suas dimensões éticas. Pois, na medida em que vinculamos decisão e objetividade, estamos diante da chave de toda responsabilidade ante o tempo.

Com a série Lilith refletimos sobre a metrópole e a maneira kieferiana de pensar o ingresso do Mal no mundo e sua dimensão temporal. Kiefer trabalha com o Mal e seu contrário: a memória, a pietas do passado e a esperança do futuro, ou melhor, a paradoxal memória do futuro, razão pela qual recentemente parece determinado a rejeitar o papel de vítima. Assim, O Livro de Jó continua a ser, por exemplo, um modelo de elaboração narrativa e 102 "d'une dimension existentielle à la spiritualité, aux méditations d'ordre cosmique."Cf. ARASSE, Daniel. op. cit., p. 200. 
paradigma constante de reflexão: deste modo, o problema do Mal já se entenda como Malum mundi, como Malum hominis - vem redirigido à temática do pecado e da culpa originária. As interrogações que Jó dirige a Deus se têm repetido inúmeras vezes no curso da história: Por que existe o Mal? Verificaremos se, para Kiefer, o Mal é a negatividade enraizada na constituição mesma do homem, se é uma negatividade referida a certos estados da existência humana ou pode configurar-se como negatividade absoluta, como deficiência ontológica insuprimível. A dor do inocente, o sofrimento inútil e inexplicável, que provoca o desabafo contido nas duras e rebeldes palavras de Jó, têm recebido respostas mitológicas, religiosas e filosóficas de distinto gênero. Lembremos que a Segunda Guerra Mundial é a ilustração por excelência de um Mal radical e transcendental que encena um Mal cometido contra inocentes. Muitas personalidades chocadas com o que estava acontecendo durante a guerra interessaram-se na leitura do O Livro de Jó para encontrar nele algum tipo de conforto. ${ }^{103}$ É em meio a

${ }^{103} \mathrm{O}$ Mal se define como complemento de um desígnio mais vasto, embora sua aceitação precise, em definitiva, de um ato de fé. Tal é em geral a posição dos amigos de Jó; tal é também o ponto de vista da Teodiceia de Leibniz (na qual, o Livro de Jó é citado apenas em duas ocasiões). No entanto, esta solução é notoriamente rejeitada no extraordinário comentário kantiano ao Livro de Jó em Ueber das Misslingen aller philosophischen Versuche in der Theodizee (1791). Segundo Kant, Deus, em sua intervenção final (caps. 38-42) honra a Jó, colocando ante seus olhos a sabedoria da criação, mas, ao mesmo tempo, enfatizarão o caráter insondável de seus desígnios. Os caminhos que manifestam a sabedoria do criador são, para o homem, insondáveis pelo que concerne à ordem física da criação, para não falar da ordem moral (Cf. A 216; ed. Weischedel, XI, 118). Na intervenção de Deus e na subseqüente resposta de Jó, de outra parte, sai à luz uma ulterior versão da problemática do mal, descuidada aqui, no entanto, por Kant. O nexo entre revolução e mal aparece aqui de manifesto quando se considera revolutio em seu sentido de retorno, de conversio. Em geral, a conversio, a conversão, indica, por um lado, a saída do próprio enclaustramento dentro de si mesmo, da soberba adesão ao amor sui, e, por outro, aponta a esse retorno, essa reditio que converge em direção à origem autêntica. De um ponto de vista, o Livro de Jó, configurase como a trajetória de uma revolutio, de uma conversio que leva a uma confrontação face a face com Deus, e que apenas a experiência do sofrimento faz possível. Desta forma, o mal é entendido como sofrimento, 
esse espírito que H. Ehrenberg pôde escrever em 1952: "Nosso tempo tem se tornado um muro para Jó". ${ }^{104}$

não como execução e condutor ao excesso, como fruto de uma ação. Apresenta-se na forma de um signo representante de um padecer, de uma passividade inata ao homem consciente que se faça, em si própria, a experiência do outro de si. Assim, o sofrimento se torna testemunha da radical passividade humana, e, lugar no qual o sujeito se descompõe, em que acontece a experiência do outro. Emmanuel Lévinas, em particular, desenvolveu esta constelação conceitual na qual o mal se configura no sujeito como um acontecimento externo a todo contexto, um evento refratário a toda possível síntese, que excede toda capacidade de compreensão, algo constitutivamente insuportável. Desenvolvendo estas sugestões levisanianas, poderíamos considerar este aspecto como a contradição absoluta do mal. Nela, o sofrimento revela-se como algo sem redenção, pela simples razão de que nenhuma compreensão pode cancelar a posteriori o fato de haver ocorrido, porque o simples fato de seu acontecimento representa um escândalo. O caráter fático refratário a toda redenção do mal e do sofrimento exemplifica-se em algumas figuras humanas como o idiota, o louco, o perseguido pela simples pertença a uma raça determinada, as crianças inocentes, vítimas de Auschwitz, figuras para as quais resulta bem difícil a remissão não apenas a uma teodicéia, senão à conversio.Ter examinado o sofrimento inexplicável e inútil de Jó é problemático, também é problemática a via do retorno à revolução na tentativa do homem, em que falava Kant, a via consistente em se apegar a um Deus cada vez mais ausente, acolhendo, por outra parte o mal, aprendendo a conviver com ele. O mal se faz cotidiano, coisa corriqueira e habitual, sem que escandalize nem se contraponha ao bem. Trata-se do mal encarnado no fazer das coisas dos acontecimentos humanos.

104 "Unsere Zeit ist Hiob-Reif geworden." Cf. EHRENBERG, H. Hiob, der Existentialist. Heidelberg, 1952, p. 5. O corpus bibliográfico que se desprende do Livro de Jó é oceânico e pode- se localizar sua relevância contemporânea a partir do Affaire Dreyfus, Bernard Lazare (1865- 1903) evocou na sua obra inacabada Le fumier de Job, a difícil situação dos judeus na França, comparando-a com aquela de Jó rejeitado por seus semelhantes. Imediatamente, após a Segunda Guerra Mundial, o poeta americano Robert Frost publica o primeiro de seus dois poemas dramáticos sobre temas teológicos, A mask of Reason (1945) em que Deus ironiza Jó. No livro Das Buch Hiob und das Shicksal des jüdischen Volkes (1946)(O livro de Jó e o destino do povo judeu), Margarethe Susman analisa a relação entre a identidade de Jó com o povo israelense representada pela figura do servo sofrido em Isaías 53. Paul Claudel no Le livre de Job, (1946) distingue três níveis de discursos: o próprio drama de Jó, o drama da Igreja que apela Deus contra si próprio e o drama da comunidade humana em diferente tempo e lugar. O dramaturgo suíço Fredrerich Dürrenmatt recoloca o relato de Jó no tempo da Guerra dos Trinta Anos em Der Blinde,(1947-48). Martin Buber também nos deixa sua interpretação sobre Jó em seu livro Prophetic Faith (1950). A presença de Jó se faz notória no livro de Ernst Bloch Atheismus im Christentum. Zur Religion des Exodus und des Reiches de 1968, (Ateísmo no cristianismo. A propósito da Religião no Êxodo e no Livro 
Nossa hipótese é a de que a peripécia pictórica de Kiefer aceita que o Mal do mundo não é redimível. Sabe que nenhuma redenção é possível, seja no Céu, seja na Terra, nem cristã nem pagã. Sabe que o Mal acompanha o Mal. Esta consciência não é impassibilidade. Pelo contrário. É compreensão do sofrimento: do próprio e de outrem. Compreensão universal da dor universal. Em uma entrevista com Roberto Andreotti e Federico de Melis, ante a pergunta se o pintor tem uma visão platônica do mundo, Kiefer responde pautando sua própria teodiceia:

Não rejeito completamente o platonismo. Só que eu tenho uma outra Anschauung [visão, opinião, intuição]. 0 Platonismo divide o mundo em dois: por um lado temos a idéia e, por outro, a marca da Idéia que corresponde à idéia [...] esta noção evoluiu depois, dando origem à diatribe sobre o Universal com a Escolástica. Existiam os nominalistas e os realistas, que se faziam a guerra: uns acreditavam que o conceito, a Idéia, veio primeiro e que o resto era acidental, enquanto os outros partiam da realidade e construiam acima disso um 'sino,' uma idéia. Um

dos Reis). Para Bloch, Jó representa uma figura contestatária, ele representa o momento prometeico do ser humano que ousa se levantar contra um Deus todo-poderoso, porque o ser humano é tal, na medida em que se apropria de seu ser e compreende que não está destinado a ser dominado por uma potência superior, extramundana e trans-histórica. Em God's Favorite, (1974), o dramaturgo Neil Simon, propõe uma reconstrução imaginária e cômica da figura de Jó. Élie Wiesel, sobrevivente de Auschwitz, para onde foi deportado com 15 anos, consagrou sua vida de escritor à memória da Shoah, o livro de Jó acompanha constantemente sua reflexão escritural, Job et le silence révolutionnaire (1975) e Job ou Dieu dans la tempête (1986). Para o crítico literário canadense, Northrop Frye o Livro de Jó é um resumo narrativo da Bíblia considerado como um todo, consiste em uma comédia da virtude, The Great Code (1982). Para Fernando Savater existimos a partir da experiência de Jó, somos filhos do grito e progenitores do grito, Diario de Job, (1983). Em La route antique des hommes pervers (1985), René Girard propõe uma leitura do Livro de Jó como o último símbolo do homem revoltado que rejeita assumir o rol de bode expiatório. Com seu Job (1975), Marc Chagall pinta uma figura de exceção no seio de todas as representações desesperadas de Jó, este Jó é meditativo e calmo perante sua miséria. William Blake e suas "Ilustrações ao Livro de Jó," carregadas de simbolismos, hermetismos e esoterismos também encontrados em diversos outros artistas dos séculos XVIII-XIX. O livro de Carl Jung sobre Jó, Antwort auf Hiob (1952), Philip Nemo, Job et l'excès du mal (1978) e Tony Negri, Job, la force de l'esclave (2002). 
desenvolvimento ulterior do platonismo tem levado ao Gnosticismo, que divide o mundo de maneira mais nítida entre o Bem e o Mal. Isto, por sua vez, tem se transformado em Maniqueísmo. O bem e mal que estamos assistindo hoje em América deriva do maniqueísmo. O mal e o bem estão apenas misturados. Não existe só um reino do Bem ou do Mal. ${ }^{105}$

Na obra de Kiefer, o Tzim-tzum (fig. 20) não é palavra e, no entanto, quebra a imobilidade do silêncio. Não é a palavra porque ela tem sido inteiramente ocupada e devastada, pelo discurso da redenção. O Tzim-tzum aponta uma palavra que é mais íntima e profunda, a palavra que não é um fenômeno acústico, embora tenha como destino o ruído do mundo, da cidade. A tragédia do Tzim-tzum define o itinerário histórico de um judaísmo intransigente, porque na afirmação desse deslocamento de Deus, acabamos sendo todos deslocados, enquanto homens, de toda visão absoluta. A revelação, como escreve Edmond Jabès, recorre o caminho que vai da metrópole das imagens até o deserto, em direção ao fogo inacessível, esse fogo negro da revelação. ${ }^{106} \mathrm{Na}$ relação com o paradigma da cidade, em que todo se torna imagem e repetição, citação de imagens e interpretação de interpretações, essa palavra rememora o vazio, esse abismo pujante, produz essa retirada, condição indispensável para que esse próprio jogo da citação possa ter lugar. A intolerância ética do Anjo da história se inverte na intolerância antiética de um judaísmo contemporâneo.

105 "Non respingo del tutto il platonismo. $\dot{E}$ solo que io ho un'altra Anschauung. Il platonismo suddivide il mondo in due: da uma parte abbiamo l'idea, dall'altra l'impronta dell'Idea [...] questa concezione si è poi evoluta, dando luongo alla diatriba sugli Universali con la Scolastica. Esistevano i nominalisti e i realisti, che si facevano la guerra: gli uni credevano che venisse prima il concetto, I'Idea, mentre tutto il resto fosse accidente. Gli altri partivano dal reale e costruivano su di esso una "campana,"un'Idea. Un ulteriore sviluppo del platonismo ha portato allo gnosticismo, che suddivideva il mondo in mod ancora più netto nel Bene e nel Male. Questo, a sua volta, si è tramutatto in manicheismo. Il bene e il male che stiamo vedendo oggi in America deriva dal manicheismo. Il male e il bene [...] no, solitamente sono mischiati. Non esiste un regno solo del bene o del male". Cf. ANDREOTTI e DE MELIS, op. cit., p. 29.

${ }^{106}$ Cf. JABÈS, Edmond. op. cit., p. 123. 


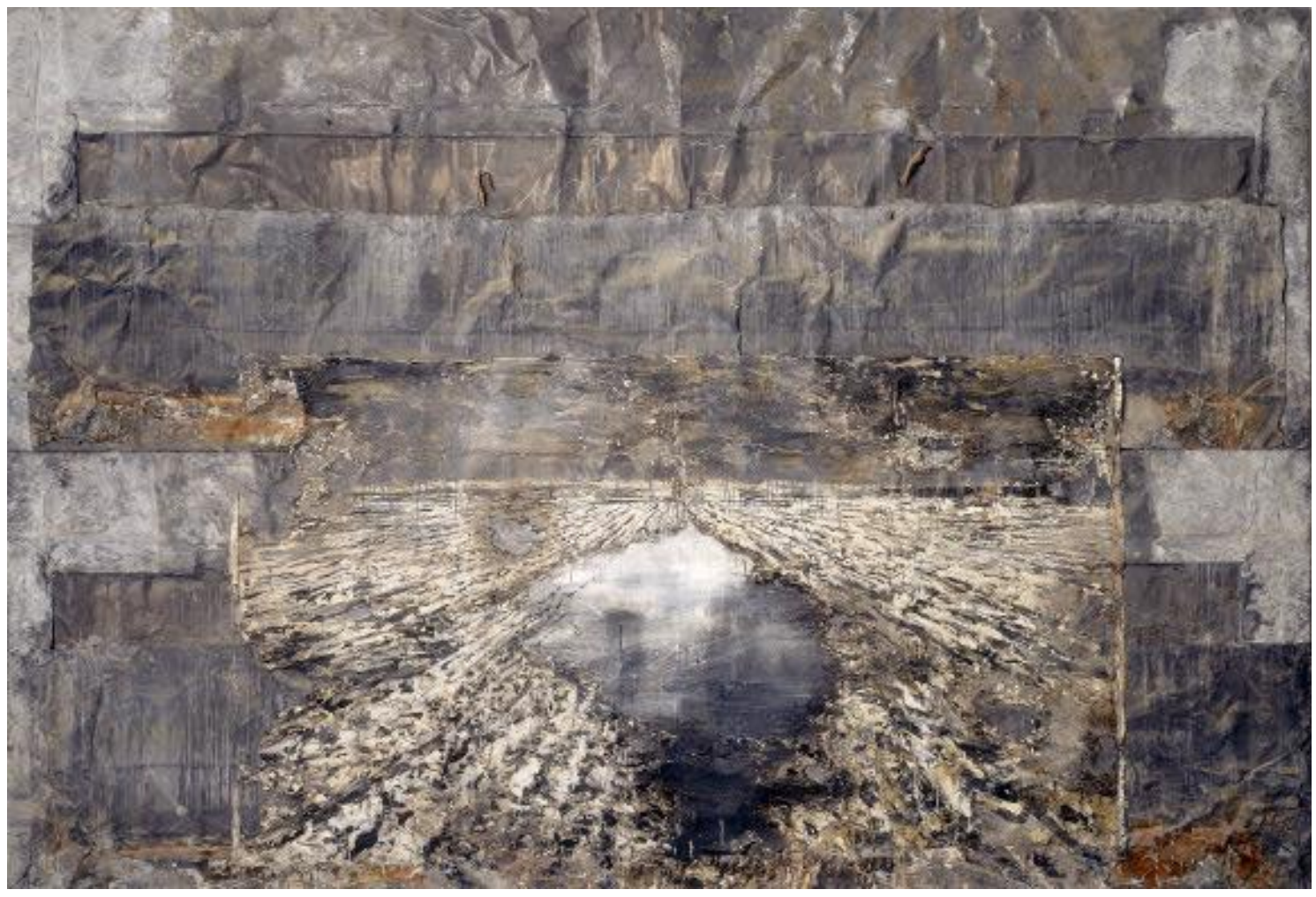

Figura 20. Tzim-tzum/Zim Zum, 1990. Acrílico, emulsão, giz, esmalte e cinzas s/tela e chumbo. $380.3 \times 560.1 \mathrm{~cm}$. Galeria Nacional de Washington.

A presença do nada, desse vazio primordial do qual nasceu a vida, se substrai a uma cultura que acredita poder articular suas relações com o mundo a partir da imagem. Em Kiefer a cidade é o âmbito privilegiado da não-imagem, do espelhismo que nos mostra a insubstancialidade de toda imagem. A memória conserva em Kiefer, o sentido de uma custódia. Custodia o Mal, o sofrimento, a dor do mundo dos irredimidos e irredimíveis. Quantas vítimas da Shoah têm incorporado a necessidade de deixar um vestígio dele, de deixar memória? A Shoah acendeu o abismo da dor e da crueldade do homem. O abismo do Mal induzido e sofrido. Os sobreviventes escreveram para conservar a lembrança, para custodiar na memória da humanidade a experiência da dor. Roney Cytrynowicz, por exemplo, analisa o conto autobiográfico "A morte do meu pai," do escritor Elie Wiesel em que existe um debate sobre rezar ou não o 
kadish, a reza judaica dos mortos, no aniversário da morte de seu pai, assassinado pelos nazistas durante a Segunda Guerra Mundial. O relato de Wiesel articula a revolta do homem diante do que ele chama de ausência de Deus, o que, segundo o conto, teria tornado possível o espaço para o acontecimento do genocídio. Para Cytrynowicz:

"A morte do pai," o conflito central de Wiesel é com Deus. Não há conflitos entre os homens: os judeus não reagem e não se revoltam contra os nazistas, e estes encarnam uma espécie de mal teológico. Em outro conto, o desfecho dá-se no plano divino. É a história de um judeu deportado que foge "milagrosamente" do vagão. O homem era um profeta e sabia o seu destino, escreve Wiesel. O sobrevivente não resistiu com armas, não ajudou os companheiros, tampouco se salvou por suas próprias forças. Foi um milagre. ${ }^{107}$

Quem sabe se exclusivamente a memória permita que se agregue dor à dor, para que se respeite a dor. Mas a experiência da dor não é exclusiva de grandes exemplos. Ante a dor, toda experiência, grande ou pequena, é análoga. Assim nos advertem Benjamin, Kiefer e a literatura universal. O Mal e o Bem não possuem uma essência separada, então a atração pelo Mal poderia chegar a ter um final, no sentido de uma vontade de aniquilação encaminhada contra a origem do Bem como ato de livre revolta, de grandiosa arrogância, de vontade de desordem. O querer impor o Bem - a razão como fator da ordem - seguindo confusas ilusões de justiça ou felicidade, engendra paradoxalmente o Mal, tanto mais vitorioso e radiante quanto mais se pretende afirmar o Bem: futuro ou presente. Então, a banalidade do Mal consiste ora em atuar com a inocência do animal ou com a ingenuidade dos antigos (como o fato de Robespierre, ao querer ressuscitar o conceito de virtude), ora em que a vontade da consciência e da razão tem corrompido o homem e se encontra a

107 Cf. CYTRYNOWICZ, Roney. "O silêncio do sobrevivente: Diálogo e rupturas entre memória e história do Holocausto," In: SELIGMANN-SILVA, Márcio (org.). História, memória e literatura. O testemunho na era das catástrofes. op.cit., pp. 125-126. 
virtude sustentada apenas pela razão pura. O Mal é algo originário, forma parte do sistema da natureza e é inseparável dela. ${ }^{108}$

Kiefer tem reavivado a discussão sobre a natureza humana frente a tradição paulina e calvinista ${ }^{109}$ ao julgar a natureza como originariamente boa, e, simetricamente, contra aqueles que sustentam a existência do Mal radical, Kiefer vale-se de toda uma literatura universal que aponta, a este nível, para aquilo que o

108 Lembremos que no quadro ideológico da tragédia grega, o conflito trágico leva, indefectivelmente, à catástrofe. E a catástrofe representa, por regra geral, um destino absoluto e inexorável. A destruição não só se impõe à personagem central, mas também, como refere Aristóteles, aos que com ela mantêm relações de afetividade, e, por vezes, as casas reais e cidades inteiras, arrastadas no destino trágico de quem as comanda. A natureza destruída pela catástrofe é redimensionada por uma compensação, inexistente na tragédia grega, ou seja, a possibilidade de redenção do sofrimento post-mortem. Embora a tragédia grega ofereça exemplos variados de catástrofes atenuadas, em nenhuma transparece a noção de compensação. A mitigação da catástrofe ou surge por intervenção divina, como nas Eumêmides, em que Atena convence às Fúrias a deixarem de assediar Orestes em troca de novas honras cívicas em Atenas, ou, como em Medéia, em que a intervenção convencional deus-ex-machina retira a personagem do conflito e lhe permite a salvação; ou ainda, em Filoctetes, em que a catástrofe é evitada por Hércules quando convence o herói a lutar na batalha de Tróia. A idéia da salvação, de que a felicidade não atingida na Terra está reservada no além, trouxe considerações significativas no plano das mentalidades e, conseqüentemente, no campo literário, filosófico, político e plástico. Com efeito, o sentido da catástrofe reconfigura-se porque os resultados de mediação, feita pelos deuses, entre a ação dos homens e castigo que sobre eles se abate, transferem-se para um plano diferente do humano. Deste modo, a idéia aristotélica de justiça natural - que relacionava crime e castigo - deixa de ser considerada como realizável apenas no plano terreno. A correlação "impolutabilidade e recompensa postmortem" - tramitada pelas religiões messiânicas - torna-se também o contraponto compensatório para essas situações em que essa correlação não é possível no contexto ante mortem. A катабтрофí inaugura um tópos, isto é, o tópos do compromisso, impossível no universo de aniquilação absoluta da tragédia grega. Na verdade, Édipo não mais terá do que cegueira e errância física e existencial. Deste modo, a catástrofe veiculada pelas religiões da salvação aparece como uma moira mitigada, na medida em que, simultaneamente, representa uma solução para a efemeridade da vida e para a inexorabilidade da dor. A natureza intrínseca das religiões da salvação (cristã e judaica), parece trazer, assim, uma mudança no paradigma do trágico. Cf. BERLANGA, José L. Villacañas. Tragedia y teodicea de la historia. Madrid: Visor, 1993.

109 Cf.TAUBES, Jacob. Die politische teologie de Paulus, Frankfurt: 1993; Cf. Agamben, Giorgio. Le temps qui reste. Paris: Rivages, 2000. 
homem se tem tornado: um negador da vida, um inimigo de si próprio, tocado por essa pulsão de autodestruição. O século $X X$ pensou triunfar sobre a barbárie e a violência graças aos progressos da ciência e da técnica. Contudo, diversos autores informam a obra de Kiefer, isso não ocorreu. Walter Benjamin e Theodor Adorno nos mostraram que os progressos não lograram superar guerras mundiais, extermínios e genocídios. A resposta da literatura e da filosofia tem sido a mesma, pois de Franz Kafka a Céline, de Robert Musil, Primo Levi, entre outros, ${ }^{110}$ se ficará convencido de que a barbárie se tornou inquietação ontológica: com estes escritores a literatura encontra sua passagem da exploração epistemológica à deriva ontológica. Já não mais se trata de um Bildungsroman, mas de um romance da deformação, da negação. Esta circunstância se expressa, exemplarmente, na auto-philia das metrópoles modernas. Assim a cidade de São Paulo torna-se a forma contemporânea mais concreta do que Kiefer pensa como catástrofe na série de pinturas designadas como Lilith. Aqui é o espaço onde se ilumina o desaparecimento do divino nos meandros escuros da cidade, da polis. A experiência sobre a qual pode descansar a philia - a amizade que não conhece limites - é a dor: a mais universal experiência do homem, já que é de todos os homens e, ao mesmo tempo, de todo homem. A dor toca a alma e o corpo, o interno e o externo; por isso dele só há experiência possível no mundo, no mundo dos homens, na cidade, na polis, esse infausto lugar do Mal necessário. Observemos, por exemplo, como a cidade de Nova York e a de São Paulo se tornaram a forma mais contemporânea de pensar esta questão: o escritor novaiorquino Paul Auster volta todos seus esforços estéticos para a cidade de Nova York, para falar justamente da catástrofe permanente que ameaça esta cidade. September 11, com certeza,

110 Pensemos também nos romances de Ernst Jünger e seus diários sobre a guerra das trincheiras, Über die Linie, (1951); Cf. Carlo Emilio Gadda, La cognizione del dolore (1963) e Cf. Alfred Döblin Berlin Alexanderplatz (1922). 
tornou essa cidade a grande senhora do Mal e a grande vencida. ${ }^{111}$

Pensemos como o crime organizado em São Paulo propagou o caos e

${ }^{111}$ Entre os artículos que consultamos sobre os ataques urbanos acaecidos nesse cruel May em São Paulo, encontramos toda a discussão da Revista Novos Estudos 80, Março 2008, com ensaios de Loïc Wacquant, Benjamin Lessing, Renato Sérgio de Lima e uma entrevista com Nagashi Furukawa, ex- secretário de Segurança Pública do Estado de São Paulo. Desses artigos, o texto do sociólogo francês parece ser o mais completo de todos. Com o detalhe que não aborda a situação carcerária brasileira, ele se refere à relação entre welfare e workfare nos Estados Unidos. Para Wacquant, escapar do paradigma angelical da imposição do cumprimento da lei e exorcizar o mito demoníaco do "complexo industrial prisional" são duas etapas necessárias e complementares para localizar de forma apropriada as novas funções que a prisão carrega em meio a hierarquia etnorracial e a marginalidade urbana nos Estados Unidos dos dias de hoje. A lâmina cega de uma "guerra contra o crime", precisa considerar o acordo secreto demoníaco entre oficiais públicos e corporações privadas com vistas a faturar muito dinheiro com as práticas de encarceramento. Destarte, Wacquant revela que o fenômeno participa da construção de um Estado reformado capaz de impor requerimentos econômicos e morais adstringentes do neoliberalismo após o descarte do pacto social fordistakeynesiano e a implosão do gueto negro. A eclosão das novas formas de administração da pobreza comprometidas com o workfare restritivo e com punições expansivas exige que tiremos a prisão dos domínios técnicos da criminologia e da política criminal, e a coloquemos diretamente no centro da sociologia política e das ações civis. Recorremos, para tal formulação, ao Agamben de Homo sacer, pois a realidade atual envolve a elaboração de estratégias em busca de "formas de vida" que escapam à política. Esse artigo de Wacquant poderia sugerir algumas pistas para entender a questão brasileira, com suas respectivas particularidades, bem entendido. Outra série de artigos apareceu na cena intelectual argentina na extinta revista Punto de Vista 85, agosto de 2006. Três artigos compõem seu dossiê: Infierno en San Pablo. Tres perspectivas. Paulo Arantes, "Dos veces pánico en la ciudad," Enrique Rodriguez Larreta, "Ciudadanías frágiles y conexiones perversas," e José Texeira Coelho, "La ciudad como selva." Não obstante esses sugerentes títulos, trata-se de três textos cujas análises são muito vulneráveis para determinar uma abstração geral e poder dar conta do que aconteceu nesses dias catastróficos de maio. Lendo um artigo sobre a Pop Art, nos deparamos, a saber, com a contundente análise formulada por Sônia Salzstein: "O populismo turbinado promete nada mais nada menos do que a promoção das massas (também das massas miseráveis dos países periféricos industrializados) por graça e obra da cultura ou da Arte, oferecidas aos militantes neófitos como "qualidade de vida" ou promessa de uma vida subjetiva proteica e atraente, espécie de dispositivo compensatório em face da decomposição social em curso. Nem toquemos na questão mais candente de que o capital que hoje patrocina em grande estilo a arte ou a cultura em iniciativas de envergadura e alcance transnacional - como bienais, festivais internacionais de arte e cultura, itinerâncias de megaexposições e eventos culturais de todo tipo - jamais poderia se dirigir diretamente ao mundo social, quando então teria de se 
o perigo impondo o risco, paranóia e medo por toda parte com uma série de ataques e atentados executados num final de semana do ano 2006. Trata-se do maior centro econômico do país, uma superpotência que, em um final de semana, tornou-se uma supervítima, tendo também seu May 11 periférico. Em ambas as cidades, fracassadas as garantias burguesas de segurança, a vida tornou- se, expressamente, um franqueamento de limites, onde as expressões de terror humano se tornaram pura superfície para a degustação da própria barbárie que as sustenta. Observamos como a estrutura da politeuesthai (forma de cidadania) contém o germe da sua própria fraqueza, a debilidade constitutiva de uma política que privilegia a morte perante uma política da vida. ${ }^{112} \mathrm{~A}$ retomada metonímica do mito de Lilith, que espalha o Mal no mundo, na cidade de São Paulo apresenta-se, então, como uma antecipação desse futuro glorioso que tem a catástrofe em cidades nascidas sem nenhuma medida, sem nenhum coeficiente de humanidade. São Paulo, como tantas outras megalópoles, nasce e exprime-se como experiência de uma permanente barbárie. Ela padece em Kiefer uma destruição

haver, não mais com militantes neófitos e bem intencionados, mas com massas enfurecidas, despolitizadas, imantadas pela violência, pelo ressentimento, pela necessidade. A esse respeito, os ataques urbanos ocorridos entre maio e julho de 2006 na cidade de São Paulo, incitados por organizações criminosas de presidiários comandando os eventos de dentro das cadeias (e contando com apoio no aparato jurídico, legislativo e administrativo do Estado, como também no meio empresarial), são um bom convite à reflexão." Aguardamos, esperançosos, por essa reflexão. Cf. SALZSTEIN, Sônia. "Cultura Pop: Astúcia e inocência." Novos Estudos 76, novembro 2006, p. 259; Cf. DUPUY, Jean-Pierre. op. cit., pp. 413-416; Cf. ROTHKER, Susana. Citizen of fear. Violence in Latin America. New Jersey: Rutgers University Press, 2000; Cf. DAVIS, Mike. "The flames of New York," New Left Review 12, November-December 2001, pp. 34-50; Cf. LAM, Kit. Media, Memory, and Moral Transcendence: The Concert for New York City. Tese de Doutorado em Ciências da Comunicação da Universidade de Iowa, julho 2007; Cf. BUCK-MORSS, Susan. "The city as dreamworld and catastrophe," October 73 Summer 1995, p. 6.

${ }^{112}$ Cf. ARENDT, Hannah. Entre o passado e o presente. Trad. São Paulo: Perspectiva, 2001; Cf. REVAULT D'ALLONS, Myriam. Ce que I'homme fait a I'homme. Essai sur le Mal politique, Paris: Seuil, 1995; Cf. BADIOU, Alain. L'Éthique. Essai sur la conscience du Mal, Paris: Hatier, 1993. 
acelerada tornando-se uma permanente ruína. Trata-se de uma cidade que não cede mais seu lugar ao tesouro da história que ela contém, abandonando sua simbólica ancestral - toda a importância do centro cultural da cidade (Semana da Arte Moderna, o modernismo Brasileiro, a arquitetura modernista, paulista) condenada sempre a ser destroço sem ter perdido sua pulsão de novidade.

Essas ruínas recentes que forjam a estética da cidade se tornam anjos guardiães de um novo mistério. Na imaginação benjaminiana de Olgária Matos:

Se o olhar entristecido é aquele que não encontra nada de durável, se em tudo vê ruínas, antes e independentemente do seu desmoranamento, é, porém, para redimir a passagem do tempo. Sua inação não é desmobilização frente à ordem das urgências. Em meio às ruínas, em toda parte há passagens, pois há que reconhecer os caminhos que se desenham entre elas. E se as ruínas revelam, do ponto de vista da duração, a insignificância das coisas, também, na mesma medida, para a imaginação, são míticas e indestrutíveis. ${ }^{113}$

Para Kiefer, o espaço sinistrado se mantém presente na sua arquitetura, essa seqüência de prédios monumentais de São Paulo, como nas memórias coletivas, ao ritmo de suas próprias metamorfoses. De fato, as figurações visuais de São Paulo, não apresentam medo, pois a cidade se constitui a partir de acidentes de transmissão, de rupturas temporais, ela se torna profundamente anamórfica. Os lugares mais devastados, mais destroçados, falam a linguagem de Lilith, gerando emoções que poderiam estar carregadas de desesperança. Nenhum demônio cumpriu tanto com uma carreira tão fantástica quanto Lilith, que começa a partir das origens mais modestas como mulher destinada a Adão, se tornado a mestre dos espíritos lascivos. Lilith tem sido comumente associada com

${ }^{113}$ Cf. MATOS, Olgária. "O sol triste das ruínas. "Folha de São Paulo, 29 out. 1995, pp. 5-6. 
interpretações teológicas judaicas. Na tradição judaica, muitas lendas nascem da defasagem existente nos mitos da criação, particularmente, o relato dual da criação da mulher e da serpente falante. Este tema é nodal no momento de vincular a serpente com o feminino e com o mito de Lilith. Muitas das fontes escritas para este mito provêm, em geral, da Apocrifia, do Talmude, do Midrash, dos textos hassídicos assim como das tradições medievais do folclore judeu, mesmo muito antes de Lilith ter-se estabelecido como uma parte indispensável da demonologia cabalística. A série de Kiefer fala do mito, novamente são os espaços que o monumento e seu ritual magnetizam. Com isto, encaminhamo-nos em direção dos aspectos mais arquitetonizantes das suas pinturas. Sua simbologia gravita em torno de um âmbito tão ambíguo como da simbologia arquitetônicacatastrófica com a qual a pintura de Kiefer encontra-se em permanente dialogia. Lilith em São Paulo fala da cidade de seu Mal, que deveríamos chamar de maléfico, mas é, sobretudo, uma pintura que mostra uma imagem impressionantemente sugestiva, mistificante da nova cidade das multidões. A cidade de São Paulo remete-nos a outras cidades, em uma espécie de genealogia da civitas malum. Com Lilith o pintor coordena sensibilidades e vontades em confronto, escaldado na tarefa de dar um sentido unitário, estético pelo menos, a um objeto tão tempestuoso como é a cidade de São Paulo. Lilith desejando imaginar uma antiutopia reproduz a caracterização do Mal, uma imagem crítica que extrema os princípios presentes na própria sociedade, partindo de uma invenção mítica do Mal. A solução narrativa e pictórica de Kiefer opera por meio de sua leitura do mito de Lilith. O epíteto de Lilith significa virgem linda ou moça linda. Mas, de fato, ela é conhecida por ser uma prostituta e uma vampiresa que uma vez tendo seduzido um amante não o larga jamais, tornando-o prisioneiro e escravo da suas perversões libidinosas. A cidade de São Paulo possui seu correlato arcaico como fonte espiritual ainda presente. Para Kiefer, São Paulo carece de 
alma, pois seu mito fundacional pode ser representado por uma figura demoníaca. O pintor compõe uma estética da cidade a partir do maneirismo entre o moderno e o mítico. A cidade a mercê da destruição tem-se representado com o Anjo da história sobrevoando por uma espécie de cidade fantasmagórica em estado de desagregação. O confronto entre o Anjo da história que sobrevoa a cidade e a civilização consumada e consumida é total. A oposição simbólica entre cultura e império sanguinário repete a visão da cidade como ápice da civilização e ao mesmo tempo como o maior centro de afastamento das fontes de vida. As figuras da destruição não são mórbidas a priori, elas criam signos de destino no nonsense de um devir. As estratégias de gestão de uma experiência vindoura asseguram a reprodução de sentidos sinistros que configuram novas formas de existência e de consciências. As figuras do desastre nessa cidade preservam a forma enlouquecida de todo devir e apelam, ao mesmo tempo, à violência da esperança. A idéia de um futuro é bem mais impossível quando ela se reúne ao estranho desejo de catástrofe.

Semelhante argumentação se justificaria no caso de Lilith de Kiefer, nos quais a deambulação urbana do pintor parece subordinarse a uma mais englobante tendência alegórica. Tal seria o caso dessas pinturas deambulatórias, cuja dimensão alegórica ressaltouse. Nessas pinturas, de uma certa perspectiva, a deambulação do pintor surge como um pretexto para a introdução dos quadros alegóricos que os constituem: a alegorização da catástrofe da empresa citadina na figura feminina de Lilith; e a complexificação dessa mesma alegoria em Lilith und Adam, como resultado do seu desdobramento num compósito oximórico de fragilidade e vitalidade excessiva, que se deixa emblematizar na figura dúplice cidadedemônio. Mas essa aparente subordinação da deambulação metonímica em relação ao propósito alegorizante confronta-nos, 
contudo, com outra questão. Se essa subordinação é assim tão óbvia, manteriam aqueles quadros a sua identidade caso o efeito deambulatório fosse suprimido? Consideremos, em primeiro lugar, a hipótese extrema de uma mera apresentação do quadro alegórico sem a presença física do pintor no espaço da pintura, à semelhança, pois, das impessoais alegorias barrocas. Parece evidente que a função alegórica das figuras femininas nestes quadros depende diretamente da sua coexistência física com o pintor, ao qual são contrastadas. A alegorização do demoníaco na figura de Lilith está claramente dependente, tanto do propósito de dedicação protetora que o pintor lhe dirige - a qual se manifesta espacialmente na possessão espectral que o pintor the confere por entre a catástrofe urbana -, como do intenso e vívido contraste que marca a relação entre as duas figuras. O mesmo se poderia facilmente demonstrar em relação com Paisagem Árida. Esta constatação não deixa, no entanto, de levantar certa sombra de dúvida sobre a associação essencial entre a deambulação e o papel central dos quadros ou figuras alegóricas, nesta série de pinturas, as quais, desse ponto de vista, se assemelham aos retratos urbanos alegóricos de Baudelaire. ${ }^{114}$

Lembremos que, nas lendas talmúdicas, Lilith será o nome de uma segunda esposa de Adão. ${ }^{115}$ Nas outras lendas, ela é um dêmonio, um homúnculo com corpo de mulher e cauda de cobra. $\mathrm{Na}$

${ }^{114} \mathrm{Em}$ que difere a alegoria baudelairiana da alegoria barroca? A principal contradição que a obra de Baudelaire apresentou aos seus contemporâneos revelava-se na sobreposição de uma nova sensibilidade estética, atenta à experiência decadente da grande cidade moderna, como um formato alegórico onde se expressavam preocupações pré-modernas, nomeadamente em torno da temática cristã do pecado e do Mal. Para Benjamin, que via em Baudelaire a figura emblemática do seu século, pensava que a melancolia barroca era justificada face às tragédias históricas e ao sofrimento humano que aquela época histórica presenciou, já Baudalaire vivera numa época de abundânica material sem precedentes. Como explicar, então, a melancolia da poesia de Baudelaire, que, além do mais, se mantém afastada dos incêndios revolucionários de seu tempo e, consequentemente, dos seus fracassos. Cf. BENJAMIN, Walter. Um lírico no auge do capitalismo. op. cit., pp.254-257.

${ }^{115}$ Cf. BORNAY, Erika. Las hijas de Lilith. Madrid: Cátedra, 1998. 
mitologia kieferiana, Lilith, a terrível, é a noite dos tempos e monstruosa magia negra em que o Demônio espalha sua semente sobre nossas cidades: o anjo do Mal chama-se Lilith, ela tem contemplado em São Paulo o desenho vacilante e borrado da cidade em meio as ruínas. A cidade coberta por uma nuvem de pó, talvez esquecida pela humanidade metódica, aprendiz eficaz da destruição: imagem de uma ameaça que nem o Cristianismo nem o Judaísmo podem integrar ou pensar. Cidades vistas do alto, em sobrevôo, complexos industriais, fusões cronofotográficas, radares e satélites de observação, grandes telas e mísseis invisíveis; o mundo desaparece na guerra e a guerra desaparece perante os olhos do mundo. ${ }^{116}$ Todo é vigiado. As fotografias aéreas são impressionantes, cada objetivo aparece virtualmente destruído pela iluminação ou pela superexposição. Estas imagens são amparadas pela beleza do Mal ou, talvez, de Lilith, esse anjo exterminador da história. Em uma paisagem, se conseguimos figurar essas paisagens sem arquitetos e sem arquitetura, encontram-se os testemunhos sem testemunhas de Paul Celan, as terras queimadas e as bibliotecas e cidades devastadas de Anselm Kiefer. As cores abatidas por uma catástrofe conhecida, uma mancha gigante com cores desbotadas e uma força enorme da atmosfera foram produzidas por Lilith e suas filhas. O fantasma de uma cidade morta e de uma natureza reduzida ao nada se apresenta obstinadamente nas metáforas determinadas, persistentes e mitológicas de Kiefer. O ecologismo mágico-bárbaro de um gnóstico

116 Ernst Jünger, encaminhou-se, com 19 anos, às filas dos primeiros voluntários da guerra de 1914, relatando, nos seus diários escritos na primeira linha de combate (In Stahlgewittern, Das Wäldchen 125, Kriegsstausbruch 1914) o autêntico horror da guerra. Esses diários de guerra, não acompanham apenas o ultrajante desenvolvimento de uma guerra que se tornou campo de experimentação de, até então, desconhecidas armas mortíferas - criando o moderno conceito de Extermínio -, mas adentra-nos nos tortuosos sentimentos que dirigem a ação e o pensamento do soldado possuído pela implacável mecânica da morte organizada. Dificilmente um documento jamais escrito tem sabido transmitir, com estremecedora lucidez, o espanto de semelhante experiência. 
fotografando o absurdo do mundo. Na cidade aparecem as figuras do deserto, do inabitável, prefigurando a eventual implosão dos elementos da Terra. 


\section{MEMÓRIA DO MAL}

\section{A. ANSELM KIEFER: PINTOR DA MEMÓRIA}

Fuego, luz, aire y sol niego que pintarse puedan; luego retratarse no podrá Beldad que compuesta está de sol, aire, luz y fuego.

Calderón-El pintor de su deshonra.

$\mathrm{Na}$ contramão do preconceito anti-biográfico das análises filosóficas, a arte evoca a pregnância do pós-guerra na obra de Anselm Kiefer. Nascido em Donaueschingen, no sul da Alemanha, meses antes da catástrofe da Segunda Guerra Mundial terminar, Kiefer cresceu na parte oriental de uma Alemanha dividida e em transe de reconstrução. Não é, por acaso, portanto, que a destruição, a saber, a guerra, a catástrofe, o extermínio executado pelo nacionalsocialismo, a história militarista alemã, tenham se tornado motivos centrais nas suas obras. É em um mundo que, como Walter Benjamin, anotou, "afunda na rigidez cadavérica", que Kiefer tenta investir em suas grandes telas a idéia da catástrofe. Sua pintura é uma narrativa que explode em estilhaços, em ruínas, mas também manifesta uma necessidade de comunicar, de reatar os acontecimentos com um passado que surge escaldado por essa violência suscitada em um século marcado por experiências autoritárias, totalitárias, e genocidas.

Kiefer cresceu no clima de amnésia geral e, ao mesmo tempo, de muita culpa, uma geração que não conta com experiências pessoais nem com lembranças individuais do regime nazista. Em seu livro Anselm Kiefer and Art after Auschwitz, Lisa Saltzman, escreve:

O trabalho de Kiefer emergeu em um momento na história alemã do pós-guerra quando os impulsos de oposição relativos ao passado e seu lugar no presente davam forma a 
sua paisagem cultural, social e política. Sua recepção está, portanto, imbuída desse contexto e o reflete. ${ }^{117}$

A consciência desta geração pôde ter a formação do Shoah através de uma mediação, então, a memória coletiva tornou-se tributária de informações diretas ou indiretas transmitidas pelo entorno, a família, toda a literatura do momento, o cinema, a televisão, a presença dos momumentos e os rituais políticos. Ao sair da guerra, a primeira geração de alemães constitui-se como uma sociedade de heróis destronados com muita vontade de esquecer rapidamente os tempos sombrios de hipnose coletiva. As instituições da República Federal Alemã assumiram toda a responsabilidade pelo passado de destruição, mas elas acabaram reclamando uma nova identidade que se mostrava desvinculada tanto da tradição alemã quando do atavismo nazista. Uma chapa de chumbo recaiu sobre as lembranças dos alemães da primeira geração, o que, conseqüentemente, abortou a transmissão da história que podia estabelecer um diálogo entre gerações. A pesquisa mnemônica destas gerações ulteriores será fortemente perturbada. Alicia Chillida, no catálogo-livro da exposição de Kiefer no Parque del Retiro em 1998 estabelece:

As qualidades e propriedades da matéria aparecem manifestas com umas ressonâncias puramente internas em toda a obra de Kiefer; o material possui o equivalente das propriedades do inconsciente. Tudo sucede-se como se o discurso da matéria, assim como o conjunto de ecos que ela gera, tivessem sido lançados a uma dimensão interior. Kiefer estabelece um diálogo profundo com Beuys durante os anos 1970-72 na Academia de Düssseldorf. Como Beuys, o trabalho de Kiefer sobre a matéria física é equivalente ao exercício sobre a matéria espiritual. Esta consideração

117 "Kiefer's work emerged at a moment in postwar German history when conflicting impulses regarding the past and its place in the present were shaping its cultural, social and political landscape. His reception is thus embedded in and reflects this context [...]". Cf. SALTZMAN, Lisa. Anselm Kiefer and art after Auschwitz. Cambridge: Cambridge University Press, 1999 , p. 67. 
aparece na instalação Vinte anos de solidão, que contém a nostalgia e a força expressiva do material) $)^{118}$

Quando as fotografias da libertação dos campos de extermínio foram reveladas, uma atmosfera de autocensura foi imposta, reforçando a impossibilidade de restauração profunda de uma memória sobre os acontecimentos. Estas imagens da catástrofe, apresentadas no marco de um processo acusatório, tinham o efeito paradoxal de estabelecer uma lógica de desimaginação. ${ }^{119}$ Didi-Huberman permite-nos pensar a história das imagens como uma história de unidades quebradas, de restos acomodados, de significações transformadas, de associações paradoxais e de anacronismos secretamente agenciados. As imagens não respondem, pois, simplesmente às demandas sociais, elas as transformam. O segredo reside, pois, nas imagens dialéticas. Como Walter Benjamin havia afirmado: "a imagem é a dialética em suspensão". E sendo dialética, ela é crítica: ao nos olhar, ela nos obriga a olhá-la e a constituir esse olhar. É somente dessa maneira que se poderia falar em ler uma imagem, segundo Didi-Huberman: no sentido benjaminiano e também freudiano. Ler não no sentido de decriptar, mas de retrabalhar a imagem na escrita, que é ela mesma imagética, portadora e produtora de imagens. A proposição da imagem como ficção é o ponto de partida na elaboração da obra de Georges Didi-Huberman. Para este autor, a imagem não é o reflexo

118"Las calidades y propiedades de la materia aparecen manifiestas con unas resonancias puramente internas en toda la obra de Kiefer; el material posee el equivalente de las propiedades del inconsciente. Todo sucede como si el discurso de la materia, así como el conjunto de los ecos que ésta genera, hubieran sido lanzados a una dimensión interior. Kiefer establece un diálogo profundo con Beuys durante los años 1970-92 en la Academia de Düsseldorf. Como en Beuys, el trabajo de Kiefer sobre la materia física es equivalente al ejercicio sobre la materia espiritual. Esta consideración aparece en la instalación Veinte años de soledad, que contiene la nostalgia y la fuerza expresiva del material". Cf. CHILLIDA, A. Veinte años de soledad. Cat. Exposición Parque del Retiro, Madrid, 1998, p. 45-67.

119 Termo caro a Georges Didi-Hubermann, "Images malgré tout," In: CHÉROUX, Clément. Mémoire des camps. Photographies des camps de concentration et d'extermination Nazis (1933-1999). Paris: Marval, 2001, pp. 103-127. Cf. BENJAMIN, Walter. Paris, capitale du XIXe siècle. Le livre des passages. Paris: Cerf, 1989, p. 480. 
do indivíduo subjetivo, mas o próprio corpo de um pensamento que carrega suas questões inerentes. Através da idéia de sintoma da memória, este autor concebe a idéia de uma estrutura onde as imagens se desvelam em suas latências e fundamentos. Num jogo entre passado e presente, as imagens são atravessadas por uma memória, "memória que jamais saberá por inteiro o que acumula."120 Olhar a obra de Anselm Kiefer, através da perspectiva de DidiHuberman, é separar-se do autor e encontrar no próprio desvelamento do corpo de imagens os elementos significantes.

As conseqüências do buraco da memória foram marcantes na cultura. Por um lado, a cultura rejeitava certas palavras do repertório lingüístico, até que as imagens que surgiram tornaram a palavra insuficiente, precipitando a República Federal Alemã em uma verdadeira crise da representação. Foi então preciso produzir e construir uma nova identidade. A história da arte da República Federal Alemã ilustra uma construção identitária prematura, estranha às experiências e aos imaginários individuais. Tanto as instituições como os artistas na República Federal terão que acolher uma brutal mudança, quase sem transição, da arte monumental e figurativa, favorecida pelo Nazismo, à abstração estética importada pelos vencedores. Neste movimento de recusa de tudo o que se considerava propriamente arte alemã ${ }^{121}$ - da morbidez e a desolação das gravuras de Dürer ao expressionismo alemão passando por Caspar David Friedrich, por exemplo -, o campo visual foi submetido à purgação do sujeito e, ao mesmo tempo, do conceito de história. Os artistas da geração de Kiefer realizaram um trabalho crítico sobre esta precipitada traslação do mito da arte alemã em mito da arte

\footnotetext{
120 Cf. DIDI-HUBERMAN, Georges. op. cit., p. 115.

121 Cf. BELTING, Hans. The Germans and their art. A trouble relationship. Trad. Scott Kleager. New Haven: Yale University Press, 1993.
} 
ocidental. ${ }^{122}$ Kiefer, em particular, não cessou de defender o direito à especificidade cultural e de denunciar as correntes da arte contemporânea introduzidas na Alemanha a partir dos Estados

Unidos. Nas palavras do pintor:

Eu acredito que as correntes do pós-guerra (minimalismo, expressionismo abstrato, etc.) e as pesquisas desenvolvidas sobre os meios de pintura (Toroni, Buren e outros), têm sido interessantes, mas, para mim, não podemos nos deter aqui. Consideremos as obras de Carl Andre: elas têm se tornado desenho. É um estilo que vemos em todo lugar nos

122 Em junho de 1980, a abertura da Bienal de Veneza desencadeou uma tempestade de controvérsias concentradas no Pavilhão alemão e os trabalhos de dois artistas de República Federal Alemã, Georg Baselitz e Anselm Kiefer. Parecia que tudo na exposição justificava o sentimento de horror, alarme e crítica. Denunciada como fascista, teutônica, bombástica e, simplesmente vergonhosa, a apresentação destes dois artistas alemães no cenário internacional tornou-se, ao contrário, a ocasião perfeita para sua burla e condenação. O Pavilhão da Alemanha estava composto por três salas. A primeira e mais notória, tinha uma escultura em madeira de Baselitz e as outras duas salas uma coleção de pinturas e livros de Kiefer. Foi a escultura de Baselitz, Modelo para uma escultura (1980) que inicialmente irritou os críticos, em seguida, o trabalho de Kiefer suscitou uma crítica mais furiosa e detalhada gerando, assim, uma retórica e um corpo de crítica que teve um legado ressoante e duradouro. A escultura de Baselitz, uma figura em madeira sentada com um braço levantado em flagrante referência à saudação Heil Hitler, recolocou o espectro do Nazismo e foi uma ação de arte vista como uma afronta, com muita indignação e vergonha. Werner Spies, crítico do Frankfurter Allgemeine Zeitung, em um artigo intitulado Überdosis an Teutschem (Overdose teutônica), o crítico detona contra o fato que o visitante do Pavilhão Alemão era cumprimentado com um gesto que: "sofort mit einem deustschen Gruß gleichgesetzt wurde" (equacionava-se imediatamente com o alemão, isto é, a saudação de Hitler). O horror que representava essa escultura era sublinhada pelo fato que "das schwarz-weiß-rote Kolorit mag Imperialismus zustande bringen" (as cores preta-branca-vermelha sugerem a idéia do passado alemão imperialista). A escultura de Baselitz cumprimentava o visitante do Pavilhão Alemão com seu "deutschen Gruß," e após deixar a primeira sala, o visitante entrava no mundo pictórico de Kiefer embebido de símbolos e referentes do mundo germânico, a partir do mito dos Nibelungos até os cenários wagnerianos, todos pintados em escala com a paleta e pareciam falar de uma potente identidade nacional, repleta de todos seus fantasmas. Documentada no catálogo, La biennale di Venezia, settore arti visive: catalogo general 1980. Venezia, 1980. Kiefer e Baselitz foram expostos dentro das categorias, "Aperto 80," e "L'arte regli anni settanta." Cf. HEIBEL, Yule F. Toward a reconstruction of modernism, or the subject's dialectic of evacuation modern painting in Western Germany after world war II. Cambridge, Mass: Harvard University Press, 1991. 
museus, nos apartamentos, ainda que antigamente tenha sido revolucionário. Não critico o valor original, é importante ter passado por essa experiência, mas, no presente, precisamos fazer a síntese de todas essas pesquisas estéticas. Meu objetivo não é o de revolucionar a história da arte. ${ }^{123}$

Sua oposição a todo formalismo, ao devir design do objeto da arte, mas também seu desprezo pelo rigidismo das teorias da Bauhaus são inseparáveis da chamada hora zero.

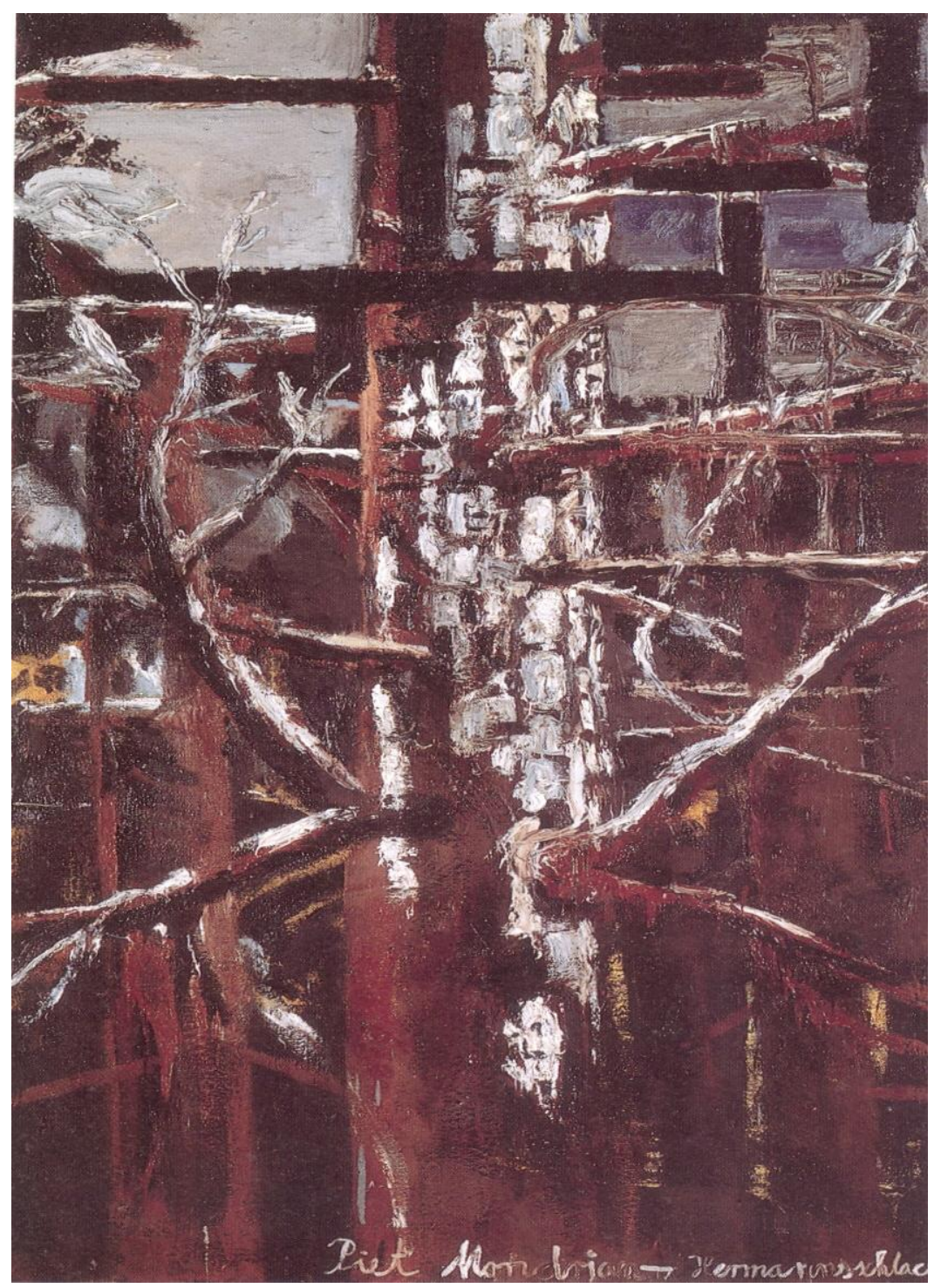

Figura 21. Piet Mondrian-A batalha de Hermann/1976. Óleo s/tela, $245 \times 112$ cm. Coleção Visser, Retie, Bélgica

${ }^{123}$ Entrevista com Bernard Comment. "Anselm Kiefer. Cette obscure clarté qui tombe des étoiles," Art press, n. 216, septembre 1996, pp. 24-25. 
Em Piet Mondrian (fig.21), por exemplo, o artista exprime essa complexidade histórica, tentando purgar da pintura toda idéia trágica, voltando-se para a afirmação da leveza, a airosidade e planura. Kiefer restaura, nas linhas de composição, o caráter narrativo e subjetivo de sua proposta estética. A árvore de Mondrian de formas embaraçadas e com uma matéria empolada, religa com seu substrato mítico e com sua memória vertical. A fundação de uma nova cultura não pode se fazer sem partir das memórias mais atávicas:

Meu pensamento é vertical, e um de seus planos é o fascismo. Contudo, eu vejo todos seus esconderijos. Nas minhas pinturas, eu conto histórias para mostrar o que está por trás da história. Eu faço um buraco e o atravesso. ${ }^{124}$

Anselm Kiefer reúne-se aqui com Walter Benjamin que percebia uma proximidade monstruosa entre a linguagem abstrata, a arte pura e a reificação do outro. Na sua crítica à abstração desencarnada ou da horizontalidade sem memória, o filósofo defende um conhecimento vertical destinado à vida e a poesia, uma inscrição das palavras na história e da história nas palavras. ${ }^{125} \mathrm{~A}$ matéria histórica reaparece na arte no final dos anos 60. Uma primeira leva de artistas denuncia frontalmente o Nazismo. A geração de Kiefer rejeitará o maniqueísmo consensual contido na arte engajada, tocando um público

\footnotetext{
${ }^{124}$ Cf. ARASSE, Daniel. op. cit., p. 264.

125 Lembremos que a teoria da escritura em Benjamin forma parte do continente da sua obra, com seus traslados da escritura do mundo (como o livro do mundo no seu enclave barroco) para uma teoria dos sistemas da escritura e da figura dos historiadores como autores de uma escritura da história. Lembremos que Benjamin, antes do mais nada, era também leitor. Então, de um modo mais geral, toda sua escritura é produto de um excesso de leitura, o que o levou articular esse transbordamento de leitura no projeto das Passagens, por exemplo. Toda sua teoria sobre a escritura aparece reverberativamente em sua teoria da alegoria barroca, suas reflexões dedicadas a Baudelaire, nos seus ensaios sobre a leitura, sobre as cidades, sobre a memória, na sua teoria sobre a doutrina das semelhanças, nos seus escritos em torno da obra de arte. Interessa-nos abordar aqui os desdrobamentos contemporâneos dessas teorias de Benjamin. Cf. SELIGMANN-SILVA, Márcio. "Walter Benjamin e os sistemas de escritura."In: SELIGMANN-SILVA. O local da diferença. op. cit., pp. 123140.
} 
heterogêneo com $o$ intuito de fragmentar o consenso, e sua estratégia era agir conscientemente sobre 0 imaginário da ambigüidade. O engajamento representava uma fórmula redutora pois o artista rejeitava abandonar a representação inteiramente, em nome da convição que tinha na necessidade de um tema. O próprio artista anota:

Eu acredito que arte tem que assumir responsabilidade, mas não deveria desistir de ser arte. Muitos tipos de arte são muito eficazes como arte. A arte minimalista é um bom exemplo contemporâneo. Mas tal arte 'pura' é perigosa para o conteúdo, que sempre deve estar presente; meu conteúdo talvez não seja contemporâneo, mas é político. É, de certo modo, uma arte ativista. ${ }^{126}$

126 "I believe art has to take reponsibility, but it should not give up being art. Many kinds of art are very effective as art. Minimal art is a good contemporary example. But such a 'pure' art is dangerous to content, which must always be there. My content may not be contemporary, but is political. It is an activist art of sorts". (Craig Owens vocifera contra Kiefer e outros artistas em sua percepção sobre a arte. Em palavras de Owen: "Chia, Cucchi, Clement, Mariani, Baselitz, Lüpertz, Middendorf, Fetting, Peck, Kiefer, Schnabel [...] these and other are engaged not (as is frequently claimed by critics who find mirored in this art their own frustration with the radical art of the present) in the recovery and reinvestment of the tradition, but rather in declaring its bankruptcy - specifically, the bankruptcy of the modernist tradition. Everywhere we turn today the radical impulse that motivated modernism -its commitment to transgression-is treated as the object of parody of insult. What we are witnessing, then, is the wholesale liquidation of the entire modernist legacy."([...] estes e outros estão engajados não (como freqüentemente alegam os críticos que encontram espelhadas nessa arte suas próprias frustrações com a arte radical do presente) na recuperação e reinvestimento da tradição, em vez de declarar sua falência - especificamente, a falência da tradição modernista - seu compromisso com a transgressão - é tratada como o objeto da paródia, do insulto. O que nós estamos assistindo, então, é a liquidação por atacado de todo o legado modernista). Além do mais, não era apenas o "antimodernismo" de Kiefer e os demais artistas que incomodava o crítico, também denunciava a sua atitude política de suspeita: "What we are witnessing, then, is the emergence of a new - or renewed-authoritarianism masquerading as antiauthoritarian [...] The celebration of 'traditional values' - the hallmark of authoritarian discourse-becomes the agenda of a supposedly politically motivated art (Syberberg, Anselm Kiefer, but also Gilbert \& George."(O que estamos assistindo, então, é a emergência de um novo - ou renovado-autoritarismo mascarado como antiautoritário [...] $A$ celebração de 'valores tradicionais' - torna-se a agenda de uma arte suposta politicamente motivada). Os alemães Wolgang Max Faust e Gerd de 
Trata-se de pintores da história, congestionados de imagens, que têm sido chamados de neoexpressionistas alemães ${ }^{127}$ e que apareceram no marco do trabalho da memória elaborado pelo mestre de todos, Joseph Beuys. ${ }^{128}$ Entre elas encontram-se personalidades diversas

Vries avaliaram Kiefer positivamente em seu livro sobre arte contemporânea alemã, Hunger Nach Bilder: Deutsche Malerei der Gegenwart, Köln: de umont, 1982, p.72. Quando se referem às pinturas de Kiefer, os autores comentam que em nemhuma hipótese podemos ler as pinturas de Kiefer como exemplos de propaganda ideológica. Seus temas aparentam ser inusuais, de certa maneira, anacrônicos e, em todo caso, carregados de problemas: "That these themes have brought forth negative criticism is no accident, because they are closely bound to repressions and taboos that are still virulent in Germany."(Que esses temas têm ressuscitado críticas negativas não é acidente, porque elas estão estreitamente vinculadas com os recalques e os tabus que ainda são virulentos na Alemanha). Interessantemente, esta discussão tem polarizado a crítica alemã entre defensores do bem e do mal, progresistas e reacionários, e o narcisismo alemão toma um papel importante. Entrevista com Donald Kuspit e Jeanne Siegel. Art talk: the early 1980s, p. 86. Cf. Craig OWENS, "Honor, power, and the love of women," In: OWENS, Craig. Beyond recognition: representation, power, and culture. Berkeley: University of California Press, 1992, p. 147.

127 Ante essa rubrica o pintor declara: "Sono sempre stato contrario a prescrivere un'interpretazione. Non la prescrivo. Qualsiasi tipo di interpretazione è possibile. Chi mi vede come un neoespressionita, vede solo un piccolo asptetto della mia pittura. Ma è meglio di niente. E poi l'espressionismo è stato un periodo molto breve [...] l'espressionismo è um movimento prevalentemente tedesco, ma, ripeto, rappresenta un'epoca molto breve e, per quanto mi riguarda, non eccessivamente significativa. Per me è stato un periodo unilaterale e questo perché quello che viene definito "espressionismo" non è altro che l'espressione dei sentimenti. Un capolavoro però non è determinato solo da ciò che esprimono i sentimenti. Un capolavoro si compone di tre elementi: la volontá, $i$ sentimenti e I'intelletto. Tutti e te gli elementi." Cf. ANDREOTTI; DE MELIS, op. cit., p. 29.

${ }^{128}$ O lugar de Beuys na história visual alemã do pós-guerra pode ser visto como inaugural, uma vez que apresentou um novo modo de aludir à história por meio da arte e da performance. Enquanto essas formas eram desenvolvidas na proximidade $e$, muitas vezes, em conjunção com movimentos como Fluxus e Arte Povera, trata-se realmente de atividades e ações de arte estimuladas por Beuys. Especificamente, ele foi capaz de encontrar e fazer uso consistente de materiais escultóricos ressoantes para inventar e encenar alegorias visuais que dramatizavam o Holocausto de maneira oblíqua, ocupando os espaços de uma maneira desconcertante. Detrás destes estrondosos nódulos traumáticos e gestos lutuosos existe, mais do que meramente as feridas da biografia pessoal do artista, o maior trauma público desta primera metade de século. A catástrofe poder-se-ia chamar a fonte de seu trabalho. A descoberta, então, do que a arte deve 
como Gerhard Richter, Markus Lüpertz, George Baselitz, Jörg Immendorf e Anselm Kiefer. ${ }^{129}$ Podemos ver corpos nas suas pinturas, figuras heróicas mutiladas, figuras totêmicas do passado nazista - pás, ramos de trigo, os bombardeiros, os palácios nazistas, a cruz gamada. Representando com esta iconografia - rejeitada pela consciência oficial -, estes pintores reclamaram para sua experiência estética a presença do nazismo na sua história, contando com o risco de incorporar o Mal como categoria estética na sua nova construção identitária. ${ }^{130}$ Anselm Kiefer foi, sem dúvida, o artista mais estridente

ser e fazer para se aproximar e se comprometer massivamente com a história traumática - o Holocausto e Hiroshima são dois acontecimentos emblemáticos - é, de fato, a maior façanha de Beuys e mais perdurável que o legado de suas provocações político-conceituais. As inovações de Beuys foram profundamente importantes para a produção artística de final de século XX. Diferentes aspectos deste modo particular de evocar a história, inflexões de seu gesto estético e a sensibilidade pela matéria, podem ser traçadas, por exemplo, na obra do pintor que estudamos nesta pesquisa, Anselm Kiefer. Dedicaremos algumas páginas à presença de Beuys na arte contemporânea e, especificamente, na obra de Kiefer na sua dupla dimensão de presença e objeção à continuidade que Beuys estabelece com o mito romântico persistente no imaginário alemão do artista como uma figura redentora. Ver RAY, Gene. The use and abuse of the Sublime: Joseph Beuys and art after Auschwitz. Tese de Doutorado apresentada ao Departamento de Filosofia da Universidade da Florida em Coral Gables, maio 1997.

${ }^{129}$ Cf. BUCHLOCH, Benjamin. "Figures of authority, ciphers of agression: Notes on the return of the representation in European Painting," October 16,1981 , pp. 39-68.

${ }_{130}$ A controvérsia deslanchada por esta inclusão da categoria do Mal aparece dividida em dois setores. De um lado, o setor reacionário de certos colecionadores, aduladores, nesses trabalhos, do regresso destravado do folclore e a pintura figurativa alemãs. De outro, o campo de intérpretes progressistas, que reconhecem um dispositivo estratétigo para agitar o debate sobre a memória recalcada para, assim, compreender os mecanismos desse fascinante fascismo, de que falava Susan Sontag, por exemplo. Estes últimos esperavam que estas imagens interditadas tivessem um efeito catártico, porque eles animavam a elaboração de uma identidade "pós-tradicional," à maneira de Habermas, pois o que eles demandavam ao espectador era sustentar a ambivalência de seus efeitos. Entre estas duas posições, sua recepção, pensava, especialmente, boa parte da imprensa, era considerar o sujeito de uma obra de arte refletindo sobre as convições políticas do artista, sendo as respostas dos críticos que os recusavam a atitude propriamente fóbica, que testemunha a constante fragilidade da relação simbólica no Nazismo. Para um delicado parecer sobre estes posicionamentos, ver BUDZYNSKI, Joseph S. Narcissistic moments in 
da sua geração e quem mais adentrou no inferno do passado para resgatar as cinzas da memória. Seus trabalhos foram acolhidos com certo grau de interdição consensual pela crítica alemã pela dimensão provocadora e aspecto propriamente catártico da mesma. Carregou a forte acusação de representar o nazismo "não para denunciá-lo, mas para prolongá-lo celebratoriamente." ${ }^{131}$ Contudo, Kiefer, como os outros artistas alemães de seu tempo, questionou sua própria herança, pintando os elementos iconográficos e mitológicos da cultura alemã. Ele pesquisou, nos mecanismos de fascinação pelo Nazismo, a esperança de compreender e de superar o bloqueio da simbolização. ${ }^{132}$ Lisa R. Saltzman descreve esse momento da seguinte maneira:

Mas era o trabalho de Kiefer que insistentemente problematizou a categoria de neoexpressionismo, variando entre abstrato, formas simbólicas e representacionais, fotografia conceitual e prática pictural. Além do mais, era o trabalho de Kiefer que constantemente explorou os assuntos duais e, freqüentemente entrelaçados, de representação e identidade. Nas suas telas densamente estendidas em

German art. Tese de Doutorado apresentada ao Departamento de História e Crítica da Arte da Universidade do Estado de Nova York, Campus de Stony Brook, maio 2005.

131 Para um resumo da recepção da obra de Kiefer na Alemanha, Cf. SCHÜTZ, Sabine, "Das Kiefer-Phänomen." In: GILLEN, Eckhart (org.) Deutschlandbilder, pp. 584-591.

132 Aqui encontraremos a matriz sado-masoquista do Nazismo, todos os discursos da década de 60 e 80 que têm constatado sua atração erótica, pensemos nas perversões dos filmes de Rainer Werner Fassbinder, especialmente seu Lili Marlene ou no filme de Liliana Cavani, The Night Porter. O segundo filme apresenta alucinadas neuroses traumáticas em meio à destruição causada pelo Holocausto. A sobrevivente regressa ao passado traumático, a partir de uma regressão histérica, a um estágio psico-sexual anterior que tem profundo impacto para sua sexualidade atual. $\mathrm{O}$ adulto perverso que, de fato, regressa a uma fase anterior, revela que a perversão é pré-existente na história do sujeito. The Night Porter representa etiologicamente o Holocausto: enquanto a opressão Nazista e os campos de concentração figuram como o trauma de Max e Lucia, o tema manifesto do filme é a sobrevivência, ou seja, este filme não trata sobre o Holocausto, mas sobre ter sobrevivido ao Holocausto. O retorno da vítima à cena do crime representa um gesto traumático do ser verdadeiramente aniquilado de que fala Primo Levi. Cf. FRIEDLÄNDER, Saul. Reflets du nazisme. Seuil: Paris, 1982. 
camadas, assim como em seus livros, o trabalho de Kiefer tornou-se a arena artística não só para confrontar a construção da identidade alemã com relação ao mito e à história, mas também com o legado histórico do Nazismo e a questão concomitante da relação problemática entre alemães e judeus e sua persistência na sociedade alemã contemporânea. É, portanto, o trabalho de Kiefer e, sua subseqüente recepção, mais que nenhum de seus compatriotas, que deve ser visto inextricavelmente ligado a um contexto alemão do pós-guerra de deslocamento das agendas culturais, políticas e históricas que têm assim definido essa era. ${ }^{133}$

A hostilidade na consideração de Kiefer parece se explicar pela singularidade de seu passo no seio de sua geração, por seu pathos, por sua implicação pessoal e empatia provocadora perante os quais ele expõe as tramas coletivas de seu trabalho da memória:"Minha biografia é a biografia da Alemanha," declara o pintor em 1988, e é com a mesma impertinência e o mesmo espírito que ele busca uma verdadeira terapia da memória com sua obra. Estabelece-se, assim, diferentes fases do trabalho de luto conforme Freud, ${ }^{134}$ a recusa de levar em conta a realidade, o desbaratamento das emoções, a separação e, finalmente, a descoberta de uma nova relação consigo mesmo e com o mundo.

133 "But it was Kiefer's work that most insistently problematized the category of neo-expressionism, ranging at his work does between abstract, symbolic and representational forms, conceptual photographic and painterly practice. Further, it was Kiefer's work which most consistently explored the dual and often interwined issues, of representation and identity. In his densely layered canvases as well as his books, Kiefer's work became the artistic arena for confronting not only the construction of German identity in relation to myth and history, but the historical legacy of Nazism and the concomitant issue of the problematic relationship between Germans and Jews as it persists in contemporary German society. And it is thus Kiefer's work and subsequent reception more than any of his compatriots which must be seen as inextricably bound up in a postwar German context of shifting cultural, political and historical agendas that have so defined that era". Cf. SALTZMAN, Lisa. op. cit., p. 28.

${ }^{134}$ Cf. FREUD, Sigmund. "Luto e melancolia." (1921) e "Reflexões para os tempos de guerra e morte." (1915). Edição standard brasileira das obras psicológicas completas de Sigmund Freud, vol. XIV. Rio de Janeiro: Imago, 1990. 
Além do mais, os alemães ocidentais do pós-guerra olhavam com alta desconfiança sua própria cultura - em parte, como resultado da identificação do movimento nacional-socialista com as idéias e figuras de muitos grandes artistas alemães, escritores, filósofos, homens de Estado e compositores, assim como o controle nazista e o estado de produção de uma cultura de massas nacional durante o período de guerra. ${ }^{135}$ Jahre Zero, uma expressão comum do pósguerra em 1945, significa o ponto mais rebaixado, não apenas da infraestrutura alemã do século $X X$, mas também significa o ponto mais reduzido da identificação da cultura consigo própria. O passado cultural - o cânone da tradição alemã - era suspeito desde sua apropriação pelos nazistas, revelando conter elementos perigosamente autoritários. Acrescente-se que a esfera da alta cultura realmente não existiu na Alemanha desde meados de 1930 com exeção da forma trágica fársica do mercado nazista de contrabando de arte -. Os praticantes da alta cultura emigraram ou permaneceram nas catacumbas, ou foram dissolvidos na cultura de massas nazista, um campo representacional estereotipado que projetava a autoridade do Estado, imagens idílicas dos típicos súditos alemães e os líderes, por oposição às aterradoras representações de ódio - mais particularmente, dos Judeus e dos comunistas - por meio de qualquer suporte técnico. ${ }^{136}$

Culturalmente administrada pelos aliados vitoriosos, a Alemanha Ocidental do pós-guerra começou reconstruir sua esfera da alta cultura, conforme uma imagem ideal do homem. A questão do Sujeito, como Yule Heibel tem comentado, era, na verdade, o

135 Cf. HEIBEL, Yule F. Reconstructing the subject: modernist painting in Western Germany. 1945-1950. Princeton: Princeton University Press, 1995. A pesquisadora argumenta que, embora a presença de diferentes vertentes de expressionismo abstrato foram produzidas na Alemanha Ocidental, o público e a crítica suprimiram as dimensões afetivas e expressivas da arte porque elas contradiziam as tentativas da sociedade de relocar uma imagem do homem (Menschenbild) no pós-guerra.

${ }^{136}$ Cf. BIRO, Matthew. op. cit., p. 157. 
fundamento da alta cultura alemã durante os primeiros cinco anos da reconstrução da Alemanha Ocidental. ${ }^{137}$ Nas artes visuais, a pergunta pelo novo sujeito aparece na cena da arte expressionisa-abstrata do Grupo Munich ZEN49, que se tinha formado em torno dos pintores Willi Baumeister e Fritz Winter e o psiquiatra-colecionador, o Dr. Ottomar Domnick, com o intuito de promover o expressionismo abstrato na Alemanha. Este grupo, a que tardiamente incorporar-iase o pintor Theodor Werner, foi apoiado, desde seus primórdios, pelas instituções museológicas alemãs e também pelos críticos. ${ }^{138}$

Depois, na entrada dos anos 50, a pintura abstrata de ZEN49 continuou a ser institucionalmente patrocinada na Alemanha, não apenas por sua radicalidade formal, mas, primeiro, porque representava uma forma descafeínada e segura de abstração - uma abstração que não desmantelava a oposição figurativa nem deslanchava o potencial semântico do signo para simbolizar profundos significados metafísicos ou arquetípicos. Foi, então, considerada segura para a população alemã assolada pela guerra uma população que só recentemente tinha sido forçada a renunciar à visão totalitária de uma subjetividade coletiva e individual e que estava sendo escrutinada sob o estilo de democracia constitucional ocidental. Em outras palavras, porque estava proibido seu conteúdo direto, esta arte foi entendida pelos administradores culturais aliados como o melhor antídoto para malaise espiritual e psíquico que sofria a população condicionada pela propaganda nazista e pelo terror. ${ }^{139} \mathrm{O}$ anti-individualismo totalitário nazista foi substituído, na arte, por uma forma conciliadora de subjetivismo. Todavia, por meio da abstração, especificamente aqueles conteúdos alemães - temas que poderiam suscitar o relapso de formas retorcidas de identidade alemã - foram

137 Cf. HEIBEL, Yule F. op. cit., p. 89.

138 Baumeister, como tantos outros de sua geração, foi leitor de Heidegger, mesclando sua produção abstrata com o pensamento heideggeriano. Ver Yule F. HEIBEL. op. cit., pp. 3-145.

139 Cf. BIRO, Matthew. op. cit., p. 157. 
interditados. Segundo, porque os artistas do ZEN49 eram principalmente pintores, seus trabalhos podiam ser facilmente apresentados entre instituções alemãs de legitimação cultural tanto públicas quanto privadas: o museu, a coleção e a imprensa. Deste modo, os administradores aliados esperavam que as instituções tradicionais alemãs pudessem colaborar na reunião e no recondicionamento da vida dos alemães ocidentais, para mantê-los concentrados na tarefa de transformação de seu país numa bemsucedida sociedade capitalista à maneira dos demais países da Europa Ocidental. Os nazistas usaram a arte com a intenção de construir a idéia de germanidade - para promover um sentido de identidade nacional e de destino alemão. Para evitar uma apropriação similar num futuro, esses assuntos, assim como as formas tradicionais e os estilos de ser Alemão, encorajadas pelos nazistas, seriam suprimidos por meio da promoção da arte abstrata. A partir do decurso dos anos 50, os museus e os críticos apoiaram a pintura abstrata de Zen49, assim como duas outras formas de expressão orgânica da abstração: as pinturas de Ernst Wilhelm Nay e Emil Schumacher. O entre-jogo de diferentes tipos de expressão abstrata ocupou-se, portanto, de eclipsar a maior parte das formas de representação na esfera de arte alemã, ajudando a engrossar a proibição especificamente no assunto tabu da germanidade. Além do mais, informe, uma modalidade da pintura expressionista abstrata de imaginação francesa, foi ansiosamente tomada e desenvolvida outro fator que contribuiu para a promoção da descaraterização alemã da pintura nos anos posteriores à guerra. ${ }^{140} \mathrm{O}$

140 O Informe, foi o conceito acunhado por Georges Bataille em 1929 e cooptado Rosalind Krauss e Yves-Alain Bois para intitular sua exposição, Informe, realizada em Paris (1996). Conforme Yves-Alain Bois, o Informe: "Não é apenas um adjetivo tendo tal sentido, mas um termo servindo para desclassificar, sem motivo estável ao qual se referir nem um tema simbolizável ou uma qualidade dada; é um vocábulo que permite operar uma desclassificação, no duplo sentido de rebaixamento e de desordem taxinômica. O Informe nada é em si; tem existência apenas operatória: é 
internacionalismo da arte visual alemã, por seu turno, foi apoiado pelos esforços combinados dos alemães e dos aliados, o que para os alemães já se tratava de um sinal de sua reintegração ao resto da Europa. Aliás, embora o pintor Otto Dix continuasse pintando em seu ateliê localizado nos territórios da Alemanha Oriental, a tradição representacional alemã exemplificada pela Neue Sachlichkeit não se mostrou muito interessada na produção destes artistas do grupo Zen49. Para muitos dos artistas e críticos da República Federal Alemã do momento, o realismo era equacionado com a cultura visual do derrotado nacional-socialismo e a emergente União Soviética e, portanto, com a truculenta imaginação do fascismo e do comunismo. Embora os trabalhos abstratos, ainda que representacionais, dos modernistas europeus tais como Paula Modersohn-Becker, Pablo Picasso, Henri Matisse, Ernst-Ludwig Kirchner e Franz Marc eram exibidos e comentados na Alemanha no decorrer dos anos 50, tratava-se de uma arte que era mais assimilada pela sua forma do que por seu conteúdo. ${ }^{141}$ Então, na sua totalidade, a arte visual da Alemanha Oriental permaneceu basicamente na sua manifestação abstrata entre o final da Segunda Guerra até os anos 60 - embora o formalismo, em um tipo de organicidade expressionista abstrata (algo que the suscitou ter, de alguma maneira, idéias sobre a natureza da

um performativo, como a palavra obscena, cuja violência não tem tanta relação com aquilo a que se refere, mas com sua mera proferição. $O$ Informel é uma operação." Cf. FERREIRA, Glória. "L'informe, mode d'emploi." Arte e Ensaio, n. 5, 1998, p. 161.

${ }^{141}$ Estes artistas, por exemplo, são todos bem apresentados em Documenta I em 1955 - a primeira quinquenal alemã do século XX. Segundo os curadores Arnold Bode and Werner Haftmann, Documenta I foi apresentada como uma exibição histórica concentrada na arte que abrangia o período de 1905 até 1945. Foi explicitamente projetada para reconduzir uma consciência das continuidades no desenvolvimento artístico alemão no decurso do século XX e documentada com as obras dos artistas abstratos e figurativos. No entanto, em 1959, Documenta II, também curada pela dupla acima referida, o foco mudou, apresentando uma ampla seleção de orientações modernistas a partir de 1945 - uma seleção que favoreceu aos artistas abstratos. Ver AVGIKOS, Jan, "Point Zero: German Art in the 50's," Arts, vol. 64, n. 7, March 1990, pp. 52-59. 
forma abstrata). Aboliu os assuntos de cunho alemão e, depois de um período de assimilação das lições do modernismo alemão, também abriu-se às novas propostas estéticas que procediam do exterior. Para Benjamin Buchloch, por exemplo, a acolhida americana do neoexpressionismo alemão deve-se, em grande parte, à típica imagem-clichê dos indivíduos europeus vinculados à identidade mantida por seus antigos Estados-Nação, isto é, uma identidade mais engrenada com a história, mais sólida e mais profunda. A apreciação americana é, portanto, relacionada com sua vontade de identidade vinculada à tradição em comparação com sua identidade relativamente jovem e pluralista. Segundo Buchloch, os americanos espelham-se no trabalho dos neoexpressionistas alemães por meio da influência do Expressionismo Abstrato Americano. Eles, de certo modo, legitimizam uma narrativa da história da arte que começa na Europa e volta-se para Estados Unidos após a Segunda Guerra mundial com figuras como Still, de Kooning, Kline e Pollock.

Embora bem intencionada, esta rejeição dos assuntos de teor especificamente alemães nas artes visuais contribuiu, contudo, para reforçar uma perigosa tendência, na sociedade alemã do pós-guerra, de se recusar em atender inquéritos sérios sobre seu passado nazista. Com a separação russa da Aliança Ocidental, a total divisão política da Alemanha em Ocidente e Oriente em 1949 e o levantamento do Muro de Berlim em 1961, a situação emergiu de uma maneira em que, para os olhares de Ocidente, a desnazificação e a punição dos criminosos de guerra pareciam ser determinações menos importantes do que a imediata transformação da República Federal Alemã em um poderoso bastião contra expansão do comunismo. O Plano Marshall injetou quantidades massivas de dinheiro na economia alemã, e os nazistas obtiveram suas penas comutadas ou foram libertados na medida em que eles também podiam contribuir para a contenção da ameaça soviética. O governo 
democrata-cristão da República Federal Alemã, que permaneceu no poder até 1969, efetivamente conduziu a Alemanha através de uma miraculosa recuperação econômica e objetiva, embora o preço desta recuperação implicasse uma disseminada cegueira popular em torno de seu próprio passado recente. O nazismo não era objeto de discussão pública e, muito menos, matéria de estudo na escola. Aliás, o passado nazista de muitos líderes empresariais e políticos foi convenientemente ignorado. A aberração acontecida entre 19331945, embora admitida, era, em grande parte, atribuida à figura de Adolf Hitler, que era visto como um gênio demoníaco que controlava, mas que realmente não representava a vontade nem o sentimento do povo alemão. ${ }^{142}$ Vale acrescentar que o domínio, pós-45, da abstração nas artes visuais da República Federal Alemã, também contribuiu com esse clima de esquecimento do passado nazista. Como observa Liza Saltzmann:

Se tomarmos o clima geral dentro da esquerda e os círculos culturais dominantes para sermos mais explícitos e definitivos sobre certos padrões no final dos 60, padrões interessantes emergem. Acompanhando as políticas culturais dogmáticas dos anos 50, a rígida idéia de equidade cultural de esquerda alemã, alguma forma perpetuava os mesmos desenlaces. Pela primeira vez em duas décadas da República Federal não havia, efetivamente, lugar determinado para a arte que pudesse estar engajada com a mesma história que tinha engendrado à República Federal. Nem para as telas abstratas que dominam a produção e as exibições nos anos 50, nem para o engajado "realismo crítico" contemporâneo da Pop Art que dominava a produção artística e as exibições nos anos 60, havia um espaço aberto para uma confrontação artística sustentada com o legado do passado. ${ }^{143}$

142 Cf. EVANS, Richard J. In Hitler's shadow: West German historians and the attempt to escape from the Nazi past. New York: Pantheon Books, 1989 , pp. 10-14.

143 "But if we take the general climate within the left and dominant cultural circles to be explanatory and determinative of certain patterns in the lates 1960 's and interesting patterns emerges. Following the dogmatic cultural policies of the 1950s, the equally rigid cultural idea is championed by the 
Nos últimos anos da década de 50 , no entanto, os temas evocativos do passado nazista começaram a reaparecer nos trabalhos de um poderoso número de artistas que moravam na República Federal Alemã: Joseph Beuys, Eugen Schönbeck e Georg Baselitz, entre outros, cuja arte oscilava entre a figuração e a abstração. Como grupo, esses artistas eram 25 anos mais velhos do que Kiefer, quem propriamente pertence à primeira geração do pós-guerra. A geração de Kiefer atingiu a maturidade em meados dos anos 60, e no momento em que já tinham testemunhado sua incorporação na força de trabalho alemã, coincidindo com a emergência da contra-cultura da República Federal Alemã e a Nova Esquerda - talvez a experiência de ativismo social mais importante acontecida na República Federal Alemã. Kiefer pertence, então, a uma geração de alemães radicalmente ativistas - uma geração cujos indivíduos não rejeitaram apenas o silêncio sobre o passado nazista mantido na vida cotidiana, mas também se recusaram ao estilo de vida imposto pelo mirabolante milagre econômico induzido no pós-guerra. Como líderes da contra-cultura e a Nova Esquerda, Beuys, Schönbeck e Baselitz passaram a ser vistos como uma espécie d'avant-garde ou líderes críticos precursores de artistas como Anselm Kiefer. Com a vontade de retornar aos assuntos alemães descuidados pelo clima de euforia e auto-indulgência produzido pela reconstrução nacional, confrontavam-se, desse modo, aos resíduos indigestos atolados pela cumplicidade nazista e que conviviam em absoluta complacência com a impunidade na sociedade alemã. Para eles, Hitler, não representava uma anomalia, nem muito menos, a única causa dos crimes

German Left in some ways perpetuated the same end results. For in the first time two decades of the Federal Republic, there was effectively no place given to an art which migth engage with the very history that had forced the Federal Republic into being. For neither in the abstracts canvases which dominate artistic production and exhibitions in 1950s, nor in the engaged, contemporary "critical realist" of Pop Art that dominated artistic production and exhibitions in the 60s, was there a space opened for a sustained artistic confrontation with the legacy of the past". Cf. SALZTMAN, Lisa. op. cit., p. 41. 
cometidos pelos alemães contra a humanidade. Alemães comuns e pacíficos participaram intensamente da máquina de horror do passado nazista, portanto, toda recusa a se confrontar com sua culpabilidade poderia estimular sua repetição no futuro. ${ }^{144}$ Para Kiefer, a postura crítica destes grandes mestres - na forma de suas sagazes referências ao passado nazista -, devia ser respeitada. Por razões tanto pessoais quanto estéticas, suas posições enquanto líderes artísticos necessitavam estar minadas - algo que Kiefer alcançou por meio da produção de obras de arte formalmente dissimilares que acompanhavam inquietações críticas semelhantes (Besetzungen, Inneraum). Ao mesmo em tempo que se retornava à pergunta pela Alemanha, ${ }^{145}$ as artes visuais alemãs da década de 60 permaneciam permeavéis às tendências estéticas internacionais, daí que manifestassem um aspecto não-alemão. A Arte Pop, de caráter

144 Na tela Onkel Rudi (Tio Rudi, 1965) (fig. 22), de Gerard Richter, parecida com uma foto em preto e branco, podemos reconhecer um oficial nazista fardado. Esssa figura do oficial não é representada como um nazista alucinado, encarnando as forças do mal. Pelo contrário, com o título ironicamente meigo, sugere laços de parentesco entre o artista e seu retratado. É bastante provável que Onkel Rudi represente, por exemplo, a esses homens comuns que participaram como executadores programáticos (willed executers) do Terceiro Reich. O próprio Kiefer comenta en entrevista com Pierre Assouline: "Comment imaginer que les gardes SS du camp avaient dans une poche de leur veste des photos de Juifs pendus et dans l'autre des photo de leurs propres enfants? [...] On peut justement exprimer du désespoir sur la condition humaine." Caberia resgatar aquele ditado de Adorno em seu ensaio "Educação após Auschwitz": "A única força verdadeira contra o princípio de Auschwitz seria a autonomia, se me for permitido empregar a expressão kantiana; a força para a reflexão, para a autodeterminação, para o não deixar-se levar." A impostação de Kiefer como nazista e de Richter louvando seu tio oficial SS, como Leila Danziger reflete, "dissolvem sutilmente a coesão da massa anônima," salientando a importância das escolhas e juízos autônomos que a imensa maioria dos alemães não foi capaz de fazer quando o momento o demandou. Cf. GOLDHAGEN, Daniel. Hitlers willing executer. Ordinary germans and the holocaust. New York: Knopf, 1996. Cf. ADORNO, T.W. Palavras e sinais. Modelos Críticos 2. Trad. Maria Helena Ruschel. Petrópolis: Vozes, 1995, p. 110; Cf. DANZIGER BRASIL, L.M. Corpos de ausências, Berlim e os monumentos a Auschwitz. op. cit., p. 60; Cf. ASSOULINE, Pierre. "Portrait, Anselm Kiefer."In: ARDENNE, Paul e ASSOULINE, Pierre. Anselm Kiefer Sternenfall. Paris: Grand Palais, 2007, pp. 319-337.

145 Cf. BRASIL DANZIGER, L. M. op. cit., p. 31. 
minimalista, conceitual, arte povera, fluxus, performance e hapennings - com seus traços de culturas forâneas - foram rapidamente assimilados na esfera da produção de arte na República Federal. ${ }^{146}$ Além do mais, por meio de um contínuo processo de assimilação do modernismo internacional antes da era nazista, os artistas alemães tornaram-se conscientes dos logros da arte modernista européia, em particular da negação da pintura alcançada em várias manifestações estéticas como o Cubismo, o Dadaísmo e o Construtivismo. A negação da pintura - a vontade permanente de parte de muitos artistas modernos na destruição das figurações estéticas que eram consideradas inerentes à obra de arte -, tornouse, aceleradamente, o grande interesse dos artistas alemães da década de 60. A respeito desse assunto, comenta Danièle Cohn:

[...] a pintura de Kiefer é fragmentada desde o começo. O que também é uma idéia muito romântica: quando se é artista, tudo é fonte. O artista faz uso de tudo e não há

${ }^{146}$ Andreas Huyssen no seu artigo intitulado The cultural politics of the pop art, explica que a esquerda alemã reconheceu a presença da Pop art em seu país como sinal de uma transformação nas instituções e no discurso estético burguês, uma mudança produzida por meio de uma desublimação revolucionária da arte. Para Benjamin Buchloch, dentro da própria esquerda se formaram duas posturas opostas. Por um lado, os mais paranóicos consideraram a Pop art como o último elo de uma conspiração ideológica, de cujo sucesso dependia a vitória do plano Marshall americano. O segundo grupo considerou esse movimento como uma força revolucionária, uma subversão das instituções tradicionais, o que Marcuse designou de desublimação subversiva. Talvez Alemanha formulou esta contradição de forma especialmente rápida, intensa e manifesta porque dos países europeus foi o que tinha se americanizado em maior proporção. Durante os anos sessenta, alcançar um grau de identificação com a febre do consumo que dominava o american way of life era participar do projeto alemão do pós-guerra, que consistia em se identificar com algo que não fosse a história alemã. Em princípio, se tratava de reprimir a cultura de vanguarda do periodo weimariano, depois, de dar fim a qualquer esforço por revisar a história do fascismo e do periodo do pós-guerra e, por último, de voltar a dar forma ao país segundo o padrão internacionalista de consumo. Portanto, há que distinguir claramente entre a produção artística e sua recepção. O que os alemães fizeram da Pop art não reflete necessariamente seu significado real. Depois de tudo, não existe apenas uma Pop art . Cf. HUYSSEN, Andreas. After the great divide. Modernism, mass culture, postmodernism. Bloomington: Indiana Universtiy Press, 1986, pp.141-159; Cf. BUCHLOCH, Benjamin. op.cit., p. i. 
limite para a possibilidade de reapropriação; não há razão alguma para recuar, e nisso ele está muito próximo de Dadá, pois Dadá é Romantismo - relação que demonstrei a propósito de Jean Arp e é, acredito, algo muito claro. Quer dizer, há relações. Minha questão é saber se Kiefer, em sua obra, propõe um novo romantismo ou (é o que creio), simplesmente (o que já é muito), uma possibilidade de reinterpretar o romantismo mostrando sua coerência com a modernidade. ${ }^{147}$

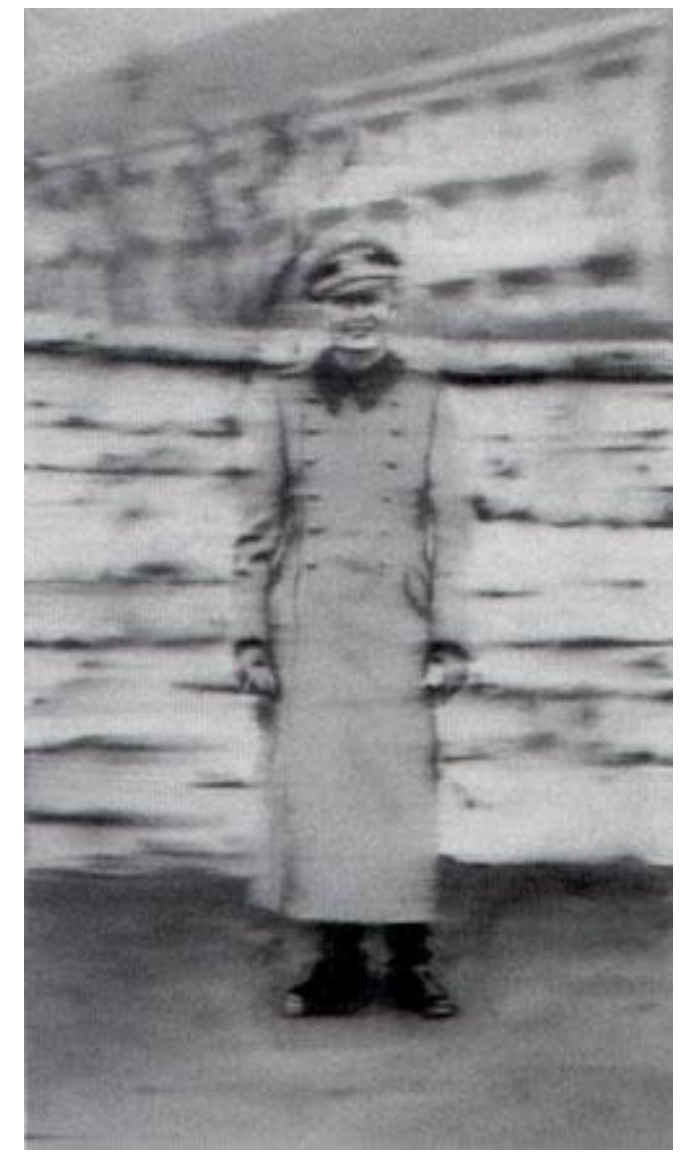

Figura 22. Figura 22.Tio Rudi /Onkel Rudi, 1965. Gerard Richter. $87 \mathrm{~cm}$ X $50 \mathrm{~cm}$. Galeria Neue Meister, Dresden, Alemanha.

147 Cf. COHN, Danièle. "Compreender é julgar". Entrevista com Glória Ferreira e Cézar Bartholomeu, Paris, 23 junho 2007. 
A negação da pintura acompanha um longo e complexo percurso. $O$ que aparecia, num sentido, na análise semiótica fundamental nas pinturas de Picasso e Braque, ${ }^{148}$ permanece em Dadá e nas fases construtivistas da arte moderna, como um projeto formal desenhado para transformar esse imaginário todo-poderoso do artista como um gênio intuitivo no artista como um produtor comum. Além do mais, com as negações da pintura operadas pelas manifestações estéticas dadaístas assim como as construtivistas, na segunda e terceira década do século vinte, a esfera da arte respondia positivamente ao clamor pela novidade. Estas vanguardas tentaram se dissolver no campo imanente das coisas da vida e, na medida em que o faziam, pretendiam perturbar todos os valores e as pretendidas formas de arte incorporadas ao modo de vida burguês. Como variados estágios de destruição da arte - por meio da arte gestual, colagem, o monocronismo, o contructivismo, o ready-made, a composição não relacional e as apropriações das imagens midiáticas - são repetidas num contexto internacional do pós-guerra, se tornando cada vez menos possível dizer a exata filiação de suas influências que pareceria ter peregrinado. ${ }^{149}$ No entanto, parece-nos evidente que as variadas posições condenatórias da pintura praticadas na República Federal Alemã durante os anos 60 reproduzam as estratégias vanguardistas que tendem à produção de um novo tipo de artista e um novo tipo de audiência engajada e, ao mesmo tempo, potencialmente revolucionária. No decorrer dos anos 60, como resultado das variadas influências históricas e estrangeiras, um considerável número de transformações aconteceram no campo da

148 Cf. KRAUSS, Rosalind. "In the name of Picasso," In: KRAUSS, Rosalind. The originality of the avant-garde and other modernist myths. Cambridge, Massachusetts: MIT Press, 1985, pp. 23-40; Cf. KRAUSS, R. "The motivation of the sign," In: ZELEVANSKY, Lynn (org.), Picasso and Braque: A Symposium, New York: MOMA, 1992, pp. 261-286; Cf. BOIS, Yves-Alain. Painting as Model, pp. 65-97; Cf. Idem, "The semiology of cubism," In, ZELAVANSKY, Lynn (org.) Picasso and Braque, pp. 169-208.

149 Cf. BOIS, Ives-Alain. "Pintura: a tarefa do luto." Trad. Taís Ribeiro. Revista Ars, 3. pp. 97-111. 
arte na República Federal. Em primeiro lugar, com o renovado interesse na matéria nacional, a representação reaparece como um elemento importante na produção cultural e artística. Foi o que resultou em Beuys ${ }^{150}$ - e sua proposta excessivamente mítica -, e sua adoção das estratégias do ready-made proposta por Duchamp, assim como a onda de imigração para a parte ocidental do país de um nutrido número de artistas educados nas academias do realismo socialista do oeste alemão. Assim, por exemplo, os pandemônios neoexpressionistas, pintados por um Baselitz ou um Eugen Schönbeck nos primórdios de 1960, empregam a representação para manifestar um mundo devastado e povoado por figuras retorcidas e motivos fragmentados (o que lembra o Jahre Zero) e que parece reler a tradição expressionista alemã por meio das medidas e ambições do expressionismo abstrato americano. Além do mais, existe também um regresso à fotografia que intervém nas obras - todas influênciadas pela Pop Art - de Sigmar Polke, Gerhard Richter, Wolf Vostell, Brehmer e Hödicke. Nas suas obras Polke e Richter, entre outros, apresentam versões pictóricas do imaginário coletivo de produção de massa, tomados das formas contemporâneas de massificação da cultura em um mundo anônimo. ${ }^{151}$ Aqui, nas obras de Polke e Richter, a representação parecia ser usada contra ela própria, para colocar, em um primeiro plano, as maneiras em que

150 Lembremos que Beuys foi, inicialmente, um escultor tradicional e representacional, cujas primeiras obras ecoam a expressão abstrata das formas naturais, presentes na arte alemã de começo de século XX como as representadas na obra de Wilhem Lehmbruck, por exemplo. Só foi a partir dos anos 50 que o artista radicalizou seus estudos adaptando as estratégias conceituais de Duchamp, redimensionando sua arte e, ao mesmo tempo, o campo de interpretação estética.

151 Polke e Richter parecem depender das técnicas dadaístas como a fotomontagem e o ready-made na mesma medida em que conscientemente foram incorporando também as técnicas de Warhol e de Richard Hamilton. Richter, por exemplo, claramente remete à influência dos artistas americanos. Ver entrevista com Benjamin H.D. Buchloch (1986), In: RICHTER, Gerhard. The daily practice of painting: writings and interviews, 1962-1993, pp. 132-166. 
várias formas de representação realista podem perder um significado específico ou particular.

Na República Federal Alemã dos anos 60, a questão da negação da pintura combinou-se cada vez mais com as questões da recepção da obra de arte sob o capitalismo ocidental. A institucionalização da esfera da arte, restaurada pelos administradores culturais das forças aliadas na metade dos anos 40, sofreu uma dramática intensificação nos anos 60, que testemunhou o desenvolvimento de um sólido mercado da arte contemporânea na República Federal. Mattew Biro, ${ }^{152}$ toma, por exemplo, o Figura 23. Stoffbilder, $1966 . \quad$ projeto de negação da pintura
Blinky Palermo. pesquisado nas obras de Blinky Palermo (Peter Heisterkamp), quem, em 1966, exibiu sua primeira série de pinturas de tecido Stoffbilder (fig. 23) na Galeria Heiner Friedrich em Munich. Num sentido formal, as pinturas de tecidos de Palermo eliminam aspectos marcantes da essência das pinturas abstratas, a impressão do tato, por exemplo, desde que as superfícies de tela de Palermo foram comparadas em uma loja. Dialeticamente, suas peças de roupa em seda costuradas a máquina criam um combinado de material pictórico com formas quase esculturais. Parecem formas tomadas dos conteúdos das pinturas russas do começo do século que aspiravam revolucionar a forma por meio do abstraccionismo puro, declarando abertamente a morte da

${ }^{152}$ Cf. BUCHLOCH, Benjamin. op. cit., p.176. 
ilusão ou da representação. Palermo produziu instalações espelhando bruscamente a redução do objeto da arte contemporânea à sua implicação arquitetural, efeito trabalhado por alguns artistas conceituais americanos como Lawrence Weiner, por exemplo. ${ }^{153} \mathrm{O}$ estreitamento dos laços com a cena da arte americana nos anos 60 acompanhou uma acelerada incorporação dos estilos americanos pop, minimalismo, expressionismo abstrato e arte conceitual - pela esfera da arte da República Federal. Assim, por exemplo, muitas das pinturas abstratas de Richter, de uma forma nova, evocavam um elemento mecânico no coração gestual da pintura expressiva - que lembra as estratégias fundamentais da mediação mecânica e tecnológica nos gestos expressivos dos artistas ensaiadas pelos dadaístas e construtivistas no começo do século XX. Richter tem falado que seu conhecimento da avant-garde alemã de entre-guerras veio até ele pela via de Rauschenberg e, além do mais, seu conhecimento de Duchamp foi mediado por Lichenstein, Warhol, assim como Beuys. ${ }^{154}$ Esta cegueira histórica ajudou a promover a

153 Para obter um bom exemplo desta querela política e formalmente inspirada na suposta essência da arte - satisfeita pela teleologia formal proposta nas teorizações essencialistas de Clement Greenberg sobre a arte -, ver, em particular duas obras de Weiner de 1968: A square removal from a rug in use e removal to the lathing or support wall of plaster or wallboard from a wall. Estas obras, literalmente, reduzem tanto a pintura como a escultura a seus respectivos redutos arquiteturais: a parede e o chão. Dessa maneira, a pintura e a escultura são feitas ainda de forma mais abstrata - elas aparecem como negações - e, além do mais, o contexto institucional e arquitetônico foi incorporado como parte integral da obra. Assim, as obras de Palermo e Weiner eram também exertos dos trabalhos da sala El Lissitzky da exposição de arte do Museu de Berlim em 1923, que também transformou, na sua curadoria, a pintura abstrata na experiência da arquitetura aos olhos do espectador atencioso. Cf. LODDER, Christina. Russian constructivism, New Haven: Yale University Press, 1983, pp. 248250.

154 Para Buchloch, uma das interpretações da obra de Warhol na Alemanha é o resultado, paradoxal, de uma profunda influência de Walter Benjamin. Ele considera a Warhol como o único artista do pós-guerra que traduziu a ideia da arte na era da reprodutibilidade técnica. Warhol representa a imagem do artista como produtor. Em princípio, esse era o paradigma do readymade. Para reparar como a esquerda recebia a obra de Warhol, se precisa lembrar como Buren, Toroni, e Parmentier fundamentaram-se 
retomada das questões propriamente alemãs nas artes visuais da República Federal Alemã, criando-se, assim, um campo de reflexão mais atraente para que os artistas pudessem examinar sua própria situação, ao mesmo tempo, que se podiam identificar com outras experiências estéticas de construção de imagens. De outro modo, tratava-se de um momento no qual eles podiam responder, simultâneamente, ao chamado de ser alemães e não-alemães.

Um bom exemplo da conjunção crescente da matéria germânica nas artes visuais da República Federal durante os anos 60 e o que era codificado e recebido como estilos ou estratégias pictóricas nãoalemãs, está presente na escultura de Joseph Beuys Fond III, (fig.24), originalmente exposta na Coleção Dia do Centro para as Artes em Nova Iorque no ano 1979. Essas estruturas sólidas em formas de folhas retangulares empilhadas de maneira maçica estão sujeitas a um número infinito de encarnações, envolvendo variadas maneiras de posicionar as fileiras empilhadas em configurações abertas ou bem estáticas. O que permanece constante, no entanto, é a referência formal ao minimalismo americano - Beuys empilha folhas pesadas ecoando especificamente os cubos esculturais de Donald Judd e Tony Smith - em uma obra projetada para subverter a

explicitamente em Warhol em suas primeiras presentações na Bienal de Paris de 1967. Depois, Buren se distanciou, mas no começo sua obra estava consciente e deliberadamente atravessada pela produção de Warhol. Em cada entorno se recebe a Warhol de modo diferente. Por exemplo, é impossível falar de Warhol para Haacke, porque ainda ele pensa que 0 americano é enfant terrible das artes. Abomina a Warhol porque representa para ele o pior da arte americana contemporânea. Para ele Warhol é o último elo na transformação da institução da arte na grande institução da indústria cultural. Uma má leitura de Jean-François Chevrier o faz concordar com Haacke, o que para Buchloch é insistir num disparate, destacando ao pintor da Pop como o primeiro artista do pós-guerra que deixa claro, de modo muito mais radical que até Yves Klein, que a fusão entre a esfera tradicional da vanguarda e a nova esfera da indústria cultural era inevitável. Warhol fez disso seu programa, colocando-lo em prática. Como afirma Buchloch, "agora confrontamos as conseqüências e não podemos culpar ao mensageiro pela sua mensagem." Cf. Richter em entrevista com Benjamin H. D. Buchloch, op. cit., pp. 132-143; Cf. BUCHLOCH, Benjamin. op.cit., p. i. 
proibição minimalista contra o conteúdo. ${ }^{155}$ A referência americana presente em Beuys foi rapidamente reconhecida pelos críticos alemães de seu tempo. Como Georg Jappe comenta:

No momento que a Arte Minimalista tinha exaurido a si própria como arte embora ainda representando o último movimento, Beuys demonstrava como a Arte Minimalista podia ser integrada e ultrapassada. ${ }^{156}$

Ao mesmo tempo, os críticos também estão informados da natureza simbólica da escolha de materiais realizada por Beuys e a

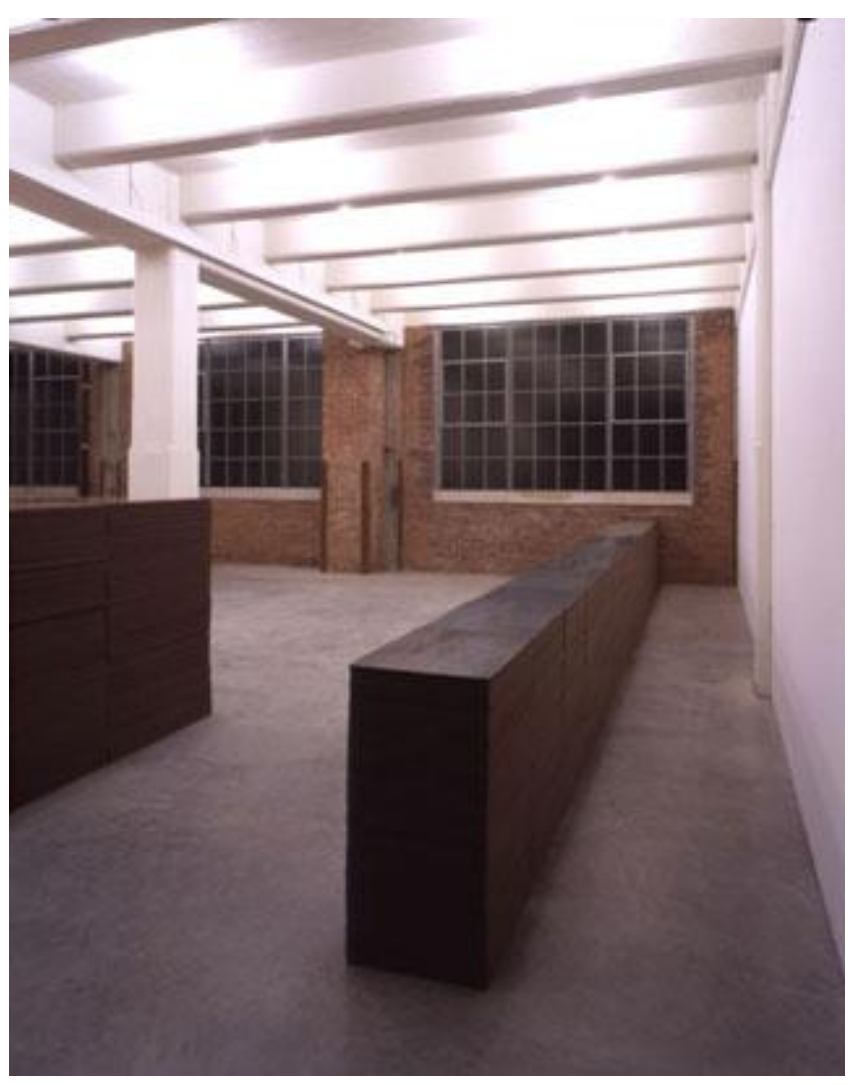
sua interconexão com as suas experiências com os tempos de guerra. Beuys utiliza materiais como feltro, cobre e baterias para executar sua referência a esses momentos de supremacia belicista. $\mathrm{O}$ artista comenta para a imprensa alemã:

Aqui a idéia essencial era a bateria. As fileiras de feltro empilhadas eram agregados, e as placas de cobre eram os condutores. o acúmulo de calor nos

Figura 24. Fond III, 1969. Joseph Beuys.

Feltro e cobre. Dimensões variadas. Museu Landes, Darmstadt.

155 Embora Beuys tenha feito experiências com estruturas primárias nos anos 50, pode ser corretamente visto como um dos precursores da estética minimalista na arte. Lembremos que o minimalismo foi levado até suas últimas potencialidades de pureza formal, abstrata e conceitual nos Estados Unidos da América nos anos 60.

156 "At the very time when minimal art has exhausted itself while still being the latest movement, Beuys demonstrates how minimal art can be integrated and overcome." Cf. George Jappe apud TISDALL, Caroline. Joseph Beuys. New York: Thames and Hudson, 1979, p. 162. 
trabalhos de feltro para mim são como uma casa iluminada, uma açaõ estática. ${ }^{157}$

A idéia central era, por seu turno, diretamente relacionada com um número de obras prévias de Beuys -esculturas, mas também ações de arte, entrevistas, leituras e publicações - correspondentes aos acontecimentos da Segunda Guerra Mundial, em que o feltro (e a gordura, entre outros materiais cujos efeitos também são isolantes como os das baterias) figurava como auxílio do artista para se recuperar de um aparatoso acidente de avião. ${ }^{158}$ Assim, referências específicas à Alemanha - à Segunda Guerra Mundial, ao papel do artista como vítima e vitimário, à indústria tecnológica e sua colaboração na magnitude do horror nazista e à necessidade para Alemanha se recuperar coletivamente e criar uma nova sociedade foram realizadas pela imaginação escultórica de Beuys que o expressou por meio do que muitos críticos alemães consideraram um releitura do estilo americano. Talvez, como uma forma de lidar com material altamente sensitivo, ou articulando numa sintaxe formal diferenciada, ou como uma forma de abrandar os assuntos de temática alemã, tornando-os mais tramitáveis para uma audiência internacional, Beuys retomou os conteúdos alemães por meio da apropriação do que era percebido como um antecedente não-alemão.

A importância das apropriações realizadas por Anselm Kiefer radica em sua relação com as duas tendências na arte da República Federal nos anos 60, preocupações manifestas em Fond III: o retorno do conteúdo dos temas descuidados pela história alemã e, por outro lado, a recolocação da arte alemã num contexto internacional. Embora acusado no começo por alguns críticos alemães de professar valores perigosamente alemães, ${ }^{159} \mathrm{e}$, um pouco mais tarde, de vender

\footnotetext{
157 Cf. TISDALL, Caroline. Idem, ibidem, p. 162.

158 Cf. BUCHLOCH, Benjamin. "Beuys: the twilight of the idol: preliminary notes for a critique," Artforum, vol. 18, n. 5, January 1980, pp. 35-43.

159 Cf. TAYLOR, Paul. "Painter of the apocalypse," New York Times Magazine. October 16, 1988, p. 103.
} 
brutalmente a idéia do arrependimento alemão no mercado da arte americana Kiefer sempre apresentou esta forma marcadamente internacionalista de produzir arte. ${ }^{160}$ Este internacionalismo é, como o exemplo que Beuys sugere, um acontecimento que era também esperado pelo público crítico internacional dos anos 70 e 80 . 0 internacionalismo de Kiefer pode ser claramente visto no seu tratamento dos estilos do minimalismo, da Pop Art e do expressionismo abstrato, que ele cita e de que se apropria de diferentes formas. ${ }^{161}$ Kiefer freqüentemente interpreta as estratégias

${ }^{160}$ Cf. BEYER, Lucie, "Anselm Kiefer," Flash Art, n. 128, May-June 1986, p. 61; Cf. FLAM, Jack. "The Alchemist," New York Review of Books, February 13 1992, p. 36.

161 "Citar" um texto não significa glosar sua totalidade, mas apenas um fragmento dele. Pois a citação não se limita à repetição literal de algum fragmento, mas interpela, por meio da metonímia, todo o texto de origem do qual foi extraído. Citar um determinado texto é, na verdade, evocá-lo através de um determinado fragmento, a citação opera na mesma ordem de significação do "vestígio" que leva o leitor ao texto integral. O fragmento da citação, sendo parte de um todo, traz consigo todo o texto de origem, em analogia benjaminiana à madeleine proustiana que traz consigo todo o edifício da memória do protagonista. Benjamin recorreu à comparação com a citação textual para elucidar sua idéia do "encontro" entre duas épocas da história. Pois é justamente a dualidade metonímica na relação entre o fragmento literalmente citado e totalidade evocada que produz o jogo entre a proximidade e a distância (entre vestígio e aura) como ele já foi observado na ocasião da rememoração. O fragmento em si, implantado com uma aparente arbitrariedade no novo con/texto, o interrompe, provocando um "choque" de distanciamento devido à sua singularidade. A interrupção aparentemente destrutiva do con/texto presente se transforma na construção de uma nova totalidade maior, construção esta que exige um leitor historiador atento e ativo. Nos estudos de Benjamin, ruína e alegoria estão intimamente relacionadas: "No campo da intuição alegórica, a imagem é fragmento, ruína [...] As alegorias são, no reino dos pensamentos, o que são as ruínas no reino das coisas". A ruína tem um equivalente da alegoria - uma corresponde à outra em diferentes planos quanto se pode observar que a linguagem alegórica recorta a imagem de que se apropria justamente para que o sentido possa deslizar do que é exposto para o que se quer representar. Essa fragmentação se dá não apenas pelo corte promovido, mas também pelas perspectivas de associações que deixam em aberto, à disposição do leitor. Disso se pode inferir que uma das formas de alegorizar um texto é retirá-lo de seu 
modernistas das primeiras duas décadas do século vinte como propriamente americanas e pertencentes ao período do pós-guerra. Mais ainda, por meio do diálogo do pós-guerra americano e o préguerra europeu, as obras de Kiefer também evocam, em um sentido, o que Benjamin define como uma disputa entre diferentes formas de ver o mundo - a conjunção de campos de representação oposicionais articulando diferentes formas ideais de subjetividade, uma idéia que Kiefer transforma, na sua arte, em um jogo complexo de regiões devastadas e sulcos queimados. Por esta razão, o exercício de apropriação dos estilos da arte americana, executados por Kiefer, parece ser conscientemente referido ao uso das formas representacionais e abstratas dos modernistas do período de entreguerra, ambas utilizadas para evocar e minar a coletividade no seu desdobramento individual e subjetivo. A resiliência a tudo o que possa ser parte do passado cruel faz desse pintor também um dos mais vigorosos e potentes críticos da sociedade alemã do pós-guerra. Na contramão do gesto pictórico fácil (do abstracionismo comovente e leniente), ele reinventa a história alemã a partir de uma forma mais acabada de narração que sugere a pintura - nesse ponto, trata-se de uma reinvenção de caráter nitidamente benjaminiano - de colecionar e apresentar fragmentos do passado alemão porque os mesmos se tornam fatos que interessam para a própria história. ${ }^{162} \mathrm{~A}$ primeira

contexto, deixando liames suficientes para multiplicar suas possibilidades de significação, entremostrando a perspectiva de restaurá-lo em uma nova articulação. Se a ruína, como a alegoria, é algo que sobra de um suposto conjunto maior que desapareceu, é também uma tensão entre o efêmero e o eterno, sempre lembrando que o todo, do qual pretensamente é parte, não se pode reconstituir. Cf. BENJAMIN, Walter. Drama Barroco. op.cit., pp. 30-31; Cf. OTTE, George. "Rememoração e citação em Walter Benjamin." Revista de Estudos Literários. Vol. 4, out, 1996, pp. 218-219.

162 Esse impulso alegórico de Kiefer foi identificado por Craig Owens como uma marca determinante na arte contemporânea para se diferenciar da arte moderna, cuja operação central é realizada através do símbolo. No seu artigo "The allegorical impulse: toward a theory of postmodernism," Owens caracteriza este impulso alegórico, reclamando seu papel em uma arte cada vez menos subsumível sob o modelo moderno do símbolo, ou seja, sob o 
clara apropriação artística deste sistema narrativo é apresentada por um conjunto de acontecimentos do período do pós-guerra contida em Koll bei Kiefer (Koll visitando Kiefer) (fig.25). Esta instalação é um livro de 112 páginas de fotografias encadernadas mostrando a influência de Donald Judd e Robert Morris e influências do homônimo Koll, um colega de Kiefer na Academia Karlsruhe, todas organizadas

modelo da unidade de forma e conteúdo que o símbolo encarna. Como sabemos, a estrutura da alegoria no pendor benjaminiano é fragmentária, sempre reportada a outro lugar através dos cacos, dos restos e das ruínas. Refere a algo do passado ou a um presente com um passado reverberante, injetando-lo do sentido de irrecuperabilidade próprio do passado. Sua referência está sempre fora, em outro parte. Compara com a plenitude do símbolo onde a forma não é veículo do conteúdo porém a carne do conteúdo, a alegoria é um signo desolado. O símbolo, para Owens, é moderno, aspira à unidade, a ser e a representar. A alegoria, por sua vez, representa, na parte, o todo; desafiando, portanto, a unidade do símbolo, a perfeita convivência do significante e do significado. Seu referente nunca está presente e se encontra sob ameaça de extinção. A alegoria é signo de outra coisa sempre desterrada. A arte alegórica poderia ser a arte do fragmentos, da colagem, da escritura. É uma arte que trabalha com os referentes, com as linguagens, para experimentar os mecanismos que se articulam no referente. As estratégias do impulso alegórico na arte contemporânea são diversas mas em todas elas está a marca da fratura do símbolo e, portanto, para Owens, estas obras são o signo de um momento fragmentário na arte. Algumas earth works de Smithson que se realizam para serem destruídas, arruinadas pela natureza, pela temporalidade não reprimida no museu ou na galeria, são exemplos que apoiam a tese de Owens. Estas obras apontam diretamente ao que Benjamin considerou como o emblema da alegoria: a ruína. O apropriacionismo, por sua vez, também se ajusta perfeitamente no esquema da alegoria, seu objeto não é outro assunto que as linguagens da arte. Trabalhar sobre imagens herdadas da tradição artística da abstração, ao reproduzi-las ou copiá-las, são esvaziadas de seu conteúdo habitual, transformadas em emblemas de uma cultura onde convivem com os produtos de consumo. A pintura simulacionista ou apropriacionista é, ao dizer de Hal Foster, "uma versão pop da abstração ou uma forma asbtrata do pop." As obras de Twombly, Ashley Bickerton, Peter Halley, Cindy Sherman, Barbara Kruger, Sherrie Levine, Smithson, D. Judd, entre outros, se inscrevem em um modelo onde a temporalidade da experiência estética é um de seus requisitos básicos. Temporalidade, textualidade, fragmentação, acumulação, cinismo, são termos que nos permitem descrever os modos de significação que arte contemporânea reporta, por sua vez, a um modelo onde a noção de alegoria parece, se acompanharmos a Owens, mais apropriada que a do símbolo. Cf. OWENS, Craig. "The allegorical impulse: toward a theory of postmodernism." In: WALLIS, Brian. Art after modernism. rethinking representation. New York: The Newe Museum of Contemporary Art, 1984, pp. 203-235: Cf. FOSTER, Hal. The return of the real. Cambridge: MIT University Press, 1999, p. 100. 
por Kiefer de diferentes formas em um ateliê em estado de recente catástrofe.

O crítico alemão, Götz Adriani, comenta que, como em Fond III de Beuys, o livro de Kiefer já parecia ser uma crítica ao minimalismo americano, que procurava negar todos os assuntos na arte, tudo o que estava fora da pura presença física. ${ }^{163}$ Neste cenário caótico

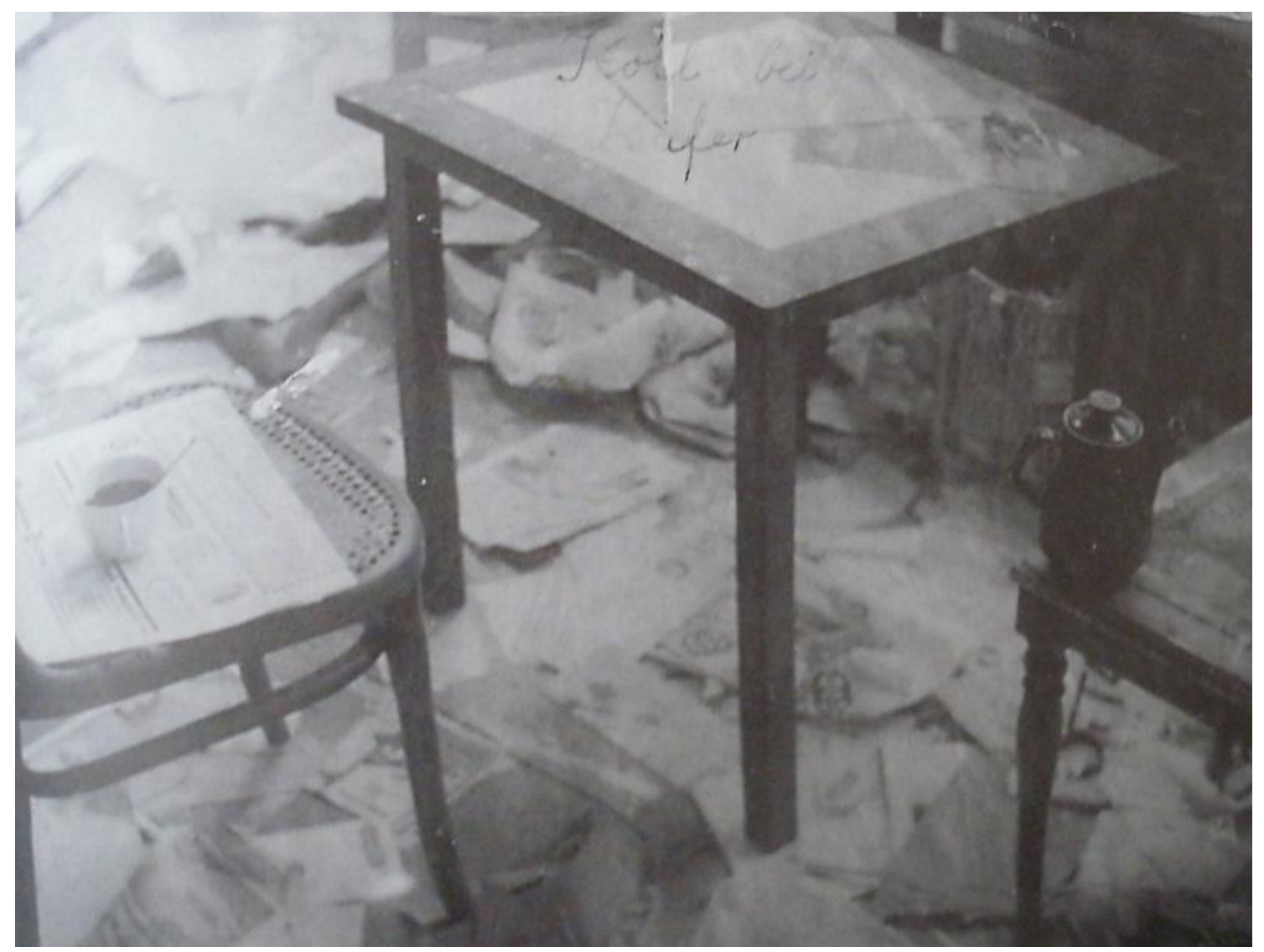

Figura 25. Koll visitando Kiefer/Koll bei Kiefer, 1969. Livro de 112 páginas com fotografias originais mostrando a influência de Donald Judd e Robert Morris mais capa. 66 × 30 × 9,5 cm. Coleção Privada.

escolhido por Kiefer, a forma retangular de Koll está posicionada e

${ }^{163}$ Deve ser notado que Kiefer produziu seu livro Koll no tempo em que os minimalistas americanos como Morris tinham transformado suas formas fortes apresentadas no começo do minimalismo em uma arte com traços mais desagregados. Assim, embora eles não estivessem produzindo uma radical forma subjetiva de arte, os americanos estavam começando a trasladar o minimalismo em direção a uma forma de produção artística menos objetiva e mais orgânica. Portanto, Kiefer, com seu Koll, ataca o minimalismo americano de meados dos 60. Cf. ADRIANI, Götz "Every present has its past," $A K B 13$, pp. 67. 
fotografada de uma maneira bufona. Assim que o leitor vai virando as páginas, as múltiplas posições assumidas pelas estruturas modulares de Koll - em conjunção com a ausência de seres humanos no ateliê, sugere que os objetos em Koll deslocam-se por sua própria vontade. Na síntese das imagens seqüenciais, o espectador cria, assim, uma narrativa rudimentar; a arte de Koll luta por reter sua pureza em meio ao caos cotidiano do pintor. Dessa forma, Kiefer, que reclamava para si o cuidadoso conhecimento dos escritos de Donald Judd e de sua arte, restaura a questão da subjetividade que os minimalistas tinham rejeitado cabalmente. ${ }^{164}$ Os minimalistas americanos tentaram eliminar da sua arte a subjetividade artística. Eles desabilitaram o processo de produzir arte, adotando diversas maneiras e técnicas industriais. Por exemplo, enquanto alguns escultores minimalistas executavam seus trabalhos, outros minimalistas simplesmente projetavam seus trabalhos e tinham seus objetos artísticos realizados pós-auraticamente por outros trabalhadores pertencentes a um contexto industrial. Para Otília Arantes, existe quem vise na eclosão da arte tecnicamente reprodutível na análise clássica de Walter Benjamin -, responsável pelo declínio da obra de arte aurática em favor do valor de exposição, esse momento decisivo de inflexão:

Por esse sendero, tanto Rosalind Krauss quanto Jean-Marc Poinsot, para dar o exemplo de duas posições críticas bastante divergentes, concordam em atribuir ao Minimalismo, mais especificamente à produção do objeto em série, a virada em que a obra passa a ser produzida para ser reproduzida e, a seu modo, consumida. $E$ "consumida" como valor de troca, de sorte que o museu passa a ter algo de empório, ou então teatro em que a mercadoria-arte seria encenada na sua forma publicitária. Além disso, o minimalismo coincidiria com o fim do artista deificado, do sujeito artista, da assinatura, da criatividade expressiva, etc., enfim, de todos os valores tradicionais da arte, que cedem lugar a um novo indivíduo - à

${ }^{164}$ Idem, ibidem, pp. 143-178. 
subjetividade vazia de um eu mínimo, para utilizar a expressão de Lasch. ${ }^{165}$

Além do mais, os minimalistas americanos tentaram desmanchar a subjetividade, negando os elementos composicionais geralmente considerados necessários para o que se considerava a essência da arte. Central aos minimalistas americanos e arte européia era a compreensão da pintura e a escultura como formas relacionais. Como o pintor Frank Stella indicou: "O fundamento de toda a idéia é o equilíbrio. Você faz algo num canto e você equilibra isto com alguma coisa no outro canto". ${ }^{166}$

Voltando para Koll, Kiefer faz tudo para dar o troco à rejeição dos minimalistas americanos pela subjetividade artística. Usando os elementos escultóricos colocados em Koll, Kiefer reitera a composição relacional que os minimalistas pretenderam superar nos seus trabalhos. Assim, como muitos dos trabalhos dos minimalistas americanos, a produção de Kiefer é fundamentalmente tecnológica; no entanto, a despeito dos americanos, seu livro esconde de uma maneira determinante, sua base industrial. Além do mais, ao invés de se referir ao básico, comumente tomado por formas visuais lógicas (identidade, contradição, o círculo, o quadrado, o triângulo), o livro de Koll de Kiefer traz o leitor de volta à particularidade das decisões, o toque e o gosto -em resumo, à existência do artista. Finalmente,

165 Cf. ARANTES, Otília Beatriz Fiori. "A virada cultural do sistema das artes." São Paulo, Abril 2005, pp. 9-10.

166 "The basis of their whole idea is balance. You do something in one corner and you balance it with something in the other corner." Em oposição a esta forma de composição pré-60, os pintores minimalistas como Frank Stella e Kenneth Noland começaram a usar em demasia formas simples (quadrados, retângulos, círculos), simetria axial, padrões de grade e pincéis comerciais, rolos, e tintas para reduzir ao mínimo todo sinal de intervenção do artista para resultar na fórmula decisão, balanço e gosto. Na tentativa de separar a lógica da racionalidade, dessa forma, os minimalistas americanos reduziram a idéia única do artista com uma forma comum - uma idéia geral bastante aceita entre os próprios artistas da época. Cf. STELLA, Frank "Questions to Stella and Judd," entrevista editada por Lucy R. LIPPARD, In: BATTCOCK, Gregory. (ed.) Minimal Art: A critical anthology, New York: E.P. Dutton, 1968 , p. 149. 
por meio da produção do livro, Kiefer, de certo modo, sintetiza práticas materiais divergentes dos escultores e pintores minimalistas - artistas que foram cuidadosos de não invadir o meio dos outros durante os anos americanos 60 (resultado, em parte, da predominância teórica das teorias modernistas esboçadas por Clement Greenberg, ${ }^{167}$ assim como o desenvolvimento de algumas premissas-chave de Greenberg reelaboradas pelo crítico do modernismo Michael Fried). ${ }^{168} \mathrm{O}$ livro de Kiefer, à diferença da pintura e da escultura minimalistas, transgride radicalmente os tradicionais vínculos modernistas dessas duas instâncias estéticas. Não combina apenas elementos da pintura minimalista (processo e flatness) ${ }^{169} \mathrm{com}$ os da escultura minimalista, mas também, o livro de Kiefer incorpora elementos cinemáticos (através de suas imagens seqüênciais e sua quase-narrativa) na experiência do espectador. ${ }^{170}$

167 Cf. FERREIRA, Glória; COTRIM, Cecília (orgs.). Clement Greenberg: O debate crítico. São Paulo: Funarte, 1997.

${ }^{168}$ Cf. FRIED, Michael. "Art and objecthood," In: BATTCOCK, Gregory ed. Minimal art: a critical anthology, pp. 116-147; Cf. Idem. Three american painters: Kenneth Nolan, Jules Olitiski and Frank Stella. Cambridge, Massachussetts: Harvard University Press, 1965.

${ }^{169}$ A flatness da imagem fotográfica comporta duas maneiras diferentes de ser direcionada. Primeiro, a flatness é sugerida pela escrita de Kiefer na fotografia da capa, que ressalta sua natureza como uma superfície bidimensional. A estratégia utilizada por Kiefer de orientar as imagens fotográficas de maneira horizontal e vertical, quebra sua ilusória pretensão, causando no espectador lê-las como superficies planas articuladas.

${ }_{170}$ A pintura minimalista parece ter seu correlato literário no Nouveau Roman ou Romance Objetivo, Escola do Olhar de Alain Robbe-Grillet, a quem se costuma associar nomes como Michel Butor e Claude Simon, Nathalie Sarraute. Existe uma atmosfera intelectual que procura recompor, com a produção artística, uma atividade analítica, a mais objetiva e científica possível. Nesse sentido, para a compreensão do que realmente se passará com livros como Projeto para uma revolução em Nova York ou $A$ Modificação, a leitura dos artigos reunidos em Por um Novo Romance é necessária. Embora Robbe-Grillet não se considere um teórico do romance e procure afastar de suas reflexões a teoria, na verdade o que fez foi elaborar um texto crítico bastante completo do romance, "uma crítica de uma ordem estabelecida e uma proposição para uma ordem nova". Com o redimensionamento do papel humano, a importância dos objetos tenderá a se desminiaturizar na narrativa. A descrição, estára tomada pelo objeto, ocupando assim um papel preeminente e decisivo. Pare Robbe-Grillet, "o 
Em Koll bei Kiefer, o pintor parece definir sua própria postura como artista alemão em oposição ao minimalismo americano, que tinha sido uma experiência estética muito influente na Alemanha. ${ }^{171}$ Sugerido pelo livro, a oposição primária que divide a obra de Kiefer da pintura e da escultura da arte minimalista americana parece ser uma divisão entre subjetivismo e objetivismo. Por um lado, os trabalhos de Kiefer manifestam um alto sentido de subjetividade que os trabalhos dos minimalistas americanos não pretendem expressar. Por outro lado, com relação à produção de Kiefer, o minimalismo apresenta-se como radicalmente objetivo, valendo-se de objetos familiares e com uma aspiração quase-científica. A grande subjetividade apresentada nos trabalhos de Kiefer sugere uma oposição à grande objetividade dos trabalhos dos minimalistas americanos e que aparenta ser revelada por um número básico de referências correspondentes aos meandros da forma e da matéria. Enquanto os trabalhos de Kiefer apresentam uma forma irregular, aqueles dos minimalistas americanos desfrutam de uma vasta forma geométrica. Também os trabalhos de Kiefer embatem questões da vida e da existência, os americanos lidam mais com assuntos relacionados com idéias abstratas e a presença física. Os trabalhos de Kiefer produzem sentidos específicos e narrativas, enquanto os trabalhos dos minimalistas americanos aspiram reduzir todo sentido e narrativa à lógica e a forma visual.

Por esta razão, Koll torna-se contraponto das representações estéticas tanto da cultura alemã como da americana: um assunto que se apresenta na opção alemã, por vezes, bricolado, subjetivo,

movimento da descrição, cansado de fazer ver e querendo, por sua vez, ser visto, revela-se, todavia, um movimento de natureza essencialmente diferente daquele instaurado pelas "ações humanas." Cf. ROBBE-GRILLET, Alain. Por um novo romance. São Paulo: Editora Documentos, 1969, p. 8.

171 Aliás, o trabalho de Koll, o artista, parece ser mais próximo de expressões artísticas como a do minimalista Donald Judd que dos próprios artistas minimalistas alemães como Franz Erhard, Gerhard Hoehme e Ulrich Rückriem. 
particular e antitecnocrático; na solução americana, ora aparece como rígido, sem alma, abstrato e tecnocrático. Apesar dessas diferenças e, de maneira paradoxal, o livro de Koll ainda reporta-se indefectivelmente à experiência minimalista americana da década de 60. Entre 1978 e 1980, Kiefer produziu uma série de livros e pinturas que, segundo os críticos de ambos os lados do Atlântico, apropria-se do estilo da Pop Art. Estes trabalhos eram compostos por gravuras em madeira simuladas - imprimidas com emulsão em papel - e retratos de figuras históricas alemãs que o artista justapõe utilizando a técnica do cuts up.

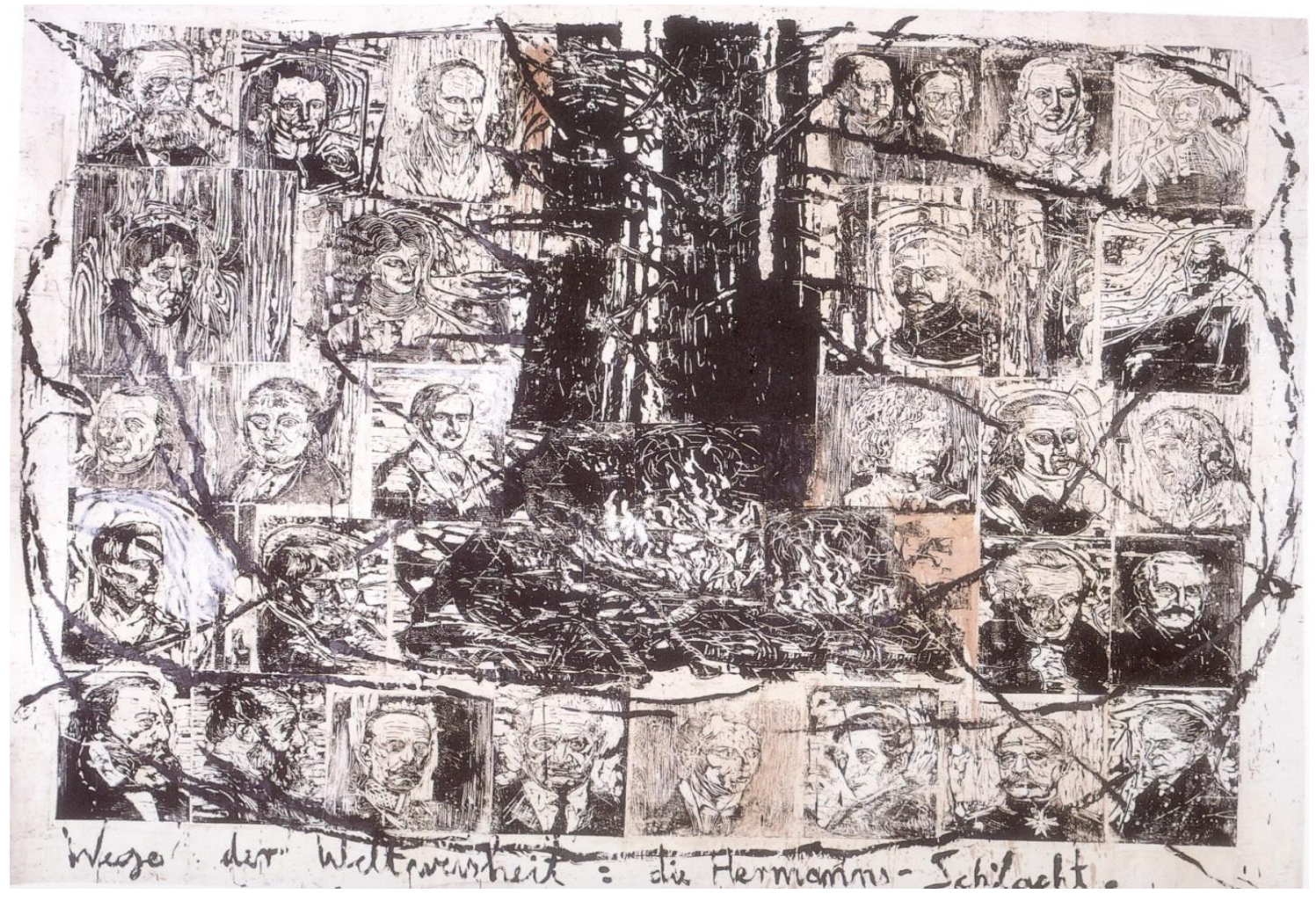

Figura 26. Caminhos da Sabedoria Universal: A Batalha de Hermann/Wege der Weltweisheit -die Hermanns-Schlacht, 1978. Acrílico e esmalte, xilogravura s/papel. 334 × $390 \mathrm{~cm}$. O Instituto de Arte de Chicago.

Talvez o melhor exemplo desta série seja a tela Wege der Weltweisheit -die Hermanns-Schlacht (Caminhos da sabedoria mundial - A Batalha de Armênio) (fig.26). A pintura é um dos trabalhos mais mal-afamados de Kiefer porque, quando foi exibido 
pela primeira vez na Bienal de Veneza em 1980, foi fortemente atacado por um grande número de críticos alemães. Paradoxalmente, essa notoriedade impulsou o trabalho de Kiefer no mercado internacional da arte dos anos 80. Nestas telas, assim como nas outras expressões de Arte Pop, Kiefer glosador, de Andy Warhol, admite $^{172}$ que se apropriou da fórmula pop de Andy Warhol com a finalidade de examinar com atenção temas alemães específicos: o uso nazista dos personagens históricos para criar um sentido de identidade nacional-socialista. Para elaborar essa tela, Kiefer começou imprimindo uma série de gravuras baseadas em retratos desenhados que ele fez de vários soldados alemães, poetas, filósofos e homens de Estado. Kiefer anexou essas gravuras - que incluem imagens de Wessel, Hölderlin, Alfred Krupp, Heinrich von Kleist, Fichte, Heidegger, Kant, Stefan George, entre outros - a telas gigantes. A escolha dessas personagens apresenta um caminho sob o ponto de vista estético, devido a sua visão de forma, que permite incluir o processo de formação da forma, que é, provavelmente, o que possibilitará reconciliar formalismo e historicismo. Isso não se limita à análise da arte, mas estende-se à cultura como objeto de reflexão, da qual as artes seriam um tipo de expressão particularmente condensado e condensador. Goethe, personagem citado, permite articular uma reflexão sobre a idéia de forma, incluindo tudo que é informe, e, assim, de certa modernidade, em vez de ser totalmente fascinado pelo informe. Com Goethe, poderíamos refletir sobre a dialética entre forma e informe, sabendo que o informe na arte, como expressa Danièl Cohn, é sempre uma formação, assim não existe informe em arte, não há o bruto em arte. A arte é sempre um processo inacabado. Parece importante, a propósito de Goethe, observar o vínculo de Kiefer com a natureza. Essa relação coloca uma reflexão ampliada sobre a arte da segunda

172 Cf. HECHT, Axel. "Interview with Anselm Kiefer." Art, January 1990, pp. 44-45. 
metade do século $\mathrm{XX}$, por exemplo. Intuímo que a relação da land art com a paisagem e com a ciência parece já estar presente em Goethe. ${ }^{173}$ Goethe reflete sobre sua época, e dada sua centralidade, não é de admirar que essa filiação não esteja imbricada com a contemporaneidade do pintor, em todo caso, que apareça como reflexão bem tecida não apenas em Walter Benjamin mas também na arte de Kiefer. O pintor reflete sobre tantos pensadores forjadores do pensamento teutônico. Para Kiefer a possibilidade da idéia de cultura alemã se torna proibitiva frente aos acontecimentos da Shoah, e por causa disso ele nos obriga a pensar de outro modo, ou seja, que de Wessel a Heidegger, para fazer uso de uma grande duração, basicamente não construímos nada. Contudo, ele retoma a cultura teutônica como um objeto arqueológico, tendo alguns desejos e algumas necessidades que o fazem reconsiderar o conceito de cultura no que tem de coerente e portador de invenção. O pintor escreve a mão o título no final da tela como $A$ Batalha de Armênio, o fogo é vinculado ao princípio simbólico da nação alemã. O fogo também está interligado aos retratos por uma série de anéis e linhas pretas. 0 traçado desta pintura lembra uma teia de aranha, que congrega um curioso panteão de figuras com as primeiras faíscas da Batalha histórica dos alemães que precipitou toda essa compreensão ominosa da história.

173 O Land Art e a pintura simulacionista também formam parte da estratégia alegórica que brinca como a ambivalência de seu resultado, questionando, por último, a própria arte. Owens localiza a técnica da repetição de unidades idénticas caraterísticas do Minimalismo como outra das estratégias do impulso alegórico na arte contemporânea. $O$ recurso da reiteração bloqueia o aparato referencial do símbolo, a narratividade inscrita nele fica interrompida pela afirmação de uma seqüência sempre idéntica, monôtona, repetitva, distentida a outros elmentos. Amontoar elementos sem cessar, torna-se uma das táticas alegóricas da arte contemporânea. Cf. OWENS, Craig. op.cit., p. 102. Cf. COHN, D., op.cit., p. 45. 
Neste trabalho Kiefer engajase num complexo diálogo com duas instalações prévias: 13 Most Wanted Men (fig.27) de Andy Warhol e 48 Portraits (fig.28), de Gerard Richter. O trabalho de Warhol foi um conjunto de 25 panéis quadrados montados na fachada de Pavilhão Philip Johnson na Feira Mundial de Nova York do ano 1964. Na instalação original, Warhol apresenta retratos de 13 rostos de homens tomados dos arquivos dos criminosos mais procurados da polícia de Nova York. Organizados numa grade

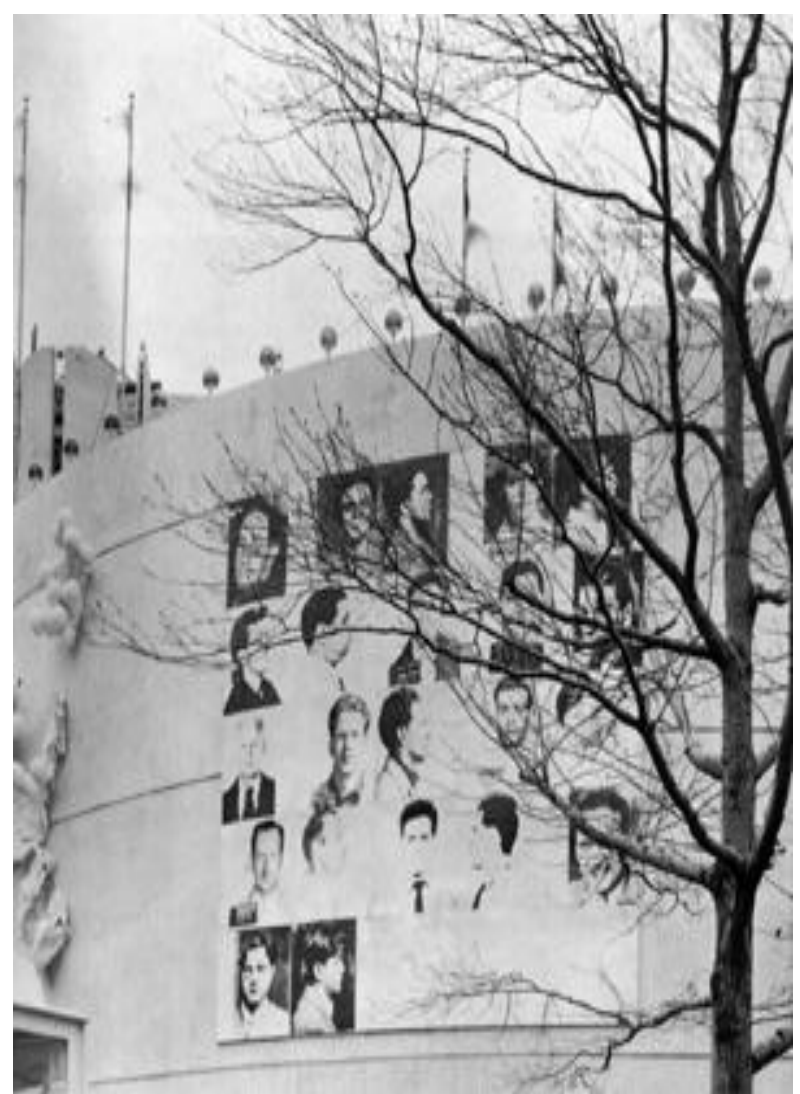

Figura 27. Os 13 homens mais cobiçados/13 Most Wanted Men, 1964. Andy Warhol. Instalado no Pavilhão de Nova Iorque na Feira Mundial de Nova Iorque 1964. Serigrafia em tinta, 25 páneis cada um de $48 \times 48$ polegadas.

quadrada, o trabalho suscita e desafia os conceitos americanos da identidade individual e coletiva em meados dos 60 de três maneiras diferentes. Essa taxonomia das fisionomias manifestando características físicas, comportamento moral e inclinações para a marginalidade é analisada por Nelson Brissac Peixoto:

A taxonomia torna-se a constituição e a manifestação da ordem das coisas. Instauração de arquivos, estabelecimento de catálogos, de repertórios, de inventários. Mundo de classificação generalizada. Um grande quadro das espécies, dos gêneros das classes [...] A fotografia - no esteio de sua vocação ao coleccionismo - servindo à identificação policial, aliás um dos primeiros usos que forma dados a essa nova ténica de produção de imagens [...] Os stigmata degenerationis, as marcas da natureza que o homo delinquens traz no corpo, constituem os signos mas visíveis de uma escrita gravada no corpo de todo criminoso. A essência demoníaca da natureza. A antropologia criminal 
nasce, portanto, junto com a descoberta do selvagem, com a identificação do absolutamente esrtangeiro. $O$ reconohecimento fisionômico transforma o criminoso na personificação do outro. ${ }^{174}$

Primeiro, o trabalho de Warhol questiona a pulsão natural pelo estatuto de celebridade em uma sociedade capitalista e de consumo, marcando o rebaixado caminho do herói do passado para a celebridade de hoje, isto é, no sentido do cotidiano que os americanos acreditavam naquela altura (e ainda acreditam), a celebridade comportava-se como um modo de ser no mundo e que as figuras que eles viam na cultura de massa representavam indíviduos passíveis de ser emulados. Apesar de ter repetido serialmente figuras icônicas nos anos prévios, o panteão de retratos de Most wanted Men estava próximo de seu tablóide de representações catastróficas nas quais os sujeitos já não mais eram figuras ancoradas no anonimato. Em outras palavras, as figuras representadas no Most wanted, eram todas aquelas pessoas cujos retratos falados tinham sido tomados do sistema de justiça americano. Assim, como os trabalhos de desastre dos anos prévios, ${ }^{175}$ os sujeitos da representação artística não procediam do panteão popular estabelecido pela indústria cultural e, além do mais, representavam a celebridade que poucas pessoas almejavam possuir: um marginal. Desta maneira, elevando os sujeitos com perfis infames ao estatuto de ícones midiáticos, o trabalho de Warhol parecia criticar a pulsão de ascenso da cultura americana, assim como a sua passividade para acriticamente acatar e consumir quase todas as imagens que os meios colocam a sua disposição.

Segundo, o trabalho de Warhol Most wanted Men reproduzia e desenvolvia uma técnica dadaísta e construtivista, a saber, a

${ }_{174}$ Cf. PEIXOTO, Nelson Brissac. op.cit., pp. 103-106.

175 Cf. CROW, Thomas. "Saturday disasters: trace and reference in early Warhol." In: MICHELSON, Annettte. Andy Warhol. October files. Cambridge, Massachusetts: MIT Press, 2001, pp.49-68. 
apropriação e justaposição da imaginária fotográfica encontrada, agora transformada pelo fato de Warhol se encontrar trabalhando em um meio da arte, extremamente lucrativo - algo que não estava disponível para os artistas de vanguarda das primeiras três décadas do século vinte. A operação de susbtituição do retrato - uma forma de pintura por meio da qual a subjetividade e a personalidade do indivíduo burguês eram preservadas e promovidas - por esta imagem fotográfica ready-made, Warhol emprega o meio da pintura para sugerir o estatuto problemático do artista autonômo e a representação artística no momento em que a esfera da arte e suas múltiplas interconexões com a indústria cultural pareciam ser evidentes. Neste sentido, Warhol evoca o começo de uma instância revolucionária correspondente ao modernismo do século vinte e sua vontade de transformação tanto do sujeito quanto da vida cotidiana e, ao mesmo tempo, seu trabalho - por meio de sua participação no mercado da arte e seu culto pelas celebridades - parece negar que essas transformações artísticas da vida poderiam acontecer na sociedade americana de meados dos 60 . Warhol não foi o único que sugeriu que a aspiração de muitos artistas do entre-guerra por novas formas não hegemônicas de coletividade individual e subjetiva eram irrealizáveis, mas também, degradando a tradição do retrato, determinou a perda, na esfera da arte, da abilidade para figurar e disseminar valores humanos de uma maneira convincente. O que antigamente era um lugar privilegiado para a produção e recepção de verdades normativas tornou-se, nas mãos de Andy Warhol, uma brincadeira vazia e amarga.

Terceiro e último, Most wanted Men atacou diretamente a subjetividade americana porque apresentava um panteão de figuras que envergonhava a cidade de Nova York. Talvez por sua romantização niilista do bandido americano (ou porque representava 
certa libido homossexual ${ }^{176}$ pois tratava-se de Os homens mais cobiçados), uma vez o trabalho foi instalado, os coordenadores da Feira pediram para Warhol remover a instalação da cena pública. $\mathrm{Na}$ representação da coleção de seus elementos menos desejados, Warhol orientou a atenção dos espectadores internacionais para o lado escuro de América - sua violência e sua pobreza. Além do mais, no fato de ter sido censurado, o trabalho de Warhol demostrou o interesse do estado de Nova York em regular as representações que projetam imagens de uma coletividade local.

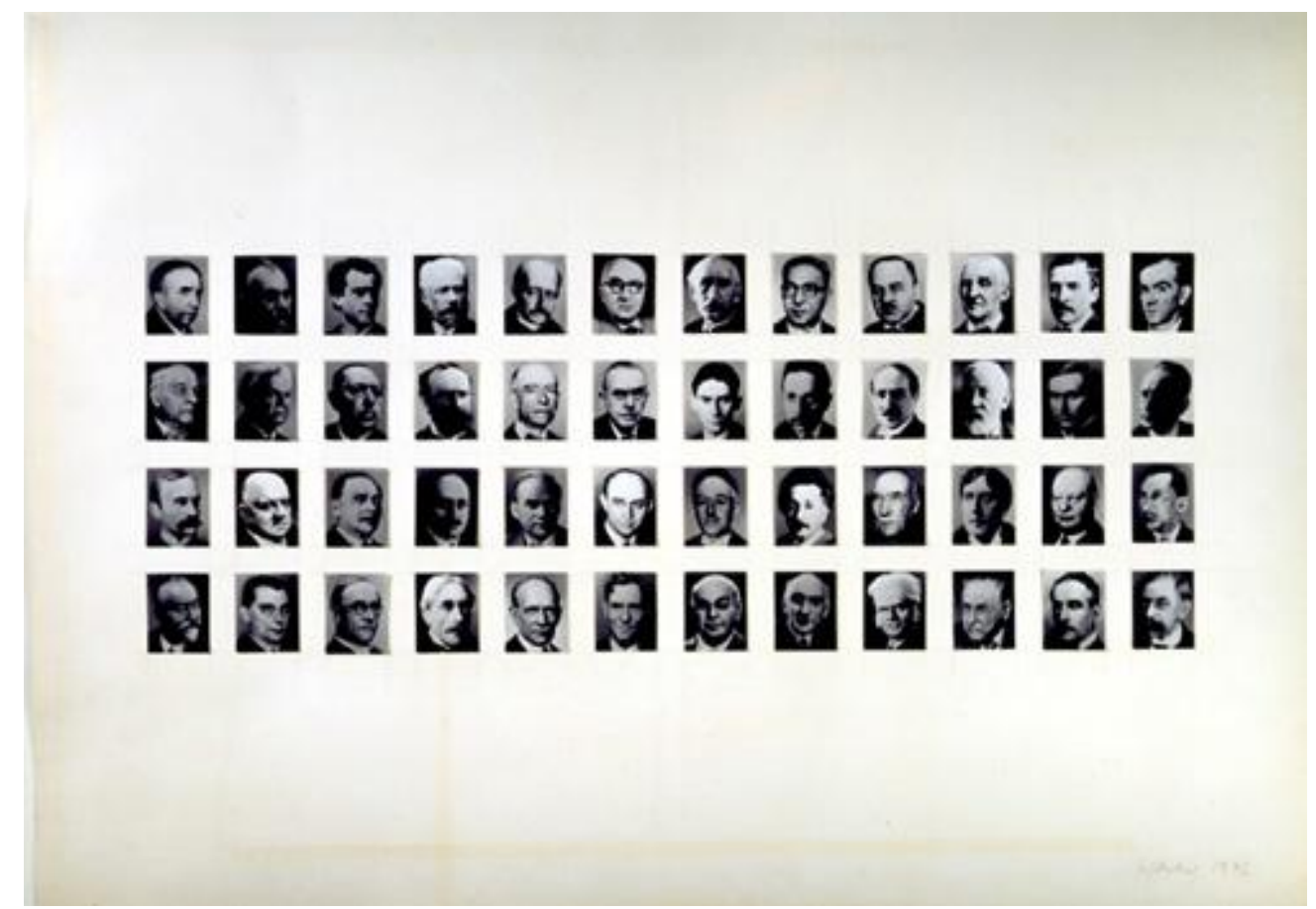

Figura 28. Atlas para 48 retratos/Atlas für 48 Porträts, 1971. Gerard Richter. Fotografias. Museu de Arte Moderna da cidade de

Paris.

Com 48 retratos, Richter também representou a República Federal da Alemanha Ocidental na Bienal de Veneza em 1972. ${ }^{177}$ Como Warhol, coube ao pintor submeter sua obra ao escrutínio

176 Cf. MEYER, Richard. "Warhol's clones," Yale Journal of Criticism, vol. 7, n. 1, 1994, pp. 79-109.

177 Cf. GILLEN, Eckhart. German art from Beckmann to Richter. Images of a divided country. Cologne: De umont, 1997. 
internacional. Uma das funções da instalação de Richter era representar a Alemanha Ocidental - como uma das funções do conjunto de retratos de Warhol era representar a cidade de Nova York - na cena da arte nacional e internacional. Dado o antecedente de Warhol, Richter elegeu o lugar da Bienal de Veneza para refletir, por meio da intervenção da Pop americana e a questão colocada na pintura do retrato histórico, sobre o problema do estabelecimento de uma nova (ou pós-tradicional) subjetividade individual e coletiva na Alemanha Ocidental do pós-guerra. ${ }^{178} \mathrm{~A}$ instalação de Richter consistia em 48 retratos de igual tamanho postos ao longo de uma linha horizontal nos espaços centrais correspondentes ao Pavilhão da Alemanha na Bienal. Pintado em tons cinzas - lembrando seu recurso ao material fotográfico - estes trabalhos representam um conjunto de intelectuais masculinos, tanto europeus quanto americanos: músicos, escritores, filósofos, cientistas do século XIX, por exemplo: Gustav Mahler, Franz Kafka, Igor Stravinsky, Max Planck, Albert Einstein, William James, Enrico Fermi, Paul Hindemith, Thomas Mann, John Dos Passos, Paul Valéry, Oscar Wilde e Wilhelm Dilthey. De acordo com Richter, estes retratos foram aleatoriamente selecionados de várias enciclopédias que circulavam no mercado. A fotografia desfocada apresenta uma descontextualização de suas fontes originais, o que sugere um misterioso panteão de modelos intelectuais, todos masculinos. Como na instalação de Warhol, a série pintada por Richter desafia conceitos dominantes de identidade num contexto contemporâneo. ${ }^{179}$ A instalação sugere a

178 Cf. BUCHLOCH, Benjamin. "Divided memory and post-traditional identity: Gerhard Richter's work of mourning," October 75, Winter 1996, pp. 61-82.

179 Para Buchloch a oposição Warhol-Richter resulta ser fascinante. Richter tem admitido em repetidas ocasiões que a presença de Warhol na Alemanha teve um impacto extraordinário em sua obra. Por exemplo, sua presentação na Bienal de Veneza de 1972 teria sido impensável sem Warhol. No entanto, Richter se afasta de Warhol, precisamente a causa de uma ambigüidade similar faz com que os artistas como Kounellis e Boltanski, por exemplo, entrem nas mais nefastas ciladas. A ambigüidade que 
impossibilidade de estabelecer um canône cultural coerente na Alemanha Ocidental pós-45. Esta série confronta o espectador com uma assemblage de personagens - representando uma assembléia de anciãos ou líderes políticos de um clássico Estado moderno. Ao mesmo tempo, a inclusão de uma quantidade de figuras não-alemãs nesse panteão faz com que o trabalho do artista pareça incompleto e, conseqüentemente, incapaz de definir uma tradição na República Federal. Richter estava consciente da falência da tradição monumental dos retratos que, nas formas de arte pesquisadas pelo nazismo e o realismo socialista, havia degenerado em representações icônicas perversas tanto dos líderes quanto das figuras políticas. Assim, Richter articulou um problema central confrontado pela Alemanha Ocidental do momento: o dilema de reconstruir a identidade alemã do pós-guerra face à bancarrota do modelo burguês de representação retratista. Como a instalação do artista sugere, embora a tradicão de representação história precise ter uma certa continuidade na Alemanha Ocidental, os esforços de construção dessa identidade não podem se basear no apelo ao espírito nacionalista.

As instalações de Warhol e Richter estão comprometidas em uma complexa série de negociações com a questão da pintura de retratos no pós- guerra e de possibilidades que essa técnica abriga para centrar e descentrar diferentes formas americanas e alemãs de construção de identidades, para que possa estabelecer uma relação com a constelação de assuntos da esfera pública e da cultura de massas em geral. Além do mais, a instalação de Richter expõe explicitamente a questão de se a história pode ser representada acuradamente no universo estético. Os trabalhos de Richter

pretende ser restaurada com um gesto de redenção, de subjetividade humanística, forma parte de um projeto destinado ao fracasso. Quanto maior é o esforço, quanto mais fortemente seja expressado, maior será a influência no projeto dos mecanismos de conversão em espectáculo, essos mesmos mecanismos que eram questionados. Cf. BUCHLOCH, Benjamin et al. Acción Paralela 5, 2000. p. i. 
representam indivíduos históricos sem um halo de mistificação e sem conferir-Ihes uma aura de grandiosidade. De fato, nas apropriações pop de Kiefer, especialmente nos Caminhos da sabedoria mundial, o pintor apanha as múltiplas linhas de questões trazidas por estes dois trabalhos que o antecederam. Como Kiefer declara, o que o levou escolher vários líderes políticos e figuras artísticas representados nos Caminhos da sabedoria mundial, foi o fato de que o poder abusou deles - o Nazismo usou estas figuras para promover sua ideologia. Apesar da recepção inicial em 1980, os críticos entenderam que Kiefer parecia, como bem Richter antes dele, ter-se apropriado das fórmulas da Pop Art para criticar a atividade contemporânea do retrato histórico - para mostrar como os alemães sabiam pouco sobre seu parnaso de heróis e como era fácil interceptar arbitrariamente estas figuras para elaborar uma justificativa autoritária. ${ }^{180}$ Deste modo, por exemplo, Mark Rosenthal se referindo as apropriações de Andy Warhol feitas por Kiefer e, especificamente à técnica da gravura, escreve:

Como o artista Americano, Kiefer olha os heróis de sua pátria de uma maneira deliberadamente inexpressiva; 0 resultado é uma espécie de jingoísmo em que estes indivíduos tomam o carácter de deuses. Os retratos tanto de Warhol quanto de Kiefer deixam seus assuntos ligeiramente vazios, apenas superfície sem núcleo interno. Quando eles queimam nas pinturas de Kiefer, nós não testemunhamos a incineração da carne e do sangue mas a cremação dos ícones. 181

Kiefer, em outras palavras, apropriou-se do antecedente estético proposto por Warhol - também empregado por Richter para analisar

180 Cf. ROSENTHAL, Mark. Anselm Kiefer. Chicago: Art Institute of Chicago and Philadelphia Museum of Art, 1987.

181 Idem, ibidem, p. 120. "Like the American artist, Kiefer looks at the heroes of his country in a deadpan way; the result is a kind of jingoism in which these individuals take on the character of gods. The portrays by both Warhol and Kiefer leave their subjects slightly hollow, all surface and no inner core. When they burn in Kiefer's paintings, we do not witness the incineration of flesh and blood but the cremation of icons". 
a tradição de pintura monumentalista do pós-guerra, para produzir uma pintura que pretendia desmitificar 0 culto das grandes personalidades da cultura alemã e para provocar questões como a representação histórica dos indivíduos ataca a reflexão contemporânea sobre uma identidade coletiva e, ao mesmo tempo, individual. Ainda mais explicitamente que Richter, a instalação de Kiefer defronta-se com o passado nazista, e refere-se a técnica de Warhol como uma maneira de glosar o persistente legado do nazismo. Como Andreas Huyssen sugere, quando a Pop Art americana se tornou popular na Alemanha Ocidental nos anos 60, estava identificada, primeiro, com a contra-cultura e, em seguida, com "as atividades públicas e políticas da nova esquerda antiautoritária." 182

Nas reproduções, Kiefer plasma um horizonte ambíguo no qual fusiona figuras como a de Martin Heidegger, Horst Wessel, Immanuel Kant e Otto von Bismarck, e, sugere, que, ao contrário de uma primeira leitura dos alemães da Pop Art americana e sua força crítica, a Pop Art não era univocamente americana nem suas propostas estéticas eram monoliticamente revolucionárias. Ao contrário, como as teorizações sobre o sujeito, a Pop Art também parecia ser uma reflexão com múltiplas soluções: individual e coletiva, alemã e americana, de pré- guerra e pós-guerra. Assim, como nas instalações de Warhol, as pinturas de Kiefer sugerem que, apesar de seu erotismo crítico, a Pop Art tende muito mais à sedução do que à idealização: um processo pictórico que recria personalidades cujas aparências capturam o espectador e com quem o espectador se identifica vicariamente. Então, os retratos justapostos de Kiefer parecem dar conta de uma elevada atitude de ambivalência dos meios de massa e as influências que os mesmos exercem na opinião

182 "the public and political activities of the anti-authoritarian New Left". Cf. HUYSSEN, Andreas. After the great divide: modernism, mass Culture, postmodernism. Bloomington: Indiana University Press, 1986, p. 141. 
pública - uma atitude que parece mais contenciosamente crítica daquela apresentada por Richter em 1972, e que se reflete num grande pessimismo no trabalho de Kiefer. Em outras palavras, o trabalho de Kiefer apresenta, paradoxalmente, um sólido conservadorismo em fase crescente na República Federal Alemã em 1970 (por meio da aparente monumentalização dos assuntos problemáticos desconsiderados nas discussões culturais alemãs) e a sensação da esquerda alemã de que todas as instituições estavam unificadas, no momento, numa indústria autoritária e terrificante.

Em Caminhos da sabedoria mundial, a apropriação de Kiefer das fórmulas da Pop Art estã justaposta com o drama teutônico. A pop americana, como 0 trabalho de Kiefer sugere, projeta questionamentos que respondem ao campo cultural americano (a dissolução das possibilidades de ser em meio à unidimensionalidade subjetiva imposta pela cultura de massa e sua condenação a uma forma desenfreada de consumo). Seu trabalho propõe, então, uma falta de atitude crítica em torno à tentativa nazista de hipostasiar e mitologizar uma imagem estandardizada de germanidade que foi uma das pré-condições para que o horror se desatasse pela Europa durante os anos da primazia nazista. Enquanto o niilismo da Pop Art parecia ser garantido - até, de certa maneira, uma experiência que poderia ser chamada de $\mathrm{cool}^{183}$ - em face ao consumismo americano

183 Warhol encarna uma figura que se apresenta a si própria como imagem substituta da realidade. Sua vida foi uma simulação, um artifício, do mesmo modo que as imagens seriadas que criou e das que ele mesmo foi seu produto principal. Nele se embaralham a noção de arte e de mercadoria, se apresentando como a quintessência do artista consumidor. No entanto, atendendo sua atitude global e suas declarações, tal pareceria que coexistia no artista tanto uma concordância com os mecanismos da produção econômica capitalista, como uma atitude crítica com sua sociedade, o poder e a instituição da arte, o que se manifesta de um modo particular, afirmativo, fazendo uso do cinismo, termo caro as análises de Hal Foster. Para Foster, a visagem referencial do pop warholiano é defendida por críticos e historiadores que relacionam sua obra a temas diversos: os mundos da moda, da celebrity, da música, da cultura gay, a Warhol Factory, a Velvet Underground, entre outras. A abordagem mais acurada 
nos anos 60, isto se torna altamente problemático quando se estabelece um paralelo com o niilismo destrutivo pulsante em Hitler. A apropriação de Kiefer, adverte-nos contra toda condescendência na produção e na recepção de representações estetizantes de personalidades públicas - uma associação que parece estar mais clandestina no trabalho de Warhol e de Richter. O contraste da forma e conteúdo através de diferentes universos, permite-nos ensaiar diversas maneiras de viajar na constelação pictórica de Kiefer. Por exemplo, na justaposição de personalidades da história alemã, Kiefer nos lembra que idealizar uma subjetividade individual no campo da

destas análises registra-se em Thomas Crow que, em seu "Saturday disasters: trace and reference in early Warhol", contende as posturas de Warhol associadas ao simulacro, que "afirmam serem as imagens indiscriminadas, e o artista, indiferente". Em meio a tanta máscaras, do fetiche das mercadorias e as pop stars das mídias, Crow escarva mais no fundo encontrando "a realidade do sofrimento e da morte" das tragédias pessoais de Marlyn, Liz, Jackie, Elvis, Eddie, que demostram a "expressão direta de sentimentos". Crow encontra não apenas um objeto referencial para Warhol, mas um tema empático em Warhol, reconhecendo o caráter crítico de Warhol - não num ataque à "velha coisa, arte" mediante a aceitação do signo da mercadoria mas antes numa exposição do "consumo complacente" por meio do "fato brutal" do fracasso exemplar. Para Crow, o artista "se sentia atraído pelas feridas abertas da vida política americana", na sua leitura das imagens de cadeiras elétricas como propaganda de agitação contra a pena de morte e das imagens da race-riot como um testemunho em favor dos direitos civis. Afirma o crítico, "longe de ser um puro jogo do significante libertado de qualquer referência", Warhol participa da tradição popular americana do truth telling (contar a verdade). Warhol, com seu cinismo, mostra as cavidades de todo construto social. Enfatiza no fato de que por trás das coisas não existe mnada, que todad realidade social carece de fundamnete. Assim, o pintor deseja conhecer famosos como o objetivo de reconhece-los nas revistas. A particularidade deste cinismo consiste em trata de mostrar a realidad e como representação não substancialista, como simulacro carente de fundamento. Warhol não establece uma diferença entre uma natureza autêntica das coisas e sua versão figurada. Neste sentido, as palavras de Warhol, por mais afetadas que possam parecer, contêm um potencial valorativo-subversivo ao trazer à superfície a ausência de valor dos valores, mediante a afirmação cínica dos mismos. Cf. CROW, Thomas. op.cit. pp. 54-55; Cf. FOSTER, Hal. "The art of cynical reason". In: The return of the real. pp. 99-126; Cf. Idem. "The return of the real". In: Idem, ibidem, pp. 127-170; Cf. AULADELL, Felip Vidal. "Cinismo y marginalidad. Andy Warhol y The Velvet Underground en Exploding Plastic Inevitable."Espéculo 22, 2002, p. 10. 
representação tem sido historicamente associada com a representação do outro como degenerado: um duplo momento de idealização e vilificação que freqüentemente toma lugar conforme a pautas de nacionalidade, de raça e de sexualidade. Num contexto associado à reprodução de massa e o que ela pode causar no espectador, há que considerar as maneiras em que os meios de massa têm sido usados para criar imagens do bem e do mal. Além do mais, as apropriações de Kiefer também sugerem a relação entre uma forma artística e a produção e dissolução da dignidade humana.

\title{
B.BESETZUNGENS: ESVAZIANDO O MITO DO HÉROI
}

\begin{abstract}
A fotografia é um inventário da mortalidade. Susan Sontag.
\end{abstract}

Tomemos um dos primeiros trabalhos de Kiefer, a série de fotografias intitulada Besetzungen (Ocupações), ${ }^{184}$ de $1969,{ }^{185}$ como um exemplo para discutir um ponto central que ordena muitas dos assuntos abordados nas suas pinturas durante os anos 70. Trata-se, talvez, da ação de arte mais provocadora e perturbadora que atacou frontalmente a iconologia heróica reverenciada pelo nacionalsocialismo. Esta aproximação de Kiefer com o material histórico estabelece interconexões com as condições contemporâneas da

${ }^{184}$ Besetzungen não significa apenas ocupações em alemão, mas também é caro ao termo alemão para se referir à catexe freudiana. Entendendo as catexes, Kiefer representa seu próprio superego. Por meio da catexia, Kiefer pode reconhecer a inabilidade de se identificar propriamente com os egos parentais como ideais do ego por eles terem resultado inapropriados em razão do passado alemão. Ele não pode se identificar propriamente com suas imagens parentais masculinas, embora a pulsão de fazê-lo ainda esteja presente, embora essas fotografias representem esta fracassada empreitada. Cf. BUDZYNSKI, Joseph. op. cit., pp. 121-122.

185 Para essa mesma data também encontramos os livros do artista: Heroische Sinnbilder (Símbolos Heróicos) e Für Genet (Para Genet), neles, Kiefer se debruça sobre as mentalidades e as implicações ideológicas do imaginário heróico capturado pela máquina de produção de imagens que foi a experiência nazista. 
produção de seu itinerário artístico, o passado nazista e as antigas tradições culturais. Tomadas em 1969, mas apresentadas em 1975 no jornal Interfunktionen, a série comprendia 18 fotos em preto e branco. A publicação desta série suscitou sérios problemas para este jornal. O escândalo causado pela publicação destas fotos, dirigido ao novo editor, naquela altura, Benjamin Buchloch, que se tornara o crítico mais vociferante da obra de Kiefer, desencadeou indignação e reações problemáticas de parte dos críticos e dos curadores, enquanto os patrocinadores retiravam apressadamente toda sua propaganda. Em cada uma delas, Kiefer, vestido com uma farda militar, com calças de equitação, botas altas pretas, assume a cerimoniosa saudação de Sieg-Heil (fig. 29). Ele se posiciona frente a monumentos, edifícios e paisagens referentes aos países visitados. Durante o outono de 1969, o jovem artista, com 24 anos na época, emprende uma viagem através da Europa e posa diante de sua lente objetiva, solitário, o braço erguido executando a saudação hitlerista, com uma tímida segurança, em diferentes locações: na Suíça (em Küsnacht e Bellinzona), na Itália (em Roma, Paestino e Pompéia) e na França (Montpellier e Arles). O texto de abertura da série era: "Anselm Kiefer. Zwischen Sommer und Herbst 1969 habe ich die Schweiz, Frankreich und Italien besetzt." ${ }^{186}$

186 Cf. ARASSE, Daniel. op. cit., pp. 40-42. (Entre o verão e o outono de 1969, eu ocupei a Suíça, a França e a Itália. Umas fotos); Cf. MITSCHERLICH Margarethe; Alexander. Le deuil impossible: les fondaments du comportement collectif, Payot: Paris, 1972. Versão para o inglês, The inability to mourn: principles of collective behaviour. Trad. Beverly $\mathrm{R}$. Plackzek. New York: Grove Press, 1975. Outros trabalhos que abordam a questão do luto impossível, Cf. ADORNO, Theodor. "What does coming to the past mean," (1959), trad. e ed. Geoffrey Hartmann, Bitburg in Moral and Politica. Perspective. Indiana: Indiana University Press, 1986, pp. 114129; Cf. MILLER, Judith. "Erasing the past: Europe's amnesia about the holocaust," Cf. One by one, by one: The landmark exploration of the holocaust and the uses of memory. New York: Simon \& Schuster, 1990. 
Uma evocação do nazismo sem a distância apropriada poderia parecer um atavismo. Nós, leitores contemporâneos, acolhemos a perfomance de Kiefer de uma forma menos escandalosa para nossa percepção, até a comparamos com a figura do Grande Ditador, franqueada por Chaplin, reduzindo-o a um registro claramente farsesco e clownesco. Lembremos que no contexto pós-68, estas estratégias paródicas eram comuns, o que não é justificativa tranqüilizadora

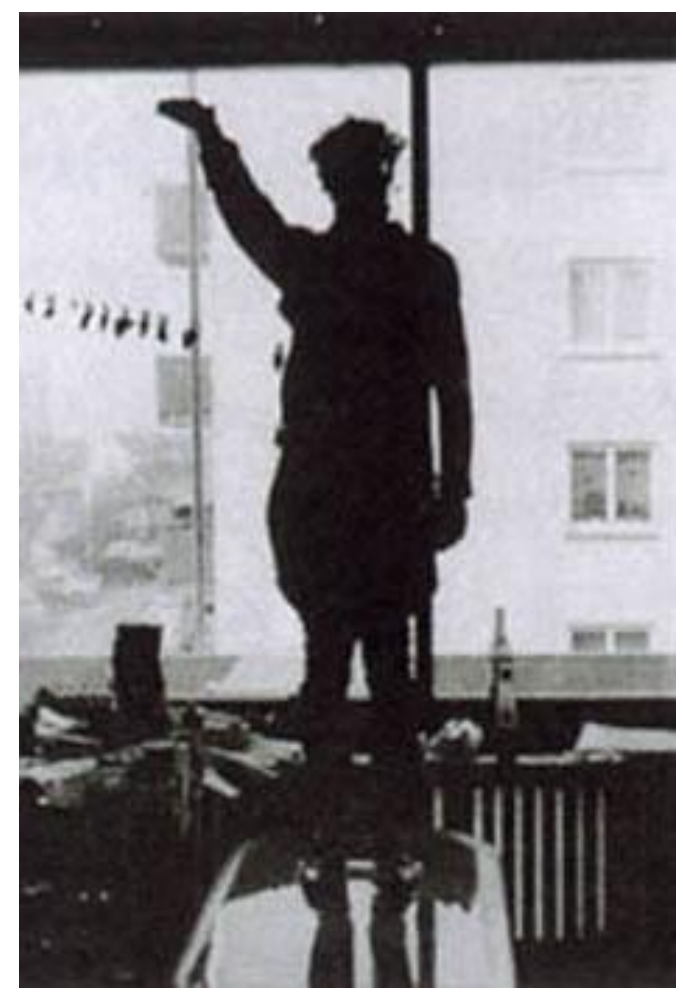

da
Figura 29. Ocupações/Besetzungens, 1969. sinceridade expressa na retomada de Kiefer. O que nos faz encontrar com Walter Benjamin quando dizia que a dimensão cômica do sério incorpora o mais extremo dos horrores. Para Andrea Lauterwein, Kiefer também extrema as significações da palavra alemã para ocupação: Besetzung. Além da operação militar e da distribuição de papéis no teatro, esse termo também nos remete à idéia freudiana de investimento (Besetzung). 0 investimento designa um compromisso com a energia pulsional sobre um objeto ou uma representação necessária à fixação de uma sensação na memória. No trabalho de luto, como o destaca Daniel Arasse, o investimento sobre sua força intensificada de sobreinvestimento (Überbesetzung) do objeto perdido, permite matar a morte desatando o investimento libidinal do objeto de amor. Vale agregar que Kiefer produz a série de Besetzungen um ano depois da publicação do livro de Alexander e Margarethe Mitscherlich, Die Unfähigkeit zu trauern (O Luto impossível). Neste livro, esta dupla de psicólogos constata a ausência de reações de luto por parte dos alemães após uma catástrofe tão terrível: segundo eles, a queda de 
Hitler, objeto de investimentos psíquicos massivos, é regressiva, produzindo uma desvalorização traumática de seu ideal, ou seja, o luto impossível não concerne aos crimes de guerra nazista, mas ao amor por Hitler no momento da tomada de consciência dos crimes cometidos. Só um super investimento do objeto perdido ou um esforço de empatia permitirão reavivar a memória do passado para, assim, poder sair do impasse do presente.

Parece que Kiefer aplicou essas exigências teóricas ao pé da letra, ele que nasceu no ano de 1945 e que faz parte dessa segunda geração. Uma maneira de acompanhar essas exigências teóricas, mais precisamente, a questão do encantamento alemão pelo seu passado e como Kiefer é afetado por este fenômeno está relacionado com o seu projeto estético e sua leitura desse trabalho antes mencionado, $O$ luto impossível, altamente influenciado pela linguagem psicanalítica. Em 1967, Alexander e Margarethe Mitscherlich publicaram esse estudo em que aplicavam a teoria de Freud sobre o luto à sociedade alemã da época, concluindo que os alemães não tinham feito um ajuste de contas com o passado. Neste estudo os Mitscherlich reiteraram repetidamente a aparente ausência de qualquer confronto emocional sustentado com o passado alemão na sociedade alemã do pós-guerra. Esses sentimentos que pareciam ter sido esperados seguindo um reconhecimento da cumplicidade em crimes abomináveis executados em nome da Vaterland; e os testemunhos dos sobreviventes do Holocausto não provocaram sentimentos de contrição, nenhum desejo de lembrar e curar essa dor desse passado em comum. Segundo eles, e central para sua tese, a população da República Federal evitou o que poderia ter sido uma reação psicológica à derrota Nazista em 1945, o confronto direto com os fatos horrendos da Solução Final e, talvez, sobretudo, a perda de Hitler enquanto Führer, nomeadamente muitos cairam em depressão e melancolia: 
Para milhões de alemães a perda do "Führer" (em todo o olvido que cobriu sua queda e a rapidez com a que se renunciou a ele) não foi a perda de identificações comuns das pessoas que têm preenchido uma função central nas vidas de seus seguidores apegados a sua "persona". Por assim dizer, ele tem se tornado a encarnação do ideal de seu ego. A perda de um objeto tão altamente identificado com energia libidinal - alguém de quem ninguém duvidava, nem ousava duvidar, mesmo quando o país estava sendo feito em escombros-era, de fato, razão para a melancolia. Por meio da catástrofe, não era apenas o ideal do ego assaltado pelo apoio à realidade, mas, além do mais, o Führer era exposto pelos vitoriosos como um criminoso de verdadeiras proporções monstruosas. Com essa inversão repentina de suas qualidades, o ego de cada indivíduo alemão sofreu uma desvalorização central e empobrecimento. Isso cria, pelo menos, as precondições para uma reação melancólica. ${ }^{187}$

Lembremos que, para Freud, o luto ocorre quando um objeto que tem se amado pelas suas qualidades intrínsecas, é reconhecido como distinto e separado de nós mesmos: sua perda. A perda do objeto amoroso, deste modo, resulta tipicamente no ato de luto: "o luto é normalmente a reação à perda de uma pessoa amada ou de uma abstração como pátria, liberdade, um ideal. Em algumas pessoas mostra-se no lugar do luto uma melancolia". ${ }^{188}$ Entretanto, os Mitscherlich alegam que dada a predominância do elemento narcísico na fabricação do homem total idealizado pelo Nazismo, devemos

\footnotetext{
187 "To millions of Germans the loss of the "Führer" (for all the oblivion that covered his downfall and the rapidity with which he was renounced) was not the loss of someone ordinary identifications that had filled a central function in the lives of his followers were attached to his person. As we said, he had become the embodiment of their ego-ideal. The loss of an object so highly cathected with libidinal energy - one about whom nobody had any doubts, nor dared to have any, even when the country was being rubble - was indeed reason for melancholia. Through the catastrophe not only was the German ego-ideal robbed of the support of reality, but in addition the Führer himself was exposed by the victors as a criminal of truly monstrous proportions. With this sudden reversal of his qualities, the ego of every single German individual suffered a central devaluation and impoverishement. This creates at least the prerequisites for a melancholic reaction". Cf. MITSCHERLICH. op. cit., p. 26.

${ }^{188}$ Cf. FREUD, Sigmund. op.cit., p. 197.
} 
insistir na prioridade da tarefa mais primitiva do trabalho de luto (associada com a melancolia) enfrentando a população alemã do pósguerra. Os alemães teriam que trabalhar as identificações que eles sustentaram com Hitler e a ideologia nazista da Volksgemeinschaft e também trabalhar com a fragmentação traumática dessa relação narcisística que eclodiu a partir da derrota em 1945, antes de eles terem compreendido a magnitude dos crimes cometidos em nome da Vaterland, menos do que ter que sentir luto pelas vítimas. O texto lacônico inscreve-se num retângulo branco no começo da primeira fotografia e sua tipografia apresenta-se de maneira informe. Sua estrutura de álbum fotográfico parece memorializar uma grandiosa viagem pela Europa. No entanto, em vez da palavra em alemão Bereist (viagem), defrontamo-nos com a palavra Besetzt (ocupação). A saudação nazista - gesto punido na Alemanha Ocidental após a guerra -, a roupa e o título Besetzungen, lembram a ocupação nazista e seu domínio por toda a Europa. Kiefer persiste na representação destes dois posicionamentos do sujeito: o de autorenúncia em favor de um próposito coletivo e a identificação com figuras de poder ou disposições de domínio e de controle. Na última foto desta série, encontramo-nos com o pintor de costas para o espectador, posicionado em meio às rocas com seu braço direito levantado ante um mar expansivo. Na citação da pintura de Caspar David Friedrich, $O$ viajante sobre o mar de neblina, afirma Benjamin Buchloch, a propósito da arte de Oldenburg, que a tradição dos modelos artísticos de vanguarda histórica, só poderão ser preservados na sua realização farsesca: o que vale recordar essa imagem em que ele imita o gesto de Caspar David Friedrich diante de um mar de neblinas, associando-o à saudação hitlerista. ${ }^{189}$ Para Leila Danziger esta obra:

189 Cf. BUCHLOCH, Benjamin. "Construire (I'histoire de) la sculpture". In: Qu'est-ce que c'est la sculpture moderne? Paris: Centre Georges Pompidou, 1989. 
pode ser compreendida tanto como reprodução quanto como tradução, deixa aparente as fraturas, as diferenças temporais, ideológicas, técnicas (da pintura para a fotografia) que orientam sua atualização. Ao contrário de tantas citações meramente formais que foram moeda corrente na pintura da década de 1980, as "traduções/reproduções" das obras de Kiefer e Richter são operações críticas, produtoras de diferenças. ${ }^{190}$

Kiefer mostra a estratégia ideológica programada pelo Nazismo: a captura de tradições veneráveis para conferir permanência e letigimidade histórica a este regime autoritário alemão. Com isto, Kiefer também nos adverte que estes símbolos e gestos, ainda estão sob a ocupação nazista na sociedade da Alemanha Ocidental do período do pós-guerra. Como Mattew Rampley declara, Kiefer propõe uma conexão entre o romantismo alemão, a Alemanha Nazista e seu próprio trabalho:

Em lugar de indicar o abismo entre o que é tradicionalmente considerado como propriamente da cultura alemã do Romantismo e a aberração do Terceiro Reich, essa tática é certamente salientada em vez de sua continuidade. Em particular, Kiefer pode ser lido como fazendo explicitamente o paralelo entre o discurso Romântico do sublime na natureza e a ideologia pastoral do anticapitalismo reacionário fundamentado na estructura ideológica do Nazismo, com sua ênfase no parentesco do Volk alemão com a natureza. Existem paralelos, também, entre o ego absoluto do sujeito romântico inspecionando os inúmeros registros do partido congregado fielmente através do

190 Todas as linguagens artísticas estão profundamente intrincadas com linguagens naturais. A arte traduz em mais elevadas formas de linguagem a linguagem das coisas, mesmo nos casos em que a linguagem da tradução artística pertença ao mesmo âmbito da linguagem da natureza. Contudo, toda a tradução artística contém, conforme Benjamin, uma dimensão significante e simbolizante que compromete necessariamente a fidelidade absoluta da tradução e a circunciza com a marca negativa do incomunicável, com o fantasma monstruoso do incomensurável. Tal duplicidade das linguagens artísticas (e as linguagens humanas em geral) foi acolhida teoricamente por Benjamin, como recurso aos termos, opostos e complementares, "mimético" e "semiótico." Cf. DANZIGER BRASIL, L. M. Corpo de ausências, Berlim e os monumentos a Auschwitz. op. cit., p. 74. 
deslocamento da sublimidade de sua fundação em espectáculo natural da experiência do espectáculo de massa. Assim, em sua escolha de um grupo tão provocante de imagens repletas de uma vasta gama de conotações culturais, a saudação no mar é um exemplo particularmente sugestivo, Kiefer está indicando a imbricação da cultura nazista no Romantismo, uma imbricação que também responde pela sua fascinação sedutora). ${ }^{191}$

Junto com as referências notórias do nacional-socialismo, a série das Ocupações de Kiefer estabelece também um diálogo com padrões e estruturas do imaginário heróico da nação alemã. Suas referências ao Império Romano, ao monumental e à imaginária heróica são recorrentes. Parece-nos interessante que os cenários escolhidos por Kiefer para executar sua tiragem de fotos, não respondam a lugares históricos onde se produziram as desprezíveis ocupações nazistas. Pelo contrário, estes lugares remetem-nos, antes, a uma viagem turística mais do que a uma viagem pelos cenários carregados de história lutuosa causada pelos anos terríveis do nazismo. Destinos como Arles, Pompéia, Montpellier, o Coliseu Romano, sugerem-nos, na verdade, uma agradável travessia pela geografia cultural da Europa. Folga reconhecer que o gesto saudatório do Sieg-heil, não foi de invenção nazista, pois o mesmo formava parte do protocolo militarista executado entre altos militares e Imperadores Romanos.

191 "Rather than indicating the gulf between what is traditionally regarded as the properly German Culture of Romanticism and the "aberration" of the Third Reich, this tactic is surely stressed instead their continuity. In particular, Kiefer can be read as making explicitly the parallel between the Romantic discourse of the sublime in nature and the pastoral ideology of reactionary anti-capitalism underpinning so much of the Nazi belief structure, with its emphasis on the kinship of the German 'Volk' with nature. There are parallels, too, between the absolute ego of the Romantic subject surveying the innumerable ranks of the rallied party faithfull through the displacement of sublimity from its foundation in natural spectacle of the experience of the mass spectacle. Thus in his choice of such a provocative set of images replete with a wide range of cultural connotations, and the salute by the sea is a particularly suggestive example, Kiefer is indicating the embeddedness of Nazi culture in Romanticism, an embeddedness which also accounts for its seductive fascination". (Cf. RAMPLEY, Mattew. "In search of cultural history: Anselm Kiefer and the ambivalence of modernism," Oxford Art Journal, vol. 23, November 2000, pp. 82-83. 
Respondia a uma expressão corporal de poder político, um gesto imperial solidamente usado para representar os monumentos dedicados aos líderes militares romanos. ${ }^{192}$ Aliás, numa das fotos da série, Kiefer posa frente à estátua eqüestre de Louis XIV em Montpellier, um comum tropo iconográfico utilizado pelos Romanos nas comemorações visuais de triunfantes líderes militares entrando nas cidades dominadas pelos Cristãos e que também é vociferante até nas representações pictóricas da própria história da arte européia. Kiefer compõe suas fotos empregando diferentes aparatos íntimos do imaginário histórico: prédios imponentes, monumentos enormes, vastas paisagens com linhas de horizonte profundas, proporções exageradas, o pintor em aberta defrontação com o espectador, uma estrita simetria divide imagem, escuridão, a pose heróica e o gesto comportamental investem em uma severa seriedade e pathos. Contudo, as locações escolhidas pelo pintor não parecem ser as mais apropriadas para que as massas comemorem e idolatrem incondicionalmente o líder. O soberano, esse exemplar virtutis, essa figura de poder e de autoridade que inspira pulsões miméticas, nas fotografias de Kiefer ausenta-se da cena da representação num primeiro plano como estabelecido nos códigos iconográficos da estatuária heróica, por exemplo. De fato, em Kiefer, essa figura aparece freqüentemente miniaturizada pela imensidão das paisagens vazias, praças e estruturas arquitetônicas onde acontece a foto. $O$ líder, vitorioso mantém firmemente seu gesto de triunfo e poder apesar da falta de reconhecimento público, aparecendo, em todas estas ocasiões, rebaixado e, suscitando, assim, um ar mais ridículo do que um enlevamento propriamente heróico.

192 Cf. LAUTERWEIN, Andrea. op. cit., p. 55; Cf. LANZETTA, Kym. The aesthetic of sacrifice in Heiner Müller, Wolf Vostell, Anselm Kiefer and Rainer Werner Fassbinder. Tese de Doutorado apresentada ao Departamento de Filosofia da Universidade de Chicago, 2008. Atender, em particular, as páginas dedicadas a Anselm Kiefer, capítulo 3 do vol. II. 

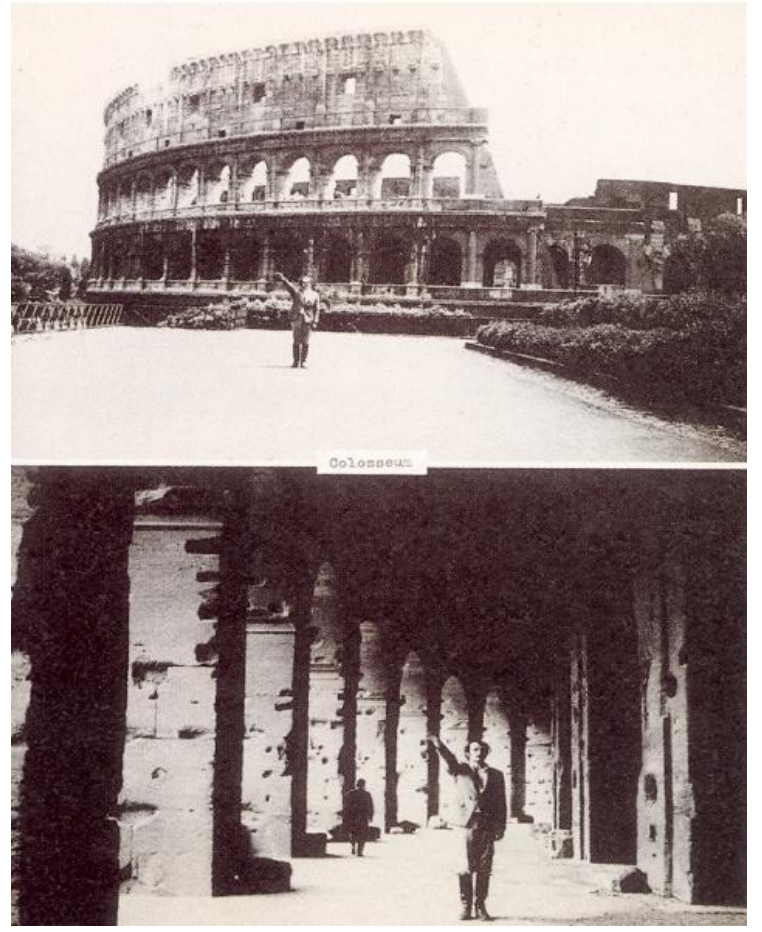

Figura 30. Símbolos Heróicos.

Kiefer usa a grandiosidade e o porte heróico do soberano, além da iconografia e o imaginário heróicos, como uma tentativa de abalar essas estratégias representacionais vinculadas à arte comemorativa. Essa teatralização farsesca de imagens bombásticas de ritualização dos soberanos acaba frustrando a fascinação pelo herói-soberano a quem encomendamos todas nossas promessas. É verdade que Kiefer representa um fracasso histórico em seus dramas pictóricos, no bloqueio de toda ação edificante, uma paralisia do futuro, uma irrupção da desesperança. Surge, assim, o desafio formador da própria vida. Sem as qualidades do drama, a herança que nos lança à compaixão seria como uma condenação, um ônus. Pois experimentar a angústia e seguir vivos já é antídoto para essa paixão. Por isso se precisa da compaixão: para participar da angústia do herói e ultrapassá-la, com o observamos na série de obras Heroische Sinnbilder (fig. 30, 31).

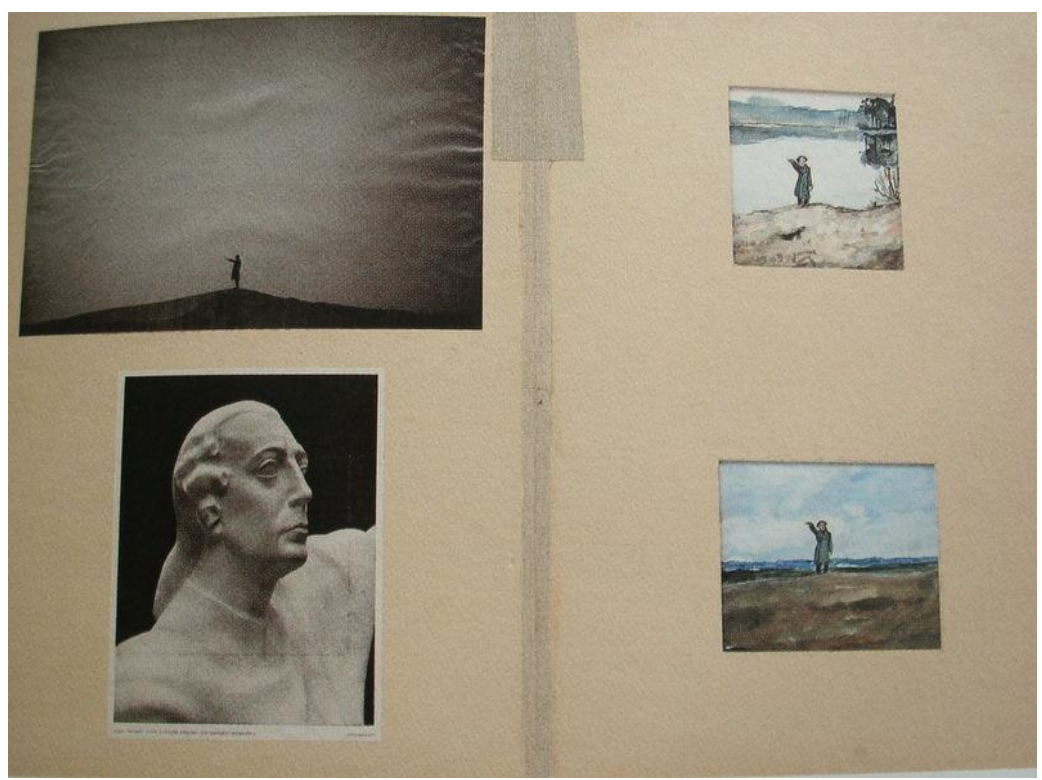

Figura 31. Símbolos Heróicos/Heroische Sinnbilder, 1969. Livro de artista. Aquarela sobre papel, grafite, fotografias originais e de revistas, cartões postais montados em cartolina, 46 páginas duplas mais capa. $66 \times 30 \times 8,5 \mathrm{~cm}$. Coleção Privada. 
Os efeitos monumentais que assaltam essa figura, revelam a abnegação e o sacrifício exigido pelos sistemas totalitários, e a submissão a esse clamor estético pode significar sua restituição. ${ }^{193}$ A primeira reação a esse tipo de obra foi, sem dúvida, de aturdimento e escândalo; o próprio artista antecipa isso. Trata-se de um tabu ultrapassado. Contudo, quando se olha cuidadosamente, múltiplas ironias começam a aparecer. Em quase todas as fotos Kiefer torna-se uma figura minúscula, reduzida pelo que o rodeia, pois as fotos foram tiradas de longe. Em uma das fotografias, Kiefer está numa banheira, como se estivesse caminhando messianicamente sobre as águas, e é vista contra uma janela iluminada por trás. Não há massas eufóricas, soldados marchando, nem nenhum outro dos emblemas do poder e do imperialismo que conhecemos dos trechos filmados na era nazista. O artista não se identifica como o gesto de ocupação nazista; ele o ridiculariza, satiriza-o. A ironia e a sátira serão realmente a maneira apropriada de lidar como o terror fascista? Será que esta série de fotos não ameniza o verdadeiro terror real que o gesto nazista evoca para uma memória construída historicamente? Existe uma dimensão de mise-en-scène consciente, que está no centro do trabalho de Kiefer. Em lugar de ver essa série de fotos somente como representação do artista ocupando a Europa com o gesto de conquista fascista, podemos, em outro registro, ver o artista ocupando vários espaços - imagens construídos; paisagens, prédios históricos, interiores, precisamente os espaços-imagem da maioria das pinturas posteriores de Kiefer. Mas porque então o gesto fascista? Trata-se de um gesto que pode ser lido como conceitual, lembrando-nos que sem dúvida a cultura nazista efetivamente ocupou, explorou e abusou do poder do visual, especialmente do poder do monumentalismo massivo. Advertem Philippe Lacoue-

193 Cf. HUYSSEN, Andreas. Memórias do modernismo. Trad. Patrícia Fabris. Rio de Janeiro: Editora UFRJ, 1999; Cf. KAES, Anton. From Hitler to Heimat: The return of history as film. Cambridge \& London: Verso, 1989. 
Labarthe e Jean-Luc Nancy, que a construção do mito ariano foi o que justificou os crimes nazistas - discurso que ainda não parece estar completamente desativado. Para eles, existe no rumor do tempo uma demanda ou uma espera surda de uma representação, uma figuração, a saber, uma encarnação do ser ou do destino da comunidade. Trata-se justamente de uma identificação simbólica (ou "imaginária", segundo o léxico que escolhermos: em todo o caso por meio de imagens, símbolos, narrativas, figuras e também de elementos que os reavivam) que o fascismo alimentou-se de modo superabundante. ${ }^{194}$

O fascismo contaminou, abusou e absorveu territórios inteiros de um mundo de imagens germânico, transformando tradições literárias e icônicas nacionais em meros redutos do poder, deixando, portanto, a cultura pós-45 pronta para causar uma crise latente de identidade. A pintura de Kiefer está em contínuo diálogo e interação com a história alemã. Sua arte permite escutar a presença do passado:

O primeiro contato a "flor de pele" com a História o tive escutando um disco, quando estava ainda na escola, com dezassete anos. O disco tinha sido lançado pelos americanos para a "reeducação": ele continha os discursos originais de Hitler, Göhring, Göbbels. Fiquei profundamente abalado: com aqueles de Hitler em particular. Tudo me impressionava: a brutalidade, a sua capacidade de explorar a História, o uso da mídia. Hitler foi o primeiro a fazer um uso artístico da mídia e Göbbels, em particular. Esta tem sido a minha abordagem direta com a História. $\mathrm{Na}$ Alemanha se fala que a língua geht unter die Haut: [literalmente: vai abaixo da pele]: te toca de perto. Discos como aquele te tocam diretamente, a pele antes que as idéias. Por isto é importante ter uma relação direta com a História, por exemplo, escutando-la. Quem se aproximar a ela apenas através dos livros, incorre em erros. ${ }^{195}$

194 Cf. LACOUE-LABARTHE, Phillipe; NANCY, Jean-Luc. O mito nazista. Trad. Márcio Seligmann-Silva. São Paulo: Iluminuras, 2000, pp. 11-12.

195 "Il primo contato "a fior di pelle" con la Storia I'ho avuto ascoltando un disco, quando ero ancora a scuola, a diciassette anni. Il disco era stato pubblicato dagli americani per la "rieducazione": conteneva i discorsi originali di Hitler, Göhring, Göbbels. Ne rimasi profondamente scosso: quelli di Hitler, in modo particolare. Tutto mi colpiva: la brutalità, la sua abilità 
Após 20 anos de uma bateria de imagens sem precedentes no mundo moderno, que inclui tudo, de marchas com tocha de fogo a espectáculos de massa políticos, da gigantesca plataforma das Olimpíadas de 1936 à produção incessante da indústria de filmes nazistas bem nos anos da guerra, das óperas com as torrentes de luzes do megalômano Albert Speer no céu noturno aos fogos de artifício antiaéreos sobre cidades incendiadas, a necessidade de imagens do país parecia exaurida. ${ }^{196}$ Fora os filmes americanos importados e o culto da realeza estrangeira em revistas ilustradas, a Alemanha do pós-guerra era um país sem imagens, uma paisagem de cascalhos e ruínas que rápida e eficientemente embarcoue na produção de uma reconstrução concreta, iluminada apenas pela iconografia da publicidade e das imagens falsas do Heimatfilm. Para Andreas Huyssen, o país que produzira o Cinema de Weimar e a riqueza da arte de vanguarda dos anos 20, e que produziria o novo cinema alemão a partir do final dos anos 60, estaria completamente morto em imagens por 20 anos, uma espécie de minimalismo negativo forçado, uma amnésia visual. A ausência de imagens

nello sfruttare la Storia, I'utilizzo dei media. Hitler fu il primo a fare un uso artistico dei media, e Göbbels in particolare. Questo è stato il mio approccio diretto con la Storia. In Germania si dice che la lingua geht unter die Haut [letteralmente: "ti va sotto la pelle"]: ti tocca da vicino. Dischi come quelli ti toccano direttamente, la pelle prima che le idee. Per questo è importante avere un rapporto diretto con la Storia, per esempio ascontandola: chil le si avvicina solo attaverso i libri incorre in errori". Cf. ANDREOTTI; DE MELIS, op. cit., p. 31.

196 O escritor Alfred Döblin que se encontraba no sul da Alemanha no ano de 1945 descreve com consternado espanto o comportamento natural das pessoas da Vila Worms face aos escombros e à destruição: "[...] Les hommes circulaient dans les rues, parmi les ruines effrayantes comme s'il ne s'était rien passé de spécial, comme si la ville avait toujours été dans cet état." Para estes aldeãos, a destruição total não parecia ser um assunto escandaloso, uma catástrofe moral, pelo contrário, resultava ser a primeira etapa da reconstrução a ser executada por todos. Destarte, os aspectos mais sombrios do ato final da destruição que foi assistida pela imensa maioria da população alemã tornaram-se secreto de família, uma vergonha, um estridente tabu. Cf. SEBALD, W. G. De la destruction comme élément de I'histoire naturelle. Trad. Patrick Charbonneau. Paris: Actes Sud, 1999, pp. 18-21. 
adequadas na Alemanha do pós-guerra e a necessidade de inventar, de criar imagens que permanecessem vivas também parecem impulsionar o projeto de Kiefer.

Por causa da gravidade das imagens empregadas por Kiefer, foi verdadeiramente difícil determinar, numa primeira instância, se o pintor identificava-se com os planos monumentalistas adotados pelo nazismo ou apenas queria mostrar a terrível hybris da destruição contida nestas posições onipotentes. Esta estratégia é, de fato, sua melhor crítica. Em vez de simplesmente provar a falsidade desta postura, sua estratégia de afirmação de todos esses ícones, coloca, no plano do simbólico, as verdades mais horribili dictu que, transfiguradas na imagem do artista, tornaram-se chocantemente visíveis. Com doses homeopáticas de terror, sua estratégia ataca a imagética nazista com suas próprias armas ideológicas. $\mathrm{Na}$ descoberta da maneira em que respondemos e, de certo modo, nos fascinamos por Herrenmenschen (Homens da raça superior) e pela estética monumental utilizada para representá-lo, assalta-nos uma incontida perplexidade perante $O$ reconhecimento de nossa cumplicidade numa ordem mundial de subjugação e de domínio. A imagem heroicizante de si como nazista é sempre estranhamente pequena em escala com respeito aos monumentos diante dos quais se apresenta.

Em outra série de fotografias, ele adota o Viajante Observando um Mar de Neblina, de Caspar David Friedrich, e inserindo a saudação nacional-socialista na herança romântica da Alemanha - ao mesmo tempo assume uma distância posando de viajante em terras ignotas. Nosso ponto de vista é indicar que o projeto para um jovem artista é o de despedaçar o tabu da representação nazista e isso agressivamente - com o que não pretende apenas se remeter ao passado, senão representá-lo, encarná-lo em seu próprio corpo para entendê-lo, para confrontar, por meio de um exercício de inversões e de artifícios, a recusa alemã pós-Auschwitz de se reconciliar com as 
dimensões estéticas do passado político. No entanto, a questão importante que permanece para nós não é se Kiefer é um protofascista, mas a retomada da iconografia nazista como modo ideal de se lidar com o terror fascista.

Seguindo as indicações de Andreas Huyssen, essa saudação Sieg Heil naquelas fotografias iniciais deve ser lida como um gesto conceitual que nos lembra que, realmente, a cultura nazista ocupou, explorou e abusou de maneira muito efetiva do poder do visual, especialmente o poder do monumentalismo maciço e de uma perspectiva de ponto central, confinadora e mesmo disclipinadora. $O$ fascismo, além disso, tinha pervertido, abusado e sugado territórios inteiros de um mundo de imagens alemãs, transformando tradições literárias e icônicas em meros ornamentos do poder e, com isso, deixando a cultura pós-1945 como uma tabula rasa destinada a provocar uma crise de identidade. Do mesmo modo que Kiefer parodia o herói-soberano, ele também ataca o pintor historicista que semelhante ao historiador historicista criticado por Benjamin, aquele que ao se voltar sobre o passado e ao identificar-se com ele, identifica-se com a história do vencedor, falsificando os combates dos vencidos, e seu particular interesse na figura heróica na Alemanha incita uma reflexão sobre a responsabilidade do artista em hipostasiar déspotas políticos e as maneiras em que os pintores e os heróis nacionais são recrutados e instrumentalizados em causas patrióticas de cunho nacionalista.

O abalo que produzem as posições dominantes sobre o sentido da história mostra como a proposta benjaminiana de se pensar a história como elaboração de um fim que não se situe no exterior ou no limite dela, que não se trata apenas de um fervoroso clamor de que a história, para que tenha sentido, isto é, seja história, acabe, não se trata, pois, da necessidade da escatologia. Para Benjamin, é igualmente essencial que qualquer apocalítica da história precise concluir, não normativamente o mundo, esse cosmos natural, mas 
antes, um cosmos temporalizado, tornado história. Essa elaboração sobre um instante temporal suspenso no nada, completamente alheio à história, mas a descoberta de um intervalo, no tempo histórico naturalizado, isto é, esvaziado do sentido de modo que faça surgir uma espessura histórica, é um recurso teológico para a construção de uma filosofia da história presente nas construções filosóficas-políticas de Walter Benjamin. O conceito de história benjaminiano responde aos enormes desafios políticos de sua época (as suas teses Sobre $o$

Figura 32. Você é pintor/Du bist Maler, 1969. Livro de 220 páginas em tinta e fragmentos de fotografia original e de revistas montadas em papel. $66 \mathrm{x}$ $30 \times 8 \mathrm{~cm}$. Coleção Particular.

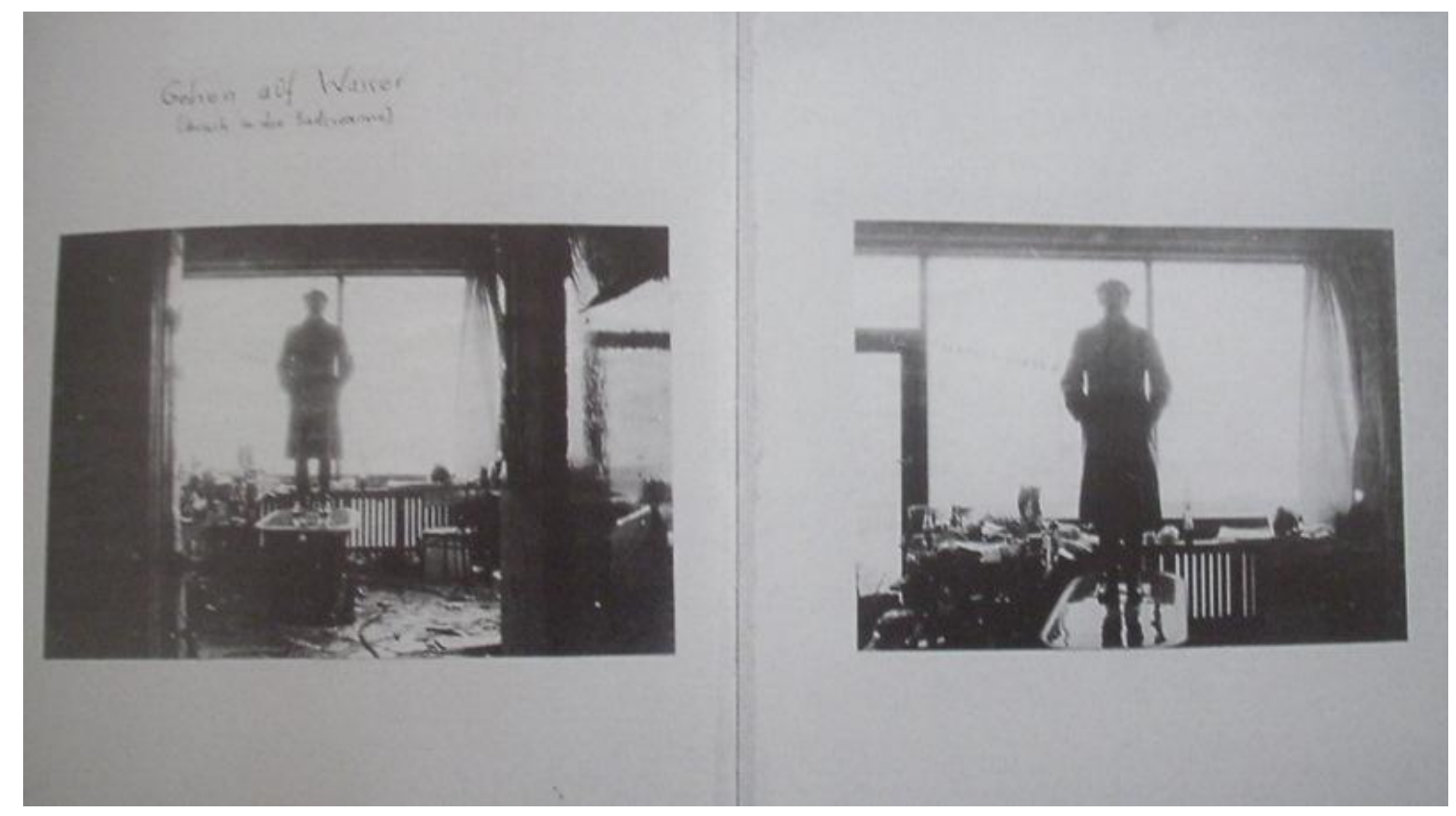

conceito de História foram escritas entre os últimos meses de 1939 e os primeiros de 1940, muito embora se encontrem já em textos muito anteriores, nomeadamente no texto sobre $A$ vida dos estudantes de 1915 algumas formulações preparatórias) e, ao mesmo tempo, propõe categorias capazes de representar uma idéia salvífica [eine rettenden Einfall] para a humanidade. No livro do artista, Du bist Maler (Você é pintor) (fig. 32), Kiefer inclui uma reprodução da estátua Mattias Grünewald de Joseph Thorak (1889-1952), o escultor nazista renomado por suas monumentais esculturas. Com uma pose heróica, a mão colocada no coração preserva um instrumento de 
desenho e com a outra mão agarra um papel. Kiefer postou nesse papel: Du bist Maler e, como em Besetzungen, o pintor estabelece uma relação identificatória entre Grünewald e a imagem heróica religiosamente transfigurada do pintor, imaginada pelos nazistas, inteiramente comprometidos com sua tarefa estética e abençoados por uma inspiração quase suprema. ${ }^{197}$ Um quadro branco cobre a mesa em desordem do ateliê do artista. Na tábua encontram-se pequenos soldados e infantes de cavalaria e acumulam-se todos em marcha para um batalha. Acima destas formações miniaturizadas encontramos escrito: Die Leibgarde (A guardiã dos cadáveres). As duas linhas de soldados entram em confronto. As últimas duas fotos de uma seção de cinco, acabam mostrando grandes perdas de soldadinhos. Encontramos a palavra Verluste (Perdas) inscrita na quarta foto. A perspectiva da foto é da distância o que novamente nos remete à miniaturização do campo visual que se pretende representar. Encontramos papéis amassados jogados no chão. $O$ efeito imediato da cena nos permite pensar essa representação como uma desvalorização da batalha heróica. Por meio da piedade,

197 Na Alemanha, a figura do artista adquire dimensões quase de um salvador heróico cujas visões estão dotadas pela habilidade de orientar o curso da natureza, da história e da vontade humana. Por isso nos referimos, embaralhando termos caros a Walter Benjamin, ao termo de artista historicista. O que explica as expectativas de salvação colocadas na arte e nos artistas alemães do século XIX. Isto é mais notório na arquitetura alemã nazista, por exemplo. Dentre dos modelos arquiteturais que Kiefer empregou como ressorte pictórico, os rascunhos de Wilhem Kreis (1873-1955) têm a melhor parte. Quase nenhum projeto de Kreis, com exeção do sítio de Luftgaukommando em Dresde, recebeu objeção sob o Nazismo. Ele formou, no entanto, junto com Paul Ludwig Troost e Albert Speer, a elite de arquitetos nazistas, ocupando funções oficiais como diretor da Academia de Belas Artes de Dresde, de 1938 a 1942, "conselheiro geral para a construção de sepulturas militares alemãs" a partir de 1941, e, além disso, foi presidente da Câmara Artística do Reich em 1943. Antes de 1933, Kreis estudou diferentes edificações do estilo Bauhaus, entre os mais conhecidos da época encontravam-se a grande loja por departamento Tietz em Colônia (1912-14) e o Museu da Higiene em Dresde (1928-30). Após 1945 , ele prosegue sua carreira de arquiteto em franca reconciliação com o estilo moderno de seus primeiros projetos. Incontáveis edifícios públicos tais como o Museu da Saúde em Colônia também foram construídos a partir de seus planos. Cf. PEHNT, Wolfgang. op. cit., pp. 146-165. 
descrições lutuosas das cenas, a pequena escala das fotos e dos livros, a distância e a falta de primeiros planos nas imagens, os pequenos soldados embrenhados na terrível batalha, todos detratam os efeitos sublimes caraterísticos das pinturas que representam feitos épicos de batalhas heróicas.

A sensação produzida pelo monumental e suas repercussões ideológicas são aspectos importantes na estética de Kiefer que também evoca estratégias sublimes para propositadamente induzir o horror, espanto e o choque. Suas recorrentes referências à estimação super-heróica em diferentes épocas históricas, inclui figuras do Império Romano (Nero), arquitetura (Coliseu) da história francesa (Luis XIV), da história alemã (Federico o Grande) assim como a arte e arquiteturas nazistas. Enquanto a monumentalidade na arte, a história aviva o medo, o estranhamento e admiração atribuindo forças sobrenaturais a uma figura, também evocam uma identificação jingoísta com as figuras e símbolos de grandiosidade coletiva assim como gera a vontade de alcançar também uma distinção. Lembremos que a imagética heróica é altamente propedêutica. Ela guarda modelos de instrução, emulação e identificação. Até heróis fracassados e notórios criminosos (como os de Andy Warhol, por exemplo), são recrutados, funcionando como modelos negativos e admonições morais. Imagens do herói trágico ou negativo apresentam as fatais conseqüências da invulnerabilidade heróica, da arrogância e do egoísmo artístico. É conseqüente, portanto, como reconhece Bazon Brock, que Kiefer em outras séries temáticas exalte pura e simplesmente a figura do artista, ou seja, esse Pintor desconhecido (fig.33), à altura de honrarias memoriais, assim como no século XX foram erigidos monumentos a determinados soldados, ao guerreiro genérico, ao trabalhador total, como falava Ernst Jünger para se referir ao mesmo anonimato. Kiefer, ao substituir os sarcófagos dos mortos da marcha de 23 nas criptas do templo da Praça Real por uma paleta posta num pedestal, elabora sua crítica 
com requintada ironia. A prática cultural, com base na veneração dos grandes vencedores, tem como pressuposto o fato de que inúmeros artistas pintores jamais atingem a fama com suas obras. Estes artistas desconhecidos, infames, são, portanto, vítimas necessárias de um fracasso exemplar que viabiliza a outros a distinção e as honras. ${ }^{198} \mathrm{Na}$ Alemanha, com exceção do soldado desconhecido, jamais se louvara o papel dos anônimos loosers, os portadores da cultura de massa, melancolicamente recuperados por Andy Warhol

Figura 33. Ao pintor desconhecido, 1983. Óleo, acrílico, emulsão, esmalte e palha s/tela. $208 \times 380$.

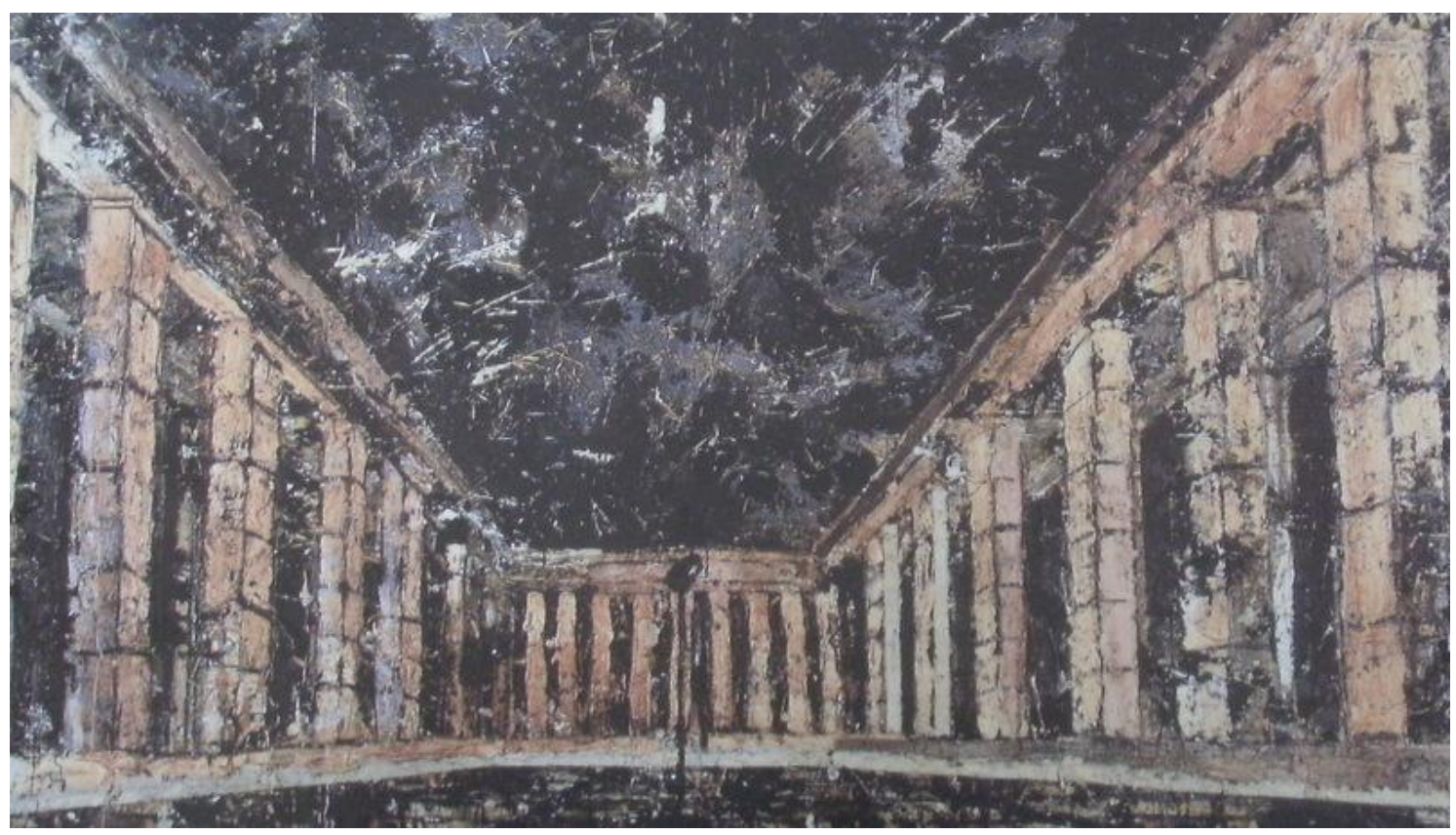

em The Most Wanted Men. Em comparação com o louvor dos grandes, eles funcionam como fracassos exemplares. O trabalhador, o cientista e o consumidor desconhecidos não são considerados dignos de monumentalização. O padrão freqüente de heroicidade em Kiefer é notório pelo seu fracasso exemplar; o soberano ou o artista que, almejando chegar muito longe, acaba por despencar, deixando uma destruição catastrófica em seu caminho. A sociedade alemã

198 Cf. BROCK, Bazon. "Exorcizar o demônio com belzebuzinhos administração do sintoma como terapia." Trad. Geraldo Dias Souza. Revista Ars, 5, pp. 91-97. 
empregou formas de violência para alcançar o poder político e não hesitou em tomar imagens dramáticas de heróis com as atitudes necessárias para justificar o assassinato e a morte. Para Kiefer, uma permanente exposição a esses modelos ideológicos de representação ajudam a formar a moralidade da coletividade e a gerar identidades, estabelecendo parâmetros para apreciar o Bem e o Mal, demarcando formas próprias de comportamento e definindo as políticas de inclusão e exclusão. A incitação imaginária da guerra e das batalhas, o pathos comovente da figura agonizante do herói, a comemoração da vitória, e a expressão espectacular e cerimoniosa na entronização das imagens são apenas figurações da arte histórica que representam grandes gestas realizadas pelos homens e posições estimadas essenciais para a permanência de uma ordem social.

A pintura histórica européia desde a Renascença até o século XIX, ${ }^{199}$ estava comprometida com a apresentação de imagens da exemplar virtutis, incluindo a obrigação pela prosperidade e a obediência ao soberano, ao Estado e aos costumes. Roma, a Grécia clássica, o cristianismo e os mitos nórdicos na Alemanha providenciaram vidas exemplares de heróis que arriscaram tudo pela virtude, pela nação e pelo soberano. ${ }^{200}$ Sua aura de heroicidade e de martirológio é dada a partir de sua obstinada determinação em face à luta, à dor e à morte. ${ }^{201}$ Similar à exemplar virtutis romana, a fé individual está dada pela imortalidade e a contínua existência da Nação. A persuasão e o poder desse imaginário em que os grandes homens (Napoleão, Federico o Grande) ou heróis míticos (Hercules, Hermann, Siegfried) desprendidamente engajaram-se com a morte

199 Cf. CROW, Thomas. Nineteen century art: a critical history. London: Thames and Hudson, 1994.

200 Cf. MEAD, Theodore C. Historical iconology and the simbolism of wood in German painting: From Friedrich to Kiefer. Dissertação de Mestrado apresentada ao Departamento de Arte da Universidade de Lamar, maio 1997.

201 Cf. FRITZSCHE, Peter. Life and death in the third Reich. Cambridge: Belknap Press, 2008. 
em favor das lutas patrióticas serão completamente utilizados pelos regimes políticos europeus nas décadas que sucederam à Revolução Francesa extremando as imagens alegóricas ou as cenas de cerimônias pomposas nas campanhas de construção nacional. Sob as transformações políticas, sociais e tecnológicas acontecidas no século XIX, tanto a didática quanto o imaginário estético do herói são intensificados e colocados à prova. Junto às noções do herói patriótico e as versões historicistas da história, a exemplaridade de alguns indivíduos, aumentava os ataques simbólicos à figura do herói. As imagens do herói vitimizado pelas forças sociais começam a aparecer com maior freqüência. Dados os custos sociais da solução política do herói, sua alucinada vontade de se sacrificar e também de sacrificar os outros, heróis negativos, anti-heróis, heróis fracassados, heróis anônimos e caricaturas dos heróis tornaram-se comuns na história da pintura. ${ }^{202}$ Então, na última década do século XIX, a incongruência entre o tratamento alegórico conferido à figura heróica e a necessidade de retratos mais realistas sobre os acontecimentos modernos suscitaram um rebaixamento simbólico da figura do herói. Também a fotografia, satisfazendo a vontade por novos meios de representação mais imediatos e realistas, exauriu as formas da pintura histórica. A estrutura alegórica das pinturas históricas não se ajustava à brutal realidade do Estado moderno e as novas formas de heroísmo que emergiram com ele.

A história da arte tem comemorado e transmitido mentalidades e ideologias em torno da figura do herói. Nessa desaforada comemoração, na mesma equação de morte e destruição de um passado honroso ou um futuro utópico, a realidade de domínio, morte e assassinato tornou-se invisível. O terror e a violência produzidos pela morte em massa são mitigados e subsumidos por versões transfiguradas de vitória e liberdade. Contudo, justamente por esse movimento, imagens idealizadas dos heróis em acontecimentos

${ }^{202}$ Cf. CROW, Thomas. op. cit., p. 99. 
coletivos determinantes, estabelecendo uma comunicação entre o passado e o presente, entre a vida e a morte, a arte histórica também contêm uma função social: ela assiste retroativamente o processamento e a cópia do trauma histórico produzido pela destruição trazida pelo acontecimento bélico. O trabalho de Kiefer orienta-se nesse caminho e tenta expor o caráter insidioso dessa ideologia, incluindo as maneiras em que a arte histórica foi cúmplice nessa propagação.

Ao mesmo tempo, revisitando os altares dos heróis, o pintor apresenta, à maneira de gesto terapêutico, um campo público para contestar a história alemã com seu trabalho Besetzungen. A análise realizada por Theodoro Adorno sobre a socialização autoritária no livro intitulado The Authoritarian Personality (1950) declara que os heróis e suas tendências destrutivas representam um subdesenvolvimento social:

[...] eles fracassaram completamente em desenvolver, de não terem sido moldados de jeito nenhum pela civilização. São sociopatas. A destruição aparece no primeiro plano de uma maneira declarada e não racionalizada. Força coporal e tenacidade também no sentido de ser capaz de pegar algo são decisivos". 203

As pesquisas de Adorno podem ser redimensionadas e radicalizadas enfatizando também o caráter masculino desta figura autoritária, subordinada a figuras de autoridade moral. Essa socialização masculina dos ideais heróicos fascistas encontraram sua

203 "[...] they have totally failed to 'develop', had not been molded at all by civilization. They are asocial. Destrutive urges come to the fore in an overt, non-rationalized way. Bodily strength and toughness - also in the sense of being able to 'take it' are decisive". Esta pesquisa estabelece a relação entre a construção da personalidade e sua suscetibilidade a práticas preconceituosas. Aqui a hipótese principal era: "relatar que as convicções políticas, econômicas e sociais de um indivíduo formam muitas vezes um modelo amplo e coerente, como se ligado por uma mentalidade ou espírito; e que neste modelo é uma expressão de tendências profundas na sua personalidade. O principal alvo era o indivíduo potencialmente fascista, aquele cuja estrutura é tal que o torna particularmente suscetível à propaganda antidemocrática." Cf. ADORNO, T. W. The authoritarian personality. New York: Harper \& Brothers, 1950, p. 125. 
expressão simbólica na própria figura do herói masculino e a longa história de sua representação estética. Kiefer se encontra, neste aspecto, na mesma constelação de outros artistas. Lembremos que o trabalho de Kiefer encarna a ereção narcisista do corpo coletivo nazista acompanhado de uma desintegração do corpo social, e seu esforço de empatia já dada em meio à separação do objeto da memória histórica. Este ato de identificação conceitual com a histeria nazista parece ter melhorado seu conhecimento da época, sem nada a elevar a seu doloroso sentimento de culpa. A terapia de choque de Kiefer concerne a sua própria geração. Pois o objeto de luto de Kiefer não se condensa na figura de Hitler, mas na própria cultura enquanto ela se constitui no material de sua identidade artística. Para Andrea Lauterwein, Kiefer, se colocando na pele de um nazista, também coloca sua própria corruptibilidade à prova. Como expressa o pintor: "Não me identifico nem com Nero nem com Hitler, mas, a fim de comprender sua loucura, eu devo, na verdade, voltar a tocar no que eles fizeram." 204

Por exemplo, em meados dos anos de 60, o pintor George Baselitz apresentou uma série intitulada Heróis/Novos Tipos, em que encorpados homens acumulam-se sobre paisagens de ruínas. Suas cabeças são desporporcionais com o tamanho de seus corpos, suas roupas todas rasgadas e sua genitália flácida exposta. Contornos escuros da pintura definem seus corpos massivos que aparecem de uma forma fragmentária e fraturada. Nessa mesma época (19631964), Eugen Shönebeck, pinta quatro crucifixações apresentando corpos mutilados e disformes. Na seção anterior, falávamos em Richter e seu panteão de figuras heróicas postadas no trabalho 48 Retratos. $^{205}$ Jörg Immendorf, por sua vez, na série Fragen eines

\footnotetext{
204 Cf. ROSENTHAL, Mark .op. cit., p. 187.

205 As imagens de Richter, previamente apresentadas aqui, não revelam a radicalidade temática abordada por Kiefer, porém reatualizam com subtileza - passado sem ter que recorrer a uma valorização moral nem a uma motivação política explícita. A razão da fatura dos ícones utilizados por
} 
lesenden Arbeiters (Perguntas para trabalhadores letrados) (1976), pergunta-se sobre as massas anônimas que conseguiram realizar os feitos dos homens grandiosos e a edificação de monumentos massivos. Markus Lüpertz, também nos anos 70, retoma da tradição heróica, numa série de Dithyrambs (fig. 34), imagens monumentais em que espadas, capacetes, artilharia, ou seja, parafernália militar, é espalhada por paisagens amarelas como antigos troféus, esses memoriais da vitória construídos fora dos campos de batalha.

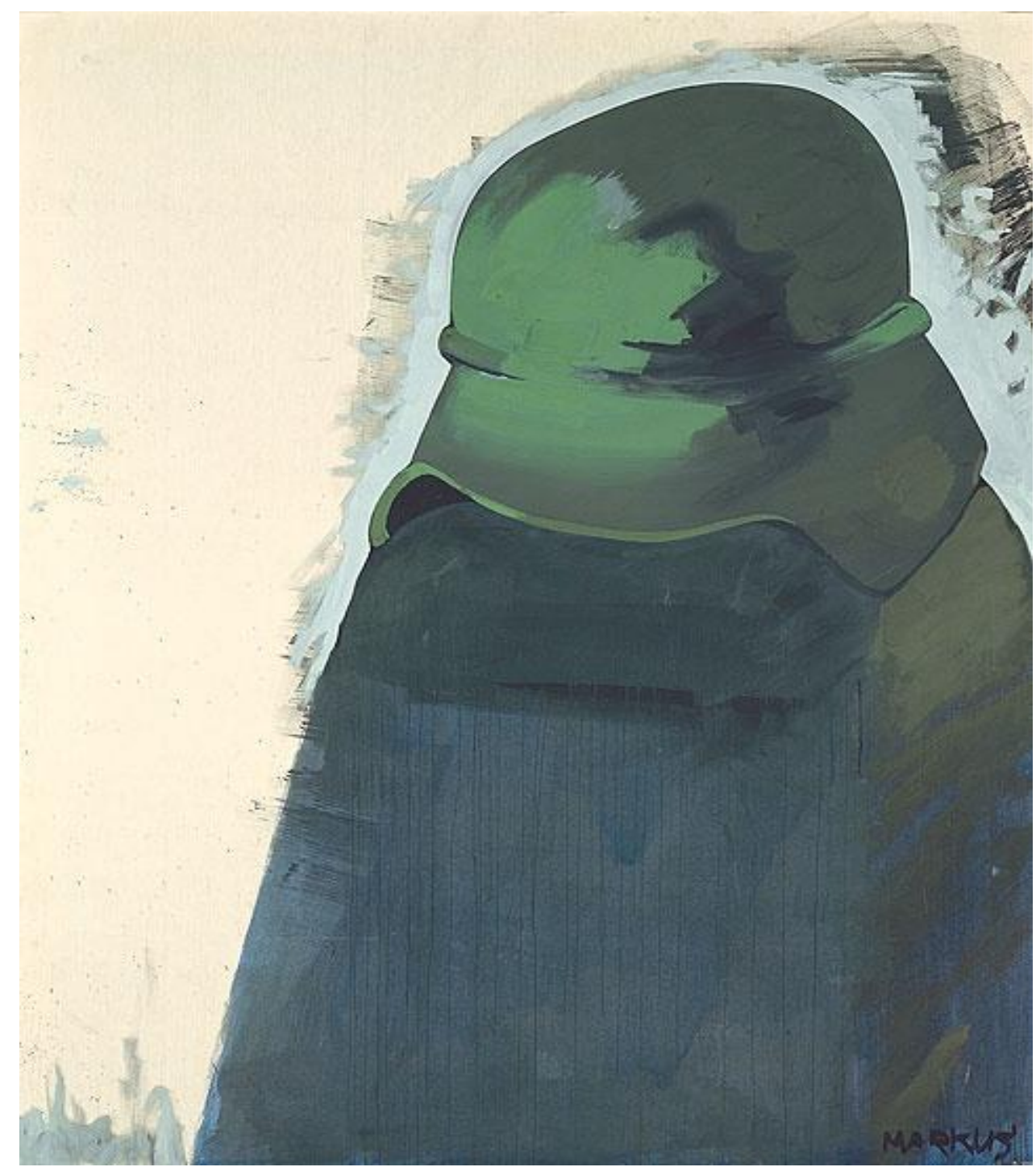

Figura 34. Ditirambos/Dithyrambs, 1970. Markus Lüpertz.

Richter é outra: sua superfície é fria e inexpressiva. O distanciamento do artista lembra-nos mais o trabalho de Warhol do que o ardor do trabalho de Kiefer. 
No livro do artista Für Genet (Para Genet) (fig. 35), percebe-se Kiefer vestido com uma indumentária militar, posando novamente com a saudação nazista, mas, dessa vez, numa banheira em seu estudo. 0 efeito miraculoso de caminhar sobre a água é alcançado por meio de um pedestal colocado na banheira que pode ser observado nas fotos. Como Kiefer colocou-se na frente de uma parede com janelas para tirar as fotos, seu corpo aparece, em várias das poses, sugerido numa silhueta. Ele está rodeado por uma luz intensa ao mesmo tempo em que seus traços faciais não se revelam.

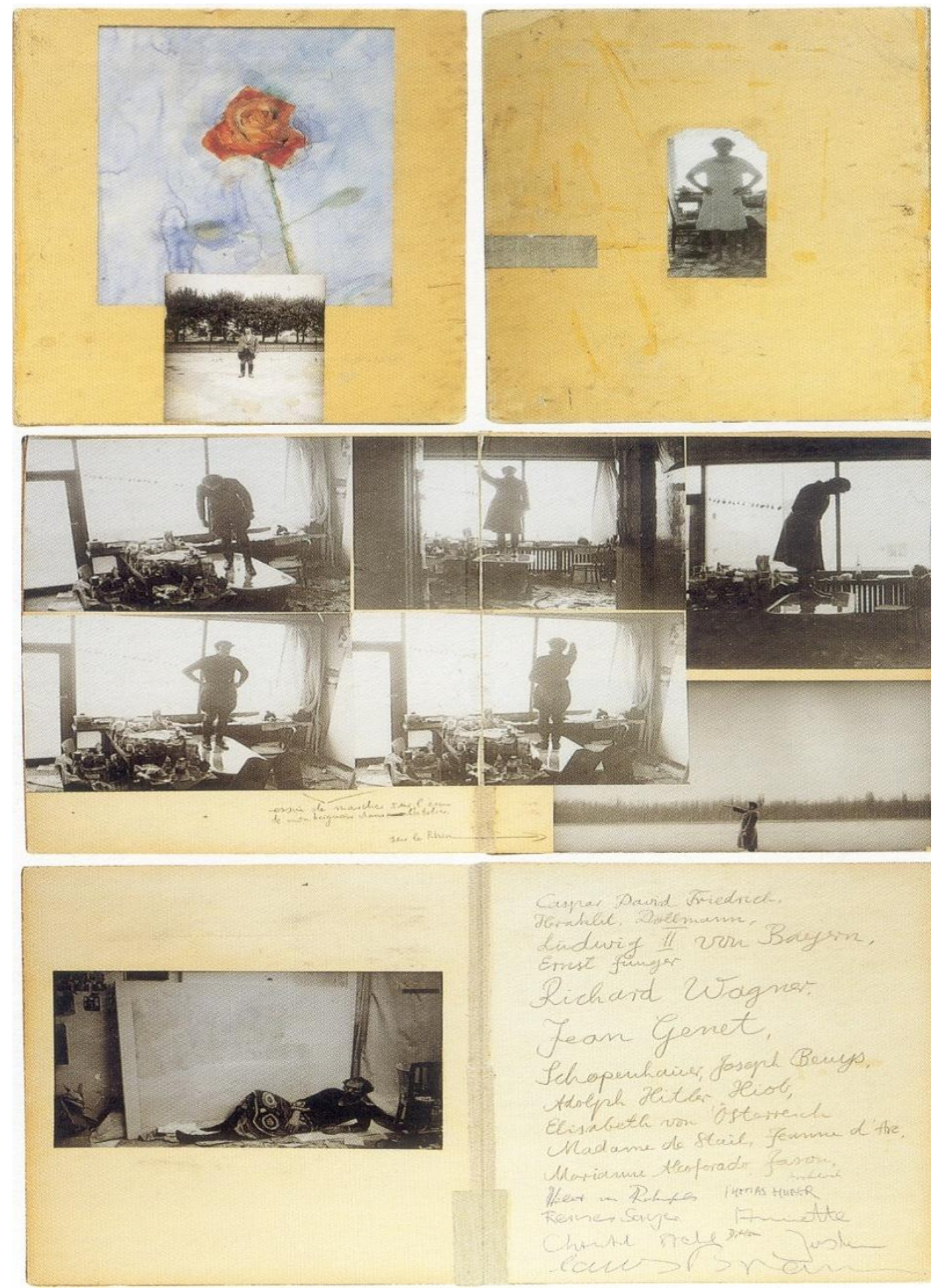

Figura 35. Para Genet/Für Genet, 1969. Livro de artista. Fotografias originais, cabelo de mulher e aquarela s/papel e cartolina, 11 páginas duplas mais capa. $70 \times 50 \times 8 \mathrm{~cm}$. 
Outra vez a figura acaba ocupando o centro da imagem, assimetricamente dividida. Como em uma cena de batalha, o ambiente do ateliê está carregado por uma desordem quase póscatástrofe. O cenário e o uso da luz alertam-nos sobre variadas questões sobre a tradição heróica que o pintor pretende minar. Com o título O Gehen auf Wasser (Caminhar sobre as águas) trata-se de estabelecer uma referência a Jesus como trabalhador e salvador, caminhando no mar de Genesarete, salvando seus discípulos de se afogarem no mar indômito. ${ }^{206} \mathrm{~A}$ luz ofuscante, o artista fantasiado com a farda militar, o gesto de saudação nazista, são elementos que permitem a perpetuação da tradição herói-salvador na qual líderes e artistas parecem estar dotados com poderes de salvação, cumprindo expectativas idealistas de mitigar o sofrimento existencial e semeando a esperança de uma melhoria espiritual e social. $\mathrm{Na}$ medida em que o artista está posando no seu ateliê, as fotos acabam se referindo ao estatuto da figura do herói na pintura histórica, assim como na tradição do retrato histórico. A cena do grande artista assumindo uma pose grandiosa num ateliê pequeno beira o absurdo quando reparamos do monumental caos de garrafas, papéis e latas jogadas espalhadas por todo o ambiente. Em todas essas imagens a figura do herói é rebaixada ao um homem ordinário e delirante. A esperança na salvação depositada na figura do artista é frustrada, e a tradição monumentalista e comemorativa da arte é revelada em sua pretensa aptidão e em sua bagatela efeitista.

As Ocupações de Kiefer fazem alusão à poluição nazista de uma iconografia nacional tradicional. Kiefer admite que todo símbolo recuperado pelos nazistas é inevitavelmente adulterado e que essa contaminação descama uma espécie de culpabilidade atmosférica que toca também, retroativamente, o contexto cultural que ela precede. Dessa maneira, como considera Andrea Lauterwein, Kiefer não

206 Cf. Mateus 14, 22-33. In: Bíblia de Jerusalém. São Paulo: Paulinas, 1985. 
vitimiza o artista, mas questiona sua postura ditatorial, seu poder demiúrgico e sua capacidade de criar ilusão. Em 1987, Kiefer explica suas Ocupações da seguinte maneira:

Eu queria colocar a pergunta a mim mesmo: sou eu um fascista? Isto é muito importante, a gente não pode responder rapidamente. A autoridade, o espírito de competição. O sentimento de superioridade [...] esses são aspectos tão meus quanto dos outros. Deve-se escolher $o$ bom caminho. Dizer que eu sou uma coisa ou a outra é muito simples. Eu quis pintar a experiência antes da resposta. ${ }^{207}$

Como nos fala Andrea Lauterwein, a verdadeira heresia das Ocupações consiste nesse momento identificatório que está na contracorrente da experiência de autovitimização contemporânea. Em 1990, perante a impossibilidade de prever sua própria resistência à corruptibilidade, Kiefer se considerará como um carrasco em teoria: "Eu faço parte dos carrascos, ao menos no plano teórico, porque eu não posso saber hoje que eu teria feito na época. O homem é capaz de tudo. Assim se explica minha aflição." ${ }^{208}$ Então, o caráter estratificado das Ocupações aciona maliciosamente a sucetibilidade do olhar de seus contemporâneos. A identificação conceitual de Kiefer não poderá ser reduzida a uma simples referência nazista. Sua travessia pelo tempo acorda elementos atribuidos ao nazismo, mas também, os artifícios dele aqui, na nossa atualidade artística, estética e existencial.

207 Cf. MADOFF, Steven. op. cit., p. 187.

${ }^{208}$ Idem, ibidem., p. 120. 


\section{C.BEUYS E A MITOLOGIA ALEMÃ DO ARTISTA REDENTOR}

Joseph Beuys concebe trabalhos alegóricos; de acordo com a sua intenção, são signos que

nos devem transmitir uma mensagem, mas atuam como símbolos.

Peter Bürger.

Parece-nos necessário mostrar como os assuntos elaborados por Kiefer podem ser mais bem compreendidos através da figura de Joseph Beuys. Joseph Beuys (1921-1986) nasceu em Krefeld, uma cidade ao norte de Düsseldorf, foi membro da geração da retomada, um fato que posiciona sua obra numa inescapável relação com o terror produzido pela experiência nacional-socialista. Uma atenciosa aproximação à sua obra orienta-nos sobre os laços estreitos que o pintor estabelece com o sublime e o trauma e a questão do Holocausto em geral. A vasta produção do artista abrange quase quatro décadas de criação ininterrupta. Podem ser reconhecidas pelo menos quatro categorias que comprendem sua produção: trabalhos em papel (desenhos, pinturas e collages), vestígios (restos manipulados de ações de arte e perfomances), múltiplas (objetos seriais e impressões), objetos esculturais e instalações de objetos em lugares específicos. Beuys acertou a coerência interna destas atividades por meio da elaboração de um discurso político-estético que parecia ser utópico, em caráter, e revolucionário, em aspiração. Rejeitando a oposição tradicional de arte/vida, Beuys reclamou para sua produção um conceito de arte expandido, na sua dimensão antropológica, em que a sociedade é contemplada como uma escultura formável e deformável, por meio da contribuição cooperativa de cada potêncial criativo individual. Ele, com efeito, disseminou seu discurso de uma maneira provocadoramente corriqueira: "Todo homem é um artista," "Nós somos a revolução," 
"Arte=Capital," entre outras. Todas estas provocações tornaram-se sérias elaborações conceituais por meio de uma profícua quantidade de entrevistas, palestras e aulas performáticas. Através de seus pronunciamentos e espectáculos orquestrados, Beuys consiguiu articular uma persona pública. Esta persona estética contribuiu para promover seu reconhecimento e inserção no mercado da arte e também outras instituções do mundo da arte. Rapidamente, o artista estava lidando com seu ascenso enquanto celebridade, uma figura que tinha tudo para dominar o mundo da arte da mesma forma que opera o sistema de estrelato da cultura de Hollywood. Este sucesso e, particularmente, sua aura estelar, complicaram a avaliação crítica da produção do artista. ${ }^{209}$

Lembremos que Beuys e Kiefer polarizaram tanto a recepção crítica americana quanto a alemã. Um dos grupos (acolhidos pelo jornal October, aliás, quase todos expuseram suas críticas neste jornal) denunciaram Beuys como um mercador de si próprio, repudiando seu discurso como um retrógrado e proto-fascista, ${ }^{210}$

\footnotetext{
209 Desde o começo até nossos dias, os críticos, geralmente deixaram de se interrogar pela coerência afirmada nas categorias - palavras, perfomances e produção material - do projeto artístico de Beuys. Gene Ray rasteja esta discussão crítica nos textos de Walter Robinson, que se pergunta que teria ficado de Beuys após seus pronunciamentos serem jogados numa trituradora, registrando, precocemente, que o trabalho de Beuys tinha de ser separado de seu discurso estético. Cf. "Beuys, art encagé," Art in America, November/December 1974, p.78. Colocando a persona de Beuys entre parêntese e tornando toda a atenção nos seus objetos, Kim Levin, descobriu inimagináveis posicionamentos em torno a Auschwitz que não tinham equivalentes explícitos no discurso de Beuys em "Joseph Beuys: the new order," Arts Magazine, April 1980, pp. 154-157. Finalmente, Thierry De Duve alfinetou precisamente nessa disjunção entre as obras de Beuys e suas palavras no seu excelente texto: "Le dernier des prolétaires," Artstudio 4, 1987. Foi reimprimido em inglês sob o título: "Joseph Beuys or The Last of the Proletarians," October 45, Summer 1988, pp. 58-59. Ver RAY, Gene. The use and abuse of the sublime: Joseph Beuys and art after Auschwitz. Tese de Doutorado apresentada ao Departamento de Filosofia da Universidade de Miami, Coral Gables, 1997.

210 O tom desta discussão foi estabelecido e moderado pela presença de Benjamin Buchloch, "Beuys: The twilight of the idol". op. cit., p. 97. Buchloch, conseqüentemente, organizou uma mesa com a participação de
} 
enquanto o outro grupo comemora a figura do artista como um modelo de ação e elogia seu discurso precisamente pelo idealismo que se pode desprender dele. ${ }^{211}$ Para a crítica, aqueles que denunciaram a Beuys nas páginas do jornal October não hesitaram em manter posições rígidas na controvérsia, o que mais tarde foi considerado como uma forte resistência às maneiras do artista apresentar sua relação com o sublime. Na parte dos defensores de Beuys, ter permitido se extraviar pela persona do artista mais do que pelos discursos parece ser uma estratégia para evitar um duro encontro com os objetos o que requereria uma imersão num complexo, contencioso e arriscado discurso. Por um lado, encontramo-nos com uma oposição do sublime sustentado por uma agenda programática atribuida ao jornal October e, por outro lado, uma resistência a uma maneira geral de lidar com a controvérsia desde um plano intelectual.

Voltando à produção de Beuys, pequena parte dos objetos e instalações são exemplos cruciais para a comprensão de Auschwitz. Evocando o holocausto pela via negativa, estes trabalhos declaram os crimes cometidos pelos nazistas e, como gestos de luto, funcionam no mundo da arte como reativadores do legado alemão de culpa no período do pós-guerra. O campo estabelecido por Beuys criou o caminho para que a próxima geração de artistas alemães confrontasse o ônus da sua própria história. Essa confrontação

Rosalind Krauss e Anette Michelson, "Joseph Beuys at the Guggenheim," October 12, Spring 1980, pp. 3-21, Buchloch arrastou Eric Michaud para a discussão com um artigo publicado na October traduzido por Rosalind Krauss, "The ends of art according to Joseph Beuys," October 45, Summer 1988, pp. 36-46 e de forma mais imprudente, Cf. Ottman, Klaus. "Heidegger, Beuys and the consequences". Flash Art, October 1990, pp. 123-124.

211 Este grupo rejeitou separar a persona da produção artística, encontramos COOKE, Lynne, "Berlin, Martin-Gropius-Bau, Joseph Beuys," The Brulington Magazine, July 1988, p. 557; Cf. KUSPIT, Donald, "Beuys: fat, felt and alchemy," Art in America, May 1980, pp. 79-89, texto do catálogo da exposição de Beuys no Guggenheim elaborado por Caroline Tisdall, 1979. 
resultou em uma ampla produção de trabalhos de outros artistas culminando, talvez, no mais poderoso exemplar da produção pósAuschwitz que jamais se apresentara, a primeira biblioteca de chumbo de Anselm Kiefer, Zweistromland (1985-89). Aqui a presença do chumbo torna-se para Kiefer uma figuração da naturalização da história de que fala Walter Benjamin no Drama Barroco Alemão, que à objetividade da natureza corresponde o essencialismo da História, contra o qual Kiefer se debate. É contra a história naturalizada do historiador historicista que Kiefer desenvolve seus trabalhos, suas narrativas plásticas e visuais.

Para o historiador historicista, a maneira mais simples de se esquecer do nacional-socialismo é caracterizando esses acontecimentos como uma aberração da história. Essa interpretação é adequada para o pensamento conservador, pois o terror que prevaleceu entre 1933-45 é totalmente explicável como uma conjunção muito particular de acontecimentos históricos que acabaram desarmando as democracias ocidentais. A Historikerstreit, ${ }^{212}$ ou a controvérsia histórica de 1986, pode ser lida como a primeira tentativa, na República Federal Alemã, de substituir essa interpretação normativa por uma postura inconfortável de perpétua lembrança amplamente advogada pelos intelectuais do pósguerra. Os intelectuais mais sofisticados despacham esse passado senhor como um cenário de reflexão intelectual fácil e ilusório. As

212 Para uma discussão sobre a Historikerstreit, consultar o artigo de HUYSSEN, Andreas, "After the wall: The failure of German intellectuals," New German Critique 52, Winter 1991, pp. 109-143. A controvérsia histórica eclodiu em junho de 1986. Incitada pela publicação do artigo de NOLTE, Ernst em Frankfurter Allgemeine Zeitung, a controvérsia começou oficialmente com um artigo de Jürgen Habermas publicado em Die Zeit em julho de 1986. Nele, Habermas atacou a apologia e às tendências relativizantes expressadas por Nolte em seu artigo que compara a solução final de Hitler com os crimes cometidos por Stalin. Para o tratamento desta controvérsia ver MAIER, Charles. The unmasterable past: history, holocaust, and German national identity. Cambridge \& London: Verso, 1988; Cf. EVANS, Richard. Hitler's shadow: West German historians and the attempt to escape from the Nazi past. London: Routledge, 1989. 
críticas ao fascismo e à ideologia, ao contrário, elaboradas pelos teóricos da Escola de Frankfurt que pesquisaram as causas e os mecanismos de terror e o genocídio, elaboraram-se mergulhando na formação econômica, discursiva e psicológica das sociedades contemporâneas. Por exemplo, Walter Benjamin e Adorno advertem, no fascismo, um deslocamento dos antagonismos de classe produzidos pelo capitalismo, deslocamento preenchido com uma mitologia incendiária que Benjamin prefere denominar, problematicamente, de estetização da política. Jean-François Lyotard, ${ }^{213}$ por exemplo, debruça sua pesquisa nos mecanismos fascistas constitutivos das formações discursivas do pensamento ocidental. Mapeando padrões repetitivos de violência discursiva, essas pesquisas ficham o impulso fascista nas operações ocidentais de busca da verdade, ou seja, na mais radical das formulações, o acontecimento de Auschwitz pode ser lido como a culminação lógica da metafísica ocidental. Uma lógica de exclusão, uma operação constitutiva da própria linguagem: a poderosa faculdade de nomear, preserva as coisas na sua essência mas aniquila-as em sua existência singular. Podemos reconhecer as aporias e a violência em nossa linguagem e na metafísica, mas ainda não temos maneiras de repudiar absolutamente a linguagem ou ir além da linguagem conceitual. A linguagem da metafísica é violenta para os frankfurtianos, porque fala em verdade eterna, passando por cima de sofrimento dos homens. Uma vez a relação entre violência discursiva e violência atual é admitida, torna-se possível, com efeito, ver nesta resposta uma ética pós-Auschwitz que transforma a leitura numa atividade memorial, uma espécie de permanente Trauerarbeit que mantém o olhar no passado refutando o fácil esquecimento da catástrofe.

213 Cf. LYOTARD, Jean-François. L'inhuman. Causseries sur le temps. Paris: Galilée, 1988. Versão para o inglês, The inhuman. reflections on time. Trad. Geoffrey Bennington e R. Bowlby, Stanford: Stanford University Press, 1991. 
Walter Benjamin, com seu método de pequena força messiânica, propôs, nos seus últimos escritos, uma maneira de impedir o poder implícito na tradição cultural. ${ }^{214}$ No caso de Kiefer, este método pode proceder por meio da elaboração de assuntos descuidados pela discussão sobre Auschwitz. Os objetos mais fortes da arte de Kiefer são justamente aqueles que dialogam com a catástrofe da época nazista: Besetzungen, Inneraum, Nero Malt, Nigredo. Do mesmo modo que Beuys, suas obras arrepiam com inscrições de feridas e de mutilação (pensemos nas decapitações de trabalho de Beuys Rei da Montanha, 1969, ou a devastação de uma comunidade no Final do Século $X X$, seus gestos sutis estão impavidamente afiliadas ao terror. Sua sublimidade não está reduzida a estes gestos, mas acaba por lhe outorgar sua profundeza e poder e, talvez, sua eficácia com os trabalhos de luto. Beuys fala incansavelmente sobre o futuro, mas estes objetos parecem olhar resoluvelmente para o passado. De acordo com o diagnóstico da Alemanha do pós-guerra, à geração da retomada apresentava-se uma resistência ao luto pelas vítimas dos crimes porque eles não puderam elaborar essa ferida narcísica deixada após o colapso nacional-socialismo. Para cumprir com os rituais do luto, tanto Beuys como Kiefer reconheceram,

214 Cf. BENJAMIN, Walter. "Teses sobre a filosofia da História," (1939) In: BENJAMIN, Walter. Obras Escolhidas. Vol. I. São Paulo: Brasiliense, 1987. Lemos pequena força messiânica como uma técnica para se reapropriar de nosso momento pós-revolucionário. Essa pequena força messiânica necessariamente retém laços com um projeto revolucionário. Essa "pequena força messiânica" consiste em não silenciar as vozes do passado e de identificá-las como vestígios, como pistas para este passado. Não se trata apenas de "redimir" as "gerações precedentes" do esquecimento, mas a "redenção" também diz respeito à geração presente, que não escapará "impunemente" à obstrução do acesso ao próprio passado. A redenção, portanto, não se limita a um resgate do passado, mas se refere também à disposição do presente de receber os sinais do passado, como se passado e presente fossem fragmentos de um todo anteriormente inteiro. Daí tanto a "espera" do passado por um presente que revele suas "correspondências" com ele, para usar o termo caro a Baudelaire que se tornou importante para Benjamin, quanto a necessidade de uma "humanidade redimida" no presente, para esta "apropriar-se totalmente do seu passado". 
primeiramente, à perda dolorosa do ideal fantástico - do Führer ao Volk - em que suas identidades coletivas e pessoais estiveram profundamente embaralhadas. O reconhecimento real dessa perda, da falsa pureza que subjaz em suas identificações narcisistas, teria sido devastador. Antes de eles serem capazes de guardar luto pelas vítimas, a geração da retomada teve que emergir de um prévio colapso para a melancolia. Mas a melancolia manifestava-se precariamente no país que se encontrava no paroxismo, num estado de absoluta euforia suscitada pelo milagre económico. A recusa de se debruçar sobre o passado traslada o peso da história nas segundas e terceiras gerações - aquelas de Kiefer, Werner Herzog, Hans-Jürgen Syberberg - que foram tomados na dupla obrigação na medida em que eles tentaram trabalhar sua inconfortável relação com o passado alemão e, ao mesmo tempo, negociar as formas de entrar numa nova ordem subjetiva.

Enquanto os trabalhos de Beuys ${ }^{215}$ memorializam as vítimas da Shoah, também manifestam a devastação narcisista deixada pelo terceiro Reich. Kiefer também possui efetivamente uma visão muito alemã da Shoah. Para ele, é um peso, uma carga, uma responsabilidade, e, no fundo, isso se torna uma ferramenta da criação que permite ultrapassar essa Shoah. Há diferentes fases em sua obra. Efetivamente, quando começa assiste a presença de Beuys, que embora rejeite neste momento, dizendo não ter nada a ver com Beuys; a figura de Beuys dominava e fazia parte de seu panteão de grandes mestres. A reflexão de Beuys alcança seu melhor gesto

215 Seria importante destacar que no ano 1995 a New School for Social Research em Nova Iorque dedicou uma semana de simpósio à figura de Joseph Beuys que convocou um grande número de estudiosos, curadores, artistas e historiadores da arte. Os temas tratados nas mesas de discussão percorriam: "Escultura Social," "Fluxus," "Impacto Internacional," "Beuys, Warhol e Duchamp," "Feminismo," "Raízes Intelectuais," "Beuys e a espiritualidade." Curiosamente, o assunto do Holocausto como assunto supremo na obra de Beuys foi omitido do simpósio. Além do mais, os participantes do debate orquestrado pelo jornal October (Benjamin Buchloch e Rosalind Krauss) também não foram convidados aos debates. 
confrontacional na figura de Anselm Kiefer, na suas Besetzungen

(1969). A posição de Beuys, na história da arte, reposa no modo de evocar a história escultoricamente. Beuys sulcou o caminho para os artistas que praticaram um sublime do pós-guerra ${ }^{216}$ - Anselm Kiefer, Janice Kounellis, Christian Boltanski, Rainer Werner Fassbinder, Rebecca Horn, Dieter Appelt e Rachel Whiteread, para nomear os mais importantes - e devemos contextualizá-los na história Vergangenheitsbewältigung (ajuste de contas com 0 passado), na República Federal Alemã.

216 "O sublime está de moda", é o intróito de um ensaio de Jean-Luc Nancy, "L'offrande sublime" dedicado a discutir sobre a categoria do sublime. Com esta sentência encontramos uma afirmação clandestina, pois o filósofo se refere ao fato de que a categoria do sublime tem se tornado um objeto de pesquisa recorrente tanto no discurso da crítica e da estética, como entre os próprios artistas. Nancy está interessado em destacar que não existe pensamento contemporâneo da arte e do seu fim que não seja tributário do pensamento do sublime, quer se refira expressamente ou não. Este transitar discursivo da arte se trata de uma forma de reintroduzir o sentido do prazer estético, já que todo os discurso sobre a beleza foi banido do juízo estético e não tem lugar senão no discurso corriqueiro. A categoria estética do sublime, do modo que é elaborada depois de Longino, e finalmente na articulação dos séculos XVII e XVIII, inicialmente, faz parte de um problema de justeza, porque de fato o sublime é uma categoria moral bem antes de ser artística e estética. É verdadeiramente em relação ao belo que temos um problema de justeza, pois o belo poderia escapar à moral, mas o sublime não. Em todas as definições do sublime em primeiro lugar somos postos em questão em nossa relação com esse sublime, e temos de lidar com isso. Assim, a rugosidade é algo que não é absolutamente antagônico com a instauração de uma justeza e de uma sublimidade, ao contrário. O choque, o vão, o abismo, todas essas instâncias que nos põem em tensão própria do sublime nos demonstram que estamos vivos, porque a experiência vivida do sublime nos situa além de nós mesmos, acompanhando-nos assim à esfera de uma justeza. Isso é coerente e algo com que a arte moderna e a contemporânea souberam lidar muito bem: se por um lado o belo caiu na lata de lixo da história, por outro lado, a categoria do sublime poderia ser rubrica em que se faz entrar um enorme número de artistas. Os artistas modernos não param de jogar com o sublime, e no momento em que fazem uma espécie de contestação da relação entre arte e moral estão ainda no sublime, o que vale dizer que finalmente deve-se ultrapassar a moral, e isso é uma posição sublime. 0 único perigo poderia ser uma espécie de esterilização desse sublime, de não sabermos mais do que se trata como fala Thierry de Duve. Cf. Danièle Cohn. op. cit., p. 139; Cf. "Sintoma e intuição." Entrevista com Thierry de Duve. Novos Estudos, novembro 2007, p. 211; Cf. NANCY, Jean-Luc. "L'offrande sublime." In: Du Sublime. Paris: Berlin, 1988. 
Na pintura de Anselm Kiefer Deutschlands Geisteshelden (Os heróis espirituais de Alemanha), é exemplar o tratatamento da Alemanha, de suas lendas, mitos e heróis, cujo fundo atemporal prenuncia o pior. O mito no lugar da história é, como mostra Walter Benjamin, violência e terror. Kiefer respondeu bem a esta premissa benjaminiana, articulando um projeto pictórico inteiramente voltado para a herança germânica, a pesquisa de objetos transicionais fixouse nos elementos iconográficos e mitológicos que adensaram a identidade nacional germânica, participando, no entanto, da elaboração do mito nazista. Os temas evoluíram na mesma proporção em que um conjunto de obras começa a figurar em meio a um itinerário pictórico cujas alegorias e desrealizações históricas condensam-se em três espaços mitológicos sobredeterminados: a floresta (mito), o templo/ateliê (civilização) e a terra devastada ou queimada (a destruição e renovação). O espaço do mito acolhe uma série de áticos que reproduzem 0 ateliê do pintor. A pintura Resurrexit (fig.36) marca essa transição do mito à civilização: um caminho na floresta sobre o qual ondula sinuosamente uma serpente conduz diretamente a uma fileira de árvores que bordejam o ateliê do artista. Esta transição é progressiva, porque a carpintaria aparente do ático lembra as origens: o ateliê do pintor alemão não é mais do que uma versão civilizada da floresta, povoada de ressonâncias escuras da mitologia germânica. Daniel Arasse ${ }^{217}$ observa que os espaços de Kiefer, os áticos ou as paisagens, seguem uma lógica mnemônica impregnada de imagens inabituais, surpreendentes e extravagantes. Essas imagens de Kiefer podem suscitar um efeito poderoso de horror. Arasse conclui que a obra de Kiefer apresenta-se como um teatro da memória que serve para interiorizar e estruturar os documentos de um passado alemão que ele apenas conheceu indiretamente. As ressonâncias afetivas e simbólicas provocadas pelo

${ }^{217}$ Cf. ARASSE, Daniel. op.cit. p. 178. 
ático nos apresentam outra interpretação de seu uso como espaço de criação ou de memória.

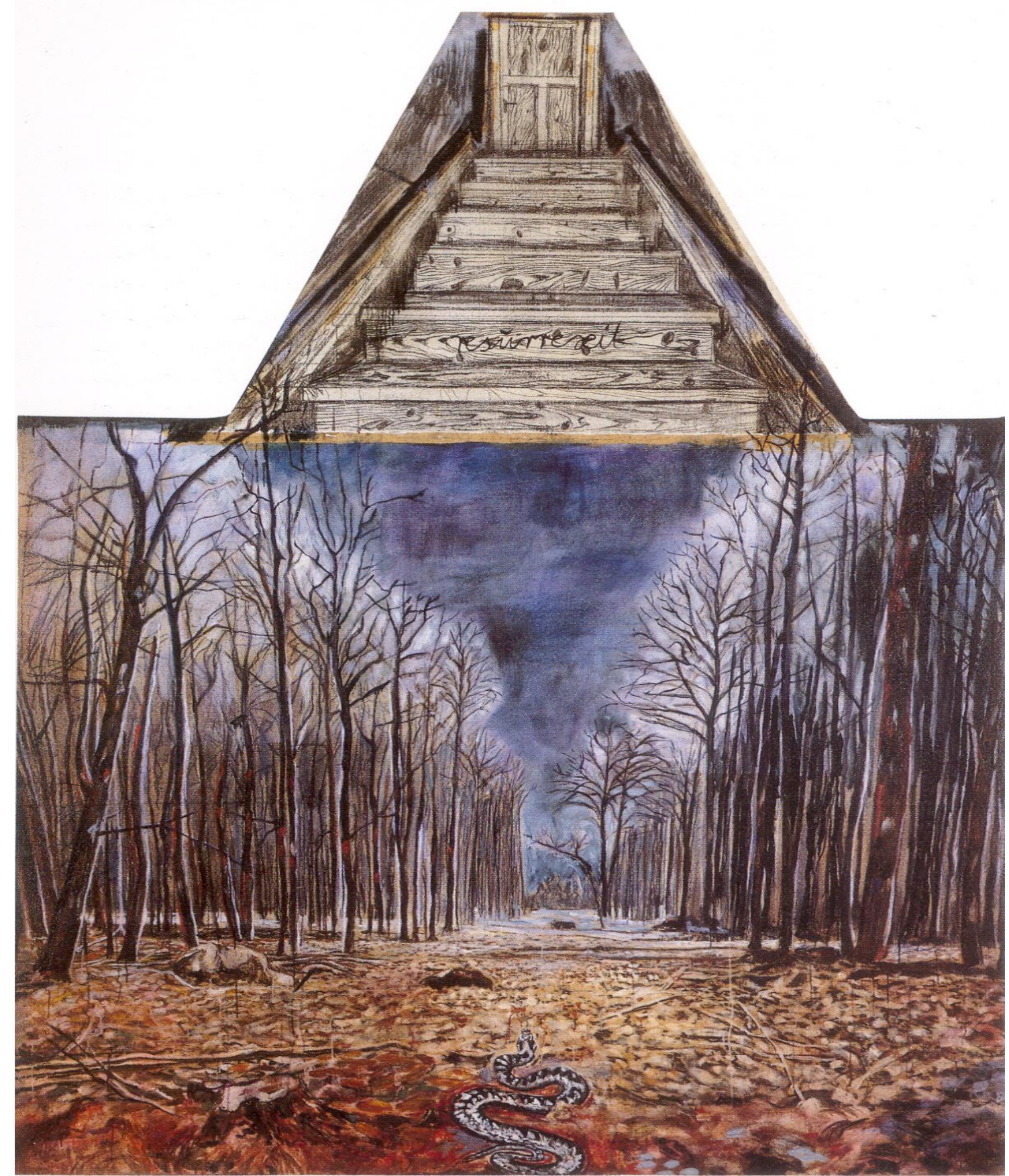

Figura 36. Resurrexit, 1973, Óleo, acrílico e carvão s/tela de fibra. 290 $\mathrm{x} 180 \mathrm{~cm}$.

Com o convite a Beuys no círculo dos heróis espirituais, Kiefer testa a própria noção de herói espiritual que geralmente responde a 
figuras mortas e, de certa maneira, instrumentalizáveis. Trata-se de uma homenagem ou de uma crítica? Kiefer acompanhou os cursos de Beuys em Düsseldorf em 1970. Após sua mudança a Hornbach em 1971, Kiefer manteve sua relação com Beuys até 1972. Podemos encontrar traços do ensino conceitual de Beuys nos trabalhos fotográficos e na simbólica do material empregada por Kiefer. O jovem pintor conserva de seu mestre espiritual a idéia do artista como testemunha e ator da história, mas essa idéia não tem outra vocação didática fora dos limites da arte. ${ }^{218}$ Beuys incita seus contemporâneos a refletir e a agir, a se tornarem artistas eles próprios, enquanto Kiefer rejeita esse idealismo, esse messianismo e proselitismo de seu mestre. Consciente das potencialidades de uma concepção heróica da arte, Kiefer tem a firme convição que a arte deve tomar suas responsabilidades, mas que não deve cessar jamais de ser arte. O que importa para Kiefer é: "despertar a memória, não para mudar a política, mas para eu também mudar." ${ }^{219}$ Este leve antagonismo entre os dois artistas merece uma leitura mais acurada, porque a presença de Beuys no panteão dos Heróis Espirituais não deve ser lida estritamente como um desprezo da figura de Beuys, mas também não se trata de uma fervorosa homenagem. Porque Kiefer reconhece que em Beuys já existe o pinhão da mitologia do artista alemão. De fato, para o historiador de arte Hans Belting, a visão do mundo de Beuys insere-se nessa genealogia heróica fundada por Dürer e, precisamente, por Nietszche que são os dois representantes do que se poderia considerar o crucificado e o santo.

\footnotetext{
${ }^{218}$ Kiefer não acreditava na solução estético-populista de Beuys de que todo homem era artista. O jovem pintor pensava que os artistas se distinguiam dos não-artistas pela sua capacidade de pressentir uma potência e, sua representação estética, não é passível de ser lograda por todos os homens. Ver ARASSE, Daniel. op. cit., p. 289.

${ }^{219}$ Entrevista com Bernard Comment. "Anselm Kiefer. Cette obscure clarté qui tombe des étoiles". op. cit., pp. 22-23.
} 
220 Trata-se dos mesmos paradigmas heróicos que percorrem a arte alemã que Thomas Mann no seu romance Doutor Fausto (1947) e na novelleta "Morte em Veneza" (1963), pretendem fazer naufragar. O embaralhamento das biografias de Dürer e de Nietzsche, de Dionísio e o crucificado, em uma confusão trágica da filiação germânica, imita o caminho de Jesus Cristo à cruz. Para Kiefer, Beuys identifica-se plenamente com esta metáfora teológica do artista redentor. A geração de Kiefer destacará a presença hipertrofiada do artista, fragmentando sua representação no decorrer da história. Beuys inscreve-se numa linhagem heróica em que a arte santifica e condena simultaneamente ao artista.

Kiefer apropria-se de diferentes objetos fetiches da linguagem metafórica de Beuys para lhe dar um sentido novo, uma vez reingressados na sua poética. A banheira da série das Ocupações é um desses elementos. Com ela, Beuys fez uma alegoria heróica do nascimento, do batizado e do renascimento enquanto para Kiefer, a banheira, que ele glosa no livro Für Genet, é simplesmente um objeto que ele encontrou no ático da avó. A alusão mais freqüente de Kiefer ao imaginário estético de Beuys é o avião, com a qual o pintor faz referência ao mito das origens, o relato de sua salvação em 1944 por nômades tártaros em Criméia. Após 1945, Beuys limitará seu relato dos anos dedicados ao regime nazista à simples história de sua queda em avião e de seu salvamento. Este relato redentor representava um puro embuste, porque Stalin tinha expulsado os tártaros da região no momento que o avião de caça em que viajava Beuys se acidentou.

A contradição mais forte que Kiefer tem oposto à mitologia beuysiana é justamente a instalação $O$ Anjo da história. No título, com empréstimo de Walter Benjamin e Paul Celan, Kiefer inscreve a

${ }^{220}$ Cf. BELTING, Hans. Identität im Zweifel. Ansichten der deutschen Kunst. De umont: Cologne, 1999. Versão para o inglês, The Germans and their art. A troublesome relationship. Trad. Scott Kleager New Haven: Yale University Press, 1998. 
simultaneidade histórica da Shoah no coração do mito beuysiano. Por um lado, o avião de Beuys torna-se alegoria do Angelus Novus de Benjamin, o Anjo da história, a testemunha estupefata e impotente para conter a funesta marcha da humanidade em direção à catástrofe. De otra parte, este avião de chumbo carrega sobre suas duas asas livros cheios de flores secas que evocam as duas faces complementares da seleção da poesia de Paul Celan: o torpor pela embriaguez, a alucinação e o sono, ou seja, o vôo da poesia e da arte, e os livros de chumbo para o arquivo do saber e da memória. O que provoca o vôo da arte tem-se tornado uma espécie de arquivo: a ação da espiga, prisioneira das páginas de chumbo do livro que quebra literalmente as asas do avião, está impossibilitada. Kiefer parece desafiar a aviação que permite manter a idéia de um combate heróico. O mito da queda heróica de Beuys é confrontado por outra verticalidade, a de sua redenção de que nos fala Walter Benjamin:

Se uma seta indica a meta em cuja direção age a dynamis do profano e uma outra a direção da intensidade messiânica, então certamente que a procura da felicidade da humanidade livre diverge da direção messiânica, mas tal como uma força ao longo do seu percurso pode promover uma outra que se dirige em sentido oposto, também a ordem profana do profano pode promover a vinda do reino messiânico. ${ }^{221}$

${ }^{221}$ BENJAMIN, Walter. "Sobre o conceito de História." op. cit., p. 203. 


\section{CATÁSTROFE E ANIQUILAÇÃo}

\section{A.O MONUMENTAL: O MITO DO ESPÍRITO ALEMÃO}

Esquecemos há muito tempo o ritual sob o qual foi edificada a casa de nossa vida. Quando, porém, ela está para ser assaltada e as bombas inimigas já a atingem, que extenuadas, extravagantes antigüidades elas não põem a nu ali nos fundamentos! Quanta coisa não foi enterrada e sacrificada sob fórmulas mágicas, que apavorante gabinete de raridades lá embaixo, onde, para o mais cotidiano, estão reservadas as valas mais profundas.

Walter Benjamin

Em 1976, Anselm Kiefer completou uma pintura que intitulou Varus (fig.37) e, no mesmo ano, um trabalho já aqui mencionado, Piet Mondrian-Hermannschlacht, com a palavra schlacht inscrita que em alemão significa batalha e Hermann que responde à forma alemã do nome latino Armenius. Ambas as pinturas representam uma floresta espessa e ameaçadora. ${ }^{222} \mathrm{Na}$ mitologia alemã, Armenius representava a figura de um líder tribal e Varus respondia ao nome de Publius Quintilius Varus, um general da armada de Augusto César. Varus foi o líder da campanha militarista que se enfrentou com Armenius e suas brutais forças na floresta de Teutoburgo, a grande floresta que se localiza entre o rio Reno e o Elba. Os romanos foram exterminados e dizimados quase por um só homem. Varus e seus oficiais cometeram suicídio antes de ser capturados. Prisioneiros foram enterrados vivos, crucificados e oferecidos em sacrifício aos

222 Francis Bacon, contemporâneo de Kiefer, discorda do brutalismo programático (willed brutalism) de Kiefer. Bacon prefere expressar brutalismo sem que apareça como uma pulsão latejante. Ver PLANTE, David. "The art world: Bacon's instinct," New Yorker 69, n. 6, Nov. 1, 1993, p. 96. Essas duas pinturas salpicadas em sangue são, talvez, exemplos desse brutalismo programático. 
deuses. ${ }^{223}$ Os desastres da batalha foram descritos com muita gravidade nos anais de Tácito. ${ }^{224}$ As conseqüências dessa batalha foram imensas no que diz respeito à história européia, à arte e à literatura alemãs. As fronteiras do Império Romano foram estabelecidas no rio Reno, em vez do Elba e Roma tornou- se, nas palavras do estudioso das batalhas de Ocidente, John Fuller, "de Império em empresa de responsabilidade limitada. ${ }^{\prime 225}$

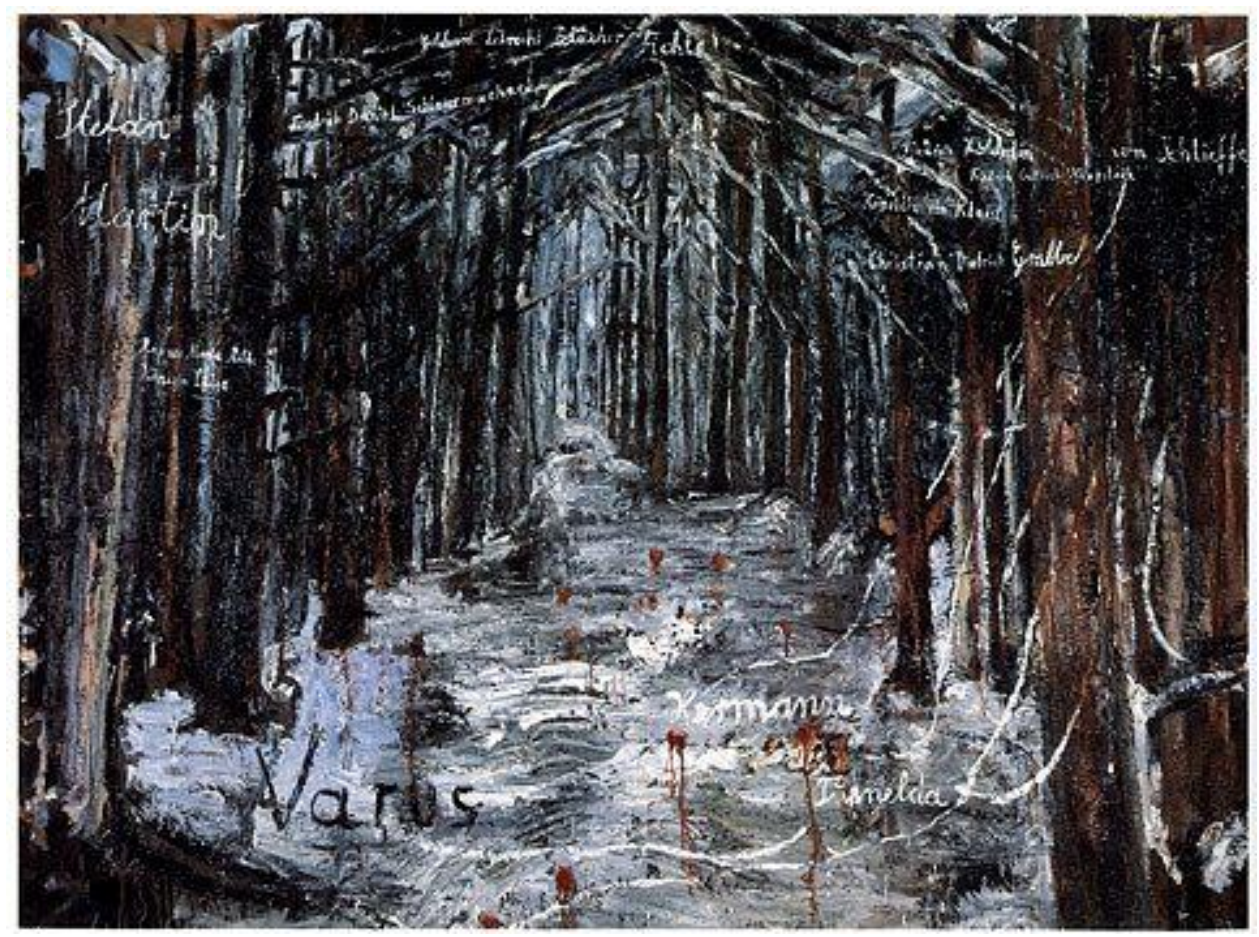

Figura 37. Varus, 1976. Óleo e acrílico sobre tela. $200 \times 270 \mathrm{~cm}$. Stedelijk Van Abbemuseum, Eindhoven.

Existem referências diretas e oblíquas a Hermann na pintura alemã como em certos poemas do romantismo alemão. O revolucionário poeta romântico Georg Herwegh invoca "Hermann, pai da raça," no seu poema de 1841, A frota alemã, assim como Ernst Morris Arndt em Sobre os alemães. Em ambos os poemas, o espírito

${ }^{223}$ Cf. FULLER, John. Decisive battles of the Western World, vol.1. London: Eyre \& Spotswood, 1954, pp. 248-251.

${ }^{224}$ Cf. TACITUS, Cornelius P. "Annals," 61, vol. 15. Cf. HUTCHINS, R.M. Tacitus, on great books of the Western World. Chicago: Encyclopedia Britannica, 1952, pp. 1-184.

225 "from an Empire to a limited liability company". Cf. FULLER, John. op. cit., p. 250. 
guerreiro de Armênio é invocado para suscitar forças nos alemães em tempos de tribulação. No seu comentário sobre a Batalha de Armênio, Alberto Tassinari afirma:

A floresta de Teutoburgo - local onde Arminius [sic] derrotou as legiões de Varus em 9d. C. E com isto afastou para sempre, muito antes da queda do Império Romano, o domínio de Roma a leste do Reno - é a referência básica para as primeiras pinturas. Já os personagens das xilogravuras, entre eles Arminius, incluem de tudo. Num caso como no outro, o tema das pinturas é muito mais propício a um nacionalismo acadêmico do século XIX do que à arte contemporânea. O tratamento nada acadêmico do tema carrega assim uma ironia. Uma ironia, porém, que nada tem de alegre, mas que é sombria e de certo modo enlutada. ${ }^{226}$

Os caminhos de Roma interligavam-se nas províncias que logo se tornaram Estados propriamente, como Itália, Espanha e França. Na ausência desses caminhos e, pela onipresença das imensas florestas, a Alemanha representava menos uma nação, em termos geológicos e geográficos, que outros países já constituídos como Estados. A Alemanha demorou em se unificar e se transformar em nação. No ano de 1789, havia exatamente 1789 unidades políticas na Alemanha, oscilando entre reinos tão poderosos como a Prússia, a Bavária e os Saxões, até pequenas cidades e povos. Cada reino tinha suas próprias regras, moeda e costumes, mas, curiosamente, todos eles compartilhavam uma mesma língua, sangue e mitologia em comum. A floresta tornou-se ícone protetor do país como foi o mar para os britânicos; a floresta, as árvores e a madeira apareceram enfaticamente no folclore alemão e, por extensão, na arte, iconografia e iconologia alemãs. Por oposição à visão do mar benévolo da Inglaterra, a floresta alemã apresentava-se em sua dupla condição de força ameaçadora e, ao mesmo tempo, força protetora do povo germânico.

226 Cf. TASSINARI, Alberto. "O Rumor do tempo," In: Anselm Kiefer. Catálogo do Museu de Arte Moderna de São Paulo, 1998, p. 15. 
Anselm Kiefer tem sido descrito como um pintor "profundamente impregnado pelo esplendor da Floresta Negra e da Floresta de Odim." ${ }^{227}$ Aliás, Kiefer fixou sua residência em Odim (a floresta de Wotan). A fonte histórica é, sem sobra de dúvidas, um dos tributos do romantismo alemão, um movimento que se desenvolve, em parte, como reação ao "empobrecimento espiritual" e seu extremo racionalismo desencantado que se manifestou no final do século XVIII. ${ }^{228}$ Outras fontes nas quais a história se debruçou correspondem ao mito, ao folclore, aos contos de fada e a uma espécie de apoteose dada pela saturação da natureza teutônica.

$\mathrm{Na}$ mitologia nórdica, que a Alemanha divide com a Escandinávia, a Islândia e as terras celtas, a fonte da origem do mundo é conhecida como Yggdrasil, ou a árvore das cinzas. Kiefer tem um profundo conhecimento tanto da mística da madeira, na sua cultuação teutônica, quanto da mitologia de Yggdrasil. Na sua discussão da pintura Árvore com Paleta (fig.38), o crítico Mark Rosenthal escreve:

A paleta, como objeto, tem vida, ao aderir a um tronco de árvore onipresente e ao despencar dele. O tronco da árvore se prolonga na madeira das pinturas dos áticos, e o ambiente geral da floresta que tem impregnado o trabalho de Kiefer [...] Kiefer produziu uma série de trabalhos com vários aspectos da árvore mítica Yggdrasil, que é a fonte imediata da Árvore com paleta. ${ }^{229}$

227 Cf. ROSENTHAL, Mark. op. cit., p. 12.

228 Cf. SELIGMANN-SILVA, M. Ler o livro do mundo. Walter Benjamin: romantismo e crítica poética. São Paulo: Iluminuras-FAPESP, 1999.

229 "The palette has an animate presence as an object, both to cling to and hang from an omnipresent tree trunk. The tree trunk joins the all-pervasive wood of the attic paintings and the general ambiance of the forest that have filled Kiefer's work [...] Kiefer produced a series of works on the various aspects of the mythical Yggdrasil tree, which is the immediate source of the Tree with Palette [...]". Ygg drasil ou Cavalo Ygg. Ygg corresponde ao nome primitivo de Odim. O que representavam as cinzas para os nórdicos era o equivalente ao carvalho para a cultura pré-celta dos druídas, ambos simbolizavam a divindade e o princípio masculino; para os romanos o carvalho representava a figura de Júpiter. A figueiro é o símbolo budista 


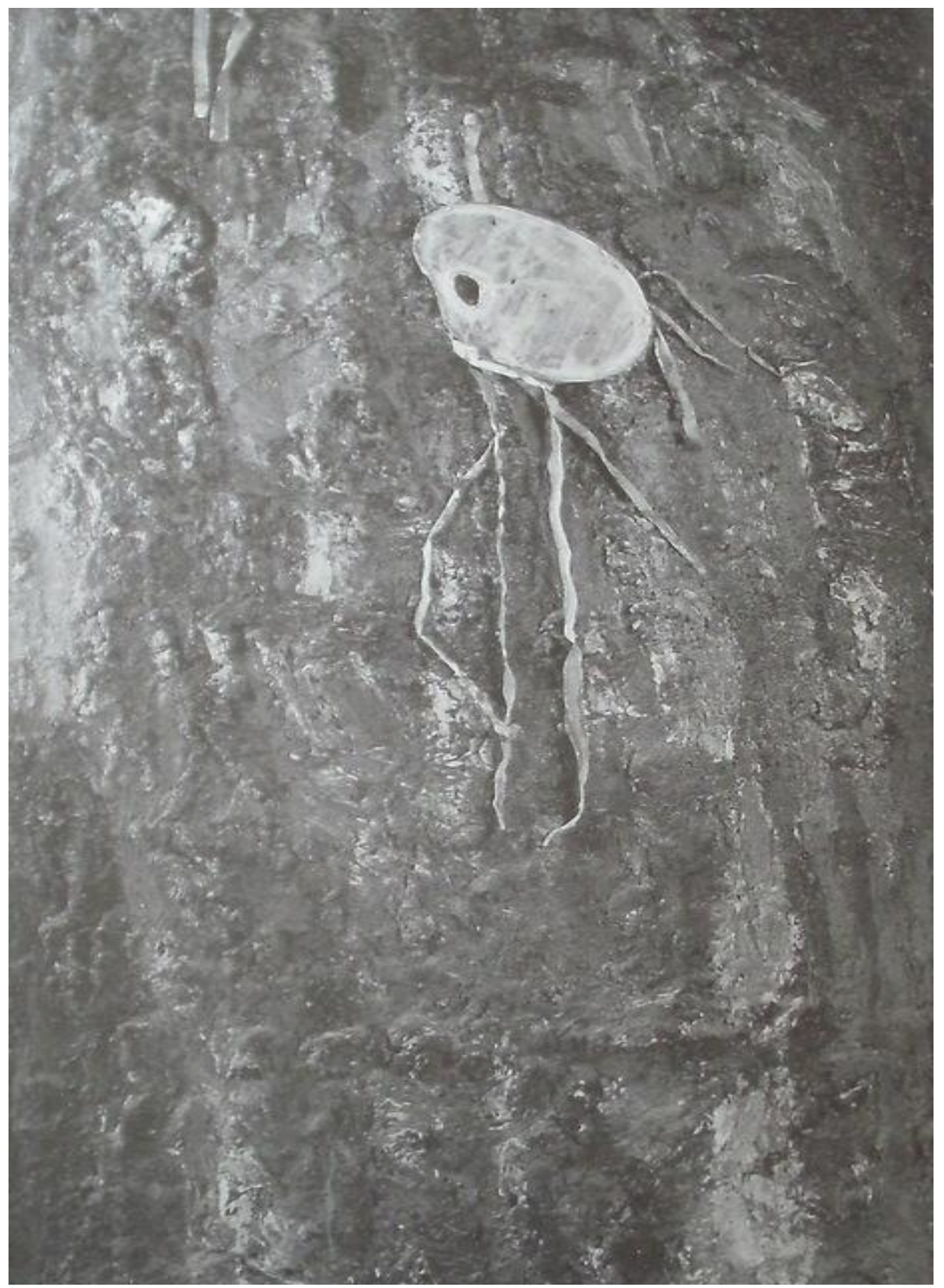

Figura 38. Árvore com a Paleta/Baum mit Palette, 1978. Óleo s/tela com chumbo. Coleção Privada.

Ao pé da árvore das cinzas do mundo flui a fonte da sabedoria. Odim (Wotan) pagou o preço de um olho ao gigante Mimir para beber da para o esclarecimento e o pessegueiro, entre os taoístas, sugere imortalidade. 
fonte, ganhando mais sabedoria interior pelo preço de menos percepção exterior. Odim, assim, ferido, após permanecer nove dias e nove noites em convalescença e suspenso na árvore das cinzas do mundo, foi capaz de obter o conhecimento que se depreende da leitura das runas. ${ }^{230}$ Ele extraiu um galho da Yggdrasil para fazer uma bengala, e a ferida que produziu na árvore, inchou-se, acabando por atrofiá-la, simbolicamente suscitando passagem de uma ordem antiga a uma nova civilização. Quando a bengala de Odim foi cortada ao meio, com a espada de um mortal - o jovem Siegfried - (isto é, a madeira é vencida pelo ferro) - o poder dos deuses tornou-se limitado. ${ }^{231}$ A espada, Nothung (fig.39), que vemos nos trabalhos de Kiefer, foi arrancada da árvore das cinzas por Siegmund, pai de Siegfried e filho de Odim. ${ }^{232}$ A primavera da sabedoria secou e os Nornos (espíritos femininos), que têm girado a corda do destino ao redor da Yggdrasil, torcem a corda até finalmente rompê-la. Eles regressaram à terra na forma da deusa Erda, por quem eles desabrocharam um dia. Estas estórias são recontadas nas sagas antigas, como em Eddas e em Nibelungenlied. Sigfried, o herói, enfrenta-se com um dragão na floresta da Saxônia, dando-Ihe a morte; ele banhou-se no sangue derramado do dragão e, a partir daí, tornou-se invencível, salvo por uma pequena pinta no seu ombro esquerdo onde uma folha de lima alojou-se durante seu banho. A árvore de lima é a preferida dos alemães, onde é conhecida como Linden. Podemos observar que a limeira é amplamente usada pelos talhadores do norte na alta Renascença. Siegfried pode ter sido

${ }^{230}$ A árvore cósmica remete-nos à "Árvore da vida" do paraíso. Na lenda de Tristão e Isolda, os amantes uniram-se após a morte, quando duas árvores cresceram nos seus túmulos, tornando-se, assim, inextricavelmente enlaçados. Cf. FONTANA, David. Secret language of symbols. San Francisco: Chronicle, 1994, pp. 101-103.

231 Siegfried é guiado até a bela adormecida Brunhilde por um pássaro encantado; esta é a versão nórdica da estória aludida na escultura de Brancusi, intitulada Maistra.

${ }^{232}$ O tema da espada é um topos recorrente na literatura. Lembremos Stephen Dedalus no Ulisses de Joyce, que amassa um candelabro num bordel de Dublim com uma planta de fresno, gritando, "Nothung!" 
atacado e assassinado com um arpão que entrou justamente pelo seu lado vulnerável enquanto caçava na floresta de Odenwald. Os deuses da floresta do panteão nórdico têm uma base moral dura e, do ponto de vista do poeta romântico, Heinrich Heine, estão associados à noção de alma da raça alemã. Essas forças apenas foram contidas pelo cristianismo.

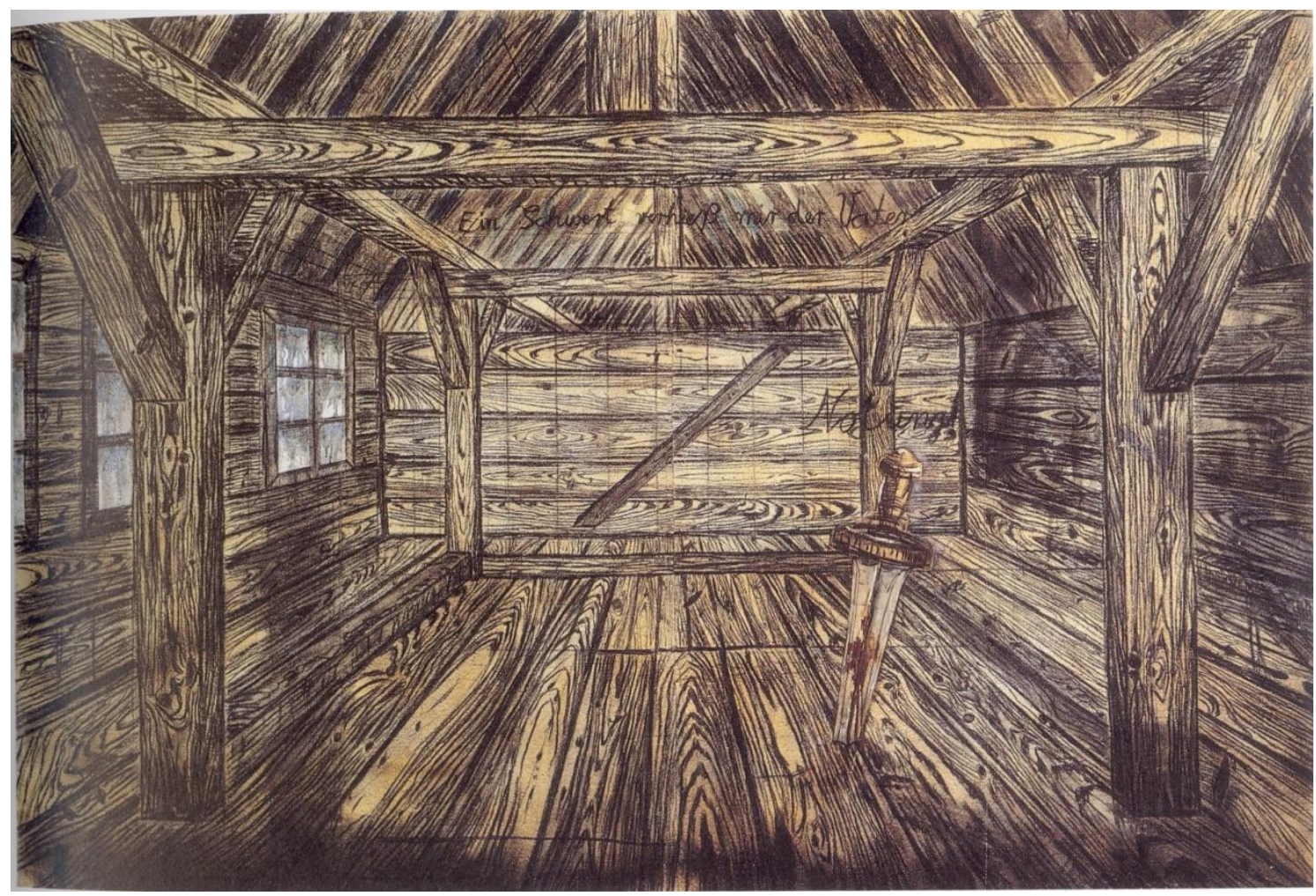

Figura 39. Nothung, 1973. Carvão e óleo s/tela de fibra, 300 x $432 \mathrm{~cm}$.

Em 1834 (quase cem anos antes do Terceiro Reich) Heine escreveu:

O talismã é quebradiço, e um dia virá em que ele lamentavelmente se quebre. Os velhos Deuses de Pedra despertarão das antigas ruínas esquecidas e sacodirão o pó de mil anos de seus olhos; e Thor, saltando para a vida com seu martelo gigante, destruirá as catedrais góticas.! ! $^{233}$

233 "The talisman is brittle, and the day will come when it will pitifully break. The old stone Gods will rise from the long-forgotten ruin and rub the dust of the thousand years from their eyes; and Thor, leaping to life with his giant hammer, will crush the gothic cathedrals!". Cf. VIERECK, Peter. Metapolitics: from romantics to Hitler. New York: Simon \& Shuster, 1941, p. 301. 
Os alemães prestaram pouca atenção a essas advertências de Heine, que foi, antes de tudo, um poeta, um cosmopolita e um judeu. A validação de sua profecia, no entanto, deu ímpeto à maioria das obras de Anselm Kiefer. ${ }^{234}$ Isto é a manifestação do conceito encarnado na palavra alemã, de espírito quase intraduzível, Waldeinsamkeit, cujo significado poderia se aproximar da sensação de solidão e melancolia que os românticos procuram aliviar retornando à natureza primordial propiciada pela vida na floresta. A Fantasia para Viajante, composição de Franz Schubert para piano sugere também, musicalmente, esse sentimento de Waldeinsamkeit. De fato, esta ambivalência da floresta é explicada por David Fontana:

A interpretação simbólica da Floresta é antiga, remonta ao tempo em que as paisagens eram marcadamente de madeira e o apuramento para a agricultura era uma tarefa árdua. A floresta é um lugar de caos, escuridão e incerteza, em contraste com a ordem e abertura de uma terra cultivada. Para aqueles que não demostram medo, no entanto, seria um lugar de sossego e refúgio; psicologicamente, é um símbolo do inconsciente, onde existem segredos para serem descobertos e talvez emoções escuras e memórias para serem enfrentadas. ${ }^{235}$

234 Outro escritor romântico, Ludwig Tieck, parece ter sido diretamente influenciado pelos desenhos de Friedrich dedicados ao viajante. Os trabalhos de Tieck caracterizam-se pelo tema da vontade do homem em regressar ao Ur primitivo do mundo, à floresta. Em Der Runenberg (1801), o protagonista, Christian, é trazido de volta por sua família e é atraído por sua casa na floresta. No romance de Tieck, Franz Sternbald, encontramos a passagem: "So Franz wandered forth and finally lost the road coming into a thick forest, which seemed to have no end. He walked further and further and still came upon no exit; the woodland became thicker and thicker." (Então Franz deambulou e finalmente perdeu o caminho, adentrando numa espessa floresta, que parecia não ter fim. Ele foi cada vez mais longe sem se deparar com uma saída. O bosque tornava-se cada vez mais denso). Cf. MEAD, Theodor. op. cit., p. 122.

235 "The symbolic interpretation of the Forest is ancient, dating back to the time when landscapes were heavily wooder and clearance for agriculture was an ardous task. The forest is a place of chaos, darkness and uncertainty, in a contrast to the order and openness of cultivated land. To those who show no fear, however, it would be a place of peace and refugee; psychologically, it is a symbol of the unconscious, where there are secrets to be discovered and perhaps dark emotions and memories to be faced."Nos 
Para Theodore Mead, na iconografia alemã de cunho cristão a floresta ocupa um lugar mais proeminente que nas culturas do sul. ${ }^{236} \mathrm{Na}$ lenda de Santa Bárbara, por exemplo, a santa é perseguida por seu pai, Dioscuros, que tenta puni-la por sua conversão ao cristianismo. Na maioria das versões, ela se esconde numa roca. Na versão de Meister Francke Perseguição de Santa Bárbara (1471), no entanto, ela é vista se escondendo na floresta. ${ }^{237}$

A floresta também aparece como uma entidade protetora e ao mesmo tempo sinistra no folclore alemão, especialmente nos contos de fadas apresentados pelos irmãos Grimm. ${ }^{238}$ Jakob e Wilhem

três desenhos de Friedrich dedicados ao viajante, a floresta aparece cada vez mais ampliada. O último desenho, Floresta com viajante descansando, poderia servir como ilustração de um fragmento de poesia de Tieck em Der Blonde Eckbert: Solidão da floresta/Me dás consolo/Serás amanhã como hoje/E, por toda a eternidade /Meu consolo/Solidão da floresta. Cf. FONTANA, David. op. cit., p. 101.

${ }^{236}$ A floresta também é cenário de catástrofes em que o sofrimento se acentua e a consciência da tragédia humana se torna real. A esse respeito, assinala Denis Rougemont: "a Guerra nasceu nos campos - inclusive seu nome chegou até nossos dias. Porém desde 1914 assistimos a sua urbanização. Para boa parte das massas camponesas, a Primeira Guerra Mundial foi um primeiro contato com a civilização técnica. Uma espécie de visita com guia à exposição universal das indústrias e artes aplicadas da morte, com demonstrações cotidianas ao vivo". Cf. ROUGEMONT, Denis. L'amour et l'occident. Paris: Plon, 1939, p. 270.

237 Cf. MEAD, Theodor. op. cit., p. 41.

${ }^{238} \mathrm{O}$ interesse de Benjamin pelos contos tradicionais ou infantis não se reduz apenas aos programas radiofônicos que realizou. Comparece tanto no seu ensaio, "O narrador", como veladamente, no interior de seu ensaio sobre o surrealismo. O livro das Passagens está impregnado por esse caráter mágico, pois a passagem representa a arquitetura do limiar: uma rua em um interior, uma casa aberta. Se refletirmos sobre as origens literárias e dramáticas de Brecht, por exemplo, podemos descobrir que ele também não era alheio à experiência do primeiro expressionismo. 0 universo mágico dos contos, de alguma maneira, é a fonte de grande parte do pensamento utópico da vanguarda moderna. Para Andrea Lombardi, os contos de fada "carregam de certa forma, o ruído de fundo de uma civilização, pois as releituras não conseguem apagar sua crueldade, a violência, a injustiça." Nas palavras do grande apreciador de fábulas que era Italo Calvino, a tarefa dos irmãos Grimm: "era descobrir os fragmentos de uma antiga religião da raça guardada pelos povos como o objetivo de despertar "a consciência germânica." Cf. LOMBARDI, Andrea. "Onde está nosso irmão Abel?" In: SELIGMANN-SILVA, Márcio. O testemunho na era 
Grimm são dois conceituados filologistas e acadêmicos cuja fama repousa longamente na sua concepção tipicamente romântica: a assemblagem de lendas e fábulas germânicas na forma de contos de fadas. Em 1815 tinham-se esgotado todos seus livros com exceção de sua versão da Bíblia Luterana. A coletânea de suas obras manteve sua posição até a publicação de outro livro de caráter ominoso, Mein Kampf. Por mais de 150 anos estas estórias dos irmãos Grimm foram uma fonte de entretenimento e leitura da infância alemã. Como Vladimir Propp comenta: "Os psicólogos modernos aprenderam que Schiller estava certo: o significado profundo repousa nos contos-defadas da minha juventude que, na verdade é ensinado pela vida." 239

As versões originais dos contos dos irmãos Grimm não eram edulcorados à maneira de Walt Disney. Mead nota que quase todas as personagens - desde os mais criminosos até a figura da Virgem Maria - eram capazes de ser cruéis. As meio-irmãs de "Cinderela" que eram cegas na versão dos irmãos Grimm, é um exemplo. A inocência dos irmãos "Hansel e Gretel," perdidos na densidade da floresta, precisava ser ornada e comida. Na "Menina sem mãos," o pai corta as mãos da sua filha com seu consentimento, por mandato do diabo. A obediência à autoridade está implícita nos trabalhos dos irmãos Grimm e deve ser profundamente engrenada nas mentalidades daqueles para quem estes contos foram lidos como "bad"-time stories" ("estórias de ninar"). ${ }^{240}$ Desconfiar do judeu como

das catástrofes. p. 212; Cf. CALVINO, Italo. Fiabe Italiane. Milano: Mondadori, 1981, p. 95.

${ }^{239}$ Cf. PROPP, Vladimir Apud TATAR, Maria. The hard fact of Grimm's fairy tales. Princeton: Princeton University Press, 1987, p. 5.

240 Uma colecção de 700 canções do floclore alemão, Des Knaben Wunderhorn, foram recolhidas entre 1804-1807 por Armim e Bretano. Moritz von Schwind pintou Im Walde: Des Knaben Wunderhorn em 1848, onde um jovem repousa na floresta com um chifre nos lábios. Na ópera Siegfried de Wagner, Sigfried usa esse chifre para chamar o dragão. 0 trabalho de Schwind antecipa a poesia de Stephan George, em cuja poesia mística, um Messias alemão é invocado em Einem jüngen Fuhrer im ersten Weltkrieg (Um jovem líder na primeira Guerra Mundial).O poeta morreu no 
estrangeiro, um não-teutão, também era ensinado pelos contos de fada. A floresta, as árvores e a madeira estão sempre disponíveis para realizar o Bem ou para imitar o Mal. ${ }^{241}$ Cinderela, por exemplo, pede ao pai um galho de árvore que, mais tarde, ela plantou no túmulo de sua mãe, sob cuja copa a menina é consolada e recebe ajuda mágica. Na lenda alemã do Blacksmith Volund (Wayland do folclore inglês), o joalheiro Blacksmith é seqüestrado pelo rei Nidud e levado para a floresta. Sua esposa avisa Nidud que mutile Volunt para evitar sua vingança: "Tenha cuidado, Nidud, não se esqueça que os moradores da floresta são selvagens, Volund, também é selvagem e inspira medo." Kiefer associa-se ao artesão-artista da lenda realizando uma série de trabalhos intitulados Wolundlied ou "canção Wayland". Neles, o artista transpõe as letras de Lied (canção) em Leid (sofrimento). Na tradição teutônica, a vingança do lenhador mutilado, justifica-se, mas voltando-se sobre inocentes: os filhos e a filha de Nidud. No conto infantil germânico Eisenkopf, o protagonista Peter é salvo da perseguição empreendida por Eisenkopf tomando como refúgio uma árvore alta como o outro Peter no conto "Pedro e $o$ lobo". O lobo, perigo arquetípico da floresta, é um objeto de fascinação, o que se revela no próprio Hitler que obcecado pela imagem do lobo e encantado com o fato de que seu nome procedia de Athalwolf, de nobre (Athal) e lobo (Wolf), denominou suas bases militares de Wolfsschlucht, Wolfsschlantz e Werwolf. Hitler se referia

ano 1933. Os nazistas admiravam muito seu trabalho. Cf. MEAD, Theodor. op. cit., p. 43.

${ }^{241}$ Como questionou Baudelaire: "Que representam os perigos do bosque e da pradaria, comparados com os choques e conflitos cotidianos da civilização?" Que o homem ampare a sua vítima no bulevar ou cace sua presa nas florestas desconhecidas, não é sempre o homem eterno e a mais perfeita vítima de sua própria presa? Nos termos de Benjamin, trata-se de "der Schuldzusammenhang des Lebendigens", a culpa generalizada do vivo. Reconhece-se a presença desse passado animal no mais profundo do ser (talvez seja este o sentido implícito dos mitos que falam de uma culpa na origem), sem que o longo processo evolutivo tenha conseguido apagar 0 instinto de crueldade, de destruição e de morte, que pode adotar as mais requintadas e espirituais manifestações. 
ao SS como "meu pacote de lobos," e seu cachorro era um pastor alemão ou, em alemão, Wolfhunde. De fato, ele aprovou nomear a fábrica Volkswagen como Wolfsburg.

Porque a floresta e as árvores são imagens reverberantes na iconografia e iconologia da arte alemã, a madeira foi um meio importante empregado pela expressão artística alemã, especificamente nos campos da gravura e da escultura:

A fama internacional de Albrecht Dürer no século XVI, devese em larga medida à exportação de milhares de suas gravuras em madeira. Dentre as mais famosas estavam $O$ apocalipse, A longa Paixão e uma série de representações sobre a vida da Virgem Maria. Dürer também talhou magníficas molduras para suas pinturas, as mais finas feitas para sua Adoração da Trindade. ${ }^{242}$

Argumenta-se que a gravura e o talhado da Renascença alemã careciam da liberdade e vitalidade dessa expressão artística na Itália do mesmo período. Contudo, um admirador do trabalho dos italianos como era Herbert Grimwood reconhece que a matéria prima dos trabalhos italianos era diferente, baseada no mármore e seu trabalho usava a madeira. Foi aqui que precisamente os alemães conseguiram

242"The international fame of Albrecht Durer in the sixteenth century rested largely on the exportation of thousands of his brilliant woodcuts. Among the most famous of these were The Apocalypse, The Large Passion and a set depicting the life of the Virgin. Durer also carved magnificent wooden frames for his paintings; the finest of wich was intended for his Adoration of the Trinity." Hans Holbein (1479-1543), mais conhecido como pintor, foi um gravurista emulador de Alfred Rethel (1816-59), Edvard Munch (18631944) e Karl Schmidt-Rottluff (1884-1976) que perpetuaram esta tradição de excelência do mesmo modo que Ernst Ludwig Kirschner (1880-1938) e Max Pechstein (1881-1955). ${ }^{242}$ Contemporâneo de Dürer em Nuremberg era o entalhador Viet Stoss e sua obra Saudação Angelical, talhada em madeira de limeira. Também em Nuremberg, na igreja Sebaldus encontra-se Crucifixão de Stoss, talvez a mais fina do gênero. Em Florença existe um São Roque talhado por Stoss na igreja de Annunziata. Stoss é considerado por muitos como o grande entalhador da história. Mas há ainda os menos reconhecidos, como Erasmus Glasser, que talhou 16 dançarinos mauritânios para o refeitório de Rathaus em Munique em 1480, e Tilman Riemenschneider quem criou peças para os altares das igrejas em Rothenburg (1499) e Creglingen (1505). Cf. MEAD, Theodor. op. cit., p. 45 
alcançar um grau de excelência. ${ }^{243}$ Nos trabalhos de Riemenschneider, particularmente, podemos observar a suavidade do maciço estilo alemão por meio da influência dos italianos, isto é, seu trabalho marcou a transição do gótico para uma forma renascentista. A tradição de gravuras em madeira do Renascimento ressurge na pintura alemã durante o Romantismo. Existe algo característico na representação da madeira nas pinturas alemãs. Na obra Mulher na janela, de Friedrich o imenso piso de madeira sugere solidez e impassibilidade em um interior dominado pela mulher, comparadas ao mistério insondável do que se vê através da janela. ${ }^{244}$ Assim como no "cadafalso" de Friederich a madeira é indestrutível, o chão maciço de carvalho é também apresentado por Kiefer em em Controvérsia Iconoclasta (fig. 40) e nos Hérois Espirituais de Alemanha ambos, o teto e o chão tabuado, reforçam os sentimentos de solidez e durabilidade. Mesmo um olhar distraído identifica este trabalho como alemão.

243 Cf. BAZIN, German. History of art. Trad. Francis Scarfe. New York: Bonanza, 1959, p. 230.

${ }^{244}$ Uma pintura similar foi Hora de Manhã, de Moritz von Schwind de 1858. O cadafalso na pintura No veleiro de Friedrich pode ser instrutivamente comparado com a representação do franzino barco de Manet em Passeio a Barco. Se neste o barco pode servir para um dia ensolarado num rio, seria de pouco uso na passagem pelo mar Báltico dos alemães. 


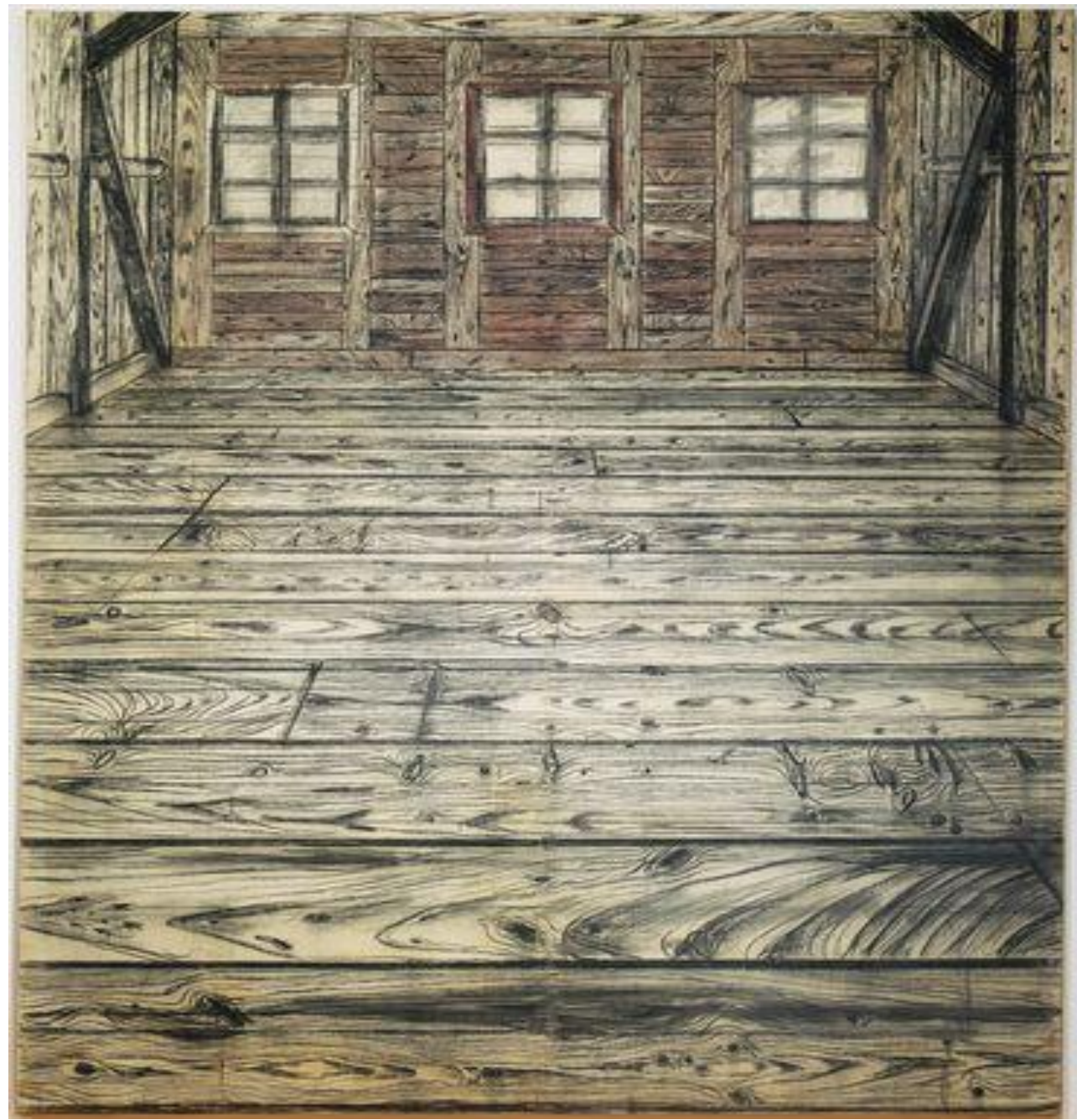

Figura 40. Controvérsia Iconoclasta/Bilder-Streit, 1980. Óleo, emulsão, esmalte e areia em fotografia montada s/tela com xilogravura. 307 x $432 \mathrm{~cm}$. Museu Boijmans Van Beuningen,

Rotterdam.

A herança germânica resgatada por Kiefer fixa-se nos elementos iconográficos e mitológicos da identidade nacional alemã e foram mobilizados na elaboração do mito nazista, para o Mal é potente a temática da floresta. Para Andrea Lauterwein trata-se de uma escalada pictórica que parte do universo representacional da floresta (o mito teutônico), se detém no templo/ateliê (passagem da natureza para uma forma de civilização) e, finalmente, desemboca na terra queimada (destruição e alquimia):

O enfâtico espaço mitológico da "floresta alemã" é substituído por uma série de "áticos" reproduzindo o ateliê do pintor, instalado no ático de uma escola de Hornbach, 
em Odenwald. A pintura Resurrexit de 1973 marca esta transição do mito à civilização: um caminho na floresta no qual uma serpente sinuosa conduz diretamente aos degraus sulcados das árvores que levam ao ateliê. Esta transição é progressiva, porque a estrutura do ático lembra suas origens; o ateliê do pintor alemão não é apenas uma versão civilizada da floresta, cheia de ressonâncias sombrias da mitologia germânica. ${ }^{245}$

O modelo arquitetônico é um elemento fundamental no contexto pictórico de Kiefer. Andrea Lauterwein, Daniel Arasse e Bazon Brock reconhecem o ático como símbolo e com funções e propriedades alegóricas. Há, em Kiefer, a presença da madeira e sua descrição verbal, pois as palavras ativam a imaginação visual sendo complexa esta relação, a unidade literária com o espaço arquitetônico do ático, reporta-se, em Kiefer, à mnemotécnica, pois a representação do elemento arquitetônico não se reduz a uma cópia da narrativa erigida ao redor da estrutura arquitetônica, mas sugere todo um mundo que subjaz ao nível literal que o artista pretende explorar. Os espaços de Kiefer nos aproximam visualmente das verdades e dos dogmas que constituem a base da cultura alemã. Sua pintura, recorre freqüentemente às imagens arquitetônicas para nos defrontar com uma linguagem que nos permita compreender tudo o que no mundo existe. Lembremos que é durante os séculos XVI e XVII que o termo arquiteto tem sentido epistemológico, tornando-se um vocábulo filosófico que não correspondia somente a uma profissão cuja única tarefa seria projetar um edifício, mas também se reportar a todo tipo de abstração intelectual, pois 0 arquiteto renascentista,

245 "L'espace mytologique surdéterminé de la "forêt allemande" fait place à une série de "greniers" reproduisant l'atelier du peintre, alors installé dans les combles d'une école à Hornbach, dans Odenwald. La peinture Resurrexit de 1973 marque cette transition du mythe à la civilization: un chemin dans la forêt sur lequel ondule un serpent conduit directement aux marches de bois méandreux menant à l'atelier. Cette transition est progressive, car la charpente apparente du grenier rappelle ses origines; l'atelier du peintre allemand n'est jamais qu'une version civilisée de la forêt, pleine des résonances obscures de la mythologie germanique". Cf. LAUTERWEIN, Andrea. op. cit., p. 39. 
artisticamente falando, é um indivíduo polivalente, muitos deles eram filósofos, matemáticos, pintores, físicos e autores literários. Eis por que uma comparação entre a arquitetura e pintura pode iluminar certos usos retóricos e alegóricos de Kiefer, o modelo arquitetônico aparece como modelo literário, os monumentos têm sua arquitetônica - o ático, o ateliê, os templos, mas também a biblioteca, os ricorsi que o pintor emprega para representar seu próprio universo pictórico.

Kiefer relaciona o espaço com a memória. ${ }^{246} \mathrm{~A}$ arte da memória dos oradores da antiguidade repousa sobre a codificação dos argumentos discursivos em imagens sobrecarregadas, postas em lugares específicos ao interior de um espaço estruturado. Os interiores de Kiefer, os espaços dos áticos ou as paisagens acompanham uma lógica mnemônica semelhante, o artista retoma os mesmos lugares associados a imagens diferentes, inabituais e chocantes. Assim como para o alegorista melancólico de Benjamin, o mundo deslindado do império da significação transforma-se em uma galeria de imagens passíveis de serem preenchidas de novos sentidos, do mesmo modo o pintor vê a história se desmoronar em imagens saturadas de atritos: ele as desperta a partir de seu Jetztzeit temporal, mais do que seu presente. Essas imagens dialéticas benjaminianas, definidas como "a memória involuntária da

246 El castillo interior de Santa Teresa de Jesus poderia servir como ilustração dessa dupla articulação de memória - morada/Inneraum arquitetônico. Existe uma vasta tradição literária em que a imagem do castelo ou morada representam a força espiritual, a sabedoria e o corpo de um ser divino, esse tema é amplamente documentado por Roberta D Cornelius em The figurative castle: A study in the medieval allegory of the edifice with special reference to religious writings. Trata-se de um estudo sobre o uso alegórico do edifício na literatura medieval espanhola analisando a relação literária do castelo alegórico com imagens arquitetônicas da literatura francesa. María Mercedes Carrión e Joseph Chorpenning defendem a idéia de que o castelo tem uma função mnemotécnica no Castillo interior de Santa Teresa. Cf. CARRIÓN, María M. Arquitectura y cuerpo en la figura autoral de Santa Teresa de Jesús. Barcelona: Antrophos, 1998; Cf. CHORPENNING, J. "The literary and theological method of the Castillo Interior," Journal of Hispanic Philology 3, 1979, pp. 121-133. 
humanidade," estão na base do conhecimento da história, o que, para Benjamin, significa reconhecimento de uma imagem do passado que, na verdade, é uma "imagem da memória," bem entendido, Benjamin e Kiefer almejam armar esse passado se apropriando de "restos" e de "reminiscências." Essa imagem coincide com a intuição interpretativa de Daniel Arasse quando alude à "thérapie des dégâts":

A obra de Kiefer apresenta-se como um "teatro da memória" de que ele se serve para interiorizar e estruturar os documentos de um passado alemão que ele só conheceu indiretamente. A ars memoriae tradicional, uma técnica que garante a performance e a disponibilidade da memória se servindo de receptáculos visuais, deve ser, no entanto, distinguida da arte contemporânea da memória, que não serve para impedir o esquecimento, mas que vem depois do esquecimento. Faz o balanço da perda e recolhe os rastros apagados da memória cultural procedendo a uma espécie de "terapia dos escombros. ${ }^{247}$

A qualidade topológica da memória conduz a espaços privilegiados como as bibliotecas, os museus e os templos, encarnações da memória coletiva. As ressonâncias afetivas e simbólicas do ático emanam de seu uso como espaço da criação ou da memória, espaço da segurança e do racional. Esta questão se esclarece à luz das observações de Gaston Bachelard que em sua Poética do espaço, considera a casa como um ser vertical com polaridades simbólicas: a

247 "[...] l'oeuvre de Kiefer se présente comme un "thêatre de la mémoire" dont il se servirait por interioriser et estruturer les documents d'un passé allemand qu'il n'a connu qu'indirectement [...] L'ars memoriae traditionnel, une technique qui garantit la performance et la disponibilité de la mémoire en se servant de réceptacles visuels, doit cependant être distingué de l'art contemporain de la mémoire, qui ne sert pas à prévenir l'oubli mais qui vient après l'oubli. Il dresse le bilan de la perte e recueille les traces effaçées de la mémoire culturelle en procédent à une sorte de "thérapie des dégâts. "L'ars memoriae é uma arte interior, como o reconhece Arasse, uma técnica de uso pessoal, em que as noções incorporadas de uma imagem correspondem a uma bricolagem pessoal. A partir desse fato, 0 funcionamento de uma imagem de memória é explícito a partir de seu autor-utilizador. A composição dos lugares e das imagens mnemônicas de Kiefer podem revelar um princípio alegórico benjaminiano, mas também representam uma alegoria privada, uma prática da mis-en-scène que explicará também a singularidade de Kiefer no seio do trabalho coletivo da memória. Cf. ARASSE, Daniel. op. cit., p. 81; Idem, op. cit., pp. 79-82. 
irracionalidade do porão opõe-se à consciência racional do telhado, uma região onde os medos racionalizam-se graças aos projetos intelectualizados. No ático, o dia pode dissipar os medos produzidos pela noite. Bachelard escreve: "No telhado os pensamentos são claros. No ático, podemos ver a ossatura nua e crua da casa. Participamos da sólida geometria do mestre de obra." ${ }^{248}$

Na cultura dos países germânicos, a alegoria do ático comporta uma significação particular. No século XIX, os românticos alemães escolheram este reduto da casa para simbolizar sua existência marginal na sociedade burguesa. A avant-garde artística de começo do século XIX fez dele o espaço da marginalização intelectual, assim como, durante as perseguições nazistas, os áticos foram usados como espaços de refúgio. Que se recorde o Diário de Anne Frank, o romance canonizado pela República Federal Alemã, em que uma menina judia belga de doze anos relata, em forma de diário, como passava seus dias escondida em um ático. Após 1945, o ático alemão torna-se uma "imagem proibida", o destino dos estorvos, a memória rejeitada pelos moradores da casa, respondendo, por assim dizer, a outras significações da palavra em alemão -Speicher - designa acumulação, memória, depósito, armazém. A sociedade do ático, romance de Ernst Kreuder de 1946, dialoga com os espaços utópicos dos românticos: nos anos do pós-guerra dominados pelo pragmatismo e pela amargura, a utopia da poesia, encarnada por uma eufórica comunidade, se reclui no ático da casa para fazer suas produções artísticas. ${ }^{249}$ Uma postulação mais enfâtica dessa reflexão sobre os áticos encontra-se em Bazon Brock segundo o qual

${ }^{248}$ Cf. BACHELARD, Gaston. La poétique de l'espace. Paris: PUF, 1957, pp. 34-36.

249 Não podemos esquecer o texto seminal das scholars americanas Sandra Gilbert e Susan Gubar, The madwoman in the attic: the woman writer and the nineteenth-century literary imagination, publicado em 1979, onde examinam a literatura vitoriana em uma perspectiva feminista. Seu texto toma de empréstimo o título da escritora Charlotte Brontë em Jane Eyre, 
Anselm Kiefer reuniu problemas deste tipo, tais como os heróis espirituais alemães, num espaço destinado àquilo que é recalcado na casa burguesa: o sótão. Ali se guarda o que não pertence ao salão, aquilo que contém a história familiar sob a forma de antiguidades obsoletas. Sob a abóbada das vigas da cobertura, que preservam a mais autêntica expressão da construção, crianças e sábios vasculham com especial interesse, na esperança de descobrirem algum segredo: manuscritos de Hölderlin ou cartas de amor da vovó [...] Os sótãos tornaram-se o pavilhão da fama tanto do oculto como do ocultável. Sob a proteção de jogos rituais, as crianças ali escondem seu conhecimento sobre coisas que, de acordo com a vontade dos pais, ainda Ihes deveriam ser inacessíveis. Sob estas vigas toscamente talhadas, os adultos ocultam suas melancolias e saudades proibidas. ${ }^{250}$

Kiefer insere-se nessa tradição de análise dos áticos: o ateliê do artista torna-se uma zona de conflito à margem das tensões coletivas onde desfilam as imagens interditadas. A mediação entre o tempo e o espaço será colocada para Kiefer pela repetição. Entre as imagens de Kiefer dos áticos existe a repetição, as imagens referem- se a um espaço, a espacialidades, o tempo é, pois, um colocar juntos os espaços que criam conexões onde não existiam antes. ${ }^{251}$ Kiefer

em que a mulher tresloucada do Senhor Rochester, Bertha, encontrava-se confinada no ático. Este texto analisa especificamente os trabalhos de Jane Austen, Mary Shelley, as irmãs Brontë, George Eliot e Emily Dickinson. Gilbert e Gubar exploram o discurso em que as escritoras do século XIX estavam confinadas, fazendo de suas personagens femininas a encarnação de um anjo ou de um monstro. Este debate enraiza-se nas tendências dos escritores masculinos de categorizar as personagens femininas como mulheres puras e angelicais ou mulheres revoltadas e tresloucadas.

${ }^{250}$ Cf. BROCK, Bazon. op. cit., p. 89.

251 Pertinente seria a referência da Tese de Doutorado de Brian J. Fitzpatrick. Temporality in Anselm Kiefer's "Varus" and Wim Wenders' "Wings of Desire," apresentada ao Departamento de História da Arte da Universidade de Ohio em maio de 1996. Este estudo examina a pintura Varus de Anselm Kiefer e As asas do desejo de Wim Wenders, para adquirir compreensão da temporalidade no contexto da arte contemporânea. É uma pesquisa analítica voltada sobre elementos artísticos das obras que são usados de tal maneira que sugerem uma concepção não linear da temporalidade. Narrativa disjuntiva, justaposição, assunto, texto, imagem e forma têm sido discutidos assim como seu uso tem sido considerado pertinente para definir a noção de temporalidade onde as dimensões de passado, presente e futuro possam operar juntas para dar conta das formas 
explora o horizonte temporal do passado. Em Sobre los espacios, ${ }^{252}$ José Luis Pardo chama nossa atenção para a distinção, primeiro, ontológica e, apenas mais tarde, epistemológica, de espaço e tempo enquanto fundamentos do pensamento ocidental. As formas da exterioridade apontam a transposição da antiga separação entre o sensível e o inteligível à de espaço e tempo, ou seja, às formas da exterioridade e as formas de intimidade referidas ao pensamento de Kant. A partir da perspectiva humeana estabelecida por Pardo, o próprio passado tem seu substrato estético ou sensível no hábito. ${ }^{253}$ A memória que aparece nas telas de Kiefer não é a memória vigilante da consciência, senão a memória do hábito, a memória primordial dos espaços justapostos. Esta memória de Kiefer é a condição mesma que sua pintura exige para que seu presente pictórico não se desfaça em um caos de cores. Este resgate do empirismo quer dar conta de um fenômeno incompreendido pela modernidade racionalista, o da exposição subjetiva à sensibilidade. José Luis Pardo observa:

Os espaços imprimem-se em nós mesmos configurando nossa exterioridade, o que somos, mas não podemos

de um novo presente tanto em Kiefer quanto em Wenders. Do mesmo modo que Wim Wenders, as imagens de Kiefer também se referem a espaços ou paisagens, diferenças isoladas, átomos de sensibilidade, condição que Wenders reconhece a partir de seu ofício de fotógrafo. Lembremos que as primeiras articulações pictóricas de Kiefer, Besetzungen, foram fotografias retrabalhadas. As histórias de Kiefer vêm-se relacionar com a História para vinculá-las entre si, construindo sistemas significativos, narrativas impregnadas de sentidos. A pintura parece se encadear no espaço para Ihe conferir um sentido; os espaços por si próprios, carecem de sentido, são sem sentido, sem um único sentido, porém, com um potencial indefinido de sentido. A pintura de Kiefer, como o cinema de Wenders, desenvolve-se no tempo, os espaços, por sua parte, constituem a exterioridade do tempo.

${ }^{252}$ Cf. PARDO, José Luis. Sobre los espacios. Barcelona: Serbal, 1991.

253 Cf. FURTADO, José Luis. "Fenomenologia e crise da arquitetura." Kriterion 112, Dezembro 2005, pp. 414-428. 
perceber, o que constitui nossa aparência e nossa presença, mas que nós não podemos presenciar. ${ }^{254}$

A percepção do espaço racional, sustentada pelo Iluminismo, é contestada por Kiefer. Aquele ser - o sujeito -, pura vontade, emancipado da natureza por beber diretamente do princípio supremo da razão abstrata, aquele animal em ascensão progressiva bem como o próprio mundo animal, encontram-se longe da idílica harmonia do paraíso. As pinturas de Kiefer mostram o espantoso holocausto que se produz no mundo dos seres vivos onde impera a voracidade e a cobiça, e o excesso de vida é corrigido pela própria vida com uma frívola crueldade. Trata-se de um círculo fechado no qual tudo tem seu momento para se salvar e para perecer, pois o vivo cresce devorando a vida e vive para produzir mais vida. A cobra solta de Kiefer na sua tela Resurrexit, não precisa de malignidade instintiva para sobreviver. Kiefer aponta o Mal que se produz quando a dor e as mortes superam as requeridas para os ciclos vitais, ultrapassando-se o exigido para a conservação ou a reprodução. Por isso, a racionalidade instrumental e funcional se apresenta incapaz de dar conta de tais fenômenos de energia excessiva.

Se na perspectiva mito-poética apresentada por Gaston Blachelard, o espaço relaciona-se com o habitar, Kiefer estabelece a relação essencial do homem alemão com seu espaço, seu modo mais próprio de habitar poético, mas ao mesmo tempo lança uma crítica fulminante ao universo nazista e sua ocupação maligna dos espaços. O domínio tecno-científico - ponto de chegada do niilismo nazista que perdeu o sentido de relação com as coisas, ou seja, que perde qualquer relação de verdade, apenas aparece em Kiefer quando se

254 "Los espacios se imprimen en nosotros mismos configurando nuestra exterioridad, lo que somos pero no podemos percibir, lo que constituye nuestra apariencia y nuestra presencia pero que nosotros no podemos presenciar". Cf. PARDO, José Luis. op. cit., p. 20. 
habita o espaço. ${ }^{255}$ Se o construir está, efetivamente, vinculado a uma forma essencial de habitar, o habitar se distingue, por sua vez, do simples morar, pois não se trata de um mero reduto espacial. Construir enquanto produzir, a partir do modelo de cuidado do cultivo - considerando o protótipo do habitar tradicional do morador da floresta - parece ser o paradigma a ser desconstruído na série de áticos de Kiefer. O pintor resgata esse espaço porque já não é passível de ser habitado em meio a tanta destruição. Portanto, habitar não mais responde à fórmula de construir. A relação em Das Geviert (Quadrinidade) (fig.41) de Kiefer, no entanto, inverte-se: não habitamos porque construímos, mas habitamos porque destruímos. Habitar como último recurso do destruir: já não se trata mais de salvar a Terra, receber o Céu na espera do divino, em conduzir dos mortais, habitar como o cuidado da quadrinidade.

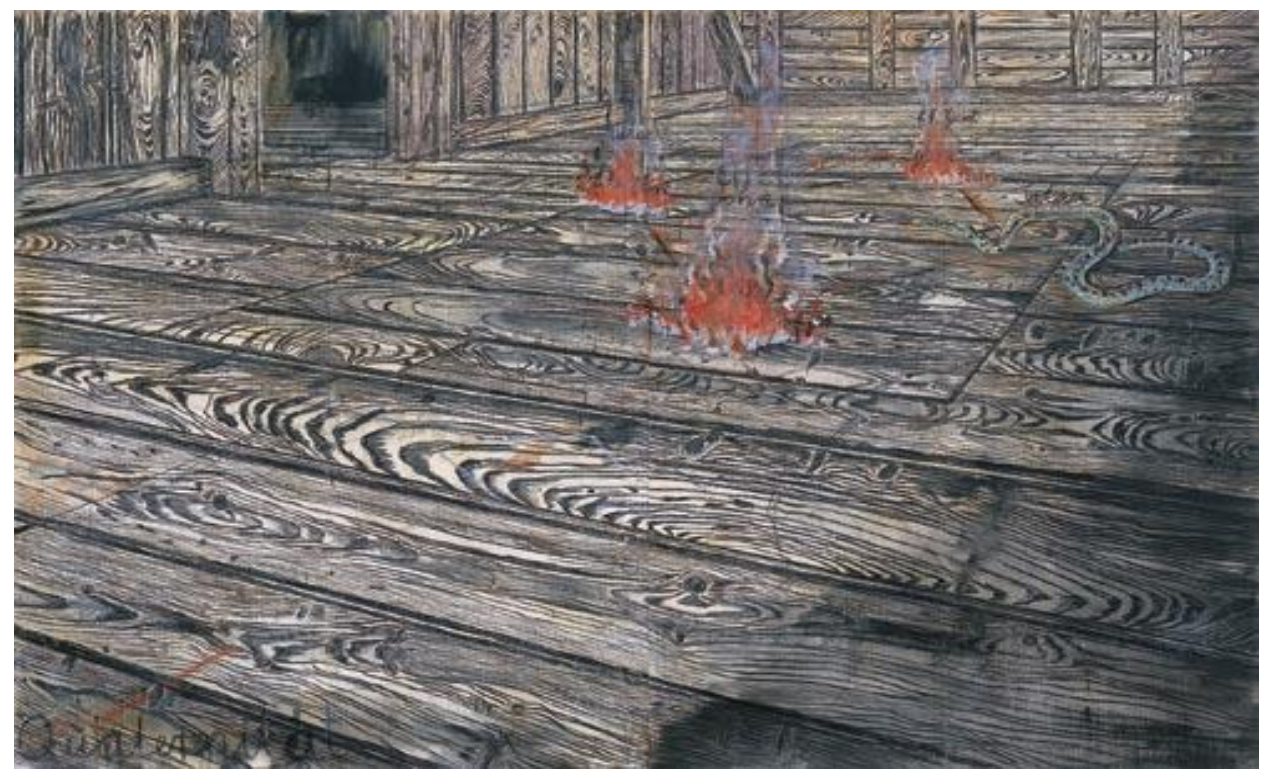

Figura 41. Quadrinidade/Das Geviert, 1980.

255 Esta questão do habitar é assunto acolhido nas reflexões de Heidegger quando retifica sua posição ontológica trasladando o campo de compreensão do ser do tempo à linguagem (Construir, habitar, pensar e Caminho da linguagem (1959). O espaço comparece como condição ineludível para compreender o humano. Para Heidegger o homem habita o espaço e relaciona-se primordialmente ao habitar. Heidegger observa: " $O$ respeito do homem com os lugares e, através dos lugares, com espaços descansa no fato de habitar [...]. O habitar relaciona-se basicamente com o construir." Cf. HEIDEGGER, Martin. "Conferências e escritos filosóficos". São Paulo: Nova Cultural, Coleção Os Pensadores, 1989. 
Cuidar das coisas, protegê-las para que alcancem sua essência é ao mesmo tempo cuidar da quadrinidade que não é mais do que o sentido, o simbolismo que aponta para além do meramente visível, em direção do que outorga medida ao homem, sentido a sua existência. Por outro lado, os homens, enquanto mortais, definem-se através do que o Heidegger tardio denominou "aqueles que são capazes de morrer"; o ser-para-a-morte permanece vigente, a relação primária com o tempo é para os mortais o confronto com seu fim, detalhadamente inscrito em cada lugar, em cada coisa. Só assim é possível cuidar da quadrinidade. Com este cuidado os extremos definem-se mutuamente, e o homem, como ponto de convergência, é obra e expressão dessa tensão, como a pintura é tensão entre a tinta e a tela.

O ático representa o lugar em uma relação especular com a quadrinidade, faz resplandecer uma aura que outorga sentido ao espaço. Ao demarcar os limites Kiefer introduz uma medida, uma relação simétrica entre os membros da quadrinidade, pois era assim que o mundo antigo traçava os limites do terreno de cultivo a partir da contemplatio do templo celeste, tal como na inauguração da cidade antiga realizavam-se as sucessivas contemplações dos templos celestes, nas misteriosas danças de suas criaturas. ${ }^{256}$ É esta a relação do homem com a medida, seu sentido essencial, até o ponto em que o homem habita medindo o que está sobre a Terra e o que está sob o Céu. A medida de Kiefer pode ser colocada em relação

\footnotetext{
256 Lewis Mumford iniciava A cidade na história se referindo ao destino da cidade em um sentido próximo à elaboração pictórica de Kiefer. No começo a cidade imitava as estrelas, em franca referência ao ritual romano da Inauguratio - que por outra parte não se comemorava tanto a fundação das cidades quanto a fundação dos campos de cultivo- , mas na cosmogonia de Kiefer, são as constelações estelares que imitam a cidade, uma cidade que tem perdido qualquer sentido de limite e medida, qualquer modelo transcendente e que desnorteada perambula em sua explosão urbana como nas telas dedicadas a Lilith. Cf. MUMFORD, Lewis. A cidade na história. Suas origens, transformações e perspectivas. Trad. Neil R. da Silva. São Paulo: Martins Fontes, 1998.
} 
ao sentido remoto do termo mimese, com a medida adequada para a afinação de um instrumento ou a distribuição precisa da tinta para pintar uma tela. Tanto para os poetas alemães e românticos em geral, como para Kiefer, o habitar do homem é poético. ${ }^{257}$ Poético

257 Uma vez adquirida a ciência dos contrários - a mesma que Deus possuía ao separar a luz das trevas, os oceanos das terras, e que o levou a criar seres bons - a existência no Paraíso protetor perde o seu sentido para Adão. No entanto, Deus há de continuar marcando a diferença insondável que o separa de suas criaturas. No Paraíso, essa diferença era estabelecida mediante o recorte da liberdade, que, conseqüentemente, ficará determinada pela perda da imortalidade, pela entrega ao cadáver consubstancial (Filon) de nossa existência. A primeira lição que o homem aprende acerca da ciência do Bem e do Mal é aquela que John Milton coloca nos lábios de Adão:[...] since your eyes/Opened we find indeed, and find we know/Both good and evil, good lost and evil got. A dureza das novas condições de vida a serem enfrentadas por Adão determina que nunca se apague o anelo pelo seu Jardim natal, o qual apenas poderá ser pensado como algo fora do espaço (utopia) e do tempo (ucronia). Por esse fato, para os românticos, a filosofia se tornou Heimweh, dor pela morada perdida, nostalgia de uma terra que está em todas as partes e em lugar nenhum, sentimento que levou Schiller a considerar que os românticos são desterrados e que languescem pela pátria. O Paraíso haverá de se definir de forma negativa: será sempre o lugar no qual não se está, o tempo no qual não se vive, pois, em palavras de Rimbaud, «la vraie vie est absente». A trágica moira do homem sem morada o leva a uma permanente peregrinação, simbolizada no castigo de Adão que foi condenado a perambular eternamente como forma de punição por seu crime. Cabe lembrar que a dura existência do pastor seminômade continua a ser o ideal profético durante muitos séculos e que eram numerosos os fiéis javistas que olhavam os tempos nômades, não apenas como um fato histórico, mas como uma época normativa, sob o peso da nostalgia pelo Paraíso perdido e, mais tarde, com a esperança da Terra Prometida. No entanto, o sentido profundo que se esconde no mito da perda do paraíso primitivo não é outro senão animar a busca de um novo paraíso criado, dessa vez, pelo homem. Assim, a esperança da recuperação da harmonia, apesar da impossibilidade do retorno, representa o mais íntimo dos desgarros, uma das notas mais humanas que Adão intuiu mesmo antes de sua queda. Pois, visivelmente, Adão percebe, nas palavras da serpente transmitidas por Eva, a possibilidade da contradição que tem sido dominada pelo fiat divino e reduzida à harmonia, mas que se mantém latente em toda a criação. Após a queda, tanto o Bem quanto o Mal se tornam opções aceitáveis. Por isso o fiat de Adão é um novo começo, uma reedição da origem. A queda de Adão introduz o tempus moral, em que existe um antes e um depois da queda. A linguagem moral e religiosa constata que o pecado de Adão é irremissível e pode ser traduzido como uma linguagem acapella, afirmando que o tempo é irreversível, por outras palavras, evitar que o factum torne-se infectum. Por isso, Adão, uma vez exercida sua liberdade desobedecendo a ordem de Deus, descobre um novo limite para sua liberdade, a irreversibilidade do tempo 
também é construir. Aliás, o termo alemão para construir (Bauen) remete-nos, por sua origem etimológica, ao termo cultivar ou cuidar da terra. Todo esse campo semântico relaciona-se diretamente com poetizar enquanto trazer à luz o que é poiesis, bem como cuidar dos campos ou construir as pontes: levar o ser ao seu Ser próprio. O território que Kiefer invadiu é uma obra de arte total, um Gesamtkunstwerk, como Wagner sonhava ao construir Bayreuth. Richard Wagner transformou em teatro este local de culto da imaginação burguesa. Lembremos que Bayreuth deveria ser uma construção em madeira ligeiramente edificada; seus palcos seriam molduras de fantasia cuja cenografia seria mais excitante que os salões da classe dominante. A presença do fogo em tais edifícios permaneceu ativa como metáfora. Bazon Brock lembra que as comemorações anuais dos nazistas encenavam minuciosamente, com sublimes sinais luminosos, uma procissão do Edifício dos Oficiais Militares na Praça Real em Munique. Ali, diante dos túmulos neoclássicos (da Escola de Troost) e em cerimonial militar, eram evocados, pelas tropas de choque nazistas em formação, os nomes dos heróis mortos em combate na primeira Marcha sobre o Edifício dos Oficiais em 1923, confirmados num eco coletivo como presentes. Tal processo de trazer ao presente os mortos é tão bem evocado por Kiefer em seu templo-ático teatral que o observador do quadro tem vontade de saltar para dentro dele, a fim de impedir que as labaredas crepitantes destruam todo o edifício. A almejada proximidade entre recordação venerável e risco de aniquilamento não se ajusta, com exceção de Richard Wagner, a nenhum dos heróis trazidos de volta

linear, no qual o homem pode projetar, mas não desfazer o já realizado. A queda não é nem sequer um fato que aconteceu no passado, mas uma categoria própria deste tempo, revelado como impossível de ser refeito e revivido. Para o homem mortal, a busca Suche de sua morada Heim, será sempre sua aflição Heimsuchung. Cf. VILLACAÑAS, José L. op. cit., pp. 110223. Cf. DUQUE, Félix. (ed.) El mal: Irradiación e Fascinación. Murcia: Serbal, 1993. 
ao presente pela inscrição de seus nomes. Robert Musil ou até mesmo Adalbert Stifter, Joseph Weinheber ou Theodor Storm não esconjuram, com seus atos e obras, a relação entre criação e destruição, mas, na melhor das hipóteses, apenas aquele entre recordação esclarecedora e falsificação histórica. Para Brock, teria querido Kiefer, em seu quadro de 1973, amenizar uma associação com Wagner, por meio do enunciado de nomes cujos portadores de modo algum poderiam ser interpretados como "bodes" guardiões de um jardim e, portanto, como heróis espirituais? Nos espaços arquitetônicos - o teatro, os áticos, os armazéns em que se empilham as pinturas, armários cheios de objetos, fósseis, materiais; torres, blocos de concreto como ondas que se derramam em meio a florestas; cidade subterrânea, com galerias que, como minas -, se abrem imensas salas que parecem surpreendentes grutas naturais. Kiefer materializa um sublime que fulmina e eleva, confrontando-nos com a memória e o imaginário de nosso tempo.

Os áticos de Kiefer reportam-se à condição de permanecer e pertencer, um enraizamento, no sentido mais acurado, vinculado de forma indireta à concepção de linguagem de Heidegger no começo de Construir, habitar, pensar. Heidegger elaborou sua compreensão sobre o espaço e sobre o habitar a partir da concepção mítico-ritual arcaica do espaço. O sentimento telúrico - pertencer à terra, ter nascido da terra - da qual se bajulavam os gregos clássicos, está unido a toda uma rede de medos e de sacrifícios rituais. Contudo, a reflexão de Heidegger auxilia-nos na interpretação de Kiefer e a retomada do ático como espaço alegórico fundamental. A arquitetura é, por sua vez, arte do fundamento mas ao mesmo tempo do abismo (Grund e Abgrund). ${ }^{258}$ Os áticos ou lugares mal assombrados, os

258 Em alemão, a oposição de complemento de Grund e Abgrund (fundação e abismo) poder-se-ia transladar para toda a ética pictórica que aparece em Kiefer fundada-desfundada sobre uma retórica das imagens e do sólido nada. Pelo fato de o Bem e o Mal não terem uma essência separada, cessa também a atração pelo mal, no sentido de uma vontade de aniquilação 
espaços sinistros dos contos de terror davam, de algum modo, conta das conexões não reconhecidas do morar e do habitar. Na tela Nothung, por exemplo, o ático está vazio, preservando uma espada, objeto que dado o nome, faz referência ao mito dos Nibelungos e o uso desse mito na ópera de Wagner. Com Nothung Kiefer recoloca o poder mágico da arma mitológica da mesma forma que sua instrumentalização ideológica. Por esta razão os Nibelungos de Wagner e o filme de Fritz Lang Nibelungen contribuíram a fazer do mito um reservatório de imagens sugestivas das quais o regime nazista valeu-se delas. A espada quebrada, símbolo por excelência do rearmamento militar e moral da Alemanha vencida em 1918, estabelece uma filiação que vai de São Jorge até São Miguel, a espada nibelunga torna-se a arma de filiação germânica brandida contra o dragão, a encarnação fantasmagórica da alteridade radical. No período de entre-guerras, as representações do combate de Siegfried contra o dragão na floresta de Odenwald, ajudaram a preterir o mito ante a realidade e a banalizar a persecução de todo um povo identificado com a alteridade. Eric Kligermann faz a seguinte síntese:

dirigida contra a origem do bem, como ato de livre revolta, de grandiosa megalomania e da vontade de desordem. O Mal é um fato corriqueiro, ou seja, forma parte do sistema da natureza. Se Rousseau reabilitou a natureza humana frente à tradição paulina e calvinista, ao julgá-la como originariamente boa, simetricamente contra aqueles que sustentavam a existência do mal radical, Jean-Noël Vuarnet qualifica Kiefer como un Rousseau du désastre. Para o crítico, ambos são dois gnósticos mascarados, Rousseau mais doce e resignado que o serralheiro tectônico de Kiefer, compartilhando com ele, sem tê-lo visto nem conhecido, a nostalgia do anterior e o medo do que pode acontecer. O Emílio de Rousseau pedia: "Homem não procures mais o autor do mal: esse autor és tu mesmo. Não existe outro mal senão aquele que tu provocas ou sofres, e tanto um quanto o outro vêm de ti?" Rousseau pretende ser o conhecedor dos mecanismos pelos quais os homens se fazem sofrer mutuamente. Rousseau procura declaradamente remédios para os males que cataloga e descreve com uma complacência que provoca por vezes um sentimento de asfixia, ele é o protótipo do construtivismo social. Com ele, o Mal se reduz ao estatuto de problema. Cf. DUQUE, Félix. op. cit., pp. 45-86. 
A espada, colada no espaço da memória do artista, é transferida para dentro do espaço teatral do público para revelar seus traços de sangue de passado culposo. Finalmente, o palco se torna um espaço potencial para a execução desses mitos, como o anti-semitismo wagneriano tece no fundo da pintura. Podemos desenhar uma linha entre os mitos da pureza do sangue em Parcifal até a lei racial de Nuremberga e do sangue impuro dos judeus que talvez manchassem a espada. ${ }^{259}$

Conforme Nicolas Abraham e Maria Torok, a impossibilidade do luto ou a incapacidade de lidar com a memória traumática força o sujeito a construir um lugar para a memória olvidada. Eles descrevem um lugar psíquico para preservar esse luto impossível. É um espaço de interiorização em que o ego precisa se modular à perda do objeto. A imagem que eles utilizam para evocar este espaço, essa trama para o enterro da memória traumática, é a cripta. ${ }^{260}$ Este ático da tela Nothung é análogo à topografia funcional da casa proposta por Abraham e Torok. O ático de Kiefer contém apenas a espada, um signo do passado mítico e cultural alemão. A espada mítica wagneriana torna-se uma alegoria do passado recalcado, escondido no ático. A espada irrompe no espaço vazio, perturbando seu silêncio visual. Ela é um fragmento disruptivo, um pedaço de aço na história e um pedaço de memória no nada e no vazio. Interessantemente, na parte de trás do espaço do ático, Kiefer inscreveu as palavras "Ein

259 "The sword, sticking in the memory space of the artist, is transferred over into the theather space of the public in order to reveal its traces of blood and its guilty past. Finally, the stage becomes a potential space of execution for theses myths, as Wagnerian anti-semitism looms in the backdrop of painting. We can draw a thread between the myths of pure German blood in Parsifal to the race law of Nuremberg and to the "impure blood" of Jews that perhaps stains on the sword". Cf. KLIGERMANN, Eric. Scenes of Witnessing. op. cit., p. 203.

${ }^{260}$ Cf. ABRAHAM, Nicolas; TOROK, Maria. "A poetics of psychoanalysis: the lost objet- me." Substance n. 43, v. 13, 1984, pp. 3-18; Cf. LANDA, Fabio, "E. Lévinas e N. Abraham: Um encadeamento a partir da Shoah. O estatuto ético do terceiro na constituição do simbólico na psicanálise." In: SELIGMANN-SILVA, Márcio (org.). História, Memória, Literatura. O testemunho na Era das Catástrofes. Campinas, São Paulo: Editora UNICAMP, 2003. 
Schwert verhieß mir der Vater," (Meu pai me prometeu uma espada). Essa inscrição estabelece a noção do legado do pai, na geração dos filhos. Para Donald Kuspit, "Voltamos para os antepassados para redimir o filho - para Ihes dar uma fresca fruição de vida artística, Ihes recordando seu grande passado cultural" 261 Com sua identificação wagneriana, a espada não rasga apenas o passado, mas também os subseqüentes tabus que circundam o passado no presente. A espada serve para localizar o espaço no presente histórico amnésico. O que Maurice Halbwachs reclama para o tema da memória e o espaço - "a memória coletiva se desdobra em uma moldura espacial" - coloca o ático, esse depósito da memória individual ou familiar, como um lugar privilegiado da memória coletiva. ${ }^{262}$ Embora os áticos de Kiefer pareçam espaços vazios, povoados por signos pictóricos ou ekphrásicos ${ }^{263}$ que adornam as colunas, as laterais e as tábuas de madeira do chão, eles estão

261 "So we go back to our fathers in order to redeem the son - to give them a fresh lease on artistic life by reminding them of their great cultural past." Cf. KUSPIT, Donald. "The nigth mind." Artforum, September 1982, pp. 6367.

${ }^{262}$ Existe um vasto repertório bibliográfico que documenta a relação entre espaço e memória. O livro de Maurice Halbwachs é um texto seminal, The collective memory. Trads. Francis J. Ditter and Vida Y. Ditter, New York: Harper \& Row, 1980.

${ }^{263} \mathrm{~A}$ relação entre poesia e artes plásticas é tão rica como antiga. Ao longo da última década temos assistido à relativa revitalização da pesquisa em torno da ékfrasis termo usado durante séculos para fazer referência à descrição verbal de obras de artes plásticas, limitando o conjunto delas às de natureza pictórica. $O$ arquétipo deste recurso, no entanto, não é um quadro, senão a descrição que do escudo de Aquiles faz Homero no canto VIII da Ilíada. Além de sua estirpe, a boa fortuna do fenômeno deu- se, em grande parte, à persistência do erro de interpretação do célebre ditado horaciano ut pictura poesis, segundo o qual a frase, removida de seu contexto, significava que o poema tinha de ser como um quadro (quando Horácio realmente argumentava que, da mesma maneira que alguns poemas, existem pinturas que surpreendem a primeira vista mas que não resistem a um reexame). Esse erro de tradução marcou decisivamente os debates relacionados com os conteúdos ekfrásicos na elaboração das imagens com palavras, particularmente nos séculos XVI e XVII. Como tem estudado J. W. Mitchell em seu livro Picture theory: essays on verbal and visual representation. Chicago: University of Chicago Press, 1994; Cf. MIRZOEFF, Nicholas, (ed.). The visual culture reader. London/New York: Routledge, 1998. 
saturados de rumores de memória, pois eles armam uma estrutura, um contexto e um suporte para a articulação do evento mnemônico. Na sua translação para as câmaras monumentais sombrias e escuras das pinturas Ao pintor desconhecido, Sulamith e Inneraum, Kiefer nos leva do ático das casas alemãs em direção à arquitetura do Nazismo, uma arquitetura que pode ser referida como arquitetura da fatalidade. Kiefer passa dos áticos para a arquitetura, retomando o cenário dos acontecimentos históricos. Sua apropriação de prédios nazistas para ressuscitar memórias torna-se um espaço equivalente às suas paisagens queimadas. Sua resignificação pictórica subverte a função original dessas construções nazistas:

Tenho estudado minuciosamente a arte do Terceiro Reich. Tenho todos os livros. Não existe nenhum elemento da arte figurativa daquele período - nem um só quadro, nem uma só escultura que apresente qualquer interesse. Para a arquitetura é diferente. Speer era um arquiteto tradicional, alimentado pela arquitetura revolucionária de Boulée Ledoux e da Bauhaus. Alguns edifícios - a maior parte deles foi destruída, não existem mais -, como o Ministério da Aeronáutica Militar em Berlim, são simples e belos, com as proporções exatas. As catedrais gigantescas de Speer nunca foram construídas porque eram totalmente absurdas: grandes demais, não faziam sentido. Lá onde os símbolos usados pelo Terceiro Reich são manifestos, eu os torno sempre ambíguos, contraditórios. Por exemplo, pintei um edifício e sobre a tela escrevi: «Monumento ao pintor desconhecido». Obviamente é uma alusão a o militar desconhecido do Arco do Triunfo. Mas, ao mesmo tempo, representa algo ambíguo, absurdo porque normalmente os pintores são conhecidos. É apenas um exemplo para mostrar que não utilizo o símbolo de forma auto-evidente: são sempre fragmentados. ${ }^{264}$

264 "Ho studiato attentamente l'arte del Terzo Reich. Avevo tutti i libri. Non esiste um elemento dell'arte figurativa di quel periodo - non un solo quadro, non una sola scultura - che presenti qualque interesse. Per l'architettura è diverso. Speer era un architetto tradizionale, si è cibato dell'architettura rivoluzionaria di Boulée Ledoux e dela Bauhaus. Alcuni edifici - la maggior parte è stata distrutta, non c'è più -, come il Ministero dell'Aeronautica militare a Berlino, sono semplici e belli, dalle proporzioni esatte. Le gigantesche cattedrali di Speer non sono mai state costruite, perché erano totalmente assurde: troppo grandi, non aveva senso [...] Là dove $i$ simboli usati dal Terzo Reich sono manifesti, io li rendo sempre 
Essas obras de Kiefer comunicam exaustivamente 0 detalhe arquitetônico de suas fontes, sugerindo para elas, um futuro que os próprios projetadores dessas estruturas jamais cogitaram. Produzidas para serem ruínas monumentais, as pinturas de Kiefer cifram e começam este inesgotável destino material: camadas de tinta, palha, cinza, emulsão e outros materiais sobre uma base de fotografia. Estes materiais criam superfícies com uma camada densa e, dada a fragilidade dos materiais usados, em seguida culminam em desintegração e decadência. ${ }^{265}$ As pinturas suscitam, assim, um esquema imaginário de noturnidade e de declínio sobre o qual se consolida a idéia generalizada de negatividade. A ubiqüidade da imagem das sombras aponta ao pessimismo de uma época que tem perdido a confiança em poder restabelecer um conhecimento sobre si mesma e, assim, após o colapso das mitologias substitutivas da política, faz-se necessário um projeto de futuro definido. As trevas, a escuridão, as sombras, prevalecentes nestas estruturas, são uma referência aos recantos mais insondáveis da construção da realidade nazista desde o Romantismo, apontando a assuntos mais complexos componentes da existência, (o desejo, a memória, o medo, o delírio, o Mal) que não podem ser compreendidos com o simples recurso aos meios racionais. Como afirma Didier Soullier "com a noite surgem

ambigui, contraddittori. Per esempio, ho dipinto un edificio e sulla tela ho scritto «Monumento al pittore sconociuto». Ovviamente è un'allusione al milite ignoto dell'Arco do Trionfo. Però, al contempo, rappresenta qualcosa di ambiguo e assurdo, perchè normalmente i pittori sono conosciuti. È solo un esempio, per mostrarvi che non utilizzo mai $i$ sombolo in modo autoevidente: sono sempre "spezzati." Cf. ANDREOTTI; DE MELIS, op. cit., p. 33.

${ }^{265}$ Seria interessante destacar que essa transição pictórica do ático para as estruturas de tijolo coincide com o deslocamento do artista do seu ático em Hornbach para o galpão industrial em tijolo em Buchen. Isto, com certeza, não pretende ser uma justificativa essencialista do uso de materiais e da colocação de assuntos na produção do artista, mas trata-se de uma mudança que orientou os derroteiros pictóricos do artista. A partir de sua mudança para Buchen ele começou produzir essas pinturas alegóricas dos espaços arquitetônicos monumentais nazistas. Cf. SALTZMANN, Lisa. op. cit., p. 196. 
todas as forças que a civilização reprime para assegurar seu estabelecimento e sua continuidade". ${ }^{266}$ Estes termos são os principais constituintes do regime noturno ordenador nestas pinturas: deste modo, encontraremos uma atmosfera saturada de claroescuros, sombras, trevas e noites. Eles estão estreitamente associados a este regime pictórico descendente: ressaltam a reincidência de figuras de degradação, ruínas e morte precipitadas por uma aliança fatal entre o tempo e a imagem.

\section{B. OS HERÓIS ESPIRITUAIS DA ALEMANHA}

Os Heróis Espirituais da Alemanha (fig.42) são os mais representativos da série dos áticos e ao mesmo tempo sua conclusão. Seu título glosa o monumento de Valhalla construído por Leo Von Klenze entre 1830 e 1842. O Valhalla mitológico que cede seu nome a esse complexo arquitetural destinado a fixar a memória coletiva é a ficção poética de um monumento dedicado à memória dos guerreiros caídos em combate: o domínio celeste de Odim, deus nórdico da poesia e da guerra. O Valhalla histórico está localizado a $7 \mathrm{~km}$ a leste de Ratisbonne, em Donaustauf, o que não é sem importância quando sabemos que Kiefer nasceu em Donaueschingen, lá onde o Danúbio tem sua origem impregnando a memória que o rodeia. ${ }^{267}$ A galeria de

\footnotetext{
266 "avec la nuit surgissent toutes les forces que la civilization réprime pour assurer son établissement et sa continuité."Cf. SOULLIER, Didier. La littérature baroque en Europe. Paris: PUF, 1998, p.113.

267 Uma representação do Danúbio é elaborada como narrativa histórica e cultural da Mitteleuropa e relato autobiográfico de viagem, no livro homônimo de Claudio Magris. O livro parte de uma viagem narrativa iniciada nas nascentes do Danúbio, recorrendo um percurso através dos países fronteiriços da Europa Central e terminando no seu desaguamento, no Mar Negro. Em outros termos: as intermináveis descrições, episódios, reflexões, galerias e enumerações caóticas acabavam, ali, refluindo para uma ordem narrativa determinada pelo próprio traçado cartográfico do rio, que garante ao livro, no limite, um panorama abrangente. O narrador Magris, assim como seu duplo, o suposto viajante empírico, parece impor a si mesmo e ao leitor um ordenamento prévio que, ao fim e ao cabo, obedece ao curso do rio, acompanhando suas etapas mais ou menos
} 
honra do Valhalla abarca uma centena de bustos de soberanos, artistas, poetas, filósofos e cientistas, todos alemães gloriosamente reconhecidos. Seu objetivo principal era o de criar um arquivo nacional e de transmitir uma identidade coletiva a partir do valor supremo do espírito alemão. O panteão de Kiefer, por sua vez, difere deste em um ponto essencial: nos materiais usados. Kiefer se vale da madeira em vez do mármore. A madeira deturpa a aura sagrada e duradoura da memória monumental a ponto de ser ameaçada pelas chamas. De uma parte a outra do ático estão fixadas tochas de fogo evocando as flamas eternas que decoram os edifícios oficiais do nazismo. O fogo é o único elemento a que podemos atribuir os valores do Bem e do Mal; sendo o próprio princípio de uma possibilidade de interpretação universal. Sob o Nazismo, o fogo conduzia inevitavelmente a um estado psicológico de intensidade exaltada pela propaganda. A totalidade do espectro de valores do fogo se torna uma realidade: pathos da regeneração (culto à figura do herói) e incomensuravelmente realidade da destruição (queima de livros, Noite de Cristal, política da terra queimada, cremação das vítimas). No trabalho de Kiefer, o fogo conserva toda sua ambigüidade, aparecendo como um elemento destrutor e ao mesmo tempo alquímico. Lembremos o assunto dos dois fogos no mundo grego: o fogo da casa e o fogo da pólis. O fogo da pólis comunica com o herói fundador da cidade enquanto o fogo da casa comunica com os mortos familiares, protetores do mundo grego. $O$ fogo da pólis não corresponde diretamente ao logos argumentativo na base da democracia, porém à physis agônica e seu estado de exceção que,

relevantes, mais ou menos carregadas de historicidade, mais ou menos evocativas e memoráveis, o que por força exige certa hierarquização dos materiais narrativos que vão aparecendo a seu passo. Cada ponto espacial do percurso pelo rio representa para nós um estilhaço por um tempo não cronológico que acaba reportando à memória de Kiefer e à noção de tempo em Benjamin. Cf. MAGRIS, Claudio. Danúbio. Trads. Elena Grechi e Jussara de Fátima Mainardes Ribeiro. Rio de Janeiro: Rocco, 1992. 
de tempos em tempos, impõe seu véu de morte. ${ }^{268}$ A fonte das imagens simbólicas dos sonhos é a mesma da expressão artística. A ambivalência do elemento fogo é sublinhada por Bachelard:

Se tudo o que muda lentamente se explica pela vida, tudo o que muda velozmente se explica pelo fogo. O fogo é ultravivo. O fogo é íntimo e universal. Vive em nosso coração. Vive no céu. Sobe das profundezas da substância e se oferece como um amor. Torna a descer à matéria e se oculta, latente, contido como o ódio e a vingança. Dentre todos os fenômenos, é realmente o único capaz de receber tão nitidamente as duas valorizações contrárias: o bem e o mal. Ele brilha no Paraíso, queima no Inferno. É doçura e tortura. Forno e apocalipse. É prazer para a criança sentada ajuizadamente junto à lareira; castiga, no entanto, toda desobediência quando se quer brincar demasiado perto de suas chamas. O fogo é bem-estar e respeito. É um deus tutelar e terrível, bom e mau. Pode contradizer-se, por isso é um dois princípios de explicação universal. ${ }^{269}$

A dupla significação do fogo marca a imaginação humana: aquece e clareia, mas pode também devorar num incêndio e tudo queimar em sua passagem, o que o associa estreitamente ao sofrimento e à morte. O fogo é um elemento paradoxal, do lado positivo é, antes de tudo, o símbolo sagrado da lareira (foyer) doméstica, aquele da inspiração e do Espírito Santo que se manifestou aos apóstolos na primeira festa de Pentecostes sob a forma de línguas de fogo. Na iconografia cristã, o fogo simboliza o fervor religioso e o martírio. O fogo também está associado à civilização, como único elemento que o homem pode produzir e que o faz assemelhar-se com a divindade. Pode também ter uma ação purificadora e sagrada, assim como pode assumir função regeneradora. Para Carl Jung, ${ }^{270}$ o fogo simboliza a libido, a energia psíquica e, de certa forma, a queima simbólica de determinados aspectos, ou seja, a transmutação da energia

\footnotetext{
${ }^{268}$ Cf. COULANGES, Foustel de. La ciudad Antigua. Madrid: EDAF, 1968.

269 Cf. BACHELARD, Gaston. A psicanálise do fogo. Trad. Paulo Neves. São Paulo: Martins Fontes, 1994, p. 11.

${ }^{270}$ Cf. JUNG, Carl. Psicologia e Alquimia. Obras Completas de Jung. Vol XII. Trads. Maria L. Appy, Margaret Makray e Dora Maria F. Da Silva. Rio de Janeiro: Vozes, 1994.
} 
estagnada no que deverá ser transcendido. O fogo, na arte de Kiefer, "arde sem queimar", e através da exploração deste elemento que a memória surge e se regenera. ${ }^{271} \mathrm{~A}$ calcinatio de Kiefer equivale, na alquimia, a um processo no qual a substância é aquecida, ressecada através do fogo, e dela são retiradas as impurezas. Assim a calcinatio simboliza a energia universal que se irradia, uma energia que é excitável e lisérgica e que, através de sua luz, dá colorido ao mundo. Diversos mitos da Grécia Antiga e da Polinésia contam que o fogo era originalmente propriedade dos deuses e que o homem o roubou. São as figuras da arte de Kiefer ligadas ao elemento fogo: as cinzas, a ave fênix, Ícaro, o relâmpago, o sol, o vulcão; as tochas, as velas e as lanternas; as cinzas das fogueiras e lareiras, os fogões e os fornos. Gaston Bachelard expõe uma interessante correspondência entre a doutrina renascentista dos temperamentos e os sonhos que poderia explicar essa recorrência do elemento do fogo em Kiefer:

Os sonhos dos biliosos são de fogo, de incêndios, de guerras, de assassínios; os dos melancólicos de enterros, sepulcros, de espectros, de fugas, de fossas, de tudo quanto é triste; os dos pituitosos, de lagos, de rios, de inundações, de naufrágios; os dos sanguíneos, de vôos de pássaros, de corridas, de festins, de concertos e até mesmo de coisas que não ousamos nomear [...] os biliosos, os melancólicos, os pituitosos e os sanguíneos serão respectivamente caracterizados pelo fogo, a terra, a água e o ar. Seus sonhos trabalham de preferência o elemento material que os caracteriza. ${ }^{272}$

A fonte das imagens simbólicas dos sonhos é a mesma da expressão artística. Observar tais correlações - os elementos que surgem nos

271 Elias Canetti fala sobre a paradigmática metáfora do fogo cujas características principais confundem-se com as das massas: contagioso e insaciável, súbito e invisível. O fogo, destrutivo, pode ser domado e pode ser controlado. A meta para Canetti era criar o fogo próprio, se apoderar de sua força e crescer. O fogo do inferno e o fogo dos ímpios ardem publicamente. Cf. CANETTI, Elias apud Dymetman, Annie. A arquitetura da indiferença. São Paulo: Perspectiva, 2002, p. 20.

272 Cf. BACHELARD, Gaston. op. cit., p. 4 
sonhos e na arte - pode ser bastante útil para compreensão da pintura de Kiefer. Da terra também os homens renascerão, como faz anualmente a vegetação, conforme os ciclos das estações. Em Kiefer a terra é considerada a origem de toda a fecundidade da riqueza que dela decorre. A operação alquímica associada a este elemento é a coagulatio que transforma as coisas em terra. A terra é pesada e permanente, a terra tem forma e posição fixas. Não desaparece no ar por meio da volatilização, nem se adapta facilmente à forma de qualquer recipiente, ao contrário da água. Sua forma e localização são fixas; assim, para um conteúdo psíquico, tornar-se terra significa concretizar-se numa forma localizada particular - isto é, tornar-se ligado a um ego. O processo de materializar as imagens (mater, matéria), os conteúdos internos do indivíduo é um processo de coagulatio, é coagular o material que vem da alma. Elaborar as imagens, partilhar seu significado, traduzir o trabalho artístico para outras linguagens como a pintura de Kiefer, atribuir-Ihe conceitos e abstrações, já são atividades que pertencem a outra etapa da Opus alquímica, a sublimatio. As imagens de Kiefer estão vinculadas à terra: a floresta, a montanha, as rochas, as pedras preciosas, as sementes, as paisagens queimadas.

Na pintura Os Heróis Espirituais, o fogo de dez tochas ilumina treze heróis - cifra tão semanticamente ambivalente como o fogo, ora benéfica, ora maléfica, conforme o caso. Nomes estão inscritos em carvão ao pé de dez abóbadas em madeira. Ficamos em companhia de quatro artistas (Joseph Beuys, Caspar David Friedrich, Hans Thoma, Arnold Böcklin) seis escritores (Richard Dehmel, Josef Weinheber, Adalbert Stifter, Niklas Lenau, Theodor Storm, Robert Musil), um Imperador (Federico II de Prússia), de um místico (Mechthild von Magdeburg) e um compositor (Richard Wagner). O escritor Weinheber (1892-1945) e o pintor Beuys (1921-1986), propuseram seus serviços ao regime nazista - o primeiro como poeta nacional e o segundo como soldado da Wehrmacht. Três deles podem 
ser considerados como precursores ideológicos do nazismo: Wagner, pela sua concepção política da obra de arte total, seu culto à pureza do sangue e seu anti-semitismo redentor, o escritor Dehmel, por seu internacionalismo sob a dominação alemã e Federico o Grande, por seu militarismo. Quanto aos pintores românticos, foram objeto de um supra-investimento nacionalista da arte destinada a compensar a ausência de tradição e de unidade política. Perguntamo-nos se estes esboços são razões suficientes para ler o panteão de Kiefer como um panteão dos heróis do nazismo. Algum denominador comum, ora ideológico ora temático, alguma combinação cronológica não confederaria estes nomes? A grande elasticidade psicológica que Kiefer Ihes confere à superposição de temas nos convida a pesquisar as filiações inexistentes ou a nos engajar com falsas pistas para induzir a problematização de uma idéia de nação fundada a partir de uma lista de heróis. Nesta série de Kiefer, discutida por Huyssen - o crítico convoca três estágios de reflexão: como Kiefer foi seduzido pelo prazer visual de suas obras, se ele realmente estava fascinado por esse fascinante fascismo $0^{273} \mathrm{e}$, finalmente, se pergunta se Kiefer

273 O conceito de fascínio tem suas raízes no romantismo, no trabalho de contadores de histórias, literatos, compositores e artistas plásticos, para assinalar a ambivalência e a ambigüidade das comunicações passionais. Por meios estéticos, eles se esforçaram em manter esta delicada linha demarcatória, para além da qual o prazer pode transformar- se em nojo, a compaixão em cólera, a alegria em sobressalto. Esse conceito também invoca o conceito de fascinating fascism acunhado por Susan Sontag, que foi um das primeiras articulações relacionadas com o fascínio que as pessoas mostram pelo fascismo e suas estratégias visuais. O trabalho de Susan lida com dois artistas em particular: Leni Riefenstahl e Hans Jürgen Syberberg. O universo de referências visuas de Syberberg tenta reconstruir a tradição fazendo uma arqueologia imaginária do passado nazista. Como diz Sontag, "Syberberg inspira-se nas fontes estilísticas mais disparatadas: Wagner, Mélies, as técnicas de distanciamento brechtianas, o barroco homossexual, o teatro de marionetes." Os motivos de montagem empregados pelo diretor lembram a idéia benjaminiana de surrealismo: um romantismo que pressupõe um mundo fraturado ou póstumo, ao qual só se pode aceder por meio de uma alegoria ou uma ironia dramática. Desse modo, Kiefer também interroga o mito. A teatralização farsesca do horror faz materiais como o chumbo, a pedra, o arame, a palha, a areia, o aço, a argila, conviverem com histórias, mitos, fábulas, poesia, filosofia, 
verdadeiramente quis nos confrontar com os nossos próprios recalques correspondentes à esfera imagética fascista. Além desta dinâmica de reevocação da estética do fascismo e a contemplação de sua sedução, foi ela precisamente a tentativa do pintor:

Os edifícios que eu pintei estavam conectados com a criminalidade, com o poder [...] Nessas primeiras imagens, eu queria evocar a questão para mim, Sou um fascista? Não se pode responder rapidamente. Autoridade, a competição, a superioridade [...] essas são facetas tão minhas quanto de qualquer outro. Você deve escolher o caminho certo. Para dizer eu sou uma coisa ou outra é demasiado simples. Queria pintar a experiência e a resposta.). ${ }^{274}$

Esta afirmação sugere que a tentativa de Kiefer de evocar e contemplar a estética e a atração dela pelo fascismo, pode ser assumida como uma crítica. Com certeza, isto não o deixa fora da fascinação. A eficácia dessa tentativa artística, embora seja

paisagens, florestas, áticos mausoléus, o que pode se chamar, em termos de Georges Didi-Huberman, "um anacronismo das imagens". Para Sontag o filme de Syberberg representa "uma escatologia do Mal e se desenrola numa espécie de fim dos tempos, num tempo messiânico que impõe o dever de tentar fazer justiça aos mortos."A perturbação suscitada pela recepção do filme de Syberberg assemelha-se ao incômodo suscitado pela obra de Kiefer. Ambas as provocações confundiram intencionalmente tragédia com afirmação do crime. A volta de Kiefer aos cenários em ruínas e sua alusão ao passado nazista como fonte protéica do Mal, através da qual delineam-se quantidades de filiações, das quais todas se garantem em fundamentos. Tanto Syberberg quanto Kiefer a partir de fragmentos de história e de ficção, arrebentam radicalmente o uso da alegoria, para transmitir experiências estéticas inspiradas no passado nazista. Cf. SONTAG, Susan, "Fascinating Fascism," In: SONTAG, S. Under the sign of saturn, New York: Farrar, Straus, Giroux, 1980; Cf. BAZON, B. op. cit., p. 17; Cf. DIDI-HUBERMAN, Georges. Devant le temps. histoire de l'art et anacronisme des images. Paris; Minuit, 2000, pp. 9-55; Cf. CANGI, Adrián. "Imagens do horror. Paixões tristes." In: SELIGMANN-SILVA, Márcio. História, Literatura e memória. O testemunho na era das catástrofes. pp.141-172.

274 "The buildings I painted were connected with crime, with power [...] In those early pictures, I wanted to evoke the question for myself, Am I fascist? You cannot answer so quickly. Authority, competition, superiority [...] these are facets of me like everyone else. You have to choose the right way. To say I'm one thing or another is too simple. I wanted to paint the experience and the answer ". Cf. MADOFF, Steven. op. cit., p. 129. 
amplamente conhecida, é altamente questionável. Ainda mais, essas revogações têm uma dupla face: elas podem afirmar a estética originária do fascismo nazista, mas também podem ser ensombrecidas pelo fascínio suscitado pelo espetáculo lutuoso do nazismo. Como Huyssen estabelece: Haveria outra forma que não a citação obsesiva para Kiefer poder conjurar a atração do que já uma vez cativou a Alemanha e não foi assim assumida? ${ }^{275}$

Se pensarmos no estudo dos Mitscherlich, através da negação e desrealização do passado, assim como outros mecanismos de defesa psíquica, os alemães efetivaram certa clausura de seu passado nazista, é esta negação coletiva que permanece como escolho de seu processo de luto. Pela citação obsessiva da estética de atração do nazismo, Kiefer induz ao espectador dentro do que para muitos alemães tem promovido algumas das atrações originárias do nazismo. Seu trabalho nos faz ir além da negação para confrontar as memórias desgarradas do nazismo. Confrontando a cultura alemã com suas representações de perda do objeto amoroso coletivo - e, portanto, com identificações que tem sido negadas e não assim superadas - Kiefer corre o risco de fortalecer a disposição melancólica dos alemães pelo fascismo em vez de combatê-la. Como Huyssen sugere, para que estas obras funcionem efetivamente como críticas para os espectadores que: "que é capturado numa trama complexa de melancolia, fascinação e repressão", deve haver algo entre elas que quebre a imediatez visual da imagem, algo que produza um efeito de estranhamento, para permitir a reflexão crítica. ${ }^{276}$ Também deve ser notada a função da atração, ela precisa ser suficientemente forte para seduzir ao espectador, imantando-o perto de uma

275 How else through obsessive quotation could he [Kiefer] conjure up the lure of what once enthralled Germany and has not been acknowledge, let alone properly worked through? Cf. HUYSSEN, Andreas, op. cit., p. 145.

276 "who is caught up in a complex web of melancholy, fascination and repression". Cf. HUYSSEN, Andrea. op. cit., p. 157. 
cumplicidade; o espectador deve experimentar a atração original antes de reconhecer suas implicações.

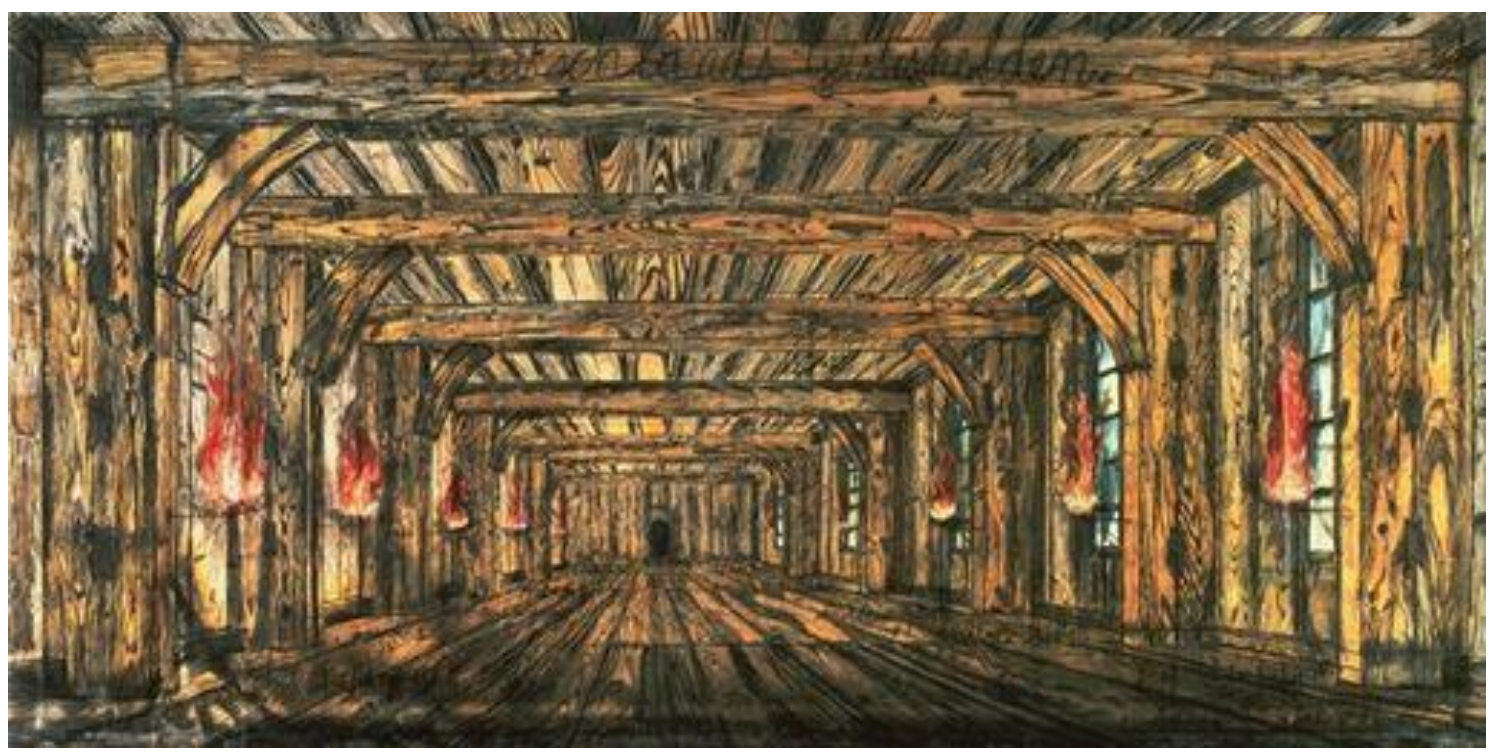

Figura 42. Os heróis espirituais da Alemanha/ Deutschlands Geisteshelden, 1973. Óleo e carvão em serapilheira s/tela de fibra. 307 x $682 \mathrm{~cm}$. Coleção de Barbara e Eugene Schwartz, Nova Iorque.

Podemos interpretar os Heróis de Kiefer como uma ilustração de uma das teses deterministas do pós-guerra para explicar o nazismo. Uma das filiações causais mais utilizadas era a linha que ia de Lutero a Hitler, passando por Federico II, Bismarck e Nietszche. Esta interpretação da história, aquela que Thomas Mann retrata no seu romance de 1954, O Doutor Fausto, transforma o herói de ontem em anti-herói contemporâneo: o que continua fundando a história alemã sobre a interpretação metafísica apoiada no valor compensatório do espírito alemão, responsável pela catástrofe histórica. Os heróis espirituais da pintura de Kiefer são eles realmente heróis da morte? O escritor austríaco Robert Musil (1880-1942), grande opositor do nazismo, reabilita o anti-heroismo contra toda noção romântica de herói espiritual, o que parece definitivamente contradizer a idéia de uma filiação causal heróica. As imagens que Hitler adotou para a execução da sua propaganda provinham do acervo cultural do Ocidente, da tradição greco-romana, cristã, dos mitos, tradições, 
rituais e símbolos da cultura germânica. O sentido transfigurador designado aos valores da morte e do sofrimento, a meta transcendental do sacrifício do herói como promessa de alcançar a salvação foi redimensionada pelos planos políticos do Nazismo. Contudo, lembremos que o regime nazista não foi único a utilizar a retórica do sacrifício heróico para avançar uma campanha ideológica de legitimação da opressão e da violência. Em toda a história européia, soberanos de todos os regimes têm empregado práticas e padrões sacrificiais religiosos para consolidar a identidade coletiva, motivando, assim, a violência. ${ }^{277}$

\section{DÉTRUIRE: DIT LILITH}

Ruínas, cujos destroços se destacam contra o céu, aparecem às vezes duplamente belas em dias claros, quando o olhar encontra em suas janelas ou à cabeceira as nuves que passam. A destruição fortalece, pelo espetáculo perecível que abre no céu, a eternidade desses destroços.

Walter Benjamin.

O trauma da fundação representa o complexo patológico que tem dominado a história da cidade. ${ }^{278} \mathrm{~A}$ imagem da cidade prevalece ante as dimensões pragmáticas exigidas por ela, o que constata mais a representação da cidade antes do que seu próprio ser. Este complexo pode ser identificado a partir dos mitos fundacionais do mundo antigo até à pólis contemporânea do marketing urbano, a partir da arquitetura monumental das metrópolis antigas até a contemporânea cidade do espectáculo. ${ }^{279}$ Kiefer torna-se guia da

277 Cf. GIRARD, René. A violência e o sagrado. Trad. Marta Conceição Gambini. São Paulo: UNESP, 1998.

${ }^{278}$ Cf. GAMARRA QUINTANILLA, Garikoitz. op.cit. pp. 20- 50.

279 Guy Debord descreveu visionariamente, na Sociedade do espetáculo: "a cultura tornada integralmente mercadoria deve também tornar-se a mercadoria vedete da sociedade espetacular". Nas considerações de Otília 
expedição sobre São Paulo, se colocando no plano de herói-demiurgo transbordado pela sua hybris, dominado pelo seu instinto, pela intuição do Mal. Benjamin reconhece a queda do paraíso como o momento de conhecimento do Bem e do Mal. No Drama Barroco ele conclui que o Mal absoluto - cuja figura é encarnada pelo demônio é uma projeção da inteligência cristalizada e isolada pela melancolia. O Mal absoluto nasce porque é o suficientemente potente para materializar na região da vida cotidiana suas tramas. Kiefer não tem que descer ao inferno para compreender o Mal, seu olhar sereno às fontes da matéria o leva a projetar imaginariamente as fontes do medo: o Mal imaginário, a antítese do Bem.

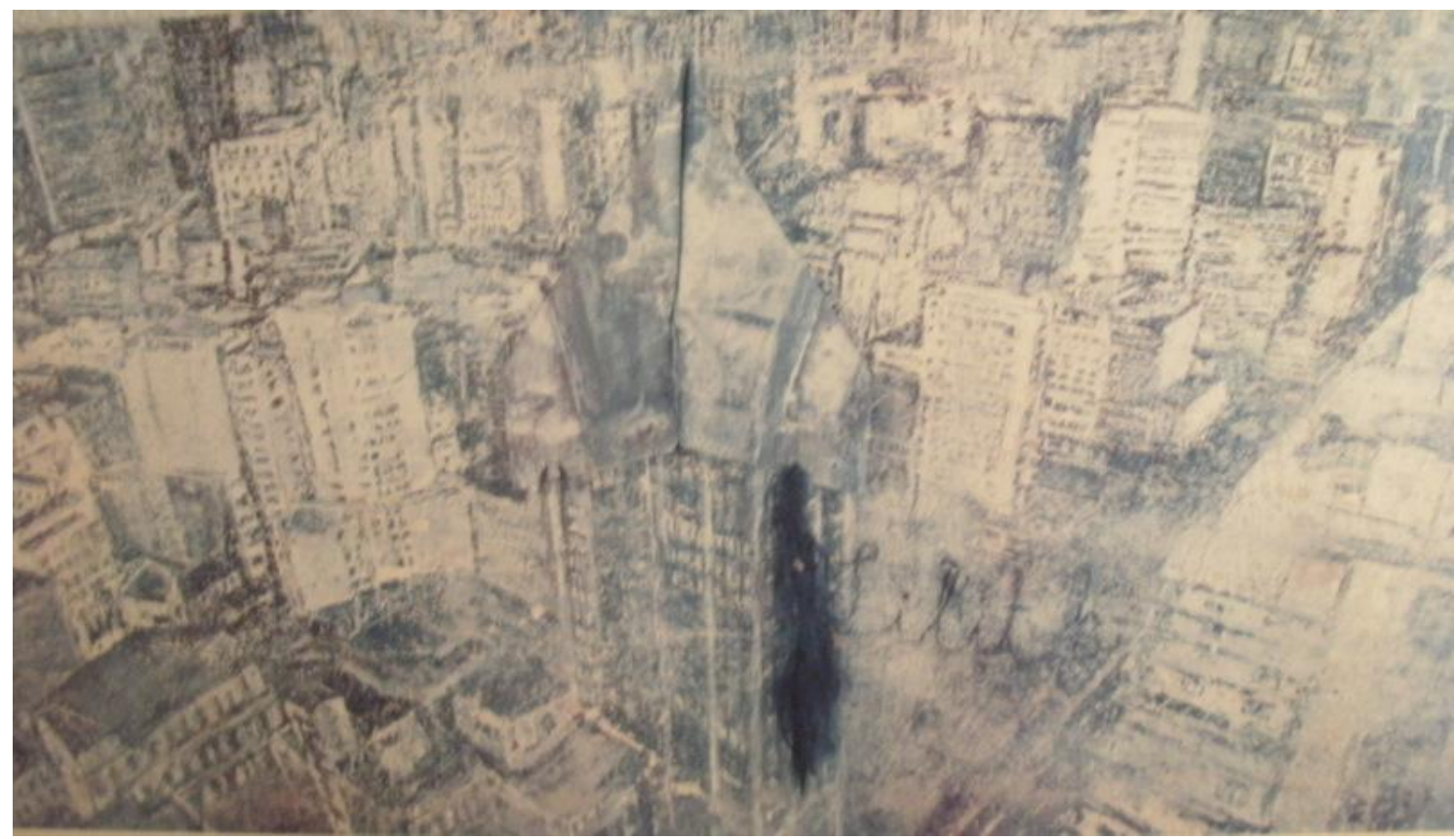

Figura 43. Lilith, 1997. Técnica mista, 131 x 272 cm. Coleção do artista.

Arantes, a realidade, então, torna-se reflexo dos contrabandeios do capital que, na sua quintessência, representa a inflação hiperrealista do mundo das imagens, mas é clara a reversibilidade de um no outro - o mundo do dinheiro e o da cultura - já que o capital ou a riqueza financeirizada é ela mesma um inchaço de ficção ou uma inflação rentista de ativos. Cf. DEBORD, Guy. A sociedade do espectáculo. Trad. Estela dos Santos Abreu. Rio de Janeiro: Contraponto, 1997; Cf. ARANTES, Otília Beatriz Fiori. "A virada cultural do sistema das artes". São Paulo, Abril 2005; Cf. SELIGMANN-SILVA, Márcio. "San Pablo: El inconsciente óptico de la ciudad. Sobre las fotografías de Carlos Goldgrub." Punto de Vista 85, Agosto 2006, pp.12-15. 
O temor e a ameaça paralogizam a razão engendrando monstruos. A implicação do Mal real supõe a dissolução do Mal imaginário. A dupla natureza dos heróis fundadores (Lilith e o Anjo da História) (fig. 43) anuncia a ambigüidade mítica que os constitui. A condição desproporcionada da cidade de São Paulo, simultaneamente sobre-humana e infra-humana, e do herói primordial é precisamente o que permite levar o trânsito impossível entre natureza e cultura, fundar a cidade onde apenas há desordem (separação entre caos e cosmos supõe a relembrança nas fontes do Cosmos e da Magna Mater), entregar o Anjo da História à nuvem de pó que encobre a cidade. ${ }^{280} \mathrm{Na}$ cidade está presente não apenas o medo do artificial

${ }^{280}$ As travessias do pó pela história alegórica ocidental tem sido muitas e variadas. A partir do indício físico da criação do primeiro homem, está ligado à origem, à matéria e à passagem do tempo e à destruição das cidades nas fontes antigo-testamentárias, aos amargos fragmentos que persistem como sinais da dor que supõe o avatar humano na poesia metafísica e amorosa de Francisco de Quevedo, Amor constante más allá de la muerte: "Su cuerpo dejará no su cuidado;/ serán ceniza, mas tendrá sentido;/ polvo serán, mas polvo enamorado". Essa imagem poética do póareia também será recorrente na modernidade poética de Blake e nos modernismos em T.S Eliot e Ezra Pound, aparecerá o pó como essa imagem alegórica que tem uma estrutura serial, uma repetição que faz desvanecer a aura do único e, no entanto, se encontra em relação perfeita para captar plenamente a subjetividade, e com ela seus motivos mais ocultos, suas intenções mais secretas: Ética e estética do tempo. Um tempo ético e estético quando quebrado se torna pó, o que alude a nossa origem ruinosa, essas cidades que se tornam pó por causa da fúria da divindade. O pó determina a passagem do tempo mas também insere o trabalho de Kiefer na história. O acúmulo de detritos, a materialidade do tempo ruínoso, essa passagem aérea tão melancólica e tediosa quanto a poeira. Ambas as sensações falam do abandono de que trata a pintura. Para Olgária Matos, o tédio é contemporâneo da filosofia do progresso, do pensamento que aboliu milagres da Bíblia e irradiou o Mal entre os homens, mas também, em conseqüência das transformações culturais e da visão de mundo mecanicista de estilo cartesiano, "desvalorizou as coisas criadas, silenciando a natura loquax, instituindo o reino de objetos mortos e regras arbitrárias em um mundo sem esperança de salvação". A poeira é análoga ao tédio, como afirma Benjamin, no capítulo, "Tédio, eterno retorno", do livro das Passagens. A poeira que sufoca o passado alerta sobre o sentido perdido, que parece anacrônico em meio a uma lisérgica emergência de uma cidade decidida a mostrar seus lados mais modernos. Os edifícios estão compostos de areia e ao mesmo tempo sempre estão ameaçados de se tornarem pó, por causa de uma catástrofe natural, por uma implosão, por um abandono, por uma explosão, sempre estão sob ameaça de desmoronamento. Para 
mas também o medo da mudança. Se trata do medo da perda da identidade, da perda do humus, ou seja, o medo imemorial do tempo e sua expressão mais absoluta, a morte. A cidade é o maior invenção de todos os artifícios humanos, a retícula que amontoa todos os recursos ténicos. Kiefer tenta colocar a cidade de São Paulo no tempo dos heróis míticos. São eles as testemunhas da origem natural e ao mesmo tempo divina da cidade. Kiefer pinta sobre duas vistas aéreas da cidade de São Paulo a partir do edíficio Copan, projetado por Niemeyer. Dessas impressões vieram as imagens que ele usou para as telas Lilith e Paisagem Árida. ${ }^{281}$ No entanto, a cidade fundada pelo anjo exterminador não representa a pólis da simetria entre os cidadãos. A fundação da cidade como casa de justiça frente ao reino natural, não conclui até a morte do herói-demiurgo, seu enterro é o último passo do rito de fundação. O trauma da fundação de uma doença da psique coletiva, uma espécie de compulsão à repetição na qual o acontecimento fundacional, não assimilado, regressa uma e outra vez. Presa neste estádio primitivo, a cidade vive obstinada em fixar suas bases simbólicas mínimas. Poderíamos dizer que a sociedade assombrada pelo trauma de fundação não tem logrado enterrar o tirano, razão pela qual vive em um estado de exceção

Georges Bataille, a poeira está associada com ambientes que trariam lembranças assombradas, espaços decadentes, abandonados (velhos quartos e áticos como em Kiefer). A poeira é indesejada, é lembrança da nossa melancolia. O pó também poderia representar a imobilidade no Mal, esse tempo dominado pelo tédio, um dos avatares do inferno, sentimento de esgotamento no espaço cristalizado e em um tempo empoçado, abandonado melancolicamente no pó, no reboco de cal, cinzas e uma costra misturada com pó de carvão. Cf. MATOS, Olgária Chain Féres. "Baudelaire: antíteses e revolução". Alea, vol. 9, num. 1, Junho-Agosto 2007, p.91. Cf. NOGUEIRA, Cristiana. A impermanência do processo: poeira, caminhos, objetos. Dissertação de Mestrado apresentada ao programa de pósgraduação em Artes da Universidade do Estado de Rio de Janeiro, 2009, pp. 22-29. Cf. BENJAMIN, Walter. Passagens. Willie Bolle (org.). Belo HorizonteSão Paulo: UFMG, Imprensa Oficial, 2006, p. 143.

281 Foi em maio de 1998 que realizou-se, no Museu de Arte Moderna de São Paulo, MAM, uma exposição de Anselm Kiefer, da qual fariam parte imensas telas com imagens de São Paulo. Kiefer confrontou o espectador com as alucinadas paulistanas perspectivas aéreas em Lilith de 1987 e Paisagem Árida de 1986/91. 
permanente, às expensas de que esse Estado a defenda de Lilith $e$ suas filhas que a assediam constantemente. ${ }^{282}$

Walter Benjamin enfrentou o problema da experiência do moderno tomando o urbano e a experiência da cidade da multidão como campo privilegiado de elaboração crítica. Seu livro Passagens devia ter sido uma análise conclusiva da pré-história do capitalismo moderno através do exame do Paris pela qual circulava Baudelaire. Contudo, não se pode determinar um sistema conceitual completo na aventura benjaminiana em relação com o urbano - tanto pela sua truncada interrupção como pelo próprio carácter de sua obra -, mas podemos reconstruir uma estética urbana, ou seja, como teoria da sensibilidade na cidade, por meio dos escritos de Benjamin. Pensamos que se a civitas malum (São Paulo), está dominada pelo

282 Na sua oitava tese "Sobre o conceito de história," Walter Benjamin escreve: "A tradição dos oprimidos nos ensina que "o estado de exceção" no qual vivemos é a regra. Precisamos chegar a um conceito de história que dê conta disso. Então surgirá diante de nós nossa tarefa, a de instaurar o real estado exceção; e graças a isso, nossa posição na luta contra o fascismo torna-se-á melhor. A chance deste consiste, não por último, em que seus adversário afrontem em nome do progresso como se este fosse uma norma histórica. O espanto em constatar que os acontecimentos que vivemos "ainda" sejam possíveis no século XX não é nenhum espanto filosófico. Ele não está no início de um conhecimento, a menos que seja o de mostrar que a representação da história donde provém aquele espanto é insustentável." Benjamin nos fala que na mesma história há duas leituras. Por um lado, temos as filosofias da história chamadas progressistas porque colocam o progresso como único objetivo da humanidade, o que as caracteriza é um optimismo militante acompanhado pelo convencimento que estamos caminhando em direção a melhores estágios de desenvolvimento, embora os preços que tenhamos que pagar e as catástrofes que precisemos superar por esse progresso sejam os mais altos. É a história dos vencedores abarrotada de figuras heróicas e geniais. Para esta história o negativo é excepcional, provisório e menor. Que precisamos entender por excepcionalidade? Essa parte da realidade que é submetida ao regime de um Estado de exceção. Por outro lado, está a leitura dos oprimidos, para eles o Estado de exceção é a regra. Sob o nome genêrico dos oprimidos se nomeia aos que subvencionam o progresso dos vencedores. $O$ que Benjamin demanda, uma vez estabelecida a tese de que para os oprimidos o Estado de exceção não é nenhuma excepcionalidade porém a regra, é que há que construir uma interpretação da história que se equalize com essa realidade. $O$ sucesso da universalidade mantida pelos vencedores estabelece-se acima do conceito de excepcionalidade. 
trauma da queda, a civitas bonum, está dominada pelo trauma do urbano (Brasília seria seu exemplo), assim tal como o compreendem pensadores sobre a cidade moderna desde Georg Simmel, passando por Henri Lefebvre, David Harvey, Marshall Berman, Manuel Castells, Richard Sennet e Lúcio Costa. ${ }^{283}$ Walter Benjamin, por seu turno, permite-nos fazer a transição dos conceitos sociológicos ou antropológicos do urbano para o conceito filosófico de estética urbana. ${ }^{284}$ Podemos reconhecer a sintomatologia do trauma de fundação nos dispositivos que reforçam de forma neurótica a identidade da cidade através de sua imagem: nas barreiras que limitam a área simbólica e na sua arquitetura monumental que

283 Cf. CASTELLS, Manuel. A cidade informacional. Madrid: Alianza, 1993 e La cuestión urbana. Madrid: Siglo XXI, 1974; Cf. LEFEBVRE, Henri. El derecho a la ciudad. Madrid: Alianza, 1969; Cf. SIMMEL, Georg. "Las grandes urbes y la vida del espíritu". In: SIMMEL, Georg. El individuo y la libertad. Barcelona: Península, 1998.

284 Cabe lembrar que Benjamin se aproxima do moderno a partir de sua leitura de Baudelaire: "A modernidade assinala uma época; designa, ao mesmo tempo, a força que age nessa época e a que aproxima da antigüidade."O moderno comparece sempre em sua remissão ao antigo, porque ele convoca permanentemente a lonjura exótica do espaço e do tempo, como ocorre com a arquitetura modernista. O modernismo arquitetônico para Benjamin é, de alguma maneira, a base para a formulação da categoria do moderno benjaminiana. A antigüidade na qual se reflete o moderno não alude às figurações gregas, senão à romana com sua maquinação e suas chacinas de poder e muito sangue; a antigüidade romana arruinada e labiríntica representada por Piranesi, esse barroco tardio, talvez um romântico avant la lettre, a casa do mito, mas também a casa falling apart, ou seja, em ruínas, se conseguimos interpretá-la a partir do olhar do alegorista ou do fazedor de emblemas. Sob a correspondência harmoniosa que Baudelaire registra entre moda e antigüidade - o antigo e o moderno se recriando no mais transitório, na moda podemos encontrar sua cotrapartida dialética. "A modernidade é o que fica menos parecido consigo mesmo; e a antigüidade - que deveria estar nela inserida apresenta, em realidade, a imagem do antiquado." O moderno se sente contemporâneo da antigüidade porque compreende a história a partir de uma concepção mítica, e seu conceito interno de progresso e o eterno retorno estão estreitamente vinculados. O conceito benjaminiano do urbano está totalmente avivado por esta concepção crítica do moderno e o historicismo. Cf. BENJAMIN, Walter. "Paris do Segundo Império: A modernidade." Baudelaire, um lírico no auge do capitalismo. Vol. III. São Paulo: Brasiliense, 1997, pp. 84-90. 
deturpa os sentidos. Na civitas malum a imagem oculta o corpo, e a doença torna-se, por definição, totalitária.

A cidade tem sido pensada pela filosofia como o lugar da política. A partir do Iluminismo, se refletindo no espelho grego, existe o clamor pelo princípio de cidadania, pois determinada tradição moderna tem identificado o sujeito político com o cidadão. $O$ fato cívico localiza-se no centro dos idéarios políticos, tornando-se fonte de direitos e deveres, núcleo das constituções democráticas contemporâneas. No entanto, paralelamente a esta hegemonia política do cívico, tem-se produzido um fenômeno de estetização das cidades contemporâneas. Walter Benjamin considerou esse fenômeno no qual a cidade se estetiza e o paradigma urbano transforma-se no fetiche. O urbano estetizado compensa a ausência da política na cidade, declarando a ausência da Pólis. ${ }^{285}$ Assistimos um fenômeno de translação: onde deveriamos ter cidade, existe apenas uma imagem da cidade, uma fantasmagoria urbana. Consideramos o urbano como o modo de vida que nasce da cidade laica moderna: certo frenesi cotidiano, aquela ocupação do espaço que improvisa constantemente, reiventando todas as tradições. Se falávamos que, para a filosofia, a cidade tem sido tradicionalmente o lugar da política, não é menos certo que quando se trata de pensar a cidade não é a política e, sim, a arte o termo que vem ao nosso encontro. Cidade e arte, cidade e arquitetura, cidade e cinema, são binômios que vêm ocupar o lugar da díada cidade e política. ${ }^{286} \mathrm{~A}$ cidade representa, para a sensibilidade contemporânea, paisagem urbana mais do que Ágora, objeto de contemplação, mais do que de uso,

285 A oposição que se estabelece neste tipo de discurso foi a que Hannah Arendt soube identificar na pólis clássica por exemplo. Cf. A condição humana. Trad. Roberto Raposo. Rio de Janeiro: Forense-Universitária, 1983; Cf. SCHULZ, Sônia H. Estéticas urbanas: Da pólis grega à metrople contemporânea. Rio de Janeiro: LTC Editora, 2007.

286 Cf. PEIXOTO, N. B. Cenários em ruínas. A realidade imaginária contemporânea. São Paulo: Brasiliense, 1987. 
segunda natureza, mais do que cultura. ${ }^{287}$ Contudo, trata-se de uma natureza desvinculada, uma alteridade que oscila agonicamente entre traços maléficos e pormenores sublimes.

O espaço construído e que nos constitui, representa a matriz simbólica de nossa experiência. Cidade e arte são termos correlativos a este espaço: aprofundam em seu duplo sentido de habitat e abismo. A cidade é, por um lado, a coleção disrítimica de narrativas e imagens, a atmosfera reconhecível que nos protege do nonsense que emerge do espaço e, por outro lado, mostra- nos, não apenas o passível de ser demostrado, mas também oculta as suas próprias sombras se sujeitando a essa ameaça ou essa salvação que vem sobrevoando que é o Anjo da História, mas que também é Lilith. Mas, ao mesmo tempo, a lógica complexa da cidade da multidão desloca suas próprias auto- imagens, a contingência torna-se lei e o abismo do espaço estaleja constantemente como um frenesi de possibilidades: a cidade de Lilith queima as tradições, ridiculiza as instituções, retira as máscaras. Lilith, imagem-movimento, é a melhor cúmplice da cidade, a complexidade e o inesperado são sua matéria prima, o que na imagem pictórica permanece oculto, enfia-se pelas margens do fotograma. ${ }^{288}$ Finalmente este jogo de

287 Cf. VERNANT, Jean-Pierre. Mito e pensamento entre os gregos. Trad. Haiganuch Sarian. São Paulo: Paz e Terra, 1990.

288 O nome de Lilith aparece uma vez no texto bíblico em Isaías 34, 14-17. A passagem faz referência à futura devastação de Édom, por causa das condições de Israel, quando Deus jogou seu poder sobre este povo. O contexto na profecia é a predicação de que a terra dos Moabitas se tornará um deserto desolado. A palavra no texto em Hebraico aqui é Lilith mas infelizmente ela é um hápax legomenon (uma palavra que aparece apenas uma vez). Tarefa de exegetas será a de determinar seu significado por comparação com outros usos na Bíblia. Fontes de tradição hebraica interpretam o fragmento: "os sátiros chamarão os seus companheiros" (a palavra hebraica aqui traduzida como "Sátiros" é "se'ir") está-se falando em Samael e outros demônios. Depois aparece a companheira dele: "Ali descansará Lilith". Em seguida fica a sentença de que a terra de Édon - a que se referia todo o texto - seria a futura morada dos demônios e daqueles animais considerados impuros "eles a possuirão para sempre". A tradução "criaturas da noite", que aparece em algumas versões para outras 
desconstrução nunca é suficiente sem o jogo simultâneo de reconstrução, de resgate da imagem e do mito.

Kiefer não só nos remete ao conceito do espaço, mas também nos defronta com o conceito do mito. O mito aparece no pólo oposto do espaço entendido como matriz e abismo. O mito é o lugar da

línguas, representa uma conjetura, uma tentativa de ler Lilith com base em sua similaridade com a palavra hebraica e árabe "laylah" (noite). As tradições exegéticas sobre Lilith fazem este vínculo etimológico particularmente desde que uma de suas figurações é como succubus, e ela foi muitas vezes associada com corujas, como nesta passagem. Se formos comparar as diversas versões e traduções da Bíblia atual, descobrimos que em muitas delas Lilith não aparece em Isaías 34: 14-15. A diferença entre a tradução da Bíblia de Jerusalém e outras refere-se a uma diferença fundamental na tradução filosófica da Bíblia. Algumas versões tem uma tradução programada, pretendem naturalizar algumas referências de criaturas mitológicas ou sobrenaturais, exceto anjos, substituindo-as por animais conhecidos. Por exemplo, pode-se encontrar Bíblias que traduzem 'leviathan' como "crocodilo". Mas o problema de Lilith é ainda mais complexo daquele de leviathan, pois este ganha descrições bastante acuradas nos capítulos 40 e 41 de Jó. Leviathan é mencionado algumas vezes (Jó 3:8; Jó 41:1; Salmos 74:14; Salmos 104:26 e Isaías 27:1). Aqui seria interessante consultar a leitura de René Girard em seus livros $A$ violência e o sagrado e $O$ bode expiatório e ver o decupamento etimológico que faz o estudioso das palavras sacríficio e bode. Note-se que as traduções também diferem na tradução de 'se' $i r^{\prime}$ - isto é um bode ou um bode/demônio/sátiro? O significado de 'se'ir' tem sido determinado pelo significado de "Lilith". Se Lilith é uma demônia, então 'se'ir' deve ser alguma espécie de demônio. Por outro lado, se Lilith é algum tipo de animal indeterminado, então "se'ir" é um bode. A tradição judaica, bem entendido, aponta- nos na direção da criatura mitológica. Um fragmento da antiga comunidade de Qumran contendo menção de Lilith foi encontrado nos Manuscritos do Mar Morto. Esta passagem é claramente baseada em Isaías 34:14 e pode ajudar a compreender o real significado do texto: " $E E u, O$ Instrutor, proclamo a majestade de seu esplendor a fim de assustar e aterrorizar todos os espíritos dos anjos da destruição e os espíritos bastardos, demônios, Liliths, corujas e chacais [...] e aqueles que atacam inesperadamente para desviar, desencaminhar o espírito de conhecimento [...]." De toda esta história de Lilith pode-se dizer apocrifamente o que Jorge Luis Borges afirmou de Emma Zunz: "La história era increíble, en efecto, pero se impuso a todos, porque sustancialmente era cierta [...]; sólo eran falsas las circunstancias, la hora y uno o dos nombres propios." Cf. BORGES, J. L. "Emma Zunz." In: BORGES, J. L. El Aleph. (1949). Obras completas. vol. I. Buenos Aires: Emecé, 1996, pp. 564-568; Cf. WARNER, Marina. Monuments and maidens: the allegory of the female form. New York: Atheneum, 1985; SCHWARZ, Howard (ed.) Lilith's cave: jewish tales of the supernatural. New York: Oxford University Press, 1998. Cf. Bíblia de Jerusalém. São Paulo: Paulinas, 1985. 
identidade, da imagem fixa e da imediatez do sentido. Na relação entre cidade e mito dirimi-se o momento de perigo da cidade de São Paulo: sua provável queda e sua única esperança de salvação. No seu sentido negativo Lilith penetra a cidade, tornando-a regressiva. 0 mito arrasta a própria linguagem na sua espiral de fatalidade, sua lei é a da imagem interior, a totalidade sem fissuras. Lilith obedece a esse momento negativo do mito: a cidade, São Paulo, é monumental. Contudo, ao contrário do que poderia parecer a superação deste cenário mítico-imaginário não está no seu oposto, no real urbano: o imaginário e o real são cúmplices do mesmo crime, o do silêncio do sentido. Localizamos o remédio desejável na sutura simbólica do Anjo da História, na sua trama narrativa, o que não implica se desfazer do mito, senão fazê- lo entrar em razão. Como Alberto Tassinari observa:

Diferente de outros temas de Kiefer, Lilith não é um mito em que à queda se segue uma regeneração. Lilith não tem salvação, e tudo que se pode fazer é evitá-la por meio de rituais de proteção. Em sua recusa em retornar ao paraíso, a que teria sido a primeira mulher de Adão abraça o mal, é mesmo a própria figura do mal, toma formas humanas para atingir seus fins, penetra o sangue das crianças. ${ }^{289}$

A Lilith de Kiefer apresenta-se ante nós como o paradigma do que podemos identificar como imagem-sonho. ${ }^{290} \mathrm{Na}$ estrutura narrativa da pintura podemos reconhecer a dupla face do mito: mito como sonho, mito como pesadelo. O primeiro momento do mito sintetiza-se na imagem da cidade como paraíso perdido: O Anjo da História tenta regressar à comunidade primordial com a natureza em sua fuga desesperada da cidade. A cidade, por sua vez, representa a negatividade do mito: a femme fatale emerge das trevas com a ambigüidade do Mal, os demônios do inframundo assomam-se à cidade difusa marcando o limite e a origem e destino da vida após a

289 Cf. TASSINARI, Alberto. op. cit., p. 19.

290 Ver esta relação no sugerente livro de Aléxia Bretas, A constelação do sonho em Walter Benjamin. São Paulo: Humanitas, 2008. 
queda. Ambos extremos, a arcádia da identidade com a natureza e o exílio no caos urbano - no império do artifício - são as duas faces da mesma moeda. Representam as antinomias da sensibilidade pura; em sua revoltada relação, definem o espaço da cidade enquanto limbo. A superação deste impasse vem dada pela via apocalíptica ou bem por uma via ético-política representada pelo Anjo da História que sobrevoa a cidade. O esquema do mito desvincula-se do logos cívico, a morte apresenta-se como a única harmonia possível e redenção do paraíso perdido. Nas palavras de Alberto Tassinari:

Que Kiefer tenha recorrido ao mito para ajudar a comunicar o sentimento de que no Brasil o presente não se sustenta e tem mais a figura de um já passado é algo admirável. As pinturas são impressionantes no que mostram de destruição numa cidade que, à primeira vista, estaria sempre em renovação. Há poucas obras tão penetrantes e ausentes de exotismo na arte brasileira e que tenham o Brasil como tema. 291

Essa mesma visão desconcertante e desconcertada é acolhida por Nelson Brisaac Peixoto e ao mesmo tempo extremada quando o crítico assinala:

Difícil identificar, à primeira vista, esse skyline desprovido de signos ou pontos reconhecíveis. Algo porém - talvez a particular textura formada pelo aglomerado caótico, pela massa de concreto erguido, uma paisagem saturada e opaca - nos dá a inequívoca sensação de olhamos São Paulo. Dois quadros de Anselm Kiefer - Lilith (1987-9) e Barren Landscape (1987-9) - mostram São Paulo visto por olhos estrangeiros, educados por uma outra paisagem. Seria possível perceber nessas imagens signos de reconhecimento, trariam essas pinturas indícios de experiência e sentido, constitutivos de um lugar? ${ }^{292}$

Quando Lilith sobrevoa a cidade de São Paulo, o herói-demiurgo parece já não ser anjo fundador e exterminador das cidades, senão o demiurgo trágico que abre com seu silêncio uma brecha preta no destino infausto da cidade paulina. Acompanhando o perfil

${ }^{291}$ Cf. TASSINARI, Alberto. op. cit., p. 15.

292 Cf. PEIXOTO, Nelson B. ibidem, p. 227. 
caraterístico deste herói reconhecemos os traços liminais do urbano. O ceticismo niilista representa sua inconformidade ante um mundo corrupto, seu laconismo e lentidão revelam-se ante o domínio mítico em que tem caído a própria linguagem, seu caráter hierático de chumbo é seu escudo frente à cidade do terror. Como Anjo da História sua tarefa é a de descontruir os argumentos do mito, descobrir os fundamentos materiais de onde emergem as figuras terrificantes da cidade: não se trata da natureza, señao de uma sociedade à deriva a que produz essas fantasmagorias urbanas. A cidade fica encantada de espíritos malignos e até a própria Lilith descobre seu rosto humano e se faz semelhante ao Anjo da História. Aliás, muitas vezes será a própria Lilith quem arraste o Anjo da História paralizado para acordar do império do medo, assim comenta Tassinari:

Mas se é possível afastar a noção de arte contemporânea a noção de mito e da figura do artista contemporâneo a de um demiurgo, isto não resolve a questão, talvez mais difícil, da relação entre a obra e o tema em Kiefer. Até que ponto é importante saber o que significa "Lilith" para que se possa sentir esta espécie de presente que nunca se alcança e que varra as paisagens de São Paulo?

O componente terrífico do mito não passa, por sua vez, pela eliminação dos conteúdos libertadores que repousavam na imagem da cidade. O Anjo da História assume os ideais utópicos expressados na vigília do mito, mas nega sua forma: salva os fenômenos desde a vigília da razão. A lei na selva de concreto deixa de ser o caos, tornando-se complexidade. A passagem do Anjo da história não nega a experiência urbana senão que a reconduz. O Anjo representa um outsider, pela sua natureza e pela sua eleição. A sua atitude ante a cidade torna-se confusa, ora funda a cidade, ora a extermina, ora se mistura com a vampiresa Lilith, ora perde-se na selva urbana, ora desmascara o poder. Tanto Lilith quanto O Anjo da História coexistem nos mesmos campos semânticos, mas a cidade de São Paulo parece 
se abrir perante o Anjo com um olhar de terror, como um abismo ante o qual reaciona negando. O Anjo parece fundar o ser que nasce do medo. O pintor-demiurgo que é Kiefer enfrenta-se com o olhar sossegado à complexidade do espaço, observa seus ritmos, suas inflexões, se detém nas suas flutuações e, acima de tudo, suspeita das promessas do progresso, da paz duradoura e da justiça infinita. ${ }^{293}$ Duas personagens ocupam o interstício do sentido, Lilith e o Anjo da História, os dois em franco encontro em um espaço aberto, na cimeira da diferença e da alteridade. Lilith é uma negadora da vida, e o Anjo é um invocador do fantasma, se condenando a viver enleado no limbo, traumatizado pela fundação de um território. A luta do Anjo é uma luta contra a imagem mítica mais feroz, ele não renuncia à comunhão com a natureza que almejava o sonho mítico, o que rejeita é o caráter de imediatez e plenitude expressado no mito. As imagens do paraíso só podem ser resgatadas através de múltiplos

293 Marshall Berman dedicou um capítulo do seu livro Tudo o que é sólido desmancha no ar a Robert Moses, o urbanista estadounidense que preencheu de highways e freeways seu país. O urbanista americano tem seu homólogo brasileiro na cidade de São Paulo na figura de Paulo Maluf. Parece-nos interessante como os bairros do Bexiga, Santa Cecília, Campos Elíseos e Barra Funda, bairros de forte cultura popular, de redes de vizinhança coesionadas e, talvez, modelos incipientes de integração social, começaram sua decadência até se tornarem imagens de exclusão social que hoje conhecemos. Lembremos que o bairro representava, em grande medida, um freduto da aldeia no interior da cidade, como todo o positivo e o negativo que isto implica. Sem dúvida, este é o único espaço político possível no contexto moderno para um pensamento obsessionado com a pólis grega como modelo democrático; nada melhor do que a unidade dos bairros. O sonho mítico dos aduladores do progresso, de sair do "mundanal ruído da cidade," tem se realizado embora se exterminasse toda uma história natural e uma história social. O sonho do público como síntese dialética entre o urbano e o não urbano é negado pelo presente do capitalismo rampante que se apega à falsificação da vida para manter o estado de exceção em todo seu apogeu. Parece difícil encontrar um cenário urbano que represente a sociedade de classes de um modo mais descarnado que o que gerou a industrialização em São Paulo. O que nos resulta mais dramático não é apenas o isolamento espacial, pois isto permanece hoje como ruína e talvez como monumento aos vencidos. 0 mais dramático parece ser o olvido, a demolição de uma estética urbana que talvez foi a esperança máxima no momento de desespero extremo. Cf. BERMAN, M. Tudo que é sólido desmancha no ar. Trad. Carlos Felipe Moisés. São Paulo: Companhia das Letras, 2007. 
rodeios, com o amplo trabalho da alquimia e apenas são resgatáveis de forma fragmentária, residual, daí o caráter trágico do Anjo assim como do urbano, essa possível morada do Anjo caído.

No misticismo judaico, especificamente na Cabala, podemos encontrar descrições recorrentes e variadas sobre a contrafigura de Eva. ${ }^{294}$ Ela se chama Lilith, que em suas variadas encarnações é mais freqüentemente imaginada como um demônio. Feita do mesmo barro de Adão, ela recusou se submeter a sua vontade sexual procurando uma saída, se tornando um espírito vingativo, uma tentadora demoníaca e estranguladora de recém-nascidos. ${ }^{295}$ Sua sucessora, Eva, feita da costela de Adão, acabou tentando-lo para comer a fruta

294 Cabala responde ao termo mais usado para se referir às doutrinas esotéricas do Judaísmo e do misticismo judaico, particularmente na Idade Média, a partir do século XII. Num sentido mais amplo abrange todos os movimentos esotéricos sucessivos no judaísmo a partir do final do período do Segundo Templo. Cabala não é idêntica ao misticismo. Refere-se de fato ao misticismo mas, ao mesmo tempo, também alude ao esoterismo e ao teosofia. Nas primeiras formações, associava-se o esoterismo ao espírito do gnosticismo, não foi até depois, quando entrou em contato com a filosofia judaica medieval, que sistematizou-se como teologia mística judaica. Cabala significa literalmente tradição. O Zohar, escrito por Moses de Leon entre 1280-1286, é o trabalho seminal da Cabala clássica. O Zohar centra-se na doutrina das Séfirot. Esta doutrina representa a estrutura central da noção de Cabala, um sistema de emanações divinas em que toda realidade está estruturada. A Cabala, a partir do século XVI até nossa contemporaneidade, ou seja, a Cabala moderna, foi criação de Isaac Lúria na Palestina durante os anos 1534-1572. A importância da Cabala para modos contemporâneos de interpretação conhecidos como teoria da retórica, aparece nos trabalhos de Harold Bloom por exemplo. Ver BLOOM, H. Kabbalah and criticism. New York: Harper, 1975 e SOSNOWSKY, Saúl. Borges y la cábala: la búsqueda del verbo. Buenos Aires: Ediciones Hispamérica, 1976. Cf. SCHOLEM, G. A Cabala e seu simbolismo.Trad. Hans Borger. São Paulo: Perspectiva, 1978. 295 Recentemente uma mulher residente em São Antônio, Texas, nos Estados Unidos, confessou que decapitou o seu filho de apenas três semanas de vida, desmembrou seu corpo com duas espadas e comeu partes dele sob influência do diabo. Otty Sánchez encarna a escura combinação da pulsão de Lilith, de um alma desapiedada e um coração maligno. Ela rendeu-se aos selvagens e terríveis impulsos que the revelam que sua verdadeira vocação é a de ser uma assassina. Parece que os motivos foram sugeridos pelo demônio. Sua retorcida mente é um estremecedor lugar a explorar. Já ela se encarregou de confessar todo o horror da sua ação. Sua loucura reflete a fase superior de loucura difundida de toda uma nação. Portanto, Lilith está em todas partes. 
proibida da árvore do conhecimento. O espírito Lilith também tentará os descendentes de Adão, não para aceder ao conhecimento, mas para obter gratificação sexual. A figura mística de Lilith - a Lilith mais comumente conhecida como tentadora e assassina - não é apenas encarnada e interpretada exclusivamente como uma figura demoníaca. Ela também representa a mãe da melancolia. Como Scholem escreve sobre Lilith, na Cabala influenciada pela astrologia, Lilith está relacionada com o planeta Saturno e "todos aqueles com disposição melancólica são seus filhos. ${ }^{296}$ Esta dupla condição de Lilith, como figura da mística cabalística, seu papel como demônio tentador e como mãe mística da melancolia, como progenitora dos filhos da melancolia tem seu correlato mitológico masculino na figura de Saturno. Saturno, dentro da tradição do humanismo renascentista da cultura ocidental associa-se com o saber médico de Hipócrates, a filosofia aristotélica e as teorias metafísicas, se tornando o pai da melancolia e, com isto, pré-condição fundante da criação artística. Assim como Lilith, Saturno também possui um lado escuro. ${ }^{297}$

A melancolia opera por meio da alegoria. Os trabalhos de Kiefer, como a alegoria, são insistentemente referenciais. Suas densas superfícies nos adentram, material e iconograficamente, num amplo campo de significação. Suas pinturas são grandes palimpsestos através das quais lemos outros textos, vemos outras imagens, nos aproximamos a outros tempos. Portanto, nas suas operações alegóricas, as telas de Kiefer sintonizam com a conceição benjaminiana de melancolia. Como resume Benjamin sobre a melancolia e a alegoria em uma de suas anotações:

\footnotetext{
${ }^{296}$ Cf. SCHOLEM, G. ibidem., p. 123.

297 Para uma discussão sobre Saturno, a melancholia e a tradição humanista, ver MINOIS, Georges. Histoire du mal de vivre. De la mélancolie à la dépression. Paris: La Martinière, 2003. Referimos o clássico de PANOFSKY et al., Saturn and melancholy: studies in the history of natural philosophy, religion and art.
} 
Se o objeto se torna alegórico sob o olhar da melancolia, ela o priva de sua vida, a coisa jaz como se estivesse morta, mas segura por toda a eternidade, entregue incondicionalmente ao alegorista, exposta a seu bel-prazer. Vale dizer, o objeto é incapaz, a partir desse momento, de ter uma significação, de irradiar um sentido; ele só dispõe de uma significação, a que lhe é atribuída pelo alegorista. Ele a coloca dentro de si, e se apropria dela não num sentido psicológico, mas ontológico. Em suas mãos, a coisa se transforma em algo de diferente, através da coisa, o alegorista fala de algo diferente, ela se converte na chave de um saber oculto, e como emblema desse saber ele a venera. Nisso reside o caráter escritural da alegoria. Ela é um esquema, e como esquema um objeto do saber, mas o alegorista só pode ter certeza de não o perder quando o transforma em algo de fixo; ao mesmo tempo imagem fixa e signo com o poder de fixar. ${ }^{298}$

$\mathrm{Na}$ arquitetura ruinosa e nas paisagens queimadas que tanto definem a pintura de Kiefer, podemos ver essas operações alegóricas da melancolia. Os objetos inanimados, ausentes de todo, mas imbuídos de sentido, podem chegar a representar a ausência de códigos inscritos na obra de Kiefer. São Paulo oferece um panorama excepcional para a construção de um imaginário que intensifica os regimes de degradação e noturnidade próprios de uma cosmovisão negativa. Ao mesmo tempo que conforma um marco de grande representação arquitetônica cuja impressão estética tem sido, em boa parte, conseqüência de sua singular presença da destruição e decadência, uma imagem querida à análise benjaminiana quando falava, "a cidade que sem cessar cresce em altura pela acumulação de seus próprios escombros que soportam novas edificações," pois São Paulo contém em sua própria origem geográfica e arquitetural o germe de sua destruição: as águas que dão vida a seus bairros são as mesmas que corrompem suas estruturas. A fecundidade da água torna-se esterilidade na cidade de São Paulo. A aliança entre a humidade e o tempo que aparece representada nas suas marginais, constitui uma força destrutora que resulta patente nas estruturas que

${ }^{298}$ Cf. BENJAMIN, Walter. Drama Barroco. op. cit., pp. 205-206. 
aos poucos vai arruinando. Lembremos que, como arquétipo imaginário negativo, a água representa uma revelação da desgraça do tempo, como nesses poemas barrocos, é clepsidra determinante. A cidade de São Paulo materializa para Kiefer a idéia da inexorável transitoriedade de nossa vida e nossas criações, o que podería salientar um deslumbramento ternamente cruel, um deslumbramento que morre paulatinamente, até o ponto que a cidade cobra um caráter atrativo porque justamente está em transe de desaparição. Lilith e o Anjo da História se presentam paralelamente no mesmo espaço, não como doadores de vida, senão em sua concepção completamente oposta: regam a morte alimentando sua descomposição. Redondeando o panorama de negatividade, a pintura torna-se paulatinamente um discurso do decaimento em todos os sentidos: por um lado, movimento centrífugo do Anjo da História e por outro, desmanchamento, extinção das energias que terminam, bem entendido, na morte.

$\mathrm{Na}$ primeira imagem pouco a pouco vai se incrementando a atração fatal do movimento de descenso: o Anjo da História vai olhar ao fundo dos derrumbadeiros da cidade e sobrevoa o pálido fundo do abismo da cidade. Para Kiefer São Paulo representa um cenário de tintas pré-lavadas que estão a ponto de se extinguir. Em São Paulo a imagem do caos apresenta certa abdicação existencial do ser, não parece ser um lugar sereno e ordenável, senão um fundo impenetrável e excludente, em cuja ininteligibilidade caótica desastra-se qualquer iniciativa desesperada do Anjo da História. A cidade condensa o imaginário mítico de utopia e distopia: a atração estética que Lilith exerce sobre a cidade se enfrenta com a realidade de declínio do Anjo. A cidade fica desvirtuada, a natureza mostra seu lado destrutivo e o Anjo da História não isola seus visitantes da pasagem do tempo, fazendo mais patente seu transcorrer. Paradoxalmente, a posição abismada de São Paulo constitui para 
Kiefer uns de seus atrativos principais, dotando seus edíficios de uma aura de fragilidade e decadência que seduz seus admiradores.

Tratar-se-ia de uma simples fascinação estética pelo perecível? Será São Paulo realmente uma cidade desolada e infecunda? Com sua Lilith Kiefer tenta articular certas características derivadas do carácter deshumanizadamente massivo da condição urbana em São Paulo. Lembremos que a cidade poética de estirpe baudelariana (o Paris de intercâmbios humanos, multitudinário, insígnia da Modernidade) é substituída pelas urbes vazias e moribundas. A pintura de Kiefer presenta uma topografia protagonizada por espaços ruínosos de cujas glórias sobrevivem apenas os restos de uma história irrecuperável. O devir temporal da cidade está marcado por conotações negativas, condizentes com a idéia de progresso e o projeto moderno que o conceito de cidade moderna representa revela seu fracasso quando esse espaço urbano acaba sendo equalizado com uma Paisagem Árida, angustiosa região da infertilidade e da morte. Em Nelson Brissac Peixoto podemos ler:

Exatamente como São Paulo, retratada como paisagem árida em colapso. Velhas imagens corroídas, como que encontradas ao acaso, cobertas de poeira e musgo. Palha, pedaços de barro cozido, areia, objetos metálicos, arame e, sobretudo, chumbo. ${ }^{299}$

Uma aura perdida encadila o Anjo da História. O pintor parece sofrer uma certa melancolia por entes que ainda estão presentes, mas cujo final é, no entanto, predezível: o mundo que compõe é frágil e carrega a condena imposta por um poder intangível mas do qual é quase impossível escapar: o tempo. Sua prevalência se cifra por meio da imagem árida usada por Kiefer. A concepção negativa do passo do tempo (fugaz e destrutor) tempera-se com a impossibilidade de mecanismos racionais para desvelar a realidade: o Anjo da História vai sozinho entre a precariedade da paisagem se desfazendo nesse

${ }^{299}$ Cf. PEIXOTO, N. B. Paisagens urbanas. op. cit., p. 242. 
horizonte limitado que oferece o skyline da cidade. A alusão ao carácter destrutivo do tempo não compõe apenas 0 presente e 0 futuro: o passado também conta e pesa como um avião de chumbo. Os esforços por eludir a aniquilação são inutéis por mais que se tente esquivá-la erigindo utopias. A, cidade, essa região do progresso, tornou-se um falso paraíso e a realidade da cidade transformou-se num labirinto assediado pela destruição. Como sugere a filósofa Ana Lucas, principal especialista em Benjamin na língua espanhola:

O teatro barroco colocou em cena uma representação do mundo que se torna ruína, mas tem sido apenas em nossos dias temos confirmado finalmente o caráter ruinoso de nossa realidade toda. Instabilidade, polidimensionalidade, mutabilidade e fragmentariedade são características barrocas que Benjamin detetou na Modernidade e que se têm explorado agora, invadindo todos os aspectos da realidade cultural e social. ${ }^{300}$

O Anjo da História passa como sombra, fazendo um eco do livro de Eclesiastes (6:12), e os relógios na paisagem de areia marcam o passo inexorável do tempo cujo poder fica perpassado por um nome: São Paulo. Kiefer não esconde a corrupção que acompanha à descida, entendendo esse risco de uma maneira similar a Benjamin para quem a descida parece ser regressão germinativa. Este processo de se reincorporar à natureza de uma maneira radical que possibilite certa regeneração se vindica, aproximando-se à pulsão de morte, que segundo Tales Ab'Sáber, impulsa a todo vivo a voltar ao inorgânico, ao indiferenciado. ${ }^{301}$ Verdadeiramente a regeneração

300 "El teatro barroco había puesto en escena una representación del mundo que se torna ruina, pero ha sido sólo en nuestros días cuando hemos confirmado finalmente el carácter ruinoso de nuestra realidad toda. Inestabilidad, polidimensionalidad, mutabilidad $y$ fragmentariedad son características Barrocas que Benjamin detectó en la Modernidad y que se han explotado ahora, invadiendo todos los aspectos de la realidad cultural y social." Cf. LUCAS, Ana. El trasfondo de lo moderno: Estética y crisis de la modernidad en la filosofía de Walter Benjamin. Madrid: UNED, 1992, p. 22. ${ }^{301} \mathrm{Cf}$. AB'SÁBER, Tales. "Freud e o outro sonho". In: O Sonhar restaurado. Formas do sonhar em Bion, Winnicott e Freud. São Paulo, Editora 34, 2005, pp. 245- 308. 
orgânica e uma certa participação na vida a partir da morte é o ideal que parece mover a pintura de Kiefer. Nelson Brissac Peixoto no seu livro Paisagens Urbanas apresenta trechos do relato de um estrangeiro que visitou São Paulo pela primeira vez. Para Brissac, as impressões desse viajante poderiam coincidir com 0 exercício pictórico de Kiefer sobre a cidade:

Vi São Paulo pela primeira vez da janela de meu hotel e devo dizer que parece uma cidade dos mortos. Visto do alto de um edifício de trinta andares, a cidade se apresenta ao observador como um submundo, como um reino das sombras, no qual os arranha-céus, em sua uniformidade, se apresentam como lápides num cemitério. E quando a gente passeia pela cidada, vê-se logo o incabado e o que já está decaindo. ${ }^{302}$

A consciência própria da decadência pujante na cidade de São Paulo tem a ver com a pulsão por uma morte que não seja súbita, que possa ser acompanhada com certo grau de reflexão. A individualidade não está lastrada aqui pela consciência da própria caducidade, antes, disfruta de ser parte da natureza. Para isso acontecer precisa de uma reconsideração social do falecimento e que se assuma novamente, como fala Benjamin do Barroco, quando a significação e a morte amadureçam juntas:

Nisso consiste o cerne da visão alegórica: a exposição barroca, mundana, da história como história mundial do sofrimento, significativa apenas nos episódios de declínio. Quanto maior a significação, tanto maior a sujeição à morte, porque é a morte que grava mais profundamente a tortuosa linha de demarcação entre a physis e a significação. ${ }^{303}$

Ao lado dessa aceitação barroca da morte - que dos aspaventos dramáticos do Romantismo e com uma percepção renovada que assume com naturalidade o que se apresenta socialmente como uma exceção execrável, - Kiefer e Benjamin acabam transformando a negatividade em potência. Trata-se, para ambos, de um saber que

302 Cf. PEIXOTO, N. B. ibidem, p. 241.

${ }^{303}$ Cf. BENJAMIN, Walter. Drama Barroco. op. cit., p. 188. 
se constrói mediante esse ato de aniquilação das coisas, dando- Ihes morte, arrancando-Ihes a falsa, a bela aparência (a sua organicidade interna) para as obrigar a significar, ressuscitando-as. No caso de Kiefer, sua São Paulo desbotada já se encontra apta para significar (como o poderia dizer o próprio Benjamin), chegam-lhe mortos às suas mãos, visto que já se encontra destituída das suas relações internas e dos elos que the garantem a organicidade. Se houvesse uma distinção a lembrar, entre filósofo e pintor, a fundamental seria: a luta de ambos é, justamente contra os sonhos fantasmagóricos da sociedade imersa num imenso estado de letargia. Lilith encarrega-se de promover esses sonhos, recriando essas fantasmagorias com seu sex-appeal demoníaco, denunciando o Anjo da história ou herói moderno, erguendo o estandarte da sua luta contra a tempestade de areia que ameaça uma sociedade decadente e iludida com as suas fantasmagorias. Usando a técnica do esgrimista, de que fala Benjamin a propósito da lírica de Baudelaire, o Anjo da História improvisa formas que funcionam como pequenos choques que anulam a falsa continuidade da experiência, fazendo-a explodir do seu interior. Esse parece ser o sentido da expressão sibilina de Benjamin, que importa aqui retomar, que se encontra no texto sobre - Barroco Alemão: "Com isso, a alegoria reconhece estar além do belo". ${ }^{304}$ Destruir representa um gesto que conhece em si mesmo o seu termo. Em última análise, não é disso que ele nos fala quando refere as palavras aniquilação, morte ou destruição. Trata-se, antes, de arrancar as coisas às suas correlações habituais (orgânicas), para as obrigar a penetrar, redimindo- as, numa nova ordem ou num novo círculo: o das significações. Essa é a pretensão que lhe subjaz, por forma a criar uma nova ordem, a de um saber durável ou, como o próprio Benjamin o afirma, para criar uma "beleza durável". Arrancála à ordem do precário, do contingente, do transitório, para a petrificar numa ordem do "durável", se assim o podemos afirmar. Só 
desta forma poderíamos entender a aniquilação, no gesto alegórico, preparando o teor de redenção nas coisas por ela aniquiladas.

Então, do que nos fala Kiefer? O que se entende aqui por "Lilith" ou o "Anjo da História" ou, ainda, "São Paulo."A história irrompe numa desertificação que se encontra latente na experiência urbana, ainda que oculta, disfarçada ou mascarada pelas fantasmagorias coletivas da sociedade. Os sonhos fantasmagóricos do Anjo da história, ora flâneur, ora colecionador constituem-se como esse saber inconsciente, um "saber sonhado" que procura constantemente esquecer-se, evitando, ele próprio, o momento doloroso do "despertar". Esta remissão mútua e infinita entre sonho e imagem tem seu momento crítico na imagem reificada que se nega a retornar ao corpo para confrontar sua hipóteses e reconhecer seu fundamento material ao mesmo tempo que seu abismo. A esta forma de máscara aderida ao rosto, Benjamin chama de fantasmagoria, é a forma imaginal da ideologia. O que em Kiefer pode ser reconhecido na figura de Lilith, pois tem a forma monstruosa do morto vivo: persegue e desvaira para transformar suas vítimas, por sua vez, em sonâmbulos arrojados a um limbo de desrealização que suspende a razão prática entregando a todos a uma indolência perniciosa. A fantasmagoria urbana é o momento crítico da experiência moderna do espaço. Não se relaciona com alguma forma de morar, ao contrário, é o modo mais dramático de não aceder ao espaço: um se enterrar em vida ou ser um morto vivo. Doloroso, sem dúvida, porque a história aparece sempre marcada pela morte e pela ruína, pela "catástrofe em permanência". Essa catástrofe (caraterística de uma cosmovisão barroca da história) ressurge com outros aspectos na modernidade: sob a forma de choque, de repetição infernal ou do eterno retorno, deflagadores da melancolia do homem moderno e, por conseguinte, da visão alegórica, tão próxima do barroco. Benjamin foi mais longe ainda do que Kiefer, pois designou o século 
XIX, não apenas como um espaço de tempo, mas como um sonho de tempo [Zeit-traum], ou seja, entendendo esse espaço de tempo como uma fantasmagoria coletiva, toda ela decorrente entre espaços e arquiteturas fantasmagóricas (essa é, sem dúvida, a função própria das galerias parisienses no tecido urbano), expressão do sonho coletivo, ou melhor, do pesadelo profundo do qual partilha toda a sociedade burguesa. No cerne da raiva destrutiva, tanto de Lilith quanto do Anjo da História, que tudo atinge, mortificando, aniquilando, parece habitar um desejo secreto, o de interromper $o$ curso do mundo, que tão bem Walter Benjamin entendeu, e que concentra todo o dinamismo da obra baudelaireana que tantas delicadas páginas de suas análises dedicou. $O$ gesto de Lilith consagra-se, pois, nesse canto secreto que adormece e apazigua o mundo, petrificando-o ou coagulando-o alquimicamente por meio de seu passo. Poderíamos, mesmo, relacionar este gesto de Lilith com uma passagem de Benjamin, da obra sobre o Trauerspiel, onde o autor afirma: "O que persiste é o detalhe bizarro das regras alegóricas: um objeto de saber, que se esconde no edifício de ruínas intelectualmente elaboradas. ${ }^{1305}$

Na série Lilith a cidade de São Paulo aparece como lugar onde Kiefer se depara com o vazio após o eclipsamento das tradições herdadas do Egito, Bayreuth e Jerusalém. Sobrevoar São Paulo é se adentrar em outra constelação onde o pintor se encontra com figurações contemporâneas de cidades que flutuam entre a ameaça do apocalipse e a possibilidade de ressureição. O olhar estrangeiro de Kiefer deve ser considerado dentro de uma tradição que tem em Baudelaire e na personagem quintessencial do flâneur, duas figuras fundacionais para a compreensão escópica da moderna experiência citadina. O deambular de Kiefer por São Paulo pode ser o mesmo que define Baudelaire, o pintor da vida moderna, um espectador

${ }^{305}$ Idem, ibidem, p.200. 
alucinado confundido em meio as proporções tentaculares da cidade, que a sobrevoa, a olha desde seu centro e permanece oculto dela. Lembremos que Walter Benjamin tematizou a experiência moderna, entendida como experiência vivida do choque [Chockerlebnis]. ${ }^{306} \mathrm{O}$ clamor por uma experiência arruinada e em crise perpassou a sua obra, convertendo-se num objeto fundamental da sua análise. As figuras da modernidade, representadas nas suas infinitas alegorias, assaltam-Ihe o pensamento, no sentido em que se constituem como formalizações concretas dessa perda de experiência, ou seja, articulam em si, simultaneamente, a fantasmagoria alucinada do coletivo e o espírito agudo e resplandecente da imersão da história na catástrofe. Contra essas experiências resultantes da visão moderna do homem, Baudelaire lançará o seu olhar alegórico (e heróico) de poeta, denunciando-as. Como o entendeu Benjamin, Baudelaire sabe que o olhar mítico ou olhar arcaico, aquele que acredita nas correspondências originárias e na aura das coisas, é um olhar que não revela senão que padece de uma ilusão, carecendo de lucidez. Ora Baudelaire, denunciando esse olhar como tal, um sonho fantasmagórico, combate alegoricamente o mito da aura, em declínio no mundo moderno, em que homem se submete à ditadura do tempo homogêneo e vazio, o qual, evidentemente, concorre para o aparecimento da única experiência possível: a experiência vivida do choque [Chockerlebnis]. Esta, opondo-se à experiência autêntica [Erfahrung], designa a experiência que é vivida individualmente,

306 Dizer perda de experiência significa falar da experiência de choque [Chockerlebnis], visto que toda a experiência do homem do século XIX aparece à luz dessa impossibilidade de uma experiência autêntica [Erfahrung]. A experiência do choque nasce e desenvolve-se, lado a lado com a consciência do declínio da aura, declínio que faz nascer um mundo ilusioriamente transfigurado, "fantasmagorizado", mediante a necessidade de tornar suportável a história arruinada, num mundo marcado pelo fetiche da mercadoria. Cf. BENVENUTI, Giuliana. La cenera lieve del vissuto. Il concetto di critica in Walter Benjamin. Roma: Bulzoni, 1994. Ver CANTINHO, Maria J. "Modernidade e alegoria em Walter Benjamin." Espéculo 24. Revista de Estudios Literarios de la Facultad de Ciencias de la Información, UCM, Julio-Octubre, 2003, p. 25. 
atomizada e fragmentária. Necessariamente por isso, ela não é comunicável, como o é a experiência autêntica, marcada pela continuidade, fruto do trabalho. A experiência vivida do choque, corresponde ao efeito de uma transfiguração do espaço e do tempo, inerente a uma zona onírica, da qual o seu melhor exemplo é, sem dúvida, a arquitetura das galerias parisienses. Na ótica de Baudelaire, o heroísmo do homem, na modernidade, equivale, sem dúvida, ao (re)conhecimento desse desencanto e perda de experiência autêntica. A promessa de uma aura e a paisagem viva e em movimento, acenaIhe. No caso de Kiefer, seu gesto de flâneur segue-Ihe os 'vestígios', tentando decifrar o que a paisagem labiríntica e ao mesmo tempo árida e impenetrável de São Paulo, tem para Ihe oferecer. ${ }^{307} \mathrm{O}$ laberinto representa para Benjamin, a arquitetura sonhada pela antigüidade assim como o destino da cidade moderna caída no mito. Tem sido, bem entendido, uma arquitetura objeto de franca reflexão pela modernidade tardia. O labirinto do minotauro representa a metáfora dos labirintos reais e dos espaços indesejáveis. A cidade é sentida como um labirinto que separa o lugar de origem (a metropolis) do kairós para uma fundação (destino). Existem três lugares que nos concernem porque podem ser reconhecidos na pintura de Kiefer: o cosmos, o deserto e a floresta. Todos representam espaços sem caminhos, as pegadas se apagam imediatamente, tornando indistinta qualquer orientação. Nos mitos

307 Seria apropriado esclarecer a relação entre aura e vestígio. Enquanto que a aura nos remete para o longínquo, algo que, mesmo que nos pareça próximo, nos confronta com uma grande distância, o vestígio indicia o que está próximo, por oposição à aura. Na sua carta a Theodor Adorno, em 09/12/1938, Benjamin afirma claramente ao seu amigo: "Sobre o plano filosófico, a noção de «vestígio» é determinada por oposição à de aura." Cf. Passagens, [M 16a, 4], G.S., V, 1, p. 560: "Vestígio e aura. O vestígio é a aparição de uma proximidade, por longínqua que possa ser o que o deixou. A aura é a aparição de um longe, por próxima que possa ser aquilo que a evoca. Com o vestígio nós acercamo-nos da coisa; com a aura é ela que se apodera de nós." Cf. ADORNO, T.W. Correspondencia: 1928-1940/ Theodor W. Adorno y Walter Benjamin. Trad. Jacobo Muñoz y Vicente Gómez Ibáñez. Madrid: Trotta, 1998. 
de fundação gregos, antecedidos pela Ilíada, o mar se expressa em todo seu pendor labiríntico como espaço particularmente ambíguo tão relativo à vida e tão próximo da morte. O labirinto é um espaço limiar, de trânsito e, de fato, a passagem por ele implica uma viagem sem retorno que significa ou se perder nos abismos (morrer) ou atravessá-lo com a ajuda de Hermes, no segundo sentido o labirinto é ponte, no primeiro é limbo. O labirinto do bosque está habitado por bestas simbólicas que encarnam a natureza desse espaço, a cobra, como em Kiefer, com sua sinuosa forma viciosa e seu sangue frio de morto, ou o touro, com sua força, costuma ser o zelador da água de manantial do labirinto. Ambos são zeladores do labirinto. Além deles, senhos guardiões do labirinto, existem os personagens que habitam esse espaço, os monstruos em cuja pele se desenha a enredada forma do caos; Medusa e a Gorgona são suas figuras mais conhecidas, o dragão seu quintessência. Neles se encarna a crueldade desproporcionada e gratuita da natureza em seu semblante mais catastrófico. O labirinto representa o espaço perturbador por excelência para a inteligência mítica. Também representa o modelo arquetípico do espaço-exterior terrorífico para a imaginação mitopoética. Benjamin visava que na modernidade, a própria cidade, que tinha nascido como refúgio da intempérie caótica do exterior, se tornava ela própria, labirinto. Regressa a esse elaboração a questão do urbano, ou seja, sobre o tipo de labirinto que se estabelece na modernidade e natureza específica desse espaço propriamente sinistro. A cidade labiríntica, como espaço negativo, parece ser um lugar cheio de cadáveres, Olgária Matos o expressa no seguinte trecho:

Ruas, arcadas e escadarias constituem uma Babel espacial, em que o "assombro do espaço é o assombro da privação do espaço". Refletindo sobre o labirinto baudelairiano, Benja- min contrapõe a "rua" ao antigo "caminho": "Ambos são completamente diferentes no que diz respeito a sua natureza mitológica. O caminho traz consigo os terrores da 
errância. Um reflexo deles deve ter recaído sobre os líderes dos povos nômades. Ainda hoje, nas voltas e decisões incalculáveis dos caminhos, todo caminhante solitário sente o poder que as antigas diretrizes exerciam sobre as hordas errantes. Entretanto, quem percorre uma rua parece não precisar de uma mão que o aconselhe e guie. Não é na errância que o homem sucumbe à rua; ele é submetido, ao contrário, pela faixa de asfalto, monótona e fascinante, que se desenrola diante dele. A síntese desses dois terrores, no entanto - a errância monótona - é representada pelo labirinto", prisão em que a infinidade do espaço coincide com seu fechamento. ${ }^{308}$

O mito deambula libremente pelas ruas do labirinto constituindo a cidade como pura fantasmagoria urbana e fantasmagoria tecnológica:

Fantasmagoria do espaço e de privação do espaço, o labirinto identifica-se com a fonte de todas as perversidades e, também, de ânsia por novidades, no labirinto do consumo. A produção em série das mercadorias, a monotonia da multiplicação ao infinito do Mesmo, o medo pânico da deriva entre prateleiras e vitrines das galerias e lojas de departamento, dissimulam-se nas pequenas variações nos protótipos de maneira a dissimular o sentimento de angústia e induzir à compra, para manter o circuito em funcionamento. Esse período é o do crescimento do proletariado e do capital especulativo, a produção de mercadorias em série afetando o devir temporal. Por isso Benjamin afirma que, na modernidade, mesmo os acontecimentos históricos se repetem como artigos em série no labirinto do consumo. ${ }^{309}$

Para Olgária Matos, o olhar divinatório do colecionador ou do flâneur, apela aos "fantasmas das coisas materiais", despertando, benjaminianamente, a sobrevida de objetos para redimir tempo espacializado e incutido pelo mundo das mercadorias, para redimir o tempo passado e perdido. ${ }^{310}$ Por essa razão, Benjamin afirma: "Sabese que na flânerie, os extremos - quer se tratem de países ou de

${ }^{308}$ Cf. MATOS, Olgária Chain Féres. op.cit., pp. 94-95.

309 Idem, ibidem, pp.94-95.

310 Cf. MATOS, Olgária Chain Féres. "A cena primitiva-capitalismo e fetiche em Walter Benjamin." In: Idem, Discretas esperanças. São Paulo: Nova Alexandria, 2006, p. 69. 
épocas - irrompem na paisagem e no instante presente". 311 A dialética apresenta-se, também, sob esta forma, ao flâneur. Aproximar-se daquilo que se lhe escapa continuamente, perseguindo o alvo. É desse modo, em todo seu paradoxo, que se desdobra a cidade e a sua multidão, ante o olhar do flâneur. Como o detetive que persegue a sua vítima, Kiefer e seu gesto flâneur parecem estar no centro do mundo - na multidão - embora protegido, dissimulando-se, ao abrigo dos olhares. Essa dialética lhe é inerente, devendo ser tomada como a sua condição natural: "Dialética da «flânerie»: por um lado, o homem que se sente olhado por tudo e por todos, como um verdadeiro suspeito, por outro, o homem que não se chega a encontrar, o que está dissimulado [...]". ${ }^{312}$ Como Benjamin o afirma, o flâneur é um pesquisador da natureza humana. Sob a aparência de um olhar desatento e distraído, esconde-se Kiefer cuja volúpia reside na decifração dos sinais e das imagens: algo que pode ser revelado por uma figura deixada ao acaso, uma expressão capaz de fascinar o olhar do pintor, um rumor que espera o ouvido de um pintor ou poeta atento. Por isso, reconhecemos que o olhar do flâneur esconde a mais profunda agitação interior e é esse fato que leva também Benjamin a afirmar: "[...] A maioria dos homens de gênio foram grandes flâneurs[...]". ${ }^{313}$ Não se trata aqui do olhar de um pensador ingênuo e iludido, mas sim sarcástico e parasita, gélido, à maneira de um olhar barroco, o qual inflecte sobre si mesmo, mediante o ato da rememoração e que constrói imagens picturais ou poéticas. É ainda de uma inflexão que falamos, da ordem de um ensimesmamento, de um saber reflexivo que pode conduzir o homem aos seus limites e, mesmo, como advertimos no Trauerspiel, à loucura e à bestialidade, por via de uma queda vertiginosa no abismo da acedia, impelindo-o à estranheza, à alienação e consequente impossibilidade absoluta de

${ }^{311}$ Cf. BENJAMIN, Walter. "Sobre alguns temas em Baudelaire."Um lírico no auge do capitalismo, p. 189.

${ }^{312}$ Idem, ibidem., p. 190.

${ }^{313}$ Idem, ibidem, p. 176. 
agir. Essa afinidade, entre pintor e flâneur, é passível de divergências e desencontros. Trata-se, para Kiefer, de efetuar a transfiguração ou transmutação da experiência vivida do choque em imagem pictórica, construída pela imagem alegórica/lírica. Benjamin, na sua visão aguda e fulminante, apreende esse gesto, extraindo dele as consequências mais fecundas, e estabelecendo uma equação da seguinte forma:

Os poetas encontram o refúgio da sociedade na rua e o seu sujeito heróico com ele. Desta forma, a imagem distinta do poeta parece produzir uma imagem mais vulgar que deixa transparecer os traços do trapeiro, deste trapeiro de que se ocupou freqüentemente Baudelaire. ${ }^{314}$

No caso de Kiefer, opera-se, então, como já intuimos, uma transmutação, a que determinamos chamar, "alquímica" (a recordar os textos benjaminianos acerca da alegoria barroca do Trauerspiel), que, por sua vez, originará a imagem dialética e alegórica. A pergunta benjaminiana "os desperdícios da sociedade são, eles próprios, os heróis da grande cidade? Ou o herói não será sobretudo o poeta que construi esta obra com este material ? $^{\prime 315}$ deixa bem à vista a convição do pintor de Lilith e Paisagem Árida ambas as pinturas representam esse gesto transfigurador e "alquímico" do pintor, que leva a cabo a alegoria, como bem o nota Walter Benjamin. Embalado pela vontade de reunir os destroços e as ruínas, a imagem do flanêur que aqui se define, por analogia com a visão do pintor, poderia ainda ser aproximada de uma outra visão: a do Anjo alegórico, impotente perante a catástrofe da história humana. É bem a visão ou um olhar sobre a história humana que aqui se patenteia, como se, no interior da visão moderna, cada figura alegórica se constituísse como um ângulo diverso de um mesmo olhar e esse não poderia senão devolver-nos uma visão retalhada do mundo:

314 Cf. BENJAMIN, Walter. "Paris do Segundo Império em Baudelaire." ibidem, p.178.

${ }^{315}$ Idem, ibidem., p. 187. 
fragmentada, arruinada e que se repete na sua simultaneidade, em estilhaços. Por isso, à semelhança do anjo alegórico e, no que respeita a Kiefer, o que se procura é salvar as coisas ou encontrar fraternidades, partilhadas com horror e prazer, por entre os detritos ou escolhos dessa experiência histórica, destituída de alma, do homem moderno, a experiência vivida do choque.

O rosto alucinado em que ninguém repara, embora muitos vejam, é o do pintor, Kiefer, deambulando pela cidade em busca de um objeto difícil, capaz de prendê-lo e que possa mitigar esse espírito alucinado, em uma cidade, a de São Paulo, urbe desancorada da história. Nenhuma categoria analítica parece ser possível para compreendê-la, além do conceito de não-lugar e da impressão de sertão vertical convocados pela grande cidade. O sentimento habitual de imersão na cidade transborda nas telas avassaladoramente, de forma movediça, a passagem do tempo se adere ao olhar, fazendo lembrar uma citação de Liana Cardoso Soares e Maria Luiza Sandoval:

O redemoinho literal de Copan, tradicional prédio/monumento da cidade, extravassa a tela, deixando o espectador fora de lugar. Forasteiro, volta-se para Lilith concentração de tempos aglutinados e ruínas sobrepostas. Um mundo desértico em numerosas camadas grossas de tinta, pó e areia. Tudo ali é desalento! Na cidade, uma imensa asa metálica sobre construções insepultas: matéria ferida, calcinada, paradoxalmente pálida e vigorosa, na qual o olhar é capturado, sensível às coisas do mundo. ${ }^{316}$

Essa mirada estrangeira é mais do que o olhar do criador cosmopolita em uma cidade alheia, pois é, acima de tudo, a de um observador que mostra claramente o trâmite que supõe a mediação e o processo de representação frente ao tipo de mimesis negativa e conflitiva escolhida para representar "uma realidade." Entender o gesto

${ }^{316}$ Cf. SOARES, Liana Cardoso; SCHMIDT, Maria Luisa. "Sobre alguns temas em Anselm Kiefer." Imaginário-USP, n. 5, 1999, pp. 67-81. 
alegórico de Kiefer, esse abismo que subsume a cidade de São Paulo, abismo do espaço e, simultaneamente, alegoria do abismo do tempo, é também querere dialogar com a sentença benjaminiana, "a alegoria mostra ao observador a facies hippocratica da história como protopaisagem petrificada." ${ }^{\prime 317} \mathrm{Em}$ outras palavras, é tentar pôr à vista essa paisagem árida que destina todo olhar à costra, essa ferida mal cauterizada, mal secada pela falta de símbolos de expressão, de gestos humanos, porque como em Benjamin, "a história em tudo o que nela desde o início é prematura, sofrido, malogrado, se exprime num rosto." ${ }^{318}$ Para Nelson Brissac Peixoto a paisagem deserta apresenta-se como um momento substantivo da emblemática de Kiefer:

São Paulo é transformada numa massa petrificada, desencarnada pelo vento, escombros que afloram no meio do deserto. O que deveria ser mantido se perde para sempre, o que deveria transformar-se se conserva. E um mundo em que o novo é sempre arcaico, em que o arcaico aparece com os traços do novo - o tempo do inferno. ${ }^{319}$

Também é denúncia da barbárie que tem conduzido o modelo de modernidade triunfante, um modelo baseado no capitalismo tecnológico e do fracasso do bem cultural que não tem servido de consolo nem de instrumento humanizador do próprio sistema social e produtivo que o gera. Essa incapacidade do Anjo da história de desativar os instintos geradores de um horror desumano, corresponde ao que afirmava Benjamin na sua sétima tese Sobre o conceito de História, "Nunca houve um monumento de cultura que não fosse também um monumento da barbárie, ${ }^{\prime \prime 320}$ tanto Lilith quanto Paisagem Árida apontam a presença da morte e o papel que ante ela têm nas criações humanas. Talvez a resposta de Kiefer e da pintura

\footnotetext{
317 Cf. BENJAMIN, Walter. Drama Barroco. op. cit., p. 188.

${ }^{318}$ Idem, ibidem., p. 188.

319 Cf. PEIXOTO, N. B. ibidem., p. 244.

320 Cf. BENJAMIN, Walter. "Teses sobre o conceito de História."op. cit., p. 225.
} 
seja, precisamente, sobreviver ao horror e denunciar seus mecanismos, já que o homem tem mostrado sua impotência para preveni-los. Benjamin assume a responsabilidade de tomar para si o sofrimento das gerações passadas e, também, a dor da natureza. Sua visão redentora é edificante e não se projeta como uma escatologia do destino, pelo contrário, a teologia benjaminiana, como a de Kiefer, é negativa. Em seu ensaio sobre Kafka, Benjamin se detém em um texto de Max Brod:

Recordo-me de uma conversa com Kafka, cujo ponto de partida foi a Europa contemporânea e a decadência da humanidade. Somos, disse ele, pensamentos niilistas, pensamentos suicidas, que surgem na cabeça de Deus. Essa frase evocou em mim a princípio a visão gnóstica do mundo: Deus como um demiurgo perverso, e o mundo como seu pecado original. Oh não, disse ele, nosso mundo é apenas um mau humor de Deus, um dos seus maus dias. Existiria então esperança, fora desse mundo de aparências que conhecemos? ${ }^{321}$

Benjamin recolhe o legado da tradição judaica que pensa o tempo messiânico como o espaço da conjugação de todas as gerações. Como reconhece Ricardo Forster, o quiasma de esperança e catástrofe é o que salva a esperança de ser desmascarada e mostrada unicamente como catástrofe, como a ilusão e o insatisfeito desejo que destruiriam tudo. A fundação da esperança torna-se reminiscência, atualizando a tarefa do historiador e do crítico. ${ }^{322} \mathrm{Na}$ Paisagem Árida, a cidade de São Paulo mostra-se em sua dimensão desértica e estéril. Apenas edíficios dissimulados se evidenciam sobre a superfície arenosa e erma. Para Nelson Brissac Peixoto, "através desta cartografia da perda, a civilização parece transformarse em momentos passageiros da história natural." ${ }^{323} \mathrm{Na}$ estrutura

${ }^{321}$ Cf. BENJAMIN, Walter. "Franz Kafka. A propósito do décimo aniversário da sua morte." Magia e técnica, arte e política. op. cit., pp. 141-142.

322 Cf. FORSTER, Ricardo. El exilio de la palabra. Ensayo entorno a lo judío. Santiago, Chile: Arcis-Lom, 1997.

${ }^{323}$ Cf. BRISSAC, N.B. ibidem, p. 244. 
alegórica dessa cartografia árida de Kiefer destacam-se as ruínas como elementos formais da obra de arte redimida. Pois, como nota Benjamin, "a própria história da salvação contribuiu para a guinada da história em direção à natureza, que está na base da alegoria". ${ }^{324}$ $\mathrm{Na}$ experiência urbana de Kiefer encontram-se 0 alegorismo desapiedado de Benjamin, que vê em Baudelaire o revulsivo crítico ante a voragem capitalista que Ihe arrebata sua arte e sua cidade, e a iluminação mítica que torna a cidade de São Paulo reino do Mal. As condições que a cidade oferece não são muito diferentes das que apresenta a natureza em seu estado mais selvagem, o que traz de volta os mecanismos do mito, ameaça permanente na cidade encantada dos outdoors. Kiefer é capaz de imaginar as condições para enfentar a barbárie da história. O mito parece adquirir um rosto mais ambíguo, sem deixar de ser o tensiolítico da humanidade. 0 urbano identifica-se aqui com uma experiência complexa e sempre em pugna entre a razão e a imaginação mítica mas, acima de tudo, com uma experiência em que a cidade de SãoPaulo é a protagonista indiscutível. O âmbito dessa cidade parece ser a areia onde se entrecruzam forças diversas: os impulsos do Anjo da História com o perigo da letargia mítica de Lilith, os valores destrutivos da natureza com os anelos distópicos da cidade.

${ }^{324}$ Cf. BENJAMIN, Walter. Drama Barroco. op. cit., p. 204. 


\section{PICTURA E POESIS DA CATÁSTROFE}

\section{A.FIlOSOFIA, PINTURA E POESIA: TRANSPOSIÇÕES METAFÓRICAS DA CATÁSTROFE}

Writing and reading must continue even when silence infuses the space, time and circumstance of the poem. In continuing to speak the "Ever-Yet"

[Immer-noch], all the ecstasy of experience still possible in the face of catastrophe transforms into the task of our "creatureliness" [Kreatürlichskeit].

Aubry L. Glazer.

A pictórica de Kiefer remete, também aqui, para a esfera das relações entre a representação visual e a escrita poética. ${ }^{325}$ Mais uma vez, o espaço dessa articulação é ocupado pela relação entre atividade pictórica e atividade lírica. Uma devoção pictórica que possibilita a imediatez representacional dos quadros poéticos metamorfoseados em infinidade de telas. Tal exercício não afeta o pintor, porém, compensa-o com uma impressionante série de pinturas dedicadas a Paul Celan. Como entender a relação entre a produção pictórica e o descompasso poético? Esta passagem toma por base o embate entre um projeto de "rememoração" pictórica e todas as resistências retóricas e fenomenológicas que se lhe interpõem nessa empreitada de traslação poética do mundo

325 Os quadros da memória e da poesia são constituídos por letras, por sinais ekfrásicos. A dimensão ekfrásica está pressuposta pelo caráter da impressão dos tempos. A dimensão iconográfica da memória suscita a questão da relação entre representação e imaginação. A recordação parece ser outra forma de pintura. A atividade de pintar letras e sinais retorna ao passado morto. A tela iconográfica é pintada pelo abalo do passado morto. O movimento das pinceladas de Kiefer, desses pequenos abalos em cada traço, é também movimento de uma escrita, de uma poesia. No espaço iconográfico habita a voracidade incessante do tempo, da história, do real. Ao redor desse espaço monumental, prolifera na tela o devaneio alegórico que se inscreve na matéria dócil do imaginário, este, em retribuição, assombra aquela tela com seus fantasmas. Cf. LAUTERWEIN, Andrea. op.cit., p 122. 
perceptivo. Tal resistência pressupõe um fenômeno de leitura que incute e assegura o processo de tradução que é, ao mesmo tempo, uma mimesis e um processo de simbolização: uma representação e uma abstração. Este motivo da aproximação e da translação entre pictura e linguagem se expressa em termos muito curiosos no registro de uma conversa de Goethe:

Devíamos falar menos e desenhar mais. Por meu lado, gostaria de me desacostumar de falar e, tal como a natureza plástica, de me expressar em desenhos sonoros. Aquela figueira, esta pequena serpente, o casulo que está ali em frente da janela e espera tranquilamente o dia seguinte, são tudo assinaturas carregadas de conteúdo; sim, quem pudesse decifrar corretamente a sua significação, estaria em posição de prescindir imediatamente de tudo o que foi escrito. ${ }^{326}$

A figura do desenho sonoro é invocada por Goethe como limite ideal da linguagem enquanto cognição da realidade. Kiefer, nos desenhos sonoros revela as assinaturas carregadas de conteúdo das coisas. Nessa signatura rerum o poeta-artista-pintor aproxima-se, como nota Benjamin, da linguagem originária dos nomes e que lhe é comunicada pela linguagem natural das coisas. A capacidade de decupar a linguagem da natureza é proporcional ao desamparo da linguagem formuladora, abstrata, linear, redutora, fazendo exercitar continuamente a passagem da imagem ao ruído acústico, de modo a ler, na sua concentrada multiplicidade expressiva, o sinal, o traço, a pincelada. Neste texto, Goethe traduz a oposição entre a palavra e intuição pela oposição entre falar, escrever e desenhar, reafirmando a compreensão da natureza como uma linguagem, como escrita viva; o que nos leva pensar que as assinaturas de Kiefer estão em todas suas pinturas. Maria Filomena Molder interpreta a afirmação de Goethe como a indicação de quem possuísse a chave para decifrar a linguagem das coisas estaria em posição de prescindir imediatamente

326 Cf. MOLDER, Maria Filomena. O pensamento morfológico de Goethe. Lisboa: INCM, 1995, p. 271. 
de tudo o que foi escrito, em termos de uma renúncia, ou supressão, ou superação da linguagem de nomenclaturas. Tal abdicação da linguagem representacional associa-se, por outro lado, ao motivo hermético da queima de livros (que aparece em Goethe, em Kafka), o que não é de estranhar, tendo em conta a familiaridade de Goethe com a tradição alquímica ocidental. Nesse motivo alude-se a uma radical combustão da experiência cognitiva no resultado da qual a letra morta da escrita representacional é recusada, não apenas porque se tornou dispensável, mas também porque, conseqüentemente, se tornou prejudicial, atrofiante.

Tanto na queima de livros alquímica quanto na queima da matéria pictórica, alegoriza-se o atingir de uma clarividência espiritual dos fenômenos da natureza, cuja densidade cognitiva transcende as capacidades expressivas da linguagem representacional na linguagem de signos. Persistir na linguagem representacional seria, para Benjamin e para Kiefer, um permanecer na especularidade cognitiva de um sujeito consciente que se projeta antropomorficamente (pictórica ou liricamente) na representação que faz do mundo. Entenda-se aqui esta imagem do livro a ser queimado ou a pintura a ser queimada, não em binária oposição ao lirismo mais dilacerado, mas antes como uma originária exterioridade de toda representação e, conseqüentemente, de toda a linguagem, que nunca pode escapar totalmente à sua dimensão representacional. A poesia e a imagem seriam, portanto, a marca fundante da alteridade representacional, do signo, da arbitrariedade, da alegoria, que se inscreve, está em toda a linguagem. Como marca da incontornável mediação que constitui a linguagem, a escrita é um borrão que se espalha por toda nossa relação com o mundo e impossibilita sua imediatez experiencial e o seu conhecimento imediato. Por outro lado, contudo, a linguagem indecifrável das coisas é ela própria uma forma de escrita: uma assinatura - signatura rerum -. Na nossa 
hipótese de leitura, a poesia de Celan adquire então uma natureza paradoxal: por um lado, é o verdadeiro conhecimento escrito nos fenômenos. Assim, a escrita oscila entre ser letra morta e escrita viva. A letra morta é tudo o que foi escrito, a escrita como produto acabado, como monumento, representação verbal; a escrita viva são os desenhos sonoros em permanente criação e metamorfose, são as formas da natureza na sua permanente originação e transformação, uma reverberação criadora na qual coincidem, paradoxalmente, conservação e alteração, criação e leitura - os Ur-processos do mundo: a experiência aurática. Em virtude deste abismal paradoxo originário, que possibilita a própria origem, ou seja que é, paradoxalmente, condição da sua própria possibilidade, estes dois limites da escrita - o desenho e a letra - tocam-se no extremo do seu afastamento. Na escrita mais abstrata e nomeadora persiste a sua incontornável materialidade, a materialidade sonora e gráfica dos signos, e considerando com Benjamin que a natureza fala através de tudo o que há, que o todo se exprime em cada uma das suas partes, há que considerar nessa materialidade lingüística uma presença, ainda que residual, da linguagem da natureza. ${ }^{327}$ Contudo, temos, por outro lado, os fenômenos originários que constituem a escrita viva, a linguagem da natureza. Por outro lado, os fenômenos originários que constituem a escrita viva, a linguagem dos nomes de Benjamin, só se manifestam, só se revelam como traços inscritos nas formas singulares das coisas, como as assinaturas onde se escreve a natureza. No extremo rigor intrínseco das formas naturais, na sua metamórfica geometria, expõe-se a materialidade visível, tangível, da sua originação.

Kiefer restaura tanto a linguagem como a memória da morte de Paul Celan. A poesia de Celan transmite o horror por meio do silêncio guiando ao leitor a lugares substitutos do trauma para memorializar o

${ }^{327}$ Cf. MOLDER, Maria Filomena. op. cit., p. 267. 
momento perdido do terror histórico. A insularidade da linguagem de Celan tende a transformar o poema em uma alegoria particular, colocando, assim, a poesia em um lugar de extrema opacidade. Para Uta Werner, a poesia de Celan executa um ato de resgate da morte do total aniquilamento do acontecimento da Shoah. ${ }^{328}$ Claude Lanzmann, descreve o termo Shoah como "uma alegoria." Alegoria que, como em Benjamin, inscreve na face da natureza a ruína e que busca que o irrepresentável da testemunha se torne voz, "um luto radical, que suspende o tempo." ${ }^{329} \mathrm{O}$ poema se torna a cripta onde as mortes provocadas pelo Holocausto se materializam como fósseis no interior da sedimentação do poema. Para António Guerreiro, a poesia - que Celan elaborou tragicamente -, está voltada para retornar ao caminho interrompido da arte, o que o poeta com sua linguagem pretende prosseguir. ${ }^{330}$ Para Kiefer, a condição da gesta poética de Celan é a de pós-catástrofe, sua palavra de sobrevivente que embate contra ameaça da hipertrofia e, sendo quase o último a falar, presta seu irrefutável testemunho. ${ }^{331}$ Kiefer manifesta o trabalho de luto e memória assimilando o trauma nas cores e materiais de sua pintura. As cores de sua pintura Jerusalém, por exemplo, são cinza, chumbo, preta e um amarelo acastanhado. Estas cores, curiosamente, são as cores predominantes no Zohar. O fogo e a cor cinza vão juntos no Zohar, como também a cor amarela se descreve nessa obra como a cor da luz que recebe todas as outras luzes, é uma luz que não brilha mas que reúne todas como em uma bola de cristal localizada frente ao sol. ${ }^{332} \mathrm{~A}$ repetição se torna um elemento necessário para o trabalho de luto onde os processos repetitivos tornam-se atos de

328 Cf. WERNER, Uta. Textgräver. Paul Celans geologische Lyrik. München: Verlag, 1998, p. 8.

${ }^{329}$ Cf. CANGI, André. op.cit., p. 162.

330 Cf. GUERREIRO, António. "Paul Celan e o testemunho impossível." In: op. cit., p. 31.

331"Le dernier à parler," corresponde ao título de um texto de Maurice Blanchot sobre Paul Celan. Cf. BLANCHOT, Maurice. Le dernier à parler. Montpellier: Fata Morgana, 1984.

332 Cf. BENITO-VESSELS, C. op.cit., p. 176. 
rememoração. O pintor faz um decupamento da poesia de Celan onde não se deixam feridas abertas, porém cicatrizes históricas na tela, cuja função é a de sulcar o lugar do luto, rememorar a cena do trauma. Pois a poesia, como fala André Cangi, divide a tarefa com a filosofia de interrogar o mundo num nível geral, sendo especialmente adequada para aproximar-se do impossível, tornando-o verossímil na invenção. ${ }^{333} \mathrm{~A}$ aspiração desta atividade nas telas dedicadas à dupla Margarethe e Sulamith é a de representar uma negação radical onde as lágrimas e a terra calcinada encenadas nas pinturas sejam traços das manchas históricas. O decupamento representa simultaneamente a re- figuração do outro enquanto vítima e o agourento retorno do trauma.

Kiefer torna-se um pintor que adere, em termos ideológicos, a uma longa tradição de respostas "judaicas" que existem com o fim de explicar ou, talvez, mitigar os efeitos da catástrofe. Kiefer, na suas telas, dispõe uma cadeia de acontecimentos sucessivos entre as passadas catástrofes e a exterminação alemã dos judeus durante a Segunda Guerra Mundial. Como David Roskies afirma, a presença de nomes judeus representa uma acirrada luta contra o total extermínio. As telas de Kiefer tornam-se parte quintessencial nas respostas judaicas que pretendem explicar a catástrofe: natureza reinterpretada, analogias bíblicas, dúvidas religiosas quanto ao divino, dimensões todas importantes na pesquisa judaica para responder à catástrofe. Portanto, lembremos que todas elas são inquietações abordadas nas telas do pintor. De fato, Kiefer opta por transformá- las executando truques de alquimia com a tradição lírica e filosófica que Ihe cabe como cidadão alemão. Nesse sentido, Kiefer transporta a catástrofe para dentro do itinerário estético da cultura alemã. Nas palavras de David Roskies:

333 Cf. CANGI, André. ibidem, p.165. 


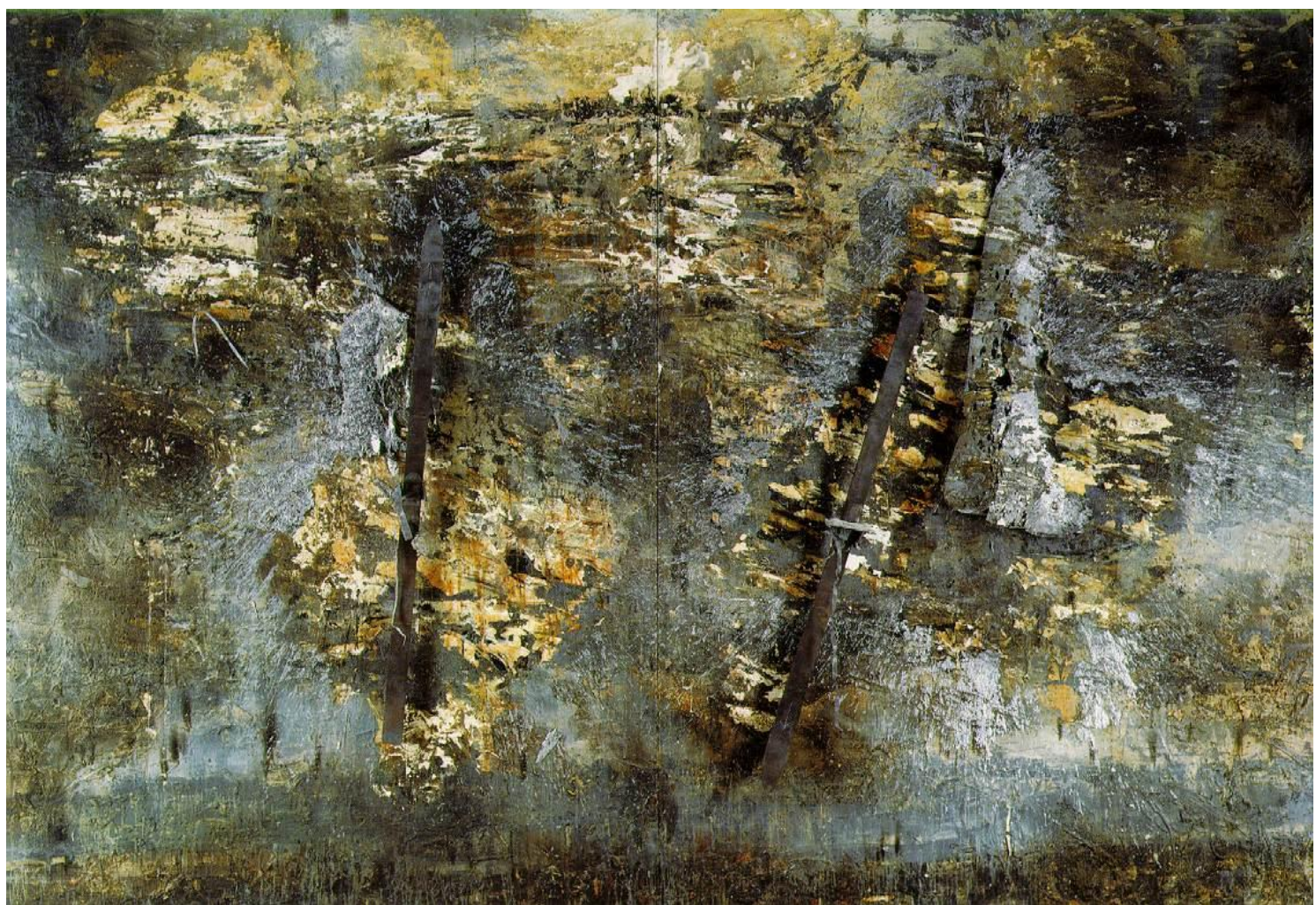

Figura 44.Jerusalém/Jerusalem, 1986. Acrílico, emulsão, esmalte e uma folha de ouro s/tela com aço e chumbo. 150 x 220. Coleção Susan e Lewis Manilow, Chicago.

A catástrofe muniu o artista judeu com uma autoridade sem precedentes. No momento em que as doutrinas de retribuição e redenção haviam perdido seu poder de consolo, ícones visuais do sofrimento judeu vieram para simbolizar o poder permanente das pessoas e esses ícones assumiram uma vida própria. ${ }^{334}$

Anselm Kiefer recupera um passado abatido e, a partir de uma reinterpretação radical dos arquétipos religiosos antigos e novotestamentários, pretende encontrar respostas a interrogações que pertencem a uma região da retórica que pesquisa incessantemente perguntas sem investir muito no encontro de uma resposta. Imagens do Gênesis, Exxodo, a destruição do Templo do Livro das Lamentações, são colocados num contexto de história, filosofia e

334" Catastrophe endowed the Jewish artist with unprecedent authority. At a time when traditional doctrines of retribution and redemption had lost their power to console, visual icons of Jewish suffering came to symbolize the staying power of the people and these icons assumed a life of their own." Cf. ROSKIES, David F. Against the apocalypse. responses to catastrophe in modern jewish culture. Cambridge, Massachusetts: Harvard University Press, 1984, p. 275. 
literatura alemãs. Kiefer tem demonstrado como os detalhes da redenção também pertenciam a esta tradição, até a própria Shoah, apresentando como um motivo redentório por detrás da desgraça do extermínio.

A pintura Jerusalém (fig.44) de Kiefer torna-se um amálgama das primeiras imagens e assuntos da história judaica que versam sobre o tema do exílio e a possibilidade do eterno retorno à casa. ${ }^{335}$ Kiefer aborda um dos arquétipos não apenas da catástrofe judaica, mas também da sua poética: o exílio. Enquanto o Êxodo sugere um

335 Jerusalém, também é o título do romance do escritor português Gonçalo M. Tavares, que apresenta personagens dilaceradas que "se cruzam, se entrelaçam, se movimentam, por vezes se amam e geralmente se magoam na noite (e na vida) de uma fria e emblemática cidade, supostamente, alemã". Trata-se de um romance que é uma espécie de texto extraído da homônima pintura de Anselm Kiefer. Ao resgatar a memória da Shoah, o romance forma parte da tetralogia $O$ Reino e pertence à série dos "livros pretos, segundo o jovem autor, "livros feitos para desencantar" e cujos "temas apontam os limites da violência e do Mal", evidenciando a falta de felicidade, o vazio que perigosamente se enche de dor e loucura. Gonçalo M. Tavares revela-se consciente da barbárie historicamente cometida nos campos de extermínio e de concentração - espaço de referência da maldade humana assinalado pela ausência da transcendência. Basta dizer que uma das personagens - o médico Theodor Busbeck - "procurava na biblioteca documentos acerca dos campos de concentração, o seu modo de funcionamento, localização em diversos países e épocas" para traçar um "gráfico que permitisse estabelecer uma relação entre o horror e o tempo." A necessidade do trabalho da memória e do luto melancólico passa pela chave alegoria para poder carregar, transportar, reportar e transformar o fardo do passado precisa ser refletido a partir deste romance. Jerusalém, além de incorporar a tela de Kiefer e misturá-la com fragmentos de relatos dos sobreviventes do campo de concentração, simbolicamente alude a eles, ao ressuscitar a crueldade física, moral e ontológica, associada ao sofrimento do existir e à miséria do corpo humano rebaixado a escombro. Suas personagens habitam um "tempo de não-humanidade, tempo onde não se constrói". Jerusalém, "a cidade universal onde se agruparia todo o gênero humano fonte de civilização", na acepção de François Mattéi, não é reconhecida em Jerusalém, de Gonçalo M. Tavares, uma vez que predomina, indiscutivelmente, a barbárie em plenilúnio. Cf. TAVARES, Gonçalo M. Jerusalém. São Paulo: Companhia das Letras, 2006; Cf. MATTÉI, Jean- François. A barbárie interior: ensaio sobre o i-mundo moderno. Trad. Isabel Maria Loureiro. São Paulo: UNESP, 2002; Cf. CARVALHO, Ângela B. "A memória do holocausto em Jerusalém, de Gonçalo M. Tavares". Comunicação apresentada no Colóquio "O vigor memorialístico e ecológico do literário", realizado na Faculdade de Letras da UFRJ, nos dias 14 e 16 de abril, 2006. 
lugar específico destinado ao retorno à Terra Prometida, o exílio na arte da Shoah revolve em torno da ausência de lugar se enfocando no acontecimento genocida (o Êxodo transita para a Shoah). Para Kiefer, o consolo na possibilidade do retorno à morada, é denegado, o que transforma o momento de redenção não em exílio, mas em destruição da casa, no devir real de não ter casa. A imagem do exílio encaminha-nos inevitavelmente à discussão sobre o Umheimlich. ${ }^{336}$ Enfrentamos a categoria de Umheimlich na sua acepção freudiana, pois nela há, essa inquietante estranheza que antecipa um sentido de retorno à casa num lugar substituto. 0 Unheimlich não é um retorno da morte, um conceito que desenha um luto e uma destruição no espaço da arte de Kiefer. O pintor sorteia esse retorno da morte tomando controle desse movimento, se encaminhando em direção a ele, ou seja, já não se trata mais das vítimas retornando ao pintor, mas é o pintor que se vê entrando no espaço da morte. Kiefer determina o leste de Europa como um lugar potencial para uma redenção messiânica vindoura. Do mesmo modo, reclama esse espaço como lugar de resistência política, rejeitando, por sua vez, toda possibilidade desse acontecimento redencional. Enquanto concordamos com Kiefer sobre a falta de promessa redencional para a Europa de Leste, outro Leste parece entrar no

336 Depois de uma significativa pesquisa, Freud encontra num dicionário alemão um tipo de fenômeno semântico: a palavra Heimlich encerra dois sentidos opostos - significa aquilo que é familiar, íntimo, amistoso, mas também pode significar escondido, misterioso, estrangeiro, que desperta temor, ganhando assim o sentido de Umheimlich. Freud encontra na leitura de Schelling a chave para entender em que modo esses dois sentidos se relacionam. Segundo Schelling, Umheimlich responde àquilo que deveria permanecer oculto e secreto, mas que extravasou, se tornando manifesto. Freud articula sua reflexão sobre o Umheimlich quando estabelece que essa inquietante estranheza é um estranho que é conhecido e familiar, tendo sido no entanto recalcado, trazendo destarte o efeito de estranhamento quando é expressado. Cf. FREUD, Sigmund. "O estranho". In: Obras psicológicas completas, vol. 17. Rio de Janeiro: Imago, p. 275; Cf. WALDMAN, Berta. "Badenheim, 1939: Ironia e alegoria." In: SELIGMANNSILVA, Márcio. História, literatura e memória. O testemunho na era das catástrofes, p.184. 
cenário de suas telas: Jerusalém. ${ }^{337}$ A Europa de Leste representa para o pintor, uma nova espécie de Hades. Kiefer aparece no seu papel de Hermes, o deus mítico que leva a morte para o Inferno. No entanto, trata-se agora do pintor encaminhando seus espectadores em direção a essas paisagens de morte com a finalidade de manter acesa sua memória. Não se retorna à Jerusalém para recuperar a morte senão para manifestar um alto sentido de piedade, pois ela representa uma volta à destruição, seus cacos tem sido coletados e levados à cidade para seu enterro e preservação. Para Celan, a destruição é catastrófica, mas também existe um eco que se escuta na cidade de Jerusalém:

Alcançável, próximo e não perdido permaneceu em meio das perdas este único: a língua. Ela, a língua, permaneceu não perdida, sim apesar de tudo. Mas ela teve que atravessar as suas próprias ausências de resposta, atravessar um emudecer, atravessar os milhares de terrores e os discurso que traz a morte. Ela atravessou e não deu nenhuma palavra para aquilo que ocorreu; mas ela atravessou este ocorrido. Atravessou e pôde novamente sair, "enriquecida" por tudo aquilo. ${ }^{338}$

A língua é a única sobrevivente da catástrofe e a única que carrega tanto o ocorrido como a possibilidade de trazê-lo para o nosso presente. Essa atualização será, portanto, necessariamente violenta, e atravessará todos os muros e portas da cidade, amálgama de

337 Similar a Jerusalém, Berlim também se tornou um tropo recorrente nos trabalhos de literatura, arte e filosofia a partir do século XX. O foco em Berlim em figuras como Paul Klee e Walter Benjamin, concentra-se no desastre e na perda em relação a cidade. Nas pinturas de Klee, "Berlim, a nossa fortaleza, conta com um aumento de dez vezes do seus cidadãos" e "Destruição e esperança" Berlim é a imagem do caos e de ruína imanente durante os eventos da Primeira Guerra Mundial. Benjamin continua com esta imagem de ruína e esperança para construir suas teorias sobre a história e a memória no seu trabalho Infância em Berlim. Suas descrições de Berlim, escritas durante seu exílio na França, refletem sobre a perda pessoal da topografia de sua infância, antecipando, assim, a catástrofe vindoura que Ihe aguarda em Berlim. Cf. BENJAMIN, Walter. Infância em Berlim por volta de 1900. In: Rua de mão única. São Paulo: Brasiliense, 1987, pp. 71-142.

${ }^{338}$ Cf. CELAN, Paul apud SELIGMANN-SILVA, Márcio.ibidem, pp. 401-402. 
histórias bíblicas confundidas com imagens do exílio localizadas de lado de novos signos de uma catástrofe vindoura. É preciso ver Jerusulém tanto na poesia de Celan quanto no trabalho de Kiefer como a somatória de todas as imagens possíveis, de todos os sofrimentos possíveis e de todas as cidades possíveis, pois essa terra prometida tem como centro de gravidade a tradição de seus lugares santos, os velhos monumentos que a povoam, a estabilidade de suas muralhas e, por último, a imagem da imobilidade do tempo que nos transmite a impressão de sempre encontrar 0 passado no presente. 339

Na concepção mística de Jerusalém, a cidade não é apenas o lugar onde o divino mora. É também representada como a mãe mística ou a Mãe de Sion, a fonte de toda criação assim como o lugar de toda purificação. Através dos escritos bíblicos, a cidade toma características femininas: ela é a mãe de todos os israelenses. $\mathrm{Na}$ consulta de uma passagem de Esdra, podemos ler o vínculo entre a cidade perdida e a perda do maternal, uma perda que conduz a um estado de profunda pena, "Não vês nosso luto. Para Sion, a mãe de todos nós é uma profunda pena e uma grande aflição. É mais apropriado sentir luto agora, porque todos estamos de luto por nossa mãe." ${ }^{340} \mathrm{~A}$ mãe em ruínas se refere à destruição do templo em $70 \mathrm{ac}$. O Novo Testamento colocará a reconstrução da cidade na celestial Jerusalém e também falará dela em termos femininos. ${ }^{341}$ Kiefer procura confortar a morte na sua citação da cidade: Jerusalém funciona como a mãe substituta como o lugar de seu sepulcro substituto, o lugar onde as mortes produzidas pelo Holocausto e a

339 Cf. BULLE, Sylvaine. "Le Havre, Berlim, Jerusalém: Cartografia do mundo." Novos Estudos 72, Julho 2005, pp.177-189.

340 Cf. Esdras, 10, 7. Bíblia de Jerusalém. São Paulo: Edicões Paulinas, 1985.

341 Cf. GALAMBUSH, Julie. Jerusalem in the Book of Ezekiel: the city as Yahweh's wife. Tese de Doutorado apresentada ao Departamento de Religião da Universidade de Emory, 1991. 
falta de túmulos têm dado um procrastinado enterro das vítimas. $\mathrm{Na}$ paisagem externa da pintura em meio a barra de ferro, Kiefer pretende transformar sua leitura de Celan em experiência material e terrestre. A paisagem interior que pertence ao poeta é apresentada na sua relação entre memória pessoal e espaço comunal da cidade. Jerusalém não representa apenas um espaço transicional, mas também o que Winnicott poderia ter designado como "potential space" através do qual o evento traumático pode ser recuperado e recomposto na presença de outro. ${ }^{342}$ Este espaço potencial está vinculado com o jogo entre a mãe e a criança. Com a perda da mãe (a destruição de Jerusalém) esta mediação também está perdida. Ela seria a barreira que auxilia a criança a assimilar os afetos destrutivos do trauma. Enquanto o espaço potencial original é conceptualizado como a distância entre a mãe e a criança, na tela de Kiefer aparece como uma relação entre tela, pintor e poeta. Celan inscreve a experiência no poema e Kiefer, por sua vez, o transcreve na tela. A presença de uma testemunha num espaço potencial é crucial, e o leitor se torna para Celan agente intermediário que o insere em sua poesia entre o afeto traumático e a pintura. Kiefer como leitor também compartilha a dor. A responsabilidade ética depende no outro que recebe o poema e o lê atentamente. A memória de um acontecimento traumático exige que se estabeleça um afeto com a perda. Só através dessa união a memória pode cristalizar o trauma.

Celan almeja retornar a Jerusalém. Esse retorno obedece à vontade do poeta de se restabelecer na cidade celestial e voltar aos braços da mãe imaginada. A linguagem será a ferramenta empregada para trazer essa retícula de substituições para, assim, a cidade se tornar reflexão principal sobre a linguagem no seu texto Meridiano.

342 Cf. AB'SÁBER, Tales. op.cit. pp. 125-22; Cf. HAMAM, Jaco J. The restoration of Job: A study based on D.W. Winnicott's theory of object usage and its significance for pastoral theology. Princeton: Princeton UP, 2000; Cf. RAUCH, Angelika. "Post-traumatic hermeneutic: melancholia in the wake of trauma."Diacritics, Winter 1998, pp. 111-119. 
Na pintura Jerusalém de Kiefer, há duas peças de aço incrustadas, serão elas as molduras das portas da misericórdia enferrujadas num terreno vazio que lembra vagamente a existência de uma cidade? A palavra em hebraico para porta é Ha'rahamim que deriva da palavra Rechem que, por sua vez, significa útero. Como Emmanuel Lévinas explica em seu livro sobre o Midrash, "Rachamin (piedade) vem da palavra Rechem, que significa útero. Rachamim é maternidade em si mesma. Deus misericordioso é Deus definido pela maternidade." ${ }^{343} \mathrm{~A}$ porta é um espaço de uma natureza muito especial dentro dos muros, pois representa o umbral ou a abertura que conecta várias esferas do ser. Simbolicamente conecta os dois âmbitos mais afastados, o dentro e o fora, a ordem e o sentido, e o caos e o sem sentido. A porta participa da natureza do labirinto como conexão hermenêutica entre o mais separado. É o espaço limite, comparável em sua simbologia com a ponte. Se a ponte põe o acento na união entre duas partes separadas, a porta separa o continuum físico ao mesmo tempo que vincula na necessária relação do ser e da identidade. No poema de Gilgamesh, título de outra pintura de Kiefer, se faz referência à natureza paradoxal das portas da cidade quanto ao material de que estão construídas (a madeira dos ciprestes). As portas falam para Celan (o poeta entrando em Jerusalém) como a matéria que conserva a lembrança de sua fonte: a memória da Shoah. Os túmulos da cidade prometida devastada estão justapostos com o fundamento da vida, o útero materno. Na pintura de Kiefer, a porta se tornou o lugar através do qual o regresso do poeta à Terra Prometida e devastada toma lugar. Assim, a cidade e sua porta

343"Rachamim (mercy) [...] goes back to the word Rechem, wich means uterus. Rachamim is the revelation of the uterus to the other, whose gestation takes place within it. Rachamin is maternity itself. God as merciful is God defined by maternity." Cf. LÉVINAS, Emmanuel. Nine talmudic readings. Trad. Annette Aronowicz. Bloomington: Indiana University Press, 1990 , p. 183. Esta porta, também alude ao lugar por onde a presença divina ou Schekinah abandonou a cidade quando Titus queimou o Templo da Divina Presença, ela precisou sair da terra através da Porta Dourada. 
selada em aço estão configuradas como a mãe com a porta da misericórdia servindo como lugar de recepção. Jerusalém volta ao poeta, mas ele é o único que pode se deslocar em direção da mãe mística de Jerusalém. O movimento do poeta não é físico mas se torna uma expressão sobre a origem, sobre a Jerusalém, onde o útero representa a origem e o centro. "Sag, das Jerusalem i s $t^{\prime}$, abre o espaço da dor na linguagem pictórica. A voz da dor parece estar encrustada nessas duas vigas de aço. Jerusalém alegoriza ambas, a perda e a recuperação, o que representa ao mesmo tempo a dor e seu conforto. O chamado por Jerusalém torna presente o que se encontra por trás do muro: a cidade como receptáculo da dor e do conforto. A cidade terrena e temporal enterrada nos escombros da devastação e a cidade substituta emparedada nas portas de sua história, fazem seu aziago reclamo: "Se eu me esquecer de ti, Jerusalém, que seque a minha mão direita".

O aprendizado de Kiefer desprendeu-se necessariamente da leitura delicada que fez de Celan: o pintor inscreveu nas suas telas uma profunda e, portanto, trágica concordância com seu tempo. Tanto Celan quanto Kiefer, responderam ao desafio do "depois" em termos que levaram, respectivamente, uma condição da poesis e da pictura, ambas entendidas como a poesia última a ser escrita e a pintura última a ser pintada.

\section{FUGA DA MORTE}

Leite negro da madrugada nós o bebemos de noite nós o bebemos ao meio-dia e de manhã nós o bebemos de noite nós o bebemos bebemos cavamos um túmulo nos ares lá não se jaz apertado Um homem mora na casa bole com cobras escreve escreve para a Alemanha quando escurece teu cabelo de ouro Margarethe escreve e se planta diante da casa e as estrelas faíscam ele assobia para os seus Mastins assobia para os seus judeus manda cavar um túmulo na terra ordena-nos agora toquem para dançar 
Leite negro da madrugada nós te bebemos de noite nós te bebemos de manhã e ao meio-dia nós te bebemos de noite nós bebemos bebemos

Um homem mora na casa e bole com cobras escreve escreve para a Alemanha quando escurece teu cabelo de ouro Margarethe Teu cabelo de cinzas Sulamita cavamos um túmulo nos ares lá não se jaz apertado

Ele brada cravem mais fundo na terra vocês aí cantem e toquem agarra a arma na cinta brande-a seus olhos são azuis cravem mais fundo as pás vocês aí continuem tocando para dançar Leite negro da madrugada nós te bebemos de noite nós te bebemos ao meio-dia e de manhã nós te bebemos de noite nós bebemos bebemos um homem mora na casa teu cabelo de ouro Margarethe teu cabelo de cinzas Sulamita ele bole com cobras Ele brada toquem a morte mais doce a morte é um dos mestres da Alemanha ele brada toquem mais fundo os violinos vocês aí sobem como fumaça no ar aí vocês têm um túmulo nas nuvens lá não se jaz apertado Leite negro da madrugada nós te bebemos de noite nós te bebemos ao meio-dia a morte é um dos mestres da Alemanha nós te bebemos de noite e de manhã nós bebemos bebemos a morte é um dos mestres da Alemanha seu olho é azul acerta-te com uma bala de chumbo acerta-te em cheio um homem mora na casa teu cabelo de ouro Margarethe ele atiça seus mastins sobre nós e sonha a morte é um dos mestres da Alemanha teu cabelo de ouro Margarethe teu cabelo de cinzas Sulamita. ${ }^{344}$

A história do poema Fuga da Morte é complexa porque parece estar vinculada a uma circunstância que nunca foi completamente conhecida. O biógrafo John Felstiner lembra uma entrevista em que Celan, a propósito desse poema, diz ter lido um relato dealgo acontecido num campo nazista: os prisioneiros eram obrigados a tocar músicas de dança. Felstiner relaciona este relato com um panfleto datado de 29 de agosto de 1944, sobre o campo de extermínio de Lublin. Nesse panfleto, o seu autor, Konstantin Simonov, relatava que durante os trabalhos no campo eram tocados tangos e fox-trots. Na revista romena onde foi publicada uma

344 Cf. CELAN, Paul. Tradução Modesto Carone. Do livro: "Quatro mil anos de poesia", J. Guinsburg; Zulmira Ribeiro Tavares, Ed. Perspectiva, 1969, SP. 
tradução do poema, um ano antes da publicação do original, uma nota de apresentação dizia: "O poema que aqui publicamos é construído a partir da evocação de um fato real." Em Lublin, tal como em outros campos de extermínio nazistas, um grupo de prisioneiros era obrigado a cantar canções nostálgicas enquanto outros abriam valas comuns. ${ }^{345}$ Existe uma outra versão que explica por que o poema, na tradução romena, se chamava "Tangoul da Mortii" (Tango da Morte): num campo próximo de Czernowitz, um comandante das SS obrigava violinistas judeus a tocar um tango que era a versão de um sucesso de Eduardo Bianco, enquanto eram cavados túmulos e transcorriam marchas, torturas e execuções, até que um dia este SS disparou contra toda a orquestra.

O poder de evocação metafórica deste poema e a musicalidade funesta que ele impõe explicam a enorme difusão que teve logo no início dos anos 50, quanto o assunto de que tratava ainda estava sujeito a bastantes reservas na Alemanha. O poema entrou nas coletâneas escolares, mas aquilo que tinha sido o motivo do seu sucesso tornou-se, ao mesmo tempo, motivo de alguma contestação. Num momento em que uma enorme oposição moral contra a estetização imperava e que Adorno tinha contribuído para implantar, se manifestava tanto na arte como na cultura em geral, a "Fuga da Morte" aparecia, como um exemplo doloroso da Ästhetische Stilizationsprinzip. Contudo, a preocupação do poeta era certamente outra: a de não se deixar identificar com um pathos elegíaco que estava ainda próximo de uma transformação lírica da realidade. Por essa razão, se ter chegado a recusar o poema, paralisou, tanto quanto pôde, a sua disseminação. A declaração que fez numa entrevista, em Bremen, esclarece o motivo dos seus receios: "No

${ }^{345}$ Cf. FELSTINER, John. op. cit., p.28. 
meu primeiro livro (Der Sand aus den Urnen, 1948), estava ainda na fase de transfiguração das coisas - algo que não voltarei a fazer." 346

As pinturas de Kiefer dedicadas a Margarethe e a Sulamith são geralmente consideradas uma versão pictórica de Fuga da Morte, em torno da poesia de Paul Celan. Mas não existem em Kiefer concessões ao princípio da representação, da mimesis. Elas deixam de ser representação: se tornam realidade. Esta idéia da pintura que se constitui na própria realidade, da paisagem-texto de Celan, para onde o espectador é transposto sem possibilidades de dar com a saída certa da obra porque deixou de haver um fora e um dentro, um antes e um depois, é da maior importância para avaliar o alcance tanto do poema quanto da obra de Kiefer, e o modo como ele fornece uma chave essencial para percebermos o que significa o lugar a partir do qual o poeta e o pintor se orientam e projetam a realidade a partir de suas próprias linguagens. O que significa que o poema faz um percurso que não consiste em integrar ou reelaborar os dados do vivido ou as circunstâncias históricas, mas segue uma via oposta que um leitor como Kiefer, procedendo com uma interpretação filosófica literária e uma entrada no universo poético lingüístico de Celan, extrema esse universo mais à frente na abstração que o próprio Celan leva a cabo na sua poesia. Trata-se, de fato, de um exercício pictórico de abstração sobre a abstração poética celiniana. Como afirma o crítico Vincenzo Vitiello a palavra poética de Celan é originariamente abstrata. ${ }^{347}$ Interpretações deste tipo, que nas suas versões mais formalistas vêem em Celan o poeta que corresponde a um ponto extremo de chegada do textualismo da poesia moderna, como declarou Peter Szondi, têm o seu pólo simétrico naquelas que, incidindo sobre o significado histórico da poesia de Celan, procuram nos textos um caminho direto conduzindo a uma experiência pessoal

\footnotetext{
${ }^{346}$ Idem, ibidem, p. 125.

347 Cf. VITIELLO, Vincenzo. Non dividere il si dal no. Roma: Laterza, 1996, pp.103-104.
} 
ou coletiva dos acontecimentos catastróficos da história. A poesia de Celan apresenta uma dimensão crítica em termos políticos e sociais, cuja condição é precisamente o seu absolutismo poético. A leitura de Kiefer faz uma síntese de todas as interpretações, para chegar a um resultado que, no essencial, está na contraluz de todas as análises literárias dedicadas à poesia de Celan. Antes de mais, ele reclama uma intenção política da poesia de Celan que de nenhum modo deveria ser amenizada. Política seria, com certeza, a intenção de absoluta liberdade que, em vários aspectos, sua poesia afirma, inclusive em sua resistência a toda realidade discursiva. O compromisso exclusivo como uma verdade que não podia cair no esquecimento e que tinha afetado a própria matéria da língua em que podia ser dita é uma questão essencial a que Celan se refere no discurso de Bremem e também no discurso de agradecimento do Prémio Büchner, quando nomeia o perigo a que o poema, "Hoje", está exposto: o emudecimento. Dois poemas do livro De Limiar em Limiar de 1955 são uma exortação veemente a que se regastem as palavras ao silêncio e à noite, descendo ao abismo de um tempo que as contaminou e as expropriou. Seja ele determinado de maneira histórica ou teológica, o silêncio é o confim onde a poesia, exposta sem ilusões às categorias negativas do Ser e do Nada, é remetida para a pura imanência das palavras sem garantia, isto é, para a própria matéria da língua que atravessou esses acontecimentos.

Nas pinturas de Kiefer estas categorias negativas se mostram de maneira ambivalente: no seu significado histórico e teológico. Podemos agora perceber porque é que é possível inscrever Celan na filiação hölderliniana da poesia - como faz Philippe Lacoue-Labarthe entre outros - até o ponto de chamá-lo mesmo o "Hölderlin do nosso tempo," sem que isso signifique, no entanto, um compromisso com o formalismo e se traduza num esvaziamento a que Celan sempre reagiu com muita impaciência, como se pode ler nestas palavras que 
fazem parte de uma carta a Petre Salomon: "Acredite-me todas as palavras foram escritas numa relação direta com a realidade. Mas isso, eles não entenderão." ${ }^{348} \mathrm{~A}$ questão essencial da poesia de Celan formula-se desta maneira: a possibilidade de responder à experiência singular é consubstancial à própria questão da possibilidade da poesia. Por isso o poema é sempre afirmação à margem de si próprio, em conquista da sua própria possibilidade. Philippe Lacoue-Labarthe identificou neste quesito o elemento transbordantemente trágico da poesia de Celan. ${ }^{349}$ Sem lugar a dúvidas, os poemas evocam a realidade de extermínio, os fatos de uma verdade histórica irrefutável, através da reconstrução dos vestígios da morte, como mostrou Kiefer, nomeadamente nas suas pinturas que procedem do poema Todesfuge. Mas a análise de Kiefer empenhada na decifração dos vestígios arrisca-se a ver no poema de Celan uma idealização metafórica que dá alguma razão à desrealização catastrófica. É bastante elucidativa a passagem da "Fuga da Morte" da metáfora do leite negro para a paisagem de vestígios tumulares, assumidos como um texto que deve ser lido. Mas a evocação não dá imediatamente lugar a um discurso testemunhal, segundo o modelo da chamada literatura de testemunho. Em primeiro lugar, porque a poesia de Celan é alheia às regras da representação, não representa nem exprime o vivido subjetivo do poeta em (se tratando de uma questão de experiência e não assim de experimentação, fazendo implicitamente alusão aos conceitos notoriamente benjaminianos Erfahrung e Erlebnis); pelo seu caráter não confessional e não pessoal, subtrai-se ao lirismo. Se existe lirismo na grandeza elegíaca de um poema como "Fuga da Morte", ele articula-se com os elementos épicos e trágicos. Estamos longe do discurso testemunhal, em segundo lugar, porque a matéria de que é constituído o poema

\footnotetext{
${ }^{348}$ Cf. FELSTINER, John. ibidem, p. 263.

349 Cf. LACOUE-LABARTHE, Philippe. La poésie comme experience. Paris: ChristianBourgois, 1986.
} 
não é uma circunstância que encontraria sua tradução no plano da linguagem. Dito de outro modo, o poema não procura um lugar exterior a si, mas tende para a sua origem, para os limites da sua própria possibilidade. Para Adorno, a lírica de Celan tenta se aproximar daquilo que the escapa e que é estruturado pelas margens da ausência - o sofrimento e a morte sem nome e nem sentido:

Esta lírica, diz Adorno, está atravessada pela vergonha da arte em relação ao sofrimento que se subtrai tanto à experiência quanto à sublimação. Os poemas de Celan querem dizer o assombro extremo pelo silenciar. Seu teor de verdade mesmo se torna um negativo. Eles se assemelham a uma língua debaixo das línguas desamparadas dos homens, sim, de todas as línguas orgânicas, à língua do morto de pedra e de estrela [...] $A$ língua dos sem vida se transforma no último consolo diante da morte que perdeu qualquer sentido. ${ }^{350}$

A clivagem entre as leituras que acentuam o significado histórico da poesia de Celan, procurando nela um caráter de mensagem epocal, e aquelas que acentuam a reflexividade da linguagem e, portanto, a abstração pela qual os poemas se constituem, acaba por se anular no encontro necessário entre essas duas dimensões. Algo semelhante para ser encontrado em Benjamin que recorre à metáfora do negativo fotográfico num primeiro texto (1921-1922) que dedicou à poesia de Baudelaire:

Comparemos o tempo com o fotógrafo - tempo terrestre para um fotógrafo que captura a essência das coisas. Por causa da natureza do tempo terrestre e seus aparatos, o fotógrafo consegue registrar o negativo de essa essência de suas chapas. Ninguém pode ler essas chapas; ninguém pode deduzir dos negativos, em que tempo se capturaram os objetos, a essência verdadeira das coisas como elas realmente são. Mais ainda, o elixir que pode agir como agente revelador é desconhecido. Eis Baudelaire: ele também não possui o fluído - o fluído em que essas chapas tem que estar imersas como para obter a imagem real.

350 Cf. ADORNO, T.W. apud GAGNEBIN, Jean Marie. "Após-Auschwitz". In: SELIGMANN-SILVA, Márcio. História, memória e literatura. O testemunho na era das catastrophes. p 110. 
Mas, ele, sozinho, é capaz de extrair dos negativos a essência e o pressentimento dessa imagem real. Desse pressentimento fala a essência negativa de todos seus poemas. ${ }^{351}$

Semelhante processo de decifração, de revelação pictórica, do negativo que são impressões perceptivas do real e detectável no projeto pictórico de Kiefer: a procura de uma pintura que exacerbe a história e a decifração pictórica do negativo que a constitui: as pinturas Sulamith e Margarethe, poderiam ser dois exemplos. De acordo com a poética que transparece da metáfora fotográfica a que Benjamin recorre, a verdadeira essência das coisas experienciadas temporalmente - coisas que o tempo fotografa - são preservadas negativamente no medium perceptivo. Mas à experiência humana está vedado o acesso ao fluído vital que permitiria revelar tais negativos. A tradução ontológica é impossível, contudo, Kiefer desafia essa impossibilidade e, muito embora nunca atinja à verdadeira imagem, consegue entrever um pressentimento da verdade, decifrando-a nas chapas fotográficas mediante infinitos esforços mentais. Na obra de Kiefer tal pressentimento surge como essência negativa. A lógica de inversão que a metáfora fotográfica sugere, parece conter uma dimensão mimética, embora se trate de uma mimesis negativa. As formas, os contornos, manter-se-iam, invertendo-se a coloração, e a iluminação, que surgem em parâmetros invertidos em relação a verdadeira essência das coisas. Essa inversão é de tal ordem, contudo, que desautoriza qualquer integridade mimética. A qualidade transtornada da realidade evita o senso comum - incapaz de distinguir, de revelar na sua confusa percepção, as formas essenciais, originárias e originantes, as formas que o olhar pictórico decifra. Cabe aos infinitos esforços mentais do pintor moderno a tarefa poética de uma revelação experiencial da verdade que, dado o tamis temporal que determina a experiência

${ }^{351}$ Cf. BENJAMIN, Walter. op. cit., p. 328. 
histórica humana, Ihe é inacessível de forma direta, imediata e total. A verdade é só perceptível à experiência humana de forma velada, distorcida; e em virtude de uma privilegiada atenção mental.

Nas palavras de Benjamin, "a verdade é morte da intenção". " $A$ verdade está carregada até o ponto de ruptura com tempo". O ponto de ruptura onde a verdade relampeja é a morte da intenção. A morte da intenção é a condição essencial do projeto crítico que, desse ponto de vista, difere radicalmente da atividade do comentador que se debruça sobre os conteúdos intencionais da obra de arte ou da experiência histórica. O esforço mental do pintor é antes um esforço de neutralização de toda a intenção, se colocando nesse vórtice aintencional para o imprevisível e efêmero reluzir da verdade, para o seu pathos premonitório. ${ }^{352} \mathrm{Na}$ revelação poética é possível extrair dos negativos uma essência, um pressentimento da sua verdade. Uma das chaves centrais para a compreensão do fenômeno poético de decifração ou revelação poética passa pela esfera da semelhança poética.

No estremecimento da vida encontra-se a morada da beleza, mas a sua fixação artística depende de uma contenção da natureza mimética da estremecida força vital. O estremecimento vital que é a beleza tem que ser paralisado como que por um feitiço ${ }^{353}$ sobre a máscara petrificada do inexpressivo. A paralisia inexpressiva que deixa fulgurar a verdade na obra de arte resulta do esforço mental do poeta, de sua violência crítica:

352 Será possível entender esta revelação poética de acordo com outra, que Ihe é aparentada, a metáfora: a desses quadros conformados por padrões de cores aparentemente informes mas que, como resultado de intensa contemplação, acabam por revelar ao olhar, subitamente iluminado, as formas nítidas e definidas de um qualquer objeto, ser ou paisagem.

353 Teria sido deste termo português que derivou a palavra Fetish. Sobre a etimologia de "feitiço" e a sua correspondência com seus avatares lexicográficos como fetichismo ver AGAMBEM, Giorgio. Estâncias. A palavra e o fantasma na cultura ocidental. Trad. Selvino José Assmann. Belo Horizonte: UFMG, 2007. 
A inexpressividade é a violência crítica que, impedida de separar a semelhança da verdade na arte, evitá que se misturem. Contudo, possui essa violência como um ditame moral. ${ }^{354}$

A verdade investe a arte com sua sublime violência, a possui sob a forma de um inexpressivo ditame moral. O incômodo alegórico que preserva em negativo a chama da verdade impõe-se como um imperativo moral ao artista que se depara com a inelutável separação entre a verdade e a beleza. O estremecimento vital é informe, nunca simbólico. Menos simbólica é ainda a beleza da arte que é apenas semelhança. Por meio da semelhança, a arte toca a beleza mas nunca a possui integralmente. Por sua vez, o inexpressivo redime, purga, essa semelhança bela que persiste na obra de arte de qualquer legado do caos que nela sobrepuja.

Se formos falar sobre a condição da cultura depois de Auschwitz, pronunciou Adorno, no final de um ensaio sobre "Crítica da Cultura e Sociedade," escrito em 1949 e publicado em 1951, estas palavras, são inundadas do poder e da gravidade das tremendas fórmulas:

Mesmo a consciência mais radical do desastre ameaça degenerar em conversa fiada. A crítica da cultura vê-se confrontada com o último grau da dialética entre cultura e barbárie: escrever um poema depois de Auschwitz é bárbaro, e este fato afeta até o conhecimento que explica porque se tornou hoje impossível escrever poemas. ${ }^{355}$

A tempestade suscitada por estas palavras reuniu todas as condições para imitar um determinante interdito ou, de maneira igualmente desafortunada, darem lugar a um contrabando de conceitos como indizível e irrepresentável que, nas suas versões mais inocentes, equivalem ao kitsch erudito, como foi renomeado por António Guerreiro no seu ensaio aqui glosado. ${ }^{356}$ Por sua parte, Giorgio

\footnotetext{
${ }^{354}$ Cf. BENJAMIN, Walter. op.cit., p.

355 Cf. ADORNO, T. W. Prismas: crítica cultural e sociedade. Trad. Augustin Wernet. São Paulo: Ática, p. 23.

${ }^{356}$ Cf. GUERREIRO, António. op. cit., p. 39.
} 
Agamben denunciava, em seu livro O que resta de Auschwitz, a intromissão de categorias teológicas que fazem do Holocausto uma nova teodiceia:

Que Auschwitz tenha sido um fenômeno único (pelo menos em relação ao passado, quanto ao que o futuro nos reserva só podemos ter esperança) é bastante provável [...] Mas por que indizível? Por que conferir ao extermínio o prestígio da mística? ${ }^{357}$

Reconhecemos que a afirmação de Agamben deve ser interpretada em sua dimensão literal, como realmente tem sido feito, sem ter em conta nem o contexto em que foi enunciada nem os prolongamentos e revogações a que o próprio Adorno a submeteu, a poesia de Celan seria a mais poderosa refutação das teses da irrepresentabilidade do extermínio (no caso de Georges Didi-Huberman), e parece movida pela desgarradora necessidade de arrancar as palavras de um depósito de onde se desapareceram tanto a garantia metafísica da relação com Deus, quanto a garantia ética da relação com os outros. Tanto para Celan como para Kiefer, a condição do poema é a de ser uma palavra final, sem sujeito, que fixa a dimensão infernal do que aconteceu, testemunhando pela ausência de todo o testemunho. Cogitemos no poema "Niemand/zeugt für den/Zeugen", ninguém testemunha pela testemunha, é a última estrofe do poema "Aschenglorie", de Atemwende. ${ }^{358}$ Narra John Felstiner, ${ }^{359}$ em única biografia do poeta que abrange toda a sua vida, que Paul Celan se sentiu muito incomodado e desapontado com o interdito lançado por Adorno, chegando mesmo a pensar que era ele próprio o atacado, enquanto autor de um memorável poema "Fuga da Morte" (Todesfuge) que se começava a tornar emblema na plástica de Anselm Kiefer. A oposição de Celan ao significado mais imediato das palavras de Adorno, aquele que não podia deixar de se impor antes

357 Cf. AGAMBEN, Giorgio. op. cit., pp. 29-30.

358 Cf. CELAN, Paul. 1983 vol. 2, p. 72.

359 Cf. FELSTINER, John. Paul Celan. Poet, survivor, jew. New Haven: Yale University Press, 1995. 
dos vários corretivos a que elas foram depois sujeitas, é fácil de perceber, se tivermos em conta esta posição de princípio que já tinha sido manifestada numa carta de 1948, a familiares que viviam em Israel, citada por Felstiner: "Não há nada no mundo que possa levar um poeta a deixar de escrever, nem mesmo o fato de ser judeu e o alemão a língua dos seus poemas. ${ }^{1360} \mathrm{~A}$ poesia de Celan, em si mesma, minimizava as palavras de Adorno a mera postura enfática, dispensando qualquer intervenção pública, a que, de resto, Celan sempre resistiu. ${ }^{361}$ A reação de Celan à premissa adorniana não obedece a uma ordem meramente intelectual. Para ele, aquelas palavras, ao elevar o silêncio dos poetas à categoria quase de moral normativa, consagravam uma insuportável injustiça, a maior que podia ser cometida não só à memória dos mortos, como também àqueles que escavavam na fenda do tempo para dela arrancarem um testemunho irrefutável. No entanto, para além dessa questão moral, a afirmação de Adorno também levanta uma questão material: a poesia (e arte em geral) seria incapaz, sob qualquer forma, de estar à altura da singularidade absoluta do que aconteceu: a morte

\footnotetext{
360 Idem. ibidem, p. 57.

361 O encontro entre Adorno e Celan, recensiado por Peter Szondi, esteve marcado em julho de 1959, nos Alpes suíços. Celan regressou a Paris sem ter-se apresentado ao encontro. Desse não encontro, resultou, no mês seguinte, um texto em prosa intitulado "Diálogo na Montanha". Trata-se de uma alegoria construída a partir dos elementos do mito do judeu errante. Dois judeus, o judeu Grande e o judeu Pequeno, encontram-se na montanha e, num primeiro momento, uma lei de silêncio foi imposta pelo judeu Grande: "E assim se calou também a pedra, e fez-se silêncio na montanha por onde eles iam, este e aquele. Havia silêncio, pois, lá em cima na montanha. Mas o silêncio não durou muito, porque quando o judeu vem caminhando e encontra outro, não dura muito tempo o silêncio, nem a montanha. Pois judeu e natureza são coisas distintas, ainda e sempre, hoje também, aqui também". Apesar do caráter altamente hassídico deste texto, em que Celan revela, mais do que em qualquer outro momento da sua obra, uma enorme proximidade com a literatura judaica, ele fornece elementos que permitem interpretá-lo como uma resposta ao julgamento adorniano. Mas este diálogo da Montanha é muito mais do que uma resposta a Adorno, e certamente que as interpretações não teriam insistido tanto nesse quesito, que se tornou o mais imediato, se o próprio Celan não tivesse referido explicitamente à circunstância que o levou a escrever esse texto. Cf. GUERREIRO, Antônio. op.cit. p. 42.
} 
administrada em termos industriais e também como solução final. ${ }^{362}$ Cogitamos que a sentença de Adorno mostra uma obstinada desconfiança na poesia: ora porque perante o sofrimento das vítimas revela-se banal e todo o preciosismo poético insustentável, ora porque os meios que the são próprios revelam-se insuficientes perante aquilo a que ela tem que responder. Adorno sente a necessidade de reduzir a poesia às formas mais convencionais de

${ }^{362}$ Franz Kafka, por exemplo, começa a escrita do Processo em 1914, como uma grande contestação à Erlösung, conforme a uma utopia negativa que reverbera obstinadamente na integridade da sua obra. Franz Rosenzweig, escreveu em 1910, que toda escrita se torna culpada desde que consiga penetrar na história. Na publicação de $A$ estrela da redenção em 1921, ele encorpa à Erlösung conteúdos densamente filosóficos, como uma ruptura violenta do tecido histórico, a irrupção até à medula de uma alteridade absoluta, de uma experiência radicalmente diferente. $O$ assunto da redenção não mais concerne à relação do homem com Deus, mas também a um vínculo estético do homem com a história, no exato momento no qual a história se torna incapaz de sustentar a ingênua ilusão no progresso. Para Rosenzweig a redenção não mais exprime um salvamento definitivo, o final dos tempos ou, mais ainda, a ressurreição do que será. Ela é ora a espera de uma revolução que pode acontecer em qualquer momento, ora uma instância de resistência às garras da história quando elas avançam sobre a humanidade. Em 1931, no seu livro O messianismo judeu. Ensaios sobre a espiritualidade do judaísmo, Gershom Scholem comenta a tentativa de Rosenzweig sob a perspectiva de um ensaio de dialética histórica do conceito da redenção. Anos depois, com o nazismo no poder, Scholem empreende o estudo histórico do conceito de redenção na mística judaica. Ele descreve a redenção pelo pecado a partir da heresia sabbateana e do niilismo de Jacob Frank. Em face do problema essencial da vida, a saber, o desembaraça das redes do caos da história, podemos hesitar entre dois olhares. O primeiro enxerga o fim dos tempos, a redenção messiânica, fixando sua esperança nesse final do tempo. O olhar contrário procura a saída da mácula, da confusão, do caos e dos cataclismos da história por um vazamento do começo. Eis a importância do problema da criação. Scholem demonstrou que a noção judaica de redenção (ge'ulah) forma um contraponto rigoroso às noções de salvação histórica cristãs, hegelianas e marxistas. Trata-se de uma resposta à situação de exílio, mas uma resposta guiada por um pessimismo absoluto no que diz respeito à história e a seu prometido progresso. A tradição judaica clássica, diz Scholem, comentando um capítulo do tratado de Sanhédrin, redimensiona o aspecto catastrófico da redenção: a redenção é uma destruição, uma subversão, uma calamidade e não existe lugar para evoluir com o progresso. Isto resulta do caráter dialético da redenção nessa tradição. Essa dialética à que se refere Scholem exprime-se na Cabala em termos de contração (tsimtsum) de fragmentação (shevirah) e de reparação (tikkun). Cf. MOSES, Stéphane. L'Ange de I'histoire. Rosenzweig, Benjamin, Scholem, Paris: Le Seuil, 1992, p.56. 
expressão lírica para que sua frase seja apreciada em sua justa perspectiva. Contudo, os pressupostos vão sempre dar na aporia: aquilo que interdita a poesia (arte) é, por outro lado, o que demanda sua dimensão ética. Transformado pelo chamado princípio estético de estilização, o horror torna-se fonte de preservação do mal, princípio de prazer e, nesse sentido, uma insustentável negação da integridade da experiência. Um exemplo dado por Adorno é $O$ sobrevivente de Varsóvia, de Schönberg: por um lado, essa composição obedece à regra que exige que o sofrimento extremo não seja esquecido; mas o fato de Ihe dar uma forma, de o elaborar numa imagem, é, perante tudo, uma ofensa à dignidade das vítimas. ${ }^{363}$ Voltando a essa idéia de que a arte se encontra numa condição de aporia, e em resposta a uma dura crítica que Ihe tinha sido dirigida por Enzensberger, Adorno elabora outro texto, em 1962, intitulado "Engagement", onde comenta: "O excesso de sofrimento real não tolera o esquecimento." ${ }^{364}$ Mais uma vez, parece se estar negando o que tinha sido dito onze anos antes. Parece não ser essa a pretensão de Adorno, já que, nesse mesmo ensaio, também afirma: "Não gostaria de amenizar a afirmação de que depois de Auschwitz seria bárbaro escrever um poema." ${ }^{365}$ Como afirma Jeanne Marie Gagnebin: "Proibição do consolo, proibição da imagem, impossibilidade do sentido, desmoronamento dos princípios de formação e de estilo artísticos. ${ }^{1366}$ Adorno nunca cogitou que suas

\footnotetext{
${ }^{363}$ Essa formalização da dor objetada por Adorno aplicar-se-ia também às trenodonias musicais contemporâneas que surgiram como réquiens consoladores em meio a acontecimentos notoriamente catastróficos. Escutar a Krzysztof Penderescki e sua Trenodonia pelas vítimas de Hiroshima (1960) e Trenodonia pelas vítimas de Chernobyl,(1986) de Nancy Van de Vate.

${ }^{364}$ Cf. ADORNO, T.W. Teoria estética. Trad. Jõao Moura. Lisboa: Edições 70, 2006 , p. 390.

${ }^{365}$ Cf. ADORNO,T.W. Notas sobre literatura I. Trad. Jorge de Almeida. São Paulo: Editora 34, 2005, p. 135.

366 Cf. GAGNEBIN, Jean Marie. "Após-Auschwitz." In: SELIGMANN-SILVA, Márcio. História, memória e literatura. $O$ testemunho na era das catástrofes, p.107.
} 
palavras fossem elevadas ao imperativo de interdição. Numa última vez, em 1966, num capítulo da Dialética Negativa de título "Meditações sobre a Metafísica", Adorno reverbera no assunto, para mais uma tentativa de restituição, desta vez, sem obnibulações e, mais apoiada numa esteira teórica que encontra finalmente a sua forma acabada e que, por isso, torna suas subseqüentes afirmações muito mais admissíveis: "O perene sofrimento tem tanto direito à expressão como tem o torturado de gritar; é por isso que talvez tenha sido falso afirmar que depois de Auschwitz já não é possível escrever poemas. ${ }^{1367}$

Adorno propõe de maneira mais amena que Auschwitz representa um modelo que suspende o discurso especulativo, um eterno negativo que não é mediatizável pela dialética, na medida em que se torna epítome da destruição, para o pensamento metafísico especulativo, daquela base de sua possível harmonização com dimensões da própria experiência. Para Adorno, o fato paradoxal de pensar contra o pensamento, não sustentava necessariamente uma negação radical da produção pós-Auschwitz. Adorno parece ter avistado em Celan outro desafio que não podia deixar de assumir. Contudo, este ensaio, tal como o encontro marcado na Suíça anos antes, acabou por nunca se realizar. No entanto, sua Teoria Estética (publicada em 1970, um ano depois de ter falecido) contém algumas memoráveis passagens sobre Paul Celan, aquele que ele reconheceu como "o mais significativo representante do hermetismo da lírica alemã contemporânea. ${ }^{\prime \prime 68} \mathrm{O}$ chamado selo de hermetismo imprimido na poesia de Celan, é, assim, por mais de uma de suas inversões dialéticas, essa opacidade tornada transparência e esse silêncio exaltado pela estridência do grito. Sabemos que os poemas de Celan transpiram essa vontade de exprimir o horror supremo por meio do

367 Cf. ADORNO, T.W. Dialética Negativa. Trad. Marco Antônio Casanova. Rio de Janeiro: Jorge Zahar, 2009, p. 284.

${ }^{368}$ Cf. ADORNO, T. W. Teoria estética, pp. 446. 
silêncio. O seu próprio conteúdo de verdade torna-se negativo. A poesia de Celan encontra-se no limiar de uma linguagem que está aquém da própria linguagem dos homens, ou mesmo aquém de toda linguagem existente, com articulação orgânica, linguagem do que está extinto na existência; eliminando os últimos rudimentos do orgânico, aparece o que Benjamin reconheceu em Baudelaire, quando disse que o seu lirismo era desprovido de aura. ${ }^{369}$ Sob um olhar crítico, o hermetismo de Celan ${ }^{370}$ significa então, uma recusa em fazer o jogo da comunicação, em integrar-se na lógica de uma língua pervertida e mutilada. A literalização do campo metafórico das obras de Kiefer encontra-se na materialização da aporia memorial da poesia de Celan. É na imaginação dos materiais que Kiefer responde a uma categoria de sublime que permite expressar o horror, e atualizar os signos da destruição em uma dimensão física dos espasmos provocados pela dor do poeta.

\footnotetext{
${ }^{369}$ Cf. BENJAMIN, Walter. op. cit., p. 446.

370 É difícil reconhecer um percurso linear na poesia de Celan, ou um conjunto de etapas de produção plausíveis de serem hierarquizadas. Os poemas publicados em 1952, na República Federal da Alemanha, recolhidos no livro intitulado Papoula e Memória (Mohn und Gedächtnis) não têm ainda a vontade dialógica nem o tom trágico que encontramos em Rosa de Ninguém (Die Niemandsrose), de 1963, nem a rarefação metafórica que já se nota em Grade de Linguagem (Sprachgitter), de 1959. Mas foi um poema publicado logo no seu primeiro livro (Der Sand aus den Urnen), (As areias das urnas) editado em Viena, em 1948, e que continha tantos erros de impressão que foi renegado pelo autor, tendo uma parte dos seus poemas transferida para Papoula e Memória, poemário que impulsionou o poeta e contribuiu para a identificação de sua poesia com a tragédia do povo judeu, no século XX. O poema Fuga da Morte, tornou-se objeto de afeição que nenhum outro poema, depois da guerra, logrou. Foi considerado por John Felstiner como a Guernica da literatura européia do pós-guerra, na medida em que "ocupa na poesia de Celan um lugar semelhante à Guernica na obra de Picasso e, no efeito que produziu, desempenhou um papel comparável." Cf. FELSTINER, John, op.cit., p. 92.
} 


\section{B.SULAMITH, MULHER DE CINZA}

Sobreviver na palavra testemunhada, mas como história pessoal, senão como um trazer à palavra a morte e os mortos acontecidos, é a forma pela qual a Shoah evita o abjeto no presente. Adrián Cangi.

Em 1983, com Sulamith, Kiefer desloca seu gesto comemorativo do corpo sofrido e das paisagens cultivadas na câmara fúnebre. Lembremos que o motivo da câmara fúnebre faz parte de uma série de sugestivas pinturas produzidas entre 1980 e 1983, nas quais Kiefer retrabalhou diversas representações da arquitetura monumental hitleriana, recompondo-las num mitomotivo a partir de elementos estereotipados da estética neoclássica nazista. Com esse fim, Kiefer aumentou a escala de documentos fotográficos ou de desenhos arquitetônicos, para interferi-las com uma variedade de materiais heteróclitos da pintura - óleo, acrílico, emulsão ou esmalte - que o artista acabou misturando com outros materiais: notadamente, o chumbo e a palha. Igualmente, substituiu os elementos narrativos do modelo original, em particular, os emblemas nazistas, por alegorias particulares. Finalmente, incrustou certo número de marcas do tempo à tela que nos permitem concluir o abandono dessas construções monumentais. Os títulos dados por Kiefer a esses emblemas da arquitetura nazista raramente correspondem ao que eles representaram: Interior, (fig. 45) Ao pintor desconhecido, (fig. 46) Athanor (fig. 47), Ao Ser Supremo, (fig. 48) e, por último, Sulamith (fig. 49). 
Na sua obra, Kiefer tematiza os aspectos autoritários, regressivos e arcaizantes da arquitetura nazista. Após ter transposto o estilo vernacular como observamos na série dos áticos, ele se apega à arquitetura monumental oficial de estética neoclássica, destinada a pontificar as instituições de poder. Para compreender o efeito alucinatório dos edifícios que Kiefer reclama para sua tela, é necessário lembrar que o material com que foram construídos estes prédios não tem correspondências com materiais contemporâneos e que se trata de prédios que foram integralmente dinamitados após

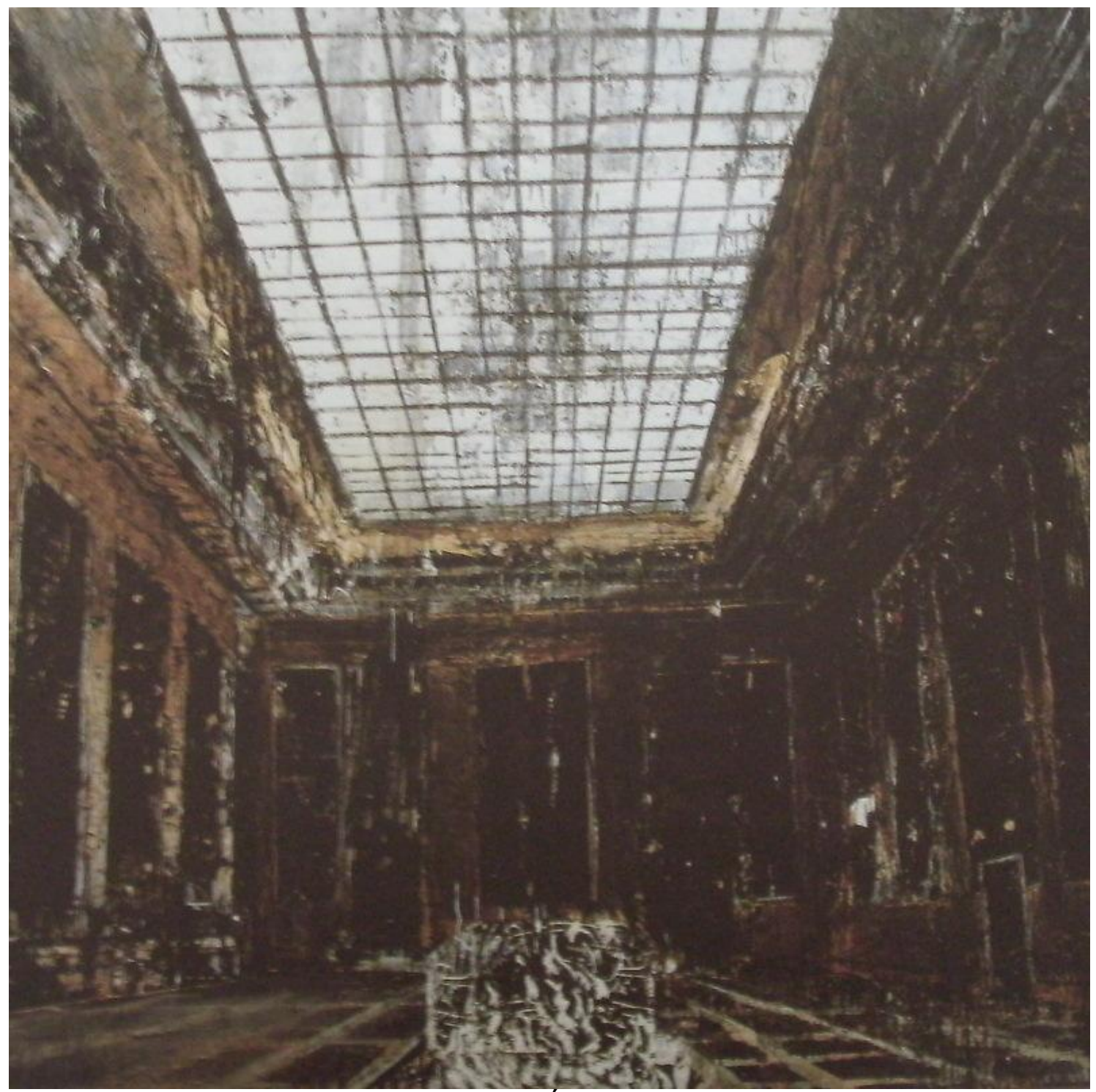

Figura 45. Interior/Inneraum, 1981. Óleo, acrílico, emulsão s/tela. 287 x $311 \mathrm{~cm}$. Museu Stedelijk, Amsterdam. 
1945 e, que seus vestígios têm sido discretamente incorporados na reconstrução das vilas.

Interior, é um palimpsesto da sala de mosaicos, enquanto a aquarela Ao pintor desconhecido, como também na pintura Athanor, tomam o modelo da Corte de honra da chancelaria do Reich, edificada no centro de Berlim em 1939 por Albert Speer e dinamitado pelos Aliados em 1945. ${ }^{371}$ Os templos de honra da praça Königs em Munique, remodelados por Ludwig Troost em 1933, que Kiefer

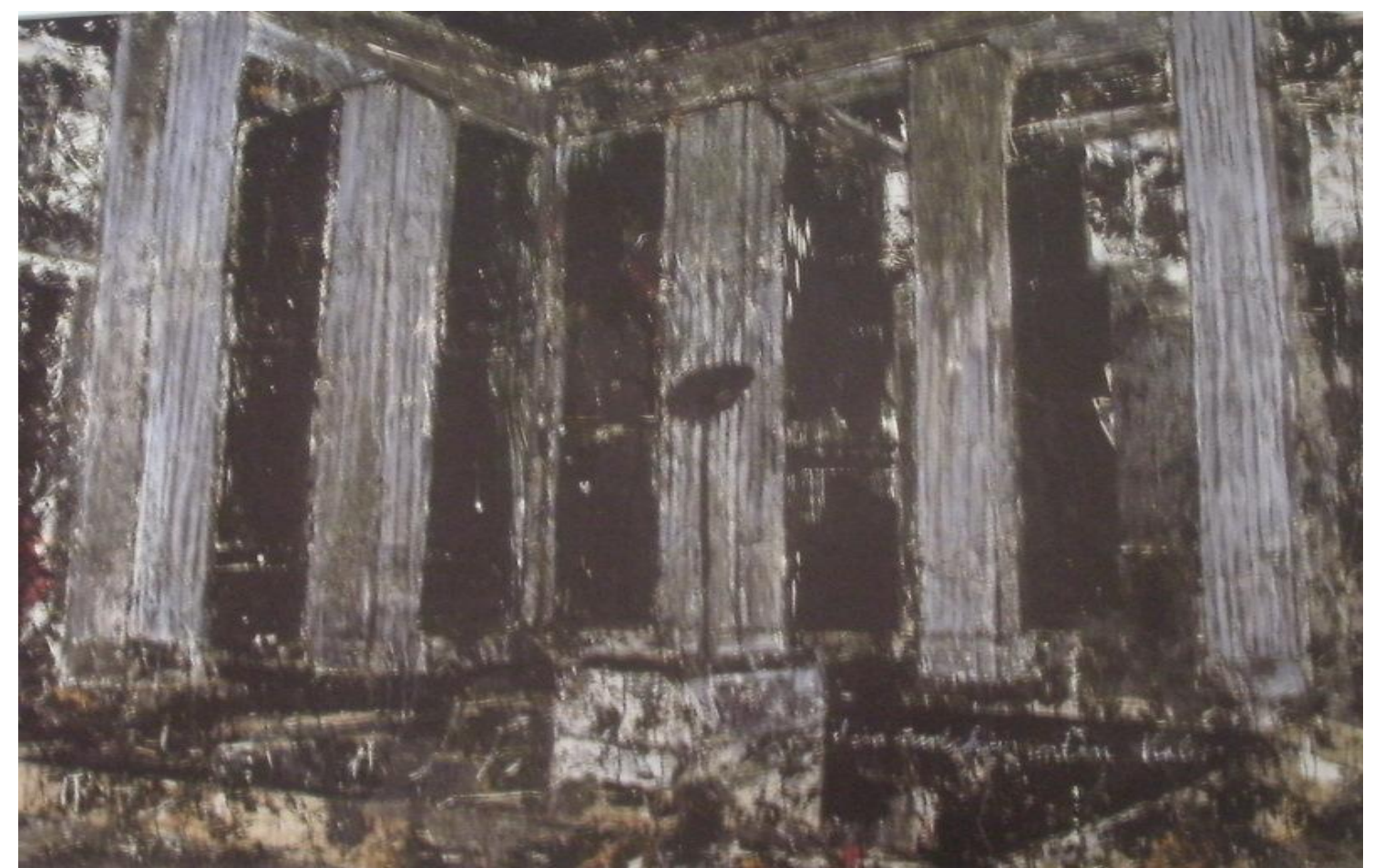

Figura 46. Ao pintor desconhecido/Dein unbekanten Maler, 1982. Óleo, acrílico, emulsão, palha e gravura s/madeira, papel s/tela. $280 \times 341 \mathrm{~cm}$.

representa na sua pintura Ao pintor desconhecido de 1982, sofreram a mesma sorte em 1947. Kiefer, nascido em 1945, não conheceu essas edificações, apenas em documentos, ele lamenta atualmente

371 O simples elemento arquitetônico nazista evocado por Kiefer em que restam traços contemporâneos é a tribuna de Zeppelinfeld em Nuremberg, que se tornara cenário de manifestações de massa. Contrariamente à chancelaria, este outro projeto de Speer em 1934 não foi totalmente destruído ao final da guerra, se tornando centro ativo de manifestações políticas após 1945. Contemporaneamente, alberga instalações e exibições. Lembremos que a fotografia utilizada por Kiefer na pintura $A$ escada (198283), mostra, no entanto, uma parte da dupla galeria de colunas inexistente hoje em dia. 
que essas testemunhas cristalizadas do nazismo não hajam sido conservadas no seu estado como monumentos comemorativos. ${ }^{372}$

As pinturas-palimpsestos da arquitetura nazista são, em

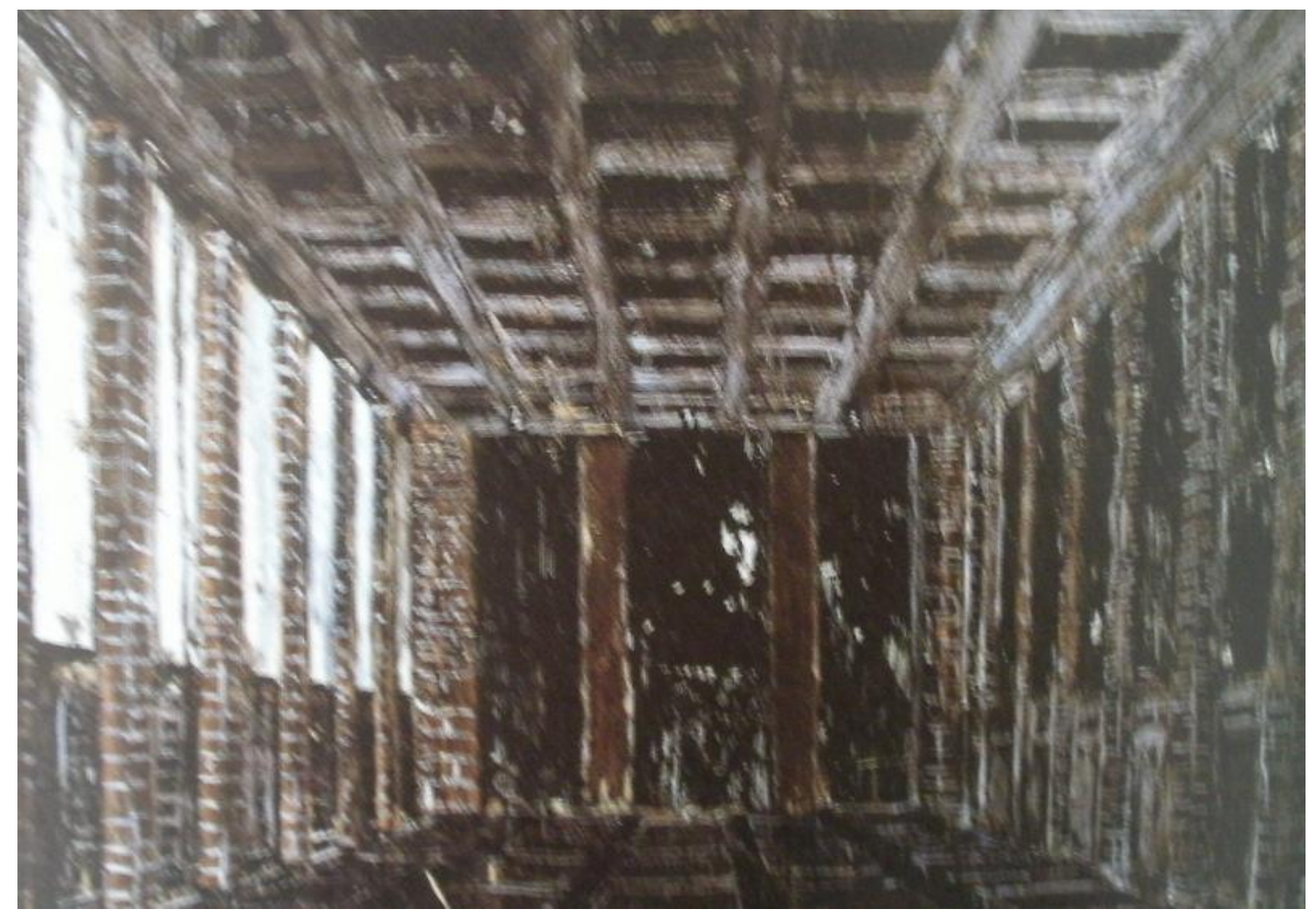

Figura 47. Athanor, 1983-84. Óleo, acrílico, emulsão, esmalte e palha s/fotografia e tela. 225 x 380. Museu de Arte de Toledo, Toledo Ohio.

conseqüência, imagens com sentido próprio, suportes memoriais do que já não existe mais ou do que nunca existiu. Ele mostra estes edifícios como se os mesmos tivessem sido deixados ao abandono em 1945, como testemunhas atuais do declínio do nazismo e do tempo esgotado; as marcas e o tratamento violento a que submete a superfície da tela não constatam apenas uma vontade de destruição do motivo, mas assina a derrota do nazismo. Esse cenário fictício produz uma espécie de inversão do que realmente aconteceu, porque a desaparição quase por completo dos traços físicos do autoritarismo no ambiente urbano teve por colorário a censura das imagens do

372 Cf. Anselm Kiefer numa entrevista com Horst Christoph e Nina Schedlmaer, Profil 6-8, 2005, p. 109. 
declínio na memória da geração que participou da história nazista. As máscaras mortuárias da arquitetura nazista apresentadas nas telas de Kiefer são, portanto, imagens memoriais assoladas pela deterioração do tempo, remanescências retinianas da geração precedente destinadas a desaparecer integralmente em um tempo vindouro. O resultado obtido, mesmo depois do encapamento da fotografia com ajuda da pintura e de materiais precários, torna-se mais ambivalente. Ante os olhos de certos intérpretes, a grossa camada de pigmento não minimiza o efeito de fascinação exercido pelos prédios, senão, pelo contrário, o amplifica. Sua aura melancólica desenterra a teoria estetizante do "valor da ruína", comumente atribuída a Speer. ${ }^{373}$

373 Speer defende esta teoria para justificar o uso de seus materiais de construção animosamente assassinos. O conceito do valor da ruína [Ruinenwert] se monta, sem dúvida, a Georg Simmel que, no seu ensaio de 1907, dedicado ao conceito de ruína, crítica a transformação das ruínas em produtos da natureza, absorventes dos poderes alheios que as tem produzido. Speer, se inspirando nos textos de Hitler, desenvolveu um programa nacional de arquitetura cuja finalidade não era a construção de edifícios à altura do III Reich, porém com o olhar posto na falência da civilização nacional-socialista, pensando nas futuras ruínas dos monumentos do império hitleriano, ruínas que deviam ser tão esplêndidas para os futuros povoadores da terra quanto as egípcias e as romanas são para nós hoje. Esta idéia o possuiu face à visão de um edifício moderno destruído na Primeira Guerra Mundial: um formigão armado se retorcendo todo. Segundo Speer: "Aquela desoladora imagem me levou a uma reflexão que ulteriormente expus a Hitler sob o título 'teoria do valor como ruína numa construção'." Seu ponto de partida era que as construções modernas não eram adequadas para edificar a ponte da tradição em direção a futuras gerações que Hitler desejava: resultava impensável que um monte de escombros enferrujados pudessem transmitir o espírito heróico que Hitler admirava nos monumentos do passado. Cf. SIMMEL, Georg. In: MORAES, F. E. (org.) Simmel. Col. Grandes Cientistas Sociais. São Paulo: Ática, 1983, p. 188. Cf. SPEER, Albert. Memorias. Barcelona: El acantilado, 2001, pp. 104106. 


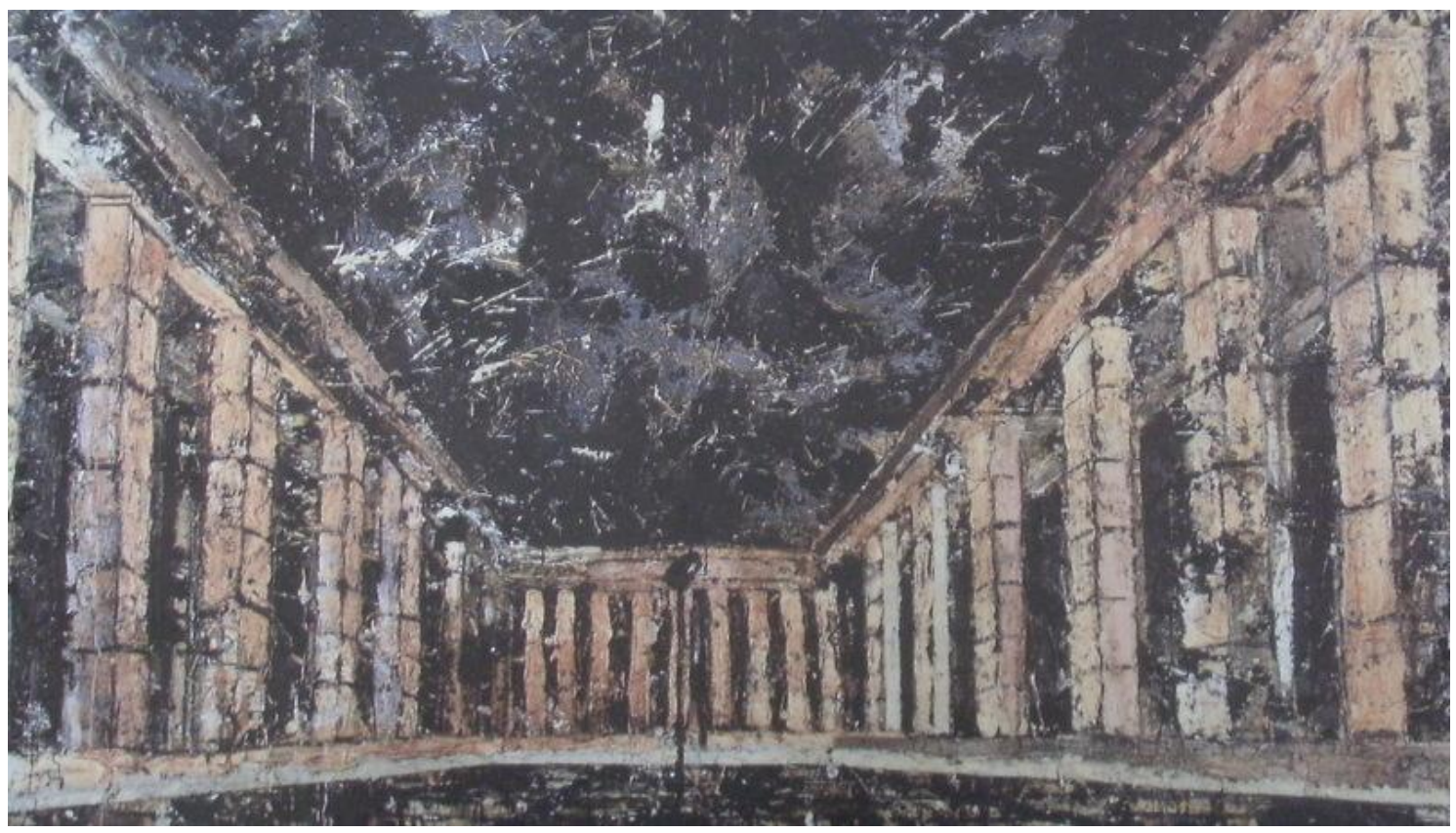

Figura 48. Ao ser supremo/To the Supreme Being, 1983. Óleo, acrílico, emulsão, esmalte, palha e fragmentos de uma gravura s/madeira incrustados na tela. $278 \times 368 \mathrm{~cm}$.

A arquitetura nazista pode suscitar tanto, a rejeição imediata ou, como assevera Andreas Huyssen, quanto "um olhar racional e político."374 Huyssen considera que são justamente essas transfigurações kieferianas que Ihe alertaram uma reflexão primeira sobre essa imaginação arquitetônica de corte fascista. As mesmas não teriam sido possíveis sem a presença do mundo alucinado de Kiefer. A adjunção de materiais de cunho transitório, tais como a palha, entram em franca oposição com essa pernosticidade perenal que as estruturas nazistas pretendem impor. Todas as transfigurações realizadas por Kiefer transformam imagens aparentemente puras, em simulacros, em imagens de letargia, poderosos emblemas de uma disposição psíquica da Alemanha do pós-guerra. ${ }^{375}$

374 Cf. HUYSSEN, Andreas. Twilight Memories: Marking Time in a Culture of Amnesia. New York: Columbia University Press, 1995, p. 59.

${ }^{375}$ Idem, ibidem., p. 64. 


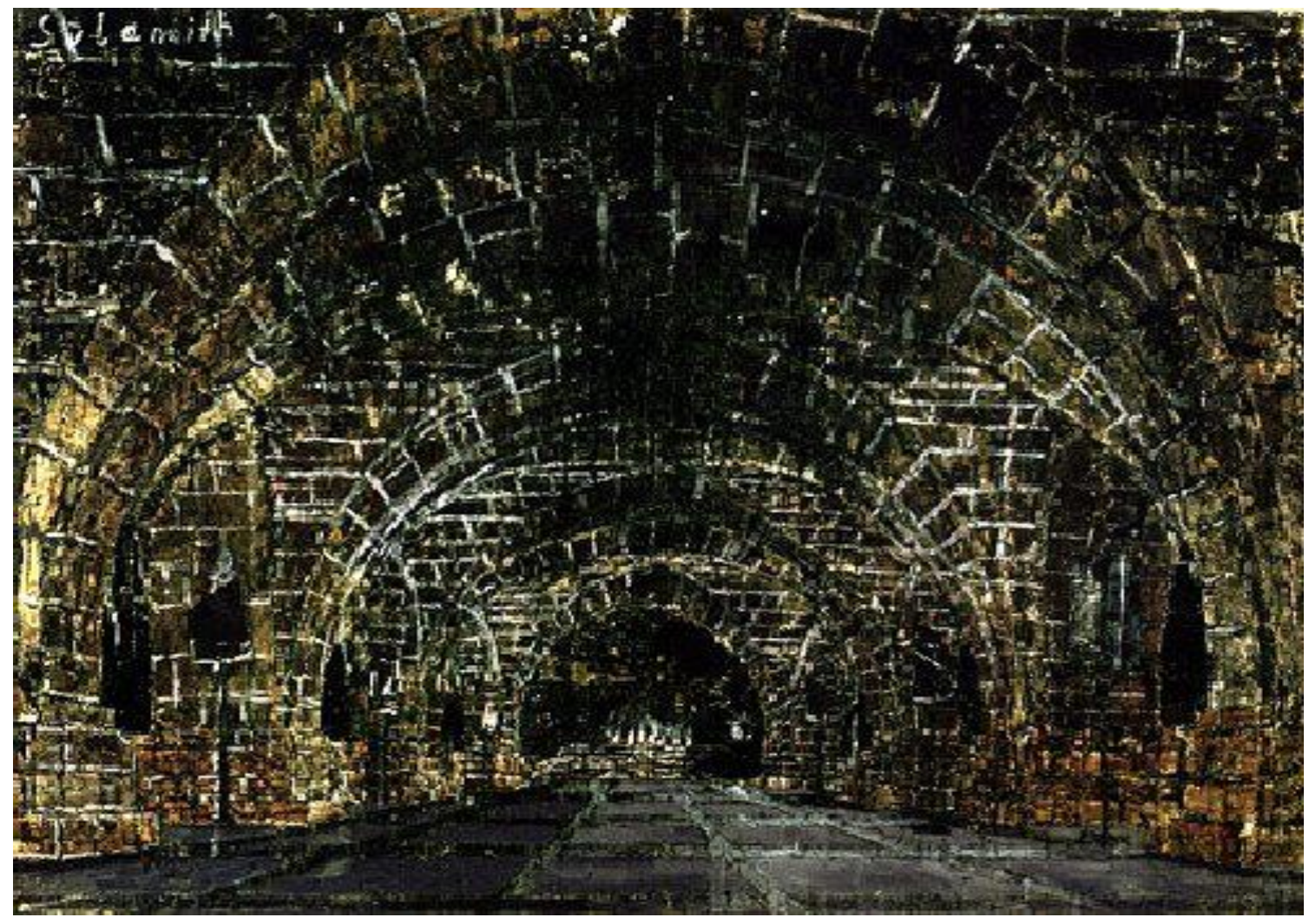

Figura 49. Sulamith, 1983. Óleo, emulsão, xilogravura, esmalte, acrílico e palha s/tela. $290 \times 370 \mathrm{~cm}$.

Sulamith encerra série dedicada aos monumentos arquitetônicos nazistas. O espaço da tela toma como fonte de produção a fotografia de um modelo de cripta de Wilhem Kreis (fig.52) de 1938. ${ }^{376}$

376 Dentre os modelos arquitetônicos que Kiefer empregou como recorte pictórico, os rascunhos de Wilhem Kreis (1873-1955) têm a melhor parte. Quase nenhum projeto de Kreis, com exceção do sítio de Luftgaukommando em Dresde, recebeu objeção sob o nazismo. Ele formou, no entanto, junto com Paul Ludwig Troost e Albert Speer, a elite de arquitetos nazista, ocupando funções oficiais como diretor da Academia de Belas Artes de Dresde, de 1938 a 1942, "conselheiro geral para a construção de sepulturas militares alemãs" a partir de 1941, e, além disso, foi presidente da Câmara Artística do Reich em 1943. Antes de 1933, Kreis estudou diferentes edificações do estilo Bauhaus, entre os mais conhecidos da época encontravam-se a grande loja de departamentos Tietz em Colônia (191214) e o Museu da Higiene em Dresde (1928-30). Após 1945, ele prossegue sua carreira de arquiteto em franca reconciliação com o estilo moderno de 

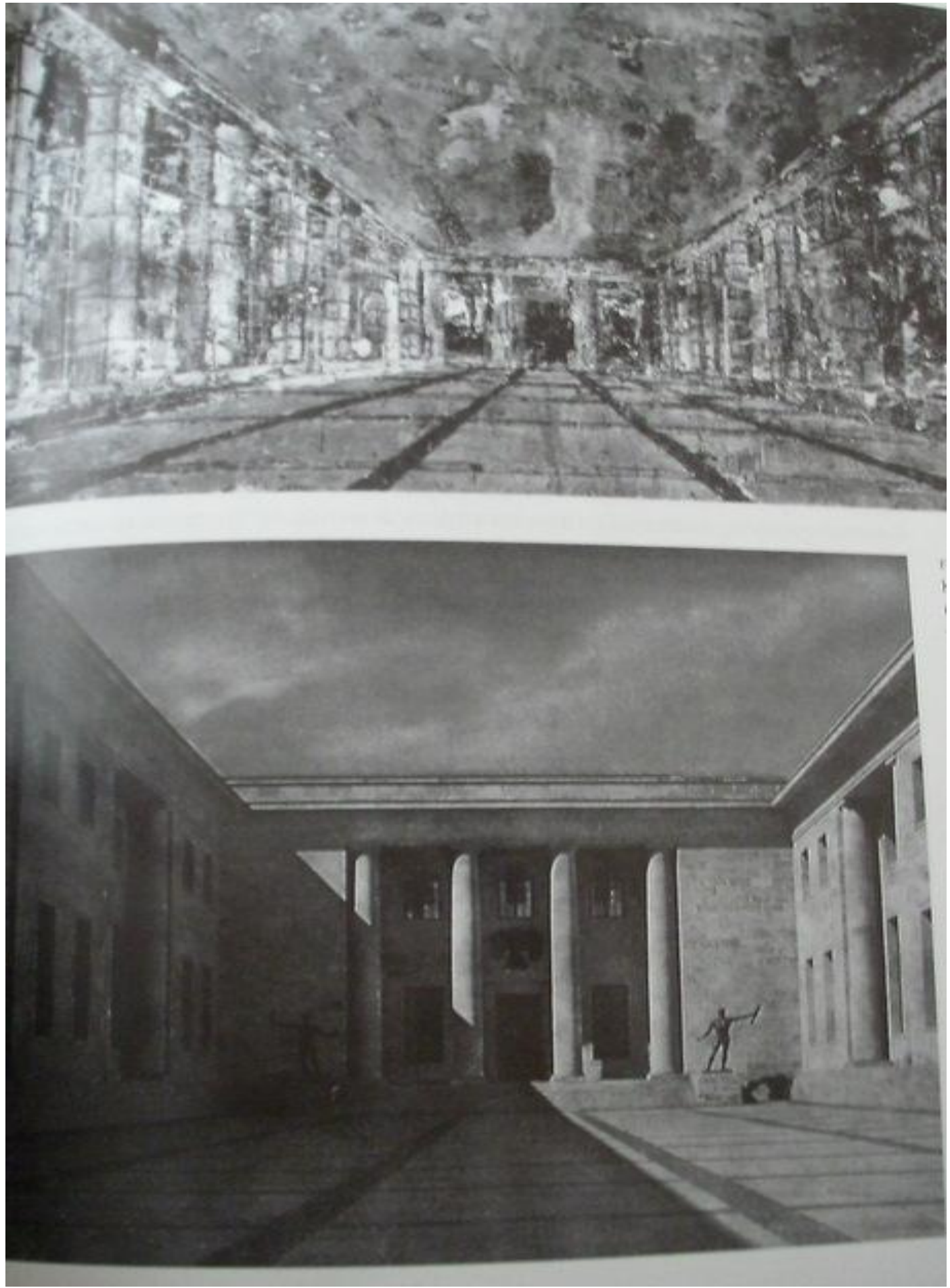

Figura 50. Albeert Speert, páteo da Chancelaria do Reich, Berlim, 1939.

seus primeiros projetos. Incontáveis edifícios públicos, tais como o Museu da Saúde em Colônia também foram construídos a partir de seus planos. Cf. LAUTERWEIN, Andrea. op.cit., pp. 87-98. 


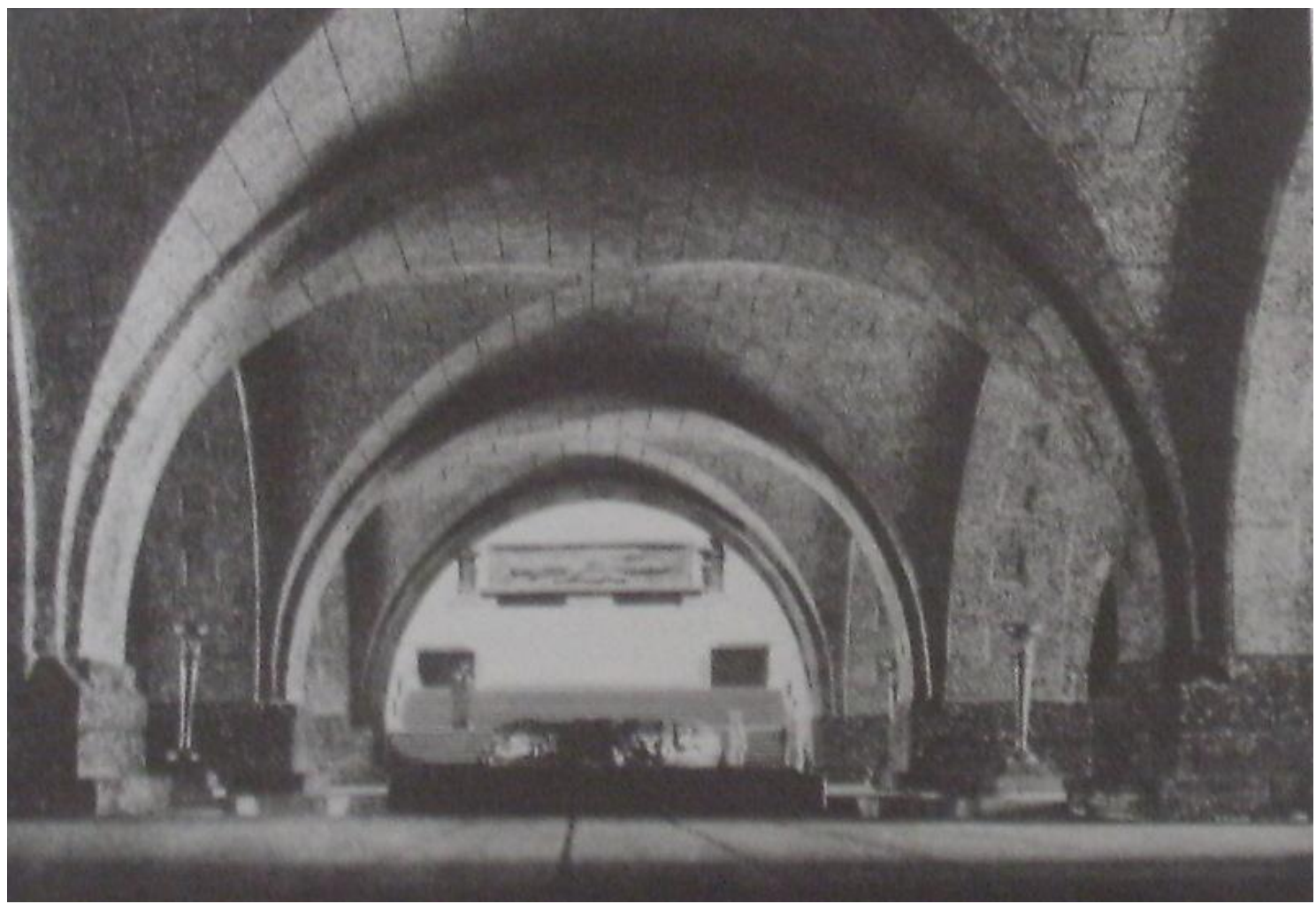

Figura 51. Wilhem Kreis. Fotografia de um modelo de cripta para os soldados alemães, interior. 1938-1941.

Destinada ao Estado maior da armada berlinense, esta cripta de estilo neo-românico deveria ser instalada na sala dos soldados. $\mathrm{Na}$ Sulamith, Kiefer reprisa o caráter medieval da peça arquitetônica prefigurado no modelo de Kreis. A cripta original sofre múltiplas modificações sob a paleta de Kiefer: os arcos de tijolo de pendor românico são alongados em duas unidades, aumentando a profundidade do espaço, produzindo, assim, uma perspectiva aclimatada em uma atmosfera autoritária que desvela a pulsão genocida do nazismo, transferindo-a à linguagem arquitetural, essa cadência lutuosa do poema Fuga da Morte. A superfície da tela é trabalhada com materiais heterogêneos corriqueiros e as gravuras em madeira foram ampliadas até alcançar o estatuto de estandartes. A palha e a cinza que o pintor mistura à plastina, remetem à complementaridade das memórias. A peça está orientada em direção a um nicho central que pode nos induzir à imagem de um semitúmulo ou um semi-altar. A pintura é iluminada pelas sete chamas da 
menorá, o candeeiro do Templo de Jerusalém. O nome do topônimo Sulamith, inscrito no alto, à esquerda, o mesmo que a menorá, representam aqui imagens impregnadas que transformam o potencial comemorativo de um mausoléu destinado aos heróis nazistas, em memoria às vítimas da Shoah. Para compreender até que ponto esta posta em cena era surpreendente, deve-se lembrar que nessa altura, 1983, não existia nenhum memorial pelas vítimas judias na Alemanha Federal. ${ }^{377}$ A substituição da paleta do pintor desconhecido

377 A primeira grande tentativa do arquiteto polaco-americano Daniel Libeskind de realizar uma fusão entre arquitetura e literatura da Shoah conjugou-se no seu projeto arquitetônico do Museu Felix Nussbaum em Berlim, uma proposta não apenas com uma intencionalidade estética arquitetural, mas também de certa relevância moral. Trata-se de uma espécie de comemoração do trauma no espaço da arquitetura. O novo museu judaico em Berlim é bem sucedido não apenas como surpreendente aparato lírico/estético, como também, enquanto estratégia rentável. Como já constatara David Harvey, as intervenções urbanas têm-se especializado em construir lugares exclusivos capazes de exercer um poder de atração significativo sobre os fluxos de capital. Neste caso, a obra tornou a Berlim recém-unificada, uma das maiores atrações da Alemanha. A crítica tradicional aos museus parece um tanto indefesa numa época em que muitos museus são inaugurados e como nunca as pessoas os procuram bem como às exposições. A morte dos museus, tão valentemente anunciada na década de 60 , não foi, evidentemente, a palavra final. Isto, no entanto, não seria suficiente para denunciar o recente boom dos museus - a partir do efeito Bilbao - como expressão do conservadorismo cultural dos anos 80, que presumivelmente trouxe de volta o museu como instituição de uma verdade estética e de uma cultura de autoridade senão mesmo autoritária. A reorganização do capital cultural como experimentamos nos anos 80 , nos debates sobre o multiculturalismo à l'americaine, não pode ser limitada a uma única linha política. Também não é suficiente criticar as novas práticas de exposição de arte como espetáculo de massa, cujo objetivo é sobrepujar o mercado da arte para a moda através do êxtase e da obscenidade. Enquanto a crescente marketização da arte representa um modelo quase incontestável, a crítica mercadológica sozinha está longe de produzir critérios estéticos e epistemológicos como ler obras específicas, práticas artísticas ou exposições. Hal Foster chega a dizer que depois do Guggenheim-Bilbao, a arquitetura e os museus não foram mais os mesmos, e vivemos a cada novo projeto de museu uma espécie de efeito Bilbao, no qual cada cidade procura construir um espetáculo de magnitude similar com o objetivo de atrair novos fluxos de capital, literalmente, culturais. Para Otília Arantes, "a imediata multiplicação da demanda de museus Guggenheim mundo afora, segundo o modelo Disney [...] permitindo [sic] assim abrigar tanto o acervo da coleção quanto fazer circular as obras e promover exposições itinerantes mais facilmente patrocináveis por terem assegurada uma rede de lugares, exponenciando a rentabilidade conforme 
- o motivo do culto da arte e da morte que, implicitamente, designa Hitler, geralmente colocado no centro das arquiteturas nazistas entre 1980-1983 - pelo nome da princesa judia do amor e a menorá, adquire, assim, um poder antagonizante.

O nome de Sulamith está inscrito em pequenas letras brancas sobre fundo negro, com giz, o que destaca a precariedade da presença desse nome. A mesma tinta branca dá corpo às sete chamas da menora e desenha a união entre as telhas que formam as paredes e as abóbadas, essas uniões são chamadas em alemão de Fugen que são, ao mesmo tempo, fugas, o que indica, apesar do caráter maciço da estrutura, que as uniões de um memorial podem se desagregar. A telha, representa a menor unidade de uma construção cultural que delimita o espaço, um muro ou a torre de Babel. Esta, lembremos, é um composto de terra, de água e de fogo, o substrato tectônico de toda cultura. Kiefer associa os quadriculados dos tijolos ao universo concentracionário, aí onde o sonho não pode ser mais do que da cor dos tijolos. ${ }^{378}$ Certos críticos tem elevado esse espaço escurecido pelo fogo a um forno crematório. Para Eric Kligerman:

A presença do fogo adiciona ainda outro risco para a tela. Além de nosso olhar estar preso nesse espaço fechado, o

se replicam as mostras". Ao ser divulgado como ápice da produção arquitetônica recente, gerou fabulosas rendas de monopólio para os diversos agentes envolvidos. $O$ museu é o resultado mais bem sucedido de co-branding urbano até o momento, associando as marcas e os nomes de Guggenheim e Frank Gehry, entre outros, numa cortina midiática conjunta. A iniciativa de Bilbao foi capaz de superfaturar grande capital na operação, enquanto as outras cidades e corporações se contagiavam e aderiam à mesma estratégia. Cf. ARANTES, Pedro Fiori. "O grau zero da arquitetura na era financeira", Novos Estudos 80, Março 2008. pp. 175-195; Cf. DANZIGER BRASIL, L. M. "Daniel Libeskind: arquitetura de vazios." op.cit., pp. 187192; Cf. ARANTES, Otília. "A virada cultural do sistema das artes." São Paulo, Abril 2005, p. 3.

378 Os desenhos que Marx Ernst preparou após a experiência traumática do campo concentracionário de Milles têm reverberado pictoricamente numa sólida estrutura em tijolos. Cf. RICHARD, Lionel. L'art en guerre. Les artistes confrontés à la Seconde Guerre mondiale. Paris: Flammarion, 1995. 
quarto em si parece ser engolido pelas chamas. Enquanto este espaço tem aspectos de uma câmara memorial corre o risco de se perder no fogo. Junto com as pranchas de madeira e os nomes inscritos, nossa posição de sujeitos no espaço ameaça ser consumido pelo fogo. Neste interior espectral, nossa tarefa envolve ambos o olhar e a leitura dos espectros. A pintura captura o momento antes da conflagração do espaço memorial e os gestos em torno dos riscos que este ato de memória, da recordação dos fantasmas, deve encontrar. ${ }^{379}$

O imperativo da arte em Kiefer não é apenas o de acender as chamas mas também o de memorializar o incêndio. Sob as abóbadas de Sulamith, enegrecidas pelo carvão, Kiefer não representa, portanto, a cremação mas certos resíduos da desaparição das vidas humanas. Contrariamente ao modelo fotográfico, sobre a iluminação, permite distinguir os soquetes das flamantes chamas eternas, a menorá é única fonte de iluminação, todos os outros têm sido colocados a meio-pau.

Andreas Huyssen tem caracterizado a transformação de uma edificação de abóbadas em epítome da necrofilia nazista em um monumento dedicado a suas vítimas, como uma mudança de função crítica, no sentido brechtiano, uma reformulação semântica, revelando as afinidades genocidas dos monumentos de morte nazistas. ${ }^{380}$ Eric Kligerman, por seu turno, definiu essa recuperação como "um processo alquímico" que permite afetar os lugares

\footnotetext{
379" The presence of the fire adds yet another risk to the canvas. In addition to our gaze being trapped in this enclosed space, the room itself is about to be engulfed by the flames. While this space has aspects of a memorial chamber memory itself runs the risk of being lost in the fire. Along with the wooden planks and inscribed names, our subject position in the room threatens to be consumed by the fire. In this ghostly interior, our task envolves both the seeing and reading of ghosts. The painting captures the moment before the conflagration of the memorial space and gestures towards the risks that this act of memory, the recalling of phantoms, must encounter". Cf. KLIGERMAN, Eric. Scenes of witnessing in Paul Celan, Anselm Kiefer and Daniel Libeskind. Tese de Doutorado apresentada ao Departamento de Literatura Comparada da Universidade de Michigan, 2001, pp. 205-206.

${ }^{380}$ Cf. HUYSSEN, Andreas. op. cit., p. 43.
} 
fetishizados do nazismo pelo luto das vítimas. ${ }^{381}$ Podemos agregar a isto que este campo de resignificação foi uma prática decorrente pouco depois da libertação dos campos, quando os deportados se reapropriaram dos monumentos nazistas pela necessidade imperante que havia de preservar a memória da Shoah. Por exemplo, em Buchenwald, após a libertação do campo, os deportados enterraram infinidade de mortos ao pé da Torre de Bismarck, construída em 1902. ${ }^{382}$ O monumento de Nathan Rappoport que comemora a revolta do gueto de Varsóvia contém outra resignificação do mesmo tipo: sua base está composta por blocos de granito que o escultor nacional-socialista Arno Breker fez cortar na Suécia em vista de extrair um monumento dedicado à vitória alemã. ${ }^{383}$ Por último, a remiotização da maquete de Kreis por Kiefer acompanha o mesmo princípio. Para transformar de uma maneira significativa o mausoléu dedicado aos heróis do Reich, ele atribui este túmulo simbólico às vítimas da Shoah. Este processo desdobrou-se a partir de uma reforma anterior, pois a maquete de Kreis inspira-se em outro modelo, na cripta representada na adaptação cinematográfica da Canção dos Nibelungos de Fritz Lang. ${ }^{384}$ Esta cripta aparece quando dos funerais de Siegfried, em um momento emblemático do filme: no claro-escuro trágico das abóbadas em berço, reconhecemos o sarcófago de pedra pousado sobre um rodapé cúbico no qual repousa o herói. Essa cena, em que Kriemhilde chora a morte do herói e jura fidelidade até a morte, tem produzido uma espécie de emblema do destino de Siegfried. Ela tornou-se, como a espada Nothung, uma

${ }^{381}$ Cf. KLIGERMAN, Eric. op.cit., pp. 102-190.

382 O museu de Yad Vashem conserva uma fotografia realizada por uma testemunha: "Monument to the Unknown who died here." Cf. KLIGERMANN, Eric. ibidem., p. 283.

383 Cf. BRASIL DANZIGER, L.M. "Berlim e os Monumentos a Auschwitz." In: op. cit., pp.137-222.

384 Sobre a influência da decoração na arquitetura monumental nazista, ver KRACAUER, Sigfried. O ornamento da massa. Trad. Carlos Eduardo Machado e Marlene Holzhausen. São Paulo: CosacNaify, 2009, pp. 91-104. 
das imagens mais sugestivas que foram adaptadas ao destino político coletivo.

Com Sulamith, Kiefer glosa, ao mesmo tempo, a decoração necrófila de um mausoléu nazista jamais realizado e uma imagem da memória coletiva que leva nela o germe do ressentimento que desencadeia o extermínio. Segundo Kiefer, a localização da cripta de Sulamith sob um prédio alemão representa, de fato, o fundamento da cultura alemã. Tudo está em repouso, constrói-se e envelhece sobre esta cripta, a imagem memorial alemã encontra-se soterrada no subsolo. A simbólica do soterrado deve, por conseqüência, ser compreendida em uma relação de polaridade com o ático: Sulamith estabelece uma afinidade eletiva com os espaços de madeira inflamáveis que Kiefer descreve no começo dos anos setenta, em particular, aqueles da tela Os heróis espirituais da Alemanha, onde a ambientação claustrofóbica e o ponto de vista centrífugo produzem uma tensão e um efeito de absorção parecidos.

A reformulação de Kiefer impõe a estes memoriais pelas vítimas da Shoah uma elevação a um nível quase subliminar: ele mostra que Sulamith, a interlocutora privilegiada tanto da poesia de Celan como da série de memoriais de Kiefer, está encriptada em um lugar supradeterminado pela memória alemã: uma cripta que agoniza sobre o túmulo de Siegfried e que é consagrada à memória dos heróis nazistas. Para esta fantasmagoria matricial, ele desvela também que o sepultamento do vivo é inesquecível na primeira geração e a criptagem do segredo de família tem feito dos descendentes alemães uma espécie de "criptóforos," que carregam em suas costas o fantasma da Shoah. ${ }^{385}$ Atualizando a memória deste fantasma, nomeado de Sulamith e, em comemoração a esse nome à luz de um chanceler judeu, Kiefer simboliza, ao mesmo tempo, uma decriptação

385 Entrevista de Anselm Kiefer em 1996 com Bernard Comment. op. cit., p. 23. 
do segredo sem nome que até agora permanece na escuridão, pois ele torna visível, por sua vez, a memória germanocêntrica encarnada pelos simulacros arquiteturais do nazismo e o próprio segredo invisível da cena familiar que está alojado em seu interior. Dessa forma, o gesto alegórico de Kiefer supera a rejeição da história que caracteriza o imaginário mítico alemão resgatando o estatuto vivencial do feito memorável da poesia de Paul Celan:

A monstruosidade do acontecimento em Alemanha, é uma combinação de fascismo e de perfecionismo. Uma aliança de uma alta técnica e de uma forma criminosa levadas a seu clímax. A arte, a poesia não têm o poder de se opor a esse crueldade a essa infâmia, a essa brutalidade. Mas, apesar disso e por causa disso, o papel da arte, para mim, é o de sobreviver. É o único meio de dar um sentido àquilo que parece não tê-lo mais, àquilo que talvez não é mais. ${ }^{386}$

\section{C.MARGARETHE: MULHER DE PALHA}

Teu cabelo dourado

Margarethe

teu cabelo de cinza

Sulamita

Paul Celan

Um dos motivos mais importantes da série de paisagens que 0 poema Todesfuge tem suscitado em Kiefer, representa uma espécie de espiga dourada em palha inserida na tela. Em Teus cabelos dourados Margarethe, espigas de trigo são agrupadas de uma parte e de outra da tela simbolizando os cabelos dourados de Margarethe. Elias Canetti em sua fenomenologia dos símbolos de massa, relaciona

386 "La monstruosité de l'événement en Allemagne, c'est une combinaison de fascisme et de perfectionisme. Une alliance d'une haute technicité et d'une forme criminelle poussée à son comble. L'art, la poésie n'ont pas le pouvoir de s'opposer à cette cruauté, à cette infamie, à cette brutalité. Mais malgré cela et à cause de cela le rôle de l'art, pour moi, c'est de survivre. II est le seul moyen de donner un sens à ce qui paraît ne plus en avoir, à ce qui peut-être n'en pas. En ce qui me concerne, mes tableaux me permettent de survivre". Cf. ARDENNE, Pierre. op. cit., p. 328. 
o trigo como um "floresta em miniatura," porque ele brota no lugar das florestas incendiadas, sem ter jamais alcançado a altura das outrora florestas. ${ }^{387} \mathrm{~A}$ aspiração ideal simbolizada pela floresta se opõe às qualidades antropomórficas do trigo, epítome de toda uma coletividade obediente, regenerando-se como o homem a partir de sua própria semente - mesmo se ela é regularmente transformada em campo de batalha ou reduzida ao nada. Os trigais acompanham a espiga evocando o nome de Margarethe, o que não é difícil de reconhecer, um campo humanizado de cabeças e de corpos aglutinados, uma massa que se abre para formar uma cor. Esta aglomeração provoca uma impressão de ameaça iminente e faz de Margarethe um elemento excluído da massa - uma constelação que não deixa de lembrar o movimento da vítima nos Heróis Espirituais da Alemanha. O nome de Margarethe não se inserta na mesma lógica de regeneração que o trigo amontoa a seu redor. Ao contrário, Margarethe representa a palha das espigas descartadas da colheita, trata-se do joio cobrindo os cereais - Lutero designou como a "má erva" [Unkaut] - o que resta logo da ceifa que está destinada, a maior parte do tempo, a ser queimada. ${ }^{388}$ As mechas loiras de

387 Cf. CANETTI, Elias. Masa y Poder. Trad. Juan José del Solar. Madrid: Espasa Calpe, 2002.

${ }^{388}$ Sob o regime nazista, certas abstrações metonímicas disfarçavam ações militares ligadas à política racial - a festa da vendima ou a ação do feno dissimulavam a realização literal da parábola neo-testamentária que fala em separar o o joio do trigo como o Bem do Mal. O código encobridor do massacre de 40000 judeus de Lublin, por volta de 1943, foi "festa da colheita". O feno empresta seu nome a uma ação pseudo-militar, "ação feno" [Heuaktion], que consistia em salvar o sangue alemão de crianças eslavas entre 10 e 14 anos de idade, susceptíveis de serem germanizados em razão de seu genótipo, nos territórios ocupados da Europa de Leste, onde a população judia e eslava estava condenada ao extermínio. Em junho de 1944, a 9a armada roubou entre 40000 a 50000 crianças polonesas para colocá-las em famílias alemãs. Nesse contexto, aparece mais claro ainda que a espiga designa a loirice de Margarethe, encarna a exclusão de um coletivo que a designa como um sujeito do Mal, como fala a explicação da parábola da espiga: "Propôs-Ihes outra parábola, dizendo: O reino dos céus é semelhante ao homem que semeou boa semente no seu campo; mas, enquanto os homens dormiam, veio o inimigo dele, semeou joio no meio do trigo, e retirou-se. Quando, porém, a erva cresceu e começou a 
Margarethe não tem aqui um peso de vitalidade e de renovação, em todo caso, uma espiga dourada pode dar a ilusão de representar o coletivo alemão.

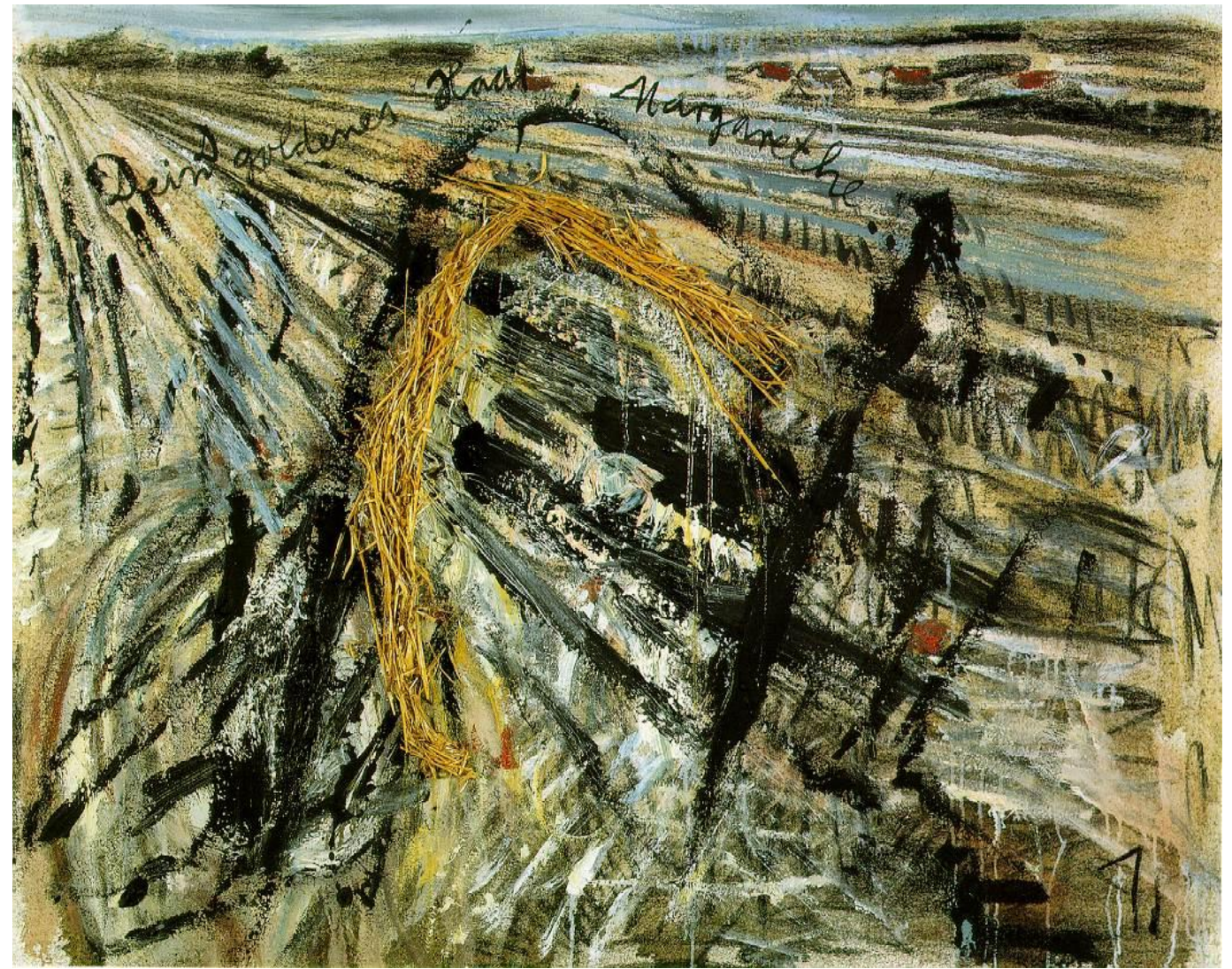

espigar, então apareceu também o joio. Chegaram, pois, os servos do proprietário e disseram-lhe: Senhor, não semeaste no teu campo boa semente? Donde, pois, vem o joio? Respondeu-Ihes: Algum inimigo é quem fez isso. E os servos the disseram: Queres, pois, que arranquemos? Ele, porém, disse: Não; para que, ao colher o joio, não arranqueis com ele também o trigo. Deixai crescer ambos juntos até a ceifa; e, por ocasião da ceifa, direi aos ceifeiros: Ajuntai primeiro o joio e atai-o em molhos para o queimar; o trigo, porém, recolhei-o no meu celeiro. Então Jesus, deixando as multidões, entrou em casa. E chegaram-se a ele os seus discípulos, dizendo: Explica-nos a parábola do joio do campo. E ele, respondendo, disse: O que semeia a boa semente é o Filho do homem; o campo é o mundo; a boa semente são os filhos do reino; o joio são os filhos do maligno; o inimigo que o semeou é o Diabo; a ceifa é o fim do mundo e os celeiros são os anjos. Pois assim como o joio é colhido e queimado no fogo, assim será do mundo. Mandará o Filho do homem os seus anjos e eles juntarão de seu reino todos os que servem de tropeço e os que praticam a iniqüidade, e lançá-los-ão na fornalha de fogo; ali haverá choro e ranger de dentes. Então os justos resplandecerão como o sol, no reino de seu Pai. Quem tem ouvidos, ouça." Cf. MATEUS 13, 36-43; Cf. FÉRAL; Thierry. Le national-socialisme, vocabulaire et chronologie. 1988, p. 41; Cf. LAUTERWEIN, Andrea. op. cit., pp. 356-389. 
Outra pintura intitulada Teus cabelos dourados Margarethe substitui a mesma espiga de palha em meio ao campo devastado. Sem ancoragem, a espiga está suspensa embaixo de um sulco desenhado; os traços oblíquos convergem em um ponto localizado à extremidade esquerda, sobre sombras negras e apagadas, pode ser a continuação da vila de telhas vermelhas que aparecem na esquina direita, pode ser uma floresta, também um campo. O horizonte comprimido pela massa de terra está sobre a margem superior do quadro. A composição faz justiça à dinâmica intimista do poema de Paul Celan: ela precipita uma espécie de aceleração sobre à esquerda, a longitude infinita dos sulcos negros evocando uma fuga retrospectiva, numa corrida desenfreada em que se perdeu o controle, literalmente uma Fuga da Morte. A fragilidade simbólica e material da espiga de palha tem por destino sua sombra: Kiefer a desenhou a carvão, o produto de uma combustão, que leva a lembrança da transformação dos cabelos de ouro em joio queimado. Outro grande traço negro num primeiro plano na direita contribui novamente a colocar em cena uma situação de encurralamento ameaçando a espiga da palha. De maneira isolada, a forma negra à direita lembra os contornos de uma espada colocada no sol, suposição que parece confirmar algumas salpicaduras da cor vermelha nos redores, uma imagem que relança a rede de associações da pintura Nothung. Esta versão de Teus cabelos dourados, Margarethe confronta-nos com uma paisagem em barbecho que, na ponta de sua leitura, transforma-se em uma situação opressiva, um campo rodeado de espinhos selvagens, tendo nos seus rascunhos o topônimo inflamável de Margarethe assim como a sombra de cinzas de, Sulamith, todos estão sob o século hereditário da espada e do sangue de Wotan.

Não se trata da única vez que Sulamith aparece alusivamente na mesma tela ao lado de Margarethe. Uma condição leva à outra. A 
paisagem Teus cabelos de cinzas, Sulamith (fig.53) apresenta a mesma composição e as mesmas dimensões que Teus cabelos dourados, Margarethe, aqui a palha e sua sombra, o carvão ou a tinta escura, são espalhadas por toda a superfície da tela e uma pintura branquicenta evoca uma fumaça de cinzas se difundindo para a parte superior, invadindo a opacidade do céu. A inscrição dos títulos sobre essas duas paisagens desenvolve um pathos ora diferente: enquanto o sintagma Dein goldenes Haar, Maragarethe, designa uma espécie de onda musical quase animada acima das configurações abstratas do centro, a inscrição Dein aschenes Haar, Sulamith, encerra o que resta do horizonte detrás da alambrada desses caracteres de cor cinza.

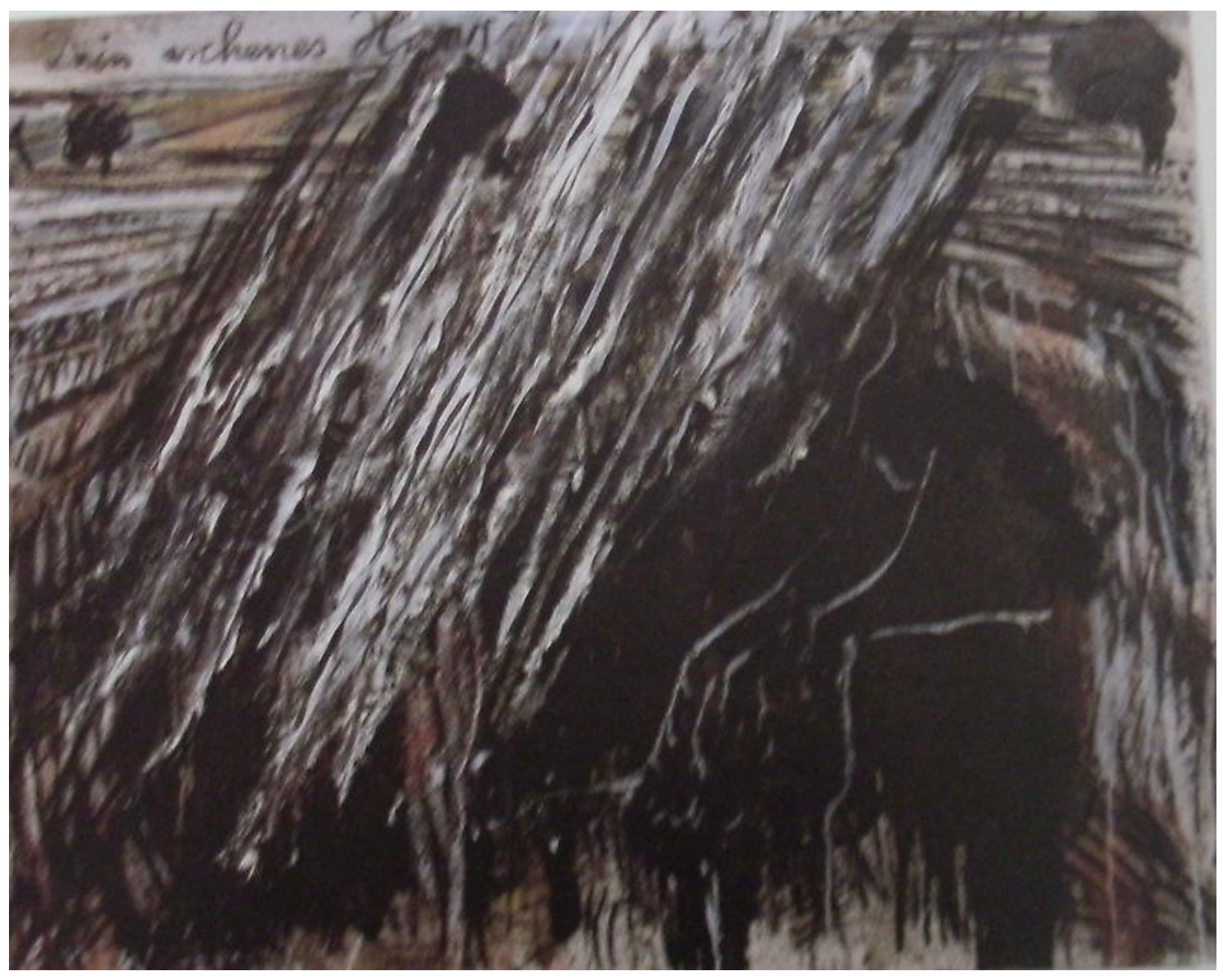

Figura 53. Teus cabelos de cinza, Sulamith/Dein aschenes Haaar, Sulamith, 1981. Óleo, acrílico, emulsão e esmalte s/tela. $130 \times 170 \mathrm{~cm}$.

Kiefer retoma aqui um mitomotivo germânico. Falamos de sua leitura do poema de Celan "Fuga da Morte", que leva em conta a 
alteração de uma obra por causa de uma recepção ideológica: ele representa Margarethe como a mulher de palha do imaginário e da ilusão da comunidade judeu-alemã, e a cinza de Sulamith como a conseqüência histórica da transformação simbólica da cabeleira de ouro em joio. ${ }^{389}$ Ao mesmo tempo, Kiefer procura atender a ambivalência poética graças a sua abordagem caleidoscópica, evitando, assim, uma leitura reducionista do poema de Celan. Dessa forma, se considerarmos que a ingestão de sementes do joio, altamente tóxicos suscita uma espécie de embriaguez que tem propriedades semelhantes às da papoula, este ciclo de pinturas acolhe e integra também a estrutura dicotômica da coletânea Papoula e memória, em que Fuga da Morte aparece como o poema central: Sulamith e Margarethe refletiram sobre a rivalidade assumida entre memória e papoula, o paradigma da embriaguez, do esquecimento e do sonho em Celan. Contudo, os traços da cor vermelha interpretados, outrora, como traços de sangue, bem poderiam figurar como papoulas num campo e, Kiefer, numa espécie de revisão da paisagem risonha de Monet, apelar ia, nessa pintura marcante, à memória rarefeita.

Daniel Arasse tem destacado que esta série de paisagens dedicadas ao binômio Margarethe-Sulamith está na origem de inovações determinantes na prática artística de Kiefer, notadamente da introdução de materiais como a palha. ${ }^{390}$ Kiefer extrai, de um material tão simples como a palha, uma fonte de energias que bem podem ser lisérgicas e, ao mesmo tempo, aniquiladoras. Pois elas

${ }^{389}$ Eis aqui outro indício da leitura atenciosa de Kiefer, que se relaciona com o citado binômio formado por Margarethe e Sulamith. Essa imagem conjugada pela assimetria dessa simbiose judeu-alemã e seu fatídico resultado: cinzas das espigas. Folga lembrar na insistência do artista em sempre escrever o nome Margarethe com th. Este giro ortográfico, que não pertence ao universo de Celan, aproxima inegavelmente o topônimo de Margarethe da sílaba fechada da única palavra de ressonância hebraica do poema, Sulamith. Cf. LAUTERWEIN, Andrea. op. cit., p. 240.

${ }^{390}$ Cf. ARASSE, Daniel. op. cit., p. 198. 
podem representar uma espécie de material químico de caráter orgânico, que pode ser produtor de calor. A representação desta energia condiciona, de alguma maneira, sua inflamabilidade extrema. Em outras palavras, trata-se de um material que, num sentido transposto, se incendeia facilmente, uma característica que o opõe às cinzas de Sulamith, pintadas em pedra branca ou com um pigmento negro, elas mesmas fabricadas com carvão. A palavra Halm está particularmente representada na coletânea Papoula e memória, o recorte literário de Kiefer. Esse termo designa o talho da erva ou a palha, o talho de uma rama, a parte aérea entre a raiz e as eventuais espigas ou panículas. Sua etimologia a aproxima do cânhamo, o junco, material do qual os gregos se serviam para escrever; sua tradução mais acurada é, portanto, a brizna de palha ou de erva. Brizna de erva ou brizna de palha, a palavra Halm convoca, então, dois estados sucessivos: o crescimento e o fenecimento. ${ }^{391}$

\footnotetext{
$391 \mathrm{Na}$ obra de juventude de Celan, esta palavra representa um elemento positivo pertencente ao ciclo natural de vida. Encontramo-la no poema de amor Noite de verão: "Uma vagalume interage com uma folha de erva para salvar as aparências, e observa o broto". Essa esperança é explicitamente renegada num poemário contemporâneo como Papoula e memória, em que "Uma vela potente emana de uma brizna do que virá." Os termos Halm e Stengel - o talho, que é à flor o que a brizna é ao fruto dos campos contém o motivo bíblico da caducidade reformulado por Celan. Lembremos O livro de Jó, o homem "nascido da mulher, é de poucos dias e cheio de inquietação. Nasce como a flor e murcha; foge também como a sombra, e não permanece". Cf. Jó, 14, 2. Em Isaías, podemos ler: "Toda carne é erva e toda sua beleza é como a flor do campo. Seca-se a erva e cai a flor, soprando nela o espírito do Senhor. Na verdade o pó é erva. Seca-se a erva e cai a flor, porém a palavra do Senhor subsiste eternamente". Cf. Isaías 40, 6, 8. A imagem celaniana ilustra a destruição simultânea do tempo da vida e da morte natural, constrói- se, por analogia, com a imagem dos cabelos que não contam com o tempo para embranquecerem. Assim as ervas no poema $O$ adeus são assimiladas aos talhos que não suportam mais as flores, mas as estrelas: "Ô ervas, vocês, talhos das estrelas: qual é essa respiração que as arranca? " O sujeito histórico do poema fórmula a questão - retórica e blasfematória - da respiração maléfica que tira as ervas antes de terem tido tempo de viver, de envelhecer e de morrer individualmente. A palavra Halm refere-se em seguida à escrita. Ela devém a calma do poeta. Em vão tu desenhas os corações, um poema de 1945, os cânhamos são assimilados pelas flores do tempo. É preciso, portanto, se imaginar a flor do tempo, essa de 1945, como o elemento de
} 
Catherine Strasser reconhece em Kiefer uma equivalência particularmente delicada e secreta no motivo celiniano da espiga da noite. Existem outras correspondências impressionantes. No poema Ajustado ao vento da coletânea Grade de palavra, ruas - plantas herbáceas de flores amarelas - encontram-se lado a lado, "ajustadas ao vento" sobre os campos, e estes campos são vazios de escrita. Após a passagem de um humilde "cloporte luminoso," símbolo de esperança em Celan, acordam-se as "vozes dos olhos," os cantos, os corais que "graças à atividade da leitura," acordam outras vozes que são "ajustadas ao vento: perto do coração, inumadas por cremação." Lido desta maneira, o poema aparece como uma matriz, talvez inconsciente, das primeiras transformações que Kiefer aplica ao topônimo Margarethe: trata-se de uma leitura mais próxima do coração, ou seja, de olho nos mortos, que a loirice sobredeterminada sobre o nazismo, que o vazio da escrita de ramos de trigo de Margarethe, teus cabelos dourados, arrasta à própria presença da sombra de Sulamith, ao lado de Margarethe em Teus cabelos do ourados, Margarethe.

No começo, Kiefer utiliza a palha para realizar os rascunhos efêmeros, trocando literalmente o giz e o pigmento contra esse traço e esse colorante de outra espécie. A aparição conjunta de Celan e do material de palha em sua obra, permite avançar a hipótese que o artista percebe da palha seca, pode, mesmo que a "flor do tempo," tornar-se "o cânhamo da noite," de Celan, ou seja, a relação especular dos mortos. Como o sublinha Daniel Arasse, Kiefer utiliza a paleta para desenvolver certas problemáticas fundamentais com as quais confronta sua arte em função da Shoah: após ter associado a uma imaginária católica antiga - em que a paleta poderia tomar o

uma natureza melancólica e caduca que marca também os cânhamos que escrevem. Em uma poesia de 1951, incluída no ciclo intitulado Os cânhamos da noite, os cânhamos identificados ao "nós" amorosos não desabrocham mais em uma terra semeada, mas nos corações e nas mentes. Cf. LAUTERWEIN, Andrea. op.cit., p. 276. 
lugar de Jesus Cristo na cruz, se tratando de uma espécie de apelo irônico da mitologia alemã do artista -, o motivo da paleta associada ao topônimo celiniano Margarethe condensa e refuta a assimilação, pelos ideólogos do nazismo e, antes deles, pela tradição alemã, do culto de Eros e Thanatos. ${ }^{392}$

${ }^{392}$ Cf. ARASSE, Daniel. op.cit. pp. 99-108. 


\section{CONSIDERAÇÕES FINAIS}

Se alguém, chamado como testemunha, após ter ouvido a adjuração do juiz, peca por não declarar o que viu ou o que soube, levará o peso de sua falta.

Levítico, 5:1

Neste trabalho de pesquisa tentamos constelar algumas imagens do percurso pictórico do pintor Anselm Kiefer com o testamento crítico-filosófico de Walter Benjamin. Kiefer pode ser nomeado como um dos pintores na Alemanha do pós-guerra que questionou não apenas a possibilidade da "representação" e o fato de "representar a história", mas independente das fórmulas problemáticas empregadas pelo pintor para realizar essa "execução pictórica", ele foi quem finalmente trouxe formalmente para o campo da pintura uma leitura do legado do passado nazista alemão, uma vez que outras pesquisas tinham começado a se desenhar em outras esferas da produção cultural e intelectual na República Federal Alemã. Como discutido no primeiro capítulo, uma das aspirações da expressão cultural da geração de 68 na República Federal Alemã foi a de transgredir os limites e tabus relacionados ao passado nazista, assunto cuidadosamente definido e confinado na sociedade dos anos 50 . Kiefer e seus contemporâneos quebraram com 0 mito da impossibilidade do luto, procurando novas linguagens para expressar a incomunicabilidade, a irrepresentabilidade e a excepcionalidade do acontecimento catastrófico. Ante a poscrição adorniana, como então produzir objetos estéticos que executem uma licitação com a história quando a própria tarefa parece ser um evento impossível? Talvez seja aí onde se faz necessária a desublimação executada por Kiefer porque se trata de uma questão de superar o tradicionalismo que é inerente à veneração da obra de arte como permanência atemporal. $O$ retorno à ordem invoca justamente isto: restaurar o ideal da obra concebida como a permanência do eterno. É certo que esta noção da 
obra em sua articulação com o político é muito perturbadora para aqueles que têm acompanhado as experimentações artísticas que se têm levado a cabo dentro de um paradigma de atividade da arte. A autoridade da obra, parece incompatível com o que poderíamos chamar de inquietação política da vanguarda. No entanto, como em Kiefer, existe um além de sua própria história. Nas suas telas dedicadas a Gilgamesh, por exemplo, ele faz referência ao modelo da cidade na antigüidade clássica e sublinha a ação memorável do ser humano que persiste na narrativa. A obra, ao se distinguir do objeto de uso e mas ainda do objeto de consumo (como mercadoria), adquire importância em relação a sua memória perene. A única solução é a de trasladar a idéia de permanência da obra a outro ponto, a algum fato ou elemento a priori que possa incorporar a experimentação artística. Isto nos auxilia para nos perguntarmos, porque, então, a arte do pós-guerra tentou imediatamente estabelecer de novo uma prática neovanguardista de acordo com a tradição modernista que deslegitima a memória histórica? Trata-se de uma pergunta importante para nós dentro deste debate sobre a cultura do pós-guerra que esboçamos até aqui. Como já apresentamos, na literatura alemã nos princípios dos cinqüenta, por exemplo, encontramos um discurso sobre a história do holocausto, e o mesmo aconteceu no cinema e no discurso da nova história. Poucas coisas encontramos nas artes plásticas, exceto Beuys com seu famoso concurso para o monumento de Auschwitz de 1953. A pergunta é retomada por Richter em seu Atlas, Für 48 Porträts, algumas obras de Baselitz e Lüpertz também, mas de modo mais clandestino e de forma mais problemática, com Anselm Kiefer. O que resulta interessante para nós é que as artes plásticas pretendem ter uma maior concisão, uma especificidade fenomenológica na análise do olhar e utilizam isto para justificar sua incapacidade de representar a história. Contudo, o objeto artístico é também uma mercadoria, como o cinema e a literatura, mas também resulta 
impossível compreender o holocausto em termos de mercadoria. Talvez esse seja o maior problema que confronta Kiefer nessa experiência artística do pós-guerra. Enfrentar-se com uma imagem traumática que produz fascinação. Esse poderia representar o problema do período do pós-guerra: o fascínio que imantam, as imagens traumáticas, o impacto psíquico, é síndrome do fato irrepresentável. Para Kiefer o processo de integração psíquica, frustrado pela imagem traumática deve entrar novamente em movimento.

O trabalho de Kiefer recenseia a história em uma forma negativa de representação. A catástrofe está evocada poderosamente com a combinação delirante de materiais com ressonância escultórica que reforçam potentes alusões históricas e culturais. Avaliamos o trabalho de Kiefer na sua singularidade e importância no contexto da contemporaneidade artística alemã e européia, bem como no quadro amplo das catástrofes históricas que arruinaram as estruturas experienciais do homem moderno nos termos em que o diagnosticara Walter Benjamin. Inúmeras e variadas foram as pistas de leitura que ao longo desde estudo constataram diferentes chaves dessa correspondência entre eles. Salientou-se, no entanto, um elo essencial na dinâmica daquela associação: referimo-nos, à obra Drama Barroco Alemão, às Teses sobre a filosofia da história e às Passagens dedicadas à obra de Baudelaire. O fascínio pela lírica baudelariana e pela história assombra, em proporções comparáveis, o percurso crítico e filosófico de Benjamin e o pathos poético-pictórico de Kiefer. A tríade - crítico-lírico-experiencial - tem sido o marco crítico da presente pesquisa.

Não se trata apenas da necessidade de que a história, para que tenha sentido (isto é, para que seja história) tenha um fim, portanto, uma escatologia. A análise que elaboramos foi uma apocalíptica da história, ou seja, que ela arrematou não genericamente o mundo, o 
cosmos natural, mas antes um cosmos preenchido de temporalidade, tornando-o história. O recurso à concepção da apocalíptica cristã por Benjamin permitiu compreender a trajetória de Kiefer no sentido de reconduzir a história à sua autoconsciência originária, subtraindo-a, assim, a uma temporalidade "alienada", a um tempo que se acelera sem parar, escandido pelo envelhecimento dos fenômenos e em relação ao qual nós estamos em franco impasse, incapazes de nos apropriarmos da nossa experiência nitidamente histórica, a não ser na forma da catástrofe.

A pesquisa procurou encontrar a duplicidade da noção de barbárie para compreendê-la na pintura de Kiefer, segundo um movimento inesperado de inversão dialética que, em Benjamin, introduz um giro positivo do conceito de barbárie:

Para onde é que a pobreza em experiência leva, então, o bárbaro. Leva-o a começar do início, a retomar tudo de novo, a construir com o pouco que tem e, assim, a não olhar nem para a esquerda nem para a direita. ${ }^{393}$

Pois é disto que se trata: depois da catástrofe nazista, dos escombros e da destruição nessa terra devastada, é possível fazer história? O convencimento de Benjamin promete que podemos sobreviver à extinção e apropriarmo-no da verdadeira temporalidade da qual fomos arrebatados pela ideologia que faz da história um continuum automático, um progresso ininterrupto. O gesto de Kiefer é de autoquestionamento, trata-se de uma autoconsciência pictórica que desmente toda mistificação. Outra questão pertinente é o revisionismo como princípio conceitual capaz de conduzir a pergunta pela identidade alemã na obra de Kiefer. O mito no lugar da história é, como mostra Benjamin, violência e terror. Kiefer respondeu bem a esta premissa benjaminiana, articulando um projeto pictórico inteiramente voltado para a herança germânica, a pesquisa de

${ }^{393}$ Cf. BENJAMIN, Walter. "Experiência e pobreza." In: Magia e técnica, arte e política. pp. 115-116. 
objetos transicionais fixou-se nos elementos iconográficos e mitológicos que adensaram a identidade nacional germana, participando, no entanto, da elaboração do mito nazista.

Lembremos que no ensaio Para uma Crítica da Violência ${ }^{394}$ e em Teorias do Fascismo Alemão, de Walter Benjamin, também encontramos os dados em que, sem a mediação do pensamento e das artes, a violência é nua - tanto que a literatura que "os alemães liam enquanto seus clássicos escreviam" era a do elogio e heroicização da guerra e do acúmulo de cadáveres como estética das massas. Benjamin, imbuído na tradição judaica, não se inseriu no

${ }^{394}$ Benjamin aborda um assunto que nos interessa para a interpretação das obras de Kiefer no seu ensaio Para uma crítica da violência (1921). Se enfrenta ao problema da violência e de sua crítica, internando-se no intrincado mundo da justiça e do direito. Benjamin discute nesse texto algo mais essencial, a contraposição entre a violência divina e a violência mítica. Esse ensaio parece atravessado pelo tema da destruição radical, da exterminação e da aniquilação total. Após a traumática experiência da Primeira Guerra, do massacre nas trincheiras, da traição dos socialistas, do extraordinário acontecimento que representou a Revolução de Outubro e das enormes contradições da República de Weimar, a tentativa de Benjamin pensar criticamente a questão da violência não podia carecer de riscos e de ambigüidades. Para Jacques Derrida, este ensaio de Benjamin trata, pois, do mal, desse mal que acontece, e que lhe chega à linguagem por meio da representação ("Nombre de pila Benjamin" Fuera de ley, Madrid, Tecnos, 1997), por outras palavras, por meio da dimensão representativa, midiática e, em conseqüência, técnica, utilitária, semiótica, informativa e outras tantas potências que arrastam a linguagem fora de seu destino original que foi a apelação, a nomeação, a doação ou a chamada da presença no nome. A perplexidade manifestada por Derrida perante esse 'duplo rosto' de Benjamin, esse rosto, por um lado judeu e, por outro, alemão (e seu vínculo com uma linha de pensamento antidemocrática, antiAufklärung e neorromântica, associada, entre outros, com Carl Schmitt). Derrida talvez não reconheça que a questão judia em Benjamin incorpora, por meio de sua marca messiânica, essa dimensão da catástrofe, estado que supõe a presença, no seio da história, de um tipo de acontecimento surpreendente e, como tal, inesperado, no qual a justiça divina quebre, em sua anunciação messiânica, com a continuidade do tempo histórico. Violência que arrasa e que surpreende os homens, arrojando-os a uma experiência inédita. Benjamin pensa a catástrofe em sua associação com a esperança (o último Benjamin, contemplador dos alcances da catástrofe européia, carece desse otimismo associativo, dessa dialética, na qual a destruição encontra sua resolução no redencional como promessa a ser cumprida). Em todo caso, a figura da destruição deve ser interpretada tanto à luz dos câmbios históricos, como, também, atendendo à sua marca místico-teológica. 
ambiente lisérgico dos jovens alemães que comemoravam o advento dos novos tempos heróicos; pelo contrário, sempre foi um crítico cáustico dessas mitologias belicistas, porém, ao igual que Ernst Jünger, compreendeu que o mundo das figuras paternas, esse universo que representava sua educação, havia-se dissolvido e, que o novo representava uma malfadada conjunção de técnica e vontade, sendo a extensão de uma contraposição invertida para a via da redenção, dessa vez, no caminho do inferno. O melhor da cultura moderna havia-se transformado em uma máquina de destruição; a razão, veículo privilegiado na vereda da liberdade, segundo à aspiração ilustrada, acabou representando o gélido domínio de uma racionalidade instrumental. Benjamin e Kiefer desde distintas e, por vezes, atritadas perspectivas, compreenderam profundamente a dialética da modernidade e o rosto do Mal que subjazia às produções da cultura. Benjamim vislumbrou toda a dimensão abominável na guerra das trincheiras, nelas observou o que significava o desdobramento da "movimentação total" e o advento, a partir da experiência da guerra de materiais, de uma nova humanidade cuja face seria a do trabalhador. ${ }^{395}$ Benjamin, como bom arcano visionário, também soube ler nos signos de seu tempo a chegada de uma forma de barbárie e a culminação de um demorado processo de perda da experiência. Kiefer, abandonado em um mundo cuja dolorosa experimentação com a catástrofe é permanente, não se permite pensar na novidade na sua época. Sua crítica adquiriu tons de nacionalismo germânico, certo ar de arcaísmo mitológico unido a uma visionária compreensão do papel aniquilante da técnica na sociedade de massas; tornando-se um observador agudo e rigoroso da decadência da cultura germânica, até se fazer um verdadeiro estoico de nossa época. O caráter ambivalente tanto da iconografia, quanto dos materiais empregados, desamarra um campo inusitado de

395 Cf. FORSTER, Ricardo. Walter Benjamin y el problema del mal. Buenos Aires: Altamira, 2001. 
interpretações. Nos livros, pinturas, esculturas e instalações de Kiefer, os significados dançam com os materiais - tinta, cinzas, areia, palavras, chumbo, palha, vidro, fotografias -, articulando uma obra de vasta complexidade. Todo fragmento da obra de Kiefer contém uma pulsão nostálgica de reincoporação a um cosmos, o que não quer dizer que sua obra nos apresente uma reconciliação. Pelo contrário, ela nos instala na labilidade e fragmentação do humano, absorto face ao enigma insondável de sua origem e de seu destino. Como nos indica Leila Maria Brasil,

[...] nem totalidade, nem consolo, nem paraíso perdido, $o$ que a obra de Kiefer nos oferece é apenas um renovado, desesperado, mas também humorado esforço de produzir sentido, que permanecerá, no entanto, parcial e provisório. ${ }^{396}$

Além do mais, o acontecimento que propõe Benjamin está preparado para se encontrar com algum conceito de revolução, de retornar ao poder mítico-substancial que, por sua vez, gera tempo morto. Para Benjamin, o instante sagrado da irrupção do poder destrutivo constitui a própria essência da história: acumula mais ruínas sobre o tempo. Tornamo-nos pobres. Por isso, a palavra literária à altura de nosso tempo, como a de Celan, é a que fragiliza efetivamente a idéia forte de experiência e busca uma nova força na qual consigamos nos mover: aquela que aceite o desafio de atravessar o poder de dissolução da mesmice para acabar com o reino da tautologia, no qual tudo se exibe e nada se vive. Contudo, o cotidiano para o qual Benjamin reivindicava, como primeiro critério, "uma verdadeira atualidade". É o que pode ser salvo, na medida em que só aí se pode dar uma vida autêntica. É isto que Benjamin fez com um sentido de missão revolucionária. Assim como o colecionador acumula objetos parciais, as ruínas são recolhidas como objetos de coleção, o que significa salvar o cotidiano por uma aproximação às

${ }^{396}$ Cf. DANZIGER BRASIL, L. M. Anselm Kiefer e a pergunta pela Alemanha. p. 20 . 
coisas pequenas para observá-las segundo um método micrológico e fragmentário, mas também significou descobrir nelas a sua parte de fantasmagoria, que faz delas delírios, sonhos de onde só mais tarde se vem a despertar. O livro composto de citações que representou o livro das Passagens quer dar a ler a cidade de Paris como um livro que apresenta, da mesma forma que compreendemos, nesta linha, as ruínas metropolitanas de Kiefer como o lugar absoluto do acontecer logo após da catástrofe. Nessa linha, a terra queimada de Kiefer também aparece como uma série de assuntos que o pintor vai colecionando como documentos que apagam qualquer vestígio de idealização e nostalgia. Kiefer insiste em enfatizar a degradação e a esterilidade dos objetos encontrados na natureza, ou mais precisamente, no solo alemão. Semelhante aos livros, em Pintar, uma paleta de pintura e o título Malen associam-se a uma estranha chuva que parece fertilizar essa paisagem queimada. Pintar para Kiefer torna-se uma ação de destruição absoluta.

As leituras deram a conhecer que a linguagem, tanto para Benjamin quanto para Kiefer, tem o sentido da projeção universal da sensibilidade sobre o Outro para sentir o mesmo que ele, além de ser portadora da vontade metodológica de captar a substância subjetiva do autor de uma obra ou da época bem como pretende ocultar a perda de substancialidade do sujeito, a sua desespiritualização. Benjamin não deseja falar do crítico, nem do sujeito, nem de sentimentos: seu tema é a interioridade do próprio objeto. Para descrever este interior, o filósofo se vale do objetivismo da forma metafísica. Assim como a vontade em Benjamin é o domínio de si próprio, é um princípio ascético de aprendizagem, a contemplação filosófica em Kiefer recupera a plenitude de suas dimensões éticas. As telas de Kiefer ainda são emblemas a serem interpretados. Reconhecemos que Kiefer, como pintor alemão carrega, como um pesado ônus, a sua tradição estética. Ele próprio reconhece que todas 
as interrogações voltadas para sua própria identidade estão, de alguma maneira, atadas à autoridade da tradição:

Acredito que os escritores e pintores interessantes têm que ver com a mitologia. Eles a perseguem. A mitologia é um grande campo que há que continuar explorando. Como aqueles, eu procuro explicar de uma maneira não científica (porque a ciência não consegue) os enigmas do mundo. $O$ esquecimento e a memória estão vinculados paradoxalmente, mas é um fato. Eu não faço nada que não esteja vinculado com a minha existência. Aí, nessa pintura, sou eu, mas não é somente eu, é um jazente, um arquétipo). ${ }^{397}$

Ele também reconhece, como artista, que possui, não apenas a habilidade, mas também a responsabilidade de mergulhar na sua tradição através de seus trabalhos. Daí Kiefer falar de seu dever de encaminhar sua tradição e, ao mesmo tempo, sua vontade de ser um catalítico da mesma:

É preciso modificar sem cessar nosso olhar sobre as representações do passado utilizando a reflexão científica que não exclui os procedimentos esotéricos ou filosóficos. É o procedimento dos artistas que sempre se instruíram com seus mestres, inclusive no século $X X$. A arte renova se inspirando no passado. ${ }^{398}$

$O$ engenho do pintor permite-lhe apropriar-se de símbolos e figuras poderosas de sua tradição de tal maneira que sua reconfiguração acaba desatando uma grande tensão entre pintura e história.

397 "Je crois que les écrivains et le peintres intéressants ont à voir avec la mythologie. Ils la poursuivent. La mythologie est un grand champ qu'il faut continuer à explorer. Comme eux je cherche à expliquer d'une manière non scientifique (parce que la science $n^{\prime} y$ parvient pas) les énigmes du monde [...] L'oubli et le souvenir sont liés - paradoxalment, mais c'est un fait. Je ne fais rien qui ne soit pas lié avec mon existence. Là, dans ce tableau, c'est moi, mais ce n'est pas seulement moi, c'est un gisant, un archetype." Entrevista com Jean-Marc Terrasse. Anselm Kiefer. Frontières, en nous, hors de nous, nous. Paris: Du Regard, 2007, p. 31.

398 "Il est nécessaire de modifier sans cesse notre regard sur les représentations du passé en utilisant la réflexion scientifique -qui n'exclut pas les démarches ésotériques ou philosophiques. C'est la démarche des artistes, qui ont toujours appris chez leurs maîtres, y compris au XX siècle. L'art renouvelle en s'inspirant du passé. "Cf. LAUTERWEIN, Andrea, op. cit., p. 31. 
Entender os trabalhos do artista é também entender a história colocada na experiência material imediata plasmada nas suas telas. Lembremos que o questionamento do romantismo em Kiefer faz parte de seu trabalho, e ele considera absurdo continuar a supor que as vanguardas produziram um corte e que há um sistema em que se encontram o iluminismo, o romantismo e as vanguardas. Ao contrário, o artista acredita que há uma longa duração. Ele considera, finalmente, que o que domina é o projeto romântico que, do modo como foi formulado, não é antagônico ao iluminismo. E Kiefer é um artista confrontado a uma tradição nacional em que o romantismo é muito potente - é uma evidência cultural, pois a produção artística romântica é a grande produção alemã. Ao mesmo tempo, Kiefer é confrontado à história alemã: ele nasce com as ruínas do Nazismo. Ele é confrontado com o fracasso do romantismo como se o Nazismo provocasse a ruína do romantismo e carregasse em sua queda toda a possibilidade romântica. Para Danièl Cohn, Kiefer possui um trabalho muito trabalhado, que pode ser pensado em um tipo de reapropriação infinidade de materiais. Há em sua obra um aspecto citacional que reporta ao romantismo, com nomes e obras. Trata-se de um uso político e estetizante, sobre o plano estritamente ideológico de sua língua de referência. Por outro lado, ele está muito subordinado à coerência do projeto romântico por misturar as artes - faz arquitetura, escultura, pintura, instalação, livro de artista. Está, assim, absolutamente vinculado à idéia de que ser pintor não significa sacrificar-se a uma gama de técnicas possíveis. Além do mais, e em correspondência com essa idéia, ele contesta toda idéia de gênero. Como definir, em termos de gênero, a obra de Anselm Kiefer?

Kiefer parte da hipótese, semelhante à dos românticos, de que, no fundo, quando olhamos uma obra de arte somos convocados a uma experiência sinestésica. Coincidimos com Cohn quando assinala que a pintura de Kiefer é extremamente sonora - a violência, a 
monumentalidade, o rumor do tempo, os materiais, a massa e a textura de sua pintura, todos têm efeito sonoro. Quando olhamos um trabalho de Kiefer nos sentimos interpelados por uma pintura extremamente dominadora, que nos obriga a entrar em seu interior e escutar seu rumor. Ela é sonora porque acolhe a queixa, inventaria o desastre, acolhe a literatura, a poesia, e uma poesia que é dita. 0 fato de as coisas estarem escritas (em sua pintura) corresponde a isso. Uma espécie de fragmento de poemas, como quando se busca lembrar-se de um poema, buscamos elementos, nos lembramos de um verso, esquecemos o seguinte, nos lembramos do que vem depois, isso produz um fragmento sonoro, e é uma música extremamente moderna - a música de sua época, em que se misturam versões contemporâneas, poemas e muito barulho. John Cadwell, curador do Museu Carnegie de Pittsburgh, por sua vez, descreve a arte de Kiefer e sua relação com a tradição, conclamandoa, "Acredito que é justo dizer que sua arte tem o tema implícito da redenção". ${ }^{399}$ Perguntamo-nos se essa é a tarefa de Kiefer, a de se redimir de sua tradição através de seus trabalhos? Não sendo assim, então, onde pretende chegar o confronto de Kiefer com sua tradição?

Cogitamos que a resposta à primeira questão, sobre a redenção, é que Kiefer não pretende se redimir através de sua produção. A potência do trabalho de Kiefer está na flagrante exposição da tradição alemã, trazendo à tona toda uma perigosa imaginária aos olhos dos observadores. Os temas teutônicos (a história bélica, a floresta, a figura do herói, a arquitetura monumental) não são revitalizados nos seus trabalhos num sentido judiciário, pelo contrário, são um chamado à memória. Com o fato de pintar a experiência de ser um artista alemão, ele responde à autoridade de sua tradição. Mas, na sua resposta, ele próprio reconhece que não existe possibilidade alguma para a redenção. Se há redenção em Kiefer, ela será 399 "I think it's fair to say that his art has the implicit subject of redemption." Cf. ROSENTHAL, Mark. op. cit., p. 79. 
alquímica, na sua relação mágica com os sentidos ocultos em oposição à razão iluminista que, como em Goya, produz monstros. A inegável melancolia exaurida nos seus trabalhos sugere que Kiefer reconhece a impossibilidade redencionária. A tristeza que permeia em seus trabalhos estabelece uma compreensão maior do inexorável peso da sua tradição. O pintor não pode se tornar não-alemão e nem pode mudar os trágicos desígnios da história alemã. Contudo, nos trabalhos de Kiefer, embora não exista a possibilidade da redenção, apresenta-se, porém, de maneira afável, a possibilidade da transformação.

O tema da transformação permeia por toda a produção do artista alemão. Alquimia, por exemplo, era uma forma arcaica de saber da magia combinado com saberes da ciência que procuravam transformar materiais pesados em ouro e também pretendiam transmutar as características de materiais em estado natural em outros materiais mais poderosos. A idéia que subjaz à alquimia era a de metamorfosear algum objeto de seu estado impuro a um melhor estado de pureza. Lembremos os usos que Kiefer faz do chumbo, assim como do ouro. Na sua pintura Zweistromland, Kiefer criou mais de duzentos livros de chumbo e os colocou numa prateleira do mesmo material unida com fios de cobre. Alguns dos livros contêm imagens e textos do antigo Egito e outras culturas antigas. O pintor alegoriza o saber colocado na prateleira de chumbo aguardando pela sua restauração através de algum processo alquímico. $O$ peso do chumbo e dos livros imprime uma sensação do peso da sua história: tempo humano e individual e o grande tempo universal. Cabe recordar que desde o final da década de 1980, o chumbo é o material predominante nas imensas pinturas, instalações e esculturas do pintor. Sabemos, desde os tempos em que astronomia e astrologia se confundiam que Saturno é o planeta associado à melancolia, enquanto o chumbo é seu elemento principal. Lembremos que nem 
todos os fogos das pinturas de Kiefer são fogos sinistros. Estes fogos também podem ser fogos no sentido de purificação. Como alquimista, Kiefer tenta transformar o que está em estado de impureza a um melhor estado de pureza. Contudo, essas tentativas de purificação e redenção estão destinadas ao fracasso. Os trabalhos de Kiefer demonstram que nem sequer o poder do artista e de seus trabalhos podem purificar e redimir a história alemã. Então, o sentido de luto e de melancolia que exprimem seus trabalhos é uma manifestação da aceitação deste fato inelutável. ${ }^{400}$

400 Cf. DANZIGER BRASIL, L. M. "Imagens e espaços da melancolia: W.G. Sebald e Anselm Kiefer," Revista Brasileira de Literatura Comparada, n. 10, 2000, pp. 127-146. 


\section{BIBLIOGRAFIA CONSULTADA}

\section{KIEFER, ARTE ALEMÃ DO PÓS-GUERRA E CRÍTICA:}

ADRIANI, G. "Every Present Has Its Past," AKB 13.

ALCARAZ, M. J. "Síntomas posmodernos y artistas desenfadados." Daimón. Revista de Filosofía, n. 22, 2001, pp. 173-181.

ARASSE, D. Cette obscure clarté qui tombe des étoiles. Cat. Exp. Galerie Yvon Lambert, Paris, 1996.

ASSOULINE, P. "Portrait, Anselm Kiefer." In: ARDENNE, Paul; ASSOULINE, Pierre. Anselm Kiefer Sternenfall. Paris: Grand Palais, 2007, pp. 319-337.

AULADELL, F. V. "Cinismo y marginalidad. Andy Warhol y The Velvet Underground en Exploding Plastic Inevitable." Espéculo 22, 2002, p. 10.

AVGIKOS, J. "Point Zero: German Art in the 50's," Arts, vol. 64, n. 7, March 1990, pp. 52-59.

BELTING, H. Identität im Zweifel. Ansichten der deutschen Kunst. De Dumont: Cologne, 1999. Versão para inglês, The Germans and Their Art. A Troublesome Relationship. Trad. Scott Kleager, New Haven: Yale University Press, 1998.

BEYER, L. "Anselm Kiefer," Flash Art, n. 128, May-June 1986, p. 61. BIRO, M. Anselm Kiefer and the Philosophy of Martin Heidegger. Cambridge: Cambridge University Press, 1998.

BOCHNER, M. "Barnett Newman: pintura escrita/ escrita pintura", Arte e Ensaio, Rio de Janeiro: EBA/UFRJ, n. 9, 2002, p. 71.

BOIS, Y-A. "Painting as Model", pp. 65-97 e "The Semiology of Cubism," In: ZELAVANSKY, Lynn (org.) Picasso and Braque, pp. 169208. ECA-USP.

BOLLACK, J. Poésie contre poésie. Celan et la littérature. Paris: PUF, 2001.

BRASIL DANZIGER, L. M. Anselm Kiefer e a pergunta pela Alemanha. Dissertação de Mestrado apresentada ao Departamento de História da PUC-Rio, abril 1996.

. Corpos de ausências. Berlim e os monumentos a Auschwitz. Tese de Doutorado apresentada ao Programa de Pós-Graduação em História Social do Departamento de História da PUC-Rio, março 2003. . "Shoah ou holocausto: A aporia dos nomes." Arquivo Maari. Revista Digital de Estudos Judaicos da UFMG. 2007.

."Imagens e espaços da melancolia: W.G. Sebald e Anselm Kiefer," Revista Brasileira de Literatura Comparada, n. 10, 2007, pp. 127-146.

. "O jornal e o esquecimento." Ipotesi. Revista de Estudos Literários. vol. 11, n. 2, 2007, pp. 167-177. 
BRISSAC, N. B. Paisagens Urbanas. São Paulo: Marca D’Água, 1996. BUCHLOCH, B. "Divided Memory and Post-Traditional Identity: Gerhard Richter's Work of Mourning," October, n. 75, Winter 1996, pp. 61-82.

."Beuys: The Twilight of the Idol: Preliminary Notes for a Critique," Artforum, vol. 18, n. 5, January 1980, pp. 35-43.

. "Figures of Authority, Ciphers of Agression: Notes on the Return of the Representation in European Painting," October 16, 1981, pp. 39-68. . et al. "El potencial del arte." Acción Paralela 5, p. i.

BUDZYNSKI, J. B. Narcissistic Moments in German Art. Tese de Doutorado apresentada ao Departamento de História e Crítica da Arte da Universidade do Estado de Nova York, Campus de Stony Brook, maio 2005.

CHILlidA, A. Veinte años de Soledad. Cat. Exposición Parque del Retiro, Madrid, 1998.

CLARK, T. J. Modernismos. Trad. de Vera Pereira. São Paulo: CosacNaify, 2006.

COOKE, L. "Berlin,Martin-Gropius-Bau, Joseph Beuys," The Brulington Magazine, July 1988, p. 557.

CROW, T. "Saturday disasters: trace and reference in early Warhol." In: MICHELSON, Annettte. Andy Warhol. October files. Cambridge, Massachusetts: MIT Press, 2001, pp.49-68.

DE DUVE, T. "Le dernier des prolétaires," Artstudio 4, 1987.

FITZPATRICK, B. J. Temporality in Anselm Kiefer's "Varus" and Wim Wenders' "Wings of Desire," Tese de Doutorado apresentada ao Departamento de História da Arte da Universidade de Ohio, maio de 1996.

FLAM, J. "The Alchemist," New York Review of Books, February 13, 1992 , p. 36.

FOSTER, H. The Return of the Real. Cambridge: MIT University Press, 1996.

FRIED, M. "Art and Objecthood," In: BATTCOCK, Gregory ed. Minimal Art: A Critical Anthology. New York: E.P. Dutton, 1968, pp. 116-147.

Three American Painters: Kenneth Nolan, Jules Olitiski and Frank Stella. Cambridge, Harvard University Press, 1965.

GILLEN, E. German Art from Beckmann to Richter. Images of a Divided Country. Cologne: De umont, 1997.

GILMOUR, J. Fire on the Earth. Anselm Kiefer and the Postmodern World. Philadelphia: Temple University Press, 1990.

HAXTHAUSEN, C. "America's Spiritual Hero: The Reception of Anselm Kiefer in the United States." Paper presented at the University of Wisconsin, Madison, March 1991.

HECHT, A. "Interview with Anselm Kiefer," Art, January 1990, pp. 4445.

HEIBEL, Y. Reconstructing the Subject: Modernist Painting in Western Germany. 1945-1950. Princeton: Princeton University Press, 1995. 
HUYSSEN, A. "The Terror of History, the Temptation of Myth," October 48, Spring 1989, p. 26.

."After the Wall: The Failure of German Intellectuals," New German Critique 52, Winter 1991, pp. 109-143.

. Memórias do Modernismo. Trad. Patrícia Farias. Rio de Janeiro: Editora UFRJ, 1999.

After the Great Divide: Modernism, Mass Culture, Postmodernism. Bloomington: Indiana University Press, 1986.

KLIGERMAN, E. Scenes of Witnessing in Paul Celan, Anselm Kiefer and Daniel Libeskind. Tese de Doutorado apresentada ao Departamento de Literatura Comparada da Universidade de Michigan, 2001.

KRAUSS, R.; MICHELSON, A. "Joseph Beuys at the Guggenheim," October 12, Spring 1980, pp. 3-21.

. The Originality of the Avant-Garde and Other Modernist Myths. Cambridge, MA: MIT Press, 1985.

. "The Motivation of the Sign," In: ZELEVANSKY, Lynn (org.), Picasso and Braque: A Symposium, New York: MOMA, 1992, pp. 261286.

KUSPIT, D. "Beuys: Fat, Felt and Alchemy," Art in America, May 1980, pp. 79-89.

LANZETTA, K. The Aesthetic of Sacrifice in Heiner Müller, Wolf Vostell, Anselm Kiefer and Rainer Werner Fassbinder. Tese de Doutorado apresentada ao Departamento de Alemão da Universidade de Chicago, 2008.

LAUTERWEIN, A. Anselm Kiefer et la poésie de Paul Celan. Paris: Du Regard, 2005.

LEVIN, K. "Joseph Beuys: The New Order," Arts Magazine, April 1980, pp. 154-157.

LITTMAN, R. Anselm Kiefer. Catálogo Museu de Arte Moderna de São Paulo, 1998.

LODDER, C. Russian Constructivism, New Haven: Yale University Press, 1983, pp. 248-250.

LUZ, A.; RIVITTI, T. et al. "Sintoma e intuição." Entrevista com Thierry de Duve. Novos Estudos 79, Novembro 2007, pp. 211-226.

LYOTARD, J.F. "Barnett Newman. O Instante" Revista Gávea n.4, Rio de Janeiro: PUC-Rio, janeiro 1987, p. 84.

MAIER, C. The Unmasterable Past: History, Holocaust, and German National Identity. Cambridge \& London: Verso, 1988.

MATOS, O. "O sol triste das ruínas." Folha de São Paulo, 29 outubro 1995, pp.5-6.

MEAD, T. C. Historical Iconology and the Simbolism of Wood in German Painting: From Friedrich to Kiefer. Dissertação de Mestrado apresentada ao Departamento de Arte da Universidade de Lamar, maio 1997.

MEYER, R. "Warhol's Clones," Yale Journal of Criticism, vol. 7, n. 1, 1994, pp. 79-109. 
MICHAUD, E. "The Ends of Art according to Joseph Beuys," October 45, Trad. Rosalind Krauss, Summer 1988, pp. 36-46.

MITSCHERLICH A. e M. Le deuil impossible: Les fondaments du comportement collectif. Payot: Paris, 1972. The Inability to Mourn: Principles of Collective Behaviour. Trad. Beverly R. Plackzek. New York: Grove Press, 1975.

OTTMAN, K. "Heidegger, Beuys and the Consequences," Flash Art, October 1990, pp. 123-124.

OWENS, C. Beyond Recognition: Representation, Power, and Culture. Berkeley: University of California Press, 1992.

PLANTE, D. "The Art World: Bacon's Instinct," New Yorker 69, n. 6, Nov 1, 1993, p. 96.

RAMPLEY, M. "In Search of Cultural History: Anselm Kiefer and the Ambivalence of Modernism." Oxford Art Journal, volume 23, November 2000, pp. 82-83.

RAY, G. The Use and Abuse of the Sublime: Joseph Beuys and Art after Auschwitz. Tese de Doutorado apresentada ao Departamento de Filosofia da Universidade de Miami, Coral Gables, 1997.

RICE, K. M. The Burden of a National Legacy: An examination of Anselm Kiefer's reflection on the German Past. Dissertação de Mestrado apresentada ao Departamento de Arte da Universidade de Rice, em Houston, abril 1994.

ROBINSON, W. "Beuys, Art Encagé," Art in America, November/December 1974, p. 78.

ROSENTHAL, M. Anselm Kiefer. Chicago: Chicago Institute of Art and Philadelphia, 1987.

SALTZMAN, L.S. Anselm Kiefer and Art after Auschwitz. Cambridge: Cambridge University Press, 1999.

SALZSTEIN, S. "Cultura Pop: Astúcia e inocência."Novos Estudos n. 76, novembro 2006, pp. 251-262.

SELIGMANN-SILVA, M. O local da diferença. Ensaios sobre memória, arte, literatura e tradução. São Paulo: Editora 34, 2005.

. (org.). História, Memória, Literatura. O testemunho na Era das

Catástrofes. Campinas: UNICAMP, 2003, pp. 125-126.

SOARES, L. C.; SCHMIDT, M. L. "Sobre alguns temas em Anselm Kiefer". Imaginário-USP, n. 5, 1999, pp. 67-81.

STELLA, F. "Questions to Stella and Judd," entrevista editada por Lucy R. LIPPARD, in BATTCOCK, G. (ed.) Minimal Art: A Critical Anthology, New York: E.P. Dutton, 1968, p. 149.

TAYLOR, P. "Painter of the Apocalypse," New York Times Magazine, October 16, 1988, p. 103.

TERRASSE, J.M. Frontières, en nous, hors de nous, nous. Anselm Kiefer, Paris: Du Regard, 2007, p. 31.

TISDALL, C. Joseph Beuys. New York: Thames and Hudson, 1979.

TRUTER, C. E. "Anselm Kiefer: Urban Spirituality." In: TRUTER, C.E. Images in, trough and for "the W/Word": A revisioning of Christian Art. Dissertação de Mestrado em Artes Visuais da Universidade de África do Sul, novembro, 2007. 
VIDAL, F. "Cinismo y marginalidad. Andy Warhol y la Velvet Underground en Exploding Plastic Inevitable." Espéculo. Revista de Estudios Literarios. Universidad Complutense de Madrid, n. 22, 2002, pp. 56-63. http://www.ucm.es/info/especulo/numero22/warhol.html ZWEITE, A. "The High Priestess," Londres: Anthony d'Offay Galery, 1989.

\section{OBRAS DE WALTER BENJAMIN:}

BENJAMIN, W. Origem do drama Barroco Alemão (1925). Trad. e apresentação Sérgio Paulo Rouanet. São Paulo: Brasiliense, 1984. . Diário de Moscou. São Paulo: Companhia das Letras, 1989. Vol.I. Magia e técnica, arte e política. São Paulo: Brasiliense, 1987. . Rua de Mão Única. São Paulo: Brasiliense, 1987. Vol.II.

. Charles Baudelaire. Um lírico no auge do capitalismo. São Paulo: Brasiliense, 1991. Vol. III.

. Passagens. Willie Bolle (org.). Trad. Irene Aron. Belo HorizonteSão Paulo: UFMG, Imprensa Oficial, 2006.

\section{OBRAS SOBRE WALTER BENJAMIN:}

ADORNO, T.W. Correspondencia: 1928-1940/ Theodor W. Adorno y Walter Benjamin. Trad. Jacobo Muñoz; Vicente Gómez Ibáñez. Madrid: Trotta, 1998.

ARENDT, H. "Walter Benjamin (1892-1940)." In: ARENDT, H. Homens em tempos sombrios. Trad. Denise Bottmann. Rio de Janeiro: Jorge Zahar, 1993.

BENVENUTI, G. La cenera lieve del vissuto. Il concetto di critica in Walter Benjamin. Roma: Bulzoni, 1994.

BOLLE, W. "Alegoria, imagens, tableau." In: NOVAES, Adauto, (org). Artepensamento. Sao Paulo: Companhia das Letras, 1994, pp. 411432.

BRANCO, L. A tarefa do tradutor. Quatro traduções para o português. (trad. Susana Kampff Lages) Belo Horizonte: UFMG, pp. 66-81.

BRETAS, A. A constelação do sonho em Walter Benjamin. São Paulo: Humanitas, 2008.

BUCK-MORSS, S. The dialectics of seeing: Walter Benjamin and the Arcades Project. Cambridge: MIT University Press, 1990, p.168. Dialética do olhar: Walter Benjamin e o projeto das Passagens. Trad. Ana Luiza Andrade. Belo Horizonte: UFMG, 2002.

CADAVA, E. Words of Light: Theses on the Fotogoragphy of History. Princeton: Princeton University Press, 1997.

CANTINHO, M. J. "Modernidade e alegoria em Walter Benjamin." Espéculo. Revista de Estudios Literarios de la Universidad Complutense de Madrid, n. 24, julio-octubre, 2003. 
DIDI-HUBERMANN, G. "L'image-aura. Du maintenant, de l'autrefois et de la modernité." In: Devant le Temps. Paris: De Minuit, 2000.

EXPOSITO, R. "Lenguaje y violencia entre Benjamin y Canetti." Daimón. Revista de Filosofia, n. 38, 2006, pp. 61-69.

FORSTER, R. Benjamin y la cuestión del mal. Buenos Aires: Altamira, 2001.

GAGNEBIN, J. M. "O Hino, a Brisa e a Tempestade: dos anjos em Walter Benjamin." In: GABNEBIN, J. M. Sete aulas sobre linguagem, memória e história, Rio de Janeiro: Imago, 1997, pp. 125-126.

Perspectiva, 1994.

Narração em Walter Benjamin. São Paulo:

GAMARRA QUINTANILLA, G. Estética Urbana. Ciudad, cine y mito. De Walter Benjamin a Metrópolis. Tese de Doutorado apresentada ao Departamento de Cinema da Universidad del País Basco, Mayo 2008. JENCKES, K. Borges, Benjamin, and the Allegorical Writing of History. Tese de Doutorado apresentada ao Departamento de Literatura Comparada da Universidade de Oregon, Dezembro 2001.

LÖWY, M. Walter Benjamin: Aviso de Incêndio. Uma leitura das teses "Sobre o conceito de História." Trad. Wanda Nogueira Caldeira Brant. São Paulo: Boitempo, 2005.

LUCAS, A. El trasfondo de lo moderno: Estética y crisis de la Modernidad en la filosofía de Walter Benjamin. Madrid: UNED, 1992, p. 22.

MATOS, O. O iluminismo visionário: Benjamin leitor de Descartes e Kant. São Paulo, Brasiliense, 1993.

MISSAC, P. Passagem de Walter Benjamin. Trad. Lilian Escorel. Sâo Paulo: Iluminuras, 1998, pp. 62-71.

MOSĖS, S. L'Ange de l'histoire. Rosenzweig, Benjamin, Scholem. Paris: Seuil, 1992.

MUÑOZ-MILLANES, J. "La presencia de Baltasar Gracián en Walter Benjamin." Ciberletras. Revista de Crítica Literaria y Cultura 1, 1999.

OTTE, G. "Rememoração e citação em Walter Benjamin." Revista de Estudos Literários. vol. 4, out. 1996, pp. 211-223.

OYARZÚN, P. La dialéctica en suspenso. Fragmentos sobre Historia. Santiago, Chile: Arcis-Lom, 1995.

SAFDIE DOUEK, S. Memória e exílio. São Paulo: Escuta, 2003.

SALGADO, J. "Alegoria e modernidade em Benjamin." In: SALGADO, José. A experiência de um ocidental: Cesário Verde, Walter Benjamin e a experiência poética da modernidade. Tese de Doutorado apresentada ao Departamento de Espanhol e Português da Universidade de Califórnia, Dezembro 1997, pp.170-177.

SCHOLEM, G. Walter Benjamin: A história de uma amizade. Trad. Geraldo Gerson de Souza. São Paulo: Perspectiva, 1989.

. O Golem, Benjamin, Buber e outros justos. Trad. Ruth Joanna Solon. São Paulo: Perspectiva, 1994.

SELIGMANN-SILVA, M. Ler o livro do mundo-Walter Benjamin: Romantismo e crítica literária. São Paul: Iluminuras, 1999. 

1999.

(org.) Leituras de Walter Benjamin. São Paulo: ANNABLUME,

"Quando a teoria reencontra o campo visual Passagens de Walter Benjamin." Concinnitas ano 8, vol. 2, n. 11, dezembro 2007. - "San Pablo: el inconsciente óptico sobre la ciudad. Sobre las fotografías de Carlos Goldgrub." Trad. Adrián Gorelik. Punto de Vista 85, agosto 2006, pp. 12-15.

VILLACAÑAS, J. L. "Walter Benjamin y Carl Schmitt: Soberanía y Estado de Excepción." Daimón. Revista de Filosofia del Departamento de Filosofía de la Universidad de Murcia, n.13, Julio-Diciembre 1996, pp. 41-60.

\section{FONTES SECUNDÁRIAS:}

AB' SÁBER, T. "Freud e o outro sonho." In: AB' SÁBER, T. O sonhar restaurado. Formas de sonhar em Bion, Winnicott e Freud. São Paulo: Editora 34, 2005.

ADORNO, T. W. The authoritarian personality. New York: Harper \& Brothers, 1950.

. "What Does Coming to the Past Mean," (1959), Trad. Geoffrey Hartmann (org.); Bitburg in Moral and Politica. Perspective. Indiana: Indiana University Press, 1986, pp. 114-129.

- Palavras e sinais. Modelos Críticos 2. Trad. Maria Helena Ruschel. Petrópolis: Vozes, 1995.

AGAMBEN, G. Le temps qui reste. Paris: Rivages, 2000.

. Estâncias. Trad. Selvino José Assmann. Belo Horizonte: UFMG, 2007.

Homo Sacer. O poder soberano e a vida nua I. Trad. Henrique Burigo. Belo Horizonte: UFMG, 2002.

ARANTES, O. O lugar da arquitetura depois dos modernos. São Paulo: EDUSP, 1993.

. Urbanismo em fim de linha e outros estudos sobre o colapso da modernidade arquitetônica. São Paulo: Editora da USP, 1998.

. "A virada cultural do sistema das artes". São Paulo, Abril 2005.

ARENDT, H. Entre o passado e o presente, trad. Mauro W. Barbosa de Almeida, São Paulo: Perspectiva, 1972.

ARIGUCCI, D. Enigma e comentário: Ensaios sobre literatura e experiência. São Paulo: Ed. Schwartz, 1987.

BACHELARD, G. A psicanálise do fogo. São Paulo: Martins Fontes, 1999.

. La poétique de l'espace. Paris: PUF, 1957.

BADIOU, A. L'Éthique. Essai sur la conscience du Mal, Paris: Hatier, 1993.

BATES, L. The Visual Experience. Englewood Cliffs: Prentice-Hall, 1987. 
BAUMAN, Z. Modernity and Holocaust. Oxford: BasilBlackwell, 1989. BAUDELAIRE, Charles. O pintor da vida moderna. Lisboa: Vega, 1993.

BAZIN, G. History of Art. Trad. Francis Scarfe. New York: Bonanza, 1959 , p. 230.

BENITO-VESSELS, C. La palabra en el tiempo de las letras. México: Fondo de Cultura Económica, 2008.

BERMAN, M. Tudo que é sólido desmancha no ar. Trad. Carlos Felipe Moisés. São Paulo: Companhia das Letras, 2007.

BERSANI, L. The Culture of Redemption. Cambridge, Massachussetts: Harvard University Press, 1990, p. 74.

BIALE, D. Cabala e contra-história: Gershom Scholem. Trad. J. Guinsburg. São Paulo: Perspectiva, 2004.

BLANCHOT, M. The Gaze of Orpheus and other Literary Essays. Trad. Lydia Davis. New York: Station Hill Press, 1981.

BLOCH, E. O princípio esperança. Vol. I-III. Trads. Nélio Schneider; Werner Fuchs. Rio de Janeiro: Editora UERJ, 2006.

BOIS, Y-A. Painting as a Model. Cambridge: MIT University Press, 1990.

BORGES, J.L. Obras Completas. I-IV. Buenos Aires: Emecé, 1996.

BORNAY, E. Las hijas de Lilith. Madrid: Cátedra, 1998.

BOZAL, V. Necesidad de la ironía. Madrid: Visor, 1999.

BRANDÃO, R. "O Mal." In: BRANDÃO, R. A ordem do mundo e o homem: estudos sobre metafísica e moral em Voltaire. Tese de Doutorado apresentada ao Departamento de Filosofia, da Faculdade de Filosofia, Letras e Ciências Humanas da Universidade de São Paulo, 2008.

BRASIL DANZIGER, L. M. "Séculos de melancolia." Concinnitas ano 7, vol. 1, n. 9, julho 2006.

BÜRGER, P. Teoria da Vanguarda. Trad. José Pedro Antunes. São Paulo: CosacNaify, 2008.

CARRIÓN, M. M. Arquitectura y cuerpo en la figura autoral de Santa Teresa de Jesús. Barcelona: Antrophos, 1998.

CARUTH, C. ed. Trauma: Explorations in Memory. Baltimore: Johns Hopkins University Press, 1995, p. 4.

CHÉROUX, C. Mémoire des camps. Photographies des camps de concentration et d'extermination Nazis (1933-1999). Paris: Marval, 2001.

CELAN, P. Arte poética. O meridiano e outros textos. Trad. João Barrento e Y. K. Centeno. Lisboa: Cotovia, 1996.

COULANGES, F. La ciudad Antigua. Madrid: EDAF, 1968.

CROW, T. Nineteen Century Art: A Critical History. London: Thames and Hudson, 1994.

CURTIUS, E. "Numerical Composition," In: CURTIUS, Ernst. European Literature and the Latin Middles Ages. Princeton, New Jersey: Princeton University Press, 1967, pp. 501-510.

DAVIS, M. "The Flames of New York." New Left Review 12, Nov-Dec 2001. 
DEGUY, M. (org.) Du Sublime. Paris: Belin, 1988.

DUPUY, J.P. "A catástrofe, o império da técnica e o desaparecimento da natureza: A tentação de apagar a política com a técnica." In: NOVAES, Adauto (org.). O esquecimento da política. São Paulo: Agir, 2006.

DUQUE, F. (ed.) El mal: Irradiación e Fascinación. Murcia: Serbal, 1993.

DYMETMAN, A. Uma arquitetura da indiferença: A República de Weimar. São Paulo: Perspectiva, 2002.

FÉRIA, J. T. "O que é um livro de artista," Imaginar, Julho 2007, pp. 9-15.

FERREIRA, G. E COTRIM, C. (orgs.). Clement Greenberg: O debate crítico. São Paulo: Funarte, 1997.

FONTANA, D. Secret Language of Symbols. San Francisco: Chronicle, 1994.

FONTES, J. Eros, Tecelão de Mitos. Rio de Janeiro: Iluminuras, 2003.

FORSTER, R. El exilio de la palabra. Ensayo en torno a lo judío. Santiago: Arcis, 1997.

FRIEDLÄNDER, S. Reflets du nazisme. Seuil: Paris, 1982.

FRITZSCHE, P. Life and Death in the Third Reich. Cambridge: Belknap Press, 2008.

FULLER, J.F.C. Decisive Battles of the Western World, vol.1. London: Eyre \& Spotswood, 1954, pp. 248-251.

GOLDHAGEN, D. Hitlers willing executer. Ordinary germans and the holocaust. New York: Knopf, 1996.

GUERREIRO, A. O acento agudo do presente. Portugal: Cotovia, 2000.

JUNG, C. Psicologia e Alquimia. Obras Completas de Jung. Vol XII. Trads. Maria L. Appy, Margaret Makray e Dora Maria F. Da Silva. Rio de Janeiro: Vozes, 1994.

HALL, P. Cidades do amanhã. Trad. Pérola de Carvalho. São Paulo: Perspectiva, 1995.

HEIDEGGER, M. "Conferências e escritos filosóficos". São Paulo: Nova Cultural, Coleção Os Pensadores, 1989.

HUTCHEON, L. "Provocação e controvérsia: o trabalho de Anselm Kiefer." In: HUTCHEON, L. Teoria e política da Ironia. Trad. Julio Jeha. Belo Horizonte: UFMG, 2000.

JABÈS, E. Del desierto al libro. Entrevistas com Michael Cohen. Madrid: Trotta, 2000.

KAES, A. From Hitler to Heimat: The Return of History as film. Cambridge \& London: Verso, 1989.

LACOUE-LABARTHE, P. La poésie comme experience. Paris: ChristianBourgois, 1986.

Larousse Dictionary of Painters. New York: Mallard, 1976.

LEICESTER, H. The historical background of chemistry, Boston: Dover Publications, 1971, p. 34.

LÉVINAS, E. Autrement qu'être ou au-delà de l'essence. La Haye: Martinus Nijhoo, 1974. 
LYOTARD, J.F. L'Inhuman. Causseries sur le temps. Paris: Galilée, 1988. The Inhuman. Reflections on Time. Trad. Geoffrey Bennington e R. Bowlby, Stanford: Stanford University Press, 1991.

MAGRIS, C. Danúbio. Trads. Elena Grechi; Jussara de Fátima Mainardes Ribeiro. São Paulo: Rocco, 1992.

MANGUEL, A. Uma história da leitura. São Paulo: Companhia das Letras, 1997.

MARRAMAO, G. Kairós. Apologia del tempo debito. Roma-Bari: Sagittari Laterza, 1992.

MATOS, O. Discretas Esperanças. Reflexões filosóficas sobre o mundo contemporâneo. São Paulo: Nova Alexandria, 2006.

MILLER, J. "Erasing the Past: Europe's Amnesia About the Holocaust," In: MILLER, J. One by One, by One: The Landmark Exploration of the Holocaust and the Uses of Memory. New York: Simon \& Schuster, 1990.

MIRZOEFF, Nicholas, (ed.). The visual culture reader. London/New York: Routledge, 1998.

MOREIRAS, Alberto. Tercer espacio: Literatura y duelo en América Latina. Santiago-Chile: Arcis-Lom, 1999.

"Circulus Vitiosus Deus: Borges y el fin de la memoria."Siglo $\overline{X X / 20 t h ~ C e n t u r y, ~ 1992, ~ p p . ~ 111-~} 130$.

MUMFORD, L. A cidade na história. Suas origens, transformações e perspectivas. Trad. Neil R. da Silva. São Paulo: Martins Fontes, 1998. MÜNSTER, A. Ernst Bloch. Filosofia da praxis e utopia concreta. São Paulo: UNESP, 1993, pp. 55-79.

NASCIMENTO, L. "Memória e testemunhas: A Shoah e o dever da memória". Ipotese. pp. 89-103.

NOGUEIRA, Cristiana. A impermanência do processo: poeira, caminhos, objetos. Dissertação de Mestrado apresentada ao programa de pós-graduação em Artes da Universidade do Estado de Rio de Janeiro, 2009.

ORDINE, N. O umbral da sombra. Trad. Luiz Carlos Bombassaro. São Paulo: Perspectiva, 2006.

ORTEGA y GASSET, J. "Introducción a Velázquez." In: Velázquez, Madrid: Espasa Calpe, 1947.

PARDO, J. L. Sobre los espacios. Barcelona: Serbal, 1991.

PÉREZ, L. Freud judío y ateo. Santiago de Chile: Ril, 2007.

REGALADO, A. Calderón: Los orígenes de la Modernidad en la España del Siglo de Oro. Vol. II. Barcelona: Destino, 1995.

REVAULT D'ALLONS, M. Ce que I'homme fait a l'homme. Essai sur le Mal politique, Paris: Seuil, 1995.

ROBBE-GRILLET, A. Por um novo romance. São Paulo: Editora Documentos, 1969.

RORTY, R. Contingência, ironia e solidariedade. Trad. Vera Ribeiro. São Paulo: Martins Fonte, 2007.

ROTHKER, S. Citizen of fear. Violence in Latin America. New Jersey: Rutgers University Press, 2000. 
RYBACK, T. A biblioteca esquecida de Hitler. Os livros que moldaram a vida do Führer. Trad. Ivo Korytowsky. São Paulo: Companhia das Letras, 2009.

SAFLATLE, Vladimir. Cinismo e falência da crítica. São Paulo: Boitempo, 2008.

SCHOLEM, G. As grandes correntes da mística judaica. São Paulo: Perspectiva, 1995.

SCHULZ, S. H. Estéticas urbanas: Da pólis grega à metrople contemporânea. Rio de Janeiro: LTC Editora, 2007.

SCHUTZ, M. "Borges y la filosofía del Tiempo." Daimón. Revista de Filosofia, n. 5, 1992, pp. 109-122.

SIEGAL, L. Caspar David Friedrich and the Age of German Romanticism. Boston: Branden, 1978.

SOSNOWSKY, S. Borges y la cábala: la búsqueda del verbo. Buenos Aires: Ediciones Hispamérica, 1976.

SONTAG, S. "Fascinating Fascism." In: SONTAG, S. Under the Sign of Saturn. New York: Farrar, Straus, Giroux, 1980.

. Diante da dor dos outros. Trad. Rubens Figuereido. São Paulo: Companhia das Letras, 2003.

SOULLIER, Didier. La littérature baroque en Europe. Paris: PUF, 1998. STEINER, G. Linguagem e silêncio. São Paulo: Companhia das Letras, 1988. TACITUS, C.T. "Annals," 61, vol. 15, Tacitus, In: HUTCHINS, R.M. (ed.). Great Books of the Western World. Chicago: Encyclopedia Britannica, 1952, pp. 1-184.

TATAR, M. The Hard Fact of Grimm's Fairy Tales. Princeton: Princeton University Press, 1987.

TAYLOR BRIGHT, B. No longer Innocent: The Book Arts in America, 1960 to 1980. Tese de Doutorado apresentada ao Departamento de Arte da Universidade de Minnesota, maio 2000.

TAUBES, J. Die politische teologie de Paulus, Frankfurt: 1993.

UDLER, M. A crisálida da filosofia. A obra Eu e Tu de Martin Buber ilustrada por sua base hassídica. São Paulo: Humanitas, 2005.

VIERECK, P. Metapolitics: From Romantics to Hitler. New York: Simon \& Shuster, 1941.

VILLACAÑAS, J. L. Tragedia y teodicea de la Historia. Madrid: Visor, 1993.

YERUSHALMI, Y. H. Zakhor: história judaica e memória judaica. Rio de Janeiro: Imago, 1992. 